SOUTHERN CALIFORNIA ALLUVIAL BASINS

REGIONAL AQUIFER-SYSTEMS ANALYSIS :

\title{
A BIBLIOGRAPHY
}

By W. R. Moyle, Jr., Peter Martin, R. C. Schluter, Linda R. Woolfenden, Karen Downing, Ann L. Elliott, and Dorothy E. Maltby

U.S. GEOLOGICAL SURVEY

Open-File Report 85-695

$m$
1
0
0
0 
UNITED STATES DEPARTMENT OF THE INTERIOR

DONALD PAUL HODEL, Secretary

GEOLOGICAL SURVEY

Dallas L. Peck, Director

For additional information

write to:

District Chief

U.S. Geological Survey

2800 Cottage Way, Room W-2234

Sacramento, California 95825
Copies of this report may be purchased from:

Open-File Services Section Western Distribution Branch U.S. Geological Survey Box 25425, Federal Center Denver, Colorado 80225 Telephone: (303) 236-7476 


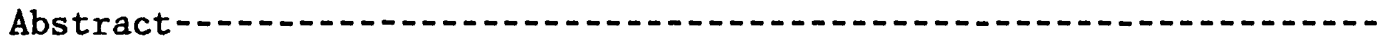

Introduction

Organization of the bibliography-

15-minute topographic quadrangle maps-

Map sheets -

Military reservations and national monuments-...

Counties-1..-

Southern California and offshore-1

Arizona, California, Mexico, and Nevada-

Use of the bibliography-

Sources of publications

The bibliography-

Category 1: 15-minute topographic quadrangle maps--..-

Category 2: Map sheets-...

Category 3: Military reservations and national monuments-.-.-

Category 4: Counties-.....

Category 5: Southern California and offshore-1...

Category 6: Arizona, California, Mexico, and Nevada-.......-

\section{ILLUSTRATIONS}

Plate 1. Index maps to the bibliography for the Southern California Alluvial Basins Regional Aquifer-Systems

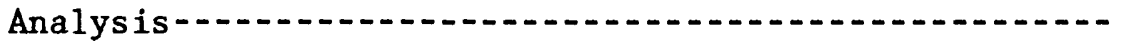

Figure 1. Location of the study area-

\section{TABLES}

Table 1. Geohydrologic disciplines and subjects used in the bibliography for the Southern California Alluvial Basins Regiona1 Aquifer-Systems Analysis-..-

Table 2. Index numbers and associated 15 - and $7 \frac{1}{2}$-minute quadrangle maps-1... 


\section{CONVERSION FACTORS}

The inch-pound system of units is used in this report. For readers who prefer the International System of Units (SI), the conversion factors for the terms used are as follows:

Multiply

miles

square miles $\left(\mathrm{mi}^{2}\right)$

\author{
By \\ 1.609 \\ 2.590
}

To obtain

kilometers

square kilometers 
SOUTHERN CALIFORNIA ALLUVIAL BASINS REGIONAL AQUIFER-SYSTEMS ANALYSIS:

\section{A BIBLIOGRAPHY}

By W. R. Moyle, Jr., Peter Martin, R. C. Schluter, Linda R. Woolfenden, Karen Downing, Ann L. Elliott, and Dorothy E. Maltby

\section{ABSTRACT}

This report provides a bibliography for the Southern California Alluvial Basins Regional Aquifer-Systems Analysis project. The bibliography includes references for about 4,000 publications related to the geohydrology of the 75,000-square-mile region, which encompasses all southern California (except the Central Valley), the Channel Islands and the Pacific Ocean floor off southern California, and parts of adjacent States and Mexico. The report indexes the publications in six geographic categories and includes a list of sources of publications.

Because of the large number of references in the bibliography, a system was developed for computer storage and retrieval. References can be retrieved by geographic location, author, or geohydrologic discipline and subject. The computer system allows for updating and addition of references. 
The Southern California Alluvial Basins RASA (Regional Aquifer-Systems Analysis) is one of many planned or ongoing national RASA studies of the U.S. Geological Survey. The objectives of the Southern California Alluvial Basins RASA are (1) to determine the geohydrologic framework of the coastal and desert alluvial basins in southern California excluding the Central Valley and (2) to identify and analyze major issues and problems affecting the use of ground water in these basins.

The study area for the Southern California Alluvial Basins RASA includes about 75,000 $\mathrm{mi}^{2}$ and extends from Santa Clara and Mono Counties on the north to the California-Mexico boundary on the south (fig. 1). Parts of western Nevada and western Arizona are included on the east, and the Channel Islands and part of the offshore area of southern California on the west. The study area is about 400 miles long and as much as 225 miles wide. The geology and hydrology of the area are as diverse as anywhere in the world.

Surface water is scarce or seasonal throughout most of the Southern California Alluvial Basins RASA study area. Because of the lack of adequate local surface-water supplies, ground water is an important and extensively used resource. A multitude of maps and reports have been produced pertaining to the geohydrology of southern California, but no comprehensive bibliography has been published. This report presents a bibliography of about 4,000 references organized by geographic location for use in the Southern California Alluvial Bas ins RASA.

Included in this bibliography are reports of Federal, State, and local agencies; academic institutions; and private firms. The coverage of Federal and State publications is extensive; the coverage of reports by local agencies, academic institutions, and private firms is not exhaustive for all areas. Selected journal articles also are included. Publications cited in this bibliography may be borrowed or purchased at one or more of the universities, colleges, libraries, and government agencies mentioned in the "Sources of Publications" section.

Because of the large number of references in the bibliography, a system was developed for computer storage and retrieval. References may be retrieved from the system according to geographic category, author, or geohydrologic discipline and subject. References may also be added and updated in the system. The geohydrologic disciplines and subjects used in the bibliography are shown in table 1 . 


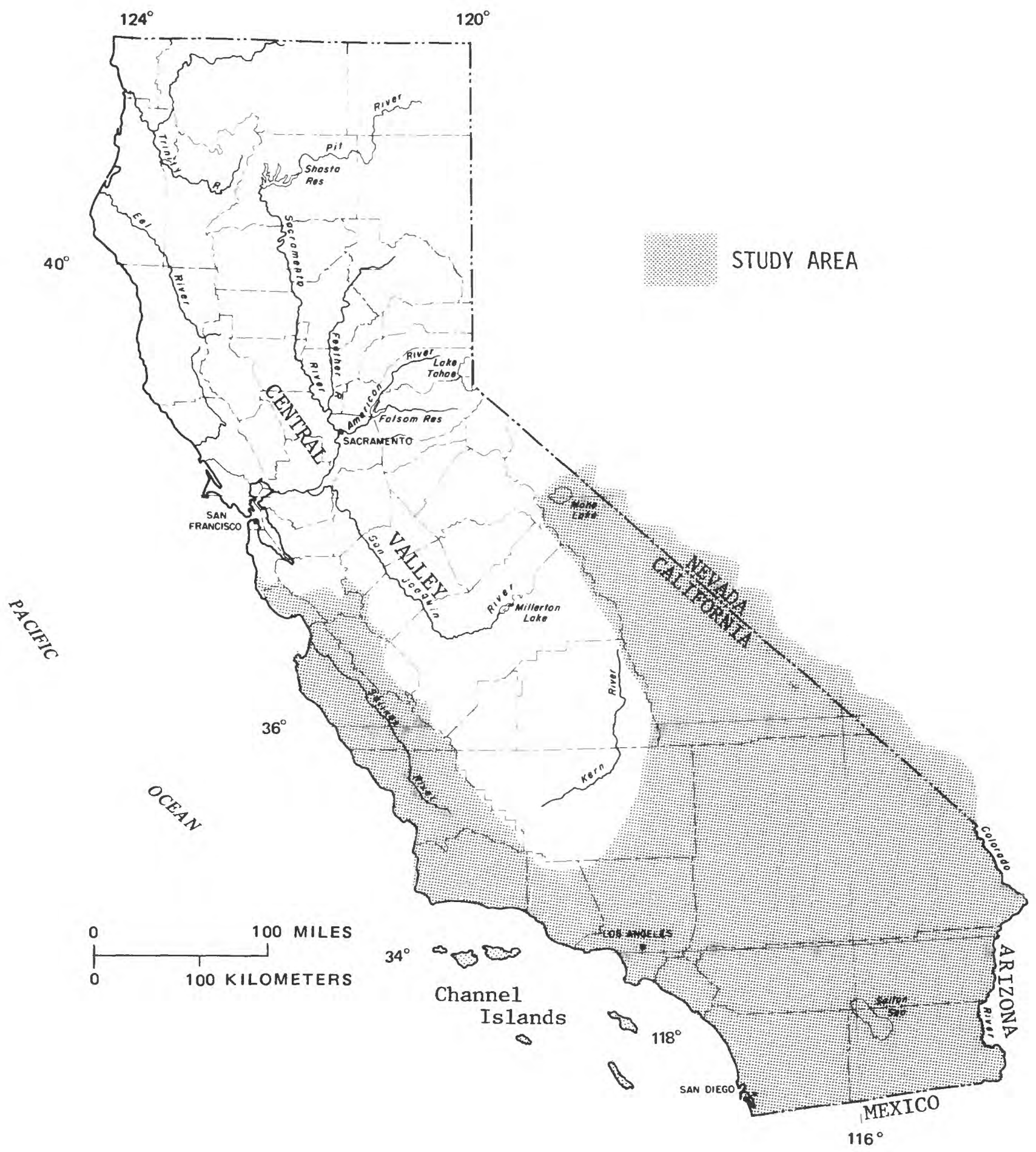

FIGURE 1.-Location of the study area. 
The bibliography presented in this report is organized into six geographical categories. The categories are ordered from most detailed to most general as follows:

1. 15-minute topographic quadrangles

2. Map sheets

3. Military reservations and national monuments

4. Counties

5. Southern California and offshore

6. Arizona, California, Mexico, and Nevada.

For example, a report cited in category 1 contains highly detailed information on a specific locality, whereas a report cited in category 6 contains general information on one of the States included in the study or on Mexico. Citations within each category and subdivision are alphabetized by senior author.

\section{5-Minute Topographic Quadrangle Maps}

The first category of references in the bibliography is based on the series of 15-minute topographic quadrangle maps prepared by the U.S. Geological Survey. References compiled for each quadrangle include reports and maps that pertain almost entirely to that particular quadrangle. Because they cover small areas, the reports and maps referenced in this category are usually more detailed studies than the reports and maps referenced in other categories of the bibliography.

The 15-minute quadrangles have been assigned a 4-digit index number using a grid system devised for this report (p1. 1), and in the bibliography the quadrangles have been serialized according to this system. The 15-minute quadrangle map index numbers and their corresponding 15-minute quadrangle map names and associated $7 \frac{1}{2}$-minute quadrangle map names are shown in table 2 .

The four-digit identification number for each 15-minute quadrangle can be derived from plate 1 as follows. The first two digits refer to row numbers, which are on the left and right edges of the map. The rows are numbered from bottom to top. The second two digits refer to column numbers, which are on the top and bottom of the map. The numbering of the columns is from right to left. For example, the identification number for the San Bernardino 15-minute quadrangle is 0714, because the San Bernardino quadrangle is in row 07 and column 14 of the map grid.

\section{Map Sheets}

The second category of references in the bibliography is based on the system of map sheets (scale 1:250,000) published by the U.S. Geological Survey (p1. 1). Most of the map sheets cover 1 degree of longitude by 2 degrees of latitude. The index map for the map sheets is in the lower left corner of 
plate 1. The name of each map sheet is included on the index map. In the bibliography, the map sheets are listed in alphabetical order, and the references compiled for each map sheet are alphabetized by senior author.

\section{Military Reservations and National Monuments}

The third category of the bibliography consists of references for selected military reservations and national monuments in southern California. Four military reservations and two national monuments were included in the bibliography. The index map for this (and the following) category is on the left side of plate 1 above the map-sheets index map. The military reservations and national monuments are listed in alphabetical order in the bibliography, and the references are alphabetized by senior author within each subdivision. The references compiled within this category include reports and maps that pertain almost entirely to the selected military reservation or national monument.

\section{Counties}

The fourth category of references in the bibliography is based on county boundaries in the study area. Included in the bibliography are 16 counties. The index map for the counties is on the left side of plate 1 , above the index of map sheets. The counties are listed in alphabetical order for each State included in the bibliography, and the references for each county are alphabetized by senior author.

\section{Southern California and Offshore}

The fifth category of the bibliography includes references for the RASA study area in general or for large, indeterminate parts of the study area. The category is subdivided into (1) southern California and (2) offshore. This category of references includes maps and reports that usually cover large areas and often refer to more than one county or map sheet. The references are listed in alphabetical order by senior author under the appropriate subdivision.

Arizona, California, Mexico, and Nevada

The sixth and final category of the bibliography consists of references to statewide studies and studies pertaining to Mexico. Because these reports cover large areas, they are usually more general than those in the other categories. The references are alphabetized by senior author under the appropriate state or country. 
The bibliography presented in this report can easily be used by systematically checking the references in the applicable subdivisions of all six categories of the bibliography. The following is a step-by-step example of a bibliographic search for the Santa Ynez River valley.

Step 1. Inspect the index to 15-minute topographic quadrangles ( 1.1 ) to determine the identification numbers of 15 -minute quadrangle maps that cover that area. The identification numbers of the quadrangle maps of interest are 0924, 0925, 0926, and 0927. The names of these 15-minute quadrangle maps and associated $7 \frac{1}{2}$-minute quadrangle maps are shown on table 2 . Use the selected identification numbers to determine the references in category 1.

Step 2. Inspect the index to map sheets (p1. 1, lower left corner) to determine which map sheet (or sheets) covers the area of interest. For this example the Santa Maria map sheet would be appropriate. Look at the Santa Maria map sheet references in category 2 to find the references pertaining to the Santa Ynez River valley.

Step 3. Check for military reservations or national monuments in the study area ( 1.1 , left side). In this example, the Vandenberg Air Force Base occupies part of the study area. Select the references pertaining to the Santa Ynez River valley from the Vandenberg Air Force Base references in category 3.

Step 4. Find the study area on the county index map (p1. 1) to determine the relevant counties. The Santa Ynez River valley is in Santa Barbara County. Check the Santa Barbara County references in category 4 to find the references pertaining to the Santa Ynez River valley.

Step 5. Check the southern California and offshore references (category 5). The Santa Ynez River drains into the Pacific Ocean; therefore, check both the southern California and offshore references.

Step 6. Check the references for Arizona, California, Mexico, and Nevada (category 6). Inasmuch as the Santa Ynez River valley is not adjacent to a State boundary, probably only the references pertaining to California are relevant.

By following this procedure one can develop a complete set of references from this bibliography for a particular study area in southern California.

\section{SOURCES OF PUBLICATIONS}

Many U.S. Geological Survey Water-Resources Investigations Reports and Open-File Reports may be purchased from the following outlet:

Open-File Services Section

Western Distribution Branch

U.S. Geological Survey

Box 25425, Federal Center

Denver, Colorado 80225 . 
Publications cited in this bibliography may be borrowed or purchased at one or more of the following universities, colleges, libraries, or government agencies in California:

California State University, Humboldt Library, Documents Department

ARCATA, CA 95521

Beale Branch

Kern County Library

G-M-P Librarian

1315 Truxtun Ave.

BAKERSFIELD, CA 93301

University of California

General Library

Documents Department

BERKELEY, CA 94720

Water Resources Center Archives

Room 40, North Gate Hall

University of California

BERKELEY, CA 94720

California State University Library

Government Publications

CHICO, CA 95926

Honnold Library for the Claremont Colleges

Government Publications Section

CLAREMONT, CA 91711

Culver City Library

Government Publications Section

4975 Overland

CULVER CITY, CA 92030

University of California Library

Documents Department

DAVIS, CA 95616

California State University

Library

Government Publications Department

FRESNO, CA 93710

Fresno County Free Library

Government Publications Section

2420 Mariposa St.

FRESNO, CA 93721

California State University

Library, Documents Section

P.0. Box 4150

FULLERTON, CA 92634
California State University

Map Room

Division of Libraries

HAYWARD, CA 94542

University of California Library

Government Publications Department

IRVINE, CA 92664

University of California Library

Serials Department

LA JOLLA, CA 92037

California Division of $0 i 1$ and Gas

245 West Broadway

LONG BEACH, CA 90802

California Division of Mines and Geology

Library

107 South Broadway, Rm. 1065

LOS ANGELES, CA 90012

John F. Kennedy Memorial Library

Government Publications Room

California State University

5151 State College $\mathrm{Dr}$.

LOS ANGELES, CA 90032

Los Angeles Public Library

Serials Division

630 West Fifth St.

LOS ANGELES, CA 90017

Occidental College Library

Government Publications Section

LOS ANGELES, CA 90041

University of California Library

Public Affairs Service/U.S. Documents

405 Hilgard Ave.

LOS ANGELES, CA 90024

University of Southern California

Library

Government Documents Section

P.0. Box 77983

LOS ANGELES, CA 90007

U.S. Geological Survey

Public Inquiries office

$300 \mathrm{~N}$. Los Angeles St., Rm. 7638

LOS ANGELES, CA 90012 
U.S. Government Printing Office

GPO Bookstore

505 South Flower Street

LOS ANGELES, CA 90017

Water Resources Center Archives

2081 Engineering I

University of California

LOS ANGELES, CA 90024

U.S. Geological Survey Library

345 Middlefield Road

Mail Stop 955

MENLO PARK, CA 94025

California State University

Library/Serials S.0.C.

18111 Nordhoff St.

NORTHRIDGE, CA 91324

California Institute of Technology

PASADENA, CA 91125

Tehama County Library

909 Jefferson St.

RED BLUFF, CA 96080

University of Redlands

Armacost Library

Government Publications Section

REDLANDS, CA 92373

University of California Library

Government Publications Department

P.0. Box 5900

RIVERSIDE, CA 92507

Sonoma State College Library

Documents Department

1801 East Cotati Ave.

ROHNERT PARK, CA 94928

California Department of Water Resources

P.0. Box 388

SACRAMENTO, CA 95802

California Resources Agency Library

1416 Ninth St., Room 117

SACRAMENTO, CA 95814

California State Library

Government Publications Section

P.0. BoX 2037

SACRAMENTO, CA 95809
California State University Library, Documents Section $6000 \mathrm{~J} \mathrm{St}$.

SACRAMENTO, CA 95819

Sacramento City-County Library

Reference Department

Ninth and I Sts.

SACRAMENTO, CA 95814

U.S. Geological Survey, WRD

2800 Cottage Way, Rm. W-2234

SACRAMENTO, CA 95825

San Bernardino County Library

Government Publications Section

104 West Fourth St.

SAN BERNARDINO, CA 92415

California State University

Documents Library

Malcome A. Love Library

SAN DIEGO, CA 92115

San Diego Public Library

Science and Industry Department

820 E St.

SAN DIEGO, CA 92101

U.S. Geological Survey, WRD

Suite F, COC Annex

5201 Ruffin Road

SAN DIEGO, CA 92123

California Academy of Sciences Library, Golden Gate Park

SAN FRANCISCO, CA 94118

California Division of Mines and Geology

Library and Map Room

Ferry Bldg.

SAN FRANCISCO, CA 94111

California State University

Social Science, Business, and Ethnic

Studies Libraries

Government Publications Collection

1530 Holloway Ave.

SAN FRANCISCO, CA 94132

San Francisco Public Library

Government Documents Department

Civic Center

SAN FRANCISCO, CA 94102 
U.S. Environmental Protection Agency Library

100 California St.

SAN FRANCISCO, CA 94111

U.S. Geological Survey

Public Inquiries office

504 Custom House

555 Battery St.

SAN FRANCISCO, CA 94111

U.S. Government Printing Office

GPO Bookstore

Room 1023

450 Golden Gate Ave.

SAN FRANCISCO, CA 94102

California Polytechnic State

University Library

Documents Section

SAN LUIS OBISPO, CA 93401

Santa Barbara Museum of Natural

History

Librarian

2559 Puesta Del Sol Rd.

SANTA BARBARA, CA 93102

University of California Library

Government Publications Department

SANTA BARBARA, CA 93105
University of California Library

Government Publications Department

SANTA BARBARA, CA 93105

Michael Orradre Library

Map Collection

University of Santa Clara

SANTA CLARA, CA 95053

University of California Library

Documents Section

SANTA CRUZ, CA 95060

San Joaquin Delta College Library

Government Publications Section

3301 Kensington Way

STOCKTON, CA 94204

Stockton Free Public Library

Government Publications Section

605 North E1 Dorado St.

STOCKTON, CA 95202

University of Pacific Library

Government Publications Section

STOCKTON, CA 95204

Stanislaus State University Library U.S. Documents Section

800 Monte Vista Ave.

TURLOCK, CA 95380 
Table 1.--Geohydrologic disciplines and subjects used in the bibliography for the Southern California Alluvial

Basins Regional Aquifer-Systems Analysis

\section{Subjects for Water-Resources Discipline}

Appraisal

Area codes

Balance, water

Bibliography

Data

Drought

Earthquake

Evaporation

Evapotranspiration

Exhibit

General

Geochemistry

Geohydrology

Geothermal

Imported water

Inventory

Law

Model

Pollution

Precipitation

Pumpage
Quality, biological

Quality, chemical

Quality, pesticide

Quality, salt balance

Quality, temperature

Quality, trace elements

Radioactivity

Remote sensing

Reports scheduling process

Safety

Saline water

Storage

Techniques

Techniques, instrumentation

Urbanization

Use

Waste disposal

Wastewater

Water plans

Water rights

Water supply

Subjects for Surface-Water Discipline

Availability

Bibliography

Channel capacity

Circulation

Culvert flow

Dams

Data

Dispersion

Drainage

Estuaries

Evaporation

Exportation

Floods

Flood frequency

General

Geochemistry

Geology

Geomorphology

Glaciers

Hydraulics
Pollution

Power

Precipitation

Quality, biological

Quality, chemical

Quality, sediment

Quality, temperature

Quality, trace elements

Runoff

Safety

Saline water

Sea level

Snow investigations, snowmelt

Storage

Streams

Streamflow

Techniques

Techniques, instrumentation

Tide

Time of travel 
Table 1.--Geohydrologic disciplines and subjects used

in the bibliography for the Southern California Alluvial

Basins Regional Aquifer-Systems Analysis--Continued

Subjects for Surface-Water Discipline--Continued

Index

Instrumentation

Lakes, reservoirs

Mode 1

Morphology

Pesticides
Urbanization

Use

Wastewater

Water supply

Yield

Subjects for Ground-Water Discipline

Appraisal

Availability

Barriers

Bibliography

Contamination

Data

Earthquake

Evapotranspiration

Faults

General

Geochemistry

Geohydrology

Geomorphology

Geophysics, areal

Geophysical logging

Geothermal

Glossary

Infiltration

Instrumentation

Inventory

Law

Liquifaction

Mode 1

Nuclear

Outflow

Permeability

Phreatophytes

Potentiometric surface

Precipitation

\author{
Pumping test \\ Pumpage \\ Quality, chemical \\ Radioactivity \\ Recharge \\ Research \\ Saline water \\ Seawater intrusion \\ Soil \\ Specific yield \\ Springs \\ Storage \\ Storage coefficient \\ Subsidence, land \\ Techniques \\ Techniques, instrumentation \\ Transmissivity \\ Underflow \\ Unsaturated zone \\ Urbanization \\ Use \\ Waste disposal \\ Wastewater \\ Water leve1 \\ Water supply \\ Well data \\ Well drill \\ Yield
}


Table 1.--Geohydrologic disciplines and subjects used

in the bibliography for the Southern California Alluvial

Basins Regional Aquifer-Systems Analysis--Continued

\section{Subjects for Geology Discipline}

Area mapping

Cross sections

Faults

Fossils

Gas (other than petroleum)

Glaciation

Heavy metals

Lands lides

Mining

offshore
Ore deposits

Petrology

Pleistocene lakes

Reclamation

Saline deposits

Structure

Trace elements

Vulcanism

We11 logs

Subjects for Geophysical Discipline

Electrical resistivity

Gravity

Induced potential

Magnetics
Magnetotellurics

Seismic

Sparker traverses

Spontaneous potential

Subjects for Oil-Well Data Discipline

Drill-stem test

Geology

Operations summary

Potential
Stratigraphy

Structure

Subsidence

We 11 logs 


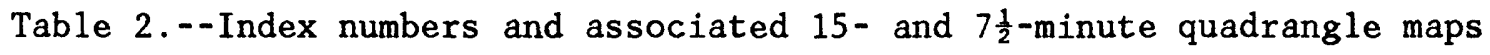
[Refer to plate 1 for index numbers and location of quadrangles]

\begin{tabular}{|c|c|c|}
\hline \multirow{2}{*}{$\begin{array}{l}\text { Index } \\
\text { No. }\end{array}$} & \multicolumn{2}{|c|}{ Quadrangle-map names } \\
\hline & 15 minute & $7 \frac{1}{2}$ minute \\
\hline 0103 & Yuma & Yuma W, Yuma E \\
\hline 0104 & & Grays Well, Grays Well NE \\
\hline 0105 & Midway We11 & $\begin{array}{l}\text { Midway We11 NW, Midway } \\
\text { Well }\end{array}$ \\
\hline 0106 & Calexico & Calexico, Bonds Corner \\
\hline 0107 & Heber & Mount Signal, Heber \\
\hline 0108 & Coyote Wells & Coyote We1ls, Yuha Basin \\
\hline 0109 & Jacumba & Jacumba, In-ko-pah Gorge \\
\hline 0110 & Campo & $\begin{array}{l}\text { Cameron Corners, Live Oaks } \\
\text { Springs, Campo, Tierra } \\
\text { de1 So1 }\end{array}$ \\
\hline 0111 & Potrero & $\begin{array}{l}\text { Barrett Lake, Morena } \\
\text { Reservoir, Tecate, } \\
\text { Potrero }\end{array}$ \\
\hline 0112 & Jamu 1 & $\begin{array}{l}\text { Jamul Mts., Dulzura, } \\
\text { Otay Mesa, Otay Mtn. }\end{array}$ \\
\hline 0113 & & $\begin{array}{l}\text { Point Loma }{ }^{1} \text {, National } \\
\text { City, Imperial Beach }\end{array}$ \\
\hline 0202 & Laguna & $\begin{array}{l}\text { Imperial Reservoir, } \\
\text { Laguna Dam }\end{array}$ \\
\hline 0203 & & $\begin{array}{l}\text { Picacho Peak, Little } \\
\text { Picacho Peak, Araz, Bard }\end{array}$ \\
\hline 0204 & Ogilby & Cactus \\
\hline 0205 & Glamis & $\begin{array}{l}\text { Glamis NW, Glamis, } \\
\text { Glamis SW, Glamis SE }\end{array}$ \\
\hline 0206 & & $\begin{array}{l}\text { Alamorio, Holtville NE, } \\
\text { Holtville E, Holtville W }\end{array}$ \\
\hline 0207 & & $\begin{array}{l}\text { Brawley NW, Brawley, } \\
\text { El Centro, Seeley }\end{array}$ \\
\hline
\end{tabular}

See footnotes at end of table. 
Table 2.--Index numbers and associated $15-$ and $7 \frac{1}{2}$-minute quadrangle maps--Continued

Index

No.

0208

0209

0210

0211

Cuyamaca Peak

0212

0213

0218

0219

0303

0304

0305

0306

0307

0308

\section{Plaster City}

Mount Laguna
Quadrangle-map names
15 minute
$7 \frac{1}{2}$ minute 
Table 2.--Index numbers and associated $15-$ and $7 \frac{1}{2}$-minute quadrangle maps--Continued

\begin{tabular}{|c|c|c|}
\hline \multirow{2}{*}{$\begin{array}{l}\text { Index } \\
\text { No. }\end{array}$} & \multicolumn{2}{|c|}{ Quadrangle-map names } \\
\hline & 15 minute & $7 \frac{1}{2}$ minute \\
\hline 0309 & & $\begin{array}{l}\text { Borrego Mtn., Shell Reef, } \\
\text { Borrego Mtn. SE, Harper } \\
\text { Canyon }\end{array}$ \\
\hline 0310 & Borrego & $\begin{array}{l}\text { Tubb Canyon, Borrego Sink, } \\
\text { Whale Peak, Earthquake } \\
\text { Valley }\end{array}$ \\
\hline 0311 & Santa Ysabel & $\begin{array}{l}\text { Warners Ranch, Ranchita, } \\
\text { Julian, Santa Ysabel }\end{array}$ \\
\hline 0312 & - & $\begin{array}{l}\text { Rodriguez Mtn., Mesa } \\
\text { Grande, Ramona, San Pasqual }\end{array}$ \\
\hline 0313 & & $\begin{array}{l}\text { San Marcos, Valley Center, } \\
\text { Escondido, Rancho Santa Fe }\end{array}$ \\
\hline 0314 & Oceanside & $\begin{array}{l}\text { Oceanside, San Luis Rey, } \\
\text { Encinitas }\end{array}$ \\
\hline 0319 & & $\begin{array}{l}\text { San Clemente Is land } \\
\mathrm{N}^{1}{ }_{2}\end{array}$ \\
\hline 0322 & & San Nicolas Island ${ }^{1} 2$ \\
\hline 0323 & & San Nicolas Is land ${ }^{1} 2$ \\
\hline 0403 & Cibola & $\begin{array}{l}\text { Palo Verde, Mule Wash, } \\
\text { Cibola }\end{array}$ \\
\hline 0404 & Palo Verde Mts. & \\
\hline 0405 & Chuckwalla Spring & \\
\hline 0406 & Iris Pass & Iris Wash \\
\hline 0407 & Frink & Frink NW, Wister, Frink \\
\hline 0408 & & $\begin{array}{l}\text { Salton, Durmid, Durmid SE, } \\
\text { Truckhaven }\end{array}$ \\
\hline 0409 & & $\begin{array}{l}\text { Rabbit Peak, Oasis, } \\
\text { Seventeen Palms, Fonts } \\
\text { Point }\end{array}$ \\
\hline
\end{tabular}

See footnotes at end of table. 
Table 2.--Index numbers and associated 15 - and $7 \frac{1}{2}$-minute quadrangle maps--Continued

Index

No.

Quadrangle-map names

$$
15 \text { minute }
$$

Collins Valley, Clark

Clark Lake

0410

0411

Warner Springs

0412

0413

0414

0415

0418

0419

0420

0421

0422

0423

0502

0503

$0504 \quad$ McCoy Spring

0505 Sidewinder Well
Lake NE, Clark Lake,

Borrego Palm Canyon

Beauty Mtn., Bucksnort

Mtn., Hot Springs Mtn.,

Warner Springs

Vail Lake, Aguanga,

Palomar Observatory,

Boucher Hill

Temecula, Pechanga, Pala, Bonsall

Margareta Peak, Fallbrook, Morro Hill, Las Pulgas

Canyon

Dana Point, San Clemente, San Onofre Bluff

Santa Catalina N, Santa

Catalina E, Santa

Catalina S

Santa Catalina W

Santa Barbara Is land ${ }^{2}$

Santa Barbara Is land ${ }^{1} 2$

San Nicolas Island ${ }^{2} 2$

San Nicolas Island ${ }^{1} 2$

La Paz Mtn.

McCoy Wash, Blythe NE,

Blythe, Ripley

See footnotes at end of table. 
Table 2.--Index numbers and associated 15 - and $7 \frac{1}{2}$-minute quadrangle maps --Continued

\begin{tabular}{|c|c|c|}
\hline \multirow{2}{*}{$\begin{array}{l}\text { Index } \\
\text { No. }\end{array}$} & \multicolumn{2}{|c|}{ Quadrangle-map names } \\
\hline & 15 minute & $7 \frac{1}{2}$ minute \\
\hline 0506 & Chuckwalla Mts. & \\
\hline 0507 & Hayfield & \\
\hline 0508 & Cottonwood Spring & Orocopia Canyon, Mortimar \\
\hline 0509 & Coachella & $\begin{array}{l}\text { Indio, Thermal Canyon, } \\
\text { Mecca, Valerie }\end{array}$ \\
\hline 0510 & Palm Desert & Rancho Mirage, La Quinta \\
\hline 0511 & Idyl1wild & \\
\hline 0512 & Hemet & Hemet, Sage \\
\hline 0513 & & $\begin{array}{l}\text { Romoland, Winchester, } \\
\text { Bachelor Mtn., Murrieta }\end{array}$ \\
\hline 0514 & & $\begin{array}{l}\text { Alberhi11, Elsinore, } \\
\text { Wildomar, Sitton Peak }\end{array}$ \\
\hline 0515 & & $\begin{array}{l}\text { E1 Toro, Santiago Peak, } \\
\text { Canada Gobernadora, San } \\
\text { Juan Capistrano }\end{array}$ \\
\hline 0516 & & $\begin{array}{l}\text { Newport Beach, Tustin, } \\
\text { Laguna Beach }\end{array}$ \\
\hline 0517 & & Seal Beach, Long Beach ${ }^{2}$ \\
\hline 0518 & & $\begin{array}{l}\text { San Pedro, Redondo } \\
\text { Beach }_{2}\end{array}$ \\
\hline 0520 & & Santa Barbara Is land ${ }^{1} 2$ \\
\hline $\begin{array}{l}0521 \\
0602\end{array}$ & & $\begin{array}{l}\text { Santa Barbara Is land }{ }^{1} 2 \\
\text { Poston }\end{array}$ \\
\hline 0603 & Big Maria Mts. & $\begin{array}{l}\text { Big Maria Mts. NW, Big } \\
\text { Maria Mts. NE, Big Maria } \\
\text { Mts. SE, Big Maria Mts. } \\
\text { SW }\end{array}$ \\
\hline 0604 & Midland & \\
\hline 0605 & Palen Mts. & \\
\hline
\end{tabular}

See footnotes at end of table. 
Table 2.--Index numbers and associated $15-$ and $7 \frac{1}{2}$-minute quadrangle maps--Cont inued

Index

Quadrangle-map names

No.

15 minute

$7 \frac{1}{2}$ minute

0606

Coxcomb Mts.

0607

Pinto Basin

0608

Hexie Mts.

0609

Lost Horse Mtn.

0610 Thous and $\mathrm{Palms}$

0611

Palm Springs

0612

Banning

0613

0614

0615

Prado Dam, Corona N, Corona S, Black Star Canyon

0616

La Habra, Yorba Linda, Orange, Anaheim

South Gate, Whittier, Los Alamitos, Long Beach ${ }^{1} 2$

0618

Venice, Inglewood, Torrance, Redondo Beach ${ }^{2}$

0622

Anacapa Island ${ }^{2}$, Santa Cruz Is land $D^{2}$

0623

Santa Cruz Is land $B^{2}$,

Santa Cruz Is land $\mathrm{C}^{2}$,

Santa Cruz Is land $D^{2}$

0624

Santa Rosa Island $\mathrm{E}^{2}$, Santa Cruz Island $\mathrm{B}^{2}$

See footnotes at end of table. 


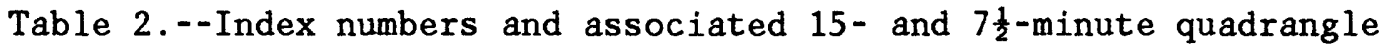
maps--Continued

\begin{tabular}{|c|c|c|}
\hline \multirow{2}{*}{$\begin{array}{l}\text { Index } \\
\text { No. }\end{array}$} & \multicolumn{2}{|c|}{ Quadrangle-map names } \\
\hline & 15 minute & $7 \frac{1}{2}$ minute \\
\hline 0625 & & $\begin{array}{l}\text { Santa Rosa Is land } \mathrm{W}^{2} \text {, } \\
\text { Santa Rosa Is land } \mathrm{N}^{2} \text {, } \\
\text { Santa Rosa Is land } \mathrm{E}^{2} \text {, } \\
\text { Santa Rosa Is land } \mathrm{S}\end{array}$ \\
\hline 0626 & & $\begin{array}{l}\text { San Miguel Is } l \text { and } W^{2} \\
\text { San Miguel Is land } E^{2} \text {, } \\
\text { Santa Rosa Island } W^{2}\end{array}$ \\
\hline 0701 & Black Peak & Cross Roads \\
\hline 0702 & & $\begin{array}{l}\text { Parker NW, Parker, Parker } \\
\text { SE, Parker SW }\end{array}$ \\
\hline 0703 & Vidal & $\begin{array}{l}\text { Vidal NW, Vidal Junction, } \\
\text { Vidal, Grommet }\end{array}$ \\
\hline 0704 & Rice & \\
\hline 0705 & Iron Mts. & \\
\hline 0706 & Cadiz Valley & \\
\hline 0707 & Dale Lake & \\
\hline 0708 & Valley Mtn. & Valley Mtn. \\
\hline 0709 & Twentynine Palms & $\begin{array}{l}\text { Sunfair, Twentynine Palms, } \\
\text { Queen Mtn., Indian Cove }\end{array}$ \\
\hline 0710 & Joshua Tree & $\begin{array}{l}\text { Yucca Valley N, Joshua } \\
\text { Tree N, Joshua Tree S }\end{array}$ \\
\hline 0711 & Morongo Valley & $\begin{array}{l}\text { Onyx Peak, Rim Rock, } \\
\text { Morongo Valley, Catclaw } \\
\text { Flat }\end{array}$ \\
\hline 0712 & San Gorgonio Mtn. & $\begin{array}{l}\text { Big Bear Lake, Moonridge, } \\
\text { San Gorgonio Mtn., Forest } \\
\text { Falls }\end{array}$ \\
\hline 0713 & Redlands & $\begin{array}{l}\text { Harrison Mtn., Keller Peak, } \\
\text { Yucaipa, Redlands }\end{array}$ \\
\hline 0714 & San Bernardino & $\begin{array}{l}\text { Devore, San Bernardino } \mathrm{N} \text {, } \\
\text { San Bernardino } \mathrm{S} \text {, Fontana }\end{array}$ \\
\hline
\end{tabular}

See footnotes at end of table. 
Table 2.--Index numbers and associated $15-$ and $7 \frac{1}{2}$-minute quadrangle maps--Continued

Index

No.

15 minute

Quadrangle-map names

$0715 \quad$ Ontario

Mount Baldy, Cucamonga

Peak, Guasti, Ontario

0716

Azusa, Glendora, San

Dimas, Baldwin Park

0717

Pasadena, Mount Wilson, E1 Monte, Los Angeles

0718

Van Nuys, Burbank, Hollywood, Beverly Hills

0719

Calabasas, Canoga Park, Topanga, Malibu Beach

0720

Newberry Park, Thous and Oaks, Point Dume, Triunfo Pass

Oxnard ${ }^{2}$, Camarillo, Point Mugu

0722

Oxnard ${ }^{2}$, Santa Cruz

Is land $\mathrm{D}^{2}$, Anacapa

Is land ${ }^{2}$

0723

Santa Cruz Is land $\mathrm{B}^{2}$, Santa Cruz Is land $\mathrm{C}^{2}$, Santa Cruz Island $\mathrm{D}^{2}$

0724

Santa Cruz Is land $A^{2}$, Santa Cruz Is land $B^{2}$

0725

Santa Rosa Island $\mathrm{W}^{2}$, Santa Rosa Is land $\mathrm{N}^{2}$, Santa Rosa Island $\mathrm{E}^{2}$

0726

San Miguel Is land $W^{2}$,

San Miguel Island $\mathrm{E}^{2}$

0801

Parker Dam

Standard Wash, Gene Wash

0802

Whipple Mts.

Havasu Lake, Lake Havasu City S, Whipple Wash, Whipple Mts. SW

See footnotes at end of table. 


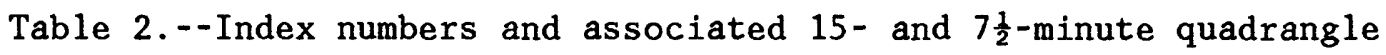
maps--Continued

Quadrangle-map names

15 minute
Index

No.

0803

0809

0810

0811

0812

0813

0814

0815
Savahia Peak

Turtle Mts.

Milligan

Cadiz Lake

Bristol Lake

Lead Mtn.

Emerson Lake

01d Woman Springs

Lucerne Valley

Lake Arrowhead

See footnotes at end of table.
Savahia Peak NW, Savahia Peak NE, Savahia Peak, Savahia Peak SW

Bristol Lake NW, Bristol Lake SW

Lead Mtn., Lead Mtn. NE, Cleghorn Lakes, Lead

Mtn. SW

Deadman Lake NW, Deadman Lake NE, Deadman Lake SE, Deadman Lake SW

Emerson Lake, Hidalgo Mtn., Goat Mtn., Landers

01d Woman Springs, Melville Lake, Bighorn Canyon, Rattlesnake Canyon

Lucerne Valley, Cougar Butte, Big Bear City, Fawnskin

Apple Valley S, Fifteen Mile Valley, Butler Peak, Lake Arrowhead

Baldy Mesa, Hesperia, Silverwood Lake, Cajon

Mescal Creek, Phelan, Telegraph Peak, Mount San Antonio 
Table 2.--Index numbers and associated $15-$ and $7 \frac{1}{2}$-minute quadrangle maps--Continued

\begin{tabular}{|c|c|c|}
\hline \multirow{2}{*}{$\begin{array}{l}\text { Index } \\
\text { No. }\end{array}$} & \multicolumn{2}{|c|}{ Quadrangle-map names } \\
\hline & 15 minute & $7 \frac{1}{2}$ minute \\
\hline 0816 & Valyermo & $\begin{array}{l}\text { Juniper Hills, Valyermo, } \\
\text { Crystal Lake, Waterman } \\
\text { Mtn. }\end{array}$ \\
\hline 0817 & Acton & $\begin{array}{l}\text { Acton, Pacifico Mtn., } \\
\text { Chilao Flat, Condor Peak }\end{array}$ \\
\hline 0818 & & $\begin{array}{l}\text { Mint Canyon, Agua Dulce, } \\
\text { Sunland, San Fernando }\end{array}$ \\
\hline 0819 & & $\begin{array}{l}\text { Val Verde, Newhall, Oat } \\
\text { Mtn., Santa Susana }\end{array}$ \\
\hline 0820 & & $\begin{array}{l}\text { Fillmore, Piru, Simi, } \\
\text { Moorpark }\end{array}$ \\
\hline 0821 & & $\begin{array}{l}\text { Ojai; Santa Paula Peak, } \\
\text { Santa Paula, Saticoy }\end{array}$ \\
\hline 0822 & & $\begin{array}{l}\text { White Ledge Peak, } \\
\text { Matilija, Ventura, Pitas } \\
\text { Point }\end{array}$ \\
\hline 0823 & & $\begin{array}{l}\text { Santa Barbara, } \\
\text { Carpinteria }\end{array}$ \\
\hline 0824 & & $\begin{array}{l}\text { Dos Pueblos Canyon, } \\
\text { Goleta }\end{array}$ \\
\hline 0825 & & Gaviota, Tajiguas \\
\hline 0826 & & Point Conception, Sacate \\
\hline 0902 & Topock & Topock, Cast le Rock \\
\hline 0903 & Sawtooth Range & $\begin{array}{l}\text { Monumental Pass, Whale } \\
\text { Mtn., Chemehuevi Peak, } \\
\text { Snaggle Tooth }\end{array}$ \\
\hline 0904 & Stepladder Mts. & \\
\hline 0905 & Essex & \\
\hline 0906 & Danby & \\
\hline 0907 & Cadiz & \\
\hline
\end{tabular}


Table 2.--Index numbers and associated 15- and 7/-minute quadrangle maps--Continued

\begin{tabular}{|c|c|c|}
\hline \multirow{2}{*}{$\begin{array}{l}\text { Index } \\
\text { No. }\end{array}$} & \multicolumn{2}{|c|}{ Quadrangle-map names } \\
\hline & 15 minute & $7 \frac{1}{2}$ minute \\
\hline 0908 & Bagdad & Amboy Crater, Bagdad SW \\
\hline 0909 & Ludlow & $\begin{array}{l}\text { Ludlow, Ash Hill, Ludlow } \\
\text { SE, Morgans Well }\end{array}$ \\
\hline 0910 & Lavic & $\begin{array}{l}\text { Sunshine Peak, Lavic Lake, } \\
\text { Lavic SE, Galway Lake }\end{array}$ \\
\hline 0911 & Rodman Mts. & Silver Bell Mine \\
\hline 0912 & Ord Mts. & \\
\hline 0913 & Apple Valley & $\begin{array}{l}\text { Turtle Valley, Stoddard } \\
\text { We11, Fairview Valley, } \\
\text { Apple Valley N }\end{array}$ \\
\hline 0914 & Victorville & $\begin{array}{l}\text { Victorville NW, Helendale, } \\
\text { Victorville, Adelanto }\end{array}$ \\
\hline 0915 & & $\begin{array}{l}\text { Adobe Mtn., Shadow Mts., } \\
\text { Shadow Mts. SE, E1 Mirage }\end{array}$ \\
\hline 0916 & & $\begin{array}{l}\text { Alpine Butte, Hi Vista, } \\
\text { Lovejoy Buttes, Littlerock }\end{array}$ \\
\hline 0917 & Lancaster & $\begin{array}{l}\text { Lancaster W, Lancaster E, } \\
\text { Palmdale, Ritter Ridge }\end{array}$ \\
\hline 0918 & Bouquet Reservoir & $\begin{array}{l}\text { Lake Hughes, Del Sur, } \\
\text { Sleepy Valley, Green } \\
\text { Valley }\end{array}$ \\
\hline 0919 & & $\begin{array}{l}\text { Liebre Mtn., Burnt Peak, } \\
\text { Warm Springs Mtn., } \\
\text { Whitaker Peak }\end{array}$ \\
\hline 0920 & & $\begin{array}{l}\text { McDonald Peak, Black Mtn., } \\
\text { Cobblestone Mtn., Devils } \\
\text { Heart Peak }\end{array}$ \\
\hline 0921 & & $\begin{array}{l}\text { San Guillermo, Lockwood } \\
\text { Valley, Topatopa Mts., } \\
\text { Lion Canyon }\end{array}$ \\
\hline
\end{tabular}

See footnotes at end of table. 
Table 2.--Index numbers and associated $15-$ and $7 \frac{1}{2}-$ minute quadrangle maps--Continued

Index

No.
15 minute
Quadrangle-map names

$7 \frac{1}{2}$ minute
0922

0923

0924

0925

0926

0927

1003

1004

1005

1006

1007

1008

1009

1010

1011

1012

1013
Gibralter Dam

San Rafael Mtn.

Lompoc

Point Arguello

Needles

Bannock

Fenner

Colton Well

F1ynn

Kerens

Broadwe11 Lake

Cady Mts .

Newberry

Daggett

Barstow
Rancho Nuevo Creek, Reyes

Peak, Wheeler Springs, old Man Mtn.

Big Pine Mtn., Madulce Peak, Hildreth Peak, Little Pine Mtn.

Figueroa Mtn., San Rafael Mtn., San Marcos Pass, Lake Cachuma

Zaca Creek, Los O1ivos, Santa Ynez, Solvang

Lompoc, Los Alamos, Santa Rosa Hills, Lompoc Hills

Surf, Tranquillon Mtn., Point Arguello

Needles NW, Needles, Needles SW
Nebo, Yermo, Minneola, Daggett

Hinkley, Barstow, Barstow SE, Hodge

See footnotes at end of table. 
Table 2.--Index numbers and associated 15 - and $7 \frac{1}{2}$-minute quadrangle maps--Continued

\begin{tabular}{|c|c|c|}
\hline \multirow{2}{*}{$\begin{array}{l}\text { Index } \\
\text { No. }\end{array}$} & \multicolumn{2}{|c|}{ Quadrangle-map names } \\
\hline & 15 minute & $7 \frac{1}{2}$ minute \\
\hline 1014 & Hawes & $\begin{array}{l}\text { Kramer Hills, Twelve Gauge } \\
\text { Lake, Wild Crossing, } \\
\text { Astley Rancho }\end{array}$ \\
\hline 1015 & Kramer & $\begin{array}{l}\text { Leuhman Ridge, Kramer } \\
\text { Junction, Red Buttes, } \\
\text { Jackrabbit Hill }\end{array}$ \\
\hline 1016 & Rogers Lake & $\begin{array}{l}\text { Edwards, Rogers Lake N, } \\
\text { Rogers Lake S, Redman }\end{array}$ \\
\hline 1017 & Ros amond & $\begin{array}{l}\text { Soledad Mtn., Bisse11, } \\
\text { Rosamond Lake, Rosamond }\end{array}$ \\
\hline 1018 & & $\begin{array}{l}\text { Tylerhorse Canyon, Willow } \\
\text { Springs, Little Buttes, } \\
\text { Fairmont Butte }\end{array}$ \\
\hline 1019 & & $\begin{array}{l}\text { Winters Ridge, Liebre } \\
\text { Twins, Neenach School, } \\
\text { La Liebre Ranch }\end{array}$ \\
\hline 1020 & & $\begin{array}{l}\text { Grapevine, Pastoria Creek, } \\
\text { Lebec, Frazier Mtn. }\end{array}$ \\
\hline 1021 & & $\begin{array}{l}\text { Eagle Rest Peak, Pleito } \\
\text { Hills, Cuddy Valley, } \\
\text { Sawmill Mtn. }\end{array}$ \\
\hline 1022 & & $\begin{array}{l}\text { Ballinger Canyon, } \\
\text { Santiago Creek, Apache } \\
\text { Canyon, Cuyama Peak }\end{array}$ \\
\hline 1023 & Salisbury Canyon & $\begin{array}{l}\text { New Cuyama, Cuyama, Fox } \\
\text { Mtn., Salisbury Potrero }\end{array}$ \\
\hline 1024 & & $\begin{array}{l}\text { Bates Canyon, Peak Mtn., } \\
\text { Hurricane Deck, Bald Mtn. }\end{array}$ \\
\hline 1025 & & $\begin{array}{l}\text { Tepusquet Canyon, } \\
\text { Manzanita Mtn., Zaca Lake, } \\
\text { Foxen Canyon }\end{array}$ \\
\hline 1026 & Santa Maria & $\begin{array}{l}\text { Santa Maria, Twitchell } \\
\text { Dam, Sisquoc, Orcutt }\end{array}$ \\
\hline
\end{tabular}

See footnotes at end of table. 


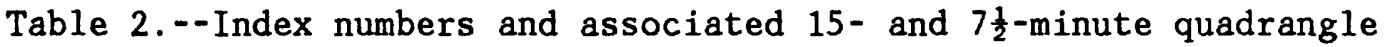
maps--Continued

\begin{tabular}{|c|c|c|}
\hline \multirow{2}{*}{$\begin{array}{l}\text { Index } \\
\text { No. }\end{array}$} & \multicolumn{2}{|c|}{ Quadrangle-map names } \\
\hline & 15 minute & $7 \frac{1}{2}$ minute \\
\hline 1027 & Point Sal & $\begin{array}{l}\text { Point Sal, Guadalupe, } \\
\text { Casmalia }\end{array}$ \\
\hline 1103 & Davis Dam & Mount Manchester \\
\hline 1104 & Homer Mtn. & \\
\hline 1105 & Lanfair Valley & \\
\hline 1106 & Mid Hills & \\
\hline 1107 & Kelso & \\
\hline 1108 & old Dad Mtn. & \\
\hline 1109 & Soda Lake & \\
\hline 1110 & Cave Mtn. & \\
\hline 1111 & Alvord Mtn. & \\
\hline 1112 & Lane Mtn. & \\
\hline 1113 & Opal Mtn. & \\
\hline 1114 & Fremont Peak & \\
\hline 1115 & Boron & $\begin{array}{l}\text { Boron NW, Boron NE, } \\
\text { Saddleback Mtn., Boron }\end{array}$ \\
\hline 1116 & Castle Butte & $\begin{array}{l}\text { California City } \mathrm{N}, \\
\text { Galileo Hill, North } \\
\text { Edwards, California } \\
\text { City S }\end{array}$ \\
\hline 1117 & Mojave & $\begin{array}{l}\text { Cache Peak, Mojave NE, } \\
\text { Sanborn, Mojave }\end{array}$ \\
\hline 1118 & & $\begin{array}{l}\text { Tehachapi N, Tehachapi NE, } \\
\text { Monolith, Tehachapi S }\end{array}$ \\
\hline 1122 & & $\begin{array}{l}\text { Taft, Mouth of Kern, } \\
\text { Pentland, Maricopa }\end{array}$ \\
\hline 1123 & & $\begin{array}{l}\text { Panorama Hills, Fellows, } \\
\text { Elkhorn Hills, Wells Ranch }\end{array}$ \\
\hline
\end{tabular}

See footnotes at end of table. 


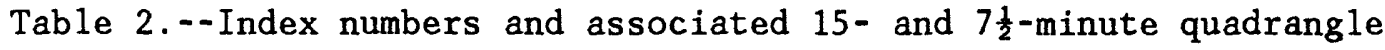
maps--Continued

\begin{tabular}{|c|c|c|}
\hline \multirow{2}{*}{$\begin{array}{l}\text { Index } \\
\text { No. }\end{array}$} & \multicolumn{2}{|c|}{ Quadrangle-map names } \\
\hline & 15 minute & $7 \frac{1}{2}$ minute \\
\hline 1124 & Caliente Mtn. & $\begin{array}{l}\text { Chimineas Ranch, Painted } \\
\text { Rock, Caliente Mtn., Taylor } \\
\text { Canyon }\end{array}$ \\
\hline 1125 & & $\begin{array}{l}\text { Los Machos Hills, Branch } \\
\text { Mtn., Miranda Pine Mtn., } \\
\text { Chimney Canyon }\end{array}$ \\
\hline 1126 & Nipomo & $\begin{array}{l}\text { Tar Spring Ridge, Caldwel1 } \\
\text { Mesa, Huasna Peak, Nipomo }\end{array}$ \\
\hline 1127 & & $\begin{array}{l}\text { Pismo Beach, Arroyo Grande, } \\
\text { Oceano }\end{array}$ \\
\hline 1128 & Port San Luis & Port San Luis \\
\hline 1203 & Spirit Mtn. & $\begin{array}{l}\text { Spirit Mtn. NW, Spirit Mtn. } \\
\text { NE, Spirit Mtn. SE, Spirit } \\
\text { Mtn. }\end{array}$ \\
\hline 1204 & Searchlight & \\
\hline 1205 & Crescent Peak & \\
\hline 1206 & Ivanpah & \\
\hline 1207 & Mescal Range & \\
\hline 1208 & Halloran Spring & \\
\hline 1209 & Baker & \\
\hline 1210 & Red Pass Lake & \\
\hline 1211 & Tiefort Mts. & \\
\hline 1212 & Goldstone Lake & \\
\hline 1213 & Pilot Knob & \\
\hline 1214 & Cuddeback Lake & \\
\hline 1215 & & $\begin{array}{l}\text { El Paso Peaks, Klinker } \\
\text { Mtn., Red Mtn., } \\
\text { Johannesburg }\end{array}$ \\
\hline
\end{tabular}

See footnotes at end of table. 
Table 2.--Index numbers and associated 15 - and $7 \frac{1}{2}$-minute quadrangle maps--Continued

Index

No.

15 minute

Quadrangle-map names

1216

1217

1218

1223

1224

1225

1226

1227

1228

1304

1305

1306

1307

1308

1309

1310

1311
Cross Mtn.

Emerald Mtn.

Simmler

La Panza

Pozo

Cayucos

Nelson

McCullough Mtn.

Roach Lake

Clark Mtn.

Kingston Peak

Silurian Hills

Avawatz Pass

Leach Lake
Saltdale NW, Garlock, Saltdale SE, Cantil

Pinyon Mtn., Dove Spring, Cinco, Cross Mtn.

Piute Peak, Claraville, Emerald Mtn., Loraine

Belridge, Lokern, West Elk Hills, Reward

Las Yeguas Ranch, Carneros Rocks, McKittrick Summit, Simmler

La Panza Ranch, La Panza NE, California Valley, La Panza

Wilson Corner, Camatta Ranch, Pozo Summit, Santa Margarita Lake

Atascadero, Santa Margarita, Lopez Mtn., San Luis Obispo

Cayucos, Morro Bay N, Morro Bay S

See footnotes at end of table. 


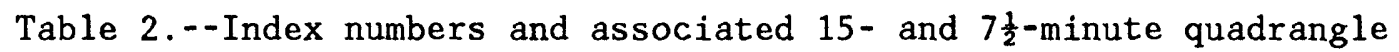
maps--Continued

\begin{tabular}{|c|c|c|}
\hline \multirow{2}{*}{$\begin{array}{l}\text { Index } \\
\text { No. }\end{array}$} & \multicolumn{2}{|c|}{ Quadrangle-map names } \\
\hline & 15 minute & $7 \frac{1}{2}$ minute \\
\hline 1312 & Quail Mts. & \\
\hline 1313 & Wingate Pass & \\
\hline 1314 & Searles Lake & $\begin{array}{l}\text { Westend, Searles Lake, } \\
\text { Christmas Canyon, } \\
\text { Spangler Hills E }\end{array}$ \\
\hline 1315 & Ridgecrest & $\begin{array}{l}\text { Ridgecrest } N \text {, Lone Butte, } \\
\text { Spangler Hills W, } \\
\text { Ridgecrest S }\end{array}$ \\
\hline 1316 & Inyokern & $\begin{array}{l}\text { Owens Peak, Inyokern, } \\
\text { Inyokern SE, Freeman } \\
\text { Junction }\end{array}$ \\
\hline 1317 & Onyx & $\begin{array}{l}\text { Onyx; Walker Pass, Horse } \\
\text { Canyon, Cane Canyon }\end{array}$ \\
\hline 1325 & Orchard Peak & $\begin{array}{l}\text { Orchard Peak, Sawtooth } \\
\text { Ridge, Packwood Creek, } \\
\text { Holland Canyon }\end{array}$ \\
\hline 1326 & Shandon & $\begin{array}{l}\text { Shandon, Cholame, Camatta } \\
\text { Canyon, Shedd Canyon }\end{array}$ \\
\hline 1327 & Paso Robles & $\begin{array}{l}\text { Paso Robles, Estrella, } \\
\text { Creston, Templeton }\end{array}$ \\
\hline 1328 & Adelaida & $\begin{array}{l}\text { Lime Mtn., Adelaida, York } \\
\text { Mtn., Cypress Mtn. }\end{array}$ \\
\hline 1329 & San Simeon & $\begin{array}{l}\text { San Simeon, Pebblestone } \\
\text { Shut-in, Cambria, Pico } \\
\text { Creek }\end{array}$ \\
\hline 1330 & Piedras Blancas & Piedras Blancas \\
\hline 1405 & Sloan & \\
\hline 1406 & Goodsprings & \\
\hline 1407 & Shenandoah Peak & \\
\hline 1408 & Horse Thief Springs & \\
\hline
\end{tabular}

See footnotes at end of table. 
Table 2.--Index numbers and associated 15- and 7/2-minute quadrangle maps--Continued

\begin{tabular}{|c|c|c|}
\hline \multirow{2}{*}{$\begin{array}{l}\text { Index } \\
\text { No. }\end{array}$} & \multicolumn{2}{|c|}{ Quadrangle-map names } \\
\hline & 15 minute & $7 \frac{1}{2}$ minute \\
\hline 1409 & Tecopa & \\
\hline 1410 & Shoshone & \\
\hline 1411 & Confidence Hills & \\
\hline 1412 & Wingate Wash & \\
\hline 1413 & Man1y Peak & \\
\hline 1414 & Trona & \\
\hline 1415 & Mountain Springs Canyon & \\
\hline 1416 & Little Lake & \\
\hline 1417 & Lamont Peak & \\
\hline 1425 & & $\begin{array}{l}\text { Garza Peak, Kettleman Plain, } \\
\text { Pyramid Hills, Tent Hills }\end{array}$ \\
\hline 1426 & Parkfield & $\begin{array}{l}\text { Parkfield, The Dark Hole, } \\
\text { Cholame Valley, Cholame } \\
\text { Hills }\end{array}$ \\
\hline 1427 & San Migue1 & $\begin{array}{l}\text { Valleton, Stockdale Mtn., } \\
\text { Ranchito Canyon, San } \\
\text { Miguel }\end{array}$ \\
\hline 1428 & Bradley & $\begin{array}{l}\text { Hames Valley, Wunpost, } \\
\text { Bradley, Tierra Redonda }\end{array}$ \\
\hline 1429 & Bryson & $\begin{array}{l}\text { Jolon, Williams Hill, } \\
\text { Bryson, Burnett Peak }\end{array}$ \\
\hline 1430 & Cape San Martin & $\begin{array}{l}\text { Cape San Martin, Alder } \\
\text { Peak, Burro Mtn., Villa } \\
\text { Creek }\end{array}$ \\
\hline 1506 & Blue Diamond & $\begin{array}{l}\text { La Madre Mtn., Blue } \\
\text { Diamond NE, Blue Diamond } \\
\text { SE, Blue Diamond }\end{array}$ \\
\hline 1507 & Mountain Springs & \\
\hline 1508 & Pahrump & \\
\hline
\end{tabular}


Table 2.--Index numbers and associated $15-$ and $7 \frac{1}{2}$-minute quadrangle maps--Continued

\begin{tabular}{|c|c|c|}
\hline \multirow{2}{*}{$\begin{array}{c}\text { Index } \\
\text { No. }\end{array}$} & \multicolumn{2}{|c|}{ Quadrangle-map names } \\
\hline & 15 minute & $7 \frac{1}{2}$ minute \\
\hline 1509 & Stewart Valley & \\
\hline 1510 & Eagle Mtn. & \\
\hline 1511 & Funeral Peak & \\
\hline 1512 & Bennetts Well & \\
\hline 1513 & Telescope Peak & \\
\hline 1514 & Maturango Peak & \\
\hline 1515 & Coso Peak & \\
\hline 1516 & Haiwee Reservoir & \\
\hline 1517 & Monache Mtn. & \\
\hline 1527 & Priest Valley & $\begin{array}{l}\text { Priest Valley, Sherman } \\
\text { Peak, Smith Mtn., Slack } \\
\text { Canyon }\end{array}$ \\
\hline 1528 & San Ardo & $\begin{array}{l}\text { Nattrass Valley, Monarch } \\
\text { Peak, Pancho Rico Valley, } \\
\text { San Ardo }\end{array}$ \\
\hline 1529 & King City & $\begin{array}{l}\text { Thompson Canyon, San Lucas, } \\
\text { Espinos a Canyon, Cosio } \\
\text { Knob }\end{array}$ \\
\hline 1530 & Junipero Serra & $\begin{array}{l}\text { Junipero Serra Peak, Reliz } \\
\text { Canyon, Bear Canyon, Cone } \\
\text { Peak }\end{array}$ \\
\hline 1531 & & $\begin{array}{l}\text { Partington Ridge, } \\
\text { Tassajara Hot Springs, } \\
\text { Lopez Point }\end{array}$ \\
\hline 1532 & & Pfeiffer Point \\
\hline 1607 & Charleston Peak & \\
\hline 1608 & Mount Stirling & \\
\hline
\end{tabular}

See footnotes at end of table. 
Table 2.--Index numbers and associated $15-$ and $7 \frac{1}{2}$-minute quadrangle maps--Continued

Index

No.

Quadrangle-map names

15 minute

Amargosa Flat, Mount Schader, Mount Schader SE, High Peak
1610

1611

1612

1613

1614

1615

1616

1617

1627

1628

1629

1630

1631

1632

1708

1709
Ash Meadows

Ryan

Furnace Creek

Emigrant Canyon

Panamint Butte

Darwin

Keeler

Olancha

New Idria

Hernandez Valley

Greenfield

Point Sur

Mercury

Specter Range
Idria, Ciervo Mtn., Santa Rita Peak, San Benito Mtn.

Rock Spring Peak, Hernandez Reservoir, Hepsedam Peak, Lonoak

North Chalome Peak, Topo Valley, Pinalito Canyon, Greenfield

Palo Escrito, Soledad, Paraiso Springs, Sycamore Flat

Carmel Valley, Rana Creek, Chews Ridge, Ventana Cones

Soberanes Point, Mount Carmel, Big Sur, Point Sur

Mercury

Specter Range NW, Camp Desert Rock

See footnotes at end of table. 
Table 2.--Index numbers and associated 15 - and $7 \frac{1}{2}$-minute quadrangle maps --Continued

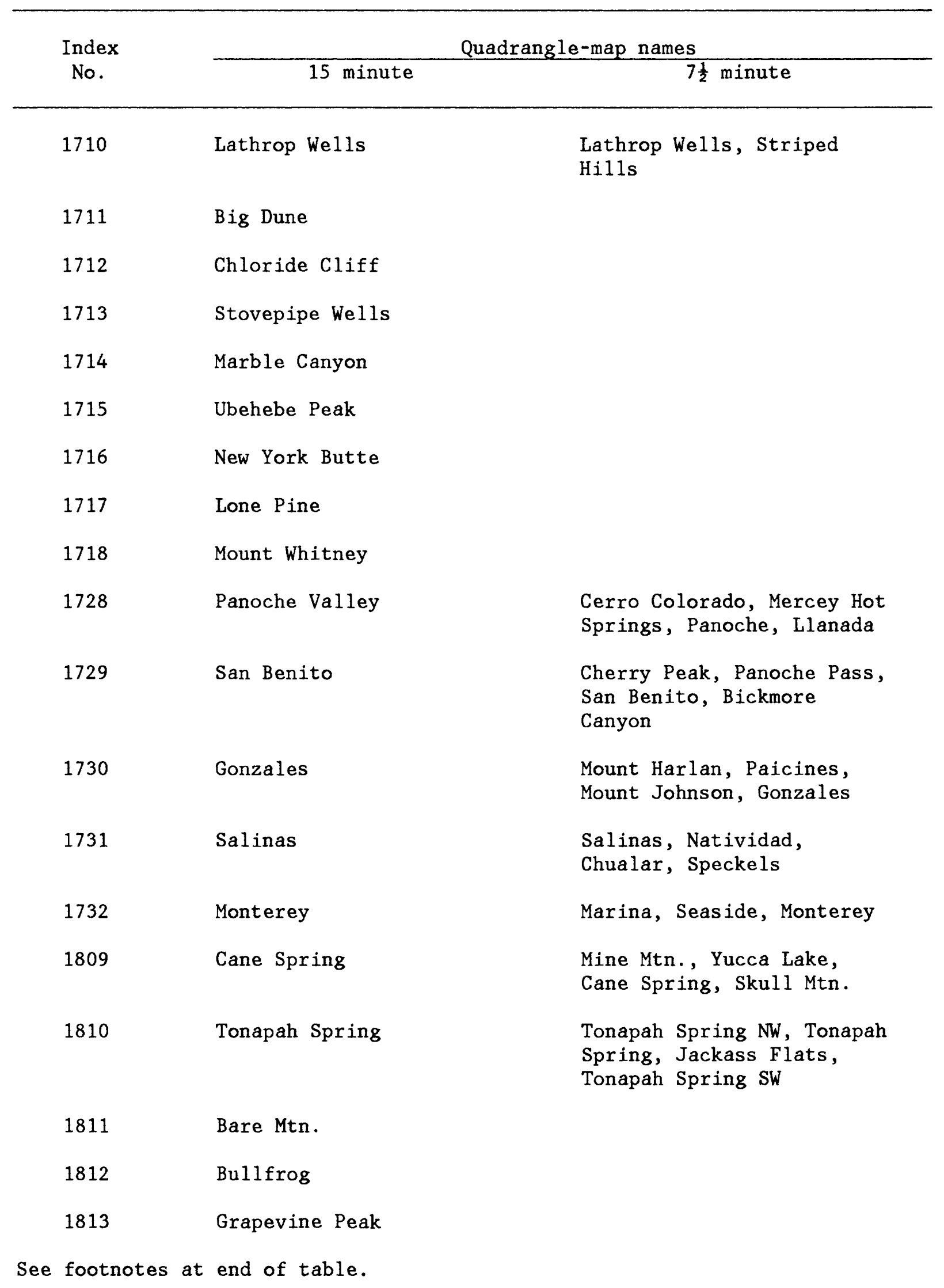


Table 2.--Index numbers and associated 15 - and $7 \frac{1}{2}$-minute quadrangle maps--Continued

Index

No.

15 minute

Quadrangle-map names

1814

Tin Mtn.

1815 Dry Mtn.

1816 Waucoba Wash

1817 Independence

1818 Mount Pinchot

$1828 \quad$ Ortigalita Peak

Ortigalita Peak NW, Charleston School, Laguna

Seca Ranch, Ortigalita

Peak

1829

Quien Sabe

Mariposa Peak, Los Banos Valley, Ruby Canyon, Quien Sabe Valley

1830

Hollister

San Felipe, Three Sisters, Tres Pinos, Hollister

1831

Watsonville E, Chittenden, San Juan

Bautista, Prunedale

1832

Soquel, Watsonville W, Moss Landing

1833

Santa Cruz ${ }^{1}$

1909

Tippipah Spring

Rainier Mesa, Oak Spring, Yucca Flat, Tippipah

Spring

1910

Timber Mtn.

Scrugham Peak, Ammonia

Tanks, Buckboard Mesa,

Timber Mtn.

1911

Thirsty Canyon

Thirsty Canyon, Thirsty

Canyon SE

1912

Springdale

See footnotes at end of table. 
Table 2.--Index numbers and associated 15 - and $7 \frac{1}{2}$-minute quadrangle maps--Continued

\begin{tabular}{|c|c|c|}
\hline \multirow{2}{*}{$\begin{array}{l}\text { Index } \\
\text { No. }\end{array}$} & \multicolumn{2}{|c|}{ Quadrangle-map names } \\
\hline & 15 minute & $7 \frac{1}{2}$ minute \\
\hline 1913 & & $\begin{array}{l}\text { Bonnie Claire NW, Bonnie } \\
\text { Claire, Bonnie Claire SE, } \\
\text { Bonnie Claire SW }\end{array}$ \\
\hline 1914 & Ubehebe Crater & \\
\hline 1915 & Last Chance Range & \\
\hline 1916 & Waucoba Spring & \\
\hline 1917 & Waucoba Mtn. & \\
\hline 1918 & Big Pine & \\
\hline 1919 & Mount Goddard & \\
\hline 1929 & & $\begin{array}{l}\text { Crevison Peak, Howard } \\
\text { Ranch, San Luis Dam, } \\
\text { Pacheco Pass }\end{array}$ \\
\hline 1930 & & $\begin{array}{l}\text { Mississippi Creek, Mustang } \\
\text { Peak, Pacheco Peak, Gilroy } \\
\text { Hot Springs }\end{array}$ \\
\hline 1931 & & $\begin{array}{l}\text { Morgan Hill, Mount Sizer, } \\
\text { Gilroy, Mount Madonna }\end{array}$ \\
\hline 1932 & & $\begin{array}{l}\text { Los Gatos, Santa Teresa } \\
\text { Hi1ls, Loma Prieta, Laurel }\end{array}$ \\
\hline 1933 & & $\begin{array}{l}\text { Big Basin, Castle Rock, } \\
\text { Felton, Davenport }\end{array}$ \\
\hline 1934 & & $\begin{array}{l}\text { Pigeon Point, Franklin } \\
\text { Point, Ano Nuevo }\end{array}$ \\
\hline 2010 & Silent Canyon & $\begin{array}{l}\text { Dead Horse Flat, Silent } \\
\text { Butte }\end{array}$ \\
\hline 2011 & Black Mtn. & Trail Ridge \\
\hline 2014 & & $\begin{array}{l}\text { Lida, Mount Jackson, Gold } \\
\text { Point, Gold Point SW }\end{array}$ \\
\hline 2015 & Magruder Mtn. & \\
\hline
\end{tabular}

See footnotes at end of table. 


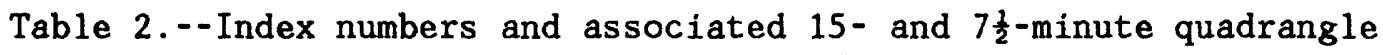
maps--Continued

\begin{tabular}{|c|c|c|}
\hline \multirow{2}{*}{$\begin{array}{l}\text { Index } \\
\text { No. }\end{array}$} & \multicolumn{2}{|c|}{ Quadrangle-map names } \\
\hline & 15 minute & $7 \frac{1}{2}$ minute \\
\hline 2016 & Soldier Pass & \\
\hline 2017 & Blanco Mtn. & \\
\hline 2018 & Bishop & \\
\hline 2019 & Mount Tom & \\
\hline 2020 & Mount Abbot & \\
\hline 2033 & Palo Alto & $\begin{array}{l}\text { Palo Alto, Mountain View, } \\
\text { Cupertino, Mindego Hill }\end{array}$ \\
\hline 2115 & Lida Wash & \\
\hline 2116 & Piper Peak & \\
\hline 2117 & Mount Barcroft & \\
\hline 2118 & White Mtn. Peak & \\
\hline 2119 & Casa Diablo Mtn. & \\
\hline 2120 & Mount Morrison & \\
\hline 2121 & Devils Postpile & \\
\hline 2122 & Merced Peak & \\
\hline 2216 & Rhyolite Ridge & \\
\hline 2217 & Davis Mtn. & \\
\hline 2218 & Benton & \\
\hline 2219 & Glass Mtn. & \\
\hline 2220 & Cowtrack Mtn. & \\
\hline 2221 & Mono Craters & \\
\hline 2222 & Tuolumne Meadows & \\
\hline 2318 & & $\begin{array}{l}\text { Little Huntoon Valley, } \\
\text { Teels Marsh, Basalt, } \\
\text { Jacks Spring }\end{array}$ \\
\hline
\end{tabular}

See footnotes at end of table. 
Table 2.--Index numbers and associated 15 - and $7 \frac{1}{2}$-minute quadrangle maps--Continued

\begin{tabular}{ll}
$\begin{array}{c}\text { Index } \\
\text { No. }\end{array}$ & \multicolumn{1}{c}{ Quadrangle-map names } \\
\cline { 2 - 2 } 2319 & Huntoon Valley \\
2320 & Trench Canyon \\
2321 & Bodie \\
2322 & Matterhorn Peak \\
2419 & Powell Mtn. \\
2420 & Aurora
\end{tabular}

${ }^{1}$ Irregularly shaped quadrangle map.

${ }^{2}$ Contained in more than one 15 -minute quadrangle. 
THE BIBLIOGRAPHY 


\section{3}

Mattick, R.E., olmsted, F.H., and Zohdy, A.A.R., 1973, Geophysical studies in the Yuma area, Arizona and 726-D, p. DI-D36.

olmsted, F.H., Loeltz, O.J., and Irelan, Burdge, 1973, Geohydrology of the Yuma area, Arizona and Calıfornia:
U.S. Geological Survey Professional Paper 486-H, $227 \mathrm{p}$.

\section{8}

Skrivan, J.A., 1977, Digital-model evaluation of the ground-water resources in the Ocotillo-Coyote Wells basin, Imperial County, California: U.S. Geological Survey Imperial County, California: U.S. Geological Survey
water-Resources Investigations Report 77-30, $56 \mathrm{p}$.

\section{9}

Brooks, Baylor, and Roberts, El11s, 1954, Geology of the Jacumba area, San Diego and Imperial Counties, in Geology
of southern California: California Division of Mines and Geology Bulletin 170, map sheet 23 , scale $1: 62,500$.

Geology Bulletin 170, map sheet 23, scale 1:62,
Minch, J.A., and Abbott, P.L., 1973, Post-batholithic geology of the Jacumba area, southeastern San Diego County, California: San Diego Society on Natural History, County, California: San Diego Society on
Transact lons, v. 17, no. 11, p. 129-135.

weber, F.H., Jr., 1962, A beryl discovery in southeastern San Diego County, California: California Division of Mines and Geology Mineral Information Service, v. 15, no. 2, p. and Geol.

\section{0}

Moyle, W.R., Jr., and Downing, D.J., 1978, Summary of water resources for the Campo, Cuyapaipe, La Posta, and Manzanita Indian Reservations and vicinity, San Diego County, California: U.S. Geological Survey Open-File Report 77-684, $41 \mathrm{p}$.

der, C.T... 1964, well site examinations in the Riverside Grazing District, California, McCaın Valley Resources Conservation Area near Jacumba, San
County: U.S. Bureau of Land Management, $3 \mathrm{p}$.

\section{1}

Dow, R.C., 1963, Reconnaissance geology of the Potrero quadrangle, Californza: San Diego, California State

University Geology Department, senior research paper. , R.S.. 1951, The geology of the Houser Canyon pegmatite with an X-Ray analysis of monazite: Pasadena

\section{2}

Bemis, C.G., I963, A geologic reconnalssance of the Jamul quadrangle: San Diego, Cal iforna State University, senior research paper

Bemıs, C.G., 1964, A gravity and magnetic traverse across the San Ysidro Mountaln: San Diego, California State University, senior research paper.

Mitchell, D., I972, VLF survey over suspected fracture. Jamul vicinity, San Diego county, California: San Diego, Jamul vicinity, San Diego county, California: San D
California State University, senior research paper.

\section{3}

Anderson, R.E., 1961, Geology and micropaleontology of Point Loma, San Drego County, California: Los Angeles, University of Southern California, M.A. thesis.

Artim, E.R., and Pinckney, C.J., 1973, La Nacion fault system, San Diego, California: Geological Society of

Jalletin, v. 84, p. 1075-1080 San Diego County, California: San Diego, California state University, senior research paper.

Bliss, K.A., 1964 , The stratigraphy and geology of the Fletcher Hills area, San Diego County: San Diego, Fletcher Hills area, San Diego County: San Diego,

Boyle Engineering, 1963, C1ty of San Diego water reclamation study for Balboa Park and Mission Bay Park (Calif.): Report

Bushnell. M.M. 1980 , Geology for planning: Imperial southern 7 1/2 minute quadrangle: California Division of Mines and Geology open-File Report 80-16 LA.

California Resources Agency, 1967, Water quality control policy for the Tijuana River basin in California: San Diego Regional water Quality Control Board, 40 p.

Diaeldin. A.M., 1967, Geology of the southwestern portion of otay Mesa, southwestern San Diego County, California: San Diego, California State University, senior research paper.

\section{$0113--$ Continued}

Elliott, w.J., 1964, Gravity survey of the southeast

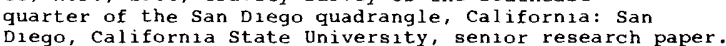

Elliott, W.J., 1966, Gravity survey and analysis of San Diego Embayment, southwest San Diego County, California (abs.): American Association of Petroleum Geologists Bulletin, v. 50, p. 646-647.

Goldstein, Gilbert, 1956, The geology of the Sweitzer Formation at San Diego, California: Los Angeles,

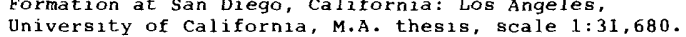

Hertlein, L.G., 1929, The geology and paleontology of the pliocene of San Diego, California: Palo Alto, Calif., Stianford University. Ph.D. dissertation.

Hertlein, L.G., and Grant, v.s., 4th, 1939, Geology and oll possibilities of southwestern San Diego County:
California Journal of Mines and Geology, v. 35, p. 57-78.

Hertlein, L.G., and Grant, U.S., 4th, 1943, Southwestern San Diego County: California Division of Mines Bulletin San Diego County: California Division of M
118 , p. 367-369, fig. 151, scale $1: 40,000$.

Hertlein, L.G. and Grant, U.S., 4th, 1944, Geology, pt. 1 , in The geology and paleontology of the marine pilocene of San Diego, California: San Diego Society of Natural History Memours, v. 2, 72 p., fig. 6, scale 1:50,000

H1llhouse, R.G., Geology of the NE quarter of the National State University, senior research paper.

Kennedy, M.P., 1967, Preliminary report, engineering geology of the City of San Diego. California: California Division of the City of San Diego, California: California Divisic scale $1: 24,000$

Kennedy, M.P., Tan, S.S., Chapman, R.H., and Chase, G.W., 1975 character and recency of faulting, San Drego metropolitan Special Report 123,33 .

Ku, T.L., and Kern, J.P., 1974, Uranium-series age of the upper pleistocene Nestor terrace, San Diego, California:

Piper, A.M., and Poland, J.F., 1945, Ground water for emergency public supply at San Diego, California: U.S. Geological Survey open-file report, $29 \mathrm{p}$.

Ross, Arnold, and Dawlen, R.J., eds., 1975, Studies on the geology and geologic hazards of the greater San Diego area, California: San Diego Association of Geologists and Engineering Geologists, 152 p.

Williams, T., 1972, Geology of the western San Ysidro mountains and eastern otay Mesa, San Diego County. California: San Diego, California State University, senior report in geology.

\section{4}

Butcher, w.S., 1951, Part 1, Lithology of the offshore San Diego area; Part 2, Foraminifera, Coronado Bank, Cal ifornia. Los Angeles, University of California and Scripps Institute of oceanography, Ph.D. dissertation.

\section{3}

Morton, P.K., 1962, Reconnaissance geologic map of parts of the Picacho Peak, Laguna, Ogilby, Grays Well NE, and Yuma quadrangles, California: Callfornia Division of Mines and Geology reconnaissance mapping for the state geologic map.

\section{4}

Black, H.T., 1975, A subsurface study of the Mesa Geothermal Anomaly, Imperial Valley, California: U.S. Department of Commerce, National Technical Information Service PB

Henshaw, P.C., 1942, Geology and mineral deposits of the

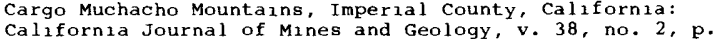
147-196, pl. 2, scale $1: 48,000$.

Henshaw, P.C., 1942, Geology and mineral deposits of the Cargo Muchacho Mountains, Imperial County, California: Pasadena, Muchacho Mountains, Imperial County, California: Pag dissertation.

U.S. Bureau of Reclamation, 1973, Geothermal resource investiga-

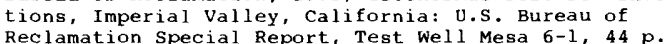

U.S. Bureau of Reclamation, 1977, Geothermal resources investigations, East Mesa Test Site, Imperial Valley, California: u.s. Bureau of Reclamation, $99 \mathrm{p}$.

\section{5}

Fournier, R.B., 1973, An X-ray and optical study of cuttings from the U.S. Bureau of Reclamation Mesa 6-1 cuttings from the U.S. Bureau of Reclamation Mesa 6-1 Survey open-file report, $35 \mathrm{p}$.

Fournier, R.B., 1976, A study of the mineralogy and lithology of cuttings from $U . S$. Bureau of Reclamation Mesa Geological Survey Open-File Report $76-88,57 \mathrm{p}$. 


\section{CATEGORY 1: 15-MINUTE TOPOGRAPHIC QUADRANGLE MAPS}

\section{5 --Continued}

Hoover, D.B., Radtke, B., Moeller, D.D., 1978, Tellurıc profile location map and telluric data for the Glamis known Geothermal Resources Area, California: U.s. Geological Survey Open-File Report 78-106-C, 3 p., 2 figs.

Senterfit, R.M. and Heran, W.D., 1978, Audio magnetoteliuric data log and station location map for the Glamis known Geothermal Resource Area, California: U.S. Geological Survey Open-File Report 78-105-c, 7 p., 1 fig.

storie, R.E., 1944, Soils of Imperial East Mesa, Imperial County, California: University of California college of Agriculture Soll Survey 1 .

\section{7}

Strahorn, A.T., Watson, E.B., Kocher, A.E., Eckmann, E.C. and Hammon, J.B., 1922, Soil survey of the El Centro area. California: U.S. Department of Agriculture report, 59 p., 2 maps.

\section{9}

Christensen, A.D., 1957, Part of the geology of the coyote Mountain area, Imperial County, California: Los Angeles, University of California, scale $1: 12,000$

Gilbert, J., 1966, Geology of the Ocotillo Badlands (Calif.): San Diego, California State University, senıor

research paper.
Hanna, G.D., 1926, Paleontology of Coyote Mountain. Imperial County, California: California Academy of Scrence Proceedings, 4th series, v. 14, no. 18, p. 434-435.

Hoggatt, W.c., 1979, Geologic map of Sweeney Pass quadrangle, San Diego County, Cal ifornı: U.S. Geological Survey OpenFile Report 79-754, $37 \mathrm{p}$.

Kew, W.S.W., 1914, Tertiary echinoids of the Carrizo creek region in the Colorado Desert (Calif.): Berkeley. University of California, M.S. thesis.

kew, w.s.W., 1914, Tertiary echinoids of the Carrizo creek region in the Colorado Desert (Calif.): University of California Department of Geological Sciences Bulletin, v. 8, p. 39-60; map, p. 41, scale 1:1,000,000.

Mendenhali, w.c. 1910 , Notes on the geology of the Carrizo Mountains and vicinity, San Diego County,

California: Journal of Geology, v. 18, p. 336-355. Fish Creek Mountains: San Diego, California state University, senior research paper.

preston, C., 1966, Geology of a portion of the Sweeney pass and Carrizo Mountain 7 1/2-minute quadrangles: San Diego, California state Oniversity senior research paper.

Ravenscroft, A., 1969, Geology of the western coyote Mountains, San Diego County, California: San Diego, California State University, senior research paper.

Smith, D.D., 1962, Geology of the northeast quarter of the Carrizo Mountain quadrangle, Imperial county, California: Los Angeles, University of Southern California, M.A. thesis,

89 p.
Southard, G., 1972, Magnetic survey, Vallecito Valley, California: San Diego, California state Oniversity, senior

research paper.
vaughan, T.W., 1917 , The reef-coral fauna of Carrizo Creek, Imperial County, California, and its significance: 0.S. Geological Survey Professional Paper 98-T, p. $355-386$.

Woodard, G., 1963, Geology and stratigraphy of the Vallecito and Carrizo badlands, San Diego and Imperial Counties, southern california: Berkeley, University of california, M.A. thesis, scale $1: 24,000$.

\section{0}

Buttram, G.N., 1961, The geology of the northeast corner of the Cuyapaipe quadrangle, California: Los Angeles, University of Southern California, M.A. thesis. Buttram, G.N., 1962, The geology of the Agua Caliente
quadrangle, California: Los Angeles, University of Southern California, M.s. thesis, $96 \mathrm{p}$.

Todd, V.R., 1977, Geologic map of the Agua Caliente Springs quadrangle, San Diego County, Cal ifornia: U.S. Geological Survey Open-File Report $77-742,20$ p., 1 pi., 3 figs.

Todd, V.R., 1978, Geologic map of Monument Peak quadrangle, San Diego County, California: U.S. Geological Survey openFile Report 78-697, 47 p., 1 pl., scale 1:24,000.

Todd, V.R., 1979, Geologic map' of the Mount Laguna 7.5-minute quadrangle, San Diego County, California: U.S. Geological Survey Open-File Report 79-862, $49 \mathrm{p}$.

\section{1}

Everhart, D.L., 1951, Geology of the Cuyamaca Peak quadrangle, San Diego County, California: California Division of Mines and Geology Bulletin 159, p. 51-1.15, pls. $2-6$.

Everhart, D.L., 1953, Geology of the Cuyamaca Peak quadrangle, San Diego County, California: Cambridge, Mass., Harvard University, Ph.D. dissertation.

\section{1--Continued}

Hudson, F.S., 1920, Geology of the Cuyamaca region of California: Berkeley, Calıf., University of California,

Ph.D. dissertation.
Hudson, F.s., 1922, Geology of the Cuyamaca region of California with special references to the origin of nickeliferous pyrrhotite: University of California Department of Geological Science Bulletin, v. 13, no. 6, p. $175-252$.

Todd, V.R., 1977, Geologic map of the Cuyamaca Peak 7 1/2minute quadrangle, San Diego County, California: U.S Geological Survey Open-File Report 77-405, 13 p., i pl.., 5 figs., scale $1: 24,000$.

Todd, V.R., 1978, Geologic map of the Viejas Mountain quadrangle, San Diego, California: U.S. Geological Survey Open-File Report 78-113, 30 p., 7 figs.

Todd, V.R., 1982, Geologic map of the Tule Springs quadrangle, San Diego County, California: $0 . S$. Geological Survey openFile Report 82-221, 32 p.. scale $1: 24,000$.

\section{2}

Carlson, R.M., 1970, Study of the El Capitan Pluton and surrounding basement rocks of the El Cajon Mountain mineralization: San Diego, California State University, senior research paper.

Fergerson, R., Fahrenbruch, R., and Wobser, J., 1968 Geophysical investigation of a portion of Santee and E Monte Valleys, San Diego County, California: Riverside, University of California, $58 \mathrm{p}$.

Moyle, W.R., Jr., and Blazs, R.L., 1977, water resources of the Barona capitan Grande and Sycuan Indian Reservations, San Diego County, California: U.S. Geological Survey Open-File Report 77-289, $33 \mathrm{p}$.

Peterson, G.L., 1971, Stratigraphy of the Poway area. southwestern California: San Diego Society of Natural

H1story Transactions, v. 16, p. 225-236.
peterson, G.L., and Kennedy, M.P., 1974, Lithostratigraphic variations in the Poway Group near San Diego, Callfornia: San Diego Society of Natural History Transactions, v. 17, p. 251-258.

Sadati, B., 1966, Geology of the southern portion of the Alpine quadrangle, San Diego County, California: San Diego, California State University, senior research paper.

Thompson, w.B., 1967, Geology of Lake Jennings area, San Diego County, California: San Diego, California state

University, senior research paper.
Todd, V.R., 1980, Geologic map of the Alpine quadrangle. San Diego County, Calıfornia: U.S. Geological Survey

Open-File Report $80-82,50 \mathrm{p}$. , scale $1: 24,000$.
Todd, V.R., 1985, Geologic map of El Cajon Mountain quadrangle. San Díego County, California: U.S. Geological Survey openFile Report $83-781,28$ p.

\section{3}

Crandall, Hector, 1916, The geology of the La Jolla quadrangle, San Diego County, California: Palo Alto Calif., Stanford University, M.A. thesis.

Hanna, M.A., 1926, An Eocene invertebrate fauna from the La Jolla quadrangle, California: Berkeley, Calif.., University of California, Ph.D. dissertation.

Hanna, M.A., 1926, Geology of the La Jolla quadrangle: University of California Department of Geological science Bulletin, v. 16 , no. 7, p. 197-246, scale 1:62,500.

Harper, N., 1966, Geology of an area in the Del Mar and Poway valley 7.5-minute quadrangles, San Diego County, California: San Diego, California State University, senior research paper.

Hubbs, C.L., Bien, G.S., and Suess, H.E., 1960, La Jolla natural radiocarbon measurements: American Journal of Science, Radiocarbon Supplement, v. 4, p. 197-223.

Kennedy, M.P., and Peterson, G.L., no date, Geology of the La Mesa, Poway, and southwest quarter of the Escondido quadrangles, eastern San Diego metropolitan area, California: California Division of Mines and Geology.

Kern, J.P., 1974, Trace fossils, body fossils, and the environment of deposition of a marin lens in the middle Eocene Mission Valley Formation, San Diego, California: Geological Society of America Abstracts with programs, v. $6,201 \mathrm{p}$.

Pierce, S.E., 1974 , Provenance and paleoclimatology of the

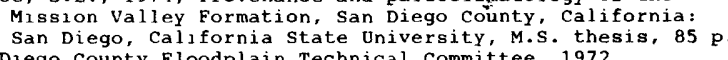

San Diego county Floodplain Technical Committee, 1972 Examination of the meteorological assumptions underlying the derivation of the standard project flood for the San Diego River, California: San Diego, Calif., 24 p. Skrivan, J.A., 1974 , Rainfall-runoff basic data, Poway
Valley, California: U.s. Geological Survey open-fil report, 7 p

slyker, R.G., 1964, Gravity investıgation of the western part of the La Jolla quadrangle, San Diego County, California: San Diego, California State University, senior

o.s. Army Corps of Engineers, 1947, Hydrology, San Diego River: U.S. Army Corps of Engineers. 
Chamberlain, T.K., 1960, Mechanics of mass sediment transport in Scripps Submarine Canyon, California: Los transport in Scripps Submarine Canyon, California: Los
Angeles, University of California and Scripps Institute of Angeles, University of Cali

Ingle, J.C., Jr., 1970, paleoclimatic and paleooceanographic implications of Pliocene foraminifera from Pacific Beach, california: Society of Economic Paleontologists and Mineralogists, Pacific Section, Annual Fall Field Trip Mineralogists, Pacific Section, Annual Fall Field Trip

Inman, D.L., 1953, Areal and seasonal variations in beach and nearshore sediments at La Jolla, California: Los Angeles, University of California,
of Technology, Ph.D. dissertation.

wimberley, C.S. 1954, Marine sediments north of Scripps submarine canyon, La Jolla: Austin, University of Texas, M. A. thesis.

\section{8}

Austin, C.F., 1968, Geologic evaluation of San Clemente Island as a location for a Rock-Site 1 installation: China Lake, Calif., D.s. Naval Weapons Center Technical Publication $4501,28 \mathrm{p}$.

0)mst ed, F.H. 1956, Geologic reconnaissance of San clemente Island, Californa: U.S. Geological Survey

open-file report, $30 \mathrm{p}$. Island Island, California: v.S. Geological Survey Bulletin 1071-B,

p. 55-68, pl. 1, scale $1: 31,680$ reconnaisgance and reconnaissance and suggested test-drilling program, San
Clemente Island, California: U.S. Geological Survey report, 75 p.

Smith, w.S.T, 1898, A geological sketch of San clemente Island, California: U.s. Geological survey 1 Bth annual report, p. 459-496.

\section{9}

Lamar, D.L., Merifield, P.M., and Stout, M.L., 1968, Engineering geology of rocks in core hole, Eel Point, San Clemente Island, California: China Lake, Calif., U.S. Naval Weapons Center Talifial

Merifield, P.M. Lamar, D.L., and Stout, M.L., 1971 Geology of central San clemente Island, California:

Geological Society of America Bulletin, v. B2, p. 1989-1994.

\section{4}

Morton, P.K., 1962, Reconnaissance geologic mapping and photo interpretation of parts of the quartz Peak guadrangle and part of the Picacho and Picacho SW, Mines and Geology, reconnaissance mapping for the state geologic map, scale $1: 62,500$.

\section{5}

Morton, P.K., Troxel, B.W., Weber, F.H., Jr., and Gray, C.H., Jr., 1961, Reconnaissance geologic mapping and photo interpretation of a part of the Acolita quadrangle (Calif.): California Division of Mines and Geology mapping for the state geologic map, scale $1: 62,500$.

\section{6}

Sharp, R.V., 1977, Map showing Holocene surface expression of the Brawley fault, Imperlal County, California: U.S. Geological Survey Misce
sheet, scale $1: 24,000$.

\section{7}

Clayton, R.N., Muffler, L.J.P., and white, D.E., 1968 Oxygen isotope study of calcite and silicates of the River Oxygen isotope study of calcite and silicates of the River
Ranch No. 1 well, Salton Sea Geothermal Field, California:

Soske, J.L., 1935. Theory of magnetic methods of applied geophysics with an application to the San Andreas fault, California: Pasadena, California Institute of Technology, Ph.D. dissertation.

veatch, J.A., 185B, Notes of a visit to the mud volcanoes in the Colorado Desert in the month of July, 1857: American Journal of Science, 2nd series, v. 26, p. $28 \mathrm{~B}-295$.
Waananen, A.o., and Moyle, W.R., Jr., 1972, waterresources effects in the Borrego Mountain earthquake of April 9, 1968: U.S. Geological Survey Professional Paper 787 , p. $183-189$.

\section{0}

California Department of Water Resources, 1984, Borrego valley water management plan: California Department of water Resources Southern District Report. basins projects, Borrego Valley, California, reconnaissance investigation: U.S. Bureau of Reclamation, $62 \mathrm{p}$.

\section{1}

Copenhaver, G.C., 1970, Geochemical prospecting for nickel in the Julian-Cuyamaca area: San Diego, California state University, M.A. thesis, $160 \mathrm{p}$.

Creasey, s.c. the Julian-Cuyamaca area, San Diego County, California: Mines and Geology, v. 42, no. 1, p.

Donnelly, Maurice, 1933, Preliminary report on the geology of the Julian region, California: Pasadena, California Institute of Technology, M.S. thesis.

Donnelly, Maurice, 1934, Geology and mineral deposits of the Julian district, San Diego County, California: California Journal of Mines and
$331-370$, pl. 4, scale $1: 62,500$.

Donnelly, Maurice, 1935, Geology and mineral deposits of the Julian district, San Diego County, California: Pasadena,

Falrbanks, H.W., 1894, A remarkable folded vein in the Ready Relief mine (Banner district, San Diego, Calif.): Engineering and Mining Journal, v. 57, p. 321-322.

Merriam, R.H., 1958, Geology of Santa Ysabel quadrangle, San Diego, California: Cal fo Bulletin 177, 42 p., 2 pl.

Sandberg, E.C., 1929, The gold quartz veins of the Julian district, California: Pasadena, California Institute of
Technology, M.s. thesis.

\section{2}

Koberg, G.E., 1964, Elimination of thermal stratification by an alr-bubbling technique in Lake Wohlford, California:
U.S. Geological Survey Professional Paper 501-D, p. D190-

Koberg, G.E., and Ford, M.E., Ir., 1965, Elimination of thermal stratification in reservolrs and the resulting benefits with special emphasis on study of Lake Wohlford, California:
U.S. Geological survey water-Supply Paper 1809-M, 28 p. $\mathrm{U}$.S. Geol

Merriam, R.H., 1941, A southern California ring-dike: American Journal of Sclence, v. 239, no. 5, p. 365-371.

Merriam, R.H. 1941, Geology of the southwestern part of the Ramona quadrangle, San Diego County, California: Berkeley, University of California, Ph. dissertation.

Merriam, R.H., 1946, Igneous and metamorphic rocks of the southwestern part of the Ramona quadrangle, San Diego County, California: Geological Socrety

Merriam, R.H., 1948, Orbicular structures in aplite dikes near Ramona, California: American Journal of Science, $v$. 246, no. 3, 129-137, figer scale 1:20,000

Merriam, R.H., 1954, Ramona-Julian a rea, in Geology of southern California: California Division of Mines Bulletin 170, Geologic Guide 5, map 10, p. 43.

Simpson, D.R., 1960, Geology of the Ramona pegmatites, San Drego County, California: Pasadena, California Institute of Technology, Ph.D. dissertation.

Simpson, D.R., 1962, Graphic granite from the Ramona pegmatite district, California: American Mineralogist, v 47, p. 1123-1138.

Simpson, D. 1965 , Geology of the central part of the Ramona pegmatite district, San Diego County, California: California Division of Mines and Geology Special Report $86, \mathrm{p}, 3-23$

Sinkankas, J., 1957, Recent gem mining at Ramona: Gems and Gemology, v. 8 , no. 12 , p. 367-374.

\section{3}

Lance, J.F., 1949, The origin of the Pioneer pyrophyllite deposit, San Diego County, California: Pasadena, Californe Institute of Technology, Ph.D. dissertation.

McLean, H. 1966, Geology of the northwest portion of the Rancho Santa Fe quadrangle (Calif.): San Diego,

Van California State University, senior research paper. Santa Fe quadrangle, San Diego County, California: san Diego, California state University, senior research paper. 


\section{CATEGORY 1: 15-MINUTE TOPOGRAPHIC QUADRANGLE MAPS}

\section{3--Continued}

Young, L.E., and Ray, H.A., 1964, Areas of potential flood inundation San Dieguito River basin, California: California Department of Water Resources, San Diego Flood Hazard Investigation Bulletin 112 , appendix $F, 31$ p.

\section{4}

Abbott, P.L., ed., On the manner of deposition of the Eocene strata in northern San Diego County (Calif.): Del Mar, Calif., San Diego Association of Geologists, field trip guidebook, $97 \mathrm{p}$.

Caldwell, S.A., 1967, Geology of the Carlsbad area, California: San Diego, California State University, senior research paper.

Euge, K.M., Miller, D.G., and Palmer, L.A., 1973, Evidence for a possible onshore extension of the Rose Canyon Fault in the vicinity of Oceanside, California (abs.): Geological Society of America Abstracts with Programs, v. 5, p. 39 .

Gastil, R.G., 1969, Geologic map of the Oceanside quadrangle: San Diego, California state oniversity Department of Geological Science.

Gastil, R.G., 1969, Geologic map of the San Luis Rey quadrangle: San Diego, California State University

Department of Geological Science, faculty research. an, D.L., 1974, Reconnaissance mapping of Tertiary-Quaternary faulting in Oceanside-Carlsbad, California: Geological Society of America Abstracts with Programs, v. 6, p. 188189.

Jones, B.F., 1959, Geology of the San Luis Rey quadrangle (Calif.): Los Angeles, University of Southern California, M.S. thesis.

Liska, R.D., 1964, Geology and biostratigraphy of Letterbox Canyon, San Diego County (Calif.): San Diego, California State University, M.S. thesis.

Miller, F.S. 1934, The petrology of the San Marcos Mountains gabbro, San Luis Rey quadrangle in California: Cambridge. Mass. Harvard University, Ph.D. dissertation.

Miller, F.s., 1937, Petrology of the San Marcos gabbro, southern California: Geological Society of America Bulletin, v. 48, no. 10, p. 1397-1425.

Miller, F.S., 1938, Hornblendes and primary structures of the San Marcos gabbro (Calif.): Geological Society of America Bulletin, v. 49, p. 1213-1231.

Murray, D., 1968, Gravity investigation of an area around Encinitas, San Diego County, California: San Diego, California State University, senior research paper.

phillips, I.L., 1940, A study of the geology and soils of the oceanside quadrangle: Berkeley, university of California. M. A. thesis.

Skrivan, J.A., 1976, Predicted effects of a proposed waterresources management plan in the lower San Luis Rey River valley, California, using digital ground-water flow models v.s. Geological Survey Open-File Report 76-754, 22 p., 10 figs., 4 tables.

Wilson, K.L., 1972, Geology of the Encinitas and San Lurs Rey quadrangles: Riverside, Unıversity of California, Department of Geology, M.A. thesis, $135 \mathrm{p}$.

\section{8}

Wrath, W.F., 1936, Marine sedimentation around Catalina and San Clemente Islands: Urbana, University of Illinois, M.s. thesis.

\section{9}

Ford, G.A., and Normark, W.R., 1980, Map showing a deep-tow geophysical study of the north end of the San Survey Miscellaneous Field Studies Map MF-1230, 1 sheet.

\section{2}

Burnham, W.L., Kunkel, Fred, Hofmann, Walter, and Peterson, W.C., 1963, Hydrologic reconnaissance of San Nicolas Island, California: 0.s. Geological Survey water-Supply Paper 1539-0, p. 1-43, 1 pl., 7 figs., 11 tables.

Burnham, W.L., and Kunkel, Fred, 1960, Hydrogeologic reconnaissance of San Nicolas Island, California: u.s. Geological Survey open-file report, $49 \mathrm{p}$.

Norris, R.N., 1951, The marine geology of the San Nicholas Island region, California: San Diego, Scripps Institute of Oceanography, Ph.D. dissertation.

vedder, J.G., Schoel lhamer, J.E., and Israelsky, M.C. 1956, Preliminary report on the geology of San Nicolas Island, California: D.S. Geological survey open-file report, map, scale $1: 12,000$

vedder, J.G., and Norris, R.M., 1963, Geology of San Nicolas Island, California: 0.s. Geological Survey Professional Paper $369,65 \mathrm{p}$
0403 salinity in ground water and soil, palo verde Irrigation District, Riverside County, California: D.S. Geological Survey Water-Resources Investigations Report 83-4111, 62 p.

Gamble, J.K., and Donehy, E.A., 1960 , Maps of areal economic R. 21 and 22 E., S.B.B.M., to accompany Minerals for Industry, southern California: San Francisco, Calif., Southern Pacific Co., Land Department, 2 maps.

Snyder, C.T., 1961, Examination of an existing well in the area, Imperial County: o.s. Bureau of Land Management, 2 p.

0404

Jennings, C.W., and Saul, R.B., 1964, Reconnaissance geologic mapping and photo interpretation of the northeast part of the Palo Verde Mountains quadrangle (Calif.): California map, scale $1: 62,500$.

Morton, P.K., 1961, Reconnaissance geologic mapping and photo interpretation of parts of the Palo verde Mountains quadrangle (Calif.): California Division of Mines and Geology mapping for the State geologic map, scale $1: 62,500$.

\section{5}

Jennings, C.W., and Morton, P.K., 1965, Reconnaissance geologic mapping and photo interpretation of a part of the Chuckwalla Spring quadrangle (Calif.): California Division of Mines and Geology mapping for the state geologic map, scale $1: 62,500$.

Morton, P.K., 1961. Reconnaissance geologic mapping and photo interpretation of parts of the chuckwalla springs quadrangle (Calif.): California Division of Mines and Geology, mapping for the state geologic map, scale $1: 62,500$.

Snyder, C.T., 1963, well site examination in the Riverside Grazing District, Imperial County, California, upper Milpitas Wash area: U.s. Bureau of Land Management, 1 p.

\section{6}

Jennings, C.W., and Morton, P.K., 1965, Reconnaissance geologic mapping and photo interpretation of a part of the Iris pass quadrangle (Calif.): California Division of Mines and Geology mapping for the state geologic map, scale $1: 62,500$.

Morton, P.K., Troxel, B.W., weber, F.H., Jr., and Gray, c.H. Jr.. 1961, Reconnaissance geologic mapping and photo interpretation of part of the Iris Pass and Iris quadrangle (Calif.): California Division of Mines and Geology mapping for the state geologic map, scale $1: 62,500$.

Snyder, C.T., 1965, Examination of two well sites in the Riverside Grazing District, Imperial County, California, 2 p.

\section{7}

Morton, P.K., and Jennings, C.W., 1966, Reconnaissance geologic mapping and photo interpretation of part of the Frink quadrangle (Calif.): California Division of Mines and Geologr $1: 62,500$.

Rogers, A.F., 1926, Geology of Cormorant Island, Salton Sea, Imperial County, California: Geological Society of America Bulletin, v. 37, p. 219.

Rogers, A.F., 1934, Salton volcanic domes of Imperial County, California: Geological Society of America, Proceedings, p. 328 .

Rook, S.H., and Williams, G.C., 1942, Imperial carbon dioxide gas field: Summary of operations, California Oil Field: California Division of Oil and Gas, July-Dec.. 28 , p. $12-33$

weismeyer, A.L., Jr., 1967, A geologic and hydrologic investigation of the Frink Spring-Hot Mineral Spa area: Los Angeles, University of Southern California, term paper.

\section{8}

Babcock, E., Rex, R.W., Meidav, Tsvi, and Randall, W., 1968, On the high density core of the Durmid Dome, Imperial Valley (abs.): American Geophysical Union Transactions, v. 49 no. 4 .

California Department of Water Resources, 1962, Investigation of sources of water supply for salton sea State Park: California Department of Water Resources. office report. 
Durrell, C.. and Bell, G.L., 1944, Calcite mines in northeastern San Diego County, California: U.S. Geological northeastern San Diego County, Calif
Survey preliminary map, scale $1: 240$.

\section{0}

Bennett, G., 1966, Geology of a portion of the Clark Lake quadrangle, California: San Diego, California state quadrangle, California: San Diego,
University, senior research paper.

osterholt, W.R.B., 1934 , The origin of the main physiographical features of Borrego Valley, california: physiographical features of Borrego Valley, California:
Los Angeles, University of Southern Callfornia, M.s. Los Angeles,
thesis, $37 \mathrm{p}$.

parcel, R.F., Jr., no date, Geology of a part of the santa Rosa Shear Zone, Riverside County, California: Riverside,

Simoni, T.R., Jr., 1980, Geophysical and lithologic data from a test well on clark Lake, San Diego County, California: U.S. Geological Survey open-File Report Callfornia: U.S.

Sims, S.J., 1960, Geology of part of the Santa Rosa Mountains, Riverside County, California: Palo Alto, Calif., Stanford Riverside County, California: Pal
University, Ph.D. dissertation.

Wright, L.B., 1946, Geology of Santa Rosa Mountain a rea, Riverside County, California: California Journal of Mines and Geology Report 95, v. 42, no. 1, p. 9-13.

\section{1}

Ballog, A.P., Jr., and Moyle, W.R., Jr., 1980, water resources and geology of the Los Coyotes Indian Reservation and vicinity, San Diego County, California: U.S. Geological vicinity, San Diego County, California:
Survey Open-File Report $80-960,25 \mathrm{p}$.

Sauer, c.o. 1929. Land forms on the Peninsular Range of California as developed about Warner's Hot Springs and Mesa Grande: University of California publications, Mesa Grande: University of Cal
Geography, v. 3, p. 199-290.

Geography, v. 3, p. 199-290.
Scheliga, J.T., Jr., 1963, Geology and water resources of Warner Basin, San Diego County, California: Los Angeles. Warner Basin, San Dlego County, Californla: Los
Unlversity of Southern California, M.S. thesis.

\section{2}

Barley, S., 1964, Ground water of the upper Cold Spring Creek drainage area, Palomar Mountain, California: San Creek drainage area, Palomar Mountain, California: San
Diego, California State University, senior research paper. Diego, California State University, senior resea
California Department of Water Resources, 1965 , Water quality report on Pauma, Pala, and Bonsali Ground water Basins: California Department of Water Resources report to
San Diego Regional Water Quality Control Board (no. 9). Donnelly, Maurice, 1935, The lithia pegmatites of Pala and Mesa Grande, San Diego County, Cal ifornia: Pasadena, California

Institute of Technology, Ph.D. dissertation.
Hedman, E.R., 1968 , Vail reservoir evaporation study progress report: u.s. Geological Survey open-file report,

Howes, T.B., 1955, A brief study of the geology and ground water conditions in the Pauma Valley area, San Diego County, Californa: Pasadena, California Institute of Technology, M.S. thesis, 64 p.

\section{3}

Flynn, C.J., 1965, Geology of a portion of the Elsinore Fault zone between Temecula and Pauma Valleys, San Diego County, California: San Diego, California state

University, senior research paper.
French, J.J., and Pearson, E.G., 1965, A brief water-resources reconnaissance of $\mathrm{Pala}$ and Rincon Indian Reservations, San Diego County, California: U.S. Geological Survey open-file report, $41 \mathrm{p}$.

Geological Survey open-file report, 41 P.
Hanley, J.B., 1951, Economic geology of the Rincon pegmatites, San Diego County, California: California Division of Mines Special Report 7-B, $24 \mathrm{p}$

Hurlbut, C.S., Jr., 1933, The structure and inclusions of the Bonsall Tonalite near Fallbrook, California:

Cambridge, Mass., Harvard University, Ph.D. dissertation. but, C.S., Jr., 1935, Dark inclusions in tonalite from
southern California: American Mineralogist, v. 20, no. 9 p. $609-630$.

Jahns, R.H., and Wright, L.A., 1951, Gem- and lithiumbearing pegmatites of the Pala district, San Diego County, California: California Division of Mines Special Report

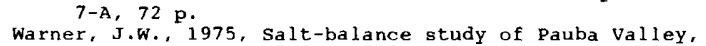
upper Santa Margarita River area, Riverside County. California: U.S. Geological Survey water-Resources Investigations report 43-74, $44 \mathrm{p}$.

worts, G.F. Jr., 1953, Report on the Pauba Ranch exploratory well, Riverside County, California: U.s. exploratory well, Riverside County, Calif
Geological Survey open-file report, 50 p.
Rantz, S.E., 1963, Annual runoff in the Santa Margarita River basın, Californıa, 1925-62: U.S. Geological Survey open-file report, $16 \mathrm{p}$

Rantz, S.E., 1964, Annual runoff in the Santa Margarıta River basin, California, 1925-64: U.S. Geological Survey open-file report, $16 \mathrm{p}$.

Ross, Arnold, and Dawlen, R. J., eds., 1975, studies on the geology of Camp Pendleton and western San Diego
County, California: San Diego Association of Geologists, county.

Warıng, G.A., and waring, C.A., 1917, Lavas of Morro H111 and vicinity, southern California: American Journal of Science,
$1: 36,000$.

\section{5}

Ball, A.R., 1961, Geology of the northern and western parts of the San clemente quadrangle, Orange County, California: Los Angeles,

Bartow, J.A., 1964, Stratigraphy and sedimentation of the Capistrano Formation Dana Point area, Orange County. California: Los Angeles, University of California, M.A. thesis.

Edgington, W.J., 1974, Geology of the Dana Point quadrangle, Orange County, California: California Division of Mines and Geology Special Report 109, $31 \mathrm{p}$ Fernandez, A.P., 1959 , Geology of a portion of the
Capistrano basin, California: Los Angeles, University of
California, M.A. thesis, 83 p., 3 pls., 4 figs., scale California,

Greene, H.G., Clark, S.H., and Seekins, B.A., 1980, offshore selsmic reflection profiles in the vicinity of the Christianitos Fault, San Onofre, California: U.S

ileological Survey open-File Report 80-945, 8 .

illen, quadrangle, California:

Morton, P.K., Edgington, W.J., and Fife, D.L., 1974 , Geology and engineering geologic aspects of the San Juan Capistrano quadrangle, Orange County, California: California Division of Mines and Geology Special Report

112,64 p.
Neblett, S.S., 1966 , Engineering geology of the Dana Point quadrangle, California: Los Angeles, University of Southern California, M.A. thesis, 113 p., 1 pl. 27 figs., 3 tables, scale $1: 12,000$

Southern California Edison Company, 1970, San Onofre Nuclear Generation station, units 2 and 3 , preliminary safety analysis report: Southern Calıfornia Edison Co., vs.

Southwick, T.S., 1929, Geology of a portion of the Santa Ana Mountains, California: Pasadena, California Institute of Technology, M.s, thesis.

Stevenson, R.E., 1948, The Cretaceous stratigraphy of the southern Santa Ana Mountains, California: Los Angeles, University of California, M.A. thesis.

Stewart. C.J., 1973, Lithofacies in the San Onofre Breccia, Laguna Beach to Dana Point, Orange County, California: A preliminary report: Society of Economic Paleontologists and Geologists, Society of Economic Paleontologists and Mineraloglsts, and Society of Exploration Geophysicists Annual oglsts, and Socrety of Explor

western Geophysical, ig72, Final report, Southern California Edison and San Diego Gas Electric Company, San Onofre offshore investigations in San Onofre Nuclear Generating station, units 2 and 3 , amendment no. 11 to preliminary safety analysis report: Western Geophysical, $34 \mathrm{p}$.

Woodford, A.o., 1923, The San Onofre breccia and conglomerate, a southern California coastal facies of the Temblor Miocen
Berkeley, University of California, Ph.D. dissertation.

\section{8}

Basley, E.H., 1941, Mineralogy, petrology, and geology of Santa Catalına Island, California: Palo Alto, Calif., Stanford Unıversity, Ph.D. dissertation.

Balley, E.H., 1954, Road log for Santa Catalina Island:

Geological Society of America Field Trip, scale 1:82,200. Santa Catalina Island (Calif.): Los Angeles, University of Southern California, M.S. thesis.

Platt, J.P. 1972 The Catalina Schist, Santa cataline Island, Calıfornia: Geological Soclety of America Abstracts with Programs, v. 4, no. 3 , p. 219

platt, J.P., 1973, The structure, petrology, and geologic history of the Catalina Schist terrain, southern California: Santa Barbara, University of California, Ph.D.

dissertation.
Smith, W.S.T., 1897, The geology of santa Catalina Island, California: Berkeley, University of california, Ph.D.

dissertation.
Smith, W.S.T., 1897, The geology of santa catalina Island, Calıfornia: California Academy of Sclence Proceedings, 3d 
Jennings, c.w., 1966, Photogeologic interpretation for the State geologic map of parts of the Blythe NE, McCoy Wash, and Ripley quadrangles (Calif.): California Division of Mines and Geology, scale 1:24,000

Peterson, D.L., Comradi, Arthur, and Zohdy, A.A.R., Principal facts for gravity stations in the Yuma, Arizona, and Blythe, California, areas: 0.s. Geological Survey open-file report. 34 p.

\section{4}

Jennings, C.W., and Saul, R.B., 1964, Reconnaissance geologic mapping and photo interpretation of the McCoy Spring Geology mapping for the State geologic map, scale 1:62,500.

\section{5}

Jennings, C.W., Saul, R.B., and Rogers, T.H., 1964, Reconnaissance geologic mapping and photo interpretation of the Sidewinder Well quadrangle (Calif.): California Division of Mines and Geology mapping for the state geologic map. scale $1: 62,500$.

Pelka, G.J., 1973, Geology of McCoy and Palen Mountains, southeastern California: Santa Barbara, Oniversity of California, Ph.D. dissertation, 16 .

simoni, T.R., Jr., 1980, Geophysical and lithologic data from test wells on Ford Dry Lake, Riverside County, California: D.S. Geological Survey Open-File Report 80-1277, 1 sheet.

\section{6}

Jennings, C.W., Saul, R.B., and Rogers, T.H., 1964, Reconnaissance geologic mapping and photo interpretation of the
Chuckwalla Mountains quadrangle (Calif.): California Division of Mines and Geology mapping for the State geologic map, scale $1: 62,500$.

\section{7}

Crowell, J.C., and Susuki, Takeo, 1959, Eocene stratigraphy and paleontology, Orocopia Mountains, southeastern California: Geological Society of America Bulletin, v. 70, p. 581-592.

Jennings, C.W., Rogers, T.H., and Morton, P.K., 1964 Reconnaissance geologic mapping and photo interpretation of part of the Hayfield quadrangle (Calif.): Californa Division of Mines and Geology mapping for the state geologic map, scale 1:62,500.

Johnston, I.M., 1961, Eocene Foraminifera from the lower Maniobra Formation, Orocopia Mountains, Riverside County, California: Berkeley, University of California, M.A. thesis.

Seastrom, w.C., 1953, Structural geology of Canyon Spring quadrangle, Riverside County, California: Los Angeles, University of Southern California, M.A. thesis.

simpson, A.L., 1958, Physiography of the Canyon Spring quadrangle, Riverside County, California: Los Angeles, University of Southern California, M.A. thesis.

williams, J.J.. 1956, Geology of a part of the orocopia Mountains, Riverside County, California: Los Angeles, University of California, M.A. thesis, $44 \mathrm{p}$.

\section{8}

Gillies, W.D., 1958, The geology of a portion of Cottonwood Springs guadrangle, Riverside County California: Los Angeles, University of California, M.A. thesis, $70 \mathrm{p}$

Hays, W.H., 1951, Geology of cottonwood Springs and part of Coachella quadrangles, California: New Haven, Conn., Yale University, M.S. thesis.

Jennings, C.W., and Rogers, T.H., 1964, Reconnaissance geologic mapping and photo interpretation of part of the Cottonwood Spring quadrangle (Calif.): Calıfornia Division of Mines and Geology mapping for the State geologic map. scale $1: 62,500$.

Raleigh, C.B., 1958, Structure and petrology of a part of the Orocopia schists: Claremont, Calif., Pomona college, M.A. thesis.

\section{9}

Eckis, R.P., 1930, Geology of a portion of the Indio quadrangle: Pasadena, California Institute of Technology, M.s. thesis.

Hays, W.H., 1957, Geology of the central Mecca Hills, Riverside County, California: New Haven, Conn., Yale University, Ph.D. dissertation, 324 p.
Mendenhal1, w.C., 1909, Ground waters of the Indio region, California, with a sketch of the Colorado Desert: v.s. Geological Survey water-Supply Paper 225, 56 p.

Moreland, J.A., 1975, Evaluation of recharge potential near Indio, California: 0.S. Geological Survey water-Resources Investigations report $33-74,36 \mathrm{p}$.

ware, G.C., Jr., 1958, The geology of a portion of the Mecca Hilis, Riverside County, California: Los Angeles, approx. 1:24,000.

\section{0}

Buono, Anthony, Moyle, W.R., Jr., and Dana, Patricia, 1979, water resources of the Santa Rosa Indian reservation and vicinity, Riverside County, California: o.s. Geological Survey OpenFile Report 79-1i72, $32 \mathrm{p}$.

Lockwood, J.P., 1961, Geology of an area in the western Santa Rosa Mountains of southern california, with special emphasis on a previously unreported mylonite belt: Riverside, University of california, senior thesis, $75 \mathrm{p}$.

sealander, I.L., 1978, Range survey and inventory of the Santa Rosa Indian Reservation, Ca inorna: $0 . s$. Department of Interior, Bureau of Indian Affairs, $44 \mathrm{p}$.

0511

Brown, A.R., 1968, Geology of a portion of the southeastern San Jacinto Mountains, Riverside County, California: Riverside, university of California, M.A.

Brown, A.R., and Ruff, R.Q., eds., 1981, Geology of the San Jacinto Mountains: South Coast Geological Society Annual Field Trip Guidebook 9, $219 \mathrm{p}$.

Buono, Anthony, Moyle, W.R., Jr., and Dana, Patricia, 1979, water resources of the Santa Rosa Indian Reservation and vicinity, Riverside County, California: J.s.

Dibblee, T. W I Survey Open-File Report 79-198. Geologic map of the Idyllwild quadrangle, California: South Coast Geological Society. Geolog1c Map SCGS-5, scale $1: 62,500$.

Durbin. T.J.. 1975, Ground-water hydrology of Garne Valley, San Jacinto Mountains, California--A mathematical analysis of recharge and discharge: 0.s. Geological Survey Open-File Report 75-305, $40 \mathrm{p}$.

Fraser, D.M., 1931, Geology of the San Jacinto quadrangle south of San Gorgonio Pass in Mining in California: California Division of Mines and Geology. State Mineralogist Report, v. 27 , no. 4, p. 494-550.

Fraser, D.M., 1932, The geology of the San Jacinto quadrangle south of San Gorgonio Pass, California: New York, Columbia University, Ph.D. dissertation.

Morton, D.M., Matti, J.C., and Cox, B.F., 1980, Geology of the San Jacinto wilderness, Riverside County, California: v.S. Geological Survey Miscellaneous Field Studies map MF-i159-A, 1 sheet, scale 1:62,500.

Moyle, W.R., Jr., 1976, Geohydrology of the AnzaTerwilifiger' area, Riverside County, California: v.s. Geological Survey Water-Resources Investigations report $76-10,25 \mathrm{p}$.

Neste, Brudin, and Stone, Inc., 1966, Preliminary engineering study of a supplemental water supply for the Idyllwild County water District (Calif.): San Bernardino, Calif., consulting report to Idyllwild County water District, $76 \mathrm{p}$.

unruh, M.E., and Ruff, R.W., 1981, History of gold mining in the San Jacinto Mountains, Riverside County. in the San Jacinto Mountains, Riverside County,
California, in Brown, A.R., and Ruff, R.W., eds., Geology of the San Jacinto Mountains: South Coast Geological society Field Trip Guidebook 9 .

\section{2}

Dibblee, T.W., Jr., 1981, Geologic map of the Hemet quadrangle, California: South Coast Geological Society, Geologic Map SCGS-4, scale $1: 62,500$.

\section{3}

Kunkel, Fred, Giessner, F.W., Bader, J.S., and Moyle, W.R., Jr. 1961, Data on water wells in the upper part of the Santa Margarita River valley, California: v.S. Geological Survey open-file report, $32 \mathrm{p}$.

Mann, J.F., Jr., 1951, Late Cenozoic geology of a portion of the Elsinore fault zone, southern California: Los Angeles, University of Southern California, Ph.D. dissertation.

Mann, J.F., Jr., 1955, Geology of a portion of the Elsinore fault zone: California Division of Mines Special

Mann, J.F... Jr., 1955 , Geology of a portion of the Elsinore $22 \mathrm{p}$. 
California Division of Mines and Geology, 1981, Mineral land classification of Pacific clay Products, Inc., clay deposits California Division of Mines and Geology Open-File Report 81-16 LA.

Daviess, S.N., and Bramlette, M.N., 1953, The Alberhill and other clay deposits of Temescal Canyon, Riverside County, California: U.

Engel, Rene, 1933, Geochemical properties of the waters of the Elsinore quadrangle: Pasadena, California Institute of the Elsinore quadrangle: Pasadena

Engel, Rene, 1933, Geology of the southwest quarter of the Elsinore quadrangle: pasadena, California Institute of Technology, Ph.D. dissertation.

Engel, Rene, 1959, Geology of the Lake Elsunor quadrangle, California, with a section on Mineral deposits of the Lake Elsinore quadrangle, California, by Rene Engel, T.E. Gay, Jr., and B.L. Rogers: California Division of Mines and Geology Bulletin 146, $154 \mathrm{p}$.

Mann, J.F., Jr., 1947, The sediments of Lake Elsinore (Calif.): Los Angeles, University of Southern California, M.S. thesis.

Mann, J.F., Jr., 1951, The sediments of Lake Elsinore, Riverside County, California: Journal of Sedimentary Petrology, v. 21, no, 3, p. 151-161.

Thompson, T.H., 1965, Seepage losses in the San Jacinto River alluvial fan, near Elsinore, Cal ifornia: v.s. Geological Survey open-file report, 24 p.

Weber, F.H., Jr., 1974, Elsinore fault study: Callfornia Division of Mines and Geology.

\section{5}

F2fe, D.L., 1974, Geology of the south half of the El Toro quadrangle, orange County, California: California Division of Mines and Geology Special Report 110, $27 \mathrm{p}$.

Fife, D.L. Minch, J.A., and Crampton, P.J., 1967, Late Jurassic age of the Santrago Peak volcanıcs, Californıa:

Fugro, Inc. 1975, Geologic investigation of the bullidozer excavation at the proposed Viejo substation site: Consulting report for Southern California Edison Company.

Greenwood, R.B. 1982. Mineral land classif Riverside Cement Company platz property deposit in Trabuco Riverside Cement Company platz property deposit in Trabuco Manyon, Orange County, Callfornia: Californ

Kroll, C.G., and Porterfield, George, 1969, Preliminary determinations of sediment discharge, San Juan drainage basin, Orange and Riverside Counties, California: u.s. Geological Survey open-file report, $28 \mathrm{p}$.

Levet, M.N., 1940, Geology of the San Juan Canyon area, Orange County, California: Pasadena, California Institute of

Meserve, C.D., 1924, A study of the faunal and stratigraphrc relations of the middle and lower Miocene of the Santa Mountains, southern California: Berkeley, University of California,

Miller, R.V., and Morton, P.K., 1984, Engineering geology of part of the western half of the Sant zago Peak quadrangle, Orange Open-File Report 84-58 LA, 62 p., scale $1: 12,000$.

Moore, B.N. 1930, Geology of the southern Santa Ana Mountains, orange County, california: Pasadena, Calıfornia Institute Orange county, California: Pasadena,

Moore, R.F., 1948. Geology of the pre-Cretaceous rocks in a portion of the Santa Ana Mountains: Pasadena, California a portion of the Santa Ana Mountains:
Institute of Technology, M.S. thesis.

Morton, P.K 1970, Geology of the NE $1 / 4$ and NW 1/4, Canada Gobernadora quadrangle, orange County, Californza: Canada Gobernadora quadrangle, Orange County, Californas: 10,3 pls.

Morton, P.K., 1974, Geology of the southern half of the Canada Gobernadora quadrangle, Orange county, Calıfornıa california Division of Mines and Geology Special Report $111,30 \mathrm{p}$.

Oates, N.D. 1960, Geology of the western portion of the Canada Gobernadora quadrangle, Orange County, California: Los Angeles, Unzversity of Southern California, M.A. thesis, $98 \mathrm{p}$

orange County Board of Engineers, 1932, Geological report on Arroyo Trabuco and Aliso Creek dam and reservolr sites: Orange County Flood Control District engineering and geological reports for flood
project, Appendix E, p. 78-80.

Popenoe, W.P., 1936, An analysis and comparison of the Trabuco and Baker conglomerates of the Santa Ana Mountains: Pasadena, California Institute of Technology, Ph.D. dissertation.

Popenoe, W.P., 1936, The Upper Cretaceous stratigraphy and paleontology of the northern Santa Ana Mountains: Pasadena,

Popenoe, W.P. 1937. Upper Cretaceous Mollusca from southern California: Journal of Paleontology, v. 11, no. 5, p. $379-402$

Popenoe, W.P., 1943, Cretaceous formations of the northern Santa Ana Mountains: California Division of Mines

Bullet in 118 , p. 364-366, fig. 151, scale $1: 110,000$ Mountains, Orange County, California: Berkeley, University of California, M.s. thesis.

Roth, J.C., 1958, Geology of a portion of the southern Santa Ana Mountains, Orange County, California: Los Angeles, Dniversity of California, M.A. thesis.
Silberling, N.J., Schoellhamer, J.E., Gray, C.H., Jr., and Imlay, R.W., 1961, Upper Jurassic fossils from the Bedford Canyon Formation, southern California: America Association of Petroleum Geologists Bulletin, v. 45, p. 1746-1748

Smith, P.B., 1960, Foraminifera of the Monterey shale and Puente formation. Santa Ana Mountains and San Juan Capistrano area, California: U.S. Geolog

stauffer, C.R., 1946, High-alumina clays of the santa Ana Mountain region, California: U.S. Geological Survey strategic Minerals Investigations Preliminary Map 3-197,

Tan, S.S., Miller, R.V., and Fife, D.L., 1984, Engineering geology of the north half of the El Toro quadrangle, Orange County, California: Calıfornia Division of Mines and Geology Open-File Report 84-28 LA.

West. J.C., 1975, Generalızed subsurface geologic and geophysical study, Capistrano area, Orange county, California: Consultant report for southern California Edison Company.

\section{6}

Bode, F.D., 1934, The structural geology of the San Joaquin Hills, Orange County, Californa: Pasadena, California Institute of Technology, Ph.D. dissertation.

Bruff, S.C., 1940, The pleistocene history of the Newport Bay area, southern california: Berkeley, University of California, M. A. thesis.

Bruff, S.C., 1946, The paleontology of the Pleistocene molluscan fauna of the Newport Bay area, California: University of California Department of Geological Science Bulletin, v. 27, no. 6, p. 213-240.

clark, G.H., 1952, The geology of the eastern flank of the San Joaquin Hills: Claremont, Calif., Pomona College, M.A.

thesis.
Ehrluch, G.G., Schroeder, R.A., and Martin, Peter, 1985, Microbial populations in a jet-fuel-contaminated shallow aquife at Tustin, California: U.S. Geological survey Open-File Report 85-335, $14 \mathrm{p}$.

Findlay, W.A.. 1932, Geology of a part of the San Joaquin Hills: Pasadena, California Institute of Technology, M.s. thesis.

Gale, H.S.. 1934, Geology of Huntington Beach oll field, Callfornia: American Association of Petroleum Geologists Bulletin, v. 18 , no. 3, p. 327-243, fig. 1, scale $1: 500,000$

Kanakoff, G.P., and Emerson, W.K., 1959, Late Plesstocene invertebrates of the Newport Bay area, Californa: Los
Angeles County Museum Contribution to Science $31,47 \mathrm{p}$.

Lowry Engineering-Science, 1969, Water reclamation master plan for the Irvine Ranch water District: Santa Ana, Calif.

consulting report, 80 p., appendix.
parker, F.s., 1943, Newport Field: California Department of Natural Resources, Division of Mines, Bulletin 118, p. 332

Stevenson, R.E., 1954, The marshlands at Newport Bay, Callfornia: Los Angeles, University of Southern California, Ph.D. dissertation.

Stevenson, R.E., and Emery, K.o., 1958, Marshlands at Newport Bay, California: Alian Hancock Foundation, Science Research Occasional paper 20, $109 \mathrm{p}$.

stuart, C.J., 1973, Stratigraphy of the San Onofre Breccia Laguna Beach area, California: Geological Society of

Thomas, D., 1979, Possible geopressured well at Huntington Beach, California: California Division of oil and Gas, Geothermal Hot Line, v. 9, no. 3, p. 8-9.

Valentine, J.W., 1959, Faunule from Huntington Beach Mesa, California, part 2 of plesstocene molluscan notes Nautilus, v. 73, no. 2, p. 51-57.

Vedder, J.G., 1971, The San Onofre Breccra in the San Joaquin Hills, in Geologic guidebook, Newport Lagoon to San clemente, Orange county, California: Society of Economic Paleontology and Mineralogy. Pacific Section, p. 12-21.

Vedder, J.G., 1973, Summary of geology of the San Joaquin Hills: Society of Economic Paleontologists and Mineralogists Gurdebook 1, American Assocration of Petroleum Geologists, Society of Economic Paleuntologists and Mineralogists, and Society of Exploratic

Woodford, A.o., 1925, The San Onofre breccla, its nature and origin: Californa University Department of Geological Science Bulletin, v. 15, no. 7, p. 159-280.

\section{7}

Hazenbush, G.C., and Allen, D.R., 1958, Huntington Beach oll field: California oll Fields, v. 44, no. 1, p. 13-25 Los Angeles County Flood control District, 1968, Alamitos barrier project: Los Angeles County Flood Control District Report $67-68,44 \mathrm{p}$, append $\mathrm{x}$.

wall, J.R., Cordes, E.H., and Moreland, J.A., 1966 Progress report on salt-water intrusion studies, sunset and Bolsa Gaps, Orange County, California: v.s. Geological 


\section{CATEGORY 1: 15-MINUTE TOPOGRAPHIC QUADRANGLE MAPS}

\section{7--Continued}

Wall, J.R., Moreland, J.A., and Cordes, E.H., 1967, An investigation of potential salt-water intrusion from inland waterways in the shallow alluvial and coastal California: o.s. Geological Survey open-file report, $64 \mathrm{p}$

\section{8}

Arnold, Delos, and Arnold, Ralph, no date, The marıne pliocene and pleistocene stratigraphy of the coast of southern California: Journal of Geology, v. 10, p. 117-138.

California: Journal of Geology, va 10, p. 117-138. Alto, Calif.. Stanford University, M.A. thesis.

Arnold, Ralph, 1903 , The paleontology and stratigraphy of California: California Academy Science Memoirs, v. 3, 420 Cali

Arnold; Ralph, 1903, The paleontology and stratigraphy of the marine pliocene and pleistocene of San Pedro, California:

Barnes, S.0., 1938, The foraminifera of the Timms Point Formation at San Pedro, Los Angeles County, California: Los Angeles, University of Southern California, M.s. thesis.

Blake, W.P., 1856, Observations on the physical geography and geology of the coast of California from Bodega Bay to San Diego: U.S. Coast Survey Report 1855, p. 376-398.

clark, Alex, 1932, The cool-water Timms point Pleistocene horizon at San Pedro, California: pasadena, California Institute of Technology, M.S. thesis.

Farrand, W.H., 1929, The relation of a fossil foraminifera fauna from timms Point, San Pedro, to a Recent foraminifera fauna from off the coast of San Pedro, California: Los Angeles, University of Southern California, M.s. thesis.

Merriam, R.H., 1960, Portuguese Bend landslide, Palos Verde Hills, California: Journal of Geology, v. 68 , no. 2 , p. $140-153$

Moyer, D.A., 1929, The relation of a fossil foraminifera fauna from Lomita quarry. San Pedro, California, to a Recent foraminifera fauna of $f$ the coast of San Pedro, Californa: Los Angeles, University of Southern California, M.S. thesis.

schultz, J.R., 1937, Geology of the whites Point outfall sewer tunnel, California: Pasadena, California Institute of Technology, Ph.D. dissertation.

\section{4}

Uchupi, E., 1954, Submarine geology of the Santa Rosa-Cortes Ridge: Los Angeles, University of Southern Cal ifornia, M.s. thesis.

\section{3}

Hamilton, Warren, 1964, Geologic map of the Big Marza Mountains NE quadrangle, Riverside County, California and Yuma County, Arizona: v.s. Geological Survey Geologic Quadrangle Map GQ-350, scale $1: 24,000$

\section{4}

Jennings, C.W., and Saul, R.B., 1964, Reconnaissance geologic mapping and photo interpretation of a part of the Midiand quadrangle (calif.): California Division of Mines and Geology mapping for the State geologic map, scale $1: 62,500$.

Shklanka, R., 1963, Repeated metamorphism and deformation of evaporite-bearing sediments, Little Maria Mountains, disgertatia: Palo Alto, Calif

ver planck, W.E., Jr., 1950, Geology of a gypsum deposit in the Little Maria Mountains, Riverside County. Cal ifornia: Palo Alto, Calif., Stanford University, M.s. thesis.

\section{5}

Harder, E.G., 1910, Gypsum deposits of the Palen Mountains, California: U.S. Geological Survey Bulletin 430 , p. $407-416$.

Hoppin, R.A., 1951, The geology of the Palen Mountains gypsum deposit, Riverside County, California: Pasadena,

Hoppin, R.A. 1954, Geology of the palen Mountains gypsum deposit, Riverside County, Cal ifornia: California Division of Mines Special Report $36,25 \mathrm{p} ., 1 \mathrm{pl} ., 32 \mathrm{f} 1 \mathrm{gs}$.

Jennings, C.W. , Saul, R.B., and Rogers, T.H.,' 1964 , Reconnaissance geologic mapping and photo interpretation of the palen Mountains quadrangle (Calif.): Ca]ifornia Division of Mines and Geology mapping for the state geologic map, scale $1: 62,500$.

\section{5--Continued}

Simoni, T.R., Jr., 1981, Geophysical and lithologic data from test wells on Palen Dry Lake, Riverside County, California: U.S. Geolog.

\section{6}

Greene, R.P., 1968, Metamorphosed McCoy Mountains Formation, Coxcomb Mountains, California: Santa Barbara Calif., Dniversity of California, M.A. thesis, 50 p.

Hadley, Division of Mines Bulletin 129, p. 3-24, pls. 2 and 3 , Division of Mine
scale $1: 2,400$.

Jennings, C.W., and Rogers, T.H., 1965, Reconnaissance geologic mapping and photo interpretation of the Coxcomb Mountain Geology mapping for the State geologic map, scale 1:62,000.

0607

Harder, E.C., 1912, Iron ore deposits of the Eagle Mountains: U.s. Geological Survey Bulletin 503, 81 p.

Rogers, T.R., and Jennings, C.W., 1965, Reconnaiseance geologic mapping and photogeologic interpretation of the pinto Basin quadrangle: California Division of Mines and Geology, scale 1:62,500.

Scharf, David, 1935, The Quaternary history of Pinto basin: Highland Park, Calif., Southwest Museum Papers 9 , p. 11-20.

\section{8}

Rogers, T.R., and Jennings, C.W., 1965, Reconnaissance geologic mapping and photogeologic interpretation of the geologic mapping and photogeologic interpretation of the and Geology, scale $1: 62,500$.

\section{9}

Babcock, J.N., 1961, Geology of a portion of the pinyon Well quadrangle, Riverside County, California: Lo Angeles, Oniversity of Cal ifornia, M.A. thesis. tunnel of the Metropolitan water District of southern California: Pasadena, California Institute of Technology. ph.D. dissertation.

Popenoe, F.W., 1959, Geology of the southeastern Indio Hills, Riverside County, California: Los Angeles, University of California, M.S. thesis, $153 \mathrm{p}$

\section{0}

Buwalda, J.P., and stanton, w.L., 1930, Geological events in the history of the Indio Hills and the Salton Basin,

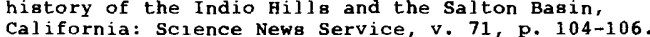
Sabins, F.S., 1967, Inf rared imagery and geology aspects of Indio Hills area, California: photogrammetric Engineering, July, p. $743-750$.

\section{1}

Bader, J.S., 1969, Data for selected water wells in the Palm Springs area, Riverside County, Cal ifornia: v.s. Geological Survey open-file report, $16 \mathrm{p}$.

Bramkamp, R.A., 1935, Stratigraphy and molluscan fauna of the Imperial Formation of San Gorgonio Pass, California: Berkeley, University of California, Ph.D. dissertation.

Calıfornia Department of Public Works, Division of Water Rights, 1923, Report on water supply and use of water from Whitewater River Stream System: California Division of Water Rights, Whitewater River Adjudication Proceedings.

California Department of Public Works, Division of Water Rights, 1928 , Order determining and establishing the several rights by appropriation to the use of the waters of Water Rights, whitewater River Adjudication proceedings.

Dibblee, T.W.. Jr., 1981, Geologic map of the Palm Springs quadrangle, California: South Coast Geological Society quadrangle, California: South Coast

Dutcher, L.C., and Bader, J.S., 1963, Geology and hydrology of Agua Caliente Spring, Palm Springs hydrology of Agua Caliente Spring, Palm Springs, California:

Garrett, A.A., and Dutcher, L.C., 1951, Possible effect of a road improvement on the flow of the Agua Caliente Spring, at Palm Springs, Riverside County, Cal ifornia: v.s. Geological Survey open-file report, 8 p. 


\section{1--Continued}

Lynch, H.B., 1949, Report on water supply at Palm Springs, California, and the Agua Caliente Indian Reservation: Consulting report.

Proctor, R.J., 1958, Geology of the Desert Hot Springs area, Little San Bernardino Mountains, California: Los Angeles. University of California, M.A. thesis.

Proctor, R.J., 1968, Geology of the Desert Hot Springs-upper Coachella valley area, California: California Division of Mines and Geology Special Report $94,49 \mathrm{p}$.

Sampson, R.J., 1932, Economic mineral deposits of the San Jacinto quadrangle, California: Mining in California, v. 28 , no. 1 , p. 3-11, map in pocket, scale $1: 125,000$.

Sydnor, R.H., 1975, Geology of the northeast lodes of the San Jacinto Pluton, Palm Springs, California: Riverside,

Tyley, S.J. 1973, Artificial M.A. thesis. River area, Palm Springs, California: $0 . s$. Geologi Survey open-file report, 51 p.

zander, G. 1923, Report on water supply and use of water from the Whitewater River Stream System: California Division of Water

zander, G., 1928, Order determining and establishing the several rights by appropriation to the use of the waters of the Whitewater River stream system, San Bernardino an Riverside Counties, California: California Division of

zander, G., 1938, Matter of determination of the relative rights of the various claimants to the waters of the Whitewater River and its tributaries: State of California, judgement of the superior court in and for the county of Riverside.

\section{2}

Allen, C.R., 1954, The San Andreas fault zone in San Gorgonio Pass, California: Pasadena, California Institute of Technology, Ph.D. dissertation.

Bloyd, R.M., Jr., 1967, Progress report on the ground-water investigation in the San Gorgonio pass area, California: U.S. Geological Survey open-file report. $6 \mathrm{p}$.

Bloyd, R.M., Jr.. 1969, Underground storage of imported water in the San Gorgonio Pass area, California: U.s. Geological Survey open-file report, $41 \mathrm{p}$.

Bloyd, R.M., Jr., 1971, Underground storage of imported water in the San Gorgonio Pass area, southern California: U.S. Geological Survey water-Supply Paper 1999-D, $37 \mathrm{p}$.

california Department of Water Resources, 1978, Water resources evaluation of the San Jacinto (Calif.) area: California Department of Water Resources Southern District Report.

clotts, H.V., 1920, Water development of Hathaway and Woods Canyon, Morongo Indian Reservation: U.S. Department of Interior, Indian Irrigation Service.

Dibblee, T.W., Jr., 1981, Geologic map of the Banning quadrangle, California: South Coast Geological Society, Geologic Map SCGS-2, scale $1: 62,500$.

Dutcher, L.C., 1960, Geology and ground-water hydrology of the Redlands-Beaumont a rea, California, with special
reference to ground-water outflow: U.S. Geological Survey open-file report, $352 \mathrm{p}$.

Gardner, D.L., 1949, Report on the water supply, geology, and hydrology of Potrero and Hathaway Canyons, Monongo Indian Reservation: Orange, Calif.. consulting report.

Russell, R.J., 1932, Land forms of San Gorgonio Pass. southern California: Unıversity of California Department of Geology, v. 5, no. 2, p. 23-121.

Tabor, E.F., 1896, Experiments on pumping from artesian wells at San Jacinto, California: Engineering News.

U.S. Army Corps of Engineers, 1974, Flood Plain information, San Gorgonio River and tributarıes, Riverside County, california: U.s. Army Corps of Engineers, $38 \mathrm{p}$.

vTN Consolidated, Inc.. 1975, Multiple purpose water resources investigation, Morongo Indian Reservation,
California: VTN Consolidated, Inc., Contract J50C14202671 for U.S. Bureau of Indian Affalrs, 160 p., apps. A-D, 56 tables, 46 figs.

\section{3}

Artim, E.R., 1968, Ground water levels and storage capacities, Moreno Valley, San Diego, California: San Daniel, Mann, Johnson, and Mendenhall, ig66, Perris Valley general plan, 1990: Riverside County planning Commission, $72 \mathrm{P}$.

Dibblee, T.W., Jr., 1981, Geologic map of the Perris quadrangle, California: South coast Geological Socrety, Geologic Map SCGS-1, scale 1:62,500.

Dudley, P.H., 1935, Geology of a portion of the Perris Block, southern California: California Journal of Mines and Geology, v. 31, no. 4, p. 487-506, scale $1: 160,000$.

English, H.D., 1953, The geology of the San Timoteo Badlands, Riverside County, California: Claremont, Calif., Pomona College, M. A, thesis

Frick, Childs, 1921, Extinct vertebrate faunas of the Badlands of Bautista Creek and San Timoteo Canyon,

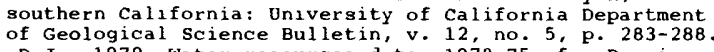

Lang, D.J., 1979 , Water resources data, $1970-75$, for Perris Geological Survey Open-File Report 79-1256, 144 p.

\section{3--Continued}

Miesch, A.T., and Morton, D.M., 1977, Chemical variability in the Lakeview Mountains pluton, southern California Batholith--a comparison of the methods of correspondence analysis and extended Q-mode factor analysis: U.S. Jan.-Feb., p. $103-116$.

Morton, D.M., 1966, Petrology of the Lakeview Mountains

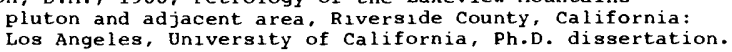

Morton, D.M., 1972, Geology of the Lakeview and Perris quadrangles, Riverside County, California: California Division of Mines and Geology Map Sheet 19, scale $1: 24,000$

shuler, E.H., 1953, Geology of a portion of the San Timoteo Canyon Badlands near Beaumont, California: Los Angeles, University of Southern California, M.S. thesis.

\section{4}

Hamliton, W.B., 1963, Geologic map of the Riverside and West Riverside Mountains: v.s. Geological Survey, scale $1: 24,000$.

Irving, E.M., 1935, The geology of a portion of the corona and Riverside quadrangles, near Corona, California: Los Angeles, University of Cailfornia, M.A. thesis.

Joshi, M.S., 1967, The genesis of the granitic and associated rocks of the Box Springs Mountains, Riverside, California: Riverside, University of California, Ph.D. dissertation. Riverside, University of California, Ph.D. dissertat
Machellan, D.D., 1936, A San Diego fauna in the vicinity of Val verde. Californı: Pasadena, California Institute of Technology, Ph.D. dissertation.

osborn, E.F., 1938, Micrometric and petrofabric studies of the Val Verde tonalite, southern California: Pasadena, the Val verde tonalite, southern California: Pasadena,

osborn. E.F., 1939, Structural petrology of the Val Verde tonalite, southern California: Geological Society of America Bu

Page, L.R., and Thayer, T.P., 1945, Tin deposits of the Temescal district, Riverside County, California: U.S. Geologica $1: 31,680$

Pampeyan, E.H., 1952, Geology of the Cajalco area, Riverside County, California: Claremont, Calif., Pomona College, M.A. thesis.

Troxell, H.C., 1933, Ground-water supply and natural losses in the valley of Santa Ana River between the
Riverside Narrows and the Orange County line: California Riverside Narrows and the Orange County line: California
Division of Water Resources Bulletin 44, pt. 2, p. 141-72.

Wilson, R.W., 1936, The heavy accessory minerals of the val Verde Tonalite: Pasadena, California Institute of Technology, Ph.D. dissertation.

\section{5}

Baier, D.C., 1970, Reevaluation of Prado water-quality objectives: American Water Works Association Journal, v. 62, p. $106-112$.

French, J.J., 1972, Ground-water outflow from chino basin. upper Santa Ana Valley, southern California: U.S. Ground-water outflow from the Chino basin, California, and Ground-water outflow from the chino basin, California, and the controling geologic and hydrologic cond

Gray, C.H. Jr. 1953 , Geologic structure southwest of Corona, California: Claremont, Calif.. Pomona college, M.A. thesis.

Gray, C.H., Jr.. 1961, Geology of the Corona south quadrangle and the Santa Ana Narrows area, Riverside, Orange, and San Bernardino Counties, California, and Mines and mineral deposits of the Corona south quadrangle, Riverside and Orange Counties, Calıfornia: California Division of Mines Bulletin 178, 120 p., 4 pls., 6 figs.

Hannah, W.G., 1952, A geologic report of the Gypsum Canyon area in the northern Santa Ana Mountians, California: Los

Hilton, G.S. 1950. Geology of a portion of the northeastern Santa Ana Mountains: Claremont, Calif. Pomona College, M.A. thesis.

Joseph, S.E., 1982, Mineral land classification of the Pacific clay Products, Inc., Thomas clay deposit, Corona, Riverside County, California: California Division of Mines and Geology County, California: Califor

Lamar, D.L., 1959, Geology of the Corona area, Orange, Riverside, and San Bernardino Countıes, California: Los Angeles, aniversity of California, M.A. thesis, 95 p., 3 charts, $3 \mathrm{fig.}$ and $6 \mathrm{pl}$.

Miller, R.v., and Tan, s.s.. 1983, Geologic map of part of the south half of the Black star Canyon quadrangle, Orange county, California: California Division of Mines and Geology Open-File Report 83-34 LA.

Vedder, J.G., 1950, The Eocene and Paleocene of the northwest Santa Ana Mountains: Claremont, Calif.. Pomona College, M.A. thesis.

wheeler, A.E., 1952, Upper Cretaceous foraminifera of the Santa Ana Mountains, California: Los Angeles, University of California, M.A. thesis. 


\section{7--Continued}

Adams, B.C., 1932, The stratigraphy of the northwestern spur of the Santa Ana Mountains: Palo Alto, Calif.. Stanford University, M.A. thesis.

Colburn, I.P., 1953, Stratigraphy and structure along the Whittier fault near Yorba Linda, California: Claremont, Calif., Pomona College, M.A. thesis.

Daviess, S.N., and Woodford, A.O., 1949, Geology of the northwestern puente Hills, Los Angeles County, California: U.S. Geological Survey Oil and Gas Preliminary Map 83, sheet 1 of 2 , scale $1: 12,000$

Durham, D.L., and Yerkes, R.F., 1959, Geologic map of the eastern Puente Hills, Los Angeles basin, California: U.s. Geological Survey $0 i 1$ and Gas Investigations Map OM-195. scale $1: 24,000$.

Durham, D.L., and Yerkes, R.F., 1964, Geology and o1l resources of the eastern Puente Hills area, southern $420-B$. B $1-B 62$.

Heath, E.G., 1954, Geology along the whittier fault north of Horseshoe Bend, Santa Ana Canyon, California:

Irwin, G.A., and Powers, W.R 3d, 1972, Water-quality reconnaissance of the lower Santa Ana Canyon, southern California: o.s. Geological survey open-file report, $18 \mathrm{p}$. southern' California: Claremont, Calif., Pomona College, M. A. thesis.

Kundert, C.J.. 1952, Geology of the Whittıer-La Habra area, Los Angeles County, California: California Division of Mines Special Report 18,22 p., pl. 1, scale $1: 24,000$

Lewis, L.A., 1941, Geology of the northern part of the Santa Ana Mountains, Orange County, California: Pasadena, California Institute of Technology. M.S. thesis.

Packard, E.L., 1916, Faunal studies in the cretaceous of the Santa Ana Mountains of southern California: University of California Department of Geological Sciences Bulletin, v. 9, p. 137-159.

Richmond, J.F., 1950, Geology of Burruel Radge, northwestérn Santa Ana Mountains, California: Claremont, Calif.. Pomona College, M.A. thesis.

Richmond, J.F., 1952, Geology of Burruel Ridge, northwestérn Santa Ana Mountains, California: Calıfornia Division of Mines Special Report 21, 16 .

Taylor, J.C., 1953, The petrology of some subsurface Miocene' sediments from the Brea oll field and vicinity. southern California: Claremont, Calif., Pomona College, M.A. thesis.

Yerkes, R.F., 1957, Volcanic rocks of the El Modeno area, Orange County, Cal ifornia: U.s. Geological Survey professional paper 274-L, p. 313-334.

Yerkes, R.F., 1957, Volcanic rocks of the El Modeno area, orange County, California: U.S. Geological Survey Professional paper 274-L, p. 313-334.

Yerkes, R.F.' 1960, Geologic map of the La Habra quadrangle,
western Puente Hills, Los Angeles basin (Calif.): U.S. Geological Survey Professional Paper 420-C, scale $1: 24,000$.

\section{7}

Berbower, R.F., 1959, Subsidence problem in the Long Beach Harbor District: American Society of Civil Engineers, 85, WW2, June 1959, Waterways and Harbors Division Proceedings. DeLong, J.H., Jr., 1939, The paleontology and stratigraphy
of the pleistocene at Signal Hill, California: Pasadena, California Institute of Technology, M.s. thesis.

Delong, J.H.' Jr., 1941, The paleontology and stratigraphy of the Pleistocene at Signal Hill, Long Beach, California: no. 25, p. $229-250$.

Dudley, P.H. 1943, East Coyote area of the Coyote Hllls oll field: California Division of Mines and Geology

Dudley, P.H., 1954, P. 349-354, fig. 146, scale $1: 40,000$. Los Angeles County in Geology of southern california: California Division of Mines and Geology Bulletin 170, map sheet 34 , scale $5 / 8$ inch $=1,200$ feet.

Eaton, G.P.. 1957, Miocene volcanic activity in the Los Angeles basin and vicinity: Pasadena, California Institute of Technology, Ph.D. dissertation.

Eaton, G.P.. 1958, Miocene volcanic activity in the Los Angeles basin (Calif.), in A guide to the geology and oil flelds of the Los Angeles and Ventura regions: American Association of Petroleum Geologists, Annual Meeting, March 1958 , p. 55-58

Eaton, J.E., 1933, Long Beach, California, earthquake of March 10, 1933: American Association of Petroleum Geologists Bulletin, v. 17, p. 732-738.

Ericson, D.B., 1933, Geology of the Whittier Hills, California: Pasadena, California Institute of Technology, M.S. thesis.

Garrett. A.A., 1949, status of salt-water contamination in the coastal part of orange County, Californa, as of 1948-49: U.S. Geological Survey open-file report, $36 \mathrm{p}$.

Garrett, A.A., 1951, Status of salt-water contamination in U.S. Geological Survey open-file report, $49 \mathrm{p}$

Garrett, A.A., 1952, Status of salt-water contamination in the coastal part of Orange County, California, as of 1951 U.s. Geological Survey open-file report, $49 \mathrm{p}$.

Gilluly, James, and Grant, U.S., 4th, 1949, Subsidence in
the Long Beach Harbor area, California: Geological Society of America Bulletin, v. 60, no. 3, p. 461-529.
Graves, D.T., 1954, Geology of the Dominguez oil field, Los Angeles County in Geology of southern California: scale $1: 12,000$.

Long Beach, City of, water Department, 1944, Historical sketch and annual report, July 1, 1943, to June 30, 1944: Long Beach, Calif., 120 o.

poland, J.F., 1944, Variations in chemical composition of Los Angeles Basin ground waters: Economic Geology, v. 39 no. 4, June-July 1944, p. 315-318.

slichter, C.s.. 1903, Measurements of the underflow at the Whitier Narrows of the Rio Hondo and San Gabriel River, California: Engineering Record, v. 48, p. 462-465.

Stolz, H.P., and Winckel, E.E., 1939, Subsurface correlation of a portion of the southwest flank of the Long Beach oll field, California, with particular reference to legal proceedings involving trespass deviational drilling: Los Angeles, University of Southern California, M.s. thesis.

Thomasson, H.G., Jr., 1961, Ground-water investigation along the Rio Hondo, Los Angeles County, California: u.s. Geological Survey open-file report, $90 \mathrm{p}$.

Thomasson, H.G., Jr., 1963, Ground-water investıgation a long the Rlo Hondo and lower Los Angeles River, Los Angeles County, California, appendix A to accompany 1961 report: U.S. Geological Survey open-file report, $134 \mathrm{p}$

Thomasson, H.G., Jr., Poland, J.F., and Eakin, T.E., 1947 , Ground-water investigation along the Rio Hondo and lower Los Angeles River, Los Angeles County, California-progress report no. 2: U.S. Geological Survey open-file report, $76 \mathrm{p}$.

Waring, C.W., 1914, Geology of southern Los Angeles and Orange county oll Fields: Petroleum Industry of Callforna: California State Mining Bureau Bulletin 69, p. 366 .

Wheatfili, E.L., 1957, The possibilities of locating and developing deeper aquifers to augment the water wel production for Long Beach, California: Los Angeles, University of California, M.A. thesis.

Willis, D.G. 1954 , Analysis of deformation in sedimentary rocks with application to the Newport-Inglewood uplift: palo Alto, Calif., Stanford Universtiy, Ph.D. dissertation.

Winterburn, Read, 1954 , Geology of the Wilmington oil fleld, Los Angeles County. Californla, in Geology of southern California: California Division of Mines and Geology Bulletin 170, map sheet 33

Zlelbauer, E.J., Burnham, W.L., and Keene, A.C., 1961, Coastal basin barrier and replenishment investigation, Alamitos barrier project geological investigation: Los Angeles county Flood Control District report, 28 p.

\section{8}

Driver, H.L., 1939, Inglewood oil fleld, Los Angeles County, California: Los Angeles, University of Southern Callfornia, M.s. thesis.

Edwards, E.c., 1933, Pl locene conglomerates of the Los Angeles Basin and their paleogeographic significance: Pasadena, California Institute of Technology, Ph.D. dissertation

Edwards, E.C., 1934, Pllocene conglonerates of the Los Angeles basin and their paleogeographic significance: American Association of Petroleum Geologists Bulletin, v. 18 , no. 6, p. 786-812.

Hopper, R.H., Bryson, R.P., 1939, Magnetic studies in the Inglewood district, California: Pasadena, California Institute of Technology, Ph.D. dissertation.

Kew, W.S.W., 1923, Geologic evidence bearing on the Inglewood (calif.) earthquake of June 21, 1920: Seismological Society of America Bulletin, v. 13, p. 155-158.

Kiessling, Edmund, 1963, Trip to Palos Verdes Hills: California Division of Mines and Geology Mineral Information Service. v. 16 , no. 11, p. $9-14$

Lawson, A.C., 1893, The post-Pliocene diastrophism of the coast of southern california: Unıversity of California Department of Geology Bulletin, v. 1, no. 4, p. 115-160.

Los Angeles County flood Control District, 1957, Sea water intrusion in California, appendix B: California Department of Water Resources Bulletin 63, 141 p.; part 2, p. 18-141.

Marlette, J.W., 1955. The breakwater at Redondo Beach, california, and its effects on erosion and sedimentation: Los Angeles, University of Southern California, M.A. thesis.

Merrlam, P.D., 1950, Geology of the El Segundo sand hills, California: Los Angeles, University of Southern California, M.s. thesis.

Miller, G.A., Bielefeld, R.J., eds., 1974, Guidebook of selected features of Palos Verdes and Long Beach, California: South Coast Geological Society, $92 \mathrm{p}$.

Moore, H.L., 1937, pleistocene fauna of Centinela Park Inglewood, California: Los Angeles, University of Southern California, M.A. thesis.

Page, G.B., 1950, Beach erosion and composition of sand dunes, Playa del Rey-El Segundo area, California: Los Angeles, University of California, M.A. thesis.

Redmond, C.D., 1936, Paleontology and stratigraphy of the Lomita Formation: Los Angeles, University of California, M.A. thesis.

Sinclair, J.T., 1943, Subsurface geology of the sentous zone development, Inglewood oil field, California: Los

sinnott, Allen, 1947, Geology, hydrology, and chemical character of the ground waters in the Torrance-santa Monica area, Los Angeles County, California: v.S.
Geological Survey open-file report, pl. 302, 1:48,000. 
Tieje, A.J., 1926, The Pliocene and Plelstocene history of the Baldwin Hills, Los Angeles County, California: American Association of Petroleum Geologists Bulletin, v. American As8ociation of

Tovel1, W.M., 1942, Geology of the nodular shale of the middle and upper Miocene of the western Los Angeles Basin:

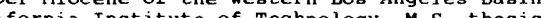

U.S. Geological Survey, 1964, Preliminary report on recent surface movements through July 1962 in the Baldwin Hills, surface movenents through July 1962 in the Baldwin Hills, open-file report, $30 \mathrm{p}$.

willett, George, 1937, An upper plelstocene fauna from the Baldwin Hills, Los Angeles County, Callfornia: San Diego Society of Natural History Transactions, v. 8, no. 30, p. Society

Wintucki, G.S., 1959, A study of subsidence in the Wilmington oul field, California: Los Angeles, University

woodring, W.P., Bramlette, M.N., and Kew, w.s.w., 1946 Geology and paleontology of Palos Verdes Hills. california: U.S. Geological Survey Professional paper 207 $145 \mathrm{p}$.

Woodring, W.P., Bramlette, M.N., and Kleinpell, R.M. 1936, Miocene stratigraphy and paleontology of Palos Verdes Hills. California: American Association of Petroleum Geologists Bulletin, v. 20, no. 2, p. 125-149,
fig. 1, gcale 1:62,500.

\section{9}

MacDonald, G.A., 1934, Sediments of Santa Monica Bay (Calif.) Los Angeles, University of California, M.A. thesis.

\section{5}

Orr, P.C., 1960, Late Pleistocene marine terraces on Santa Rosa Island, California: Geological Society of America Bulletin, v. 71, p. 1113-1119.

\section{3}

Healey, D.L., and Currey, F.E., 1980, Complete Bouguer gravity anomaly map of the Vidal area, California and Arizona: U.S. Geological

Saul, R.B., 1963, Reconnaissance geology and photogeologic interpretation of part of the vidal quadrangle. California: California Division of Mines and Geology scale $1: 62,500$

\section{4}

Saul, R.B., 1963, Reconnaissance geology and photogeologic interpretation of part of the Rice quadrangle, California
California Division of Mines and Geology, scale $1: 62,500$.

0705

Laney, C.A., 1948, Iron Mountain 1ron-ore deposits, Lava Bed district, San Bernardino, California: California Division district, San Bernardino, Califor
of Mines Bulletin 129 , p. 25-38.

\section{7}

Harder, E.C., and Rich, J.L., 1910, The Iron Age iron-ore deposit near Dale, San Bernardino County, California: u.s. $1: 3,600$.

Rogers, T.H., and Jennings, C.W., 1964, Reconnaissance geologic map and photogeologic interpretation of the Dale gake quadrangle, california: California Division of mine and Geology, mapping for the state geologic map. scale $1: 62,500$.

0708

Evans, J.R., 1964, Xenotime mineralization in the southern Music Valley area, Riverside County, California: Music Valley area, Riverside County, California: California Division of Mines and Geology Special Report 79,24 p., map 1 , Geologic map

Rogers, T.H., and Jennings, C.W., 1964 , Reconnaissance geologic map and photogeologic interpretation of the geologic map and photogeologic interpretation of southern part of the valley Mountain quadrangle, California: California Division of Mines and Geology

\section{9}

Bader, J.S., 1963, Effect of faulting in alluvium on the occurrence, movement, and quality of ground water in the Twentynine Palms area, California labs.l: Geologica Society of Amer1ca Special paper 73, p. 22

California Department of Water Resources, 1984, Twenty Nine Palms ground water study: California Department of Water Resources

Dibblee, T.W., Jr., 1968, Geologic map of the Twentynine Palms quadrangle, San Bernardino and Riverside Counties, California: U.S. Geological Survey Miscellaneous Investigations Map $1-561,3 \mathrm{p} .$. scale $1: 62,500$.

Freckleton, J.R... 1982, Ground water in the Twentynine Palms Indian Reservation and vicinity, San Bernardino County, California: U.S. Geological Survey water-Resources Investigations report $82-4060,46 \mathrm{p}$.

Koehler, J.H., Twentynine PaIms Marıne Corps Base, Bagdad area, California U.S. Geological Survey Water-Resources Investigations Report 83-4053, $19 \mathrm{p}$.

Miller, W.J., 1938, Precambrian and associated rocks nea Twentynine Palms, Cal ifornia: Geological Society of America Bulletin, v. 49, no. 3, p. 417-446. near Twenty-Nine Palms, California: Pasadena, CaIifornia Institute of Technology, Ph.D. dissertation.

\section{0}

Dibblee, T.W., Jr., 1967, Geologic map of the Joshua Tree quadrangle, San Bernardino and Riverside Counties. California: U.S. Geological Survey Miscellaneous Investigations Map I-516, 3 p., scale $1: 62,500$.

Hofmann, Walter, 1953, Estimated runoff of Pipes Creek, California: U.S. Geological Survey open-file report, 9 p. Wagner, W.o., and Associates, 1963, Water resources investigation of the Warren Valley. San Bernardino County, California: Pasadena, Calif., consulting report for the
Joshua Forest Water Company, is p.

\section{1}

Bader, J.S., and Moyle, W.R., Jr., 1958, Data on water wells and springs in Morongo Valley and vicinity, San Bernardino and Riverside Counties, California: U.s. Geological Survey open-file report, $31 \mathrm{p}$.

Dibblee T.W. Jr. 1967 Geologic map of the Morongo val ley quadrangle, San Bernardino and Riverside counties, California: U.S. Geological Survey Miscellaneous

Giessner, F.W., 1964, A reconnaissance of the geology and water resources of the Mission Creek Indian Reservation, Riverside County, California: U.S. Geological Survey

open-file report, $31 \mathrm{p}$.
Vaughan, F.E., 1916, Geology of the San Bernardino Mountains north of San Gorgonio Pass: Berkeley, University of California, M.S. thesig.

vaughan, F.E.. 1918, Geology of San Bernardino Mountains, north of San Gorgonio Pass: Berkeley, University of California, Ph.D. dissertation.

vaughan, F.E., 1922, Geology of San Bernardino Mountaing north of San Gorgonio Pass: University of California Department of Geological Science, v. 13, no. 9, p.

\section{2}

Allen, C.R., 1954, Geology of the north side of San Gorgonio Pass, Riverside County, in Geology of southern California: California Division of Mines and Geology Bulletin 170, map sheet 20 , scale $1: 62,500$.

Allen, C.R., 1957, San Andreas fault zone in San Gorgonio Pass, southern Californı: Geologic Society of America Bulletin, v. 68, no. 3, p. 315-350

1964, Geologic map of the San Gorgonio Mountain quadrangle, San Bernardino and Riverside Counties, U.S. Geological Survey Miscellaneous Investiga tions Map I-431, 3 p., scale 1:62,500

Morton, D.M. Cox, B.F and Matt 1, J,C 1980, Geologic map of the San Gorgonio Wilderness, San Bernardino county, California: U.S. Geological Survey Mrscellaneous Field Studies Map MF-1161-A, 1 gheet, gcale $1: 62,500$

\section{3}

Dana, S.W., 1970, A gravimetric survey of the Yucaipa quadrangle: Consultant report Eng-70-E3, $31 \mathrm{p}$. Dibblee, T.w., Jr., 1968, Geologic map of the Redland quadrangle: U.S. Geological Survey open-file report, scale

Dibblee, T.W., Jr., 1968, Geologic map of the Yucaipa quadrangle, San Bernardino County, California: U.s.

Dutcher, L.C., and Burnham, w.L., 1960, Geology and ground-water hydrology of the Mill Creek area, San Bernardino county, california: U.S. Geological Survey open-file report, $226 \mathrm{p}$. 


\section{3--Continued}

Eccles, L.A., and Bradford, W.L., 1977, Distribution of nitrate in ground water, Redlands, California: U.S. Geological Survey Water-Resources Investigations report 76-117, $38 \mathrm{p}$.

Eccles, L.A., and Klein, J.M., 1978, Distribution of dissolved nitrate and fluoride in ground water, Highland-East
Highlands, San Bernardino County, California: u.s. Geological Survey Water-Resources Investigations Report $78-14,42 \mathrm{p}$.

Finkle, F.C., and Rowe, W.P., 1933, Report on water spreading, Santa Ana-Mili Creek cones: Consulting letter report to The Irvine Company, $121 \mathrm{p}$.

Klein, J.M., and Bradford, W.L., 1979, Distribution of nitrate and related nitrogen species in the unsaturated zone, Redlands and vicinity. San Bernardino County, California u.s. Geological Survey Water-Resources Investigations report $79-60,81 \mathrm{p}$

Klein, J.M., and Bradford, W.L., 1980, Distribution of nitrate in the unsaturated zone, Highland - East Highlands area, water-Resources Investigations report $80-48,76 \mathrm{p}$.

Matti, J.C., 1985, Preliminary landslide map of the Yucaipa quadrangle, California: U.S. Geological Survey open-file Report 84-520, scale $1: 24,000$.

Moreland, J.A., 1970, Artificial recharge, Yucaipa, california: U.s. Geological Survey open-file report, 44 p.

Morton, D.M., 1978, Geologic map of the Redlands quadrangle, San Bernardino and Riverside Counties, California: U.S. Geological Survey Open-file Report 78-21, 1 pl.. scale $1: 24,000$.

Owens, G.v., 1959, Sedimentary rocks of lower Mill Creek, San Bernardino Mountains, California: claremont, Calif., Pomona College, M.A. thesis.

Powers, W.R., 3d, and Hardt, W.F., 1974, Oak Glen water-resources development study using modeling techniques, San Bernardino county, California: U.S. Geological Survey Water-Resources Investigations report $31-74,59 \mathrm{p}$.

Ruiz, E.J., 1954, A study of the safe yield and replenishment conditions for the Yucaipa basin area, california: Pasadena, California Institute of Technology, G.E. thesis.

Scherb, I.V.. 1936, An investigation of the Mill Creek earthquake of October, 1935: Pasadena, California Institute of Technology, M.S. thesis.

Smith, R.E., 1960, Geology of Mills Creek area, San Bernardino County, California: Los Angeles, University of California, M.A. thesis.

\section{4}

Arnett, G.R., 1949, Geology of the Lytle Creek area, California: Compass, v. 26 , no. 4, p. 205-304, fig. 2 scale $1: 62,500$

Ayers, R.s., and Branson, R.L., eds., 1973, Nitrates in the upper Santa Ana River basin in relation to ground-water pollution: University of California, Kearney Foundation, California Experimental Station Bulletin $861,59 \mathrm{p}$.

Buchholtz, H.F.. 1960, The fracture pattern in the Crestmore Mine, southern Cal ifornia: claremont, Calif. Pomona College, M.A. thesis.

Burnham, W.L., 1953, The geology and ground-wate conditions of the Etiwanda-Fontana area, California claremont, Calif., Pomona College, M.S. thesis, 88 p.

CDM, Inc., 1976, San Bernardino basin ground water levels, spring 1975: Pasadena, Calif., CDM, Inc., Environmenta Engineers, 1 map.

California Department of Public Works, Division of Water Resources, 1953, Effect of waste discharges from the Culligan Zeolite Company, San Bernardino County: California Division of Water Resources, $58 \mathrm{p}$.

Cooney, R.L., 1956, The mineralogy of the Jensen and Henshaw quarries, near Riverside, California: Los Angeles, University of California, M.A. thesis.

Daly, J.W., 1931, The geology and mineralogy of the limestone deposits at Crestmore, Riverside county, California: Pasadena, California Institute of Technology, M.s. thesis.

Daly, J.W., 1935, Paragenesis of the mineral assemblage at Crestmore, Riverside County, California: American
Mineralogist, v. 20, no. 9, p. 638-659, scale $1: 3,600$.

Mineralogist, v. 20, no. 9, p. 638-659, scale
Dibblee, T.w. Jr., 1963 , Geologic map of the San Bernardino quadrangle: v.s. Geological Survey open-file report, scale $1: 62,500$.

Dutcher, L.C., 1965, Progress report on water studies in the Bloomington-Colton area, upper Santa Ana valley. California, 1964: U.S. Geological Survey open-file report, $30 \mathrm{p}$.

Dutcher, L.C., and Garrett, A.A., 1958, Geologic and hydrologic features of the San Bernardino area, California, with special reference to underflow across the San Jacinto fault: U.S. Geological Survey open-file report, $215 \mathrm{p}$

Dutcher, L.C., and Garrett, A.A., 1963, Geologic and hydrologic features of the San Bernardino area, California, with special reference to underflow across the San Jacinto fault: u.s. Geological Survey Water-Supply Paper 1419, $114 \mathrm{p}$.

Dutcher, L.c., and Moyle, W.R., Jr. 1964 , Preliminary appraisai of the test-weil driling program in th Bloomington-Colton area, San Bernardino County, California: U.S. Geological Survey preliminary report.

Eccles, L.A., 1979, Ground-water quality in the upper

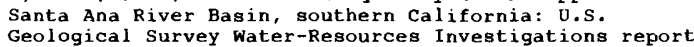
$79-113,55$ p.

\section{4--Continued}

Elliot, G.A., 1932, Effect of conservation through spreading of Santa Ana River water in the San Bernardino Valley on the water supply of Orange County: Engineering p.

French, J.J., 1966, Progress report on proposed ground-water studies in the Lytle Creek-San Sevaine area, upper Santa Ana Valley,

Garrett, A.A., and Dutcher, L.C., 1954, Tables of basic data for the San Bernardino area, California: U.S. Geological Survey open-file report, $170 \mathrm{p}$.

Gosling, A.W., 1967, Patterns of subsurface flow in the Bloomington-Colton area, upper Santa Ana Valley, California: U.S. Geological Survey Hydrologic

Investigations Atlas HA-268, scale 1:24,000.
Hardt, W.F., and Hutchinson, C.B., 1980, Development and use of a mathematical model of the San Bernardino valley ground-water basin, California: 0.S. Geological Survey Open-File Report 80-576, 80 p.

LaRue, E.C., 1916, Confidential report concerning proposed diversions on Lytle Creek (Calif.) by the Fontana Development Co.: Consulting report, $13 \mathrm{p}$.

Laverty, F.B., 1969, San Bernardino basin ground-water levels, spring 1969: Pasadena, Calif., F.B. Laverty, consulting engineer, 1 map.

Lee, C.H., 1912, Subterranean storage of flood waters by artificial methods in San Bernardino Valley, California: Sacramento, Calif., Conservation Commission of California Report for 1912, p. 335-400, 3 pls.

Lippincott, J.B., 1898, Water supply of the San Bernardino valley (Calif.): U.S. Geological Survey Annual Report 19 , pt. 4 , p. $540-632$.

MacKevett, E.M., 1950, The geology of the Jurupa Mountains, San Bernardino and Riverside Counties, California: Pasadena, Cal ifornia Institute of Technology, M.s. thesis.

Mackevett, E.M., 1951, Geology of the Jurupa Mountains, San Bernardino and Riverside Counties, California:

Mcclelland, E.J., 1963, Aquifer-test compilation for the upper Santa Ana valley area, San Bernardino County, California: U.S. Geological Survey open-file report, 29

McConaughy, C.E., 1982, Reconnalssance water-balance study of Lake Gregory, California: U.S. Geological Survey Open-File Report 82-367, 21 p.

Mendenhall, w.c., 1902, Development and application of water near San Bernardino, Colton, and Riverside, 141 p.. pt. 1, p. 1-95; Water-Supply Paper 60, pt. 2, p. 97-141.

Mendenhall, w.C., 1905, The hydrology of San Bernardino Valley, California: U.S. Geological Survey Water-Supply Paper $142,124 \mathrm{p}$.

Miller, F.K., 1979, Geologic map of the San Bernardino North quadrangle, San Bernardino County, California: v.s. Geological Survey Open-File Report 79-770, scale 1:24,000.

Morton, D.M., 1978, Geologic map of the Fontana quadrangle, San Bernardino and Riverside Counties, $78-19$ 1. pl.. scale 1:24,000

Morton, D.M., 1978, Geologic map of the San Bernardino South quadrangle, San Bernardino and Riverside Counties, California: u.s. Geological Survey Open-file Report 78-20, 1 pl., scale $1: 24,000$.

Morton, D.M., 1978, Geologic map of the San Bernardino South quadrangle, San Bernardino and Riverside Counties, California: U.S. Geological Survey Open-File Report 78-20, 1 pl., scale $1: 24,000$.

Motokane, E.S., 1971, Alternative plans of operations in Meeting water demands in the Bunker Hill-San Timeteo area, Calıfornia: California Department of Water Resources Report, p. 303-338.

Muckel, D.C., and Aronovicl, V.S., 1952, Rainfall and irrigation water penetration in the upper Santa Ana Soil Conservation Service, 101 p.

Schaefer, D.H., 1975, Letter on results of percolation test at Rialto forwarded to San Bernardino Valley Municipal Water District October 29, 1975: U.S

Geological Survey Report.
Schaefer, D.H., and Warner, J.w., 1975, Artificial recharge in the upper Santa Ana River area, San Bernardino County, California: U.S. Geological Survey water-Resource Investigations 15-75, $27 \mathrm{p}$.

Smith, Alexander, 1947, Structural petrology, Crestmore, California: Pasadena, California Institute of Technology, Ph.D. dissertation.

Warner, J.w., and Moreland, J.A., 1972, Artificial recharge, East Twin Creek-Waterman Canyon area,

water Resources Engineers, Inc., 1969, An investigation of salt balance in the upper Santa Ana River basin Consulting report presented to the California state water Resources Control Board and the Santa Ana River Basin Regional Water Quality Control Board, $197 \mathrm{p}$.

Willingham, C.R., 1968, A gravity map of the San Bernardino Valley, southern California: Riverside, University of California, M.A. thesis.

Yerkes, R.F., 1951, Geology of a portion of the Cajon Pass area, California: claremont, Calif., Pomona college, Claremont Graduate School, M.A. thesis, 96 p. 
Baird, A.K., 1956, Geology of a portion of San Antonio Canyon, San Gabriel Mountaıns: Claremont, Calıf., Pomona College, M.A. thesis.

Dennis, P.E., 1942, Geology of San Antonio Canyon, California, in relation to ground-water storage: $0 . s$.

Geological Survey open-file report, $37 \mathrm{p} ., 3 \mathrm{pls}$. district, southern California: Journal of Geology, v. 36 , no. 3, p. 225-247, fig. 3, scale $1: 160,000$.

Ehlig, P.L., 1958, The geology of the Mount Baldy region of the San Gabriel Mountalns, California: Los Angeles,

University of California, Ph.D. dissertation.
Hsu, K.J., 1954, Petrology of the Cucamonga Canyon-San Antonio Canyon area, southeastern San Gabriel Mountains, Californa: Los Angeles, University of California, Ph.D. dissertation.

Hsu, K.J., 1955, Granulites and mylonites of the region about Cucamonga and San Antonio Canyons, San Gabriel Mountains, California: University of California Publications in Geological Science, v. 30, no. 4, p. 223-352, map 1, scale 1:24,000.

Koehler, J.H., 1982, Artificial recharge in the northern part of Chino ground-water basin, upper Santa Ana Valley,
California: v.s. Geological Survey Water-Resources Investigations Report 82-4122, $27 \mathrm{p}$.

singer, J.A., and Price, McGlone, 1971, Flood of January 1969 near Cucamonga, Californa:

\section{6}

Akman, M.S., 1943, A map area south of Spadra, two and one-half miles southwest of Pomona, California: Pasadena, California Institute of Technology, M.s. thesis.

Bellemin, G., 1938, A petrologic study of the whittier thesis.

Bellemin, G.J., 1940, Petrology of whittier conglomerates, southern California: American Association of Petroleum Geologists Bulletin, v. 24, p. 649-671, fig. 2, scale $1: 42,240$.

Crowder, D.F., 1967, Mineral resources of the Devil Canyon-Bear Canyon Primitive Area, California: U.S. Geological Survey Bulletin 1230-G, 21 p.

Cutsforth, D.H., 1949, The geology of a portion of the San Jose Hills: Pasadena, California Institute of Technology, M.S. thesis.

English, W.A., 1926, Geology and oil resources of the Puente Hill region, southern California: U.S. Geological Survey Bulletin 768, 110 p., scale 1:62,500.

Giessner, F.W., and Price, McGlone, 1971, Flood of January 1969 near Azusa and Glendora, California: 0.S. Geological Survey Hydrological Investıgations Atlas HA-424, 1 sheet.

Harshman, E.N., 1933, Geology of the San Joge Hills, Los Angeles County, California: Pasadena, Calıf., California Institute of Technology, M.S, thesis.

Mul1, B.H., 1935, Miocene volcanics of the San Jose H111s (Calif.): Berkeley, University of California, M.A. thesis.

olmsted, F.H., 1948, Geology of Little Puente Hills, and western San Jose Hills, California: Claremont, Calif.

Pomona College, M.A. thesis. ed, F.H., 1950, Geology and oil prospects of western San Jose Hills, Los Angeles County, Calıfornia: Californıa pl. 23, scale $1: 24,000$.

Price, M.C., 1953, Geology of the southeastern Puente Hills: claremont, Calıf., Pomona College, M.A. thesis.

cott, K.M., 1971, Origin and sedımentology of 1969 debris flows near Glendora, California: U.s. Geological Survey Professional paper $750-\mathrm{C}$, p. 242-247.

Shelton, J.S., 1947, The Miocene Glendora Volcanics in eastern Los Angeles County, California: New Haven, Conn.. Yale Unlversity, Ph.D. dissertation.

Shelton, J.S., 1954, Miocene volcanism in coastal southern California, in Geology of southern California: California Division of Mines Bulletin 170, chap. 7, p. 31-36.

Shelton, J.S., 1955, Glendora volcanic rocks, Los Angeles Basin, Callfornia: Geological Soclety of America Bulletin, v. 66, no. 1 , p. 45-89; pl. 1, scale 1:24,000.

Trew, J.R., 1956, Slope development in the San Dimas experimental forest, Calıfornia: Providence, R.I., Brown University, M.S. thesis.

woodford, A.o., Moran, T.G., and Shelton, J.S., 1946 Miocene conglomerates of Puente and San Jose Hilis, California: American Association of Petroleum Geologists Bulletin, v. 30, no. 4, p. 514-560, scale $1: 120,000$.

woodford, A.O., Shelton, J.S., and Moran, T.G., 1944, Geology and oil possibilities of the San Jose Hills, California: 0.s. Geological Survey Oil and Gas Investigation Map 23 , scale $1: 62,500$.

\section{7}

Allen, C.w., 1949, Structure of the northwestern Puente Hills, Los Angeles County, California: Pasadena,

Baudino, F.J., 1934, The geology of the Glendale quadrangle, Los Angeles County, California: Los Angeles, University of Southern California, M.A. thesis.

Buwalda, J.P., 1940, Geologic map of Raymond basin: Consulting report prepared for Pasadena Water Department scale $1: 24,000$
Calıfornia Department of Water Resources, 1961,

Investigation of the ground water quality impairment near Investigation of the ground water quality mpairment near California Department of Water Resources, project 4104-4124, $28 \mathrm{p}$., $5 \mathrm{pls}$.

Dawdy, D.R., and Lxchty, R.w., 1968, Methodology of hydrologic model building--the use of analog and digital computers in hydrology: International Association of Science Hydrology, v. 2, p. 347-355.

Dudley, P.H., Jr., 1955, Geology of the a rea adjacent to the Arroyo Seco Parkway, Los Angeles County, California: Los Angeles, University of California, M.A. thesis.

Edwards, E.C., 1933, Foraminifera of the Repetto Hills: Pasadena, California Institute of Techology, Ph.D. dissertation.

Frankian, R.T., and Associates, 1968, Report of geologic and soll investigation, Verdugo Mountains development and conservation study: Consulting report for Glendale, Calif., scale 1 inch $=400 \mathrm{feet}$

Hsu, E.Y., 1982, Investigation and inventory of slope failures that occurred in 1978 and 1980 in the Los Angeles 7.5 minute quadrangle, Los Angeles County, California: California

Johnson, H.R., and Warren, V.C., 1927, Geological and
Johison of Mines and Geology Open-File Report structural conditions of the San Gabriel valley region: structural conditions of the San Gabriel Valley region:
California Division of water Rights Bulletin 5, p. 73-100.

Jordan, L.W., Ke1m, P.F., and Thayer, W.N., 1938, Report on spreading grounds below Whittier narrows Rio Hondo Spreading Operations (Calif.): Los Angeles County Flood Control District report, $50 \mathrm{p}$.

Karubian, R.Y., 1940, Surface and subsurface geology of Montebello Hills, California: Pasadena, California Institute of Technology, M.S. thesis.

Lamar, D.L., 1961, Structural evolution of the northern margin of the Los Angeles basin: Los Angeles, Unıversity of California, Ph.D. dissertation, scale $1: 12,000$.

Lamar, D.L., 1968, Geology of the Elysian Park-Repetto Hills area, Los Angeles County, California: California Division of Mines and Geology, map, scale $1: 24,000$.

Morton, D.M., 1968, Geologic map of the SE $1 / 4$ of the Mount Wilson quadrangle (Calif.): California Division of Mines and Geology, scale $1: 12,000$.

proctor, R.J., and Payne, C.M., 1972, Evidence for, and engineering consequences of, recent activity along the sierra Madre fault zone, southern California (abs.): Geological Society of America, Cordilleran Section, Meeting at Honolulu, Hawai, p. 220-221.

Quarles, Miller, Jr., 1941, Geology of the Repetto and Montebello Hilis: Pasadena, California Institute of Mechnology, M.S. thesis, scale $1: 24,000$.

Sanford, A.R., 1958, An analytical and experimental study ord, A.R. 1958, An analytical and experimental study
of some simple geologic structures: Pasadena, California of some simple geologic structures: Pasadena,
Institute of Technology. Ph.D. dissertation.

Institute of Technology, Ph.D. dissertation.
Sanford, A.R., 1958, Gravity survey of a part of the Raymond and San Gabriel basıns, southern California: Pasadena, California Institute of Technology, Ph.D. dissertation.

Soper, E.K., and Grant, U.S., 4th, 1932, Geology and paleontology of a portion of Los Angeles, California: Geological Society of America Bull
$1041-1067$; fig. 1 , scale $1: 14,400$.

stark, H.E., 1949, Geology and paleontology of the northern Whittier Hilis, Cal

stone, Robert. 1962, Geologic and engineerung significance of changes in elevation revealed by precise leveling, Los Angeles area, California (abs.): Geological Society of America Special Paper 68, p. 57-58.

Taylor, G.F., 1931, Geology of the Merced Hills, Los Angeles County, California, with a section on the radioactivity of the oils and waters: Pasadena, California institute of Technology, M.S. thesis.

Troxell, H.C., and Lord, R.S., 1941, Transient flood peaks (discussion): Transactions of American Civil Englneers, v. 106, p. 239-51.

Troxell, H.C., and Peterson, J.Q., 1937, Flood in La

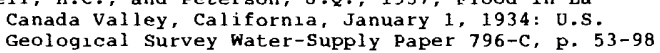

Weldon, J.B., 1955, The geology of the Pasadena-Eagle Rock area, Los Angeles county, California: Claremont, Calif.. area, Los Angeles County, Cal
Pomona College, M.A. thesis.

Wentworth, C.M., Z1ony, J.I., and Buchanan, J.M., 1970. Preliminary geologic environmental map of the greater Los Angeles area, California: o.s. Geological Survey Angeles area, Ca
TID $-25363,41 \mathrm{p}$.

Yongul, Sulh1, 1944, Magnetıc survey of the San Gabriel Wash (Calıf.): Pasadena, California Institute of Technology, M.s. thesis.

\section{8}

Carlson, H.W., 1945, Geology of the Elysian Park-Silver Lake district: Pasadena, California Institute of Technology, M.s. thesis.

Castle, R.O., 1960, Geology of the Baldwin Hills area, Californı: U.S. Geological Survey open-file report, scale $1: 12,000$

Chawner, W.D., 1934, The Montrose-La Crescenta flood of January 1, 1934, and its sedimentary aspects: Pasadena, California Institute of Technology, M.s. thesis.

Dutcher, L.C., 1955, Possibilities for developing productive water wells at the Veterans Administration open-file report, $16 \mathrm{p}$. 


\section{8--Continued}

Elliott, J.L., 1951, Geology of the eastern Santa Monica Mountains, between Laurel Canyon and Beverly Glenn Boulevards, Los Angeles County, California: Los Angeles, University of California, M.A. thesis, scale $1: 12,000$.

Frost, F.H., 1927, The pleistocene flora of Rancho La Brea (Calif.): Berkeley, University of California, Ph.D. dissertation.

Hardey, G.W., 1958, Stratigraphy of the Topanga Formation in the eastern Santa Monica Mountalns: Los Angeles,
University of California, M.A. thesis, scale $1: 12,000$.

Harding, T.P., 1952, Geology of the eastern Santa Monica Mountains between Dry Canyon and Franklin Canyon: Los Angeles, University of California, M.A. thesis, scale $1: 10,000$.

Howard, Hildegarde, 1926, A review of the fossil bird Parapavo Californicus from the pleistocene asphalt beds at Rancho La Brea (Calif.): Berkeley, Calif.. University of California, M.A. thesis.

Howard, Hildegarde, 1960 , Significance of carbon-14 dates for Rancho La Brea: Science, v. 131, no. 3402, p. 712-714.

Howell, B.F., Jr., 1954, Geology of the Little Tujunga area, Los Angeles County in Geology of southern
California: California Division of Mines Bulletin 170, map California: California Divi
sheet 10 , scale $1: 31,680$

Jennings, C.W., and Saul, R.B., 1969, Reconnalssance geologic mapping and photo interpretation of part of the Burbank

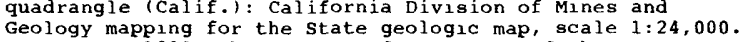

Johnston, R.L., 1938, The geology of a portion of the western Verdugo Mountains (Calif.): Los Angeles, University of California, M.A. thesis, scale approx. $1: 12,000$.

Lohman, S.W., 1932, Report on water supply for U.s. Veterans Hospital near San Fernando, California: U.S. Geological Survey open-file report, $8 \mathrm{p}$.

Neuerburg, G.J., 1951, Petrology of the pre-cretaceous rocks of the Santa Monica Mountalns, California: Los Angeles, University of California, Ph.D. dissertation, map, scale 1 inch $=400$ feet.

Neuerburg, G.J., 1953, Geology of the Griffith Park area, Los Angeles County, California: Calıfornia Division of Mines Special Report 33,29 p., pl. 1, scale $1: 20,000$

Nigra, J.O., 1946, A statistical study of the metapodials of the dire wolf from the Pleistocene of Rancho La Brea (Calif.): Pasadena, California Institute of Technology, M.s. thesis.

Pierce, R.L., 1956, Mohnian foraminifera and fish from Benedict Canyon, Sherman Oaks, Calıfornia: Los Angeles,

University of Southern California, M.A. thesis.

helton, J.s, '1946, Geologic map of northeast margin of
San Gabriel Basin, Los Angeles County, California: o.s. Geological Survey 011 and Gas Investigations Preliminary Map 63, scale $1: 24,000$

Soper, E.K., 1943 , Los Angeles city oll field, Calıfornia:
California Division of Mines Bulletin 118, p. 282-283, California Division of Mi

Stock, Chester, 1930, Rancho La Brea; a record of Pleistocene life in Callfornia: Los Angeles Museum Publication $1,82 \mathrm{p}$.

Terpening, J.N., 1951, Geology of part of the eastern Santa Monica Mountains: Los Angeles, University of cal ifornia, M.A. thesis.

Traxler, J.D., 1948, Geology of the east central santa Monica Mountains: Los Angeles, University of California, M.A. thesis, scale 1:24,000.

Truex, J.N., 1950, Geology of the northern part of the Santa Monica Mountains between Beverly glen and Laurel Canyon Boulevard: Los Angeles, University of California,

M.A. thesis.
waggoner, E.B., 1939, The nature of the schist basement in the western part of the Los Angeles Basin: Los Angeles, University of California, M.A. thesis.

\section{9}

Bergen, F.W., 1955, A restudy of the upper Mohnian-lower Delmontian boundary near Calabasas, California: Los Angeles, University of California, M.A. thesis.

Blackerby, B.A., 1965, The Conejo volcanics in the Malibu Lake area of the western Santa Monica Mountains, Los Angeles County, California: Los Angeles, Univer

Blackerby, B.A., 1965, The Conejo volcanics in the Malibu Lake area of the western santa Lake area of the western santa Monica Mountalns, Los
Angeles County, California labs.): Geological Society of America Special Paper 76 , 191.

Bolles, L.W. 1932, Geology of the Las Flores and Dry Canyon quadrangles: Pasadena, California Institute of M.s, thesis.

Brady, T.J., 1957, Geology of part of the central santa Monica Mountarns, east of Topanga Canyon, Los Angeles County, California: Los Angeles, University of California, M.A. thesis, scale 1:12,000

Brockhouse, T.E., 1932, The geology and paleontology of portion of the Santa Monica Mountains: Los Angel

Brown, G.E., 1957, Geology of parts of the Calabasas and Thousand oaks quadrangles, Los Angeles and Ventura Counties, Calıfornia: Los

Buffington, E.C., 1947 , On invertebrate fauna from the Modelo of Dry Canyon, Los Angeles County, California:
Pasadena, California Institute of Technology, M.s. thesis.

Carter, N.L., 1958, Geology of the Fernwood-Topanga Park area, Santa Monica Mountains, California: Los Angeles,
University of California, M.A. thesis, scale $1: 12,000$
$0719--C o n t i n u e d$

Champeny, J.D., 1961, Paleocene and Dpper Cretaceous stratigraphy of Santa Ynez Canyon and adjacent areas, Santa Monica Mountains, California: Los Angeles, University of California, M.A. thesis.

Cogen, W.M.. 1933, A study of the heavy minerals of the Modelo Formation in the eastern portion of the Sant Monica Mountains: Pasadena, California Institute of Technology, M.s. thesis.

Conrad, S.D., 1949, Geology of the eastern portion of the simi Hills, Los Angeles and Ventura Counties, California: Los Angeles, University of California, M.A. thesis, scale $1: 30,000$

Eantozzi, J.H., 1955, The stratigraphy and biostratigraphy of a portion of the Simi Hills on the south side of the Simi Valley, Ventura County, California: Los Angeles, University of California, M.A. thesis.

Goldberg, James, 1940, Geological significance of the coastal terraces of the Santa Monica Mountains: Los Angeles, University of California, M.A. thesis.

Hall, F.R., 1952, Geology of the southwestern portion of the Las Flores quadrangle, Los Angeles County, California:

Los Angeles, University of California, M.A. thesis.
Hazenbush, G.C., 1950, Geology of the eastern part of the Dry Canyon and Las Flores quadrangles, Los Angeles County, Calıfornia: Los Angeles, University of Calıfornia, M.A. thesis, scale $1: 12,000$.

Kerr, A.R., 1938, Littoral erosion and deposition of the Santa Monica Bay (Calıf.): Los Angeles, University of California M.A. thesis.

Lohman, K.E., 1931, Diatoms from the Modelo Formation (upper Miocene) near Girard, Cal ifornia: Pasadena, California

Institute of Technology, M.S. thesis,
MCG1ll, J.T., 1948, Geology of a portion of the Las Flores and Dry Canyon quadrangles, Los Angeles County California: Los Angeles, University of California, M.A. thesis.

Merenbach, S.E., 1931, Some leading structural features of eastern Santa Monica Mountains, Los Angeles, Cal ifornia: Los Angeles, University of Southern California, M.s. thesis.

Newton, R.C., 1958, The Malibu Bowl fault area, Santa Monica Mountains, California: Los Angeles, University of California, M.A. thesis.

o'Bert, L.K., 1948, Geology of a portion of the Dry Canyon and Las flores quadrangles, Santa Monica Mountains, callfornia: Los Angeles, University of Southern Callfornia, M.S. thesis.

Pelline, J.E., 1953, Geology of the adjacent parts of the Las Flores and Topanga quadrangles, Santa Monica California, M.s. thesis.

Robertson, G.K., 1932, The geology of the santa Monica Mountains in the vicinity of Topanga Canyon, Los Angeles County, California: Los Angeles, University of Southern California, M.s. thesis.

Roth, E.S., no date, Landslides between Santa Monica and point Dume: Los Angeles, University of Souther California, M.s. thesis.

Schoel lhamer, J.E., and Yerkes, R.F., 1961, Preliminary geologic map of the coastal part of the Malibu Beach quadrangle, Los Angeles County, California: U.s.

Geological Survey open-file map, scale $1: 12,000$.
Schupp, R.D., 1954, A study of the cobble beach cusps along Santa Monica Bay, California: Los Angeles, University of Southern California M.s thesis.

Sheldon, D.H., 1932, The geology of a portion of the solstice quadrangle, Los Angeles County, California: Los Angeles. University of Southern California, M.A. thesis.

shipley, Susan, 1978, Erosion of firebreaks in Malibu creek state Park and Topanga State Park, California: U.S. Geological Survey Open-File Report 78-968, $27 \mathrm{p}$.

Simonson, R.R., 1936, Conglomerates of the sespe an Topanga Formations of the Dry Canyon quadrangle, Santa Monica Mountains, California: Los Angeles, University of California, M.A. thesis.

Soper, E.K., 1938, Geology of the central Santa Monica Mountains, Los Angeles County, Cal ifornia: California
Journal of Mines and Geology, v. 34, no. 2, p. 131-180, scale $1: 36,000$

Spencer, F.D., 1932, Geology in the vicinity of Santa Ynez Canyon, Santa Monica Mountains, California: Los Angeles, University of Southern California, M.A. thesis.

Sullwold, H.H., Jr., 1958, The Tarzana fan, a deep submarine delta of late Miocene age, Los Angeles County, California: Los Angeles, University of Californıa, Ph.D. thesis.

Sullwold, H.н., Jr., 1960, Tarzana fan, deep submarine fan of late Miocene age, Los Angeles County, California: American Association of Petroleum Geologists Bulletin, v. 44, no. 4, p. 433-457.

Susuk1, Takeo, 1951 , Stratigraphic paleontology of the Topanga Formation at the type locality. Santa Monica Mountains, California: Los Angeles, University of California, M.A. thesis.

Terpening. J.N., 195i, Geology of a part of the eastern Santa Monica Mountains: Los Angeles, University of California, M.A. thesis, scale $1: 12,000$.

Truex, J.N., and Bali, E.A., 1969, Geologic map of Santa Monica Mountains (Calif.): Los Angeles, Calif.. American Association of Petroleum Geologists, Society of Economic Paleontologists and Mineralogists, and Society of Exploration Geophysicists Guidebook, joint annual meeting.

valentine, J.W., 1956, Upper' Pleistocene Mollusca from Potrero Canyon, Pacific Palisades, California: San Diego
Society of Natural History Transactions, v. 12, no, 10, p Society
$181-205$. 


\section{9--Continued}

West, J.W., 1955, Geology of the southwestern part of the Malibu Beach quadrangle, Los Angeles County. California: Los Angeles, University of California, M.A. thesis.

White, W.R., 1953, Miocene and Pliocene foraminifera from the vicinity of San Juan Capistrano, Calıfornia: Los
Angeles, University of Southern California, M.A. thesis.

walson, H.D.B., 1942, Stratigraphy of the Cretaceous and Eocene rocks of the Santa Monica Mountains: Pasadena, California Institute of TechnologY, Ph.D. dissertation. Yerkes, R.F., Campbel1, R.H., Schoellhamer, J.E.,
Wentworth, c.M., and Blackerby, B.A., 1968, Geologic maps of the central Santa Monica Mountains: 0.
Survey open-file report, scale $1: 12,000$.

Yerkes, R.F., Campbell, R.H., and Schoelhamer, J.E., 1954, preliminary geologic map and sections of the southwest Preliminary geologic map and sections of the southwest
part of the Topanga quadrangle, Los Angeles county, part of the Topanga quadrangle, Los Angeles

Yerkes, R.F., Campbeli, R.H., and Schoelhamer, J.E., 1954, preliminary geologic map and sections of the southwest part of the Topanga quadrangle, Los Angeles county, part of the Topanga quadrangle, Los
California: U.s. Geological Survey.

Yerkes, R.F., Campbeil, R.H., and wentworth, C.M., 1965, Geologic report on the proposed Corral canyon nuclear power plant site, Los Angeles county, California: U.s. power plant site, Los Angeles count.

\section{0}

Bass, R.o., 1960, Geology of the western portion of the Point Dume quadrangle, Los Angeles County, California: Los Point Dume quadrangle, Los Angeles County, Cal
Angeles, University of California, M.A. thesis

Cabeen, W.R., 1939, Geology of the Aliso and Browns Canyons area, Santa Susana Mountains, California: Canyons area, Santa Susana Mountalns, California:
Pasadena, California Institute of Technology, M.S. thesis. Campbell, Schoellhamer, J.E., Birkeland, P.W., and Wentworth, C.M. 1970, Preliminary geologic map of the Point Dume quadrangle, Los Angeles County, California: U.S.

Elam, J.G., 1948, Geology of the Siminole quadrangle, Los Angeles County, California: Los Angeles, University of Californı, M.A. thesis, scale $1: 20,000$

French, J.J., 1980, Ground water in the rhousand oaks area, Ventura county, California: U.S. Geological survey

Water-Resources Investigations report 80-63, $45 \mathrm{p}$. Angeles and Ventura counties, California: Los Angeles. University of California, M.A. thesis, scale $1: 12,000$.

Kelley, v.C., 1932, Geology of the santa Monica Mountains west of the Malibu Ranch, Ventura County, California: Pasadena, of the Malibu Ranch, Ventura County, California:
California Institute of Technology, M.S. thesis.

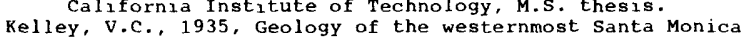
Mountains, California: Geological Society of Amerıca Mountains, Califorma: Geol

Lindsay, D.R., 1952, Geology of the central part of the Solstica Canyon quadrangle, Los Angeles county, California:

Los Angeles, Oniversity of California; M.A. thesis. Ivor, K.A., 1955, Geology of the Thousand Oaks area,
Los Angeles and Ventura Counties (Calif.): Los Angeles,

May, J.C., 1943, Conejo oil field in Geologic formations and economic development of the oil and gas fields of and economic development of the oil and gas fields of

Mead, R.G., 1953, Geology of a portion of Point Dume quadrangle, California: Los Angeles, Unıversity of Southern California, M.S. thesis.

Renke, D.F., 1957, Geology of a part of the Newbury Park quadrangle, ventura county, California: Los Angeles. quadrangle, ventura county, California: Los Angeles,

Schoellhamer, J.E., Yerkes, R. .., and Campbell, R.H. 1962, Preliminary geo $\log _{1} \mathrm{c}$ map of the coastal part of the Point Dume quadrangle, Los Angeles County; Calıfornia: Geological Survey open-file, map scale $1: 12,000$.

Sonneman, H.S., 1956, GeologY of the Boney Mountain area Santa Monica Mountains, California: Los Angeles, University of California, M.A. thesis, 73 p.; scale $1: 12,000$.

Weber, F.H., Jr., 1967, Geology of central part of Thousand Oaks quadrangle, Ventura and Los Angeles Counties, California: Calıfornia Division of Mines and Geology open-file map, scale $1: 9,600$

Weber, F.H. Jr., 1973, Geology and mineral resources study of southern ventura county, California: California 作

Wilson, R.D., 1955, Geology of the southeastern part of the Point Dume quadrangle: Los Angeles, University of the Point Dume quadrangle:
California, M.A. thesis.

\section{1}

Azmon, Emanuel, 1956, Geology of Point Mugu quadrangle:

Los Angeles, University of California, M.A. thesis.
Dosch, M.W., 1965, pliocene tar sands in Oxnard oil field: California Division of $\mathrm{Oil}$ and Gas summary of operations. v. 51 , no. 2 , p. 67-74.

logy of the Point Mugu and Camarilio quadrangles, Ventura County, California: Los
Angeles, University of Callfornia, M.A. thesis, scale Angeles, 12,000 .

\section{1--Continued}

Montgomery, J.M., 1975, Report on Foxen Canyon (Calif.) ground-water study: Irvine, calif., consulting report $38 \mathrm{p}$.

Page, R.W., 1960, Data on water wells, Naval Air Missile Test center area, Point Mugu, California: U.S. Geological Survey open-file report, $98 \mathrm{p}$.

Page, R.W., 1960, Geology and ground-water apprassal of the Naval Air Missile Test Center area, Point Mugu,

California: U.S. Geological Survey open-file report, 85 p.
Page, R.W., 1961, Ground-water conditions during 1959 at the Naval Air Missile Test Center, Point Mugu, California: o.s. Geological Survey open-file report, $35 \mathrm{p}$.

Page, R.W., 1961, Ground-water conditıons during 1960 at the 0.s. Naval Air station, Point Mugu, California: o.s. Geological Survey open-file report, $58 \mathrm{p}$.

Page, R.W., 1963 , Geology and ground water appraisal of the Naval Air Missile Test Center, Point Mugu, California: the Naval Air Missile Test Center, Point Mugu, Calif U.S. Geological Survey water-supt

Pasta, Dave, 1958, Geology of the Las posas-Camarillo Hills area, Ventura County, California: Los Angeles. University of Cal ifornia, M.A. thesis.

Poland, J.F., Garrett, A.A., and Mann, J.F., 1948 progress report on water supply for the point Mugu Naval Progress report on water supply for the Point Mugu Naval
Base, Ventura county, California: U.s. Geological Survey Base, Ventura County, Cal

Poland, J.F., Garrett, A.A., and Mann, J.F., 1949, Progress report on water supply for the Point Mugu Naval Base,
ventura County, California: U.S. Geological Survey open-file report, $51 \mathrm{p}$.

stewart, H.B., Jr., 1956, Sediments and the environment of deposition in a coastal lagoon: Los Angeles, University of Cal fornia, Scripps Institute of Oceanography, Ph.D. dissertation.

\section{2}

Scholl, D.W., 1959, Geology and surrounding recent marine sediments of Anacapa Island, California: Los Angeles, sediments of Anacapa Island, California: Los Angel
University of Southern California, M.s. thesis.

scholl, D.w. 1960, Relationship of the insular shelf sediments to the sedimentary environments and geology of Anacapa Island, California: Journal of Sedimentary Petrology, v. 30 , no. 1 , p. 123-139, fig. 3, scale
$1: 48,000$.

\section{4}

Bremmer, C., St. J., 1932, Geology of Santa Cruz Island, Santa Barbara County, California: Santa Barbara Museum of
Natural History Occasional Papers 1,33 p., pl. 4, scale Natural $\mathrm{H}$

Rand, W.W., 1931, preliminary report of the geology of Santa cruz island, Santa Barbara County, California: Calıfornia D Dision of Mines, State Mineralogist Report

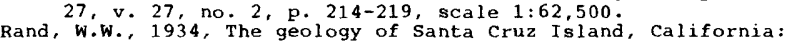
Berkeley, University of California, Ph.D. dissertation.

\section{2}

Bancroft, H., 1911, Reconnarssance of the ore deposits in northern Yuma County, Arizona: O.s. Geological Survey northern Yuma County, Arizona: U.S. Geological
Bulletin 451, 130 p., pl. 1, scale $1: 250,000$.

Dickey, D.D. Carr, W.J., and Bull, W.B., 1980, Geologic map of the Parker NW, Parker, and parts of the whipple Mountains SW and Whipple wash quadrangles, California and Arizona: 0.s. Geological Survey Miscellaneous Investigations Map I-1124, scale $1: 24,000$

Kemnitzer L.E. 1937. Structural studies in the whipple Mountains, southeastern California: Pasadena, California Institute of Technology, Ph.D. dissertation, scale 1:62,500.

\section{3}

Saul, R.B., 1963, Reconnaissance geology and photogeologic interpretation of part of the Savahia Peak guadrangle, California: California Division of Mines and Geology mapping
for the state geologic map, scale $1: 62,500$.

\section{4}

Saul, R.B., 1963, Reconnaissance geology and photogeologic interpretation of the Turtle Mountain quadrangle. California: California Division of Mines and Geology 
Bishop, C.C., and Jennings, C.W., 1963, Reconnaissance geologic map and photogeologic interpretation of parts of the Milligan quadrangle, California: California Division of Mines and Geology mapping for the State geologic map, scale $1: 62,500$.

\section{6}

Bishop, C.C., and Jennings, C.W., 1963, Reconnaissance geologic map and photogeologic interpretation of parts of the Cadiz Lake quadrangle, California: California Division of Mines and Geology mapping for the State geologic map, scale $1: 62,500$

Lamey, C.A., 1948, Ship Mountains iron-ore deposit, San Bernardino County, California: California Division of Mines Bulletin 129, p. 111-116.

\section{7}

Gale, H.S., 1951, Geology of the saline deposits, Bristol Dry Lake, San Bernardino County, California: California Division of Mines Special Report 13, $21 \mathrm{p}$.

\section{9}

Dibblee, T.W., Jr., 1967, Geologic map of the Deadman Lake quadrangle, San Bernardino County, California: U.S. Geological Survey Miscellaneous Investigations Map I-488, 3 p. scale $1: 62,500$.

0810

Dibblee, T.W., Jr., 1967, Geologic map of the Emerson Lake quadrangle, San Bernardino County, California: $\mathrm{D}, \mathrm{s}$ Geological Survey Miscel laneous Investigations Map I-490, 4 p., scale 1:62,500.

Dockter, R.D., 1980, Geophysical, Iithologic, and waterquality data from test well E-2, Emerson Dry Lake, San Bernardino County California: U.s. Geological Survey Open-File Report 80-872, 1 sheet.

\section{1}

Dibblee, T.W., Jr., 1967, Geologic map of the old Woman springs quadrangle, San Bernardino County, California: U.S. Geological Survey Miscellaneous Investigations Map I-5is, 5 p. scale $1: 62,500$.

Dockter, R.D., i980, Geophysical, lithologic, and water-quality data from Soggy Dry Lake, San Bernardino County, California: U.S. Geological Survey open-Ejle Report 80-1030, 1 sheet.

Dockter, R.D., 1980, Geophysical, lithologic, and water-quality data from Melville Dry Lake, San Bernardino County, California: U.s. Geological Survey Open-Eile Report 80-1036, 1 sheet.

Dockter, R.D., 1980, Geophysical, lithologic, and water-quality data from Means Dry Lake, San Bernardino County, California: U.s. Geological Survey Open-File Report 80-2030, 1 sheet.

\section{2}

Busby, M.W., 1977, Flood-hazard study--100-year flood stage for Lucerne lake, San Bernardino County, California: U.S. Geological survey open

pl.., 12 figs., 5 tables.

Valley quadr., 1964, Geologic map of the Lucerne Geological Survey Miscellaneous Investigations Map I-426, 6 p.. scale $1: 62,500$

Eleury, Bruce, 1961, The geology, origin, and economics of manganese at Road's End, California: Los Angeles, University of Southern California, M.A. thesis.

French, J.J., 1978, Ground-water storage in the Johnson Valley area, San Bernardino County, California: U.S. Geological Survey Water-Resources Investigations report $77-130,35 \mathrm{p}$

French, J.J., and Busby, M.W., 1974, Flood-hazard study-100-year flood stage for Baldwin Lake, San Bernardino County, Cal ifornia: U.s. Geological Survey Water-Resources Investigations report 26-74, $18 \mathrm{p}$.

Goodrich, J.A., 1978, Hydrogeology of Lucerne Valley. California: Los Angeles, University of Southern California, M.s. thesis, 84 p.

Guillou, R.B., 1951, The geology of the Johnston Grade area, San Bernardino Mountains, California: Los Angeles, University of California, M.A. thesis.
Guillou, R.B., 1953, Geology of the Johngton Grade a rea, San Bernardino County, California: California Division of Mines and Geology Special Report 31, 18 p., pl. 1, scale $1: 24,000$.

Irwin, G.A., and Lemons, Michael, 1974, A water-quality reconnaissance of Big Bear Lake, San Bernardino County, California, 1972-73: v.S. Geological Survey Water-Resources Investigations report $3-74,40 \mathrm{p}$.

Joseph, S.E., 1984, Mineral land classification of the PluessStaufer, Inc., limestone deposits, Lucerne Valley, San
Bernardino County, California (supercedes ofR 82-8 LA): California Division of Mines and Geology Open-File Report 84-21 LA.

Joseph, S.E., 1985, Mineral land classification of the PluessStaufer, Inc., white Knob limestone deposit (Calif.): California Division of Mines and Geology open-File Report 85-13 LA, 20 p.

Miller, R.v., and Morton, P.K., 1980, Mineral land classification of Pfizer, Inc. limestone depositg in Lucerne Valley, San and Geology Open-File Report 80-18 LA.

Neste, Brudin, and Stone, Inc., and C.M. Engineering Associates, 1973, Big Bear area regional waste-water management plan, progress report no. 1, summary: San Bernardino, Calif., $58 \mathrm{p}$.

Pearson, E.G., and Irwin, G.A., 1972, Lımnological studies of Big Bear Lake, California: U.S. Geological Survey open-file report, $18 \mathrm{p}$.

Pearson, E.G., and Irwin, G.A., 1972, Tabulation of chemical data and plankton populations collected for limnological studies of Big Bear Lake, California: U.s. Geological Survey openfile report, $36 \mathrm{p}$.

Richmond, J.F., 1954, Petrology and structure of the San Bernardino Mountains north of Big Bear Lake, California:
Palo Alto, Calif., Stanford University, Ph.D. disgertation.

Richmond, J.F., 1960, Geology of the San Bernardino Mountains north' of Big Bear Lake, California: California Division of Mines Special Report 65,68 p.

Schaefer, D.H., 1979, Ground-water conditions and potential for artificial recharge in Lucerne Valley, San Bernardino County, California: U.S. Geological Survey Water-Regources Investigations report $78-118,57 \mathrm{p}$.

Shreve, R.L., 1959, Geology and mechanics of the Blackhawk landslide, Lucerne Valley, California: Pasadena,
California Institute of Technology. Ph.D. dissertation.

woodford, A.O., and Harriss, T.F.. 1928, Geology of Blackhawk Canyon, San Bernardino Mountains, California: University of California Department of Geological Sciences Bulletin, v. 17, p. 265-304.

\section{4}

Yerkes, R.F., 1951, Geology of a portion of the Cajon Pass area, California: Claremont, Calif., Pomona College, M. A. thesis, $96 \mathrm{p}$.

\section{5}

McNaughton, D.A., 1934, Geology of the Lytel Canyon area, eastern San Gabriel Mountains Calif.: Pasadena,

California Institute of Technology, M.S. thesis.
Sharp, R.P., and Nobles, L.H., 1953, Mudflow of 1941, at Wrightwood, southern California: Geological Society of America Bulletin, v. 64, p. 547-560.

\section{6}

Barrows, A.G., 1978, Geology and fault activities of the Valyermo segment of the San Andreas fault zone, Los Angeles County,
California: California Division of Mines and Geology OpenFile Report 79-1 LA.

Barrows, A.G., 1978, preiliminary fault map of the valyermo segment, San Andreas fault zone, Log Angeles County ment, San Andreas fault zone, Los Angeles County, File Report 78-3 LA.

Barrows, A.G., 1980, Geologic map of the San Andreas fault zone and adjoining terrane, Juniper Hills and vicinity, Los Angeles County. California: California Division of Mines and Geology Open-file Report 80-2 LA.

Holwerda, J.G., 1952, Geology of the Valyermo area, California: Los Angeles,

Noble, L.F., 1953, Geology of the Pearland quadrangle California: v.s. Geological survey Geologic Quadrangle Map GQ-24, scale $1: 24,000$.

Noble, L.F., 1954 , Geology of the Valyermo quadrangle and vicinity, California: U.s. Geological Survey Geologic Quadrangle Map GQ-50, scale $1: 24,000$.

Wells, J.C., 1938, petrology and structure of the crystal Lake area, Los Angeles County, California: Pasadena

California Institute of Technology, M.S. thesis. quadrangle, on the north gide of the San Gabriel Mountains, Los Angeles County, California: Los Angeles, University of California, M.A. thesis. 


\section{8--Continued}

Dreyer, R.M., and Dawson, C.A., Jr., 1939, Magnetometer deposits: Pasadena, California Institute of Technology, Ph.D. dissertation.

Kimm, Diamond, 1933, The geology of the Dawn Mine district, San Gabriel Mountalns, Los Angeles County, California: Los Angeles, University of Southern California, M.A. thesis.

Phipps, R.T., 1951, Geology of the Monte Cristo mining area: pasadena, California Institute of Technology, M.S. thesis.

\section{8}

Agnew, H.w., 1948, The geology of a part of the Ravenna quadrangle, California:

Beatre, R.L., 1958, The geology of the Sunland-Tujunga area, Los Angeles County, California: Los Angeles, University of California, M.A. thesis.

Burman, J.H., 1950, Geology of the upper Tick Canyon area, Californa: Pasadena, Calıforna Institute of Technology, M.s. thesis.

California State water Rights Board, 1962, San Fernando valley reference report of referee, city of Los Angeles vs. City of San Fernando, and others, No. 650079, Superior Court, Los Angeles County: California state water Rights Board, v. 1, 258 p.; pl.4, scale 1 inch = approx. 2.5 miles.

Cebeci, Ahmet, 1944, A study of quartz deposits near Highway Highlands, Los Angeles County, Califorma: Pasadena, California Institute of Technology, M.s. thesis.

Daviess, S.N., 1942, Contact relationship between Mint Canyon Formation and upper Miocene marine beds in eastern Ventura Basin, Los Angeles County, California: Los Angeles, University of California, M.A. thesis.

Dawson, C.A., 1937, petrology of the igneous complex near Technology, M.s. thesis.

Dehlinger, Peter, 1943, A magnetic survey of Sand Canyon for placer deposits, San Gabriel Mountains, California: pasadena, California Institute of Technology, M.s. thesis.

Garrett, A.A., 1951, Possibility of excessive rise of the water table at the site of Birmungham General Hospital, San Fernando Valley, California: D.S. Geological Survey open-file report, 6 p.

Holser, W.T., 1946, Geology of the Mint Canyon area, Los Angeles County, California: pasadena, California Institute of Technology, M.s. thesis.

Howell, B.F., Jr., 1949, structural geology of the region between Pacoima and Little Tujunga Canyon, San Gabrie Mountains, California: Pasadena, Calif., California Institute of Technology, Ph.D. dissertation.

Irwin, w.P., 1950, The Vasquez series in the upper Tick Canyon area, Los Angeles County, California:

Institute of Technology, M.S. thesis.
Jahns, R.H., 1943, Stratigraphy of the easternmost ventura basin, California, with a description of a new lower Miocene mammalian fauna from the Tick Canyon Formation Pasadena, California Institute of Technology, Ph.D. dissertation.

Judson, J.F., 1935, Geology of the LeBrun and Mint Canyon quadrangles, Los Angeles County, California: Pasadena, California Institute of Technology, M.s. thesis.

Menard, H.W., 1947, The geology of the Aqua Dulce Canyon area (Calif.): pasadena, Calıfornia Institute of Technology, M.S. thesis.

Merifield, P.M., 1958, Geology of a portion of the southwestern San Gabriel Mountains, San Fernando and Oat Mountain quadrangles, Los Angeles county, California: Los Angeles, University of California, M.A. thesis.

Morrison, R.R., 1958, Geology of the Sand Canyon-placerita Canyon area, parts of the Humphreys and Sylmar quadrangles, Los Angeles County, California: Los Angeles, University of California, M.A. thesis.

Morrison, R.R., 1965, The geology of the Sand Canyon-Placerita Canyon area in placerita-Soledad-Vasquez Rocks area (Calif.): American Assoclation of petroleum Geologists, pacific Section, Guidebook, map, scale approx, 1 inch 3,100 feet.

Muehlberger, W.R., 1954, Deposition and deformation in the northern Soledad basin, Los Angeles County, California: Pasadena, California Institute of Technology, Ph.D. dissertation.

Muehlberger, W.R., 1958, Geology of the northern Soledad basin, Los Angeles County, California: American Association of Petroleum Geologists Bulletin, v, 42, no. 8, p. 1812-1844, fig. 3, scale approx. 1:48,000

oakeshott, G.B., 1936, A detalled geologic section across the western San Gabriel Mountains of Calıfornı: Los Angeles, University of Southern California, Ph.D. dissertation.

Oakeshott, G.B., 1937, Geology and mineral deposits of the western San Gabriel Mountains, Los Angeles County: California Journal of Mines and Geology, v. 33, no. 3, p. 215-249.

Oakeshott, G.B., 1948, Titanıferous 1ron-ore deposits of the western San Gabriel Mountains, Los Angeles County, 243-266, pl. 25, figs. 65-68

Oakeshott, G.B., 1954, Geology of the western San Gabriel Mountains, Los Angeles County, in Geology of southern sheet 9, scale $1: 125,000$

Oakeshott, G.B., 1956, T1tanıum: California Division of Mines Mineral Information Service, v. 9, no. 3, p. 1-6.
Oakeshott, G.B., 1958, Geology and mineral deposits of San Fernando quadrangle, Los Angeles County, Cal ifornia: California Division of Mines Bulletin 172, 5 pls.. 147 p.. 21 figs, 91 photos.

Orr J.M. 1938. An investigation of the geological occurrence and use of titanıum with special reference to the San Gabriel titanium deposits, California: pasadena, California Institute of Technology, M.S. thesis.

Saul, R.B., 1979, Geology of the south half of the Mint canyon quadrangle, Los Angeles County, California: California

Saul, R.B., and wootten, T.M. 1983, Geology of the south half of the Mint Canyon quadrangle, Los Angeles County, California: the Mint Canyon quadrangle, Los Angeles County, California: 83-24 LA.

Scott, K.M., 1973, Scour and fill in Tujunga wash--A fanhead valley in urban southern California--1969: U.S. Geological Survey professional Paper 732-B, 29 p.

Sharp, R.p., 1935, Geology of the Ravenna quadrangle, Los Angeles County, California: Pasadena, California Institute of Technology, M.s. thesis.

silver, L.T., 1966, Basement geology of a part of the Soledad basin: Pasadena, California Institute Technology faculty research, scale $1: 24,000$.

Silver, L.T., McKınney, C.R.. Deutsch, s.: and Bolinger, J. 1963, Precambrian age determinations in the western 71 , no. 2, p. 196-214.

Smith, R.J., 1948, Geology of portions of the Humphreys and Sylmar quadrangles, Los Angeles County, California:

o.s. Geological Survey, 1971, The San Fernando earthquake of February 9, 1971: U.S. Geological survey Professional Paper 733, 254 p.

Uhrig, L.F., 1936, structural study of a portion of the Lang and Humphreys quadrangles, Los Angeles County, California: pasadena, California Institute of Technology M.S. thesis.

Waananen, A.O., and Moyle, W.R., Jr., 1971, waterresources aspects in the San Fernando, California, earthquake of February 9, 1971: 0.5. Geological Survey professional Paper 733, p. 119-125.

wallace, R.E. 1940, Volcanic tuff beds of the Mint canyon Formation: Pasadena, California Institute of Technology, M.s. thesis.

White, W.s., 1937, Geology of the Pacoima-Little Tujunga area: Pasadena, California Institute of Technology, M.S. thesis.

Wozab, D.H., 1953, Chemical characteristics of the ground water in San Fernando Valley, California: Los Angeles, water in San Fernando Valley, Californa: Los Ang
University of Southern California, M.A. thesis.

wright. L.A., 1943, Geology of the Mint Canyon series and its relation to the "Modelo" Formation and other adjacent formations, Los Angeles County, California: Los Angeles, formations, Los Angeles County, California: Los

wright, L.A.. 1951, An invertebrate assemblage from the "Modelo" Formation of Reynier Canyon, Los Angeles county, california: Pasadena, Californa Institute of Technology, ph.D. dissertation.

\section{9}

Anderson, G.H., 1933, Stratigraphy and faunal relationsheps of Pliocene beds of San Diego age in the vicinity of Las Llajas Canyon simi Valley: Pasadena, California Institute Technology, Ph.D. dissertation.

Bel1, F.W., 1933, The stratigraphy and foraminiferal faun of the Santa Susana Formation: Pasadena, California Institute of Technology, M.s. thesis.

Bishop, w.C., 1950, Geology of the southern flank of santa Susana Mountains, county line to Limekiln Canyon, Los Angeles County, California: Los Angeles,
California, M.A. thesis, scale $1: 12,000$.

Browning, J.L., 1952, Foraminifera from the upper santa Susana shale: Berkeley, University of Californua, M.A. thesis.

Cooksey, C.D., Jr., 1934, The geology of portions of the Humphreys, Sylmar, Newhall, and Saugus quadrangles, Los Angeles County, California: Pasadena, California Institute of Technology, M.s. thesis.

Cooper, J.C., and Kelley, R.B., 1941, Geology of a portion of the Santa Susana quadrangle, Los Angeles and Ventura of the Santa Susana quadrangle, Los Angeles and California, M.A. thesis.

Edmunson, J.W., 1947, A study of the subsurface conditions prevaling in the Newhall-potrero oll field: Pasadena. California Institute of Technology, M.S. thesis.

Edwards, C.D., 1948, Geology of the Del Valle area, Los Angeles County, California: Pasadena, California Institute of Technology, M.s. thesis.

English, W.A., 1913, The Fernando Group near Newhall, Calıfornia: Berkeley, University of California, M.S. thesis.

Evans, J.R., and Miller, R.V., 1978, Geology of the southwestern part of the Oat Mountain quadrangle, Los Angeles County (Calif.): California Division of Mines and Geology Map sheet

33, scale $1: 12,000$.
Ford, W.E., 1941, Geology and oil resources of a portion of the Newhall district, Los Angeles County, California: Los Angeles, University of California, M.A. thesis.

Gottsdanker, E.N., 1939, Sedimentation in the Sespe Formation north of Simi valley, Ventura County, thesis. 
Grier, A.W., 1953, Lower Tertiary foraminifera from the Simi valley, California: Berkeley, Calif.. University of California, M.A. thesis.

Hetherington, G.E., 1957, Geology of the south Tapo Canyon area, Santa Susana quadrangle, ventura County, California: Los Angeles, University of California, M.A. thesis, scale $1: 12,000$

Hobson, R.D., 1943, Piru oil field, in Geologic formations and economic development of the oxl and gas fields of 3. $\mathrm{p} .400-403$.

Jahns, R.H., and Muehlberger, W.R., 1954, Geology of the Soledad basin, Los Angeles County, in Geology of southern California: California Division of Mines Bulletin 170, map sheet 6 , scale approx. $3 / 4$ inch $=1 \mathrm{mile}$.

Jennings, R.A., 1957, Geology of southeastern part of the Oat Mountain quadrangle and adjacent parts of the san Fernando quadrangle, Los Angeles County. California: Los Angeles, University of California, M.A. thesis.

Levorsen, R.I., 1947, Geology of the Las Llajas Canyon area, California: Los Angeles, Undversity of California, M.A. thesis, map, scale $1: 7,200$

Lew1s, W.D., 1940, Geology of the upper Las Llajas Canyon area, Santa Susana Mountains, california: Pasadena, California Institute of Technology, M.s. thesis.

MacNei11, R.J., 1948, Geology of the Humphreys station area, Los Angeles county, california: Pasadena, california Institute of Technology, M.s. thesis.

Martin, D.R., 1958, Geology of the western part of the Santa Susana Mountains, ventura county, California: Los Angeles, University of California, M.A. thesis, scale $1: 24,000$

Martin, J.S., 1947, Geology of the Dry Canyon area in the eastern section of the Ventura area, California: Pasadena, California Institute of Technology, M.s. thesis.

McMasters, J.H., 1932, The Eocene Llajas formation, Ventura County, California: Palo Alto, Calif., Stanford University, M.A. thesis.

Miller, J.C., and Lebow, R., 1944, Geology of the Del Valle oll field, Los Angeles county, California: U.s. Geological Survey open-file report, pl. 4, scale 1:24,000.

Morton, D.M., 1976, Reconnaissance surficial geologic maps of the Newhali, Oat Mountain, Santa Susana, and val verde 7 1/2-minute quadrangles, Los Angeles and Ventura counties, southern California: U.S. Geological Survey Open-File Report $76-211,4$ maps.

Nelson, L.E., 1948, Preliminary report on Ramona field, Los Angeles and Ventura Counties, California: American
Association of Petroleum Geologists Bulletin, v. 32 , Association of

Oakeshott, G.B., 1950, Geology of the Placerita oxl field, Los Angeles County, California: California Journal of Mines and Geology, v. 46, no. 1, p. 43-79.

Outland, C.F., 1963, Man-made disaster, the story of St. Francis dam: Glendale, Calif.. A.H. Clark, Western Land and Water studies $3,249 \mathrm{p}$.

Pertusio, S.M., 1941, A microfauna from the Vaqueros Formation lower Miocene, Simi Valley, Ventura County, California: New York, Columbia University. M.A. thesis.

Pollard, D.L., 1958, Geology of the Halsey Canyon area, Los Angeles County, California: Los Angeles, University of California, M. A. thesis, scale $1: 12,000$.

Rice, H.M.A., 1934, A San Diego (Pl locene) fauna in the Newhall quadrangle, Cal ifornia: Pasadena, California Institute of Technology. Ph.D. dissertation.

Robinson, B.B., 1956, Geology of the Holser Canyon area, Ventura County, California: Los Angeles, University of California, M.A. thesis, scale $1: 11,725$.

Ross, T.P., 1959, Subsurface sequence of Eocene foraminifera, Simi Valley, California: Berkeley, University of California,

Sams, R.H. . 1964, Geology of the charlie canyon area, northwest Los Angeles County, California: Los Angeles,

Saul, R.B., 1968, Geologic map of the SE $1 / 4$ of the Oat Mountain quadrangle, California: California Division of Mines and Geology, scale $1: 9,600$. Smith, D.p. 1984 , Geology of the northeast quarter of the
Newhali quadrangle, Los Angeles County, California: California Division of Mines and Geology Open-File Report $84-49$ LA

Townsend, J.R., 1940, Geology of a portion of the Newhall quadrangle, Los Angeles county, California: Los Angeles University of California, M.A. thesis.

weber, F.H., Jr., 1984, Geology of the Calabasas-Agoura-Eastern Thousand Oaks area, Los Angeles and Ventura counties, California: California Division of Mines and Geology OpenFile Report 84-1 LA.

White, R.C., 1947, Age of the "Modelo" in Haskell Canyon, easternmost Ventura basin, California: Pasadena,
California Institute of Technology, M.s. thesis.

winterer, E.L., 1954, Geology of southeastern Ventura basin, Los Angeles county, California: Los Angeles, University of California, Ph.D. dissertation.

winterer, E.L., and Durham, D.L., 1962, Geology of southeastern Ventura basin, Los Angeles county, $334-\mathrm{H}, \mathrm{p} .275-366$.

wosk, D., 1940, Future oil possibilities of NewhallCastaic district: $O_{11}$ and Gas Journal, v. 39, no. 23, p. 24-26, fig. 1, scale $1: 125,000$

zebal, G.P., 1943, The Upper cretaceous paleontology and stratigraphy of the Simi Hills, Los Angeles and Ventura Counties, California: Pasadena, California Institute of
Technology, M.S. thesis.
Baddley, E.R., 1947, Oak Ridge oil fields, Santa clara Valley, Ventura County, California: American Association p. 46-49 fig.

Bain, R.J., 1954, Geology of the Eureka Canyon area, Ventura County, California: Los Angeles, University of California, M.A. thesis, scale $1: 12,000$.

Brown, R.S., 1959, Geology of the Grimes Canyon area, Moorpark and Fillmore quadrangles, Ventura County, California: Los Angeles, University of California, M.A. thesis.

California Department of Water Resources and U.S. Geological Survey, 1972, Flood insurance study, unincorporated areas in ventura County, California: v.s. Geological Survey.

Cordova, Simon, 1956, Geology of the piru area, ventura County, Calıfornia: Los Angeles, University of Californa, M.A. thesis.

Corey, W.H., 1929, Paleontology and stratigraphy of the vaqueros Formation (lower Miocene) of Oak Ridge and South Mountain, Ventura County, California, with notes on Vaqueros sections adjoining and in the western Santa Ynez Mountains of Santa Barbara County: Berkeley, University of California, M.A. thesis.

Eschner, Stanford, 1957, Geology of the central part of the fillmore quadrangle, ventura county, california: Los Angeles, University of California, M.A. thesis.

Hal1, E.A., Rickels, G.H., and Plant, W.o., 1958, Oakridge oil field, in $A$ guide to the geology and oil fields of the Los Angeles and Ventura regions: American Association of Petroleum Geologists, Pacif ic Section.

Jestes, E.C., 1958, Geology of the Wiley Canyon area, ventura county, California: Los Angeles, University of California, $M . A$. thesis.

Johnson, R.L., 1959, Geology of the northeastern quarter of Fillmore quadrangle, Ventura county, California: Los Angeles, University of California, M.A. thesis.

kew, W.S.W.. 1919, stucture and oil resources of the simi valley, southern california: U.s. Geological Survey Bulletin 691-M, p. $323-347$.

Larrabee, Mike, Geology of the Piru and Fillmore quadrangles, Ventura county, California: Los Angeles, University of Southern California.

Morton, D.M., 1976, Reconnalssance surficial geologic maps of the Fillmore, Moorpark, Piru, and Simi $71 / 2$-minute
quadrangles, Ventura county, southern California: U.s. Geological Survey Open-File Report 76-210, 4 maps.

Nelson, L.E., 1952, Del Valle and Ramona oil fields: Pacific sections, American Association of Petroleum Geologists, Society of Economic Paleontologists and Mineralogists, and
Society of Exploration Geophysicists joint annual meeting. March 1952, Guidebook.

Scott, K.M., Ritter, J.R., and Knott, J.M., 1968, Sedimentation in the Piru Creek watershed, southern california: v.s. Geological Survey Water-Supply Paper $1798-\mathrm{E}, 48 \mathrm{p}$.

Snedden, L.B.. 1943 , Bardsdale area of the Bardsdale oil field in Geologic formations and economic development of the 011 and gas fields of Callfornia: California Division of Mines Bulletin 118 , p. 406.

Snedden, L.B., 1943, Shiells Canyon area of the Bardsdale 011 field in Geologic formations and economic development of the oil and gas fields of california: california Division of Mines Bulletin 118, p. 407

Stıpp, T.F., 1943, Simi oll field in Geologic formations and economic development of the oxl and gas fields of californa: california Division of Mines Bulletin 118, p. $417-423$.

van Camp. Q.W., 1959, Geology of the Big Mountain area, Santa Susana and Siml quadrangles, ventura county, california: Los Angeles, University of california, M.A. thesis.

winterer, E.L., and Durham, D.L., 1954, Geology of a part of the eastern ventura basin, Los Angeles county, Calıforna, in Geology of southern california: california Division of Mines and Geology Bulletin 170, map sheet 5 .

\section{1}

Baddley, E.R., 1954, Geology of the South Mountan oil field, Ventura county, California in Geology of southern California: Californa Division of Mines and Geology
Bulletin 170, map sheet 29, scale 1 inch = approx. 1,550 feet.

Bailey, W.c., 1944, South Mountain oil field: california Oil Fueids, v. 29, no. 2, p. 12-16, pl. 1, scale $1: 125,000$.

Bertholf, H.W., 1967, Geology and oil resources of the Tumber Canyon area, ventura county, California: Los Angeles, University of California, M.A. thesis.

Bush, G.L., 1956, Geology of upper Ojai valley, california: Los Angeles, University of California, M.A.

Dibblee, T.W., Jr., 1982, Geologic map of the Ojai quadrangle, california: U.s. Geological Survey Open-File Report 82-74, scale $1: 24,000$

Dibblee, T.W., Jr., 1982, Geologic map of the Santa Paula Peak quadrangle, California: v.S. Geological Survey open-File Report 82-73, scale $1: 24,000$.

Fine, S.F., 1952, North Sulphur Mountain area, ojai oil field: Los Ángeles, Calif.. American Association of Petroleum Geologists. Society of Economic Paleontologists and Mineralogists, and Society of Exploration Geophysicists joint annual meeting, Guddebook, p. 74-76. 


\section{2--Continued}

Fine, S.F., 1954, Geology and occurrences of oil in the Ojai-Santa Paula area, Ventura County in Geology of southern California: California Division of Mines and

Hinds, J., 1953, Investigations, plans, and estimates for a supplemental water supply in the Santa clara Valley and vicinity: Santa Paula, calif., Onited water Conservation District, $164 \mathrm{p}$.

Jeffreys, S.R., 1958, Saticoy oil field in A guide to the geology and oil fields of the Los Angeles and Ventura regions: American Association of Petroleum Geologists, Pacafic Section.

Leeds, Hill, and Jewett, Inc., 1976, Effects of sand and gravel mining on safety of gas pipelines crossing the Santa clara River near Satıcoy (Calif.): San Francisco, Calif., consulting report, 27 .

Loof bourow, J.S., 1941, Geology of a portion of the Santa Paula quadrangle, Ventura County, California: Los Angeles, University of California, M.A. thesis.

Lung, Richard, 1958, Geology of the South Mountain area, Ventura County, California: Los Angeles, University of California, M.S. thesis.

Mccullough, T.R., 1957, Geology of the Timber Canyon area, Santa Paula Peak quadrangle, Ventura County, California: Los Angeles, University of Californza, M.A. thesis.

Morton, D.M., 1976, Reconnalssance surficlal geologic maps of the Santa Paula, Santa Paula Peak, Satıcoy, and Ojai 7 1/2-minute quadrangles, Ventura County, California: U.S. Geological Survey Open-File Report 76-212, 4 maps.

oliver, G.W., 1940, Geology of a part of the Santa Paula quadrangle, California: Los Angeles, University of Californa, M.A. thesis.

Pressler, E.D., 1928, Contribution to the paleontology and stratigraphy of the upper part of the Fernando Group of the Las Posas-South Mountain district, Ventura County, California: Berkeley, university of California, M.A. thesis.

Putnam, W.C., 1930, Terrace levels in the Ventura district California: Palo Alto, Calif., Stanford University, M.A. thesis.

Putnam, w.C., 1937, Physiography of the Ventura regron, California: Pasadena, California Institute of Technology, Ph.D. dissertation.

Reinhart, P.W., 1928, Geology of the South Mountain oxl field, Ventura County, California: Palo Alto, Calif., Stanford University, M.A. thesis.

ware, G.C., and Stewart, R.D., 1958, Bridge area, South Mountain oil field in a guide to the geology and oil fields of the Los Angeles and Ventura regions: American Association of Petroleum Geologists, Pacific Section.

Waterfall, L.N., 1943, Santa Paula oil field in Geologic formations and economic development of the oil and gas
fields of California: California Division of Mines and Geology Bulletin 118, p. 394.

wiese, J.H., 1941, Geology of a portion of the Santa Paula quadrangle, California: Los Angeles, university of Californıa, M.A. thesis. Yeats, R.S., 1965, Pliocene seaknoll at South Mountain,
Ventura basin, California: American Association of Petroleum Geologists Bulletin, v. 49, no. 5, p. 526-546, fig. 2 , scale $111 / 16$ inch $=1 \mathrm{~m}$ le.

\section{2}

Artusy, R., 1939, A survey of the Pliocene mxcrofauna in the Pico Formation of Ventura County, California: Los Angeles, University of Southern California, M.s. thesis.

Cartwright, L.D. Jr., 1927, Sedimentation of the Pico Formation in the Ventura quadrangle, California: Palo Alto, Calif., Stanford University, M.A. thesis.

cartwright, L.D.', Jr.., 1928, Sedimentation of the Pico formation in the Ventura quadrangle, California: Amerzcan Association of Petroleum Geologists Bulletin, v. 12, no. 3 , p. $235-269$

Chauvel, J.P., 1958, Geology of the Arroyo Parlda fault, Santa Barbara and Ventura Counties, California: Los Angeles, University of Calzfornia, M.A. thesis. Dibblee, T.W., Jr., 1982 , Geologic map of Matalija quadrangle,
California: U.s. Geological Survey Open-File Report 82-75, scale $1: 24,000$.

Dutton, W.G., 1962, Geology of the Casitas Pass region, Ventura County, California: Los Angeles, University of California, M.A. thesis.

Edwards, R.D., Rebey, D.F., and Kover, R.W., 1970, Soil survey of the Ventura area: U.S. Department of Agriculture, Soll Conservation Service, in cooperation with University of California Agricultural Experiment Station, $148 \mathrm{p}$.

Haines, R.B., 1969, San Miquelıto 011 freld: American Association of Petroleum Geologists, Soclety of Economic Paleontologists and Mineralogists, and Society of Exploration Geophysicssts, Pacific Sections, 44 th annual meeting, Guidebook, p. 38-39.

Haines, R.B., and Minshall, F.E., 1954, Geology of the San Miguelito oil field, Ventura county, in Geology of southern California: California Division of Mines Bulletin 170 , map sheet 27 .

Kerr, P.F., and Schenck, H.G., 1928, Significance of the Matilija overturn: Geological Society of America Bulletin, v. 39, p. 1087-1102.

knutson, C.F., 1959, An investigation of some petrophysical aspects of the Third Grubb zone, San Miguelito field,
Ventura county, California: Los Angeles, University of California, Ph.D. dissertation.
Nagle, H.E., and Parker, E.S., 1971, Future oil and gas potential of onshore Ventura Basin, California: American Associa

Nel of Petroleum Geologists Memour 15, v. 1, p. 254-297. California: Washington, D.C., U.S. Department of Agriculture.

Paschall, R.H., 1954, Geology of the Rincon oil field in Geology of southern California: California Division of Mines Bulletin 170, map sheet 26, scale 1:24,000.

sınger, J.A., and Price, McGlone, 1971, Flood of January 1969 near Ventura, California: U.S. Geological Surv
Hydrologyc Investigations Atlas HA-423, 1 sheet.

stewart, R.E., 1943, Rincon oxl field in Geologic formations and economic development of the oil and gas fields of California: California Division of Mines Bulletin 118, p. 387-390.

Thoms, C.C.. and Balley, w.C., 1943, Ventura Avenue oil field in Geologic formations and economic development of the oil and gas fields of California: California Division of Mines and Geology Bulletin 118, p. 391-393.

Vander Leck, L., 1920, Report on the Ventura oil field: California Division of Oil and Gas Summary of Operations, v. 5, no. $8, \mathrm{p} .6-22$.

waterfall, L.N., 1927, A contribution to the paleontology of the Fernando Group of Ventura County, California of the Fernando Group of Ventura County, Californ
Berkeley, University of Californza, M.A. thesis.

Berkeley, University of California, M.A. thesis.
watts, E.V., 1948, Some a spects of high pressures in the D-7 zone of the Ventura Avenue freld: American Institute of Mining 205 .

0823

Arnold, Ralph, 1907, Geology and oxl resources of the Summerland District, Santa Barbara County, California: U.S. Geological Survey Bulletin 321, 93 p., pl. 1, scale $1: 62,500$.

Brown and Caldwell, 1969, Water supply and distribution, a report prepared for the City of Santa Barbara: Alhambra, calif., consulting report, $183 \mathrm{p}$.

Brown and caldwell, 1973, Caty of Santa Barbara groundwater supply: Alhambra, Calif., consulting report, $92 \mathrm{p}$.

Diving Association, 1964 , Geological-oceanographic reconnazssance, Santa Barbara-Summerland offshore area: Diving Association, $9 \mathrm{p}$.

Diving Association, 9 p.
Fenzel, F.W., and Price, McGione, 1971, Flood of January 1969 near Carpinteria, Californza: 0.s. Geological Sur

Hydrologic Investigations Atlas HA-422, 1 sheet.
Geotechnical consultants, Inc., 1976, Hydrogeologic investigation of Carpenteria ground-water basın, California: Consulting Report v2075-C, 205 p., 23 pls., 7 app.

Hoover, M.F., 1978, Geologxc hazards evaluation of the city of Santa Barbara, California: Santa Barbara, calif.. consulting report, $35 \mathrm{p}$.
Bnson, C.B. 1979 , Ground-water monitoring at Sant Barbara, California, phase 1 , coastal monitor-well
installation and initial measurements: v.S. Geological Installation and initial measurements:

Jeffreys, S.R., 1940, The Foraminifera of the formation represented at Packard's Hill, Santa Barbara, California:

Los Angeles, University of Southern California, M.s. thesis. asphait 1946 , Evidence of termites in the Pleistocene asphait of Carpinteria, California: Pas

Lian, H.M., 1952, Geology and paleontology of the Carpinteria district. Santa Barbara county, California: Los Angeles, vniversity of California, Ph.D. dissertation.

Lian, H.M., 1954, Geology of the Carpinteria district, santa Barbara County in Geology of southern California:

Lippincott, J.B., 1905, water problems of Santa Barbara, Californza: U.S. Geological Survey Water-Supply Paper 116,

99 p.
Lownes, R.E. 1960, Geology of portions of the Santa Barbara and Goleta quadrangles, California: Los Angeles, University

Maltby, D.E., 1984, Map of Carpenteria area and vicinity, Santa Barbara County, California, showing water-level contours for March 1982: U.S. Geological Survey Water-
Resources Investigations Report $83-4273$, scale $1: 24,000$.

Martin, Peter, 1982, Ground-water monitoring at Santa Barbara, California, phase 2, effects of pumping on water levels and water quality in the Santa Barbara ground-water basin: water quality in the Santa Barbara ground-water basin:

Moyle, W.R., Jr., 1984, Map of Carpinteria area and vicinity, Santa Barbara County, California, showing water level between March 1982 and March 1983: v.s. Geological Survey Water Resources Investigations Report 84-4067, scale 1:24,000.

Muxr, K.S., 1968, Ground-water reconnasssance of the Santa Barbara-Montecito area, Santa Barbara County, California.

U.S. Geological Survey Water-Supply Paper 1859-A, 28 p.
lorris, R.M., 1968, Sea cliff retreat near Santa Barbara. California: California Division of Mines and Geology, California: Callfornia Division of Mines and Geology,
Mineral Information Service, v. 21, no. 6, p. 87-91.

Mineral Information Service, v. 21, no. 6,
Page, B.M., Marks, J.G., and Walker, G.W., 1951, Stratigraphy and structure of mountains northeast of Santa Barbara, California: Amerzcan Association of Petroleum

Peterogists Bulletin, v. 35, no. 8, p. 1727-1780. cooperative investigation of springs and streamf low in the Tecolote Tunnel area of Santa Barbara County, California:
u.S. Geological Survey open-file report, $145 \mathrm{p}$. 
Peterson, w.C., 1959, Eighth progress report on the cooperative investigation of springs and streamflow in the Tecolote Tunnel area of Santa Barbara County, California: U.S. Geological Survey open-file report, 140 p.

snedden, L.B., 1931, stratigraphy and micropaleontology of the Rincon Formation of California: Palo Alto, Calif.. Stanford University, M.A. thesis.

Webber, I.E.S., 1927, Pleistocene woods from Carpinter1a, California: Berkeley, University of California, M.A. thesis.

Wilson, R.W., 1932, Rodents and lagomorphs of the Carpinteria asphalt: Pasadena, California Institute of Technology, M.S. thesis.

\section{4}

Carver, J.A., 1960, The sedimentation of the Sespe and Alegria Formations, Santa Barbara County, California: Los Angeles, University of California, M.A. thesis.

Dolman, S.G., 1941, Mesa oil field: California Oil Fields, v. 24 , no. 2 , p. 5-14, pl. 2 , scale $1: 24,000$

Hofmann, Walter, 1953, Fifth progress report on the cooperative investigation of springs and streamflow in the Tecolote Tunnel area of Santa Barbara County, California: o.s. Geological Survey open-file report, $185 \mathrm{p}$.

Hofmann, Walter, 1955 , Sixth progress report on the cooperative investigation of springs and streamflow in the Tecolote Tunnel area of Santa Barbara County, Califoriı: U.S. Geological Survey open-file report, 150 .

Rantz, S.E., 1961, effect of tunnel construction on flow of springs and small streams in the Tecolote Tunnel area of Santa Barbara County, California: U.S. Geological Survey Professional Paper 424-c, Article 277, p. C $360-\mathrm{C} 361$

Rantz, S.E.. 1962, Flow of springs and small streams in the Tecolote Tunnel area of Santa Barbara County California: 0.S. Geological Survey Water-supply paper $1619-R, 26$

vickery, F.P., 1943, Goleta oil field: California Division of Mines and Geology Bulletin 118, p. 377-379, fig. 155 scale $1: 100,000$

Wal rond, Henry, 1952, Geology of the upper Santa Ynez Valley area, Santa Barbara County, California: Los

\section{5}

Grender, G.C., 1960, Petrology of the Vaqueros Formation near Gaviota, California: University Park, Pa., Pennsylvania State University, Ph.D. dissertation.

Kolpack, R.L., 1961, Tertiary sedimentology of the Tecolote section, southern California: Los Angeles, University of Southern california, M.S. thesis.

Miller, G.A., and Rapp, J.R., 1968, A reconnaissance of the ground-water resources of the Ellwood-Gaviota area, Santa Barbara County, California: U.S. Geological Survey open-file report, $50 \mathrm{p}$.

protzman, D.L.. 1960, The facies relationships of the Sespe and Alegria Formations, Santa Barbara County, thesis.

Upson, J.E., 1951, Former marine shore lines of the Gaviota quadrangle, Santa Barbara County, California: Journal of Geology, v. 59, p. 415-446.

\section{6}

Herlyn, H.T., 1948, Lower Tertiary foraminifera from the western Santa Ynez Mountains, California: Berkeley, Unıversity of California, M.A. thesis.

Norris, R.N., 1949, Geology of a portion of the Santa Ynez Range, Santa Barbara County, California: Los Angeles, University of California, and Scripps Institute of Oceanography, M.A. thesis.

\section{4}

Bishop, C.C., 1963, Photogeologic interpretation of part of the Stepladder Mountains quadrangle, California: California Division of Mines and Geology mapping for the state geologic map, scale $1: 62,500$

\section{5}

Bishop, C.C., and Jennings, C.W., 1963, Reconnaissance geologic map and photogeologic interpretation of parts of the Essex quadrangle, California: California Division of Mines and Geology mapping for the State geologic map, scale 1:62,500. ard, J.C., and Dosch, E.F., 1937, Archean rocks in the Piute and old Woman Mountains, San Bernardino County. California (abs.): Geological Society of America Proceedings for 1936 , p. 308-309.
Bishop, C.C., and Jennings, C.W., 1963, Reconnaissance geologic map and photogeologic interpretation of parts of the Danby quadrangle, Calıfornia: California Division of Mines and Geology mapping for the state geologic map, scale $1: 62,500$.

Hazzard, J.C., 1932, Paleozoic and associated rocks of the Marble and Ship Mountains, San Bernardino County, California: Berkeley, University of Callfornia, M.A. thesis.

Lamey, C.A., 1948, Vulcan iron-ore deposit, San Bernardino county, California: California Division of Mines Bulletin 129 , p. 87-95.

0907

Lamey, C.A., 1948, Iron Hat (ironclad) iron-ore deposits, San Bernardino county, Californat Californa Division of Mines Bulletin 129, p. 97-109.

Riccio, J.F., 1951, Morphology of the Lower Cambrian Mesonacidae of the southern Marble Mountains, California: Los Angeles, University of Southern California, M.S. thesis.

\section{8}

Otton, J.K., Glanzman, R.K., and Brenner, Elizabeth, 1980, Uranium, rare earth, and thorium mineralization at the Hope Mine, eastern Bristol Mountalns, San Bernardino County, Calıfornia: U.S. Geological Survey Open-File Report 80-821,20

parker, R.B., 1963, Recent volcanism at Amboy Crater, San Bernardino County, California: California Division of Mines and Geology Special Report 76,23 p., 6 figs. 1 pl., 12 photographs.

\section{9}

Dibblee, T.W., Jr., 1967, Geologic map of the Ludlow quadrangle, San Bernardino County, Calıfornia: U.S. Geological Survey Miscellaneous Investigations Map I-477, 4 p.. scale $1: 62,500$.

\section{0}

Beeby, D.J., and Hill, R.L., 1975, Galway Lake fault: California Geology, v. 28, no. 10, p. 219-221.

Dibblee, T.W... Jr.. 1966, Geologic map of the Lavic quadrangle. San Bernardino County, California: U.S. Geological Survey Miscellaneous Investigations Map I-472, 5 p. scale $1: 62,500$.

\section{1}

Dibblee, T.W., Jr., 1964, Geologic map of the Rodman Mountalns quadrangle, San Bernardino County, California: v.S. Geological Survey Miscellaneous Investigations Map I $-430,5$ p., scale $1: 62,500$

Wlebelt, F.J., 1947. Bessemer iron project, San Bernardino County, California: U.S. Bureau of Mines Investigation Report $4066,13 \mathrm{p}$.

\section{2}

Dibblee, T.W., Jr., 1964, Geologlc map of the ord Mountains quadrangle, San Bernardino County, California: U.S. Geological Survey Miscellaneous Investigations Map I-427,6 p., scale $1: 62,500$.

Dockter, R.D., 1980, Geophysical, 11thologic, and water-quality data from Lucerne Dry Lake, San Bernardino County, California: U.S. Geological Survey open-File Report 80-1032, 1 sheet.

Gardner, D.L., 1933, Geology of the Newberry and ord Mountains, southeastern California: Berkeley, University of California, M.A. thesis.

Gardner, D.L., 1940, Geology of the Newberry and ord Mountains, San Bernardino County: California Journal of Mines and Geology, v. 36, no. 3, p. 257-292.

Tucker, W.B., and Sampson, R.J., 1940, Economic mineral deposits of the Newberry and Ord Mountains, San Bernardino county, California: Californiz Journal of Mines and Geology, v. 36, no. 3, p. 232-254.

0913

Bowen, O.E., Jr., 1950, Geology of the Sidewinder and Granite Mountalns, Californa: Berkeley, University of California, M.A. thesis. 


\section{3--Continued}

Busby, M.W., 1975, Flood-hazard study--100-year flood stage for Apple Valley dry lake, San Bernardino County, California: U.S. Geological Survey water-Resources Investigations report $11-75,40 \mathrm{p}$

Dibblee, T.W., Jr., 1960. Preliminary geologic map of the Apple Vailley quadrangle, Cal ifornia: v.s. Geological Survey Mineral Investigations Field Studies Map MF-232, scale $1: 62,500$

Dutcher, L.C., 1965, Progress report on water studies in the San Timoteo-Smiley Heights area, upper Santa Ana report, $31 \mathrm{p}$.

\section{4}

Dibblee, T.W., Jr., 1960, Preliminary geologic map of the Victorville quadrangle. California: U.S. Geological Survey $1: 62,500$.

Kocher, A.E., and Cosby, S.W., 1924, Soil survey of the Victorville area, California: U.S. Department of Agriculture, Bureau of Soils, p. 623-672.

Moritz, E.A., 1952, Report on Victor Valley project, California: U.s. Bureau of Reclamation report, $42 \mathrm{p}$.

Webb, R.W., 1937, Paleontology of the Plexstocene of Point Loma, San Diego County, Californa: Pasadena, California Institute of Technology, Ph.D. dissertation.

\section{5}

Dibblee, T.W., Jr., 1960, Preliminary geologic map of the Shadow Mountains quadrangle, Los Angeles and San Bernardino Counties, California: U.S. Geological Survey Mineral Investigations Field Study Map MF-227, scale $1: 62,500$.

Dockter, R.D., 1980, Geophysical, lithologic, and water-quality data from El Mirage Dry Lake, San Bernardino County, California: U.S. Geological Survey open-File Report 80-1200, 1 sheet.

Novotny, J.R., 1955, The geology of the northeastern Shadow Mountains, western San Bernardino County, California: Los Angeles, University of California, M.A. thesis.

Riddell, G.C.., and Foster, E.D. 1927, Geology and ores of Shadow Mountains: Phoenix, Ariz., Mining Journal, v. 11 no. 12, p. 3-6, 33-34.

Troxel, B.W., 1954, Geology of a part of the Shadow Mountains, western San Bernardino County, in Geology of southern California: California Division of Mines and Geology Bulletin 170, map sheet 15, scale 1:20,850.

Troxel, B.W., 1958, Geology of the northwestern part of the Shadow Mountains, western San Bernardino County California: Los Angeles, University of California, M.A. thesis.

Troxel, B.W., and Gunderson, J.N., 1970, Geology of the Shadow Mountains and northern part of the Shadow Mountains southeast quadrangles, western San Bernardino County, California: California Division of Mines and Geology Preliminary Report 12 .

\section{6}

Dibblee, T.W., Jr., 1959, Geologic map of the Alpine Butte quadrangle, California: U.S. Geological survineral

\section{7}

Dibblee, T.W., Jr.. 1960 (1961), Geologic map of the Lancaster quadrangle, Los Angeles County, California: U.S. Geological Survey Mineral Investigations Field Studies Map MF-76. scale $1: 62,500$

Ponti, D.J., Burke, D.B., and Fedel, C.W., 1981, Map showing Quaternary geology of the central Antelope Valley and vicinity, California: U.S. Geological Survey openFile Report $81-737$, scale 1:62,500.

\section{8}

Beeby, D.J., 1978, Preliminary fault map of the Lake Hughes segment, San Andreas fault zone, Los Angeles County. Californa: California Division of Mines and Geology openFile Report 78-2 LA.

Beeby, D.J., 1979, Geology and fault activities of the Lake Hughes segment of the San Andreas fault zone, Los Angeles County, California: California Division of Mines and Geology Open-File Report 79-2 LA.

Beverly, Burt, Jr., 1933, Some graphite deposits of Los Angeles, California: Ithaca, N.Y., Cornell University.

Blaisdeli, R.C., 1955, Stratigraphy and foraminifera of the Matilija, Cozy Dell, and Coldwater Formations near Ojai, California: Berkeley, University of California, M.A. thesis.

\section{8--Continued}

Dibblee, T.W., Jr., 1961, Geologic map of the Bouquet Reservoir quadrangle, Los Angeles County. California: U.S. Geological Survey Mineral Investigations Field Studies Map MF-79, scale $1: 62,500$.

Evans, J.G., 1976, Geologic map of the San Andreas fault zone, Leona Valley, California: v.s. Geological Survey

Miscellaneous Field Studies Map MF-76, scale 1:10,000. Canyon area, Los Angeles County, California: Pasadena,

Jennings, C.W., and Dibblee, T.W., Jr., 1968 Reconnaissance geologic mapping in parts of the lake and Geology and v.s. Geological Survey, scale $1: 24,000$.

Konigsberg, R.L., 1967, Geology along the San Francisquito fault, Los Angeles County, (Calif.): Los Angeles, University of california, M.s. thesis, scale $1: 12,000$.

Nickell, F.A., 1928, Geology of the southwestern part of the Elizabeth Lake quadrangle between San Francisquito and Bouquet Canyons (Calif.): Pasadena, California Institute of Technology, M.A. thesis.

Otte, Carel, Jr., 1950, Geology of the upper Tick Canyon area, Los Angeles County, California: Pasadena, California Institute of Technology, M.S. thesis.

Simpson, E.C., 1933, Geology of the Elizabeth Lake quadrangle, California: Berkeley, University of California, Ph.D. dissertation.

Simpson, E.C., 1934, Geology and mineral deposits of the Elizabeth Lake quadrangle, Californda: California Division Elizabeth Lake quadrangle, Californda: Californd
of Mines Report 30, chap. 4, p. 371-415, 5 pl.

Wallace, R.E., 1946, A portion of the San Andreas $r$ ift in southern California: Pasadena, California Institute of Technology. Ph.D. dissertation.

Webb, R.W., 1932, The geology of eastern Sierra Pelona Ridge and vicinity, in the southeastern part of the Elizabeth Lake quadrangle, California: Pasadena, California Institute of Technology, M.S. thesis.

\section{9}

Bettinger, C.E., 1948, The geology of portions of Beartrap Canyon and Quall quadrangles, California: Los Angeles, University of Southern California. M.s. thesis.

Chambers, E.F., 1947, Geology of portions of the whitaker Peak and Beartrap Canyon quadrangles, California: Los Angeles, University of Southern California, M.S. thesis.

clements, Thomas, 1929, Geology of a portion of the southeast quarter of the Tejon quadrangle, Los Angeles County, California: Pasadena, California Institute of Technology, M.s. thesis.

clements, Thomas, 1932 , The geology of the southeastern portion of the Tejon quadrangle: Pasadena, California Institute of Technology. Ph.D. dissertation.

Clements, Thomas, 1937, Structure of southeastern part of Tejon quadrangle, California: American Association of Petroleum ogists Bulletin, v. 21, no. 2, p. 212-232.

Crowell, J.C., 1953, Geology of the Santa Felicia-Canton Canyon area, Los Angeles and Ventura Counties, California: Los Angeles, University of California, faculty research, scale $1: 14,400$.

Croweli, J.C., 1954, Geology of the Ridge Basin area, Los Angeles and Ventura Counties, in Geology of southern
California: California Division of Mines and Geology Bulletin 170, map sheet 7 , scale $1: 93,750$.

Crowell, J.C., and others, 1956, Geologic map of Ridge Basin, southern California: Los Angeles, University of California, faculty research, scale $1: 24,000$.

Faggiol 1, R.E., 1952, The geology of the Liebre fault: Los Angeles, University of California, M.A. thesis.

Fife, D.L., 1968, Pyramid reservoir slope stability, State water facilities, California Aqueduct, West Branch California Department of water Resources office Report, 18 p., 3 pls., scale 1 inch $=400$ feet.

Jennings, C.w., and Dibblee, T.W., Jr.., 1968, Reconnaissance geologic mapping in part of the Burnt Peak guadrangle (Calif.): California Division of Mines and Geology and u.s. Geological Survey, scale $1: 24,000$.

Johnson. B.K., 1952, Geology of the Castaic Creek-Elizabeth Lake Canyon area (Calif.): Los Angeles, University of California, M.A. thesis.

Kriz, S.J., 1947, Stratigraphy and structure of the whitaker Peak-Reasoner Canyon area, Ventura and Los Angeles Counties. Californa: Princeton, N.J., Princeton University, Ph.D. dissertation, map, scale $1: 24,000$.

Miller, C.J., 1952, Geology of portions of Red Mountain and San Francisquito quadrangles, California: Los Angeles, University of California, M.A. thesis.

Pfaffman, G.A., 1941, The geology of the Martinez California: Los Angeles, University of Southern California, M.s. thesis.

Ruiz, E.J., 1953, Geology of the St. Francis Dam area, Los Angeles county, California: Pasadena, California Institute
of Technology, M.s. thesis.

Scanlin, D.G., 1958, Geology of the basal Modelo unconformity, Canton Canyon area, Los Angeles County, Californ thesis.
pherd, G.L., 1960, Geology of the whitaker Peak-Canton Canyon area, southern California: Los Angeles, University of California. M.A. thesis.

Smith, V.M., 1951, Geology of the upper Castaic creek region, Los Angeles County, Cal ifornia: Los Angeles University of California, M.A. thesis. 
Stanley, K.0., 1966, Structural history of the clearwater fault, northwest Los Angeles County, California: Los Angeles,
$1: 24,000$.

stanton, R.J., Jr., 1960, Paleoecology of the upper Miocene Castaic Formation, Los Angeles County, California: Pasadena, California Institute of Technology, Ph.D. dissertation.

Szatai. J.E., 1961, The geology of parts of Redrock Mountain, Warm Spring, Viol in Canyon, and Red Mountain quadrangles, Los Angeles County, California: Los Angeles, university of Southern California, Ph.D. dissertation, scale $1: 24,000$.

\section{0}

Adams, W.L., 1956, Geology of the Dry Canyon area, northeastern ventura County, southern California: Los Angeles, University of California, M.A. thesis.

Anderson, R.M., 1960, Geology of part of the lower P1ru Creek area, Ventura and los Angeles Counties, California: Los Angeles, University of California, M.A. thesis.

Shepard, J.B., Jr., I961, The geology of part of the San Gabriel fault' zone, Los Angeles and Ventura counties, California: Los Angeles, University of California, M.A. thesis.

\section{1}

Badger, R.L., 1957, Geology of the western Lion Canyon quadrangle, Ventura County, Californua: Los Angeles, University of Southern California, M.A. thesis.

Dibblee, T.W., Jr., 1979, Geologic maps of the San Guillermo, Lion Canyon, Topatopa Mountains, and Lockwood Valley quadrangles, California: U.s. Geological Survey Open-File Report 79-1464,4 sheets, scale $1: 24,000$.

Kiessling, Edmund, 1958, Geology of the southwest portion of the Lockwood valley quadrangle, Ventura County, Calxfornia: Los Angeles, University of Californua, M.A. thesis.

Merrill, W.R.. 1954, Geology of the Sespe Creek-pine Mountain area, Ventura County, in Geology of southern
California: Cal ifornia Division of Mines Bulletin 170 , sheet 3 , scale $1 / 2$ inch $=1 \mathrm{mile}$.

Newman, P.V., Geology of the Round Spring Canyon area, northwestern Ventura County, California: Los Angeles, University of California. M.A. thesis.

Poyner, W.D., 1960, Geology of the San Guillermo area and its regional correlation, Ventura County, Calıfornia: Los Angeles, University of California, M.A. thesis.

Rupnik, J.J., 1941 Geology of the Whley Canyon area, Oak Ridge anticline, T. 3-4 N, R. 18-19 W, Ventura county. California: Pasadena, California Institute of Technology. M.S. thesis.

Schlee, J.S.. 1952, Geology of the Mutau Flat area, Ventura County, California: Los Angeles, Unıversity of California, M.A. thesis.

welday, E.E., 1960, Geology of the San Guxllermo Mountain area, California: Claremont, Calıf., Pomona College, M.A. thesis.

\section{2}

Gross, D.J., 1958, Geology of the Ortega area, Ventura County, California: Los Angeles, Unxversity of California, M.A.

Hagen, D.W., 1957, Geology of the wheeler springs area: Los Angeles, University of California, M.A. thesis.

Keenan, M.F.. 1932, The Eocene Sierra Blanca Limestone at the type locality in Santa Barbara County, Californa:

palo Alto, Calif., Stanford University. M.A. thesis.

Larson, E.E., 1958, The geology of the Potrero Seco area, Ventura County, California: Los Angeles, Unıversity of Californua, M. A. thesis.

Maxson, J.H., 1928, A Tertiary mammalian fauna from the Mint Canyon Formation, southern California: Calufornia Institute of Technology, M.S. thesis.

Rust, B.R., 1966, Late Cretaceous paleogeography near Wheeler Gorge, Ventura County, California: American Association of Petroleum Geologists Bulletın, v. 50 , no. 7 , p. 1389-1398, fig. 2, scale 1 inch $=3.5 \mathrm{miles}$

Stanford Geological Survey, 1964, Geology of the pine Mountain area, Ventura County, California: Palo Alto, Calif. Stanford University, scale $1: 24,000$.

\section{3}

Nelson, R.N., 1923, The geology of the hydrographic basin of the upper Santa Ynez River, Californi
Burgess, C.E., 1951, Third progress report on the cooperative investigation of springs and streamflow in the Tecolote Tunnel area of Santa Barbara County, California: U.s. Geological Survey open-file report, $177^{\prime} \mathrm{p}$.

Burgess, C.E., 1952, Fourth progress report on the cooperative investigation of springs and streamflow in the Tecolote Tunnel area of Santa Barbara County. California: U.s. Geological Survey open-file report, $166 \mathrm{p}$.

Busby, M.w., 1973, Air injection at Lake Cachuma, California: U.S. Geological Survey open-file report, $31 \mathrm{p}$.

Hedman, E.R., 1968, Preliminary results of alr injection to eliminate stratification at Lake Cachuma, Californa: v.s. Geological survey open-file report, 7 p.

Hedman, E.R., and Tyley, S.J., 1967, Progress report, elimination of stratification at Lake Cachuma,

Koberg, G.E., 1962, U.S. Geological survey evaluation of evaporation savings accomplished during Lake Cachuma,
Callfornia, Fleld Tests: Contribution to U.S. Bureau of Reclamation Chemic

Troxel1, H.C., Burgess, C.E., and Warren, M.A., 1949, Progress report on the cooperative investigation of springs and streamflow in the Tecolote Tunnel area of Santa Barbara County: U.S. Geological Survey open-file report, 174 .

Troxell, H.C., and Burgess, C.E., 1950, Second progress report on the cooperative investigation of springs and streamflow in the Tecolote Tunnel area of Santa Barbara county, California: U.S. Geological Survey open-file report, $174 \mathrm{p}$.

u.s. Bureau of Reclamation, 1971. Twelfth progress report on investigations, measurements, and studies during water year 1970, Santa Ynez River, Cachuma project: U.s. Bureau of Reclamation, $13 \mathrm{p}$.

v.S. Bureau of Reclamation, 1972, Thirteenth progress report on investigations, measurements, and studies during water year 1971, Santa Ynez River, Cachuma project: U.S. Bureau of Reclamation, $12 \mathrm{p}$.

U.S. Bureau of Reclamation, 1973, Fourteenth progress report on investigations, measurements, and studies during water year 1972, Santa Ynez River, Cachuma project: 0.s. Bureau of Reclamation, 12 .

u.s. Bureau of Reclamation, 1977, Cachuma Project, California, Progress report on investigations, measurements, and studies, during water year 1977: U.S. Bureau of Reclamation, $15 \mathrm{p}$.

Vedder, J.G., Gower, H.D., Clifton, H.E., and Durham, D.L., 1967, Reconnalssance geologic map of the central san Rafael Mountains and vicinity, Santa Barbara County, California: U.S. Geological Survey Miscellaneous Invest gations Map I-487, scale $1: 48,000$.

\section{5}

Classen, w.J., Jr., 1953, Eocene foraminifera from the vicinuty of Las cruces, Santa Barbara County, California: Berkeley, University of California, M.A. thesis.

crook, T.H., 1922, The geology of a portion of the Santa Ynez Mountains south of the town of Solvang, California: Berkeley, University of California, M.A. thesis.

Drumond, C.H., 1941, Stratigraphy of the Nojoqui and Las cruces Creeks district, Santa Barbara county, California: Palo Alto, Calif., Stanford university, M.A. thesis.

Everhart, D.L., 1950, Quicksilver deposits of the Cachuma district. Santa Barbara County, California: California pl. 74 , scale $1: 24,000$.

Girard, C.M., 1949 , Geology of a part of the western Santa Ynez Range, Santa Barbara County, Calufornia: Palo Alto, Calif.. Stanford University, M.S. thesis.

Grant, U.S., and Son, C2v2l Engineers, 1975, Santa Ynez sewerage facilities, design study and project report: Consulting report prepared for Santa Ynez, Calif., Community Services District, $79 \mathrm{p}$.

Grant, U.S.. and Son, Civil Engineers, 1976, Santa Ynez sewerage facilities, collection system eligibility study. Consulting report prepared for Santa Ynez, Calif. Community Services District, 35 p.

Grant, U.S., and Son, Civil Engineers, 1976, Santa Ynez sewerage facslities, environmental impact report (draft). Consulting report prepared for Santa Ynez, Calif. Community services District, 104 p.

Hawley, H.J., 1918, The stratigraphy and paleontology of a portion of the Santa Ynez Mountains, Santa Barbara county, California: Palo Alto, Calif., Stanford university, M.A. thesis.

Hookway, L.C., 1930, Geology of the region about Gaviota Pass: Pasadena, Calif.., California Instxtute of Technology, M.S. thesis.

Hornaday, G.R., 1954, Upper Eocene Foraminifera from south of Refugio Pass, California: Berkeley, Calıf. university of California, M.A. thesis.

LaFreniere, G.F., and French, J.J., 1968, Ground-water resources of the Santa Ynez upland ground-water basin, Santa Barbara County, California: U.S. Geological Survey open-file

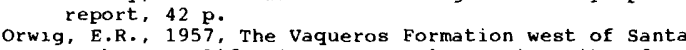
Barbara, California: Los Angeles, University of California. Ph.D. dissertation. Singer, J.A.. 1979, Water resources of the Santa Ynez
Indian Reservation, Santa Barbara County, California: U.S. Geological Survey Open-File Report 79-413, 27 p. 


\section{5--Continued}

Weaver, D.W., 1957, Eocene Foraminifera from west of Refugio Pass, California: Berkeley, University of California, M.A. thesis.

Weaver, D.W.: 1960, The paleontology and stratigraphy of the Gaviota Formation, Santa Barbara County, California: Berkeley, University of California, Ph.D. dissertation.

wilson, E.J., 1950, Foraminifera from the Gaviota Formation east of Gaviota Creek, California: Berkeley, University of California, M.A. thesis.

\section{6}

Arnestad, K.H., 1950, The geology of a portion of the Lompoc quadrangle, Santa Barbara County, California: Los Angeles, University of California, M.A. thesis.

Brown and Caldwell, 1972, Lompoc Valley regional wastewater management study and preliminary design: Al hambra, Calif., Brown and Caldwell consulting Engineers, $164 \mathrm{p}$.

Evenson, R.E., 1964, Suitability of irragation water and changes in ground-water quality in the Lompoc subarea of the Santa Ynez River basin, Santa Barbara County. california: o.s. Geological Survey open-file report, 57 p.

Evenson, R.E., 1965, Suitability of irrigation water and changes in ground-water quality in the Lompoc subarea of the Santa ynez River basin, Santa Barbara County, california: 0.s. Geological Survey Water-supply Paper $1809-\mathrm{s}, 20 \mathrm{p}$.

Evenson, R.E., and Worts, G.F., Jr., 1966, Hydrologic inventory of the Lompoc subarea, Santa Ynez River basin, Santa Barbara County, California, 1957-62, with a section on perennial supply by R.E. Evenson and G.F. Worts, Jr.: u.s. Geological Survey open-file report, $27 \mathrm{p}$.

Foxhali. H.B., 1942, Geology of the upper Jalama valley area, Santa Barbara County, California: Palo Alto, Calif.. stanford Oniversity, M.A. thesis.

Geotechnical Consultants Inc., 1978, Summary of operations for Los Alamos Community Service District No. 3 water well, Los Alamos, Cal ifornia: Consulting Report v76110-A, $10 \mathrm{p}$.

Hansen, D.A., 1953, Electromagnetic prospecting with application to ground water problems: Los Angeles, University of California. Ph.D. dissertation.

Kelley, F.R., 1941, Stratigraphlc allocation of Eocene foraminifera from the western Santa Ynez Mountains of Calıfornia: Palo Alto, Calif., Stanford Unıversity, M.A. thesis

Kelley, F.R., 1943, Eocene stratigraphy in western Santa Ynez Mountains, Santa Barbara County, California: American Association of Petroleum Geologists Bulletin, v. 27, no. 1 p. $1-19$.

Miller, G.A., 1976, Ground-water resources in the Lompoc area, Santa Barbara County, California: 0.s. Geological Survey Open-File Report 76-183, 78 p.

Molander, G.E., 1956, Lower Tertiary stratigraphy and foraminifera of the eastern Santa Rosa Hills, Santa Barbara County, California: Berkeley, University of California, M.A. thesis.

upson, J.E., 1943, Preliminary report on water-storage capacity of unconsolidated deposits beneath the Lompoc plain, Santa Barbara County, California: U.S. Geologica Survey open-file report, $37 \mathrm{p}$.

Weaver, W.R., 1957, Upper Eocene Foraminifera from the southwestern Santa Ynez Mountains, Cal ifornia: Berkeley. University of California, M.A. thesis.

\section{7}

Dill, R.F., 1952, Environmental analysis of sediment from the sea floor off Point Arguello, California: Los Angeles, University of Southern California, M.S. thesis.

Evenson, R.E., 1961, Ground-water conditions, Naval Missile Facility, Point Arguello, California, 1958-60. o.s. Geological Survey open-file report, $22 \mathrm{p}$.

Evenson, R.E., 1961, Ground-water conditions, Naval Missile Facility, Point Arguello, California, June 1960-June 1961: U.S. Geological Survey open-file report, $21 \mathrm{p}$.

Evenson, R.E., 1962, Ground-water conditions, U.S. Naval Missile Facility, Point Arguello, California, June 1961-June 1962: U.S. Geological Survey open-file report, $22 p$.

Evenson, R.E., 1963, Results of test drilling, Naval Missile Facility, Point Arguello, Santa Barbara County, Cal ifornia, 1962-63: 0.S. Geological Survey open-file report, $18 \mathrm{p}$.

Evenson, R.E., 1964, Results of test drilling, Naval Missile Facility, Point Arguello, Santa Barbara County, California: 0.S. Geological Survey open-file report, $17 \mathrm{p}$.

Evenson, R.E., and Miller, G.A., 1963, Geology and ground-water features of Point Arguello Naval Missile Facility, Santa Barbara County, Cal ifornia: U.S. Geological Survey Water-Supply Paper 1619-F, $35 \mathrm{p}$.

Miller, G.A., 1963, Ground-water conditions, O.s. Naval Missile Facility, Point Arguello, California, July 1962-June 1963: 0.s. Geological Survey open-file report. $21 \mathrm{p}$.

Miller, G.A., 1965, Ground-water conditions, U.S. Naval Missile Facility, Point Arguello, California, July 1963-June 1964: U.S. Geological Survey open-file report. $20 \mathrm{p}$.

\section{3}

Kunkel, Fred, 1969, Test-well and soil data, Fort Mohave Indian Reservation area, Cal ifornia: U.S. Geological Survey open-file report, $77 \mathrm{p}$.

Kunkel, Fred, 1970, The deposits of the Colorado River on the Fort Mojave Indian Reservation in California, 1850-1969: o.s. Geological Survey open-file report. 29 p., 3 app.

Metzger, D.G., and Loeltz, o.J., 1973, Geohydrology of the Needles area, Arizona, California, and Nevada: U.S. pl.. 25 fig.. 11 tables.

schrader, F.c. 1909, Mineral deposits of the cerbat Range, Black Mountains, and Grand Wash cliffs, Mojave County, Arizona: 0.S. Geological Survey Bulletin 397, 226 p., pl. 1, scale 1:250,000.

vitaliano, c.J., 1950 , Neediles magnesite deposit, San Bernardino County, California: California Journal of Mines and Geology, v. 46, no. 3, p. 357-372.

1006

Bishop, C.C., 1963, Photogeologic interpretation of the northern part of the Colton Well quadrangle, California: California Division of Mines and Geology mapping for the state geologic map, scale $1: 62,500$.

1007

Hazzard, J.C., 1938, Paleozoic section in the Providence Mountains, San Bernardino County, California: Geological Society of America proceedings for 1937, p. 240-241.

Hazzard, J.C., 1954, Rocks and structure of the northern Providence Mountains, San Bernardino County, in Geology of southern Cal ifornia: Cal ifornia Division of Mines Bulletin 170 , chap. 4, contribution 4, pls. 2 and 4 , scale $1: 31,680$.

Hazzard, J.C.. and Mason, J.F., 1936, Middle Cambrian formations of the Providence and Marble Mountains, California:

Landwehr, W.R., 1933, Factors of ore control: Palo Alto, Calif. stanford University, Ph.D. dissertation.

1009

Dibblee, T.W., Jr., 1967, Geologic map of the Broadwell Lake quadrangle, San Bernardino County, California: 0.s. Geological Survey Miscellaneous Investigations Map I-478, 3 p., scale $1: 62,500$.

Hadley, J.B.. 1942, Manganese deposits in the paymaster mining district, Imperial County, California: 0.s. Geological Survey Bulletin 931-S, p. 459-473, pl. 75, scale $1: 6,000$.

1010

Dibblee, T.W., Jr., and Bassett, A.M., 1966, Geologic map of the Cady Mountains, San Bernardino County, California: U.S. Geological Survey Miscellaneous Investigations Map I-467, scale 1:62,500.

Madsen, B.M., 1970, Core logs of three test holes in Cenozoic Lake deposits near Hector, California: 0.s. Geological Survey Bulletin 1296, 43 p.

Miller, R.C.. 1950, Geology of a part of the Afton fluorite maning district, San Bernardino county. California: Palo Alto, Stanford University, M.S. thesis.

\section{1}

Dibblee, T.W., Jr., and Bassett, A.M., 1966, Geologic map of the Newberry quadrangle, San Bernardino County, California: 0.S. Geological Survey Miscellaneous
Investigations Map I-461, 4 p.. scale $1: 62,500$.

Dockter, R.D., 1980, Lithologic and water-quality data from Troy Dry Lake, San Bernardino County, California:

mith, G.A., 1957, The archaeology of Newberry Cave, San Bernardino County, Newberry, California: San Bernardino County Museum Association, no, 1, 58 p.

winters, H.H., 1954, The Pleistocene fauna of the Manix California Institute of Technology, M.s. thesis.

1012

Brown, K.W., and Caldwell, D.H., 1970, Domestic and industrial waste study, Marine Corps Supply Center, Barstow, California: Consulting report to the 0.S.'Marine Corps, 66 p., app. A-G.

DeLeen, J.L. 1950, Geology and mineral deposits of Calico Mining District: Berkeley, Oniversity of California, M.A. thesis. 


\section{2--Continued}

Dibblee, T.W., Jr., 1970, Geologic map of the Daggett quadrangle, San Bernardino County, California: U.s. Geological Survey Miscellaneous Investigations Map I-592, 6 p., scale $1: 62,500$.

Eccles, L.A., 1981, Ground-water quality along the Mojave River near Barstow, California: U.s. Geological Survey WaterResources Investigations Report 80-109, $63 \mathrm{p}$.

Erwin, H.D., and Gardner, D.L., 1940, Notes on the geology of a portion of the Calico Mountains, San Bernardino County, California: California Journal of Mines and Geology, v. 36, no. 3, p. 293-304, pl. 3, scale $1: 62,500$.

Hughes, J.L., 1975, Evaluation of ground-water degradation resulting from waste disposal to alluvium near Barstow,
California: U.S. Geological Survey Professional Paper 878 $33 \mathrm{p}$.

Hughes, J.L., Eccles, L.A., and Malcolm, R.L., 1974. Dissolved organic carbon (DOC), an index of organic contamination in ground water near Barstow, California Ground Water, v. 12, no. 5, 8 p

Hughes, J.L., and Patridge, D.L., 1973, Data on wells in the Barstow area, Mojave River basin, California: U.s. Geological Survey open-file report, $102 \mathrm{p}$.

Hughes, J.L., and Robson, S.G., 1973, Effects of waste percolation of groundwater in alluvium near Barstow, California: Underground Waste Management and Artificial Recharge symposium, New Orleans, Louisiana, American Association of Petroleur Geologists, U.S. Geological Science, v. 1, p. 91-129.

Koehler, J.H., 1969, Water resources at Marine Corps Supply Center, Barstow, California, for the 1968 fiscal year: u.s. Geological Survey open-file report, $15 \mathrm{p}$.

Koehler, J.H., 1970, Water regources at Marine Corps supply center, Barstow, California, for the 1969 fiscal year: U.s. Geological Survey open-file report, $22 \mathrm{p}$.

koehler, J.H., 1972, Water resources at Marine Corps supply center, Barstow, California, for the 1971 fiscal year: u.s. Geological Survey open-file report, $18 \mathrm{p}$.

koehler, J.H., and Banta, R.L., 1969, Water resources at Marine Corps Supply Center, Barstow, California, for the 1967 fiscal year: U.S. Geological survey open-file report, $17 \mathrm{p}$.

McCulloh, T.H., 1965, Geologic map of the Nebo and Yermo quadrangles, San Bernardino County, California: U.S. Geological Survey open-file report, 1 map.

Miller, G.A., 1969, water resources of the Marine Corps Supply Center area, Barstow, California: v.s. Geological Survey open-file report, $51 \mathrm{p}$.

Robson, s.G., 1974, Feasibility of digital water-quality modeling illustrated by application at Barstow, California: U.s. Geological survey water-Resources Investigations Report $46-73,66 \mathrm{p}$.

Robson, S.G., 1978, Applicatıon of digital prof 1 le modeling techniques to ground-water solute transport at Barstow, California: U.s. Geological Water-supply Paper $2050,28 \mathrm{p}$.

storms, W.H., 1890 , The mines of calico district, California: Engineering Mining Journal, v. 49, p. 382-383.

weber, F.H., 1956, Geology and mineral deposits of the ord Mountain District, San Bernardino County, California: Los Angeles, University of California, M.A. thesis.

weber, F.H.' Jr., 1963 , Geology and mineral deposits of the ord Mountain District, San Bernardino County, California: California D Special Report 77,45 p.
weber, F.H.. Jr., 1966, Silver mining in old Calico:
California Division of Mines and Geology Mineral Information Service, v. 19 , no. 5 , p. $71-80$.

weber, F.H., Jr., 1967, Silver deposits of the Calico District: California Division of Mnes and Geolog Mineral Information Service, v. 20, no. 1, p. 3-8.

Weber, F.H., Jr.. 1967, silver deposits of the Calico District: California Division of Mines and Geology
Mineral Information Service, v. 20, no. 2, p. 11-14.

\section{3}

Bowen, O.E., Jr., 1954, Geology and mineral deposits of the Barstow quadrangle, San Bernardino County, California: california Division of Mines and Geology Bulletin 165, 185 p.

Bowen, O.E., Jr., 1954, Geology of the Barstow area, San Bernardino County, in Geology of southern California California Division of Mines and Geology Bulletin 170, map sheet 18, scale 1:125,000.

Burke, D.B., Hillhouse, J.W., McKee, E.H., Miller, S.T., and Morton, J.L.. 1982, Cenozoic rocks in the Barstow basin area of southern california--stratigraphic relations, radiometric ages, and paleomagnetism: v.s. Geological Survey Bulletin 1529-E, P. E1-E16, 2 pl.

California Department of Public Health and California Department of Water Resources, 1960 , Ground-water quality studies in Mojave River valley in vicinity of Barstow, San Bernardino County: California Department of Water Resources report to California Regional water Quality Control Board, Lahontan Region, $60 \mathrm{p}$.

California Department of Public Health, 1970, Barstow ground-water study: California Department of Public Health report to California Regional Water quality Control Board, Lahontan Region, $14 \mathrm{p}$

Dibblee, T.W., Jr., 1960, Geologic map of Barstow quadrangle, San Bernardino County, California: U.s. Geological Survey Mineral Investigations Field studies Map MF-233, scale $1: 62,500$.

\section{3--Continued}

Miller, w.J., 1944, Geology of the Barstow quadrangle, San Bernardino County, California: California Journal of Mines and Geology, v. 40, p. 73-139, 13 figs., map.

Snyder, C.T., 1966, Examination of five well sites in the Riverside Grazing Digtrict, California, Barstow area, San Bernardino County: U.S. Bureau of Land Management, $3 \mathrm{p}$.

\section{4}

Dibblee, T.W., Jr., 1960, Geologic map of the Hawes quadrangle, San Bernardino County, California: U.s. Geological Survey Mineral Investagations Fueld Studies Map MF-226, scale $1: 62,500$.

Pack, R.W. , 1914, Reconna1ssance of the Barstow-Kramer region, California: U.S. Geological Survey Bulletin 541 ,

1015

Benda, W.K., Erd, R.C., and Smith, W.C., 1960, Core logs from five test holes near Kramer, Calufornia: U.S. Geological Survey Bulletin 1045-F, p. 319-393.

Dickey, D.D., 1957, Core logs from two test holes near Kramer, San Bernardino County, California: U.S. Geological Survey Bulletin 1045-B, $16 \mathrm{p}$.

Frıschknecht, F.C., and Petrafeso, F.A., 1964, Aeromagnet 1 c map of the Kramer area, Kern, San Bernardino, and Los Angeles Counties, California: U.S. Geological Survey open-file report, I sheet.

Hughes, J.L., 1975, Hydrologic evaluation of the Haystack Butte area with emphasis on possible discharge of class-I waste, Edwards Air Force Base, California: U.S. Geological Survey Water-Resources Investigations report 7-75, 34 p.

\section{7}

Borys, Edmund, 1936, A horizontal intensity magnetic Survey across the Rosamond fault: Pasad

Nelson. A.G. 1940, The geology of the northwestern portion of Soledad Mountain, Kern County, California: Los Angeles, University of Southern California, M.A. thesis.

Noble, J.A., 1954, Geology of the Rosamond Hills, Kern County, California: Californa Divigion of Mines Bulletin 170, map sheet 14 , scale $1: 125,000$

Roberts, W.B., 1951, Geology of a part of the Rosamond Hills area, Kern County, Calıfornia: Pasadena, California Institute of Technology, M.s. thesis

Schroter, G.A., 1935, A geologist visits the Mojave mining district: Englneering and Mining Journal, v. 123, no. 4 p. 185-188; map p. 186, scale $1: 140,000$

Tucker, w.B., and Sampson, R.J., 1935, Minıng activity at Soledad Mountain and Middle Buttes-Mojave maning district, Kern County, California: California Journal of Mines and Geology, v. 31, no. 4, p. 465-485.

Walker, G.W., 1953, Rosamond uranium prospect, Kern County, California: California Division of Mines and Geology Special Report 37,8 p., E1g. 2, scale $1: 1,200$.

\section{8}

Buwalda, J.P., 1916, New mammalian faunas from Miocene sediments near Tehachapi Valley in the southern sierra Nevada: University of California Department of Geologica Science Bulletin, v. 10, no. 6, p. 75-85.

Dibblee, T.W., Jr., 1963, Geology of the Willow Springs and Rosamond quadrangles, Calufornia: U.S. Geological Survey Bulletin 1089-c, $253 \mathrm{p} .$, pl. 10, scale 1:62,500.

Jordan, J.T., 1941, Geology of the Cactus mines, Rosamond, Kern County, Calıfornia: Pasadena, Calıfornia Institute of Technology, M.s. thesis.

Kunkel, Fred, 1957, Data on water wells in the willow Springs, Gloster, and Chaffee areas, Kern County, California: U.S. Geological Survey open-f $f_{\text {le }}$ report, $67 \mathrm{p}$.

Maynard, R.G., 1947, Geology of the Tropico mine, Rosamond, California: Los Angeles, University California, M.A. thesis.

Smith, Alexander, 1947, The geochemistry and paragenesis of the ores of the Cactus mine, Kern County, California: Pasadena, California Institute of Technology, Ph.D. dissertation.

\section{9}

Bloyd, R.M., Jr., 1966, A progress report on the test-well drilling program in the western part of Antelope Valley, California: U.s. Geological Survey open-file report, $20 \mathrm{p}$. Bromery, R.W., and Tyson, N.S., 1964, Aeromagnetic map of the Garlock area, Kern and Los Angeles Counties, Ca 


\section{9--Continued}

Buwalda, J.P., 1954, Geology of the Tehachapi Mountains, California, in Geology of southern California: Californa Division of Mines and Geology Bulletin 170, chap. 2 , contribution 9, fig. 1. scale $1: 360,000$.

Evans, M.H., 1936, The geology and ore deposits of the Manzana quadrangle, Los Angeles County, California: Pasadena, California Institute of Technology, M.s. thesis.

Jennings, C.w. 1952, Geology of the southern part of the Quail quadrangle, Los Angeles County, California: Los Angeles. quadrangle, Los Angeles County, Califorr

Jennings, C.w., 1953, Geology of the southern part of the Quail quadrangle, California: California Division of Mines Special Report 30, $18 \mathrm{p} ., \mathrm{pl}$. 1, scale $1: 24,000$.

Parsons, R.L.. Geology and ore deposits of the Neenach mining district of California: Los Angeles, University of Southern California, M.S. thesis.

Turner, F.E., 1928, Geology of the Quail lake region: Pasadena, California Institute of Technology, M.s. thesis. , J.H., 1947, Geology and mineral resources of the Neenach quadrangle, California: Los Angeles, University of California, Ph.D. dissertation.

Wiese, J.H., 1950, Geology and mineral resources of the Neenach quadrangle, California: California Division of

Mines Bulletin 153, 53 p.
wiese, J.H., and Fine, S.F., 1950, Structural features of western Antelope Valley, California: American Association of Petroleum Geologists Bulletin, v. 34 , no. 8, p. 1647-1658, fig. 2, scale $1: 160,000$

wiese, J.H., and Page, L.R., 1946, T in deposits of the Gorman district, Kern County, California: California

1020

Aggas, R.D., 1964, Determination of underflow at the Castaic Damsite: California Department of Water Resources report, $48 \mathrm{p}$

Bass, M.N.' 1951, A vertebrate fauna from late Tertiary beds near Frazier Mountain, California: Pasadena, California Institute of Technology, M.s. thesis.

Burnett, J.L., 1960, The geology of the southern portion of Frazier Mountain near Gorman, California: Berkeley, University of California, M.S. thesis.

Crowell, J.C., 1948, Geology of the Tejon Pass region, California: Los Angeles, University of California, Ph.D. dissertation.

Crowell, J.C., 1950, Geology of Hungry Valley area, southern Californa: American Association of Petroleum Geologists Bulletin, v. 34, no. 8, p. 1623-1646.

Crowell, J.C., 1952, Geology of the Lebec quadrangle: California Division of Mines and Geology Special Report 24,23 p., pl. 1, scale $1: 31,680$.

Dehlinger, Peter, 1950. The relationship of the Modelo and Ridge Route Formations in the southern Ridge Basin, California: Pasadena, California Institute of Technology, Ph.D. dissertation.

Dehlinger, Peter, 1952, Geology of the southern Ridge Basın, Los Angeles County, California: Calıfornia Division of Mines and Geology Special Report 26, 11 p., pl. 1 , scale $1: 31,680$.

Fine, S.F., 1947, Geology of part of the western end of Antelope Valley, California: Los Angeles, University of California, M.s. thesis.

Guymon, G.L., 1963, office report on flood hydrology, Castaic Reservoir: Calıforna Department of water Resources, $47 \mathrm{p}$

Harris, Herbert, 1950, Geology of Palomas Canyon-Castaic creek area, Los Angeles County, California: Los Angeles, University of California, M.A. thesis.

Harris, P.B.. 1954 , Geology of the Tunis-Pastoria creek area, Kern County in Geology of southern California:
California Division of Mines Bulletin 170, map sheet 2 scale $1: 312,500$.

Kasline, F.E., 1953, Tejon Hills oil Fleld: Callfornia Oil Fields, v. 39, no. 1, p. 5-10, pl. 11, scale 1:62,500.

Lustig, L.K., 1965, Sediment yield of the Castarc watershed, western Los Angeles County, California--a quantitative Paper $422-\mathrm{F}, 23 \mathrm{p}$.

Marks, J.G., 1943, Type locality of the Tejon formation (Calif.): California Division of Mines Bulletin 118, p. $534-538$.

Weber, F.H., Jr., 1985, Geologic relationships between the San Gabriel and San Andreas faults (Calif.): California Geology,

\section{1}

Carman, M.F., Jr., 1954, Geology of the Lockwood Valley area, Kern and Ventura Counties, Calıfornia: Los Angeles, University of Californa, Ph.D. dissertation.

Carman, M.F., Jr., 1964, Geology of the Lockwood Valley area, Kern and Ventura Counties, Callfornia: California Division of Mines and Geology Special Report 81, 62 p. pI. 1, scale approx. $1: 31,680$

Gazin, C.L., 1930, Geology of the central portion of the Mount Pinos quadrangle, Ventura and Kern Counties. southern California: San Diego, California Institute of Technology, Ph.D. dissertation.

Kirkpatrick, J.c., 1958, A study of some marine middle Eocene formations in southern California: Los Angeles, University of California, M.A. thesis.

\section{1---Continued}

Kupfer, D.H., 1942, Geology of the colemanite deposits near Stauffer, Ventura County, California: Los Angeles,

Lofgren, G.E., Geologic map of the Mount Pinos basement complex (Calif.): Palo Alto, Calif., stanford University, scale approx $1: 48,000$

ziony, J.I., 1958, Geology of the Abel Mountain area, Kern of California. M.A. thesis.

\section{2}

Exum, F.A., 1957, Geology of a portion of eastern Cuyama valley, Ventura and Santa Barbara Counties, California Los Angeles, University of California, M.A. thesis.

Frakes, L.A., 1959, The geology of the Quatal Canyon area, Kern, Ventura, and Santa Barbara Counties, California: Los Angeles, University of California, M.A. thesis.

Gazin, C.L.' 1928, Tertiary mammal-bearing beds in the upper Cuyama drainage basın, California: Pasadena

Hartman, D.c., 1957, Geology of the upper Wagon Road
, Wathe Canyon area, southern California: Los Angeles, University of California, M.A. thesis.

sierveld, F.G., 1957, Geology of a part of Pattiway Ridge, Kern and Ventura Counties, Cal ifornia: Los Angeles, University of California, M.S. thesis.

\section{3}

English, W.A., 1916, Geology and oil prospects of Cuyama valley, California: U.S. Geological Survey Bulletin 621-M, p. $191-215$.

Hart, J.M., 1959, The geology of a portion of the Santa Barbara Canyon area, northeastern Santa Barbara County, southern California: Los Angeles, University of California, M.A. thesis.

James, G.T.. 1961, The paleontology and nonmarine stratigraphy of the Cuyama valley badlands, California:

Madsen, S.H., 1959, The geology of a portion of the Salisbury Canyon area, northeastern Santa Barbara county, southern California: Los Angeles, university of California, M.A. thesis.

Singer, J.s., and Swarzenski, W.V., 1970, Pumpage and ground-water storage depletion in Cuyama valley, California, 1947-66: 0.s. Geological Survey open-file report, $22 \mathrm{p}$.

Swarzenski, w.V., 1967, Progress report: Ground-water appraisal of cuyama Valley, Cal ifornia: U.S. Geological Survey open-file report, $10 \mathrm{p}$.

Upson, J.E., and Worts, G.F., Jr., 1951, Ground water in the Cuyama valley, California: U.s. Geological Survey Water-Supply Paper 1110-B, p. 21-81.

vedder, J.G., 1968, Geologic map of Fox Mountain quadrangle, Santa Barbara County, California: U.s. Geological survey Miscellaneous Investigations Map I-547, scale $1: 24,000$.

1024

Fritsche, A.E., 1968, Mrocene geology of the central Sierra Madre Mountains, Santa Barbara County, California: Los Angeles, University of California, Ph.D. dissertation, scale $1: 24,000$

1026

Carollo, John, 1975, Report on wastewater treatment and disposal facilities: Consulting report to the city of Santa Maria, Calif., 150 p.., apps. A-H.

Crawford, F.D., 1971. Petroleum potential of Santa Maria Province, California: American Association of Petroleum Geologists Memoir 15, v. 1, p. 316-328.

Hutchinson, C.B., 1980, Appraisal of ground-water resources in the San Antonio Creek Valley, Santa Barbara County, California: U.s. Geological Survey Open-file Report $80-750,52 \mathrm{p}$.

Mallory, M.J., 1980, Potential effects of increased ground-water pumpage on Barka Slough, San Antonio Creek valley, Santa Barbara county, California: U.S. Geological Survey WaterResources Investigations Report 80-95, $16 \mathrm{p}$.

Miller, G.A., and Evenson, R.E.. 1966, Utilization of ground water in the Santa Maria valley area, California: U.s. Geological Survey Water-Supply Paper 1819-A, $24 \mathrm{p}$.

Muir, K.S., 1964, Geology and ground water of San Antonio creek valley, Santa Barbara County, California: u.s. Geological Survey Water-Supply Paper $1664,53 \mathrm{p}$.

Toups, J.M., 1970, An evaluation of the future need for santa Maria, Calif.. consulting report, $43 \mathrm{p}$.

williams, M.D., and Holmes, C.N., 1945, Geology of oil-impregnated diatomaceous rock near casmalia, santa Barbara County, California: U.S. Geological Survey oil and Gas Investigations Preliminary Map 34, scale 1:3,600. 


\section{CATEGORY 1: 15-MINUTE TOPOGRAPHIC QUADRANGLE MAPS}

\section{6--Continued}

Woodring, W.P., and Bramlette, M.N., 1950, Geology and paleontology of the Santa Maria District, California: 0.S Geological Survey Professional Paper 222, $185 \mathrm{p}$

Worts, G.F., Jr., 1951, Geology and ground-water resources of the Santa Maria Valley area, California, with a section on Surface-water resources, by H.G. Thomasson, Jr.: U.S. Geological Survey Water-Supply Paper 1000, $169 \mathrm{p}$.

\section{7}

Evenson, R.E., 1961, Availability of ground water, Point Pedernales area, California: U.s. Geological Survey open-file report, $47 \mathrm{p}$

Kilbourne, R., and Mualchin, L., 1980, Geology for planning: Guadalupe and Point sal 7 1/2 minute quadrangles, Santa Barbara and San Luis obispo counties, California: California Division of Mines and Geology Open-File Report 80-5 SF.

\section{4}

Spencer, J.E., 1985, Miocene low-angle normal faulting and dike emplacement, Homer Mountain and surrounding areas, southeastern California and southernmost Nevada: Geological Society of America Bulletin, v. 96, no. 9, p. 1140-1155.

1105

Thompson, D.G., 1920, Ground water in Lanfair Valley, Calıfornia: U.S. Geological Survey Water-Supply paper $450-B$, p. $29-50$

\section{7}

Greenwood, R.B., 1984, Mineral land classification of the Kelso 15 minute quadrangle, San Bernardino county, California: California Division of Mines and Geology Open-File Report 84-3 LA.

\section{8}

Barca, R.A., 1960, Geology of the northern portion of the old Dad Mountain quadrangle, San Bernardino County. California: Los Angeles, University of Southern California, M.A. thesis, scale $1: 24,000$

Lamey, C.A., 1948, old Dad Mountain iron-ore deposit, San Bernardino County, California: California Division of Mines Bulletin 129, p. 59-68.

\section{9}

Troxel, B.W., and Gray, C.H., Jr., 1961, Reconnaissance geologic map of part of the Soda Lake quadrangle, California: California Division of Mines and Geology mapping for the State geologic map, scale 1:62,500.

\section{0}

Blackwelder, Eliot, and Ellsworth, E.W., 1936, Pleistocene lakes of the Afton Basin, California: American Journal of Science, 5th series, v. 31 , p. 453-463, 4 figs.

Buwalda, J.P., 1914, Pleistocene beds at Manix, in the eastern Mojave Desert region: University of California
Department of Geology Bulletin, v. 7 , no. 24, p. 443-464.

El lsworth, E.W., 1932, Physiography history of the Afton basin, San Bernardino County, California: Palo Alto, Calif., Stanford University. Ph.D. dissertation.

Howard, Hildegarde, 1955, Fossil birds from Manix Lake, California: U.s. Geological Survey Professional Paper 264-J, p. 199-205, pl. 50

Lamey, C.A., 1948, Cave Canyon iron-ore deposits, San Bernardino County, California: California Division of Mines Bulletin 129 , p. 69-84

Troxel, B.W., and Gray, C.H., Jr., 1961, Reconnaissance geologic map of part of the Cave Mountain quadrangle, California: California Division of Mines and Geology mapping for the State geologic map, scale 1:62,500.

\section{1}

Byers, F.M., Jr., 1956, Geologic map of the Alvord Mountain quadrangle: U.S. Geological Survey open-file report, scale $1: 48,000$

\section{1--Continued}

Byers, F.M., Jr., 1960, Geology of the Alvord Mountain quadrangle, San Bernardino County, California: U.S. Geological Survey Bulletin 1089-A, p. 1-71, pls. 1-6, figs. 1-2.

\section{2}

Dockter, R.D. and Server, G.T., Jr., 1980, Geophysical, 1 tho $\log 1 \mathrm{c}$, and water-quality data from test well Co-1, Coyote Dry Lake, San Bernardino County, California: U.s. Geological Survey Open-File Report 80-1031, 1 sheet.

Dockter, R.D., 1980, Lithologic and geophysical data from test well Co-2, Coyote Dry Lake, San Bernardino County, California: U.S. Geological Survey Open-File Report $80-873,1$ sheet.

Hazenbush, G.c., 1952, Geology of the Starbright tungsten mine, San Bernardino County, California: California pl. 11, scale $1: 480$

McCulioh, T.H., 1952, Geology of the southern half of the Lane Mountain quadrangle, California: Los Angeles, University of California, Ph.D. dussertation.

Mcculloh, T.H., 1960, Geologic map of the Lane Mountain quadrangle, California: U.S. Geological Survey open-file report, scale $1: 48,000$

\section{3}

Burke, D.B., Hillhouse, J.W., McKee, E.H., Miller, S.T. and Morton, J.L., 1982, Cenozorc rocks in the Barstow Basin area of southern California: U.S. Geological Survey Bulletin 1529-E, p. E1-E16, 2 pls.

Dockter, R.D., 1980, Geophysical, lithologic, and waterquality data from Superior Dry Lake, San Bernardino county, California: U.s. Geological survey Open-File Report 80-1029, 1 sheet.

Taylor, D.w., 1954, Nonmarine mollusks from Barstow Formation of southern California: U.S. Geological Survey Professional paper 254-c, p. 67-77.

\section{5}

Dibblee, T.W., Jr., 1958, Geologic map of the Boron quadrangle, Kern and San Bernardino Counties, California: U.S. Geological Survey Mineral Investigations Field Studies Map MF-204, scale 1:62,500.

Gale, H.S., 1946, Geology of the Kramer borate district. Kern County, California: California Journal of Mines and Geology, v, 42, no. 4, p. 325-378, 2 pls., map.

Hewett, D.F.', Callaghan, Eugene, Moore, B.N., Nolan, T.B., Ruben W.W., and Schaller, W.T., 1936, Mineral resources of the region around Boulder Dam: U.S. Geological Survey Bulletin $871,197 \mathrm{p}$.

Noble, L.F.. 1926, Borates in the Kramer district, kern county, california: U.S. Geological Survey Bulletin $785-\mathrm{C}$ p. $45-61,6$ figs.

\section{6}

Dibblee, T.W., Jr., 1958, Geologic map of the Castle Butte quadrangle, Kern county, cal ifornia: o.S. Geological Survey Mineral Investigations Field Studies Map MF-170, scale $1: 62,500$

\section{7}

Batason, C.E.W., 1906, The Mojave mining district of California: American Institute of Mining and Engineering Bulletin, v, 7, no. 1, p. 65-82.

Dibblee, T.W., Jr., 1959, Preliminary geologic map of the Mojave quadrangle, California: U.S. Geological survey Mineral Investigations Field Studies Map MF-219, scale $1: 62,500$.

Hostrup, C.F., and Associates, 1957, Development of an additzonal water supply, Marine Corps Auxilliary Air Station, Mojave, California: Hostrup and Associates, consulting report, $35 \mathrm{p}$.

Smith, G.I., 1951, The geology of the cache creek region, Kern County, California: Pasadena, California Institute of Technology, M.S. thesis, scale $1: 24,000$

\section{8}

Buwalda, J.P., 1915, New mammalian faunas from Miocene sediments near Tehachapi Pass in the southern Sierra Nevada: Berkeley, University of California, Ph.D. dissertation.

Lawson, A.C., 1904, The geomorphogeny of the Tehachapi Valley system: University of California Department of Geology Bulletin 4 , p. $431-462$. 
Louke, G.P., 1964, Reconnaissance geologic map of the northwest part Tehachapi quadrangle (Calif.): California Division of Mines and Geology mapping for the state geologic map, scale
$1: 62,500$.

Michael, E.D., 1960, The geology of the Cache Peak area, California, M.A. thesis.

\section{3}

Pack, R.W., 1920, The Sunset-Midway oil field, California: part 1, geology and o1l resources: U.S. Geological Survey Professional paper $116,179 \mathrm{p} ., 45 \mathrm{pls} ., 15 \mathrm{figs}$.

Vedder, J.G., 1964 , Geology of the southern part of the Callente Range including the preliminary Wells Ranch and part of Elkhorn Hill (71/2-minute) quadrangles: U.S. Geological Survey, scale $1: 24,000$

Vedder, J.G., and Repenning, C.A., 1965, Geologic map of the southeastern Caliente Range, San Luis obispo County, Calıfornia: U.S. Geological Survey oil and Gas Investigations Map om-217, scale $1: 24,000$.

\section{4}

Dougherty, J.F., 1939, A new Miocene mammalian fauna from the Caliente Mountains, California: Pasadena, Californa Institute of Technology, M.S. thesis.

Hill, M.L., Carlson, S.A., and Dibblee, T.W., Jr., 1958 Stratigraphy of Cuyama Valley, Caliente Range area. California: American Association of Petroleum Geologists Bulletin, v. 42, no. 12 , p. 2973-3000.

Johnson, H.R., 1909, Sodium sulphate in Soda Lake, Carrizo plàn, San Luis obıspo County, California: v.s. Geological Survey Bulletin 380, p. 369-71.

\section{5}

Taliaferro, N.L., no date, Geologic map of part of the Branch Mountain quadrangle (Calif.): Berkeley, University of california, scale $1: 62,500$.

\section{6}

Johnson, F.A., 1931, A petrographic study of the San Pablo Formation in the Nipomo quadrangle of California:

Knott, J.M., 1976, Sediment discharge in the upper Arroyo Grande and Santa Rita Creek basins, San Luis obispo county, California: U.S. Geological Investigations Report 76-64, 29 p.

oakeshott, G.B., 1929, The petrography of the stanley Moutan Franciscan of the Nipomo quadrangle: Los Angeles. University of Southern Calıfornia, M.S. thesis.

oakeshott, G.B., 1929, The petrography of the Stanley Mountain Franciscan of the Nipomo quadrangle: Berkeley, University of California, M.S. thesis.

Tallaferro, N.L., 1943, Geology of Huasna area in Jenkins, O.P., Geologic formations and economic development of the oil and gas fields of California: California Division of Mines and Geology Bulletin 118, p. 443-447, fig. 185, Huasna area, map, scale 1:125,000

Taliaferro, N.L., no date, Geologic map of the Nipomo quadrangle (Calif.): Berkeley, University of California, scale $1: 62,500$.

\section{7}

California Department of Water Resources, 1979, Ground water in the Arroyo Grande area (Calif.): California Department of Water Resources Southern District Report.

California Division of Mines and Geology, 1954, Western portion of Pismo basin, San Luis obispo County (Calif.): California Division of Manes and Geology State Map sheet, on file. scale 1 inch $=2,000$ feet.

Krueger, M.L., 1943, Arroyo Grande (Edna) o1l field: California Division of Mines Bulletin 118, p. 450-452.

Muehlberger, E.B., 1955, Pismo Beach-Point Sal dune field, Cal ifornia: Lawrence, University of Kansas, M.S. thesis.

Page, B.M., and others, 1944, Geology of the bituminous sandstone deposits near Edna, San Luis obispo County, Calıfornia: v.s. Geological Survey 011 and Gas Preluminary Map 16, scale $1: 24,000$.

Tresselt, P., 1960, Recent beach and coastal dune sands at Pismo Beach, California: Los Angeles, University of California, M.A. thesis.
Callaghan, Eugene, 1939, Geology of the Searchlight district: U.S. Geological Survey Bulletin 906-D, p. 135-188.

\section{6}

Hewett, D.F., 1947, Stratigraphic and structural features of the Ivanpah quadrangle, California-Nevada: Geological Society of America Bulletin, v. 58, p. 1252-1253.

Hewett, D.F., 1956, Geology and mineral resources of the Ivanpah quadrangle, California and Nevada: U.S. Geological Survey Professional Paper 275, 172

Richards, Arthur, and Brokaw, A.L., 1944, Kokoweef Mountain area, San Bernardino County: v.s. Geological Survey Preliminary Map, scale 1:3,000.

\section{7}

Evans, J.R., 1958, Geology of the Mescal Range, San Bernardıno County, California: Los Angeles, Unıversity of Southern California, M.A. thesis, scale 1:24,000.

Evans, J.R., 1966, California's Mountain Pass Mine now producing europium oxide: California Division of Mines and Geology Mineral Information Service, v. 19, no. 1, p. $23-32$.

Jaffe, H.W., 1955, Precambrian monazite and z1rcon from the Mountain Pass rare-earth district, San Bernardino County, California: Geologic Society of America Bulletin, v. 66 , no. 10 , p. $1247-1256$

Joseph, S.E., 1984, Mineral land classification of the Mescal Range 15 minute quadrangle, San Bernardino county California: Calıfornia Division of Mines and Geology openFile Report B4-2 LA.

olson, J.c., 1952 , A geologle setting of the Mountain Pass rare-earth deposits, San Bernardino County, California: v.S. Geological Survey open-file report. $109 \mathrm{p}$.

olson, J.C., 1952, Preliminary report and geologic map of the Mountain Pass District, San Bernardino County, California: U.S. Geological Survey open-file report, 5 p., 1 map.

olson, J.c., 1953, Geologic setting of the Mountain Pass rare-earth deposits. San Bernardino County, California: Los Angeles, University of California, Ph.D. dissertation.

olson, J.C., Shawe, D.R., Pray, L.C., and Sharp, W.N., 1954, Rare-earth mineral deposits of the Mountain pass District, San Bernardino county, California, with a foreword on the history of the discovery at Mountain Pass. by D.F. Hewett: U.S. Geological Survey Professional Paper $261,75 \mathrm{p.}$. scale 1:20,000

olson, J.C., and Pray, L.c., 1954, The Mountain Pass rare-earth deposits, in Geology of southern California: California Division of Mines Bullet in 170, chap. 8 , contribution 3, p. 23-29, pl. 1, 4 figs.

Patchick, P.F., 1959, Economic geology of the Bullion mining district, San Bernardino County, California: Los

pray, L.C., 1952, The Mocam bastnaesite deposit, San Bernardino County, California: Pasadena, California Institute of Technology, Ph.D. dissertation.

Sharp, R.P.. 1954, The nature of Cima Dome in Geology of southern Californa: California Division of Mines Bulletin 170 , chap. 5, contribution 8 ; fig. 3 , scale $1: 105,000$.

Sharp, R.P., 1957, Geomorphology of cima Dome, Mojave Desert, California: Geological Society of America Bulletin, v. 68 , no. 3, p. 273-290; fig. 2, scale $1: 192,000$.

Sharp, W.N., and olson, J.C., 1951, Geologic map of the baritic carbonate body near Mountain Pass, San Bernardino County, Cal ifornia: U.S. Geological survey open-file map. scale $1: 1,200$.

Sharp, W.N., and Pray, L.C., 1952, Geologic map of bastnaesite deposits of the Birthday claims, San Bernardino County, Cal ifornia: U.S. Geological survey Mineral Field Studies Map MF 4, scale 1:600.

wiebelt. F.J., 1949, Investigation of the Mohawk lead-zinc mine, San Bernardino County, California: U.S. Bureau of
Mines Investigation Report $4478,7 \mathrm{p}$.

\section{8}

Greenwood, R.B., 1984, Mineral land classification of the Halloran' Springs 15 minute quadrangle, San Bernardino County, California: California Division of Mines and Geology open-File Report 84-51 LA.

\section{9}

Blaney, H.F., 1957, Evaporation study at Silver Lake in the Mojave Desert, California: American Geophysical Union Transactions, v. 38, no. 2, p. 209-215.

Grose, L.T., 1955, Rocks and structure of the northeast part of the Soda Mountains, San Bernardino County, California: Palo Alto, Calif., stanford university, Ph.D. dissertation. 
CATEGORY 1: 15-MINUTE TOPOGRAPHIC QUADRANGLE MAPS

\section{9--Continued}

Grose, L.T., 1959, Structure and petrology of the northeast part of the Soda Mountains, San Bernardino County, California: Geological Society of America Bulletin, v. 70, no. 12, pt. 1, p. 1509-1547, pls. 1 and 10

Troxel, B.W., and Gray, C.H., Jr., 1961, Reconnalssance geologic map of part of the Baker quadrangle, Californa: California Division of Mines and Geology mapping for the State geologic map, scale $1: 62,500$.

\section{0}

Forester, R.D., 1953, The magnetite-rich breccia masses at Iron Mountain, Silver Lake District, San Bernardino County, California: Pasadena, California Institute of Technology, ph.D. dissertation.

Lamey, C.A., 1948, Iron Mountain and Iron King iron-ore deposits, Silver Lake district, San Bernadino County, California: California Division of Mines Bulletin 129 , p. 39-58.

wiebelt, F.J., and Ricker, Spangler, 1948, Iron Mountain deposits, San Bernardino County, California: U.S. Bureau of Mines Investigation Report 4236, 11 p.

\section{4}

Dockter, R.D., 1980, Geophysical, lithologic, and water-quality data from test well Co-2, Cuddleback Dry Lake, San Bernardino County, California: J.S. Geologica Survey Open-File Report 80-1033, 1 sheet.

Dockter, R.D., 1980, Geophysical, lithologic, and water-quality data from test well Co-1, Cuddleback Dry Lake, San Bernardino County, Calıfornia: U.S. Geologica Survey Open-File Report 80-1034, l sheet.

Smith, G.I., 1956, Geology and petrology of the Lava Mountains, San Bernardino County, Cal Ifornia: Pasadena, California Institute of Technology, ph.D. dissertation.

Smith, G.I., 1956, Geology and petrology of the Lava Mountains, San Bernardino County, California: o.s. Geological survey open-file report, scale $1: 24,000$.

Smith, G.I., 1964, Geology and volcanic petrology of the Lava Mountians, San Bernardino County, Callfornia: U.S. Geological Survey professional Paper 457, $97 \mathrm{p}$.

\section{5}

Hillis, D.M., 1924, The Randsburg mining district: Palo Alto, Calif., Stanford University, M.A. thesis.

Hoover, D.B., Tippens, C.L., and Brougham, G.W., 1976, Telluric profile data and traverse location map for the Randsburg Known Geothermal Resource Area, California: o.s. Geological Survey Open-File Report $76-315,3$ p., 2 figs.

Hulin, C.D., 1924, Geology and ore deposits of the Randsburg quadrangle, California: Berkeley, Calif., University of California, Ph.D. dissertation.

Hulin, C.D., 1925, Geology and ore deposits of the Randsburg quadrangle, California: California state Mining Bureau Bulletin 95, $152 \mathrm{p} .$, scale $1: 62,500$.

Lemmon, D.M., and Dorr, J.V.N., 2d, 1940, Tungsten deposits of the Atolia district, San Bernardino and Kern Counties, California: U.S. Geological Survey Bulletin 922-H, p. 205245 .

Neste, Brudin, and Stone, Inc, 1971, Financial analysis for domestic water supply and service improvement, district no. 1, Rand Community County Water District, Randsburg, California: San Bernardino, Calif., engineering report, $49 \mathrm{p}$.

Peck, D.L., 1953, Geology of Paradox No. 3 mine area: Pasadena, California Institute of Technology, M.s. thesis.

\section{6}

Barnard, R.M., 1950, Geology of the Ricardo beds in the western portion of Saltdale quadrangle, Kern county, California: Los Angeles, University of Southern California, M.A. thesis.

Ceylan, Rasit, 1952, Geology and ground water resources of Saltdale quadrangle, California: Los Angeles, University of Southern California, M.s. thesis.

\section{7}

Dibblee, T.W., Jr., 1952, Geology of the Saltdale quadrangle, California: California Division of Mines and Geology Bulletin 160,66 p., scale 1:62,500. Canyon-Last Chance Canyon area, Kern County in Geology of southern California: California Division of Mines and Geology Bulletin 170, map sheet 13, scale $1: 62,500$.

Nelson, H.E., and Hillier, R.L., 1954, Preliminary report on the uranium occurrence of the Silver Lady claim, Jaw Bone mining district, Cross Mountain quadrangle, Kern county, California: U.S. Atomic Energy Commission RME-2012, pl. 1, scale $1: 1,680$.

\section{7---Continued}

Samsel, H.S., 1952, Geology of the southeastern quarter of the Cross Mountain quadrangle, Kern County, California: Los Angeles, University of California, M.A. thesis.

Samsel, H.S., 1962, Geology of the southeast quarter of the Cross Mountain quadrangle, Kern County, California: California Division of Mines and Geology Map Sheet 2, scale $1: 39,354$

\section{8}

Axelrod, D.I., 1938, A Miocene flora from the western border of the Mohave Desert: Berkeley, University of California, Ph.D. dissertation.

Bradley, C.C., 1950, Petrogenesis of the granite of Mount whitney, California and its relationship to depth of erosion: Madison, University of Wisconsin, Ph.D. dissertation.

Louke, G.P., 1963, Reconnalssance geologic map of the Emerald Mountain quadrangle (Calıf.): Reconnalssance mapping for the State geologic map, scale 1:62,500

\section{3}

Taff, J.A., 1933, Geology of McKittrick oil field and vicinity, Kern County, California: American Association of Petroleum Geologists Bulletin, v. 17, no. 1, p. 1-15.

\section{4}

Arnold, Ralph, and Johnson, H.R., 1910, Preliminary report on the McKittrick-Sunset oil region, Kern and San Luis Obispo Counties, California: v.s. Geological Survey Bulletin 406, 225 p., pl. 1, scale 1:125,000.

Dibblee, T.W., Jr., 1977, Geologic map of the Las Yeguas Ranch quadrangle, Kern and San Luis Oblspo Counties, California: U.S. Geological Survey Open-File Report $77-610,1 \mathrm{pl} .$, scale $1: 24,000$

\section{5}

Welby, c.w., 1949, The geology of the central part of the La Panza quadrangle, San Luis Obispo County, California: Berkeley, University of California, M.S. thesis.

\section{6}

Glysson, G.D., 1977, Sedimentation in Santa Margarita Lake, San Luis Obispo County, California: U.S. Geological Survey Water-Resources Investigations report 77-56, $15 \mathrm{p}$.

Richards, G.L., Jr., 1933, Geology of the Santa Margarita Formation, San Luis obispo County, Californ

u.s. Department of Agriculture, 1953, Reconnaissance sedimentation surveys of Salinas Reservolr, San Luis Obispo County, California: Soll Conservation Service-Forest Service file report, 8 p.

\section{7}

Smith, C.T., and Griggs, A.B., 1944, Chromite deposits near San Luis Oblspo, San Luis Obispo County, California: u.s. Geological Survey Bullet in 945-B, p. 23-44.

\section{8}

Cleveland, G.B., 1978, Geologic map of the Point Buchon area, San Luis Obispo County, California: California Division of Mines and Geology Open-File Report 78-17 LA.

Repecka, A.L., 1940, Geology of the type Toro Formation, San Luis obispo County, California: Berkeley, University of California, M.A. thegis.

\section{7}

Clary, M.R., 1959, Geology of the eastern part of the Clark Mountain Range, San Bernardino County, California: Los Angeles, University of Southern California, M.A. thesis, scale $1: 24,000$

Clary, M.R., 1967, Geology of the eastern part of the clark Mountain Range, San Bernardino County, California: California Division of Mines and Geology, Map Sheet 6 scale 1:24,000. 
Dobbs, P.H., 1961, Geology of a portion of the clark Mountain quadrangle, California: Los Angeles, University of Southern California, M.A. thesis.

Hillier, R.L., 1954, Preliminary report on the uranium occurrence of the Jeep No. 2 claim, Clark Mountain mining district, San Bernardino County California: U.S. Atomic Energy Commission R.M.E. 2011, fig. 2, scale $1: 1,500$.

\section{8}

Wright, L.A., 1960, Geologic maps of the Excelsior mine area and the talc-bearing belt on the northwestern side of the Kingston Range, California: Californua Division of Mines and Geology, scale 4 inches = $1 \mathrm{mile}$.

Wright, L.A., 1968, Talc deposits of the southern Death Valley-Kingston Range region, California: California Division of Mines and Geology Special Report 95, 79 p.

\section{9}

Kupfer, D.H., 1951, Structural geology of the Silurian Hills, San Bernardıno County, Californua: New Haven, Conn,, Yale University, Ph.D. dissertation, map, scale $1: 24,000$.

Kupfer, D.H., 1951, Thrusting and chaos structure in the Silurian Hills, San Bernardino County, California:

Kupfer, D.H., 1954, Geology of the Silurian Hills, San Bernardino County: California Division of Mines Bulletin 170 , map sheet 19 , scale $1: 36,000$

Kupfer, D.H., 1960, Thrust faulting and chaos structure, Silurian Hills, San Bernardino county, California: Geological Society of America Bulletin, v. 71, p. 181-214.

roxel, B.W. and Gray, C.H., Jr., 1962, Reconnalssance geologic map of part of the Silurian Hills quadrangle, California: Californa Division of Mines and Geology mapping for the state geologic map, scale 1:62,500.

wright, L.A., 1954, Geology of the silver Lake talc deposits, San Bernardino County, California: California Division of Mines and Geology Special Report 38,30 p.

Wright, L.A., 1961, Geologic map of part of the Silurian Hills quadrangle, California: California Division of Mines and Geology mapping for the State geologic map.

\section{0}

Henshaw, P.C., 1938, A Tertiary mammalian fauna from the Avawatz Mountains, California: Pasadena, Calif. California Institute of Technology, M.S. thesis.

Jahns, R.H., and Wright, L.A., 1962, Geologic map of the Avawatiz Mountains, San Bernardino County, California: University

Kunkel, Fred, 1966, A geohydrologic reconnalssance of the Saratoga Spring area, Death Valley National Monument, California: U.S. Geological Survey open-file report, $27 \mathrm{p}$.

Wright, L.A., 1951, Geology and origin of talc deposits of eastern California: Pasadena, California Institute of Technology, Ph.D. dissertation.

Wright, L.A., 1952, Geology of the Superior Talc area Death Valley, California: California Division of Mines and Geology Special Report 20, 22 p.

\section{1}

Troxel, B.W., 1961, Reconnalssance geologic map of part of the Leach Lake quadrangle, California: California Division of Mines and Geology mapping for the state geologic map. scale $1: 62,500$.

\section{2}

Muehlberger, W.R., 1954, Geology of the Quall Mountains, San Bernardino County, in Geology of southern California: California Division of Mines Bulletin 170, map sheet 16 , scale $1: 48,000$.

Troxel, B.W., and Gray, C.H., Jr., 1961, Reconnaissance geologic map of parts of the Quail Mountains quadrangle, California: California Division of Mines and Geology mapping for the state geologic map, scale 1:62,500.

\section{3}

Troxel, B.W., and Gray, C.H., Jr., 1961, Reconnaissance geologic map of parts of the Wingate Pass quadrangle California: California Division of Mines and Geolog mapping for the state geologic map, scale 1:62,500.
Blackwelder, Eliot, 1941, Lakes of two ages in Searles Basin, California: Geological Society of America Bulletin, vasin, p. 1943-1944.

Dyer, B.W., 1950, Searles Lake development: Colorado School of Mines Quarterly, v. 45, no. 4B, p. 39-44.

Eugster, H.P., and Smith, G.I., 1965, Mineral equilibria in the Searles Lake evaporites, California: Journal of petrology, v. 6, pt. 3, p. 473-522.

Flint, R.F., and Gale, W.A., 1958 , Stratigraphy and radiocarbon dates at Searles Lake, California: American Journal of Science, v. 256, p. 689-714.

Haines, D.V., 1959, Core logs from Searles Lake, San Bernardino County, California: 0.s. Geological Survey Bulletan 1045-E, p. 139-317.

Hardt, W.F., Moyle, W.R., Jr., and Dutcher, L.C., 1972, proposed water-resources study of Searles Valley,
California: v.s. Geological Survey open-file report, $69 \mathrm{p}$.

Hay, R.L., and Moiola, R.J., 1963, Authigenic silicate minerals in Searles Lake, California: Sedimentology, v. 2 no. 4, p. $312-332$

Hellmers, H.D., 1938, Borax, soda ash, lime hydrate, their recovery by west End Chemical Co., Searles Lake, California: Pacific Chemical and Metallurgical Industries. v. 2 , no. 9 , p. 3-11.

Hicks, w.B., i917, Evaporation of brıne from Searles Lake, California: U.S. Geological survey Professional Paper $98-A, p .1-8$.

Pabst, A., Sawyer, D.L., and Switzer, George, 1955 Galeite, a new mineral from Searles Lake, California
(abs.): Geological Society of America Bulletin, v. 66, p. 1658 .

Pabst, A., and Sawyer, D.L., 1948, Tincalconite crystals from Searles Lake, San Bernardino County, California American Mineralogist, v. 33, p. 472-481.

pratt, J.H., 1896, Northupite; pirssonite, a new mineral; gaylussite; and hanksite, from Borax Lake, San Bernardino county, Calıfornia: New Haven, Conn., Yale University, Ph.D. dissertation.

Ryan, J.E., 1951, Industrial salts; production at Searles Lake: Mining Englneering, v. 3, p. 447-452.

Scholl, D.W 1960 , Plelstocene algal pinnacles at searles Lake, California: Journal of Sedimentary Petrology, v. 30

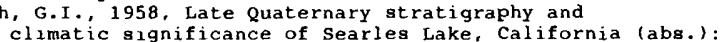
American Association of Petroleum Geologists Bulletin, v. American Associ.

Smith, G.I.. 1962, Subsurface stratigraphy of late Quaternary deposits, Searles Lake, Calıfornia, a sumary: U.S. Geolor

Smith, G.I., 1965, Late Quaternary geologic and climatic history of Searles Lake, southeastern California (abs.): International Association of Quaternary Research, $7 \mathrm{th}$ Congress, Boulder and Denver, Colo., 1965, General Session, p. 436

Smith, G.I., 1966 , Geology of Searles Lake, a guide to prospecting for buried continental salines, reprinted from Rau, J.L., ed. Second symposium on salt: Cleveland,

Smith, G.I., 1967, pleistocene geology and paleontology, searles valley, with section on field guide to examples of late Quaternary geology, Searles valley, california: Eriends of the pleistocene, Pacific coast section, Guidebook, $67 \mathrm{p}$.

Smith, G.I., 1968, Late Quaternary geologic and climatic history of Searles Lake, southeastern california. reprinted from Means of correlation of Quaternary successions: Congress of the International Association for Quaternary Research, University of Utah Press, v. 8, proc. Quaternary Resea

Smith, G.I., Barczak, V.J., Moulton, G.F., and Liddıcoat, J.C. 1983, Core KM-3, a surface-to-bedrock record of Late Cenozolc sedimentation in Searles Valley, California: u.s. Geological Survey professional Paper 1256, $24 \mathrm{p}$.

Smith, G.I., and Haines, D.V.. 1964, Character and distribution of nonclastic minerals in the Searles Lake distribution of nonclastic minerals in the Searles lake
evaporite deposit, California: v.S. Geological Survey Bulletin 1181-P, p. p1-P58.

Stuiver, Minze, 1964 , Carbon 1sotopic distribution and correlated chronology of Searles Lake sediments: American
Journal of Science, v. 262, p. 377-392.

Teeple, J.E., 1929, The industrial development of Searles Lake brines with equilibrium data: New York, Chemical Lake brines with equil
Catalog Co., 192 p.

Troxel, B.W., and Gray, C.H., Jr., 1961, Reconnasssance geologic map of parts of the Searles Lake quadrangle, Cal forna: California Duvision of Mines and Geology mapping for the state geologic map.

\section{5}

Snyder, C.T., 1965, Well site examination in the Bakersfield Grazing District, California, Ridgecrest area, Kern County: U.S. Bureau of Land Managetnent, 2 p.

Troxel, B.W., and Gray, C.H., Jr., 1961. Reconnaissance geologic map of parts of the Ridgecrest quadrangle, California: California Division of Mines and Geology
mapping for the State geologic map, scale $1: 62,500$. 


\section{9--Continued}

Dibblee, T.W., Jr., 1954, Geologic map of the Inyokern quadrangle, Kern County, California: U.S. Geological Survey open-file map.

\section{5}

Marsh, O.T., 1954, Geology of the orchard Peak area (Calif.): Palo Alto, Calif., Stanford University, Ph.D. dissertation, scale $1: 31,680$

peryam, R.C. 1951, Geology of the Annette quadrangle, San Luis obispo and Kern Counties, California: Berkeley,
University of California, M.A. thesis, scale $1: 31,680$.

\section{6}

Isaacs, K.N., 1951, Geology of the northern portions of the Commatti Canyon and Grant Lake quadrangles, San Luis obispo County, California: Berkeley, University of California. M.A. thesis.

Murata, K.J., Dibblee, T.W.., Jr., and Drinkwater, J.L. 1979, Thermal effects of large bodies of intrusive serpentinite on overlying Monterey Shale, southern Diablo Range, Cholame area, California: U.s. Geological Survey professional Paper $1082,8 \mathrm{p}$.

\section{8}

Childs, T.S., Jr., 1941, Stratıgraphic significance of Lepidocyclina in the Vaqueros Formation, San Luis obispo County californa: Palo Alto, calif. San Luis University, M.A. thesis.

Dosch, E.F., 1932, The Las Tablas fault zone and the assoclated rocks: Berkeley, Unıversity of Californı, M.A. thesis.

Goudy, C.L., 1937, A structural and petrographic study of the vaqueros and associated formations in the southeast portion of the Adelaida quadrangle: Berkeley, Oniversity of California, M.A. thesis.

stanton, W.L., Jr., 1931, Geology of the Adelaida guadrangle, California: Pasadena, Californa Institute of Technology, Ph.D. dissertation.

Van Gundy, C.E., 1934, The relations of the opper Cretaceous and Martinez Formation in the northern part of the Adelaida quadrangle: Berkeley, University of California. M.A. thesis.

wilson, R.R., 1930, A reconnaissance of the geology of the Adelaida guadrangle, San Luis obispo County, California, with special reference to the stratigraphy of the Miocene formations: palo Alto, Calif., Stanford University, M.A. thesis.

\section{0}

Hall, C.A., 1976, Geologic map of the San Simeon-piedras Blancas region, San Lu1s obispo County, California: U.S. Geological survey Miscella

\section{6}

Hewett, D.F., 1931, Geology and ore deposits of the Goodsprings quadrangle, Nevada: U.S. Geological Survey Professional Paper 162, $172 \mathrm{p}$.

\section{7}

Brokaw, A.L., 1951, Green Monster Mine, Clark County,

Nevada: U.S. Geological Survey open-file report, 9 p.

\section{8}

Malmbery, G.T., 1967, Hydrology of the valley-fill and carbonaterock reservoirs, Pahrump Valley, Nevada-California: U.S. Geological Survey Water-Supply Paper 1832, 47 p

u.s. Bureau of Reclamation, 1969, Inland basins projects, Pahrump-Mesquite valleys, California-Nevada: v, S. Bureau of Reclamation Interim Report, $70 \mathrm{p}$.

\section{9}

Mason, J.F., 1948, Geology of the Tecopa area, southeastern California: Geological Society of America Bullet in 59, no. 4 , p. 333-352, scale $1: 62,500$.
Stoertz, G.E., 1955, oxidized lead-zinc ores of the Shoshone mines, Tecopa, Calıfornıa: New York, Columbia University, $M$, thesis.

Wright, L.A., 1954, Geology of the Alexander Hills area, Inyo and San Bernardino Counties, in Geology of southern California: cal ifornia Division of Mines and Geology Bulletin 170 map sheet 17 , scale $1: 31,680$.

Wright, L.A., 1961, Geologic map of part of the Tecopa quadrangle, California: California Division of Mines and Geology mapping for the State geologic map.

\section{0}

Chesterman, C.W., 1962, Geolog1c map of the northeastern quarter of the Shoshone quadrangle, California: California Division of Mines and Geology, scale $1: 15,840$.

Wright, L.A., 1961, Geologic map of parts of the Shoshone quadrangle, California: California Division of Mines and Geology mapping for the State geologic map.

\section{1}

Noble, L.F., 1941, Structural features of the virgin spring area, California: Geological Society of America Bulletin, v. 52, no. 7, p. 941-999.

Wright, L.A., and Troxel, B.W., 1961, Reconnassance geologic map of a part of the Confidence Hills quadrangle, California: California Division of Mines and Geology mapping for the state geologic map, scale $1: 62,500$.

\section{2}

Troxel, B.W. and Gray, C.H., Jr., 1961, Reconnalssance geologlc map of part of the Wingate wash quadrangle, mapping for the state geologic map scale 1.62500

wright. wash guadrangle, California: Cal fornia Division of Mines and Geology, scale 1:15,625.

1413

Johnson, B.K., 1954, Geology of a part of the Manly Peak quadrangle, southern panamint Range, California: Los Angeles, University of California. Ph.D. dissertation. Johnson, B.K., 1957, Geology of a part of the Manly peak guadrangle, southern Panamint Range, Cal fornia: University of California Department of Geological Science Publication

Miller.J.M.G. 1985, Geologic map of a portion of the Manly peak quadrangle, southern Panamint Mountalns, California: California Division of Mines and Geology open-File Report 85-9 LA, scale $1: 24,000$.

Ragan, D.M., 1954, Geology of Butte Valley, Inyo county. Californa: Los Angeles, University of Southern California: Los Angeles

Smith, G.I., Troxel, B.W., Gray, C.H., Jr., and Von Huene, R., 1968, Geologic reconnaissance of the Slate Range, San Bernardino and Inyo Counties. California. Cal ifornia Division of Mines and Geology Special Report 96,33 p.

Troxel, B.W.. and Gray, C.H., Jr.., 1961, Reconnaissance geologic map of parts of the Manly peak quadrangle, Callfornia: California Division of Mines and Geology mapping for the State geologic map. scale $1: 62,500$

\section{4}

Troxel, B.W., and Gray, C.H., Jr., 1961, Reconnaissance geologic map of parts of the Trond quadrangle, California California Division of Mines and Geology, mapping for State Geologic Map, scale 1:62,500.

\section{5}

Von Huene, R.E., 1955, Geological investigation of Alrport Lake as a clay target site: China Lake, Calif., Naval $1197,50 \mathrm{p}$.

\section{6}

Putnar, W.C., 1955, pleistocene overflow channel at Little Lake: Geological Society of America, v. 66, p. 1607. 


\section{3--Continued}

Herrera, L.J., Jr., 1951, Geology of the Tent Hills quadrangle: Berkeley, Calif., University of California, M.A. thesis, map, scale $1: 31,680$.

\section{6}

Bailey, E.H., 1942, Quicksilver deposits of the Parkfield district, California: 0.s. Geological Survey Bullet in 936-F, p. 143-169, pl. 17, scale $1: 17,200$.

Bradbury, A.E., 1941, Geology of part of the Parkfield syncline, Monterey County, California: Palo Alto, Calif., Stanford University, M.A. thesis.

Hay, E.A., 1961, Geology of the Cholame Ranch quadrangle, California: Berkeley, Calif., University of California, M.A. thesis.

Taliaferro, N.L., no date, Geologic map of northern part of Parkfield quadrangle (Calif.): Berkeley, University of California, gcale $1: 31,250$. will1s, Robin, 1924 , The physography of the San Andreas
fault between the Pajaro Gap and the Cholame Plains, California: Palo Alto, Calif., Stanford University.'Ph.D. dissertation.

\section{8}

Taliaferro, N.L., 1943, Bradley-San Miguel district in Geologic formations and economic development of the oil and gas Geology Bulletin 118, p. 456-462, fig. 189, scale $1: 187,500$

\section{9}

Bell, G.L., 1940, A geologic section of the Santa Lucia Mountains, Coast Range, California: Berkeley, University of California, M.A. thesis.

Pike, R.W., 1925, Geological studies in the Bryson and Cape San Martin quadrangles, Monterey County, California: Palo Alto, Calif., Stanford University, M.A. thesis.

\section{0}

Crippen, R.A., Jr., 1951, Nephrite jade and associated rocks of the Cape San Martin reglon, Monterey County, Special Report 10-A, fig. 2, scale $1: 19,000$.

\section{8}

Harrill, J.R., 1982, Ground-water storage depletion in Pahrump Valley, Nevada-Cal ifornia, 1962-75: v.s.

Hughes, J.L., 1966, Some aspects of the hydrogeology of the Spring Mountains and Pahrump Valley, Nevada, and environs, as determined by spring evaluation: Reno, Nevada, University of Nevadd, M.S. thesis, $116 \mathrm{p}$.

\section{9}

Hazzard, J.C., 1937, The Paleozolc section in the Nopah and Resting Springs Mountains, Inyo County, California: Los Angeles, University of Southern Calıfornia, Ph.D. dissertation.

Hazzard, J.C., 1938, Paleozoic section in the Nopah and Resting Springs Mountains, Inyo County, California California Journal of Mines and Geology, v. 33, no. 4, p. $273-339$

Hazzard, J.C., 1951, Revision of Devonian and Carboniferous gections, Nopah Range, Inyo County, California (abs.):

\section{1}

Drewes, Harald, 1963, Geology of the Funeral Peak quadrangle, California, on the east flank of Death valley: v.s. Geological Survey Professional Paper $413,78 \mathrm{p}$.

\section{3}

Albee, A.L., Labotka, T.C., Lanphere, M.A., and McDowell, S.D. 1981, Geologic map of the Telescope Peak quadrangle, California: v.s. Geological Survey Geologic Quadrangle Map GQ-1532, gcale $1: 62,500$.
Murphy, F.M., 1930, Geology and ore deposits of a part of the Panamint Range, California: Pasadena, California Institute of Technology, M.S. thesis.

Murphy, F.M., 1930, Geology of the Panamint gilver district, California: Economic Geology, v. 25, no. 4, p. 305-325.

Murphy, F.M., 1932, Geology of a part of the Panamint Ranges, California:

Wright, L.A.', and Troxel, B.W., 1958, Geologic reconnaissance map California Division of Mines and Geology, scale $1: 62,500$.

\section{6}

Dupuy, L.W., 1948, Bucket-drilling the Coso mercury deposit, Inyo County, California: 0.S. Bureau of Mines Investigation Report $4201,45 \mathrm{p}$.

Frazer, H.J., Wilgon, H.B.D., and Hendry, N.W.. 1942, Hot springs deposits of the Coso Mountains: California Journal of Mines and Geology, v. 38, nos. 3 and 4, p. 223-242.

Goranson, C., and Schroeder, R., 1978, Static downhole characteristics of well CGEH-1, Coso Hot Springs, China Lake, California: Berkeley, Calif., Univergity of California, Lawrence Berkeley Laboratory, 27 .

Hulen, J.B., 1978, Geology and alteration of the Coso geothermal area, Inyo County, California: Salt Lake city, University of utah Regearch ingtitute, $28 \mathrm{p}$.

Humiston, L.E., and Zbur, R.T., 1963 , Comparigon of surface features of teklites and geothermally etched obsidian: China Lake, Calif., D.s. Naval Ordnance Test Station Technical Publication $3142,28 \mathrm{p}$.

Jackson, D.B., O'Donnel, J.E., and Gregory, D.I., 1977 Schlumberger soundings, audio-magnetotelluric soundings, and telluric mapping in and around the coso Range, California: 0.S. Geological Survey Open-file Report $77-120,51 \mathrm{p}, .6 \mathrm{pl} . .1 \mathrm{fig}$.

Koenig, J.B., Gawarecki, S.J., and Austın, C.F., 1972, Remote sensing survey of the Coso geothermal area, Inyo County, Calıfornia: China Lake, Calif., o.s. Naval Weapons Center Technical Publication $5233,32 \mathrm{p}$.

Lanphere, M.A., Dalrymple, G.B., and Smith, R.L., 1975, K-Ar age of Pleistocene rhyolitic volcaniam in the Coso Range, California: Geology, v. 3 , no. 6 , p. 339-341.

Plouff, Don, and Isherwood, W.F., 1980, Aeromagnetic and gravity surveys in the Coso Range, California: Journal of Geophysical Research, v. 85, no. 5, p. 2491-2501.

Power, W.R., Jr., 1958, Preliminary report on the geology and uranium deposits of Haiwee Ridge, Inyo County, California: v.S. Atomic Energy Commission report. RME-2066, 37 P.

Power, W.R., Jr., 1959, Geology and petrology of Halwee Ridge, Inyo County, California: Baltimore, Md., Johns Hopkins Oniversity, Ph.D. dissertation.

Ross, C.P., and Yates, R.G., 1943, The Coso quicksilver district. Inyo County, california: v.S. Geological Survey bulletin 936-Q, P. 395-416.

Spene, F.A., 1978, Hydrogeologic investigation of Coso hot Springs, Inyo County, California: Hydro-Search, Inc., consulting report for the U.S. Naval Weapons Center, China Lake, Calif., Technical Publication 6025, 56 p.

st. Amand, P., and O'Hara, N.W., 1975, The Coso geothermal area: Geological Society of America, Abstracts with Programs, v. 7 , no. 3, p. 366-367.

Stinson, M.C., 1977, Geology of the Haiwee Reservoir 15 minute quadrangle, Inyo County (Calif.): California Divigion of Mines and Geology Map sheet 37 , scale $1: 62,500$

v.s. Bureau of Land Management, 1980, Report on the Coso geothermal study area, in support of Coso geotherma development environmental statement: $0 . S$. Bureau of Land Management, Contract YA-512-CT8-216, $146 \mathrm{p}$.

onion Pacific Mining Corp., 1973, Geologic map, Coso project, Halwee, Inyo County, California (to accompany J.R.N. Coso project progress report of June 11, 1973): Union Pacific Mining Corp., 1 map.

Warner, Thor, 1930, Mercury deposits in Coso Range, Inyo County, California: California Division of Mines and Geology Report 26 of the State Mineralogist, v. 26 , no. 1 , p. 58-63.

Weber, Dwight, 1970, Kornelite at Coso Hot Springs: California Division of Mines and Geology Mineral Information Service, v. 23 , no, $1, p$. 6 .

Wilson, H.D.B., and Fendry, N.W., 1939, Geology and quicksilver deposits of the Coso Hot Springs area, Inyo County, California: Pasadena, California Institute of Technology, M.s. thesis.

\section{7}

Weber, E.H., Jr., Saul, R.B., Morton, P.K., and Gray, C.H., Jr., 1960, Reconnaigsance geologic map of the Monache Mountain quadrangle: California Division of Mines and Geology mapping for the state geologic map, scale 


\section{CATEGORY 1: 15-MINUTE TOPOGRAPHIC QUADRANGLE MAPS}

\section{1}

Wright, L.A., and Troxel, B.w., 1957, Geologic reconnaissance map of the southern part of the Ryan quadrangle, California: California Division of Mines and Geology, scale 1:62,500.

\section{2}

\section{8}

Long, R.E., 1958, The stratigraphy and paleontology of the type area of the Pancho Rico Formation, Salinas valley, California: Los Angeles, University of Southern California, M.A. thesis

Nicholls, W.M., 1925, A geologic section across the middle Salinas valley of California, from the San Antonjo River to San Lorenzo Creek: Berkeley, University of California, M.A. thesis.

\section{9} Weidman, R.M., 1959, Geology of the King City quadrangle,
California: Berkeley, University of California, Ph.D. dissertation.

1530

Kleinpell, R.M., 1934, Miocene Foraminifera from Reliz Canyon, Monterey County, California: Palo Alto, Calif., Stanford University, Ph.D. dissertation.

Thorup, R.R., 1942, The stratigraphy of the Vaqueros Formation at its type locality, Monterey county, California: Palo Alto, Calif.. Stanford University, M.A. thesis.

Thorup, R.R., 1943, Type locality of the Vaqueros Formation in Geologic formations and economic development of the oil and gas fields of California: California Division of Mines and Geology Bulletin 118, p. 463-466, fig. 190 , scale $1: 62,500$.

wardle, W.C., 1957, Eocene foraminifera from the Lucia Shale: Berkeley, University of California, M.A. thesis.

\section{1}

Nomland, J.O., and Schenck, H.G., 1932, Cretaceous beds at Slate's Hot Springs, Cal ifornia: University of California
Department of Geological Sciences Bulletin, v. 21 , no, 4, p. $37-49$, fig. 2 , scale $1: 375,000$.

Reiche, Perry, 1934, The geology of the Lucia quadrangle, dissertation.

Reiche, Perry, 1936, Geology of the Lucia quadrangle, California: University of Californla Department of Geologic Science Bulletin, v. 24, no. 7, p. 115-168, scale $1: 62,500$.

Richardson, R.W., 1924, Shoreline physiography of the Santa Lucia Mountains: Palo Alto, Calif., Stanford University, M.A. thesis.

Ross, D.C., 1976, Maps showing distribution of metamorphic rocks and occurrences of garnet, coarse graphite, sillimonite, orthopyroxene, clinopyroxene, and plagioclase amphibolite, San Lucia Range, Salinian block, California: U.S. Geological Survey Miscellaneous Field Studies MF-791, 1 sheet.

\section{8}

Wyant, D.G., and Lemmon, D.M., 1951, Tungsten deposits in the Tem piute district, Lincoln County: U.S. Geological Survey open-file report.

\section{0}

Dudley, W.W., Jr., and Larson, J.D., 1976, Effect of irrigation pumping on desert pupfish habitats in Ash Meadows, Nye County, Nevada: v.S. Geological Survey professional paper $927,52 \mathrm{p}$.

Hanes, W.T., 1976, Water-resources data collected in the Devils Hole area, Ash Meadows, Nevada, 1975-76: U.S. Geological Survey Open-File Report 76-797, 16 p., 7 figs., 1 table.

Loeltz, O.J., 1960, Source of water issuing from springs in Ash Meadow Valley, Nye County, Nevada (abs.): Geological Society of America Bulletin, v. 71, p. 1917-1918.

worts, G.F.. Jr.. 1963, Ef fects of ground-water development on the pool level in Devil's Hole, Death Valley National Monument, Nye County, Nevada: U.S. Geological Survey open-file report.
Troxel, B.W., 1974, Manmade diversion on Furnace Creek Wash, Zabriskie Point, Death Valley, California: California Division of Mines and Geology, California

Geology, v. 27 , no. 10, p. 219-223.
Ward, F.N., Nakagawa, H.M., and Hunt, C.B., 1960, Geochemical investigation of molybdenum at Nevares spring in Death Valley, California: U.S. Geological Survey Professional Paper 400-B, p. B454-B456.

\section{3}

White, D.E., 1940, Antimony deposits of the Wildrose Canyon area, Inyo County, California: U.S. Geological Survey Bulletin 922-K, p. 307-325.

\section{4}

Hall, W.E., and Stephens, H.G., 1957, Geologic map of the Panamint Butte quadrangle, Callfornla: U.S. Geological Survey, scale $1: 62,500$.

Hall, W.E., and Stephens, H.G., 1962, Preliminary geologlc map of the Panamint Butte quadrangle, Inyo County, california: U.s. Geological Survey Mineral Investigations Field studies Map MF-251, scale 1:48,000.

v.s. Geological Survey, 1982, Aeromagnetic map of the panamint Dunes area, Californı: U.S. Geological Survey Open-File Report 82-1085, scale $1: 62,500$.

\section{5}

Austin, C.F., 1958, Geochemical exploration in silicated limestones at Darwin, California: Salt Lake City. University of Utah, Ph.D. dissertation.

Davis, D.L., 1955, Anaconda's operation at Darwin Mines. Inyo County, California: Reno, University of Nevada, M.s. thesis.

Glass, H.D., 1947, Fluorite-bearing clay from Darwin, California: New York, Columbia University, M.A. thesis.

Hal1, W.E., 1958, Structure and ore deposits of the Darwin quadrangle, Inyo County, California: Cambridge, Mass.. Harvard university, Ph.D. dissertation.

Ha11, W.E., and Mackevett, E.M., Jr., 1963, Geology and Calıfornia: U.S. Geologlcal Survey professional paper 368, $87 \mathrm{p}$.

Kelley, v.c., 1937, Geology and ore deposits of the Darwin silver-lead mining district, Inyo County, California: Pasadena, Calif

Kelley, V.C., 1937, OrIgin of the Darwin silver-lead deposits: , 32, no. 8, p. 987-1008, fig. 3, scale $1: 62,500$.

Kelley, v.C., 1938, Geology and ore deposits of the Darwin sllver-lead mining district, Inyo County, California: California

Knopf, Adolph, 1914, The Darwen Silver-Lead District, California: U.S. Geological Survey Bulletin 580-A, 18 p.

wilson, L.K., 1943, Tungsten deposits of the Darwin Hills, Inyo County.

\section{6}

Mackevett, E.M., 1953, Geology of the Santa Rosa lead mine, Inyo County, California: Calıfornia Division of Mines Special

Schultz, J.R., 1937. A late Cenozolc vertebrate fauna from the Coso Mountains: Carnegre Institute of Washington. Publication 487 .

starry, R.M., 1970, Dirty Sock and beyond: Palm Desert, Calıf., Desert Magazine, v. 33, no. 11, p. 12-15.

stinson, M.C., 1964, A trip to a vertebrate fossil locality: California Division of Mines and Geology Keeler is-minute quadrangle. Inyo County, Callfornia California Division of Mines and Geology, Map Sheet 38 , scale $1: 62,500$ Report 34,9 p.

stinson, M.C., 1977 , Geologlc map and section of the 
Gray, C.H., Jr., Morton, P.K., and Saul, R.B., 1961, Reconnaissance geologic map of parts of the olancha quadrangle (Calif.): California Division of Mines and Geology mapping for the state geologic map, scale $1: 62,500$.

Weber, F.H., Jr., Saul, R.B., Morton, P.K., and Gray, C.H., Jr., 1960, Reconnaissance geologic map of the
olancha quadrangle: California Division of Mines and Geology mapping for the state geologic map, scale $1: 62,500$.

1628

Pack, R.W., and Englısh, W.A., 1914, Geology and oll prospects in Waltham, Priest, Bitterwater, and Peachtree valleys, California: D.s. Geological Survey Bulletin 581, p. 119-160.

1629

Akers, J.P., 1967, The geohydrology of Pinnacles National Monument, California: o.s. Geological Survey open-file report, $14 \mathrm{p}$.

Evenson, R.E., 1962, Ground-water reconnaissance at Pinnacles National Monument, California: U.S. Geological Survey Water-Supply Paper 1475-K, p. 375-382.

1630

Dickinson, W.R., 1956, Tertıary stratıgraphy and structure west of the Arroyo Seco, Monterey County, California: Palo Alto, Calif., stanford University, M.S. thesis.

Lee, H.W., 1923, Description of some new species together with notes on the stratigraphy of the upper Miocene and lower Pliocene of lower Reliz Creek, Monterey County, California Berkeley, Oniversity of California, M.A. thesis.

Nickell, F.A., 1931, Geology of the Soledad quadrangle, central California: California Institute of Technology. Ph.D. dissertation.

Schombel, L.F., 1940, Preliminary report on the geology of the Soledad quadrangle, Monterey County, California: Berkeley, University of California, M.A. thesis.

\section{1}

Fiedler, W.M., 1942, The geology of the Jamesburg quadrangle California: Berkeley, Onıversity of California, Ph.D. dissertation.

Fiedler, W.M., 1944, Geology of the Jamesburg quadrangle, Monterey County: California Journal of Mines and Geology, p. $177-250$

1632

Oakeshott, G.B., 1951, Guide to the geology of Pfeiffer-Big Sur state Park, Monterey County, Calıfornıa: Californıa Divisıon of Mines Special Report 11, 16 p., 1 pl., 28 figs. Trask, P.D., 1923, The geology of the Point Sur quadrangle,
California: Berkeley, oniversity of California, Ph.D. dissertation.

Trask, P.D., 1926, Geology of Point Sur quadrangle, California: California Unıversity Department of Geological Science Bulletin, v. 16, no. 6, p. 119-186, scale $1: 62,500$

\section{4}

Johnson, E.A., 1971, Geology of a part of the southeastern side of the Cottonwood Mountans, Death Valley, California:

\section{5}

Mackevett, E.M., 1949, The Sally Ann copper area, Ubehebe Peak quadrangle, Inyo County, California: U.S. Geological Survey open-file report, 11 p.

McAllister, J.F., 1949, Geology of the Lippincott lead area, Inyo County, Calıfornia: U.S. Geological Survey open-file report, 10 p.,pl. 1 , scale $1: 2,400$.

McAllister, J.F., 1955, Geology of mineral deposits in the obehebe Peak quadrangle, Inyo County, California: California Division of Mines Special Report 42,63 p.

MCAllister, J.F., 1956, Obehebe Peak, California, geology o.s. Geological Survey Geologic Quadrangle Map GQ-95, scale $1: 62,500$.
Flint, D.E., 1941, The geology of the Beveridge mining district, California: Evanston, Ill., Northwestern University, M.S. thesis.

Lombardi, O.W., 1957, Observations on the distribution of chemical elements in the terrestrial saline deposits of Saline Valley, California: Socorro, N.M., New Mexico Institute of Mining and Technology, M.S. thesis.

Lombardi. O.W., 1963, Observations on the distribution of chemical elements in the terrestrial saline deposits of Saline Valley, California: China Lake, Calif., u.s. Naval Ordnance Test station Technical Publication 2916, 42 p.

\section{7}

Trowbridge, A.c., 1911, The geology of the Owens Valley, California, with special reference to the terrestrial deposits: Chicag

Trowbridge, A.C. 1911. The terrestrial deposits of owens valley, California: Journal of Geology, v. 19, p. 706-747, pl. 1, scale 1:187,500.

\section{8}

Mayo, E.B., 1941, Deformation in the interval Mount LyellMount Whitney, California: Geological Society of America Bulletin, v. 52, no. 7, p. 1001-1084.

Moore, J.G., 1981, Geologic map of the Mount whitney quadrangle, Inyo and Tulare Counties, California: U.S. Geological survey Geologic Quadrangle Map GQ-1545, scale $1: 62,500$.

Patnode, H.W.. 1935, Petrographic study of an intraseptum intrusion in the Sierra Nevada: Ithaca, N.Y., Cornell Oniversity, M.A. thesis.

\section{9}

Dibblee, T.W., Jr., Preliminary geologic map of the Bickmore Canyon quadrangle, San Benito and Monterey Counties, California: 0.S. Geological Survey Open-File Report 79-701, scale $1: 24,000$

Dibblee, T.W., Jr., Preliminary geologic map of the cherry Peak quadrangle, San Benito County, California: D.S. Geological Survey Open-File Report 79-703, scale 1:24,000.

Dibblee, T.W. Jr., Preliminary geologic map of the San Benito quadrangle, San Benito County, California: D.S. Geological Survey Open-File Report 79-376, scale 1:24,000.

Wilson, I.F., 1943, Geology of the San Benito quadrangle, California: California Journal of Mines and Geology, $v$. , no. 2 , p. 183-270, pl. 3, scale $1: 62,500$.

\section{0}

Dempster, R.E., 1951, Geology of the northeastern part of the Gonzales quadrangle, California: Berkeley, University of Callfornia. M.A. thesis.

Dibblee, T.W., Ir., 1979, Prelminary geologic map of the Paicines quadrangle, San Benito and Monterey Counties, California: U.S. Geological Survey Open-File Report 79-290, scale $1: 24,000$.

\section{1}

Herold, C.L., 1935, Preliminary report on the geology of the Salinas quadrangle, California: Berkeley, Calif. University of California, M.S. thesis.

\section{2}

Beal, C.H., 1915, The geology of the Monterey quadrangle, California: Palo Alto, Calif., Stanford Oniversity, M.A. thesis.

Beard, C.N., 1941, Drainage development in the vicinity of Monterey Bay, California: Urbana, University of Illinois, Ph.D. dissertation.

Cassell, J.K., 1949, Variation of the type Monterey Formation, California, near the type locality: Palo Alto, Calif.. Stanford University, M.A. thesis.

Clifton, H.E., 1982, Sedimentation units in conglomerate grainflow deposits, Point Lobos, California (abs.): Internationa Congress on Sedimentology (Congres International de Sedimentologie), v. 11, p. 54-55.

Galliher, E.W., 1932, Geology and physical properties of bulling stone from Carmel valley, California: Mining in California, v. 28 , no. 1, p. 14-41, pl. 2, scale 1:48,000.

Galliher, E.W., 1932, Sediments of Monterey Bay, California: Palo Alto, Calif., Stanford University, Ph.D. dissertation.

Greene, H.G., 1970, Geology of southern Monterey Bay and its relationship to the ground-water basin and salt water 


\section{2--Continued}

Greene, H.G., 1977, Geology of the Monterey Bay Region, California: V.s. Geological Survey Open-Eile Report 77-718, 343 p.. 9 plates, 43 figures.

Hill, G.W., 1983, Bioturbation patterns in a channel-leveeoverbank sequence of paleocene submarine-canyon $f 11$, Point Lobos, California (abs.): American Association of petroleum Geologists Bulletin, v. 67, no. 3, p. 483-484

Lawson, A.C., 1893, The geology of Carmelo Bay (Calif.): University of California Department of Geological Science Bulletin, v. 1, p. 1-59, pl. 1, scale 1:31,680.

Martin, L.T., 1932, Observations on living foraminifera from the intertidal zone of Monterey Bay, California: Palo Alto, Calif.. Stanford University, M.A. thesis.

Muir, K.s., 1977, Initial assessment of the ground-water resources in the Monterey Bay region, California: U.s. Geological Survey Water-Resources Investigations report $77-46,38 \mathrm{p}$.

Muir, K.S., 1982, Ground water in the Seaside area, Monterey County, California: U.s. Geological Survey Water-Resources Investigations Report $82-10,37 \mathrm{p}$.

\section{2}

Ransome, F.L., Emmons, W.H., and Garrey, G.H., 1910, Geology and ore deposits of the Bul lfrog district, Nevada: U.S. Geological Survey Bulletin 407, $130 \mathrm{p}$.

\section{4}

Tischler, H., 1955, Devonian and Mississipplan of Rest Spring area, California: Berkeley, University of California, M.s. thesis.

\section{5}

McAllister, J.F., 1951, Rocks and structure of the Quartz Spring area, northern Panamint Range, California: Palo Alto, Calif., Stanford University, Ph.D. dissertation. lister, J.F., 1951, Rocks and structure of the Quartz Spring area, northern Panamint Range, california: U.S.

Geological Survey open-file report, pl. 1, scale $1: 31$,
McAllister, J.F., 1952 , Rocks and structure of the Quartz Spring area', northern panamint Range, California: California Division of Mines Special Report 25, $38 \mathrm{p}$.

\section{6}

Hoover, D.B., Fisher, D.L., and Radtke, B., 1978, Telluric Profile location map and telluric data for the Saline
Valley known Geothermal Resource Area, Callfornia: U.S. Geological Survey Open-File Report 78-106-B, 3 p., 2 figs.

Senterfit, R.M. and Moeller, D.D., 1978, Audiomagnetoteliuric data $l o g$ and station location map for the Saline Valley Known Geothermal Resource Area. California: U.S. Geological Survey Open-File Report 78-105-D, 4 p., 1 fig.

\section{7}

Greife, J.L., 1959, Stratigraphy and paleontology of the Mazourka Formation, Middle ordovician, Independence quadrangle, California: Berkeley, Calif., Undversity of California, M.A. thesis.

Langenheim, R.L., Jr., and others, 1956, M1ddle and upper Ordovician rocks of Independence quadrangle, California: American Association of petroleum Geologists Bulletin, v. 40, no. 9, p. 2081-97, fig. 1, scale 1:75,000.

Nelson, R.W., 1959, stratigraphy and paleontology of the Kearsarge area, Inyo county, California: Berkeley. University of California, M.A. thesis.

Pestana, H.R., 1965, Stratigraphy and paleontology of the Johnson Spring Formation, Middle Ordovician, Independence quadrangle, California: Berkeley, University of California, M.A. thesis.

phleger, K.B., Jr., 1932, Notes on certain Ordovician faunas of the Inyo Mountains: Pasadena, Calıfornia Institute of Technology, M.S. thesis.

Ross, D.C., 1962, preliminary geologic map of the Independence quadrangle, Inyo County, California: U.S. Geological Survey Miscellaneous Field studies MF-254, scale 1:62,500.

Ross, D.C., 1965, Geology of the Independence quadrangle, Inyo County, California: U.s. Geological Survey Bulletin $1181-0,64$ p., scale $1: 62,500$

VTN Consolidated, Inc., 1976, Multiple purpose water resources investigations, Fort Independence Reservation, California: VTN Consolidated, Inc, prepared for the Fort Independence piute Tribal Council, $52 \mathrm{p}$.

Waite, R.H., 1953, The Silurian of the Kearsarge area, California: Berkeley, University of California, M.A. thesis.
1818

Moore, J.G., 1955, Geology of the Sierra Nevada front near Mount Baxter, California: Baltimore, Md., Johns Hopkins University, Ph.D. dissertation.

Moore, J.G., 1963, Geology of the Mount Pinchot quadrangle, southern Sierra Nevada, California: U.S. Geological Survey Bulletin 1130, 152 p., pl. 1, scale $1: 62,500$.

\section{9}

Leith, C.J., 1947, Geology of the Quien Sabe quadrangle, California: Berkeley, University of California, Ph.D. dissertation.

Leith, C.J., 1949, Geology of the quien Sabe quadrangle, California: California Division of Mines and Geology Bulletin 147 , p. $1-35$.

\section{0}

Dibblee, T.W., Jr., Preliminary geologic map of the Tres pinos quadrangle, San Benito County, California: U.S. Geological Survey Open-File Report 79-702, scale 1:24,000

Kapple, G.W., 1979, Digital model of the Hollister Valley groundwater basin, San Benito County, California: U.S. Geological

Survey water-Resources Investigations Report
Tal aferro. quadrangle, Cal fornia: Cal fornia Division of Mines Bulletin 143, scale $1: 62,500$.

warren, D.H., 1978, A study of fault plane mechanisms preceding the Thanksgiving Day, 1974, earthquake at Hollister, California: U.S. Geological Survey Open-File Report 78-255, $28 \mathrm{p}$.

Washburn, J.E., 1945, Geology of part of the Hollister quadrangle, San Benito and Santa Clara Counties, California: Berkeley, oniversity of California, M.A. thesis.

\section{1}

Allen, J.E., 1945, Geology of the San Juan Bautista quadrangle, California: Berkeley, Unıversity of Calıfornı, Ph.D. dissertation.

Allen, J.E., 1946, Geology of the San Juan Bautista quadrangle, California: Calıfornia Division of Mines and Geology Bulletin 133, p. 9-75.

Dibblee, T.W., Jr., 1979, preliminary geologic map of the San Juan Bautista quadrangle, San Benito and Monterey Counties, California: U.S. Geological Survey Open-File Report 79-375, scale $1: 24,000$

Jones, W.F., 1911, The geology of the Sargent oll field: University of Californua Department of Geological Science Bulletin, v. 6, p. 55-78.

Mccroden, T.J., 1949, Geology of a portion of the Gabilan Range, California: Palo Alto, Calif., Stanford University, M.S. thesis.

\section{2}

Alexander, C.S., 1950, The marine and stream terraces of the Capitola-Watsonville area, California: Berkeley,

University of California, M.A. thesis.
Bloy, R.M., 1981, Approximate ground-water-level contours, April 1981, for the Soquel-Aptos area, Santa Cruz county, California: v.S. Geological Survey Open-File Report 81-680,

3 p.' 1 pl
Bradley, w.c., 1956, Marine terraces and sedimentation in the Santa Cruz area, California: Palo Alto, Calif., Stanford University, ph.D. dissertation.

McAndrews, M.G., 1948, Petrography of upper Miocene sandstones, southern Santa Cruz County, California Berkeley, University of California, M.A. thesis.

Muir, K.S., 1980, Sea water intrusion and potential yield of aquifers in the Soquel-Aptos area, Santa Cruz County, Cal ifornia: U.S. Geological Survey Water-Resources Investigations Report 80-84, 29 p.

\section{3}

Page, B.M., Williams, M.D., and Henrickson, E.L., 1945, Geology of the bituminous sandstone deposits near Santa cruz, Santa Cruz County, California: U.S. Geological Survey Oıl and Gas Investıgations preliminary Map 27.

\section{5}

Stewart, J.H., 1965, Precambrian and Lower Cambrian formations in the Last Chance Range area, Inyo County. California: U.S. Geological Survey Bulletin 1224-A, p. A $60-\mathrm{A} 70$. 


\section{5--Continued}

Stewart, J.H., and Troxel, B.W., 1964, Geologic map of the Last Chance Range, California: U.s. Geological Survey and California Division of Mines and Geology mapping for the State geologic map, scale $1: 62,500$.

Tabor, L.L.. 1936, Geology of the Crater sulphur deposits, Inyo County, California: Berkeley, University of California, M.A. thesis.

\section{6}

Dorsey, R.E., 1960, Geology of the Marble Canyon area, Waucoba spring quadrangle, Inyo County, California: Los Angeles, Oniversity of California, M.A. thesis.

Nelson, C.A., 1966, Geologic map of the Waucoba Spring quadrangle, Inyo County, California: U.S. Geological Survey, scale $1: 48,000$

scott, K.M., 1960, Geology of the Waucoba springs area, Inyo Mountains, California: Los Angeles, University of California, M.A. thesis.

\section{7}

Bryson, R.P., 1937, Faulted fanglomerates at the mouth of Perry Aiken creek, northern Inyo Range, Cal ifornia-Nevada: Pasadena, California Institute of Technology, M.s. thesis.

Nelson, C.A., 1966, Geologic map of the Waucoba Mountain quadrangle, Inyo County, California: U.S. Geologlcal survey Geologic quadrangle Map $G Q-528$, scale $1: 62,500$.

Saul, R.B., 1959, The geology of the southwest quarter of the Waucoba Mountain quadrangle, California: Los Angeles, University of California, M.A. thesis.

\section{9} Bateman, P.C., and Moore, J.G., 1965, Geologic map of the
Mount Goddard quadrangle, Fresno and Inyo Counties, California: U.S. Geological Survey Geologic Quadrangle Map $\mathrm{GQ}-429$, scale $1: 62,500$

\section{9}

Mckee, E.B., Jr., 1958, The geology of the Pacheco Pass area, California: Palo Alto, Calif., Stanford University, Ph.D. dissertation.

\section{1}

Buhn, W.K., 1951, The geology and ore deposits of the Rianda Mine, Santa clara County, Californa: Moscow, University of Idaho, M.S. thesis.

clark, W.o., 1917, Ground water for irrigation in the Morgan Hill area, California: 0.s. Geological Survey Water-Supply Paper 400-E, p. 107-108.

Muır, K.S.. and Coplen, T.B., 1981, Tracing ground-water movement by using the stable isotopes and hydrogen, upper Penitencia creek alluvial fan, Santa clara Valley.

California: U.S. Geological Survey Water-Supply Paper 2075 , $18 \mathrm{p}$.

\section{2}

Beveridge, A.J., 1958, Heavy minerals in lower Tertiary formations in the Santa Cruz Mountains, California: Palo Alto, Calif., Stanford University.

Dibblee, T.W., Jr., Brabb, E.E., and Clark, J.C., 1978, Preliminary geology map of the Laurel quadrangle, Santa Cruz and Santa clara Counties, California: U.S. Geological Survey Open-File Report 78-84, 1 pl.., scale $1: 24,000$

Dibblee, T.W., Jr., and Brabb, E.E., 1980, Preliminary geologic map of the Loma Prieta quadrangle, Santa Cruz and Santa Clara Counties, California: U.S. Geological Survey Open-File Report 80-944, scale $1: 24,000$

wieczorek, G.F., 1982, Map showing recently active and dormant landslides near La Honda, central Santa Cruz Mountains. California: U.s. Geological Survey Miscellaneous Field Studies Map MF-1422, scale 1:4,800

\section{3}

Brabb, E.E., and Dibblee, T.W., Jr., Preliminary geologic map of the Castle Rock Ridge quadrangle, Santa Cruz and Santa clara Counties, Cal ifornia: U.S. Geological Survey Open-File Report 79-659, scale $1: 24,000$

Braff, E.E., 1960, Geology of the Big Basin area, Sant Cruz Mountains, California: Palo Alto, Calif.. Stanford University, Ph.D. dissertation.

\section{3--Continued}

Muir, K.S.. 1981. Assessment of the Santa Margarita Sandstone as a source of drinking water for the Scotts Valley area, Santa Cruz County, California: U.s. Geological Survey WaterResources Investigations Report 81-6, 22 p.

\section{5}

McKee, E.H., 1968, Geologic map of the Magruder Mountain quadrangle, Nevada-California: U.S. Geological Survey
Bulletin 1251-H, p. H1-H4, scale $1: 62,500$.

\section{6}

Eakin, T.E., 1950, Preliminary report on ground water in Fish Lake valley, Nevada and California: Nevada state Engineer water Resources Bulletin 11, $33 \mathrm{p}$.

McKee, E.H., and Nelson, C.A., 1967, Geologic map of the Soldier Pass quadrangle, California and Nevada: 0.s. Geological Survey Geologic Quadrangle Map GQ-654, scale $1: 62,500$.

Whetten. J.T. 1959, The geology of the central part of Berkeley, University of California, M.A. thesis.

\section{7}

Beaty, C.B., 1960, Gradational processes in the white Mountains of California and Nevada: Berkeley, University of California, Ph.D. dissertation.

Blanc, R.P., 1958, Geology of the Deep Spring Valley area, white-Inyo Mountains, California: Los Angeles, University of California, M.A. thesis.

Harris, W.S., 1958, Geology of the southwestern portion of the Blanco Mountain quadrangle, Inyo County, California: Los Angeles, University of California, M.A. thesis.

Jones, B.F., 1965, The hydrology and mineralogy of Deep Springs Lake, Inyo County, California: U.S. Geological Survey Professional Paper 502-A, 56 p.

Lustig, L.K., 1963, Competence of transport on alluvial fans: o.s. Geological Survey Professional Paper 475-c, p. C126-C129.

Lustig, L.K., 1963, Distribution of granules in a bolson environment: U.S. Geological Survey professional paper $475-\mathrm{c}$, p. $\mathrm{c} 130-\mathrm{c} 131$

Miller, W.J., 1928, Geology of Deep Spring Valley, California: Journal of Geology, v. 36, no.6, p. 510-525 fig. 1, scale 1:200,000.

Nelson, C.A., 1966, Geologic map of the Blanco Mountain quadrangle, Inyo and Mono Counties, Californa: 0.s. Geological Survey Geologic Quadrangle Map GQ-529, scale $1: 62,500$

Perry, L.J., 1954, Geology of the east-central portion of the Blanco Mountain quadrangle, Inyo County, California: Los Angeles, University of California, M.A. thesis.

Pittman, E.D. 1958, Geology of the northwest portion of the Blanco Mountain quadrangle, California: Los Angeles. University of California, M.A. thesis.

Ross, D.C., 1963. Preliminary geologic map of the Blanco Mountain quadrangle, Inyo County, California: U.S. Geological Survey Miscel laneous Field Studies MF-256, 1 map.

\section{8}

Bateman, P.C., 1957, The geology of the Bishop 15-minute quadrangle, California: Los Angeles, University of California, Ph.D. dissertation.

Taylor, G.F., 1933, Quaternary fault structure of the Bishop region, east-central California: Pasadena, Cal

Institute of Technology, Ph.D. dissertation.
watson, E.B., and Storie, R.E., 1928, Soil survey of the Bishop area, California: v.s. Department of Agriculture, Bureau of Chemistry and Soils, 95 .

williams, R.P., 1975, Erosion and sediment transport in the Owens River near Bishop, Cal ifornia: U.s. Geological Survey Water-Resources Investigations 49-75, 49 p.

\section{9}

Bateman, P.C., 1945, Pine Creek and Adamson tungsten mines, Inyo County, California: California Journal of Mines and Geology, v. 41, no. 4, p. 231-249, pl. 36, scale $1: 600$.

Bateman, P.C., 1951, Geology of the Tungstar and Hanging Valley tungsten mines: D.S. Geological Survey open-file report, 12 p., pl. 1, scale $1: 1,200$.

Bateman, P.C., 1953, Geology of the Tungstar and Hanging Valley tungsten mines: 0.S. Geological Survey open-file report, pl. 1, scale 1:480; pl. 2, scale 1:480.

Bateman, P.C., 1965, Geology and tungsten mineralization of the Bishop district, California: U.s. Geological survey Professional paper $470, \mathrm{pls} .2,3,4$, and 7 , scale $1: 62,500$. 


\section{9--Continued}

Bateman, P.C., Erickson, M.P., and Proctor, P.D., 1950 , Geology and tungsten deposits of the Tungsten Hills, Inyo County, California: Cal ifornia Journal of Mines and Geology, v. 46, no. 1, p. 23-42, pl. 7, scale $1: 24,000$.

chapman, R.w., 1937, The contact metamorphic deposit of Round Valley, California: Journal of Geology, v. 45, no. 8, p. 859-87í.

Chasey, K.L., 1933, Preliminary report on the geology and structure of the Sierra Nevada west of Bishop, California Rochester, N.Y., University of Rochester, M.S. thesis.

Lemmon, D.M., 1941, Tungsten deposits in the Sierra Nevada nea Bishop, California, a preliminary report: U.s. Geological Survey Bulletin 931-E, p. 79-104

Lemmon, D.M., 1941, Tungsten deposits in the rungsten H11ls, Inyo County, California: v.s. Geological Survey Bulletin 922-Q, p. $497-514$

Snyder, C.T., 1965, Well site examinations in the Bakersfield Grazing District, California, Horton Creek Recreation Area, Owens Valley, Inyo County: U.S. Bureau of Land Management, 3 p.

\section{0}

Lydon, P.A., 1965, Geology of the south half of the Mount Abbot quadrangle: California Division of Mines and Geology openfile report, map, scale $1: 31,680$.

\section{3}

Dibblee, T.W., Jr., 1966, Geology of the Palo Alto quadrangle, Santa Clara and San Mateo Counties, California: California Division of Mines and Geology Map Sheet 8 .

\section{7}

Krauskopf, K.B., 1966, Geolog1c map of the Mount Barcroft quadrangle (Calıf.): 0 .S. Geological Survey, scale $1: 48,000$

\section{8}

Crowder, D.F., and Sheridan, M.F., 1966, Geologic map of the White Mountain Peak quadrangle, Mono County,

Lemmon, D.M., 1937, Geology of the andalusite deposits in the northern Inyo Range, California: Palo Alto, Calif.. Stanford University, Ph.D. dissertation.

Moddle, D.A., 1941, On a crystal of augite from the commercial deposit of andalusite at white Mountain, California: Toronto, Canada, University of Toronto, M.A. thesis.

Sheridan, M.F., and Crowder, D.F., 1964, Geologic map of the southwest quarter of the White Mountain Peak quadrangle, Mono County, Calıfornia: v.S. Geological Survey open-file map, scale $1: 24,000$.

Sheridan, M.F., and Crowder, D.F., 1964, Geologic map of the northwest quarter of the white Mountain Peak quadrangle, Mono County, Californıa: D.S. Geological Survey open-file map, scale $1: 24,000$.

\section{9}

Bailey, R.A., 1974, Preliminary geologic map and cross section of the Casa Diablo geothermal area, Long valley caldera, Mono County, California: U.S. Geological Survey open-file report, scale 1:20,000.

Bailey, R.A., Lanphere, M.A., and Dalrymple, G.B., 1973, Volcanism and geochronology of Long Valley caldera, Mono County, California (abs.): EOS, v. 54, no. 11, p. 1211. Lemmon, D.M. ' 1941 , Tungsten deposits of the Benton Range, Mono
County, Cal1fornat v.s. Geological Survey Bulletin 922-s, p. 581-593.

Rinehart, C.D., and Ross, D.C., 1956, Economic geology of the Casa Diablo Mountain quadrangle, California California Division of Mines and Geology Special Report 48,17 p., 5 pl

Rinehart, C.D., and Ross, D.C., 1957, Geology of the Casa Diablo Mountain quadrangle, California: u.s. Geologica Survey Geologic Quadrangle Maps of the United states. GQ-99, scale $1: 62,500$.

\section{0}

Bailey, R.A., Dalrymple, G.B., and Lanphere, M.A., 1976 Volcanism, structure, and geochronology of Long Valley caldera, Mono County, California: Journal of Geophysica Research.

Blake, A.H., and Matthes, F.E., 1938, The new Casa Diablo geyser: Sierra club Bulletin, v. 2, p. 82-83.

\section{0--Continued}

Chelikowsky, J.R., 1940, Tectonics of the rhyolite in the Mammoth embayment, California: Journal of Geology, v. 48 no. 4, p. 421-435.

Cleveland, G.B., 1961, Economic geology of the Long Valley diatomaceous earth deposit, Mono County, California: California Divisic

cleveland, G.B., 1962, Geology of the Little Antelope valley clay deposits, Mono County, California: Calıforna

Eccles, L.A., 1976, Sources of arsenic in streams tributary to Lake Crowley, California: v.s. Geological Survey Water-Resources Investigations report $76-36,39 \mathrm{p}$.

Fournier, R.O., Sorey, M.L., Mariner, R, H, , and Truesdeli, A.T., 1976, Geochemical predictions of aquifer temperatures in the Geothermal System at Long Valley. California: U.S. Geological Survey Open-File Report $76-469,22 \mathrm{p}$.

Hill, D.P., Baıley, R.A., and Ryall, A.S., eds., 1985, Proceedings of workshop 19; active tectonic and magmatic processes beneath Long Valley Caldera, Californla: U.S. Geological Survey open-file Report. 84-939, 952 p.

Iyer, H.M. and Hztchcock, T1m, 1973, A seismic noise survey in Long Valley, California (abs.): EOS, v. 54, no. 11 , p. 1212 .

Jackson, D.B., Stanley, W.D., and Zohdy, A.A.R., 1973, Direct current and electromagnetic sound ings in Long

Lachenbruch, A.H., Lewis, R.E., and Sass, J.H., 1974, Prospecting for heat in Long Valley (Calif.) (abs.): Eos, v. 54, no. 11 p. 1211 .

Lachenbruch, A.H., Sass, J.H., Munroe, R.J., and Moses, T.H. Jr., 1976, Geothermal setting and simple heat conduction models for Long valley Caldera (Calif.): Journal of Geophysical Research, v. 81.

Lachenbruch, A.H., Sorey, M.L., Lew1s, R.E., and Sass, J.H., 1976, The near-surface hydrothermal regime of Long Valiey caldera (Calif $)$ :

Lewis, R.E. , 1974, Data on wells, springs, and thermal springs in Long Valley, Mono County, Calıfornia: U.S. Geological Survey open-file report, $52 \mathrm{p}$.

Lew1s, R.E., 1975, Data from a 1,000-foot (305-metre) core hole in the Long Valley caldera, Mono County, California: v.s. Geological Survey open-file report, 16 p.

Mariner, R.H., and Willey, L.M., 1976, Geochemistry of thermal waters in Long Valley, Mono County, California: Journal of Geophysical Research, v. 81.

Mayo, E.B.. 1929, The geology of the Mammoth Lakes area, Mono County, California: Palo Alto, Calif., Stanford University, M.A thesis.

Mayo, E.B., 1934, Geology and mineral deposits of Laurel and Convict Basins, southwestern Mono County, California: California Journal of Mines and Geology, v. 30, no, 1, p. 79-87.

Mayo, E.B., 1934, The Pleistocene Long Valley Lake in eastern California: Science, New Series, v. 80, no. 2065 p. $95-96$.

Muffler, L.J.P., and Willıams, D.L., 1976, Geothermal investigations of the U.S. Geological Survey in Long Valley, California, 1972-1973: Journal of Geophysical Research, v. 81, no. 5, p. 721-724.

Pakıser, L.C., 1961, Gravity, volcanısm, and crustal deformation in Long Valley, Calıfornia: v.s. Geological Survey Professional paper 424-B, p. 250-253.

Rinehart, C.D., and Ross, D.C., 1964, Geology and mineral deposits of the Mount Morrison quadrangle, Sierra Nevada. California, with a section on a gravity study of long Valley, by L.C. Pakiser: D.S. Geological Survey professional Paper 385,106 p., scale 1:62,500.

Sass, J.H., Lachenbruch, A.H., and Munroe, R.J., 1974 , Thermal data from heat-flow test well is near Long valley. California: U.S. Geological Survey open-file report, 46 p.

Sorey, M.L., Lew2s, R.E., and olmsted, F.H., 1977, The Hydrothermal system of Long Valley caldera, California: U.S. Geological Survey Open-File Report 77-347, 188 p., 18 tables, 1 pl., 34 figs.. scale $1: 62,500$.

Sorey, M.L., Lewis, R.E., and olmsted, F.H., 1978 Hydrothermal system of Long Valley caldera, California: U.S. Geo1

Sorey, M.L., and Lewis, R.E., 1976, Connective heat flow from Hot Springs in the Long valley caldera, Mono County, California: Journal of Geophysical Research, v, 81, no, 5 p. $785-791$.

Stanley, W.D., Jackson, D.B., and Zohdy, A.A.R., 1973, A total-field resistivity map of Long valley, Calıfornia \{abs. 1: EOS, v. 54, no. 11, p. 1212 .

Stanley, W.D., Jackson, D.B., and Zohdy, A.A.R., 1974, Preliminary results of deep electrical studies in the Long Valley caldera, Mono and Inyo Counties, California: v.S. Geological Survey open-file report, 62 p., $14 \mathrm{pl}$.

Steeples, D.W., and Pitt, A.M., 1973, Microearthquakes in and near Lon

Werner, S.L., Mukal, M., and Schiffman, A., 1967, Investigation of geothermal water in the Long valley area, Mono County: California Department of Water Resources Report 141, $112 \mathrm{p}$.

Wllley, L.M., O'Neil, J.R., and Rapp, J.B., 1974 , Chemistry of thermal water in Long Valley, Mono County,

W1lley, L.M., Rapp, J.B., and Barnes, Ivan, 1973, Geochemistry of thermal waters in Long valley, Calufornia (abs.): EOS, v. 54, no. 11, p. 1212 .

Williams, D.L., 1976, Implications of a magnetic model of the Long valley caldera, California: U.S. Geological Survey Open-File Report 76-439, 11 p. 


\section{0--Continued}

Woods, E.H., 1924, Geology of Long Valley, California: Iowa City. University of Iowa, M.S. thesis.

\section{2}

Lee, W.T., 1905, Note on the glacier of Mount Lyell, California: Journal of Geology, v. 13, p. 358-362.

\section{6}

Toenge8, A.L., Turnbull, L.A., and Schoff, J.M., 1946, Exploration, composition, etc., of a coal occurring near Coaldale, Esmeralda County: U.S. Bureau of Mines Technical Paper 687 Turner, H.W.: 1900, Esmeralda formation, a fresh-water lake
deposit: U.S. Geological Survey Annual Report 21, pt. 2c, p. $191-208$.

\section{8}

Anderson, G.H., 1933, Geology of the north half of the white Mountain quadrangle (Calif.): Pasadena, California Institute of Technology, ph.D. dissertation.

Barnes, Ivan, 1965, Geochemistry of Birch Creek, Inyo County, California, a travertine depositing creek in an arid climate: Geochem. et Cosmochim. Acta, v. 29, p. 85-112.

\section{9}

Krauskopf, K.B., and Bateman, P.C., 1977, Geologic map of the Glass Mountain quadrangle, Mono County, California, and Mineral County, Nevada: U.s. Geological Survey Geologic Quadrangle Map GQ-1099, 1 sheet, scale $1: 62,500$.

Ransome, A.L.. 1937. Descriptive geology and ores of the Blind Spring Hill mining district. Mono County. California: palo Alto, Calif.. stanford University, M.A. thesis.

Ransome, A.L., 1940, General geology and ores of the Blind Spring Hill minang district, Mono County, California: California Journal of Mines and Geology, v. 36, no. 2, p. 159-197.

Snyder, C.T.. 1966, Examination of six well sites in the Bakersfield Grazing District, California, Adobe Valley area, Inyo County: 0.S. Bureau of Land Management, 3 p.

Kesseli, J.E., 1938, Pleistocene glaciation in the valleys between Lundy Canyon and Rock Creek, eastern slope of the Sierra Nevada, California: Berkeley, University of California, Ph.D. dissertation.

\section{0--Continued}

Mayo, E.B., 1932, Petrography of a portion of the SierraNevada Batholith, California: Ithaca, N.Y., Cornell University, Ph.D. dissertation.

\section{1}

Jackson, D.B., 1977, Schlumberger soundings in the Acolian Buttes and Mono Craters, California: U.S. Geological
Survey Open-File Report 77-291, 18 p., 1 pl. 14 figs Kesseli, J.E., 1939 , The origin of the valley of June, Guli, and
Silver Lakes (Horseshoe Valley). Mono County. California: Journal of Geology, v. 47, no. 7, p. 748-758, fig. 4, scale $1: 125,000$.

Kistler, R.W., 1960, The geology of the Mono Craters quadrangle, California: Berkeley, University of California, Ph.D. dissertation.

Kistler, R.W., 1966, Geologic map of the Mono Craters quadrangle, Mono and Tuolumne Counties, California: U.S. Geologica Survey Geologic Quadrangle Map GQ-462, scale $1: 62,500$.

Kistler, R.W., 1966, Structure and metamorphism in the Mono Craters quadrangle, Sierra Nevada, California: U.S. Geological Survey Bulletin 1221-E, 53 p.

Martin, R.C., and Welday, E.E., 1977, Lake bottom therma gradient survey at Clear Lake and Mono Lake, California Geothermal Resources Council Transactions, v. 1, p. 201203

Putnam, W.C., 1937, Geology of the Mono Craters, California: Pasadena, California Institute of Technology, Ph.D. dissertation.

Putnam, W.C., 1938, The Mono Craters, California: Geographical Review, v. 28 , no. 1 , p. 58-82, fig. 16 , scale $1: 40,000$.

Putnam, w.c., 1949, Quaternary geology of the June Lake district, California: Geological Society of America Bulletin, v. 60 , no. 8, p. 1281-1302, pl. 1, scale $1: 62,500$

Putnam, W.C., 1950, Moraine and shoreline relationships at Mono Lake, California: Geological Society of America Bulletin, v. 61, no. 2, p. 115-122.

stanford Geological Survey (under the direction of Robert L. Rose), 1957, Geologic map of the Tioga Pass area, Mono and Tuolumne Counties, California: Palo Alto, Calif. stanford University, scale $1: 20,400$.

\section{2}

Bateman, P.C., Kistler, R.W., Peck, D.L., and Busacca, A.J., 1982, Geologic map of the Tuolumne Meadows quadrangle, Yosemite National Park, California: U.S

\section{0}

Dohrenwend, J.C., 1982, Reconnaissance surficial geologic map of the Aurora quadrangle, Nevada and California: v.s. Geological Survey Miscellaneous Field Studies Map MF-1373, scale $1: 62,500$ 
CATEGORY 2: MAP SHEETS

\section{Bakersfield}

Hanna, W.F., Oliver, H.W., Sikara, R.F., and Robbins, S.L., 1975, Bouguer gravity map of California, Bakersfield sheet: Califo $1: 250,000$.

Kundert, C.J., 1955, Geologic map of Calıfornia, Bakersfield sheet: California Division of Mines, scale
$1: 250,000$.

U.S. Geological Survey, 1979, Land use and land cover and associated maps for Bakersfield, California: U.S. Geological Survey Open-File Report 79-349, scale 1:250,000.

U.S. Geological Survey 1980 . Land use and land cover 1973-76, Bakersfield, California: U.s. Geological Survey. scale $1: 250,000$.

\section{Death Valley}

Chapman, R.H., 1979, Principal facts and sources for 857 gravity stations on the Death Valley 1 by 2 degree quadrangle of California: California Division of Mines and Geology OpenFile Report 79-9 SAC.

Chapman, R.H., Healey, D.L., and Troxel, B.W., 1971 (1973), Bouguer gravity map of California, Death Valley sheet: $\mathrm{Cal}$ iffo

Curry, H.D., 1954, Turtlebacks in the central Black Mountains, Death Valley, Calıfornia, in Geology of southern Calıfornia California Division of Mines Bulletin 170, chap. 4, contribution 7 , fig. 3, scale $1: 48,000$.

Fournier, R.o., Thompson, J.M., Austin, C.F., 1978, Chemical analyses and preliminary interpretation of waters collected from CGEH no. 1 geothermal well at coso, California: u.s.

Geological Survey Open-File Report 78-434, 11 p.
Isherwood, W.F. . and Plouff, Donald, 1978, Principal facts for gravity observations in the coso Hot Springs area. California: U.S. Geological Survey Open-File Report 78-298, $14 \mathrm{p}$.

Jennings, C.w., 1958, Geologic map of California, Death Valley sheet: Calufornua Duvision of Mrnes, scale $1: 250,000$.

Kane, M.F., and Pakiser, L.C., 1961, Geophysical study of subsurface structure in southern Owens valley, California: Geophysics, v. 26 , no. 1, p. 12-26.

Kundert, C.J., 1955, Geologic map of Californua, Death Valley sheet: California Division of Mines, scale 1:250,000

Maxey, G.B., and Jameson, C.H., 1948, Geology and water resources of Las Vegas, Pahrump, and Indian Spring Valleys, Clark and Nye Counties, Nevada: Nevada Water Resources Bulletin 5, 292 p.

Maxey, G.B., and Robinson, T.W., 1947, Ground water in Las vegas, Pahrump, and Indian Spring Valleys, Nevada: Nevada Water Resources Bullet in 6,23 .

Moyle, W.R., Jr., 1977. Summary of basic hydrologic data collected at coso Hot Springs, Inyo county, California u.s. Geological Survey Open-File Report 77-485, $93 \mathrm{p}$.

Nelson, C.A., 1955, Geology of the Death Valley (Cainf.) sheet: Californa Duvision of Mines, scale $1: 250,000$.

Smith, R.M., 1977, Map showing mineral exploration potential in the Death Valley quadrangle, California and Nevada: U.S. scological $1: 250,000$

Stock, Chester, and Bode, F.D., 1935, Occurrence of lower oligocene mammal-bearing beds near Death Valley, California: National Academy of Science Proceedings, v. Callfornia: National Academy of Science

u.s. Geological Survey, 1981, Land use and $i$ and cover and assocrated maps for Death Valley, Calıfornia, Nevada: o.s. associated maps for Death Valley, California, Nevada: 0.S.

walker, G.E., and Eaken, T.E. 1963, Geology and ground water of the Amargosa Desert, Nevada and California: Nevada Department of Conservation and Natural Resources Report 14, $53 \mathrm{p}$.

\section{El Centro}

Coplen, T.B., and Kolesar, P., 1974, Investigations of the dunes geothermal anomaly, Imperial Valley, California: part. 1, geochemistry of geothermal fluids: Riverside, University of California, UCR-IGPP, $21 \mathrm{p}$.

Kocher, A.E., Carpenter, E.J., Dean, W.C., Smith, A., Cosby, S.W., and Wank, M.E., 1923, Soil survey of the Brawley area, California: U.S. Department of Agriculture report, p. 641-716.

Koenig, J.B., 1967. The Salton-Mexicali geothermal province: California Division of Mines Mineral Information Service, v. 20, no. 7, p. $75-81$

v.s. Geological Survey, 1979, Land use and land cover and associated maps for El Centro, California. Arizona: U.s. Geological Survey Open-File Report 79-1175, scale $1: 250,000$.

\section{Fresno}

Oliver, H.W., and Robbins, S.L., 1982, Bouguer gravity map of California, Fresno sheet: California Division of Mines and Geology, scale $1: 250,000$.

U.S. Geological Survey, 1980, Land use and land cover and associated maps for Fresno, California: U.S. Geologica Survey Open-File Report 80-270, scale $1: 250,000$.

\section{Kingman}

Glancy, P.A., 1968, Water-resources apprassal of Mesquite-Ivanpah Valley area, Nevada and California:

Haskell, B Division of Water Resources Report 46, $57 \mathrm{p}$. York Mountains and Lanfair valley (Calif.): Los Angeles, University

Healey, D.L. 1973, Bouguer gravity map of California, Kingman sheet: California Division of Mines and Geology, scale $1: 250,000$.

Hewett, D.F.. 1956, Modified by Lauren $A$. Wright in area covered by parts of Horse Thief Springs, Shenandoah Peak, Kingston peak, and clark Mountain (Calif.) quadrangles: California Division of Mines mapping for the State geologic map, scale $1: 62,500$.

Jennings, C.W., 1961, Geologic map of Calıfornia, Kingman sheet: Ca $1: 250,000$

Kane, M.F., and Carlson, J.E., 1964, Bouguer gravity a nomaly map of clark county. Nevada: U.s. Geological Survey open-file report, 1 sheet.

Moyle, W.R., Jr., 1972, Water wells and springs in Ivanpah valley, San Bernardino County. California: California Department of Water Resources Bulletin 91-21, $56 \mathrm{p}$.

Rush, F.E., and Huxel, C.J.., Jr., 1966, Ground-water appraisal of the Eldorado-Piute Valley area, Nevada and California: Nevada Department of Conservation and Natural

u.s. Bureau of Reclamation, 1971, Inland basins projects Ivanpah-Piute Valleys, Nevada-California, inter 1 m reconnalssance report: U.S. Bureau of Reclamation, $57 \mathrm{p}$.

warıng, G.A., 1921, Ground water in Pahrump, Mesquite, and Survey Water-Supply Paper 450-C, p. 51-86.

\section{Long Beach}

Beyer, L.A., and Biehler, Shawn, 1983, Long Beach (Calif.): California Division of Mines and Geology Bouguer Gravity Atlas of California, scale $1: 250,000$

California Department of Public Works, 1934, South coastal basin investigation (Calif.): Geology and ground-water storage capacity of valley fill:

Gorsline, D.S., 1958, Marine geology of San pedro and Santa Monica Basins and vicinity, California: Los Angeles, University of Southern California, Ph.D. dissertation.

Johnson, D.L., 1967, Caliche on the Channel Islands (Calif.): California Division of Mines and Geology Mineral Information Service, v. 20 , no. 12 , p. 151-158.

Junger, Arne, and Wagner, H.C., 1977, Geology of the Santa Monica and San Pedro Basins, Calıfornia: U.s. Geological Survey

Kemnitzer, L.E., 1933, Geology of the San Nicolas and Santa Barbara Islands, southern California: Pasadena,

California Institute of Technology, M.S. thesis. Beach sheet: California Division of Mines, scale $1: 250,000$.

Platt, J.P., and Stuart, C.J., 1974, Newport-Inglewood fault zone, Los Angeles Basin, Calıfornia: Discussion: Bulletin of American Association of Petroleum Geologists. v. 58 , p. $877-883$.

v.s. Geological Survey, 1976, Land use and land cover and assocrated maps for Long Beach, California: U.S. Geological Survey Open-File Report 76-118, 4 maps, scale $1: 250,000$.

Woodford, A.O., 1924, The Catalina metamorphic facies of the Franciscan series: University of California Department of Geological Science Bulletin, v. 15, no. 3, p. 49-68, (b) fig. 1, scale $1: 1,500,000$.

\section{Los Angeles}

American Association of Petroleum Geologists, 1952, Cenozoic correlation section across eastern Ventura basin (Calif.): American Association of Petroleum

Andreason, G.E., Pitkin, J.A., and Petrafeso, F.A., 1964, Aeromagnetic map of Oxnard and vicinity, Ventura County, California: U.S. Geological Survey Geophysical Investigations Map GP-463, scale $1: 48,000$

Andreason, G.E., Pitkin, J.A., and Petrafeso, F.A., 1964 Aeromagnetic map of the Long Beach-Santa Ana area, Los Survey Geophysical Investigations Map GP-464, scale $1: 48,000$.

Arnold, C.B., and Federman, J.M., 1964, Feasibllity of serving the Upper Santa Clara Valley (Calif.) Water Agency
from the State Water Project: California Department of Water Resources Bulletin 119-18, $57 \mathrm{p}$.

Bandy, O.L. and Emery, K.O., 1954, Geologic map of southwestern part of the Los Angeles Basin in Geology of
southern California: California Division of Mines Bulletin 170, Guidebook 4, 14 p.; fig. 3, scale $1: 62,500$.

Barbat, W.F., 1958, Los Angeles basin area, California, in Higgins, J.W., ed., A guide to the geology and o Association of Petroleum Geologists. Pacific section, p. $37-49$. 


\section{Los Angeles--Continued}

Bowers, J.C., and Irwin, G.A., 1978, water-quality investıgation, upper Santa Clara River basin, California: U.S. Geological Survey Water-Resources Investigations report 77-99, 43 p.

Brown, A.B., and Kew, w.s.w., 1932, Occurrence of oil in metamorphic rocks of the San Gabriel Mountains, Los Angeles County, California: American Association of Petroleum Geologists Bulletin, v. 16, no. 8, p. 777-785;
(a) fig. 1, scale $1: 250,000$; (b) fig. 2, scale 1:24,000.

Bruington, A.E., 1968, The amelioration or prevention of salt-water intrusion in aquifers--experience in Los Angeles, California: Louisiana State University, Loussiana water Resources Institute Bulletin 3, p. 153-168, 1 fig.

California Department of Water Resources 1961, Ventura County and upper Santa Clara River drainage area (Calif.), land and water use survey: California Department of water Resources Bulletin $122,59 \mathrm{p}$.

California Department of Water Resources, 1966, Planned utilization of ground-water basins, San Gabriel valley (Calif.), appendix A, geohydrology: California Department of water Resources Bulletin 104-2, pl. 18 .

California Department of water Resources, 1966, Salinity barrier studies, oxnard Plain, Ventura County (Calif.). reconnaissance investigation: Cal fornia Department of water Resources Bulletin 147-6.

California Department of Water Resources, 1968, Ground water basin protection projects; Santa Clara River valley (Calıf.), water quality study: California Department of Water Resources, $128 \mathrm{p}$.

Coluzi, A.A., 1968, Santa Clara River valley (Calıf.), water quality study: California Department of Water Resources, $128 \mathrm{p}$.

Conkling, Harold, 1947 , water supply of Santa clara wate Conservation District, Ventura County (Calif.): Consultant report, 81 p., 26 tables, 11 plates.

Conrey, B.L., 1958, Depositional and sedimentary patterns of lower pliocene-Repetto rocks in the Los Angeles basin (Calif.), in A guide to the geology and oll fields of the Petroleum Geologists, Annual Meeting, March 1958, p. $51-54$

Durrell, Corde11, 1954, Geology of the Santa Monica Mountains, Los Angeles and Ventura Counties, in Geology of southern California: California Division of

170, map sheet 8 , scale $1 / 21$ nch $=1 \mathrm{mile}$ 11, Cordell, 1956, Preliminary report on the geology of the Santa Monica Mountains (Calif.), in Los Angeles Forum: Los Angeles, American Association of Petroleum Geologists, Pacific section, Pacific Petroleum Geologists (newsletter), v. 10, no. 4, p. 1-3.

Dutcher, L.C., and Miller, R.E., 1968, Proposed water-resources study of the lower Santa Clara River-Oxnard Plain area, California: U.S. Geological Survey open-file report, $52 \mathrm{p}$.

Eaton, J.E., 1939, Geology and oil possibilities of Caliente Range, Cuyama Valley, and Carrizo plains, California: Calıfornia Journal of Mines and Geology, $v$. 35 , no. 3, p. 255-274.

Eaton, J.E., 1943, Caliente Range, Cuyama Valley, and Carrizo plain (Calif.): Calıfornia Division of Mines Bulletin 118, p. 453-455; fig. 188, scale $1: 187,500$.

Eaton, J.E., Grant, v.S., 4th, and Allen, H.B., 1941, Mlocene of Caliente Range and environs, California: American Association of Petroleum Geologists

Hacker, R.N., chalrman, 1969 , Geology and oil flelds of coastal areas, Ventura and Los Angeles basins, California: American Association of Petroleum Geologists, Society of Economic Paleontologists and Mineralogists, and Society of Exploration Geophysicists, Pacific sections, 44 th Annual Meeting, Guidebook, $60 \mathrm{p}$.

Hamlin, Homer, 1905, Underflow tests in the drainage basin of the Los Angeles River (Calif.): 0.S. Geological Survey water-Supply Paper 112, $55 \mathrm{p}$.

Hanna, W.F., Rletman, J.D., and Bleler, S., 1974 (1975), California Division of Mines and Geology, scale $1: 250,000$.

Higgins, J.W., ed., 1958, A guide to the geology and oil flelds of the Los Angeles and Ventura regions (Calif.). American Association of Petroleum Geologists, Pacific section.

Hill, M.L., 1971, Newport-Inglewood zone and Mesozoic subduction, California: Geological Society of America Bulletin 82, p. 2957-2962.

Holman, W.H., 1958, Correlation of producing zones of ventura basin oil fields, in $A$ guide to the geology and oll fields of the Los Angeles and Ventura regions (Calif.): American Association of Petroleum Geologists, Pacific section.

Jennings, C.w., and Strand, R.G., 1969, Geologic map of California, Los Angeles sheet: Callfornia Division of Mines and Geology, scale 1:250,000.

Johnson, H.R., 1911, Water resources of Antelope Valley, California: U.S. Geologlcal Survey Water-Supply Paper 278 , 92 p., 7 pls., 11 figs.

Kew, W.S.W., 1924, Geology and oil resources of a part of Los Angeles and Ventura Counties, California: V.S. Geological Survey Bulletin 753, $202 \mathrm{p}$.

Kundert, C.J., 1955, Los Angeles sheet, Geologic map of California: California Division of Mines and Geology Map sheet.

Miller, R.E., 1967, A proposed water-resources study of the upper Santa Clara River valley, Califor

ponti, D.J. 1985, Antelope Valley, California: Geological Society of America Special Paper, v. 203, p. 79-96.

\section{Los Angeles--Continued}

Roberts, A.E., 1979, Analytical and stratigraphic data on the upper phosphatic mudstone member of the Santa Margarita Formation at Newsome Canyon, southern Cuyama Valley. California: U.S. Geological Survey Open-File Report 79-1466,

65 p.
Robson, S.G., 1972, water-resources investigation using analog model techniques in the Saugus-Newhall area, Los Angeles County, California: V.S. Geological Survey

open-file report, 58 p., 9 pls.

U.S. Forest Service, 1953, Santa Clara-Ventura Rivers and Calleguas Creek watersheds (Calif.): U.s. Forest Service report of survey, 34 p., 5 app.

U.S. Geological Survey, 1976, Land use and land cover and associated maps for Los Angeles, California: U.S. Geological Survey open-file report 76-119, 4 maps, scale $1: 250,000$.

Weber, F.H., Jr., and Wills, C.J., 1983, Map showing landslides of the central and western Santa Monica Mountains, Los Angeles and Ventura Counties, California: California Division of Mines and Geology Open-File Report 83-16 LA, scale $1: 4,800$

Willuams, R.P., 1979, Sediment discharge in the Santa Clara River basin, Ventura and Los Angeles Counties, California: U.S. Geological Survey Water-Resources Investigations report 79-78, 51 p.

Investigations report 79-78, 51 p.
Woyski, M.S., ed., 1977, Geologic guidebook to the Ridge Basin, northwest Los Angeles County (Calif.): South Coast Geological Society, $130 \mathrm{p}$.

Yerkes, R.F.. Campbell, R.H., Schoel hamer, J.E., Wentworth, C.M., and Blackerby, B.A., 1968, Geologic maps of the central Santa Monıca Mountains (Calif.): U.s. Geological Survey open-file report, scale $1: 12,000$.

Yerkes, R.F., and Campbel1, R.H., 1979, stratigraphic nomenclature of the central Santa Monica Mountains, Los Angeles County, California: v.s. Geological Survey Bulletin 1457-E, $31 \mathrm{p}$.

\section{Mariposa}

Alpha, T.R., Balley, R.A., Lajole, K.R., and Clark, M.M., 1983, Physiographic diagrams of Long Valley, Mono and Inyo Field Studies Map MF-1659, scale 1:100,000.

Anderson, L.A., and Johnson, G.R., 1973, The application of the self-potential method in the exploration for geothermal energy in Long Valley, California (abs.): EOS, v. 54, no. $11, \mathrm{p} .1212$.

Anderson, L.A., and Johnson, G.R., 1973, The application of the seif-potential method in the search for geothermal energy (abs.): Geophysics, v. 38 , no. 6, p. 1190.

Anderson, L.A., and Johnson, G.R., 1974, A self-potential survey of Long valley caldera, Mono County, Callfornia: U.S. Geological Survey open-file report, 3 p.

Bryant, W.A., 1984, Evidence of recent faulting along the owens valley, Round Valley, and white Mountains fault zones, Inyo and Mono Counties, Calıfornia: California Division of Mines and Geology Open-File Report 85-54 SAC, 2 maps, scale $1: 48,000$.

Clark, M.M., Yount, J.C., Vaughan, P.R., and Zepeda, R.L., 1982, Lakes. Cal forniace ruptures assoc lated with Survey Miscellaneous Field Studies Map MF-1396, scale $1: 24,000$.

Fiedler, W.M., 1937, Structure and stratigraphy of a section across the White Mountains, California: Pasadena,

Moslem, K., Amini, A., Anderson, J.G., and Heaton, T.H., 1981, Mammoth Lakes aftershock accelerograms recorded on a temporary array (abs.): Earthquake Notes, v. 52, no. 1 ,
p. 21 .

Oliver, H.W., and Robbins, S.L., 1982, Bouguer gravity map Mines and Geology, 1 map, scale $1: 250,000$.

Rush, F.E., and Katzer, T.L., 1973, Water-resources appraisal of Fish Lake valley, Nevada and California: Nevada Department of Conservation and Natural Resources. Reconnalssance Series Report $58,70 \mathrm{p}$.

Savage, J.C., and Lisowsk1, M., 1984, Deformation in the white Mountain seismic gap, California-Nevada, 1972-1982: Journal of Geophysical Research, B, v. 89, no. 9, p. 7671-7687.

Strand, R.G., 1967, Geologic map of Californa--Mariposa

\section{Needles}

Carr, W.J., Dickey, D.D., and Quinlivan, W.D., 1980, Geologic map of Vidal Nw, Vidal Junction, and parts of the Savahia Peak SW and Savahia Peak quadrangles. San Bernardino County, California: U.S. Geological Survey Miscellaneous Investigations Map $\mathrm{I}-1126,1$ sheet, scale $1: 24,000$.

Carr, W.J., and Dickey, D.D., 1980, Geologic map of the vidal, California, and Parker SW, California-Arizona quadrangles: U.S. Geological Survey Miscellaneous

Chapman, R.H., and Rietman, J.D., 1978, Bouguer gravity map of California, Needles sheet: Californa Division of Mines and Geology, scale 1:250,000.

Miller, W.J., 1944, Geology of the Needles-Goffs region, San Bernardino County, California: California Journal of Mines and Geology, v. 40, no. 1, p. 113-129; pl. 7, scale $1: 187,500$. 


\section{Needles--Continued}

Moyle, W.R., Jr., 1961, Data on water wells in the Dale Valley area, San Bernardino and Riverside Counties, Bulletin $91-5,55 \mathrm{p}$.

otton, J.K., Glanzman, R.K., Brenner-Tourtelot, Elizabeth, 1979 A uranium occurrence in an altered volcanic flow near
Essex, California: v.s. Geological survey Open-File Report $79-1523,7$ p

Raines, G.L., 1983, preliminary map of limonitic hydrothermal aiteration for portions of the Needles 1 degree by 2 degree quadrangle, Arizona and California: v.s. Geological survey open-File Report 83-421, 8 p.

Tucci, Patrick, 1983, Use of a three-dimensional model for the analysis of the ground-water flow system in Parker valley,
Arizona and Cal ifornia: v.S. Geological Survey Open-file Report 82-1006, 60 p.

v.s. Geological Survey, 1979, Aeromagnetic map of the Marble Mountains area, California: U.S. Geological Survey Open-file Report 79-1228, 1 sheet.

\section{Salton Sea} Arnal, R.E., 1957, Limnology, sedimentation, and microorganisms
of the Salton Sea, California: Los Angeles, University of Southern California, Ph.D. dissertation.

Arnal, R.E., 1961, Limnology, sedimentation, and microorganisms of the Salton Sea, California: Geological Society of America Bulletin, v. 72, p. 427-478

Augur, I.V., 1920 , Resume of oil well operations in Imperial Valley, California: California State Mine Bureau Summary of Operations, California oil Fields.

Berry, F.A.F., 1966, Proposed origin of subsurface thermal brines, Imperial Valley. California (abs.): American Association of Petroleum Geologists Bulletin, v. 50, no. 3, p. 644-645.

Berry, F.A.F., 1967, Role of membrane hyperfiltration on origin of thermal brines, Imperial valley, California (abs.): American Association of Petroleum Geologists Bulletin, v. 51, no. 3, pt. 1, p. 454-455.

Biehler, Shawn, 1964, Geophysical study of the Salton trough of southern California: Pasadena, California Institute of Technology, Ph.D. dissertation, $139 \mathrm{p}$.

Biehler, Shawn, 1971, Gravity gtudies in the Imperial valley in Cooperative geological-geophysical-geochemical investigations of geothermal resources in the Imperial valley of California: Riverside, University of California. IGPP Report, p. 29-42.

Biehler, Shawn, Kovach, R.L., and Allen, C.R., 1964, Geophysical framework of northern end of Gulf of California structural province: American

Petroleum Geologists Memoir 3, p. 126-143.
Biehler, Shawn, and Rex, R.W. 1971, Structural geology and tectonics of the Salton Trough, southern California: Riverside, University of California Department of
Geological Science Report, Field Trip 2, p. 30-42.

Biehler, Shawn, and Rotstein, Y., 1982, Bouguer gravit map of California, Salton Sea sheet: California Division of Mines and Geology, scale 1:250,000.

Biehler, Shawn, and Rotstein, Y., 1982, Salton Sea (Calıf.): California Division of Mines and Geology Bouguer Gravity Atlas of California, scale 1:250,000

Blake, W.P., 1854, Ancient lake of the Colorado Desert Calif.): American Journal of Science, v. 17, p. 435-438

Blake, W.P. 1908, Destruction of the salt works in the Colorado Desert by the Salton Sea (Calif.): American Institute of Mining and Metallurgical Engineers.

19, P. 81-82; Transactions, v, 38 , p. 848-849.
Blaney, H.F., 1955, Evaporation from and stabilization of Salton Sea (Calif.) water surface: American Geophysical union Transactions, v. 36, no. 4, p. 633-640.

Brown, J.S., 1920, Routes to desert watering places in the Salton sea region, California: U.S. Geological survey Water-Supply Paper 490-A, 86 p., 7 pls.. 2 figs.

Brown, J.S., 1922, fault features of salton Basin. California: Journal of Geology, v. 30, no. 3, p. 217-26.

Brown, J.S., 1923, The Salton Sea region, California, a geographic, geologic, and hydrologic reconnaissance, with a guide to desert watering places: v.s. Geological Survey Water-Supply Paper 497,292 p. 19 pls.. 18 figs.

california Department of Fish and Game, 1929, A biological survey of the Salton Sea (Calif.): California Department of Fish and Game, v. 15, no. 3.

California Department of Fish and Game, 1965, Report on insecticide accumulation in Salton sea (Calif.) fish:

California Department of Fish and Game office Report.
California Department of Public Health, 1958, Salton Sea (Calif.) bacteriological study: California Department of Public Health office Report.

California Department of Public Works, 1953, Pollution study of the Salton Sea drainage area (Calif.): Report to Colorado River Basin Regional Water Pollution Control Board.

California Department of Public Works, 1953, Quantity-quality survey of New and Alamo Rivers and sanitary survey of Salton Sea (Calif.): Report to Colorado River Basin Regional water Pollution Control Board.

California Department of Water Resources, 1970, Geothermal wastes and the water resources of the Salton Sea area (Calif.): California Department of water Resources

Bulletin 143-7, 123 p.
California Department of Water Resources, 1978, water wells and springs in Palo Verde Valley, Riverside and Imperial
Counties, Callfornia: California Department of Water Resources Bulletin 91-23, 262 p.

\section{Salton Sea--Continued}

California Division of Mines and Geology, 1967, Salton Sea (Calif.): California Division of Mines and Geology Geologic Atlas of California, scale $1: 250,000$

Campbell, E.W.C., and Campell, W.H., 1935, The pinto Basin site (Calif.): Highland Park, Calif.. Southwest Museum Papers 9.

Clarke, F.W., 1903, Mineral analyses from the laboratories of the United States Geological Survey, 1880-1903: U.S. Geological Survey Bulletin 220, 119 p.

coplen, T.B., 1971, Isotopic geochemistry of water from the Imperial Valley in Cooperative geological-geophysicalgeochemical investigations of geothermal investigations in the Imperial Valley of California: Riverside, University of California VCR-IGPP Report, P. 113-118.

coplen, T.B.. 1972, Origin of the geothermal waters in the Imperial valley of southern california in Cooperative investigation of geothermal resources in the Imperial Valley area and their potential value for desalting of water and other purposes: Riverside, University of
Califfornia UCR-IGPP Final Report, p. E-1 to E-33.

Coplen, T.B., 1973, Cooperative geochemical investigation of geothermal resources in the Imperial Valley and Yuma areas (Calif.): v.S. Bureau of Reclamation; Riverside,

University of California report UCR-IGPP-73-48, $22 \mathrm{p}$.
Cralg, H.. 1966, Isotoplc composition and origin of the Red Sea and Salton Sea geothermal brines: Science, v. 154, no. 3756, p. 1544-1547.

Craig, H.. 1969, Discussion source fluids for the salton Sea (Calif.) geothermal system: American Journal of science, v. 267, p. 249-255.

Development Research Associates, 1969, Economic benefits derived from the waters of and lands surrounding the Salton Sea (Calif.): Development Research Associates.

Dibblee, T.W., Jr., 1954, Geology of the Imperial Valley region, California, in Geology of southern California: California Division of Mines Bulletin 170 , chap. 2 , pt. region, Calif.. scale 1 inch $=6$ miles.

Doe, B.R., Hedge, C.E., and White, D.E., 1966, Preluminary investigation of the source of lead and strontium in deep geothermal brines underlying the Salton Sea geothermal area (Calif.): Economic Geology, v. 61, no. 3, p. 462-483.

Garfunkel, Z., 1972, The tectonics of the Salton Trough, southern California and Mexico, and their relation to plate tectonics, in Cooperative investigation of geothermal resources in the Imperial Valley area and their potential value for desalting of water and other purposes: Riverside, University of California UCR-IGPP Final Report. p. $\mathrm{H}-1$ to $\mathrm{H}-33$.

Giessner, F.W., 1963, Data on water wells and springs in the Chuckwalla Valley area, Riverside County, California:

Gzessner, F.W., 1963, Data on water wells and springs in the Rice and Vidal Valley areas, Riverside and San Bernardino Counties, California: Calıfornia Department of

Water Resources Bullet in 91-8, 35 p.
Goldman, H.B., 1957, Carbon dioxide, in Mגneral commodities of of California: Californua Division of Mines Bulletin 176, p. 105, 106-108, and 111

Griscom, Andrew, and Muffler, L.J.P. 1971, Aeromagnetic map and interpretation of the Salton Sea geothermal area. California: U.S. Geological Survey Geophysical Investigations Map GP-754.

Grubbs, D.K., 1964, Ore-bearıng magmatic and metamorphic brine from the salton Sea volcanic domes geothermal area Imperial County, California (abs,): Virginia Journal of
Science, v. 15, new series, no. 4, p. 333; also, 1963, Charlottesville, Va., University of Virginia, M.s. thesis.

Hanks, H.G., 1882, Mud volicanoes and Colorado Desert (Calif.): California Mining Bureau Report 2, p. 227-240.

Helferty, M.G. and Erdman, C.F., 1985, Principal facts for 113 gravity stations in the Salton Sea 1 by 2 degree quadrangle,
southern California: U.S. Geological Survey Open-File Report $85-520,85 \mathrm{p}$.

Helgeson, H.C, , 1968, Thermodynamic and geochemical characteristics of the Salton sea (Calif.) geothermal system (abs.): Bakersfield, Calif.. American Association of petro-

leum Geologists, Symposium on Geothermal Resources.
Hely, A.G., 1963, Hydrologic regimen of the Salton Sea, from progress report of March 1963: U.S. Geological Survey open-file report, $p$. 30-38.

Hely, A.G., Hughes, G.H., and Irelan, Burdge, 1966, Hydrologic regimen of Salton Sea, California: v.s.

Geological Survey professional Paper $486-\mathrm{C}, 32 \mathrm{p}$.
Hely, A.G., and Peck, E.L., 1964 , precipitation, runoff, and water loss in the lower Colorado River-salton Sea area (Calif.): U.s. Geological Survey professional Paper 486-B,

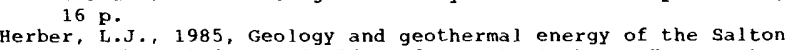
Trough (calif.), a fleld guide: Santa Barbara, University of

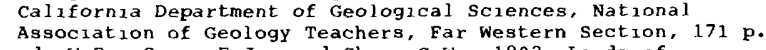

Hilgard, W.E., Snow, F.J., and Shaw, G.W., 1902, Lands of the Colorado delta in the Salton Basin, California: Berkeley, University of California Agricultural Experiment station Bulletin 140,51 p.; and a review in U.S. Department of Agriculture office Experimental station Record 13, p. 1025-1026.

H111, D.P., Peake, L., Mownckel, P., and Hıleman, J.A., 1974 , Sersmicity of the Imperial valley, California, 1973 (abs.): EOS, v. 55, no. 4, p. 346 .

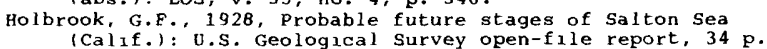
(Caiff.): v.S. Geological Survey open-file report, $34 \mathrm{p}$.

Hughes, G.H. 1967. Analysis of techniques used to measure evaporation from the Salton Sea, California: U.S.
Geological Survey Professional Paper 272-H, p. 151-176. 


\section{Salton Sea--Continued}

Irwin, G.A., 1971, water-quality data for selected site tributary to the Salton Sea, California, August 1969-June 1970: U.S. Geological Survey open-file report, $12 \mathrm{p}$.

Ives, R.L. (Calif.): Rocks and Minerals, v. 26, no. 5-6, p. 227-235.

Iyer, H.M. 1974, Search for geothermal seismic noise in the east Mesa area. Imperial Valley, California: v.s. Geological Survey open-file report, $35 \mathrm{p}$

Jennings, C.W., 1966, Photogeologic interpretation for the state geologic map of some Quaternary units and faults in the Amos, Acolita, and Frink NW quadrangles (Calif.): California Division of Mines and Geology, scale $1: 24,000$.

Jennings, C.w., 1967, Geologic map of California, Salton Sea sheet: California Division of Mines and Geology, scale $1: 250,000$.

Jones, J.C., 1913, Origin of travertine or tufa deposits of Salton Sea sink (abs.): Carnegie Institution of washington Yearbook 12 , p. 60-61.

Jones, J.C., 1914, The tufa deposits of the Salton Sink, in the Salton Sea: Carnegie Institution of Washington, Publication 193, p. 79-83.

Keith, T.E.C., Muffler, L.J.P., and Cremer, Marcelyn, 1968 Hydrothermal epidote from the Salton Sea geothermal field, california: American Mineralogiat, v. 53, no. 9-10, p. 1635-1644.

Kelly, V.C., and Soske, J.L., 1936, Origin of the Salton-Volcanic Domes, Salton Sea, California: Journal of Geology, v. 44 .

Lang, w.B.. i959, The origin of some natural carbon dioxide gases: Geophysical Research Journal, v. 64 , no. 1 p. 127-131.

Lawrence, C.J., 1964, steam well drilling pace is picking up along California's Salton Sea: Oil and Gas Journal, p. 66-67.

Lawrence, C.J., 1964, What's involved in the new stream play (Calif.): Oil and Gas Journal, p. 60-63.

LeConte, J.L., 1855, Account of some volcanic springs in the Desert of the colorado, in southern california: American Journal of Science, $2 d$ series, v. 19, p. 1-16.

Littlefield, W.M., 1966, Hydrology and physiography of the Salton Sea, California: v.s. Geological Survey Hydrologic Investigations Atlas HA-222, gcale $1: 125,000$.

Meidav, Tsvi, 1968, Report on a marine seismic survèy Salton Sea, southern part (Calif.): California Department of Water Regourceg office Report.

Meidav, Tsvi, 1968, Structural characteristics of the Salton Sea Cálifornia (abs.): American Geophysical Union Transactions, v. 49 , no. 4 .

Moyle, W.R., Jr., and Mermod, M.J., 1978, Water wells and gprings in Palo Verde Valley, Riverside and Imperial Resources Bulletin 91-23, $261 \mathrm{p}$.

Powell, J.W., 1891, The flooding of the Colorado Desert (Calif.): Engineering and Mining Journal, v. 52 , p. 9.

Powell, J.W., 1891, The new lake in the desert iCahuilia Basin, Californial: Scribner's Magazine, v. 10, p.
463-468.

Preston, E.B., 1893, Salton Lake (Calif.): California Mining Bureau Report 10, p. 387-393

Redway, J.A.. 1892, The new lake in the Colorado Degert California: London, v.K.. Royal Geographical Society, Proceedings. New Series, v. 14, p. 309-314.

Redway, J.W., 1893, Salton Lake (Calif.): The Geographical Journal, v. 2, p. 170-171.

Ross, w.H., 1914, Chemical composition of Salton Sea and its annual variation in concentration, 1906-1911, in the Salton Sea: Carnegie Institution of Washington Publication 193 , p. 35-48.

Rotstein, Y., 1974, Geophysical investigatıons in southeastern Mojave Desert, California: Riverside,
University of California, Ph.D. disgertation, 175 p.

Rotstein, Y., Combs, J., and Biehler, Shawn, 1976, Gravity investigation in the southeastern Mojave Desert, California: Geological Society of America Bulletin, v. 87 p. 981-993, 11 figs.

Skinner, B.J., White, D.E., Rose, H.J., and Mays, R.E. 1967. Sulfides associated with Saiton Sea (Calif.) geothermal brine: Economic Geology, v. 62, no. 3 .

sturrock, A.M., Jr., 1977 , Evaporation and radiation measurements at Salton Sea, California: U.S. Geological Survey Open-File Report 77-74, 49 p., 4 figs.. 8 tables.

v.s. Department of Agriculture, Soil Conservation Service, 1922, Soil survey of El Centro area, California: U.S. Department of Agriculture, Soil Conservation Service.

v.s. Department of Agriculture, Soil Conservation Service, 1923, Soil survey of the Brawley area, California: U.s.

v.s. Department of the Interior and the Resources Agency of California, 1974, Salton Sea project. California, April 1974, Federal-state feasibility report: U.S. Department of the Interior and the Resources Agency of California, 139

u.s. Geological Survey, 1976, Land use and land cover and associated maps for Santa Ana, California: U.S. Geological Survey open-file report 76-114, 4 maps, scale $1: 250,000$.

White, D.E., 1963, Geothermal brine well: Mile-deep hole may tap ore-bearing magmatic water and rocks undergoing metamorphism: Science, v. 139, no. 3558, p. 919-922.

\section{San Bernardino}

Arnold, R., and Strong, A.M., 1905, Some crystalline rocks of the San Gabriel Mountains, California: Geological Society of America Bulletin, v. 16, p. 183-204.

\section{San Bernardino--Continued}

Bader, J.S., Page, R.w., and Dutcher, L.C., 1958, Data on water wells in the upper Mojave Valley area, San
Bernardino County, California: 0.S. Geological Survey open-file report, 238 p.

Bader, J.S.. and Moyle, W.R.., Jr., 1960, Data on water wells and springs in the Yucca Valley-Twentynine Palms area, San Bernardino and Riverside Counties, California: California Department of Water Resources Bulletin 91-2, $163 \mathrm{p}$.

Bailey, T.L., and Jahng, R.H., 1954, Geology of the Transverse Range province, in Geology of southern California: California Division of Mines and Geology Bulletin 170, chap. 2, p. 83-106, contribution 6, pl. 4, scale $1: 375,000$.

Bassett, A.M., Kupfer, D.H., and Barstow, F.C., 1959, Core loga from Briatol, Cadiz, and Danby Dry Lakes, San 1045-D. $97-138$

Beattie, G.W., 1951, Origin and early development of water rights in the East San Bernardino Valley, supplemented by H.P. Hinckley, J.J. Prendergast, and E.J. Dibble: Redlands, Calif., San Bernardino valley water Conservation District Bulletin $4,70 \mathrm{p}$.

Biehler, Shawn, Tang, R.W., Ponce, D.A., and Oliver, H.W., 1983, Bernardino Bouguer gravity map of California--San 83-96, scale $1: 250,000$. Blaney, H.F., and Ewing, P.A., 1935, Utilization of waters
of Mojave River, California: U.S. Department of

Agriculture, Division of Irrigation. e, .., 1968, Comprehensive plan of water resources to the Board of Directors, Chino Basin Water Congervation District, 49 p.

Buono, Anthony, and Lang, D.J., 1980, Aquifer recharge from the 1969 and 1978 floods in the Mojave River Basin, California: U.S. Geological Survey Water-Resources Investigations report $80-207,25$.

Busby, M.W., and Hirashima, G.T.. 1972, Generalized streamflow relations of the San Bernardino and eastern San Gabriel Mountaing, California: U.S. Geological Survey open-file report, 72 .

California Department of Engineering, 1917, Preliminary report on conservation and control of flood water in Engineering Bulletin

California Department of Engineering, 1918, Report on the utilization of Mojave River for irrigation in victor valley. California: California Department of Engineering Bullet in $5,93 \mathrm{p}$.

California Department of Public Works, Division of Water Resources, 1952, Investigation of Mojave River, Barstow to Yermo: California Department of Public Works, Division of Water Resources, report to Lahontan Regional Water Quality Board, $40 \mathrm{p}$.

California Department of Water Resources, 1962 , Feasibility of serving the Desert Water Agency service area from the state water facilities: California Department of Water Resources Bulletin 119-1, $122 \mathrm{p}$.

California Department of Water Resources, 1964, Coachella Valley investigation: California Department of Water Resources Bullet in 108, $180 \mathrm{p}$.

California Department of Water Resources, 1966, Upper Santa Ana River drainage area, land and water use gurvey: California Department of water Resources Bulletin 71-64, $90 \mathrm{p}$.

California Department of Water Resources, 1970, Meeting water demands in the Chino-Riverside area, appendix $A$, water supply: California Department of Water Resources Bulletin 104-3, 108 p., 20 pla.

California Department of Water Resources, 1970, Meeting water demands in the Bunker Hill-San Timoteo area:
California Department of Water Resources Bulletin 104-5, $75 \mathrm{p}$.

Campbell, I., 1948, Magnesium metasomatism in dolomite from Lucerne valley, California: International Geological Congress Report of the Eighteenth Session, pt. 3, p.
$118-124$, fig. 1, scale $1: 1,500$. Reprinted in California Institute of Technology Division of Geological Science Contribution 511 .

Coe, J.J.. and Florian, F.S., 1957, Quality of surface and ground waters in upper Santa Ana Valley: California Department of Water Resources Bullet in 40-57, $148 \mathrm{p}$.

Durbin, T.J., 1974, Digital simulation of the effects of California: U.S. Geological Survey Water-Resourceg Invegtigations report 41-73, 44 .

Durrell, C., and Daley, A.C., 1954, Barite deposits near Barstow, San Bernardino County, California: California Division of Mines and Geology Special Report 39, 8 p., (a) p1. 1, scale $1: 3,600$.

Dutcher, L.C., and Fenzel, F.w., 1972, Ground-water outflow, San Timoteo-Smiley Heights area, upper Santa Ana Valley, southern California, 1927 through 1968: U.S. Geological Survey open-file report, $30 \mathrm{p}$.

Fife, D.L.., Rodgers, D.A., Chase, G.W., Chapman, R.H., and sprotte, E.C., 1976, Geologic hazards in southwestern San Bernardino County, California: California Division of Mines and Geology Special Report 113.

Hil1, H.S., 1939, Petrography of the Pelona Schist of southern California: Claremont, Calif., Pomona College, M.A. thesis.

Hill, R.A., 1940, Geochemical patterns in Coachella Valley: American Geophysical Union Transactions, pt. 1 , p. 46-58. 


\section{CATEGORY 2: MAP SHEETS}

\section{San Bernardino--Continued}

Hill, R.I., 1981, Geology of the Gorman Valley and vicinity, in Brown, A.R., and Ruff, R.W., eds., Geology of the San Jacinto Mountains: South Coast Geological Society Field Trip Guidebook 9, $219 \mathrm{p}$.

Knopf, Adolph, 1918, Strontianite deposits near Barstow, California: U.S. Geological Survey Bulletin 660-I, p. $257-270$.

Lewis, R.E., 1972, Ground-water resources of the Yucca Valley-Joshua Tree area, San Bernardino County. California: U.S. Geological Survey open-file report, 51 p.

Lippincott, J.B., 1902, Development and application of water near San Bernardino, Colton, and Riverside, California: U.S. Geological Survey water-Supply Paper 59 , part 1, 95 p.; Water-Supply Paper 60, part 2, $38 \mathrm{p}$

Lofgren, B.E., 1971, Estimated subsidence in the Chino-Riverside and Bunker Hill-Yucalpa areas in southern California for a postulated water level lowering. 1965-2015: U.S. Geological Survey open-file report, 20 p.

Mendenhall, w.C., 1908 , Ground water and irrigation enterprises in the foothill belt, southern California: v.S. Geological Survey Water-Supply Paper $219,180 \mathrm{p}$.

Moyle, W.R.. Jr., 1960, Data on water wells and springs in the Yucca Valley-Twentynıne Paims area, San Bernardıno and Riverside Counties, California: California Department of Water Resources Bulletin 91-2, $164 \mathrm{p}$.

page, R.w., Moyle, w.R., Jr., and Dutcher, L.C., 1960 Data on wells in the west part of the middle Mojave Valley area, San Bernardino County, California: Calıfornia Department of Water Resources Bulletin 91-1, 126 .

page, R.W., and Moyle, W.R., Jr., 1960, Data on water wells in the eastern part of the middle Mojave Valley area, San Bernardino County, California: California Department of Water Resources Bulletin 91-3, 224 p.

Riley, F.S., 1956, Data on water wells in Lucerne, Johnson, Fry, and Means Valleys, San Bernardino County,

Rogers, T.T., 1967, Geologic map of California, San Bernardino sheet: California Division of Mines and Geology, scale 1:250,000.

Tang, R.W., and ponce, D.A., 1982, Princlpal facts, accuracies, and base station descriptions for 4,915 gravity stations on the San Bernardino 1 X 2 quadrangle,
California: U.s. Geological Survey, National Technical Information Service Report PB82-200312, $99 \mathrm{p}$.

Troxell, H.C., 1948, Hydrology of the San Bernardino and eastern San Gabriel Mountains, California: U.s. Geological Survey open-file report, 2 v., 739 p. (Abridged version published in 1954 as U.S. Geological survey HA-1.)

Troxel1, H.C., 1953, The influence of ground-water storage on the runoff in San Bernardino and eastern San Gabriel Mountians of Southern California: Transactions of American Geophysical Union, v. 34, p. 552-62.

Troxell, H.C., 1954, Hydrology of the San Bernardino and Eastern San Gabriel Mountains, California: U.S. Geological Survey Hydrologic Investigations Atlas HA-1, 13 sheets.

v.s. Bureau of Reclamation, 1967, Interim report, Inland Basins Projects, Morongo-Yucca, Upper Coachella Valley. California: U.s. Bureau of Reclamation, $92 p$.

u.s. Geological Survey, 1976, Land use and land cover and associated maps for San Bernardino, California: U.S. Geological Survey Open-file Report 76-115, 4 maps, scale $1: 250,000$.

Webb, A.A., Associates, Inc., 1959, Preliminary report on water resources and water quality in the Coachella valley
region of Riverside County, California: Riverside, Calif., $12 \mathrm{p}$.

Webb, A.A., Associates, Inc., 1973, Water extractions from Beaumont, Big Bear, and Bunker Hill ground-water basins, 1947-71: Riverside, Calif., v. 1A, 212 p.

Webb, A.A., Associates, Inc., 1973, water extractions from city Creek, Devil Canyon, Devil Creek, Cajon, Lytle, Lytle Creek, Mill Creek, Oak Glen, Plunge Creek, San Timoteo, Santa Ana, Strawberry Creek, Waterman Canyon, and Yucaipa ground-water basıns, 1947-71: Riverside, Calif., v. 1B, p. $213-368$.

\section{San Diego}

Allison, M.L., 1974, Geophysical studies along the southern portion of the Elsinore fault: San Diego, California State University, M.s. thesis, 229 p.

Allison, M.L., 1974, Tectonic relationship of the Elsinore fault zone and the Chariot Canyon fault, San Diego County, California: Geological Society of America, Cordilleran Section, Abstracts with Programs, p. 138.

California Department of water Resources, 1964, San Diego County flood hazard investıgation, San Diego River areas of potential inundation, appendix C: California Department of Water Resources Bulletin 112, p. C1-C37.

California Department of Water Resources, 1965 Ground-water conditions in San Diego River valley California Department of Water Resources report to San Diego Regional Water pollution Control Board (No. 9).

California Department of Water Resources, 1965, Groundwater quality survey of lower Otay River valley: California Department of Water Resources report to San Diego Regional Water pollution Control Board (No. 9).

Cleveland, G.B., 1960, Geology of the Otay bentonite deposit, San Diego County, California: California Division of Mines Special Report 64, 1 pl., scale $1: 12,000$.

\section{San Diego--Continued}

Kennedy, M.P., 1969, Preliminary geologic maps of portions of San Diego city, California: California Division of Mines and Geology open-file reports 69-1 (Del Mar sheet), 68-10 (Del 69-14 (Point Loma sheet), 68-1 (Rancho Bernardo sheet), scale $1: 9,600$

weber, F.H., Jr., 1959-62, Reconnalssance geology of all or parts of the San Diego, El Cajon, Jamul, Potrero, Cuyamaca Peak, Carrızo Mountain, and Jacumba quadrangles, California: California Division of Mines and Geology
mapping for State geologic map, scales $1: 62,500$ and $1: 24,000$.

\section{San Diego-El Centro}

Biehler, S., 1982, Bouguer gravity map of California, San Diego-E1 Centro Sheet: California Division of Mines and Geology, scale 1:250,000.

Parry, C.C., 1857, Reconnalssance to the mouth of the Gila River from San Diego, California: Report of the United States and Mexican Boundary Survey, v. 1 , 34th Congress, ist session, External Document 135, p. 125-130.

Strand, R.G., 1977, San Diego-El Centro: California Division of Mines and Geology Geologic Atlas of Calıfornia, map, scale $1: 250,000$.

U.S. Geological Survey, 1976, Land use and land cover and associated maps for San Diego, California: U.S. Geological

Woodard Colorado Desert, San Diego and Imperial counties, southern Californa (abs.): Geological Society of America Bulletin. v. 72, pt. 2, Proceedings, Cordilleran Section Meeting, p.

\section{San Francisco}

v.S. Geological Survey, 1979, Land use and land cover maps for Big Basin, California: U.S. Geol
Report 78-753, scale 1:24,000.

\section{San Luis Obispo}

Burch, S.H., Grannell, R.B., and Hanna, W.F., 1971 Bouguer gravity map of California, San Luis Obispo sheet: California Division of Mines and Geology, scale 1:250,000.

Kundert, C.J., 1955, Geologic map of California, San Luis Obispo sheet: California Division of Mines, scale $1: 250,000$.

Tallaferro, N.L., 1944, Cretaceous and Paleocene of Santa Lucla Range, California: American Association of Petroleum Geologists Bulletin, v. 28, p. 449-521, fig-9, Map of parts of Adelaida, Bradley, Bryson and San Simeon
quadrangles, scale approx. $11 / 16$ nch $=1$ mile.

v.s. Geological Survey, 1979 , Land use and land cover and Geological Survey Open-File Report 78-1036, scale $1: 250,000$.

\section{Santa Ana}

Alf, R.M., 1948, A mylonite belt in the southeastern San Gabriel Mountains, California: Geologlc Society of America Bulletın, v. 59, p. 1101-1120; fig. 2, scale 1:190,000.

Blaney, H.F., Taylor, C.A., and Young, A.A., 1930, Rainfall penetration and consumptive use of water in Santa Ana River Valley and coastal plain (Calif.): Californa Department of Water Resources Bulletin 33, $162 \mathrm{p}$.

Bookman, Max, Edmonston, R.M., and Gianell1, W.R., 1960 , Report on water district organization for the whitewaterCoachella area, Riverside County, California: Glendale,
Calif., Bookman, Edmonston, and Gianelli, p. 3-1 to 3-24.

Boss, R.F., Olmsted, F.H., Riley, F.s., and worts, G.F. Jr., 1958, Map of Camp Pendleton, California, showing geology and location of wells: v.s. Geological Survey open-file map.

Bower, C.A., Spencer, J.R., and weeks, L.O., 1969, Salt. and water balance, Coachella Valley, California: Journal the American Society of Clvil Engineers, 6437, IR1.

Burnham, W.L., 1954, Data on water wells in Borrego, Ocotillo, San Felipe, and Vallecito Valley areas, eastern San Diego County, California: U.S. Geological Survey open-file report, $60 \mathrm{p}$.

Burnham, W.L., and Dutcher, L.C., 1960, Geology and ground-water hydrology of the Redlands-Beaumont area. California, with special reference to ground-water outflow: U.S. Geological Survey open-file report, 352 p.

California Department of public Works, Division of Water Resources, 1956, Santa Margarita River investigation (Calif.): California Department of Public Works, Division of water Resources, Bulletin 57, v. 1, 273 p., 30 pls.; v. 2, $450 \mathrm{p}$.

California Department of water Resources, 1964, Ground-water quality objectıves, San Jacinto River valley, Riverside Water Resources, project code 4108-014, $131 \mathrm{p}$. 
CATEGORY 2: MAP SHEETS

\section{Santa Ana--Continued}

California Department of Water Resources, 1966, Reclamation of water from wastes: Coachella valley (Calif.): California Department of water Resources Bulletin $80-3,82 \mathrm{p}$.

California Department of Water Resources, 1969, Progress report, San Jacinto Valley (Calif.) cooperative study:

California Department of Water Resources, $172 \mathrm{p}$.

California Department of Water Resources, 1975, Impact of waste treatment and disposal on the quality of water supplies, Santa Margarita watershed (Calif.): Californ

California Division of Mines and Geology, 1965, Santa Ana (Calif.): California Division of Mines and Geology Geologic Atlas of California, scale $1: 250,000$.

California Division of Water Rights, 1923 and 1928 , Report on water supply and use of water from Whitewater River (Calif.) stream system: Whitewater River Adjudication Proceedings.

California State water Resources Board, 1955, Geology of San Jacinto and Elsinore basins (Calif.): California state Water Resources Board, append $x$ B of Santa Ana River Water Resources Board, append1x B of Santa

investigation, pl. B-1, Scale $1: 125,000$.
Donnan, W.W., and Litz, G.M., 1954, Irrigation and consumptive use of water, investigations in the Santa Margarita River basin, Riverside and San Diego Counties, California: Los Angeles, Calif., U.S. Department of Agriculture Research Service, $57 \mathrm{p}$.

Eastern Municipal Water District, 1969 , Reutilization of wastewater recycled through groundwater: vol. 1 and 2 : Available from the clearinghouse as PB-190 790 (v. 1), 125 Available from the Clear inghouse as PB-190 790 (v. 11,125
p., 45 figs., 20 tables; and PB-190 791 (v. 2), 87 p., 3 app.

Fett, J.D., 1968, Geophysical investigation of the San Jacinto Valley, Riverside, California: Riverside, university of California, M.A. thesis.

Erench, J.J., 1974, Maps of San Gorgonio Pass-Upper Coachelia Valley area, Cal fornia, showing water-level Coachella Valley area, Cal ifornia, showing water-1 contours, 1936 and $1966-67:$ U.S. Geologic
open-file maps, 3 maps, scale $1: 63,360$,

Giessner, F.W., Winters, B.A., and McLean, J.S., 1971 , Water welis and springs in the western part of the upper Santa Margarita River watershed, Riverside and San Diego Counties, California: California Department of Water Resources Bulletin 91-20, 377 .

Giessner, F.W., and Mermod, M.J., 1974, Water wells and springs in the eastern part of the upper Santa Margarita watershed, Riverside and San Diego Counties, California: California Department of Water Resources Bulletin 91-22, $213 \mathrm{p}$.

Gray, C.H., Jr., 1954, Geology of the Corona-ElsinoreMurrieta area, Riverside County, in Geology of southern California: California Division of Mines Bulletin 170, map sheet 21, scale $1: 187,500$.

Irwin, G.A., and Giessner, F.W., 1971, Maps of the watersheds of the Santa Margarita and San Luis Rey Rivers, Riverside and San Diego Counties, California, showing ground-water-quality data, $1971:$ U.S. Geological Survey
open-file maps; 4 maps, scale $1: 48,000 ; 6$ maps, scale $1: 96,000$.

Keaton, J.R.. ed., 1979, Guidebook to selected geologic features, coastal areas of southern orange and northern San Diego counties, California: South Coast Geological Socrety, $184 \mathrm{p}$.

kundert, C.J., 1955, Geologic map of California, Santa Ana sheet: California Division of Mines, scale $1: 250,000$. 1. Fred, 1959. Map of Murrieta. Bachelor Mountain, and parts of Wildomar. Pechanga, and Temecula quadrangles, California, showing geology, location of wells, and warvey open-file map; Exhibit 15E, USA v. Fallbrook PuD, and others, 1247-SD-C, U.S. Dist. Court, So. Dist., Calif.. So. Div.. Hon. J.M. Carter.

Loel, W., and corey, W.H., 1932, The Vaqueros Formation, lower Miocene of California: I Paleontology: University of California Department of Geological Science Publications, v. 22, no. 3, p. 31-410.

Mendenhall, w.c. , 1905 , Development of underground waters

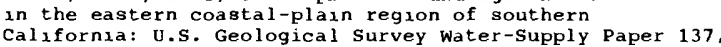
$140 \mathrm{P}$.

Miller, R.E., 1967, Proposed water-resources study of the upper Coachella valley area, California: U.S. Geological Survey open-f le report 25 .

Mrller, R.E., and Singer, J.A., 1971. Subsidence in the Bunker Hill-San Timoteo area, southern California: v.s. Geological Survey open-file report, $28 \mathrm{p}$.

Moreland, J.A., 1972, Maps of the watersheds of the Santa Margarita and San Luis Rey Rivers, Riverside and San Diego counties, California, showng water-level contours and water-quality diagrams: U.S. Geological Survey open-file

Moreland, J.A.'1974, Hydrologic and salt-balance investigations utilizing digital models, lower san Luss Rey River area, San Diego County, California: U.S. Geological Survey Water-Resources Investigations 24-74, 66

Morton, Paul, 1972, Geologic guidebook to the northern Peninsular Ranges, orange and Riverside Counties, California: South Coast Geological Society, $97 \mathrm{p}$.

Moyle, w.R., Jr., 1973, Geologic maps of the eastern and the western parts of Camp Pendleton, southern Cal ifornia: v.s. Geological Survey open-file maps, 2 maps.

Moyle, W.R., Jr., 1973, Map of the Santa Rosa Rancho area Riverside and San Diego Counties, Calif.. showing reconnaissance geology and location of wells and springs: v.s. Geological Survey open-file map.

\section{Santa Ana--Continued}

Moyle, W.R., Jr., 1982, water resources of Borrego valley and vicinity, California, phase 1, definition of geologic Survey open-file report $82-855,39$ p., 12 pls., 3 figs., 8 tables.

Moyle, W.R., Jr.. and Downing, D.J., 1975, Bouguer gravity anomaly map of the Temecula area, Riverside County. Planning Agency, scale 1:62,500.

Pillsbury, A.F., 1941, Observation on use of irrigation California Agriculture Experimental Station Bulletin 649, $48 \mathrm{p}$.

Rogers, T.н., 1965, Geologic map of Calıfornia, Santa Ana (Calif.) sheet: Calıfornia Division of Mines and Geology, scale $1: 250,000$.

Schoel lhamer, J.E., Kinney, D.M., Yerkes, R.F., and Vedder, J.G., 1954, Geologic map of the northern Santa Ana Mountains, Orange and Riverside Counties, Cal ifornia: v.s. Geological Survey $O_{11}$ and Gas Investigations Map OM-154; Geological Survey
scale $1: 24,000$.

Schoellharer, J.E., Vedder, J.G., Yerkes, R.F., and Kinney, D.M. 1981, Geology of the northern Santa Ana Mountains. California: U.S. Geological Survey Professional Paper 420-D, P. D1-D109.

Schwarcz, H.P., 1960, Geochemical investigations of and arkosic quartzite of the Winchester-Hemet area, Ph.D. dissertation.

Schwarcz, H.P., 1960 , Geology of the Winchester-Hemet area, Riverside' County, California: Pasadena, California Institute of Technology, Ph.D. dissertation, 427 p.

Schwarcz, B.P., 1967. Pre-Cretaceous sedimentation and metamorphism in the Winchester area, northern Peninsular panges, California: Geological Society of America Special Paper $100,63 \mathrm{p}$.

Sharp, R.V. 1967, San Jacinto fault zone in the Peninsular Ranges of Southern California: Geological

Sharp, R.v., 1968, The San Andreas fault system and contrasting pre-San Andreas structures in the Peninsular Ranges of southern California (abs.), in Dickinson, W.R. and Grantz, A., eds., Conference on geologic problems of San Andreas Fault system, Stanford University, Sept. 14-16: Stanford University Publications Geological Soclet $Y$, Proceedings, v. 11, p. 292-293.

Swain, L.A., 1978, Predicted water-level and water-quality effects of artificial recharge in the upper coachella valley, California, using a finite-element digital model: u.s. Geological Survey Water-Resources Investigations report $77-29,54 \mathrm{p}$.

Ta1t, C.E., 1917, Preliminary report on conservation and control of flood water in Coachella valley. California: California Department of Engineering Bulletin 4, $31 \mathrm{p}$. roxell, H.C., 1936, The diurnal fluctuation in the ground water and flow of the Santa Ana River (Calif.' and its meaning: Trans
p. $496-504$.

Tyley, S.J., 1970, Analog model of the ground-water basin of the upper Coachella valley (Calif.): U.S. Geological Survey open-file report, $5 \mathrm{p}$.

Tyley, S.J., 1971, Analog model study of the ground-water basin of the upper Coachella valley, California: U.S.

Geological Survey open-file report, $89 \mathrm{p}$.

ley, S.J., 1974, Analog model study of the ground-water basin of the upper Coachella Valley, California:
Geological Survey Water-Supply Paper 2027, $77 \mathrm{p}$.

waring, G.A., 1919, Ground water in the San Jacinto and Temecula basins, California: U.S. Geological Survey Water-Supply Paper 429, $113 \mathrm{p}$.

Young, A.A., Ewing, P.A., and Blaney, H.F., 1941 , Utilization of the waters of Beaumont Plains and San Jacinto Basin, California: U.S. Department of Agriculture, $336 \mathrm{p}$.

\section{Santa Cruz}

Bishop, C.C., and Chapman, R.H., 1980, Santa Cruz (Calif.): Californa Division of Mines and Geology Bouguer Gravity Atlas of California, scale 1:250,000.

Bramlette, M.N.. and Daviess, S.N., 1944, Stratıgraphy as California: U.S. Geological Survey oil and Gas Preliminary Map 24, scale $1: 126,720$.

Bryant, W., and others, 1981 , The Sargent, San Andreas, and Calaveras fault zones: Evidence for recency in Watsonville California Division of Mines and Geology Open-File Report $81-7$ SE.

Chapman, R.H., and Bishop, C.C., 1978, Principal facts and sources for 1734 gravity stations on Santa Cruz 1 by 2 of Mines and Geology Open-File Report 78-14 SAC. of Mines and Geology Open-File Report 78-14 SAC.
Dibblee, T.W. and Brabb, E.E., 1978, Preliminary geologic maps
of the Chittenden, Los Gatos, and Watsonville East of the Chittenden, Los Gatos, and Watsonville East Report 78-453,3 pls., scale $1: 24,000$.

Robbins, S.L., and Roberts, C.W., 1981, Principal facts, accuracies, sources, and plot for 930 gravity stations on and adjacent to the Hollister 15-minute quadrangle. Cal ifornia u.s. Geological Survey Open-File Report 81-511, 31 p. assoglated maps for Cambria, California: v.s. Geological Survey Open-File Report 78-1037, scale 1:100,000. 


\section{CATEGORY 2: MAP SHEETS}

\section{Santa Maria}

Blaney, H.F., Nixon, P.R., Lawless, G.P., and wiedmann, E.J., 1963, Utillzation of the waters of the Santa ynez River basin for agriculture in southern Santa Barbara County, California: U.S. Department of Agriculture Research Service, Soil and Water Conservation Research Division, Southwest Branch, open-file report, 53 p.

Crandall, B.G., 1961, The stratigraphy of the Buckhorn Sandstone, Santa Barbara, San Luis obispo Counties, California: Los Angeles, University of California, M.A.

thesis.
Curran, J.F., Hall, K.B., and Herron, R.F., 1971, Geology, oil fields, and future petroleum potential of Santa Barbara channel area, California, in Future petroleum provinces of the United States--their geology and potential: American Association of Petroleum Geologists Memoir 15, p. 192-211

Rietman, J.D., and Beyer, L.A., 1982, Santa Maria (Calif.): California Division of Mines and Geology Bouguer Gravity Atlas of California, scale $1: 250,000$

v.s. Geological Survey, 1976, Land use and land cover and assocrated maps for Santa Maria, California: U.S. Geological Survey open-File Report 76-117, 4 maps, scale $1: 250,000$

\section{Tonopah}

Ferguson, H.G., and Muller, S.w., 1949, Structural geology of the Hawthorne and Tonopah quadrangles, Nevada: U.S. Geological Survey Professional Paper 216, 55 p.

Muller, S.W., and Ferguson, H.G., 1939, Mesozoic stratigraphy of the Hawthorne and Tonopah quadrangles, Nevada: Geological Society of America Bulletin, v. 50, p. $1573-1624$

\section{Trona}

Anderson, w.L., 1978, Interpretation of electromagnetic extralow-frequency soundings in the Randsburg, California, Known Geothermal Resource Area: 0.S. Geological Survey Open-Fale Report 78-562, 22 p

Baker, C.L., 1912, Physiography and structure of the western El Paso Range and southern Sierra Nevada (Calif.): Unıversity of California Department of Geological Sciences Bulletin, v. 7 , no. 6, p. 117-142.

Bowen, E.R. , 1943, Report of water resources of camp Irwin Reservation: 43 p. (J.F. Poland assisted in the preparation of this open-file report in cooperation with the Corps of Engineers who assumed the authorship,

included as appendix to Poland and Worts, 1951 Cronise, Soda, and Silver Lake Valleys, California: U.s. Geological Survey open-file report, 48 p., pl. 1, scale $1: 125,000$.

Dibblee, T.W., Jr., 1968, Geology of the Fremont Peak and Opal Mountain quadrangles, California: Californıa Diviszon of Mines and Geology Bullet in $188,64 \mathrm{p}$

Dutcher, L.C., 1959, Data on water wells in the Fremont vailley area, Kern County, Cal afornia: U.S. Geological Survey open-file report, $128 \mathrm{p}$.

\section{Trona--Continued}

Jennings, C.w., Burnett, J.L., and Troxel, B.w., 1962, Geologic map of California--Trona sheet: California Division of Mines, scale 1:250,000.

Kundert, C.J., 1955, Geologic map of California, Trona sheet: California Division of Mines, scale 1:250,000.

Kunkel, Fred, 1956, Data on water wells in cuddeback, Superior, and Harper valleys, San Bernardino County, California: U.S. Geological Survey open-file report, 73 p.

Kunkel, Fred, and Riley, F.S., 1959, Geologic reconnalssance and test-well drilling, Camp Irwin, Calıfornıa: U.S. Geological Survey Water-Supply Paper 1460-F, p. 233-271, 1 fig., 1 pl.

Lee, C.H., 1913, Ground-water resources of Indian Wells Valley, Californza: Sacramento, Calif., California state Conservation Commission, p. 403-29.

Moyle, W.R., Jr., 1967, Water wells and springs in Soda, Silver, and Cronise Valleys, San Bernardino County, California: California Department of Water Resources Bulletin $91-13,16$ p., 5 app.

Nelson, C.A.. 1955, Geology of the Trona Sheet: California Division of Mines, scale $1: 250,000$.

N1 lsen, T.H., and Chapman, R.H., 1974, Bouguer gravity map of California, Trona sheet: California Division of Mines and Geology, 9 p., scale 1:250,000.

Sass, J.H., Galanis, S.P., Jr., Marshall, B.V., Lachenbruch, A.H., Munroe, R.J., and Moses, T.B., Jr., 1978, Conductive heat flow in the Randsburg area, California: U.s. Geological Survey Open-File Report 78-757, 14 p.

Smath, G.I., 1960, Time of the last displacement of the middle part of the Garlock fault, California, in Geological Survey Research, Short papers in the geological sciences: U.S. Geological Survey professional Paper 400-B, p. B-280.

U.S. Bureau of Reclamation, 1967 (revised 1968), Interım report, inland basins projects, Indian Wells and Searles
Valleys, California: U.S. Bureau of Reclamation, Region 3 ,

v.s. Geologrcal Survey, 1979, Land use and land cover and associated maps for Trona, California: U.S. Geologica Survey Open-File Report 79-350, scale 1:250,000.

U.S. Geological Survey, 1980, Land use and land cover, 1976, Trona, California: U.S. Geological Survey, scale $1: 250,000$.

\section{Walker Lake}

Oliver, H.W., Plouff, D., Robbins, S.L., 1982, Bouguer gravity map of Calıfornia, Walker Lake sheet: Calıfornı Division of Mines and Geology, scale 1:250,000.

purdy, T.L., 1985, Map showing distribution of altered rocks, faults, and linear features in the walker Lake 1 by 2 degree quadrangle, Nevada and California: U.S. Geological Survey Miscellaneous Investigations Series Map I-1643, scale $1: 250,000$.

U.S. Geological Survey, 1980, Land use and land cover and associated maps for Walker Lake, Calıfornıa, Nevada: U.S. Geological Survey Open-File Report 80-151. 
CATEGORY 3: MILITARY RESERVATIONS AND NATIONAL MONUMENTS

Death Valley National Monument

Buono, Anthony, and Packard, E.M., 1982, Delineation and hydrologic effects of a gasoline leak at Stovepipe Wells Hotel, Death Valley National Monument, California: U.S. Geological Sur

Buono, Anthony, and Packard, E.M., 1982, Evaluation of increase in dissolved solids in ground-water, Stovepipe Wells Hotel, ile Report 82-513,19

Crippen, J.R. 1979, Potential hazards from floodflows and debris movement in the Furnace Creek area, Death Valley National Monument, California-Nevada: U.S. Geological Survey open-file report $79-991,23 \mathrm{p}$.

Crippen, J.R., 1981, Potential hazards from floodflows in Wildrose Canyon, Death Valley National Monument. California and Nevada: U.S. Geological Survey open-file report 81-407,23 p.

crippen, J.R.' 1981, Potential hazards from floodflows in Wildrose Canyon, Death Valley National Monument, CaliforniaNevad

Croft, M.G., 1964, Results of drilling test well 27N/1E-16R1 near Furnace Creek Ranch in Death valley National Monument, Cal Ifornia: v.s. Geological Survey open-file report, 4 p.

croft, M.G., 1966, Water-resources reconnaissance of Áshford Mill and Emigrant Ranger Station, Death Valley National Monument (Calif.): U.S. Geological Survey open-file report, 18 p.

Engineering-Science, Inc.. 1960, Report on quantities of spring waters available at Lower Ranch, Grapevine Canyon,
Scottys Castle, Death Valley, California: Arcadia, Calif. Engineering-Science, Inc., 9 p.

Gale, H.S., 1914, Prospecting for potash in Death Valley, California: U.S. Geological Survey Bulletin 540-N, 407-415.

Hunt, C.B., Robinson, T.W., Bowles, W.A., and Washburn, A.L., 1966, Hydrologic basin, Death Valley, California:

Hunt, C.B. Geological Survey Professional Paper 494 , structure, Death valley, California: U.S. Geological Survey Professional Paper 494-A, 162 p.

Kunkel, Fred, 1959, Report on exploratory drilling at Death Valley National Monument, Inyo County, California: o.s. Geological Survey adminstrative report, $15 \mathrm{p}$.

Kunkel, Fred, 1963, a brief summary of ground water in the Furnace Creek Wash area, Death Valley National Monument,

California: U.S. Geological Survey open-file report, 7 p.
Lamb, C.E., and Downing, D.J., 1979, Hydrologic data, 1974-77, Stovepipe Wells Hotel area, Death Valley National Monument, Inyo County, California: v.s. Geological Survey Open-File Report 79-203, $19 \mathrm{p}$.

Lanphere, M.A., 1962, Geochronologic studies in the Death Valley-Mojave Desert region, California: Pasadena, California Institute of Technology, Ph.D. dissertation, pl. 8, Geologic map of part of the Marble Mountains, scale
$1: 24,000$.

Ludwig, H.F., 1958, Report on quantities of spring waters available at Scottys Castle, Death Valley (Cailf.): Englneering consultant report.

Mabey, D.R. 1963, Complete Bouguer anomaly map of the Death Valley region, California: U.S. Geological Survey Geophysical Investigations Map GP-305, scale 1:250,000. Majmundar, H.H., 1985 , Borate mining history in Death valley
(Calif.\}: California Geology, v, 38, no. 8 , p. 171-177.

McAllister, J.F., 1970, Geology of the Furnace Creek borate area, Death Valley, Inyo County, Cal ifornia:
California Division of Mines and Geology Map Sheet 14 , scale $1: 24,000$

Miller, G.A., 1970, Data on water regources of the Hunter Mountain area, Death Valley National Monument, California: v.s. Geological Survey open-file report, $22 \mathrm{p}$. Geologic guide to the Death Valley area, California Geological Society of Sacramento annual field trip guidebook, p. 33-39.

Miller, G.A., 1977, Appraisal of the water resources of Death valley, California-Nevada: U.S. Geological Survey open-file report $77-728,68$.

Noble, L.F., and Wright, L.A., 1954, Geology of the central and southern Death Valley region in Geology of southern California: California Division of Mines Bulletin 170 chap. 2 , contribution $10 ; \mathrm{pl}$. 7, scale 1:250,000.

Pistrang. Contribution $10 ;$ pl. 7 , scale $1: 250,000$. and hydrologic reconnalssance of the Furnace Creek Wash area, Death Valley National Monument, California: U.S

Geological Survey Water-Supply Paper $1779-Y, 35 \mathrm{p}$.
Reynolds, M.W., 1966, Structure of the southern Grapevine Mountalns, Death Valley, California (abs.): Geological Society of America Special Paper 87, p. 226-227.

Richards, C.A., 1958, Geology of a part of the Funera Mountains, Death Valley National Monument, California: Los Angeles, University of Southern California, M.S. thesis.

Robinson, T.W., 1952, Investigation of the water resources of the Nevares property in Death Valley National Monument, California: U.S. Geological Survey open-file report, $21 \mathrm{p}$.

Robinson, T.W., 1957, Determination of the flow of Saratoga Spring in Death Valley National Monument, California: 0.S. Geological Survey open-file report, $19 \mathrm{p}$.

Robinson, T.W., and Hunt, C.B., 1961, Some extremes of climate in Death Valley, California: U.S. Geological Survey Professional Paper 424-B, p. 192-194.

Smith, R.M., 1977, Map showing mineral exploration potential in the Death Valley quadrangle, California and Nevada: o.s. Geological Survey Miscellaneous Field Studies Map MF-873, scale $1: 250,000$.

\section{Death Valley National Monument--Continued}

Throckmorton, M.L., Villalobos, H.A., Smith, R.M., and Calzia, J.P., 1981, Leasable mineral and waterpower land classification map of Death Valley 1 degree by 2 degrees quadrangle, California and Nevada: U.S. Geolo

Welles, R.E., and Welles, F.B., 1959, Preliminary study of wildife water sources in Death valley National Monument (Calif.): Report prepared under National Park Service contract 14-10-434-375.

\section{Edwards Air Force Base}

Dutcher, L.C., 1959, Ground-water inventory for 1958, Edwards Air Force Base, Calıfornia: 0.s. Geological Survey open-file report, $69 \mathrm{p}$

Dutcher, L.C., Bader, J.S., Hiltgen, W.J., and others, 1962. Data on wells in the Edwards Air Force Base area, California: California Department of Water Resources Bullet in $91-6,209 \mathrm{p}$.

Dutcher, L.C., and Hiltgen, W.J., 1954, Appendix B, tables of basic data for areas outside Edwards Air Force Base (Calif.): U.S. Geological Survey open-file report.

Dutcher, L.C., and Hiltgen, W.J., 1955, Appendıx A, tables of basic data for wells on Edwards Alr Force Base (Calıf.): U.S. Geological Survey open-file report, $84 \mathrm{p}$.

Dutcher, L.C., and Worts, G.F., Jr.. 1958, Geology and ground-water appraisal of Edwards Air Force Base and report,

Dutcher, L.C., and worts, G.F., Jr., 1963, Geology, hydrology, and water supply of Edwards Air Force Base, Kern County, California: o.s. Geological Survey open-file

report, 225 p.
Giessner, F.W., and Robson, S.G., 1965, Ground-water inventory for 1964, Edwards' Air Force Base, California: U.s. Geological Survey open-file report, $28 \mathrm{p}$.

Giessner, F.W., and Westphal, J.A., 1966, Ground-water inventory for 1965, Edwards Air Force Base, California:

U.S. Geological Survey open-file report, $24 \mathrm{p}$.
koehler, J.H., 1969, Ground-water inventory for 1967 , Edwards A1r Force Base, California: 0.s. Geological Survey

open-file report, $15 \mathrm{p}$. Edwards Alr Force Base, California: D.s. Geological survey

open-file report, $35 \mathrm{p}$.
Moyle, W.R., Jr., 1961, Ground-water inventory for 1960, Edwards Air Force Base, California: 0.s. Geological Survey open-file report, 45 p.

Tyley, S.J., 1967, Ground-water inventory for 1966. Edwards Air Force Base, California: o.s. Geological survey

Weir, J.E., Jr., 1962, Ground-water inventory for 1961, Edwards Aír Force Base, Californı: U.s. Geological Survey open-file report, $54 \mathrm{p}$.

weir, J.E. Jr., 1963, Ground-water inventory for 1962 , Edwards Air Force Base, California: U.S. Geological survey open-file report, $30 \mathrm{p}$.

Weir, J.E., Jr., 1964, Ground-water inventory for 1963 , Edwards Air Force Base, California: U.s. Geological survey open-file report, 28 p.

\section{Joshua Tree National Monument}

Downing, D.J., 1974, Records of water level and pumpage for 1973 in Joshua Tree National Monument, Calıfornia:

D.s. Geological Survey open-f lle report, 15 p.
Downing, D.J., 1977, Ground-water data for $1974-75$ in Joshua Tree National Monument, California: U.S. Geologica Survey Open-File Report 77-80, 34 p.. 2 figs.. 4 tables.

Downing, D.J., 1978, Ground-water data for 1976-77 in Joshua Tree Natıonal Monument, Cal ifornıa: o.s. Geological Survey openFile Report 78-854, 34 p

Kunkel, Fred, 1960 , Summary of hydrologic conditions at Joshua Tree National Monument, Riverside County, report, $18 \mathrm{p} .6 \mathrm{pls}$

Kunkel, Fred, 1963, Hydrologic and geologic reconnaissance of Pinto Basin, Joshua Tree National Monument, Riverside county, California: U.S. Geological Survey Water-Supply Paper 1475-0, p. 537-561

Miller, G.A., 1968, Test-drilling and pumping-test data, Joshua Tree National Monument, California, 1968: U.S. Geological Survey open-file report, $13 \mathrm{p}$.

Miller, G.A. 1970, Records of water level and pumpage 1969 in Joshua Tree National Monument, California: o.s. Geological Survey open-file report, $17 \mathrm{p}$.

Miller, G.A., 1971, Records of water level and pumpage for 1970 in Joshua Tree National Monument, California: D.s. Geological Survey open-file report, $16 \mathrm{p}$.

Miller, G.A. 1972, Records of water level and pumpage for 1971 in Joshua Tree National Monument, California: 0.s.

Geological Survey open-flle report, $17 \mathrm{p}$.
Miller, G.A., 1973, Records of water level and pumpage for 1972 in Joshua Tree National Monument, California: U.s. Geological Survey open-file report, $17 \mathrm{p}$. Price, W.M., Jr., and Associates, 1958 , Report on proposed
pleasant Vailey (Calif.) pipeline distribution system: $79 \mathrm{p}$.

Rogers, J.J.W., 1954, Geology of a portion of Joshua Tree National Monument, Riverside County, in Geology of southern California: California Division of Mines Bulletin 170 , map sheet 24 . 
CATEGORY 3: MILITARY RESERVATIONS AND NATIONAL MONUMENTS

\section{Joshua Tree National Monument--Continued}

Rogers, J.J.W., 1961, Igneous and metamorphic rocks of the western portion of Joshua Tree National Monument, Riverside and San Bernardino Countres, Calıfornia: $68,26 \mathrm{p}$

Trent, D.D. , 1984, Geology of the Joshua Tree National Monument, Riverside and San Bernardino Counties (Calif.): California Division of Mines and Geology, California Geology, v. 37, no. 4, p. 75-86,

weir, J.E.. Jr., and Bader, J.s., 1963, Ground water and related geology of Joshua Tree National Monument. California: v.S. Geological Survey open-file report, 123 p.

\section{Twentynine Palms Marine Corps Base}

Dutcher, L.C., 1960, Ground-water conditions during 1959 at the Marine Corps Base, Twentynine Palms, California: o.s. Geological Survey open-file report, $26 \mathrm{p}$.

Dyer, H.B., 1960, Ground-water conditions during 1960 at the Marine Corps Base, Twentynine Palms, California: o.s. Geological Survey open-file report, $32 \mathrm{p}$

Fife, D.L., 1985, War Eagle mine, San Bernardino County California: California Geology, v. 38 , no. 5 , p. 109-111.

Giessner, F.w., 1965, Ground-water conditions during 1964 at the Marine Corps Base, Twentynine Palms, Calıfornia: o.s. Geological Survey open-file report, $30 \mathrm{p}$.

Giessner, F.W., and Robson, S.G., 1965, Ground-water conditions during 1964 at the Marine Corps Base, Twentynine Palms, Californıa: U.S. Geological Survey open-file report, $28 \mathrm{p}$

Giessner, F.W., and Robson, S.G., 1966, Ground-water conditions during 1965 at the Marine Corps Base, Twentynine Palms, California: U.S. Geological Survey open-file report, 27 p.

Johnston, P.M. . 1963, Ground-water conditıons durıng 1963 at the Marine Corps Base, Twentynine Palms, California: U.S. Geological survey open-file report, $37 \mathrm{p}$

Moyle, W.R., Jr., 1984, Bouguer gravity anomaly map of the Twentynine palms Marine Corps Base and vicinity, Californa: o.s. Geological survey Water-Resources Investigations Report 84-4005, 1 sheet.

Riley, F.S., and Bader, J.S., 1961, Data on water wells on Marine Corps Base, Twentynine Palms, California: U.s. Geological Survey open-file report, 72 p.

Schaefer, D.H., 1978, Ground-water resources of the Marine Corps Base, Twentynine Palms, San Bernardino County, California: U.s. Geological Survey Water-Resources Investigations report 77-37, $29 \mathrm{p}$.

U.S. Geological Survey, 1973, Water-resources data collected on the Marine Corps base area, Twentynine Palms. California, July 1970 through June 1973: U.S. Geological Survey, 9 p.

wagner, w.o., 1951, Investigation of water resources for Marine Corps Artillery Training Camp, Twentynine Palms

weir, J.E., Jr., 1962, Ground-water conditions during 1962 at the Marine Corps Base, Twentynine Palms, California: 0.s. Geological survey open-file report, $54 \mathrm{p}$.

Weir, J.E., Jr., and Dyer, H.B., 1962, Ground-wate conditions during 1961 at the Marine Corps Base, Twentynine Palms, California: 0.s. Geological Survey open-file report, $50 \mathrm{p}$

\section{China Lake Naval Weapons Center}

Austin, C.F., and Pringle, J.K., 1970, Geologic investigation at the coso thermal area: China Lake, Calif., 0.s. Naval weapons Center Technical Publication 4878, $40 \mathrm{p}$.

Banta, R.L., 1972, Ground-water conditions during 1971 in Indian' wells valley, Californa: o.s. Geological survey open-file report, $9 \mathrm{p}$.

Banta, R.L., 1973, Ground-water data, 1972, Ind lan wells valley', California: v.s. Geological Survey open-fole report, $12 \mathrm{p}$

Banta, R.L., 1974, Ground-water data, 1973, Indian wells valley, California: U.S. Geological Survey open-file report, $9 \mathrm{p}$.

Bloyd, R.M., Jr., and Robson, S.G., 1971, Mathematical ground-water model of Indian wells valley, California: U.S. Geological Survey open-file report, $36 \mathrm{p}$.

Dutcher, L.C., and Moyle, W.R.. Jr.. 1973, Geologic and hydrologic features of Indian wells valley, Call fornia

v.s. Geological Survey water-Supply Paper 2007, $30 \mathrm{p}$.
Koehler, J.H., 1970. Ground-water conditions during 1969 in Indian Wells valley, Californa: U.S. Geological Survey open-file report, $21 \mathrm{p}$.

\section{China Lake Naval Weapons Center--Continued}

Koehler, J.H., 1971, Ground-water condıtıons during 1970 in Indian Wells Valley, California: O.S. Geological Survey open-file report, 19 .

Kunkel, Fred, Chase, G.H., and Hiltgen, W.J., 1954, Tables of selected data to accompany U.S. Geological Survey report on geology and ground water of the Inyokern Naval ordnance rest Station and vicinity: U.S. Geological Survey open-file report, $115 \mathrm{p}$.

Kunkel, Fred, and Chase, G.H., 1969, Geology and ground water in Indian wells Valley, Cal ifornia: U.S. Geological Survey open-file report, 84 p.

Lamb, C.E., and Downing, D.J., 1978, Ground-water data, 1974-76. Indian wells Valley, Kern, Inyo, and San Bernardino Counties, California: U.S. Geological survey

Lee, C.H., 1912, Ground-water resources of Indian wells valley, Calıfornia: California State Conservation Commission Report for 1912, p. 401-429.

Lee, C.H., 1913, Ground-water resources of Indian wells Valley, California: California state conservation Commission Report, p. 403-429.

Lipinski, Paul, 1980, Map of Indian wells Valley. California, showing change in water level, 1963-78, and hydrographs of selected wells: U.S. Geological Survey Open-File Report 80-342, 1 sheet.

Lipinsk1, Paul, and Knochenmus, D.D., 1981, A 10-year plan to study the aquifer system of Indian wells valley. California: U.S. Geological Survey Open-File Report 81-404, $16 \mathrm{p}$.

Mallory, M.J., 1979, Water-level predictions for Indian wells valley ground-water basin, Calıfornia: v.s. Geological Survey Open-File Report 79-254, 28 p.

Moyle, W.R., Jr., 1963, Data on water welis in Indıan Wells Valley area, Inyo, Kern, and San Bernardino Counties, California: California Department of Water Resources Bulletin 91-9, $243 \mathrm{p}$.

Roquemore, G.R., 1982, Reconnassance geology and structure of the Coso Range, California: China Lake, Calif., U.S. Naval Weapons Center Technial Publication 6036.

von fuene, R.E., 1960, Structural geology and gravimetry of Indian Wells Valley, southeastern California: Los Angeles, University of California, Ph.D. dissertation, $138 \mathrm{p}$.

Warner, J.W. 1975, Ground-water quality in Indian wells Valley, Californa: 0.S. Geological Survey Water-Resources Investigations report $8-75,59 \mathrm{p}$

wilcox, L.V., Hatcher, J.T., and Blair, G.Y., 1951, Quality of water of the Indian wells Vailey, California: v.s. Salinity Laboratory Report 54, 33 p.. i1 tables.

zbur, R.T.. 1963, A geophyscal investigation of Indian wells valley, California: China Lake, Calif.. U.S. Naval Ordnance rest station Technical Publication 2795,98 p.

\section{Vandenberg Air Force Base}

Descheneaux, R.V., 1975, New water wells in San Antonio watershed: Vandenberg Alr Force Base, 4392d Civil Englneering Squadron, Environmental Impact Report, $19 \mathrm{p}$.

Giessner, F.W., 1968, Ground-water conditions during 1967, Vandenberg Aır Force Base area, Calıfornia: 0.S Geological Survey open-file report, $15 \mathrm{p}$.

koehler, J.H., 1970, Ground-water conditions during 1968, Vandenberg Alr Force Base area, California: 0.s. Geological Survey open-file report, 20 p.

koehler, J.H.. 1971, Ground-water conditions during 1969. Vandenberg Alr Force Base area, Callforna: v.s. Geological Survey open-file report, $19 \mathrm{p}$.

Lamb, C.E., 1980, Ground-water data, 1969-77, Vandenberg Alr Force Base area, Santa Barbara County, California: U.S. Geological Survey open-file report 80-736, $53 \mathrm{p}$.

Miller, G.A., and Evenson, R.E., 1962, Geologic reconnaissance and test-weil driling at proposed Air Force facility near Lompoc, California: U.S. Geological Survey open-file report, $18 \mathrm{p}$.

Robson, S.G., 1966, Ground-water conditions during the 1966 figcal year, south Vandenberg area, Vandenberg Air Force Base, Californa: U.S. Geological Survey open-file report, $19 \mathrm{P}$

Robson, S.G., 1968, Data on wells and springs on Vandenberg Alr Force Base and vicinity. Santa Barbara County, California: U.S. Geological Survey open-file report, $132 \mathrm{p}$.

Robson, S.G., and Giessner, F.W., 1966, Ground-water conditions during 1965, south vandenberg area, Vandenberg A1r Force Base, California: 0.s. Geological Survey open-file report, $19 \mathrm{p}$.

Robson, S.G.. and Giessner, F.W., 1966, Progress report on investigation of the water resources of the north Vandenberg area, Vandenberg A1r Force Base, Santa Barbara County, California: v.s. Geological survey open-file report, $21 \mathrm{p}$. 


\section{Imperial County}

Bransford, J.C., 1942, Imperıal carbon dioxide gas field: California Journal of Mines and Geology, v. 38, chap. 2

Brook, C.A., and Mase, C.W., 1981, The hydrothermal system at the East Brawley KGRA, Imperial Valley, California: Geothermal Resources Council Transactions, v. 5, p. 157-160.

Chen, A.T., and Bennett, M.J., 1982, site characterization for stations 6 and 7, El Centro strong motion array, Imperial $82-1040,40 \mathrm{p}$.

Chen, A.T.F., 1983, A study of selsmic response at stations 6 and 7, El Centro strong motion array, Imperial Valley, California: U.S. Geological Survey, Natıonal Technical Information Service document PB-84 119924 .

Detra, D.E., and Kilburn, J.E., 1985, Analytical results and sample locality map of heavy-mineral-concentrate samples from the Jacumba/In-Ko-Pah Mountalns Wilderness Study Area (CDCA 368), Imperial County, California: v.S. Geological Survey Open-File Report $85-272,13$ p.

Detra, D.E., and Kilburn, J.E., 1985, Analytical results and sample locality map of heavy-mineral-concentrate samples from the Fish Creek Mountains Wilderness Study Area, (CDCA 372), Imperial County, California: U.S. Geologícal Survey Open-File Report 85-524,8 p.

Hardt, W.F., and French, J.J., 1976, Selected data on water wells, geothermal wells, and oll tests in Imperial Valley, California: U.S. Geological Survey open-file

report, 251 P.
Hart, E.W., 1981, Preliminary map of October 1979 fault ruptures, Imperial County, California: California Division of Mines and Geology open-File Report 81-5 SF.

Holmes, J.G., 1903, Soil survey of the Imperial area, Cal ifornia: U.S. Department Agriculture, Soil Conservation Service report, p. 1219-1248, 2 maps.

Imperial Irrigation District, 1958, West Mesa and Coyote a rea well Is, Imp

Imperial Irrigation District, 1966, Imperial Valley salt balance: Imperial Irrigation District.

Kovach R.L., Allen, C.A., and Press, Frank, 1962, Geophysical investigation in the Colorado Delta region: Journal Geophysical Research, v. 67, no. 7, P. 2845-2871.

Kovach, R.L. 1962, Geophysical investigations in the Colorado
Delta region: Pasadena, California Instatute of Technology Ph.D. dissertation, scale approx. $1.2 \mathrm{nch}=1 \mathrm{mxle}$.

Lamanuzz1, v., Johnson, C.E., and German, P.T., 1979, Prel umanary catalog of earthquakes in northern Imperial valley, Callfornia, October 1978-December 1978: U.s. Geological Survey Open-Fale Report 79-930,13 p.

Lamanuzz1, v., and Johnson, C.E., 1979, Prelimanary catalog of earthquakes in northern Imperial valley, California, July 1978-September 1978: U.S. Geological Survey Open-File Report $79-931,14 \mathrm{p}$

Loeltz, O.J., Irelan, Burdge, Robıson, J.H., and olmsted, F.H., 1975, Geohydrologic reconnalssance of the Imperial Valley, California: U.S. Geological Survey Professional

Paper 486-K, 54 p.
Loeltz, O.J., and Leake, S.A., 1979, Relation between proposed developments of water resources and seepage from the All-American Canal, eastern Imperial valley, Calıforna: U.S. Geological Survey Open-File Report 79-744, 60 p.

Loeltz, o.J., and Leake, S.A., 1979, Relation between proposed development of water resources and seepage from the AllGeological Survey open-File Report 79-744, $60 \mathrm{p}$.

Lofgren, B.E., 1978, Measured Crustal Deformation in Imperial Valley, California: U.S. Geological Survey open-file report 78-910, 4 p.

Maley, R.P., and Etheredge, E.C., 1981, Strong-motion data from the Westmorland, California, earthquake of April 26, 1981: u.s. Geological Survey Open-File Report $81-1149,20$ p.

McHugh, E.L., 1985, Mineral resources of the Jacumba Study Area Imperial County. California: U.S. Bureau

McJunkin, R.D., and Ragsdale, J.T., 1980, Compilation of strongmotion records and preliminary data from the Imperal valley (Calif.) earthquake of 15 October 1979: California Division of Mines and Geology Prelimanary Report 26.

Meidav, Tsvi, and Furgerson, R.B., 1971, Electrical resistivity for geothermal exploration in the Imperial valley, in Cooperatıve geological-geophysical-geochemical investigations of geothermal resources in the Imperial Valley (Calif.): Riverside, University of Californa UCR-IGPP Report, p. 43-88.

Morton, P.K.. 1966, Geologle map of Imperıal County, California with gravity contours: California Division of Mines and Geology. Imperial County Report 7.

Morton, P.K., 1972, Geology and mineral resources of Imperial County, Calıfornıa: Californıa Division of Mines and Geology County Report.

Morton, P.K.. 1977, Mines and mineral resources of Imperial County (Calif.): Calıforna Division of Mines and Geology County Report 7.

Mueller, C.S., and Boore, D.M., 1981, Site amplification at El Centro strong motion array station no. 6 (abs.): Earthquake Notes, v. 52 , no. 1 , p. 84 .

Muffler, L.J.P., and white, D.E., 1968, Origin of $\mathrm{CO} 2$ in the Salton' Sea geothermal system, southeastern California. v.S.A., in Genesis of mineral and thermal waters: International Geological Soclety 23d Congress, Prague, Czechoslovakia, August 1968, Proceedings, v. 17, p. $185-194$.

Randall, Walter, 1971, Percent volume of sand bodies in the Imperial valley (preliminary report), in Cooperative geological-geophysical-geochemical investigations of geothermal resources in the Imperial Valley: Riverside,
University of California UCR-IGPP report, p. 119-128.

CATEGORY 4: COUNTIES

\section{Imperial County--Continued}

Randall, Walter, Meidav, Tsvi, Rex, R.W., and Coursey, Leonard, 1968, Electrical resistivity and geochemistry of aquifers in the Durnaval Dome, Imperial valley (abs.): American Geophyscial Union Transactions, v. 49, no. 4, p. 759 .

Rex, R.W., 1968, Geochemical water facies in the Imperial Valley of Callfornla (abs.): American Geophyscial Union Transactions, v. 49 , p. 758 .

Rex, R.W., 1970, Investigation of geothermal resources in the Imperial Valley, California, and their potential value for desalination of water and electucity production: Ruverside, University of California UCR-IGPP Report 92502. $14 \mathrm{p}$.

Rex, R.W., 1971. The waters of the Imperial Valley, in Cooperative geological-geophysical-geochemical investigations of geothermal resources in the Imperial Valley: Riverside, University of California UCR-IGPP report, p. 89-106.

Rex, R.W., 1972 , Origin of the salt of the Imperial valley and surrounding watershed areas, in Cooperative investigation of geothermal resources in the Imperial valley area and their potential value for desalting of water and other purposes: Riverside, University of water and other purposes: Riverside, Univ
California, final report, p. F-1 to $\mathrm{F}-37$.

California, final report, p. F-1 to F-37.
Riney, T.D. Pritchett, J.W., and Rice, L.F., 1982, Integrated model of the shallow and deep hydrothermal systems in the model of the shallow and deep hydrothermal systems in the
East Mesa area, Imperial Valley, California: U.S. Geological East Mesa area, Imperial Valley, Calif
Survey Open-File Report $82-980,118$ p.

Rojahn, Christopher, Ragsdale, J.T., Raggett, J.D., and Gates, J.H., 1980, October 15, 1979, mann-shock strong-motion records from the Meloland Road-Interstate Route 8 overcrossing. Imperial County, Cal ifornia: U.S. Geological Survey Open-File Report 80-1054, 15 p.

Sampson, R.J., and Tucker, W.B., 1942, Mineral resources of Imperial County (Calif.i: California state Mineralogist Report 38, chap. 2, p. 105-145.

Sedgwick, A.E., 1941, Location of major fault zones in the Imperial valley: El Centro, Calif., Imperial Irrigation District.

Setmire, J.G., 1985, Water quality in the New River from Calexico to the Salton Sea, Imperial County, California: U.S. Geological Survey water-Supply Paper 2212, $42 \mathrm{p}$.

Smith, R.S.U., Yeend, W.E., Dohrenwend, J.C., and Gese, D.D., 1985. Mineral resources of the North Al godones Dunes Californa: U.S. Geological Survey Open-File Report 84-630, $13 \mathrm{p}$.

Tarbet, L.A., 1951, Imperial Valley: American Association of Petroleum Geologists Bulletin, v. 35, no. 2, p. $260-263$, fig. 40, scale $1: 750,000$.

Tarbet, L.A., 197i, Petroleum potential of Imperial valley California: American Association of Petroleum Geologists, Memoir 15, v. 1, p. 384-391.

Tarbet, L.A., and Holman, W.H., 1944, Stratigraphy and micropaleontology of the west side of Imperial Valley. California: American Association of Petroleum Geologists Bulletin, v. 28, no. 12, p. 1781-1782.

Tucker, w.B., 1926, Imperial county, Mining in Calufornia California State Mineralogist Report 22, chap. 2, p. 248285 , scale $1: 31,680$.

U.S. Bureau of Reclamation, 1971, Geothermal resource investigations, Imperial Val ley, California: v.S. Bureau
of Reclamation Status Report, 47 p.

U.S. Bureau of Reclamation, 1971, Geothermal resource investigations, Imperial Valley, Californda: U.S. Bureau of Reclamation site location report, deep geothermal test well, $11 \mathrm{p}$.

U.S. Burest 1gations of Reclamation Status Report, 63 .

u.s. Department of Agriculture, Soll Conservation Service, 1952, Ground water Investigations of Imperial County,

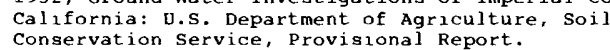

virich, F.P., 1941, The Imperial Valley earthquake of 1940: Bulletin of Selsmological Society of America, v. 31 , p. 13-31, fig. 20, Map showing damage caused by the earthquake of May 18, 1940 , to the canal system in the

Imperial Valley, scale approx. $31 / 3$ inches $=1$ mile.
Youd, T.L., and Wreczorek, G.F., 1984 , Liquefaction during the T.L., and Wreczorek, G.F., 1984 , Liquefaction during the
1981 and previous earthquakes near Westmoreland, Cal ifornia: U.S. Geological Survey Open-File Report $84-680,38 \mathrm{p}$.

\section{Inyo County}

Anderson, G.H., 1937, Granitızatıon, albitizatıon, and related phenomena in the northern Inyo Range of California-Nevada: Geological Society of America
v. 48 , no. 1, p. $1-74$, pl. 11, scale $1: 348,480$.

Bacon. $\mathrm{C}$, no and Drake, R.E., 1982, Age of the Coso Formation, Inyo County, California: U.s. Geological Survey Bulletin 1527. $18 \mathrm{p}$.

Bacon, C.R., Kurasawa, Hajime, Delevaux, M.H., Kistler, R.w., and Doe, B.R., 1984, Lead and strontium isotopic evidence for crustal interaction and compositional zonation in the source regions of pleistocene basaltic and rhyolitic magmas of the Coso volcanic field, Californat Contributions to Mineralogy and Petrology, v. 85, no. 4, p. 366-375.

Bacon, C.R., and Metz, Jenny, 1984 , Magmat 10 inclusions in rhyolites, contaminated basalts, and compositional zonation to Mineralogy and Petrology, v. 85 , no. 4, p. 346-365. 
CATEGORY 4: COUNTIES

\section{Inyo County--Continued}

Bateman, P.C., and Merriam, C.W., 1954, Geology of the Owens Valley region, Inyo County, in Geology of southern California: California Division of Mines Bulletin 170, map sheet 11 , scale $1: 250,000$

Blakely, R.J., and McKee, E.H., 1985, Subsurface structural features of the Saline Range and adjacent regions of eastern California as interpreted from isostatic residual gravity anomalies: Boulder, Colo., Geology, v. 13, no. 11, p. 781785 .

Boyle Engineering Corp., 1975, Report for Inyo County, Owens valley water resources: Inyo, Calif., Boyle Engineering Corp., 106 p., 1 app.

Briggs, O.E., 1920, The relation between the faults and igneous flows of the Sierra Nevada mountains: Palo Alto. Calif., Stanford University, A.M. thesis.

California Department of Water Resources, 1980 , Owens Valley ground water investigation, phase 1: California Department
of water Resources, 33 p.; appendix 3,77 p.: appendix $C$, $145 \mathrm{p}$.

Conrad, J.E., Kilburn, J.E., McKee, E.H., McCarthy, J.H. and willet, S.L., 1985, Mineral resources and resource potential of the wildrose Canyon Wilderness study Area, Inyo County, California: U.S. Geological Survey Open-File Report $84-665,8$ p.

Detra, D.E., Goldfarb, R.J., and weaver, S.C., 1985, Analytical results and sample locality map of stream-sediment and panned-concentrate samples from the slate Range Wilderness
Study Area (CDCA). Inyo County, Cal fornia: U.S. Geological Survey Open-File Report 84-84, 24 p.

Detra, D.E., Kilburn, J.E., and Chazin, B., 1985, Analytical results and sample locality map of stream-sediment and panned-concentrate samples from the Inyo Mountains (CDCA 122). Hunter Mountains (CDCA 123), Panamint (CDCA 127), and Wildrose ( $\mathrm{CDCA} 134$ ) Wilderness Study Areas, Inyo County, California: u.s. Geological Survey Open-File Report 84-11, $58 \mathrm{p}$.

Detra, D.E., Marsh, S.P., and Roemer, T.A., 1985, Analytical results and sample locality map of stream-sediment, heavymineral-concentrate, and rock samples from the Little Sand Spring Wilderness study area (CDCA-119), Inyo County, California: U.s. Geological Survey Open-File Report 85-121, $30 \mathrm{p}$.

Detra, David, Erickson, M.S., Tucker, R.E., Diggles, M.F., and Parduhn, N.L., 1984, Analytical results and sample locality map of stream-sediment and heavy-mineral-concentrate samples from the El Paso Mountains Wilderness Study Area (CDCA 164). Inyo County, California: u.s. Geological Survey Open-File Report 84-571, $13 \mathrm{p}$.

Diggles, M.F., Tucker, R.E., Griscom, Andrew, Causey, J.D., and Gaps, R.S., 1985, Mineral resources of the Owens Peak and Little Lake Canyon Wilderness Study Areas, Inyo and Kern Counties, California: U.S. Geological survey Bulletin $1708-\mathrm{B}, 14 \mathrm{p}$

Duffield, W.A., 1975, Late Cenozolc ring faulting and volcanism in the Coso Range area of California: Geology, v. 3 , no. 6 , p. 335-338.

Duffield, w.A., 1975, Late Cenozorc volcanism and ring faulting in the coso Hot springs area of Californ (abs.): Second United Nations symposium on the development and use of geothermal resources. San Francisco,

California, May 20-29, 1975, v, 2-12.

Duffield, W.A., and Bacon, C.R., 1976, Preliminary geologic map of the Coso rhyolite domes and adjacent areas, Inyo County, California: U.S. Geological Survey open-file report 76-238, scale $1: 50,000$

Duffield, W.A., and Bacon, C.R., 1981, Geologic map of the Coso volcanic field and adjacent areas. Inyo County. California: U.s. Geological Survey Miscellaneous Investigations Map I-1200, scale 1:50,000

Eichelberger, J.C., Lysne, P.C., Miller, C.D., and Younker, L.w. 1985, Research drilling at' Inyo Domes, Cal ifornia; 1984 results: Eos, Transactions, American Geophysical Onion, 66, no. 17 , p. $186-187$.

Elliott, G.S., Chaffee, M.A., and Capstick, D.O., 1983, Mineral resource potential map of the Coyote $S E$ and Table Mountain roadless areas, Inyo County, California: U.s. Geological Survey Misce

Elliott, G.S., and McKee, E.H., 1982, Geologic map of the Coyote SE and Table Mountain Roadless Areas, Inyo County, California: U.S. Geological Survey Miscellaneous Field Studies Map MF-1426-A, scale 1:62,500.

Elliott, G.W., Diggles, M.F., Chaffee, M.A., Fey, D.L., Sutley, S.J., HII1, R.H., and Van Gaalen, G., 1983, Chemica analyses of samples of rock and stream-sediment, and nonmagnetic heavy-mineral concentrate, Coyote-SE, and Table Mountain roadless areas, Inyo County, California: U.S. Geological Survey Open-File Report 82-996, 119 p.

Emerson, D.O., 1958, Granitic rocks of the northern portion of the Inyo batholith: University Park. Pennsylvania state University, Ph.D. dissertation, $6 \mathrm{p}$.

Erickson, M.S., Marsh, S.P., and Roemer, T.A., 1985, Analytical results, geology, and sample locality map of mercury-sulfurgypsum mineralization at Crater, Inyo County, California:
u.s. Geological Survey Open-File Report $85-512,25$ p.

Erickson, M.S., Smith, C.L., Detra, D.E., 1984, Analytica results and sample locality map of stream-sediment, heavymineral-concentrate, and rock samples from the Nopa Mountain (CDCA-150) and Resting Spring (CDCA-145) Wilderness Study Areas. Inyo County. CaI Ifornia: U.S. Geological Survey open-File Report 84-676, 42 p., scale $1: 62,500$.

Gay, T.E., Jr., and wright, L.A., 1954, Geology of the Talc city area, Inyo County, in Geology of southern sheet. 12 , scale $1: 24,000$

\section{Inyo County--Continued}

Hardt, W.F., 1980, Owens Valley ground water investigation, phase 1 , appendix $B$ : Review of hydrologic information for adequacy in developing a water-management plan in the Owens Valley, southern California: California Depart

Healey, D.L., and Miller, C.H. 1965, Gravity survey of the Amargosa Desert area of Nevada and California: Denver

Healy, J.H., 1961, Geophysical studies of the basin structures along the eastern front of the Sierra Nevada: Pasadena, California Institute of Technology. Ph.D. dissertation, $90 \mathrm{p}$.

Healy, J.H., and Press, Frank, 1964, Geophysical studies of basin structures along the eastern front of the sierra

Hopper, R.H., 1939, A geologic section from the Sierra Nevada to Death valley, California: Pasadena, Californa Institute of Technology, Ph.D. dissertation.

Hopper, R.H., 1947, Geologic section from the Sierra Nevada to Death valley, California: Geological Society of America Bulletin, v. 58, p. 393-432; pl. 1, structure section and accompanying geologic map, Sierra Nevada to Death Valley, scale approx. $7 / 8$ inch $=3$ miles.

Hunt, C.B., and Robinson, T.W., 1960, Possible interbasin circulation of ground water in the southern part of the Great Basin: U.s. Geological Survey Professional Paper 400-B, p. 273-274.

Inyo County Planning Commssion, 1974, Geothermal resources development: Inyo county Planning Commission, Title 19, p. 528-1 to 528-24.

Kennedy, G.L., Kilburn, J.E., and Conrad, J.E., 1984, Mineral resources and mineral resource potential of the Panamint Dunes Wilderness Study Area, Inyo County, Californ

Knopf, Adolph, and Kirk, Edwin, 1918, A geological reconnalssance of the Inyo Range and the eastern slope of the southern graphy of the Inyo Range, by Edwin Kirk: U.S. Geological graphy of the Inyo Range, by Edwin K1

Langenheim, V.A.M., Donahoe, J.L., and MCKee, E.H., 1982 Geologic map of the Andrews Mountaln, Mazourka, and paiute roadless areas, Inyo County, Calıfornia: v.s. Geological Survey Miscellaneous Field Studies Map MF-1492-A, scale $1: 62,500$ Lee, C.H., 1912, An intensive study of the water resources
of a part of Owens Valley, California: U.S. Geological Survey Water-Supply Paper 294, $135 \mathrm{p}$.

Lee, W.T., 1906, Geology and water resources of Owens valley, California: U.S. Geological Survey water-supply and Irrigation Paper $181,28 \mathrm{p}$.

Los Angeles Department of Public Service, 1978, Increased pumping of the Owens Valley ground-water basin: Los Angeles Department of Public Service, Draft Environmental Impact Report, 152 p., 8 app.

Los Angeles Department of water and Power, 1973, Ground water quality in the Owens Valley. California: Los Angeles Department of water and Power, 88 p.

Los Angeles, City of, Department of Public Service, 1974, Ground-water quality in the Owens Valley, 1973: Las Angeles Department of Public Service, $88^{\prime} \mathrm{p}$.

Los Angeles, City of, Department of Public Service, 1976 Increased pumping of the Owens Valley ground-water basin: Los Angeles Department of Public Service, Final Environmental Impact Report, v. 2, $125 \mathrm{p}$., app., and technical supplement.

Lustig. L.K., 1969, Trend surface analysis of the Basin and Range Province and some geomorphic implications: U.S. Geological Survey Professional Paper 500-D, $70 \mathrm{p}$.

Mayo, E.B., 1937, Sierra Nevada pluton and crustal movement: Journal of Geology, v. 45, no. 2, p. 169-192; fig. 2 , scale $1: 750,000$, fig. 6, scale 1:875,000 (tecton 1 E.B., 1947, Structure plan of the southern sierra

Mayo, Nevada, California: Geological Society America Bulletin, v. 58, no. 6, p. 495-504, pl. 1, scale $1: 500,000$.

McKee, E.H., Donahoe, J.L., Blakely, R.J., Schmauch, S.W. Lipton, D.A. ' and Gabby, P.N., 1983,' Mineral resource potential map of the Andrews Mountain, Mazourka, and Paiute roadless areas, Inyo County, California: U.s. Geological Survey Miscellaneous Field Studies Map MF-1492-B, scale $1: 62,500$.

McKee, E.H., Kilburn, J.E., McCarthy, J.H., Jr., Conrad, J.E. , Blakely, R.J., and Close, T.J., 1985, Mineral resources the Inyo Mountains wilderness Study Area, Inyo County,

McKee, E.H., and Iverson, S.R., 1982, Mineral resources of the Buttermilk Roadless Area, Inyo County, California: u.s. Geological Survey Open-Eile Report $82-380,12 \mathrm{p}$.

Morgan, J.D., 1979, Lithologic log, lithium content, and mineralogy of sediments in test borıng drilled in Eureka Valley, Inyo County, California: U.S. Geological Survey Open-File Report 79-1089, 8 p.

Noble, L.F., and Wright, L.A., 1957, Geologic reconnalssance maps of parts of Nopah Range, Resting Spring Range, and Funeral Mountains: California Division of Mines, scale $1: 62,500$

Novak, S.W., and Bacon, C.R., 1983, Magma mixing and fractionation recorded in $\mathrm{Pl}$ locene volcanic rocks of the coso Range, California (abs.): Geological Society

Pakiser, L.C., Kane, M.F., and Jackson, W.H., 1964, Structural geology and volcanism of Owens Valley region. California--A geophysical study: U.S. Geological Survey Professional paper 438,68 p. 
CATEGORY 4: COUNTIES

\section{Inyo County--Continued}

Palmer, A.R., and Halley, R.B., 1979, Physical stratigraphy and trilobite biostratigraphy of the Carrara Formation (Lower and Middle Cambrian), southern Great Basin: U.S. Geological

Survey Professional Paper 1047, 131 P.
Russell. I.c., 1887, Notes on the faults of the Great Basin and of the eastern base of the Sierra Nevada: Phil. soc. Washington, Bulletin, v. 9 p. 5-8.

Snyder, C.T., 1964, Well site examnations in the Bakersfield Grazing District lOwens valley area, Inyo

County, 12 sites), California: $5 \mathrm{p}$.
Snyder, C.T., 1965, Examination of two sites for water supply in the Bakersfield Grazing District (Owens valley

area, Inyo County), California: 2 p.
Snyder, C.T., 1966, Examination of one field station site and evaluation of another in the Bakersfield Grazing District (Chimney Meadow, Inyo County), California: $2 \mathrm{p}$.

snyder, C.T., 1967 Revision of a report for a stock well site in the Bakersfield Grazing District (North Lee Flat.

Inyo County), California: 2 p.
Starkey, H.C., and Blackmon, P.D., 1979, Clay mineralogy of pleistocene Lake Tecopa, Inyo County, California: U.S. Geological Survey Professional Paper 1061, 34 p.

starkey, H.C., and Blackmon, P.D., 1984, Sepiolite in pleistocene Lake Tecopa, Inyo County, California, in Singer, Arleh, ed., Palygorskite-sepiolite occurrences, genesis and uses: Amsterdam, Elsevier Sci. Publ..,v. 37, p. 137-147.

Troxel, B.w., 1963-64, Geologic map of northern Death Valley and Eureka Valley area: Calxfornia Division Mines and Geology, mapping for state geologic map, scale $1: 62,500$.

U.s. Geological Survey, 1982, Aeromagnetic map of the Owens Lake area, Cal ifornia: D.S. Geological Survey Open-File Report 82-1081, scale 1:62,500.

waring, C.A., 1917, Geological map of Inyo County, Californa: California Mineral Bureau Map, scale $1: 250,000$.

Whitney, J.D., 1865, Geology of the Sierra Nevada: California Geological Survey, v. 1, p. 456 .

whitney, J.D., 1872, The Owens valley earthquake: Overland Monthly, v. 9, p. 130-140, 266-278.

Walliams, D.E. 1969, Preliminary geohydrologic study of a portion of the Owens valley ground-water reservorr (Calıf.): Socorro, New Mexico Institute of Mining and Technology, Ph.D. dissitation, $194 \mathrm{p}$.

Will lams, D.E., 1970 , Dse of al,uv, al faults in the storuge and retention of groundwater: Groundwater, v. 8 no. 5, p. $2=-29,5$ figs.

williams, P.B., 1978, Changes in the Cwens valley shallow ground-water levels from 1970 to 1978 : Prepared for the Inyo County Board of Supervisors, $50 \mathrm{p}$

Winograd, Amargosa Desert of Nevada and Death valley, Californa: Dniversity of Arizona Department of Geosciences, Ph.D.

dissertation, 170 p.
Wrucke, C.T., Marsh, S.P., Raines, G.L., Werschky, R.s., Blakely R.J., and Hoover, D.B., 1984, Mineral resources and mineral resource potential of the Saline Valley and Lower Saline Wldderness Study Areas, Inyo County, California: 0.S. Geological Survey Open-File Report 84-560,45 p., scale $1: 62,000$.

Wrucke, C.T...Marsh, S.P., and Miller, M.S., 1985, Reevaluation of the mineral resource potential of part of the Little Geological Survey Open-File Report 85-215, 5 p.

wrucke, C.T., werschky, R.S., Raines, G.L., Blakely, R.J., and Hoover, D.B. 1984 , Mineral resources and mineral resource potential of the Little Sand Spring Wilderness Study Area, Inyo County, California: v.s. Geologi

\section{Kern County}

Anderson, F.M., and Hanna, G.D., 1925, Fauna and stratigraphic relations of the Tejon Eocene at the type locality in Kern County, California: California Academy of Science Occasional Papers 11, 249 p., pl. 16, scale $1: 250,000$.

Diggles, M.F., Cox, B.F., Tucker, R.E., and Gaps, R.S., 1985 Mineral resources of the El Paso Mountains Wilderness Study Area, Kern County, California: D.s. Geological Survey Bulletin 1708-C, 12 p.

Dockter, R.D., 1979, Preliminary lithologic and water quality data from test wells on Koehn Dry Lake, Kern County. California: V.S. Geological Survey Open-File Report 79-1348, $19 \mathrm{p}$.

Goodyear, W.A., 1888, Kern County: California Bureau of Mines Report 8, p. 312 .

Kern County Water Agency, 1980, A compilation of peak discharge data on selected streams, Kern County, California, 1958-1979: Bakersfield, Calif., Kern county

Water Agency, 64 p.
Koehler, J.H., 1977, Ground water in the Koehn Lake area, Kern County, California: U.S. Geological Survey WaterResources Investigations report 77-66, $34 \mathrm{p}$.

Kunkel, Fred, and Dutcher, L.C., 1960, Data on water wells in the Willow Springs, Gloster, and Chaffee areas, Kern County, California: California Department of water Resources Bulletin 91-4, 85 p.

Moyle, W.R.. Jr., 1969, Water wells and springs in the Fremont Vailey area, Kern County, California: California

Department of Water Resources Builetin 91-16, 157 p.
Tucker, W.B., and Sampson, R.J., 1933, Gold resources of Kern County: California Journal of Mines and Geology, v
29 , nos. 3-4, g. 271-339, (a) $f$ ig. 2 , scale 1:1,800.

\section{Los Angeles County}

Bennett, M.J., 1985, Subsurface investigation of ground failure at the San Fernando valley Juvenile Hall, Sylmar, California (abs.): Association of Engineering Geologists Annual Meeting, v. 28 , p. 57

Blake, W.P., 1856, General report on the geological collections (made on whipple's reconnalssance near the war Department Explorations and Surveys for Railroad, Mississippi River to Pacific Ocean Reports, v. 3, pt. 4, no. 1,164 p.

Bookman, M. 1978, Legal and Economic aspects of saltwater encroachment into coastal aquifers: Louisiana University, Lo

California Department of water Resources, 1976, Recommended controls of Raymond basin (Calif.) ground water levels by
adjusting pumping patterns: California Department of water Resources Southern District Report.

California Department of Water Resources, 1976, water quality monxtoring in Raymond basin (Calif.): California Department of Water Resources Southern District Report.

california Department of Water Resources, 1977, Results of areawide water quality monitoring program in the Raymond basin District Report.

Calıforna Department of Water Resources, 1978, Nitrates in ground water in the Los Angeles drainage province (Calif.): California Department of water Resources Southern District Report.

California Department of Water Resources, 1979, A ground water storage program for the State water project, San Fernando basin theoretical model: califor

Resources Bulletin 186,88 p.
California Department of Water Resources, 1979, Areawide water quality monitoring program for the Raymond basin (Calif.): California Department. of water Resources Southern District Report.

California Department of Water Resources, 1981, Results of areawide water quality program for the Raymond basin (Calif.), July 1, 1980-June 30, 1981: Californ

California Department of Water Resources, 1982, Results of areawide water quality program for the Raymond basin (Calif.).
July 1, 1981 -June 30 , 1982: California Department of Water Resources Southern District Report.

California Department of Water Resources, 1983, Results of water quality monitoring in Raymond basin (Calif.), July 1, 1982June 30, 1983: California Department of Water Resources Southern District Report.

Campbell, R.H.. Yerkes, R.F., and Wentworth, C.M., 1966, Detachment faults in the central Santa Monica Mountains, California, in Geological Survey Research 1966: U.S. Geological Survey Professional Paper 550-c, p. Cl-cil.

Carpenter, E.J., and Cosby, S.W., 1926, Soil survey of the

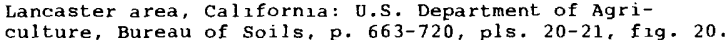

Castle, R.O.. 1960, Surficial geology of the Beverly Hills and Venice quadrangles, California: U.S. Geological Survey open-file report, scale 1:24,000.

Chapman, R.H., Chase, G.W., Saul, R.B., and weber, F.H., Jr., 1980 , Earthquake hazards associated with the verdugo-Eagle Rock and Benedict Canyon fault zones, Los Angeles County, File Report 80-1 LA.

Corbato, C.E., 1960, Gravity investigation of the San Fernando valley, California: Los Angeles, University of California, $\mathrm{Ph}$. D. dissertation.

Corbato, C.E.. 1963, Bouguer gravity anomalies of the San Fernando valley, California: University of California p. 1-32, map 1, scale 1:48,000, and fig. 7, scale 1 inch approx. 5 miles.

Corey, G.L., Litz, M.G., Donnan, W.W., and Blaney, H.F., 1955 Irrigation and water supply investigations, Upper Santa clara Soll Conservation District, Los Angeles County. Calıfornı: U.S. Agriculture Research Service report, $33 \mathrm{p}$.

Cox, B.F., Powell, R.E., Hinkle, M.E., and Lipton, D.A., ig83, Mineral resource potential map of the pleasant valley Roadless Area, Los Angeles County, California: J.S. Geological Survey Miscellaneous Field Studies Map MF-1649-A. scale $1: 62,500$

Durbin, T.J., 1978, Calibration of a mathematical model of the Antelope valley ground-water basin, California: U.s. Geological survey water-Supply Paper 2046, $51 \mathrm{p}$.

Eaton, J.E., 1926, A contribution to the geology of Los Angeles Basin, California: American Association Petroleum Geologists Bulletin, v. 10, no. 8, p. 753-767, (b) fig. scale 1:625,000; reprinted in oil Bulletin, v. 12, p. 970-977.

Evans, J.G., 1982, The Vincent thrust, eastern San Gabriel Mountains, California: U.S. Geological Survey Bulletin 1507 $15 \mathrm{p}$.

Evans, J.R., Anderson, T.P., Manson, M.W., Maud, R.L., Clark, W.B., and Fife, D.L., 1979, Aggregates in the greater Los Angeles area: California Division of Mines and Geology Special Report 139 .

Fumal, T.E., Gibbs, J.F., Roth, E.F., 1983, In-situ measurements of seismic velocity at 22 locations in the Los Angeles. California, region: o.S. Geological Survey Open-File Report $82-833,140 \mathrm{p}$.

Gay, T.E., Jr.., and Hoffman, S.R., 1954, Mines and mineral deposits of Los Angeles County, California: California pl. 4, scale $1: 375,000$. 


\section{CATEGORY 4: COUNTIES}

\section{Los Angeles County--Continued}

Gilmore, T.D., and Elliott, M.R., 1985, Sequentially and alternatively developed heights for two representative bench marks near Palmdale, California, and along the Bill Williams River, Arizona: U.S. Geological Survey Open-File Repor

Grant, U.S., 4th, and Sheppard, W.E., 1939, Some recent changes of elevation in the Los Angeles basin of southern California, and their possible significance: Seismological Soclety of America Bulletin, v. 29, no. 2, p. 299-326.

Gutenberg, Beno, and Buwalda, J.P., 1936, Sersmic reflection profile across Los Angeles Basin (abs.): Geological Society of America Proceedings 1935, p. $327-328$.

Hart, E., Smith, D., and Sm2th, T., 1978, Summary report California fault evaluation program 1977 area--Los Angeles basin region: California D2vision of Mines and Geology OpenFile Report 78-10 SF.

Higgins, C.T., 1982, Reconnasssance of geothermal resources of Los Angeles County, California: California Division of Mines and Geology open-File Report 82-3 SAC.

Higgs, D.V., 1950, Anorthosite and related rocks of the western San Gabriel Mountains, southern California: Los Angeles, University of California, Ph.D. dissertation.

Hill, M.L. 1929. A contribution on the structure of the San Gabriel Mountains: claremont, Calif., Pomona college, M.A. thesis.

Hill, M.L., 1930, Structure of the San Gabriel Mountains north of Los Angeles, California: University of California Department of Geological Science Bulletzn, vo 19 , no. 6 , p. 137-170, pl. 15, scale 1:38,000.

Hill, R.L., Sprotte, E.C., Chapman, R.H., Chase, G.w., Bennett, J.H., Real, C.R., Slade, R.C., Borchardt, G., and weber, F.H., Jr., 1979, Earthquake hazards assoc 2 ated with faults in the greater Los Angeles metropolitan area, Los Angeles county, Caldfornia, including faults in the Santa Monica, Raymond Hills, Verdugo-Eagle Rock, and Benedict Canyon zones: Californua Division of Mines and Geology Open-File Report 79-16 LA.

Holloway, J.N., 1940, Areal geology and contact relations of the basement complex and later sediments, west end of the San Gabriel Mountains, California: Pasadena, California Institute of Technology, M.s. thesis.

Hoots, H.W. 1931, Geology of the eastern part of the Santa Monica Mountains, Los Angeles County, Californa: o.s. Geological Survey Professional Paper 165-C, p. B3-134.

Inderbitzen, A.L., 1960, Geology of part of the Santa Monica Mountains with special reference to the geographical hazards: Los Angeles, University of Southern California, M.A. thesis.

Isaacs, C.M., 1984, Marine petroleum-source and reservorr rocks, Miocene Monterey Formation, Californıa, USA (abs.), in Beijing petroleum geology symposium: China National $0_{11}$ and and Mineral Resources Council.

Kahle, J.E., 2978, Prel iminary fault map, east half of the Quail Lake segment, San Andreas fault zone, Los Angeles County, California: Californ

Kahle, J.E., 1979, Geology and fault activity of the San Andreas fault zone between Quail Lake and Three points segment, Los Angeles County California: California Divisıon of Mınes and Geology Open-File Report $79-3$ LA.

Kahle, J.E., and Barrows, A.G., 1980, Fault activity of the Three Point and Pine Canyon segments, San Andreas fault zone, Los Angeles County, California: California Division of Mines and Geology Open-File Report 80-13 LA.

Kahle, J.E., and Barrows, A.G., 1981, Fault activity of the Three Points and Pine Canyon segments, San Andreas fault zone, Los Angeles County, California: U.S. Geological Survey open-File Report $81-257,44 \mathrm{p}$.

Koehler, J.H., 1966, Data on water wells in the eastern part of the Antelope Valley area, Los Angeles County, aper Resources Bulletin 91-12, 17 p., 6 app.

LaRocque, G.A. . Jr., 1941. Fluctuations of water level in wells in the Los Angeles Basin, California, during five strong earthquakes, 1933-1940: American Geophysical Union Transactions, 2d Annual Meeting, pl. 2, p. 374-386.

Levi, Shaul, Schuitz, D.L., Yeats, R.s., stitt, L.T., and Sarna-Wojcrcki, A.M., 1983, Paleomagnetism of the Saugus Formation, Los angeles County, California (abs.): Geological Society of America, Abstracts with Programs, v. 15, no. 5, p. 391 .

Martin, L., 1952, Some Pliocene foraminifera from a portion of the Los Angeles Basin, Cal ifornia: Cushman 3 and 4 . Foraminifer Research Contribution

MCClelland, E.J., 1963, Aquifer-test compilation for the central coastal region, California: U.s. Geological survey open-file report, 53 p.

McCulloh, T.H., 1957, Simple Bouguer gravity and generalized geologic map of the northwestern part of the Los Angeles basin, Calıfornia: U.S. Geological Survey Geophysical Investigation GP 149, scale 1:48,000. (Map indicates faults and major time-rock units).

MCGill, J.T., 1982, Map showing relationship of historlc to prehistoric landslides, Pacific Palisades area, City of Los Angeles, California: U.S. Geological Survey

MCGill, J.T., 1982, Preliminary geologic map of the Pacific Palisades area, City of Los Angeles, California: U.S. Geological Survey Open-File Report 82-194, 16 p. scale $1: 4,800$.

McLaughlin, R.P., and Waring, C.A., 1914, Petroleum industry of California: California Mining Bureau Bulletin 69 , map folio, 519 .

\section{Los Angeles County--Continued}

Mendenhall, w.C., 1905, Development of underground waters

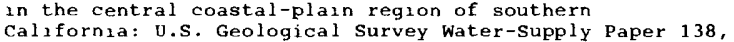

162 p.
Mendenhall, w.c., 1905, Development of underground waters in the western coastal-plain region of southern
California: U.S. Geological Survey water-Supply Paper 139 , $103 \mathrm{p}$.

Miller, W.E., 1971, Pleistocene vertebrates of the Los Angeles basin and vicinity (exclusive of Rancho La Brea) (Calif.): Los Angeles County Museum of Natural History Scrence Bulletin 10, $123 \mathrm{p}$.

Miller, W.J., 1926, Glaciation in the San Gabriel Mountains, California: Journal of Geology, $v, 34$, no. 1 Mountains, California: Journal of

Miller, W.J., 1934, Geology of the western San Gabriel Mountains of California: University of California Publication of Math and

Milne, Clinton, 1968, The hydrologic setting in Los Angeles County, California: Lousiana Water Resources Research Institute Bulletin 3, Loulsiana State University, p. $127-151,8$ figs., 7 tables.

Mrlne, Clinton, and Carrier, D.R., 1966, Report on required facilities for replenishing and protecting groundwater reserves in the central and west coast groundwater basins, part 3: Dominquez Gap Barrier project: Los Angeles County flood Control District, 53 p., 9 figs. 2 tables.

Morton, D.M., and Streitz, R., 1969, Preliminary reconnaissance map of major landslides. San Gabriel Mountains, California: California Division of Mines and Geology Map Sheet 15, scale 1:62,500

Moser, F.C., and Frizzel1, V.A., Jr., 1983, Geologic map of the Lion Canyon, Matılija, Ojai, Wheeler Springs, and white Ledge Peak quadrangles, California: 0.S. Geological Survey Open-E1 le Report 82-818-A, scale 1:50,000.

Peterson, H,V 1942, Runoff conditions in 1940-41 on the south coast basin. Callfornia: American Geophysical union Transactions, v, 22, no. 1, p. 103-108.

poland, J.F., Garrett, A.A., and Sinnott, Ailen, 1947, Appendix to accompany report entitled "Geology, hydrology, and Santa Monica area, Los Angeles County, California: U.S. Santa Monica area, Los Angel
Geological Survey, $115 \mathrm{p}$.

Popenoe, W.P., 1942, Upper Cretaceous formations and faunas of southern California: American Association of
Petroleum Geologists Bulletin, v. 26, no. 2, p. 162-187.

Powell, R.E., Cox, B.F., Matt1, J.C., and Gabby, P.N., 1983 , Mineral resource potentral map of the Arroyo Seco roadiess Mineral resource potent 2 al map of the Arroyo Seco roadless area, Los Angeles County, California: D.S. Geological Surve

Miscellaneous Fleld Studies Map MF-1607-A, sca
Reed, R.D., and Hollister, J.S., 1936, St ructural evolution of southern California: American Association of Petroleum Geologists Bulletin, v. 20, no. 12, p. 1529-1692, (b) pl. 1, scale 1:500,000

Rodda, P.u., 1957, Paleontology and stratigraphy of some marine pleistocene deposits in northwest Los Angeles Geologists Bulletin, v. 41, no. 11, p. 2475-2492.

Rogers, A.M., Borcherdt, R.D., Covington, P.A., and Perkins, D.M., 1984, A comparative ground response study near Los 1971 San Fernando earthquake: Seismological Society of America Bulletin, v. 74, no. 5, p. $1925-1949$.

Rogers, A.M., Tinsley, J.C., and Borcherdt, R.D., 1984, Geographıc variation in ground shaking as a function of changes graphic variation in ground shaking as a function of changes Angeles. California: World Conference on Earthquake Engineering, Proceedings, v. 8, no. 2, p. 737-744.

Savage, J.C., and Guohua, Gu, 1985, The 1979 Palmdale, California, strain event in retrospect: Journal of Geophysical Research, B, v. 90, no. 12, p. 10,301-10,309. son, J.E., 1958, Lithofacies and sedimentary-paleographic analysis of the Los Angeles Repetto basin (Calif.): Los

Stafford, H.M., and Troxell, H.C., 1953, Coastal basins near Los Angeles, California, Subsurface facilitıes of water management and patterns of supply--type area studies: U.S. Congress, House of Representatives, Interior and Insular Affalrs Committee report on the physical and p. $21-50,29$ figs.

Tinsley, J.C., Youd, T.L., and Perkins, D.M., 1983, Evaluation of liquefaction potential in the Los Angeles area, California labs.): Geological Socsety of America, Abstracts with Programs, v. 15 , no. 5 , p. 373 .

with Programs, v. 15, no. 5, p. 373 .
Troxel, B.w., 1954, Los Angeles Basin in Geology of southern California: California Division of Mines Bulletin southern California: California Division of Mines Bul
170 , Geologic Guidebook 3 , maps 1-11, scale $1: 92,000$.

Troxell, H.C., 1954, The influence of ground-water storage on the runoff in southern California: Western Snow on the runoff in southern Californ
Conference, proceedings, p. 33-40.

Troxell, H.C., Poland, J.F., and others, 1951, some aspects of the water supply in the South Coastal Basin, California: U.S. Geological Survey Circular 105, $10 \mathrm{p}$ Troxell, H.C., and Poland, J.F., 1951, Water supply of the
South Coastal Basin, California, answers to 24 questions South Coastal Basin, California, answers to 24 question
by Mr. Richard Queen, staff consultant, Committee on by Mr. Richard Queen, staff consultant, Committee on
Interior and Insular Affairs, House of Representatives: Interior and Insular Affairs, House of Represe
u.s. Geological Survey open-file report, $26 \mathrm{p}$.

Tucker, W.B., 1923, Los Angeles field division: California Mining Bureau, State Mineralogist Report 29, p. 154-173.
B. 1923 , Los Angeles field division: Califor

U.S. Bureau of Reclamation, 1967, Water requirements for Reclamation, Region 2, table 6. 


\section{Los Angeles County--Continued}

Vickery, F.P., 1927, The interpretation of the physiography of the Los Angeles coastal belt (Calif.): American Association vickery, F.P., 1928, Geology of the Los Angeles basin: oil
Bulletin, v. 14, no. 4, p. 355-361.

Walker, A.L., McCulloch, T.H., Petersen, N.F., and Stewart, R.J. 1983 , Discrepancies between anomalously low reflectance of vitrinite and other maturation indicators from an upper Miocene 011 source rock, Los Angeles basin, California (abs.): American Association of Petroleum Geologists Bulletin, v. 67 , no. 3, p. 565 .

Walker, A.L., McCulloh, T.H., Petersen, N.F., and Stewart, R.J., 1983, Anomalously low reflectance of vitrinite, in comparison with other petroleum source rock maturation indices, from the Miocene Modelo Formation in the Los Angeles basin, Californza, in C.M. Isaacs, ed., Petroleum generation and occurrence in the Miocene Monterey Formation, California: Los Angeles, Calif., Society of Economic Paleontologists and Mineralogists, Pacific Section, p. 185-190.

weber, F.H., Jr, 1982, Slope stability and geology of the Division of Mines and Geology specialif.): Cal1for

Weber, F.H., Jr., Chapman, R.H., Chase, G.w., Bennett, J.H., and Saul, R.B.' 1980, Final technical report, fiscal year ig79, earthquake hazards associated with the Verdugo-Eagle Rock and Benedict Canyon fault zones, Los Angeles County, California: California Division of Mines and Geology openFile Report 80-10 LA.

White, R.T., 1952, Cenozoic correlation section across Los Angeles basin from Palos Verdes Hills to San Gabriel Mountains, California: American Association of Petroleum Geologists, Pacific Section, scale 1 inch $=1,000$ feet vertical, $i$ inch $=5,000$ feet horizontal.

wissler, S.G., 1943, Stratigraphic formations (relations) fields: California Division of Mines Bulletin 118 , 209-234.

Woodford, A.O., Schoellhamer, J.E., Vedder, J.G., and Yerkes, R.F., 1954, Geology of the Los Angeles basin: California Division of Mines Bulletin 170 , cha

Woodring. California Coast Ranges: American Journal of Science, $v$. 250 , no. 6 , p. $401-410$.

Ziony, J.I., and Yerkes, R.F., 1984, Fault slip-rate estimation for the Los Angeles region; challenges and opportunities (abs.): Earthquake Notes, v. 55, p. 8.

\section{Mono County}

Alpha, T.R., Balley, R.A., Morley, J.M., 1983, Oblique map of Mono-Inyo craters, California: U.S. Geological Survey OpenFile Report 83-230, 1 map.

Basley, R.A., Harp, E.L., Keefer, D.K., Bennett, M.J., Miller, C.D., Wood, S.H., and Steine, S., 1984, Mono Craters, Long valley Caldera; seismicity, volcanism, and engineerıng geology; field trip 2 roadlog, in Joseph Lintz, ed., Western geological excursions, volume 2: Reno, University of Nevada Department of Geological Sciences, v. 2, p. 36-87.

Bateman, P.C.. 1979, Cross section of the Sierra Nevad. from Madera to the White Mountains, central California Geological Society of America Map and Chart Series MC-28E. 4 p., 2 sheets.

Bateman, P.C., and others, 1963, The Sierra Nevada batholith, a synthesis of recent work across the central part: U.S. Geological Survey Professional Paper 414-D, pl. 1, scale $1: 250,000$

Bennett, M.J., 1982, Subsurface geology at liquefaction sites in Mono county, California (abs.): Geological Society of

Bezo America, Abstracts with Programs, v. 14, no. 4, p. 149. wells and spring conditions in selected areas of Cal ifornia for earthquake precursors: California Division of Mines and Geology Open-File Report 85-12 SAC, $56 \mathrm{p}$.

Boylan, R.T.. 1982, Drill-hole logs and logging procedures for the Mammoth Lakes/Long Valley (Calif.) DOE microearthquake project, December 1981: California Division of Mines and Geology Open-File Report 82-5 SAC.

Bryant, W.A., 1984, Evidence of recent faulting along the Antelope valley fault zone, Mono County, California: California Division of Mines and Geology Open-File Report 85-56 SAC, 1 map, scale 1:48,000. Bryant, W.A. I 1984 , Evidence of recent faulting along the Mono
Lake fault zone, Mono County, California: California Division of Mines and Geology Open-File Report 85-55 sAC 1 map, scale $1: 48,000$

Burkham, D.E., 1978, Sedimentation in Hot Creek in California: U.S. Geological Survey Open-File Report 78-661, $9 \mathrm{p}$.

California Department of Water Reources, 1979 , Report of Interagency Task Force on Mono Lake: California Department of Water Resources report, $140 \mathrm{p}$.

California Department of Water Resources, 1967 Investigation of geothermal waters in the Long valley area, Mono County: California Department Water Resources, $141 \mathrm{p}$.

Castle, R.O., Estrem, J.E., and Savage, J.C., 1984, Uplift across Long Valley Caldera, California: Journal of Geophysical Research, B, v. 89, no. 13, p. 11,507-11,516.

Chaffee, M.A., Bannister, C.A., Bernard, J.B., Gıusso, J.R. Hi11, R.H., Ke1th, w.J., Seitz, J.F., Speckman, W.S., and Sutley, S.J., 1979, Geochemical analyses of samples of rock, stream-sediment, and panned heavy-mineral concentrate, Hoover Wilderness and adjacent study areas, Cal ifornia
U.S. Geological Survey Open-File Report $80-79,41 \mathrm{p}$.
CATEGORY 4: COUNTIES

\section{Mono County--Continued}

Chaffee, M.A., Hill, R.H., and Sutley, S.J., 1983, Geochemrcal element maps of the Hoover W2lderness and adjacent study area, Mono and Tuolume Counties, California: U.S. Geological Survey Open-File Report 82-283, 13 p.

chaffee, M.A.. Hill, R.H., and Sutley, S.J., 1984, Summary geochem 2 cal maps, Hoover Wilderness and adjacent study Geological Survey Miscellaneous Field Investigations Map MF-1101-B, scale 1:62,500.

Christensen, M.N.. Gilbert, C.M., Layoie, K.R., and Al-Rawi, Y. 1969, Geological-geophysical interpretation of Mono basin, california-Neva $5221-5239$.

Cleveland, J.M., Rees, T.F., and Nash, K.L., 1983, Plutonium speciation in water from Mono Lake, California: Science, v. 222, no. 4630, p. 1323-1325.

Cramer, C.H., Stierman, D.J., and Lee, T.C., 1985, A detailed microearthquake survey of Long Valley, California, known geothermal area, July-september 1981: California Division of Mines and Geology Open-File Report 84-53 SAC.

Dalrymple, G.B., and Lanphere, M.A., 1974, Preliminary potassium-argon age data on volicanic rocks of Long valley caldera and vicinity, Mono county, California: U.S. Geological Survey open-file report, scale 1:65,000.

Deemer, S., Humphreys, M.C., Johnson, R.A., Smithson, S.B.. Eilsworth, W.L., and Hill, D.P., 1985, Structure of the long valley Caldera interpreted from seismic reflection data (abs.): Eos, Transact 10

Denlenger, R.P.. Boling, J.K., Carpenter, M.C., and Riley, F.S. 1985, Horizontal distance measurements within Long Valley Caldera, eastern California, from 1978 to 1983; U.S. Geological Survey Open-File Report 85-433, 21 p.

Denlinger, R.P., and Riley, Francis, 1984 , Deformation of Long valley Caldera, Mono County, California, from 1975 to 1982 Journat 8314

Donahoe, M.A., Chaffee, M.A., Fey, D.L., Hill, R.H., and sutley, S.J., 1982, Geochemical map showing anomalous drainage basins, Benton Range Further Planning (RARE II) Area, Mono County, California: U.S. Geological Survey Miscellaneous Field Studies Map MF-1317-B, scale 1:62,500.

Donahue, J.L., McKee, E.H., Rains, R.L., Barnes, D.J., Campbell, H.W... Denton, D.K., Jr., Iverson, S.R., Jeske, R.E., and Stebbins, S.A., 1983, Mineral resource potential map of the Range roadless area, Mono County, California: U.S. Geological Survey Miscellaneous Field studies Map MF-1317-C, 7 p., scale $1: 62,500$.

Dunn, J.R., 1951, Geology of the western Mono Lake area: Berkeley, University of Californıa, Ph.D. dissertation, scale $1: 62,000$

Dzurisin, Daniel, Cashman, Katherine, Johnston, D.A, and Sylvester, A.G., 1983, Tilt measurements at Long Valley Caldera, Cal ifornia, May-August 1982: v.s. Geological Survey Open-File Report 82-893, 34 p.

Eakle, A.S., and Mclaughiı, R.P., 1919, Mono County: California Mining Bureau, State Mineralogist Report scale $1: 220,000$; (b) pl. 4, scale $1: 31,680$.

Farrar, C.D., Sorey, M.L., Rojstaczer, S.A., Janık, C.J.. HydroMariner, R.H., Winnett, T.L., and Clark, M.D., 1985, Hydrologic and geochemical monitoring in Long Valley Caldera,
Mono County, California, 1982-1984: U.S. Geological Survey Water-Resources Investigations Report 85-4183, $137 \mathrm{p}$.

Fuma 1, T.E., Warrick, R.E., Etheredge, E.C., and Archuleta, R.J., 1985, Downhole geology, seismic velocity structure and instrumentation at the McGee Creek, California, recording

site (abs.): Earthquake Notes, v. 55 , no. 1, p. 5 .
Gilbert, C.M., 1938, The Cenozolc geology of the region southeast of Mono Lake, California: Berkeley, University of California, Ph.D. dissertation.

Harp, E.L., Sarmiento, John, and Cranswick, Edward, 1984 Seismic-induced pore-water pressure records from the Mammoth Lakes, California, earthquake sequence of May 25-27, 1980 (abs.): Earthquake Notes, v. 55, p. 26.

Harp, E.L., Tanaka, Kohe1, Sarmiento, J., and Keefer, D.K., 1984, Landsildes from the May 25-27, 1980, Mammoth Lakes, California, earthquake sequence: U.S. Geological Survey Miscellaneous Investigations Series Map I-1612, scale $1: 62,500$.

Hendersen, J.R., and White, B.L., 1963, Aeromagnetic map of Long Valley and northern Owens Valley, California: U.s. scale $1: 62,500$

Hil1, D.P., McHugh, S., and Pakiser, L.C., 1973, structure of the Long Valley caldera from detalled seismic1211 .

Hinkle, M.E., and Kilburn, J.E., 1980, Survey of helium soil gases of Long Valley, California: U.S. Geological Surve Open-Eile Report $80-612,21 \mathrm{p}$.

Hoover, D.B., Frischknecht, F.C., and Tippens, C.L., 1973, Audio-magnetotelluric sounding as a reconnaissance exploration technique in Long valley, California (abs.): EOS, v. 54, no. 11 , p. 1212 .

Hoover, D.B., Erischknecht, F.C., and Tippens, C.L., 1974, Evaluation of audio-magnetotelluric techniques as a reconnaissance exploration tool in Long Valley, Mono and Inyo County, California: U.S. Geological Survey open-file report, $38 \mathrm{p}$.

Johnson, R.F., 1951 , Geology of the Masonic mining district, Mono County, California: Berkeley, University of California, M.A. thesis, scale $1: 31,680$.

Julian, B.R.. 1983, Evidence for dyke intrusion earthquake mechanisms near Long Valley Caldera, Cali fornia: London, 
CATEGORY 4: COUNTIES

\section{Mono County--Continued}

KeIth, W.J. and Seitz, J.F., 1981, Geologic map of the Hoover Wilderness and adjacent study area, Mono and
Tuolumne Counties, California: U.S. Geological Survey Miscellaneous Field Studies Map MF-1101-A, scale $1: 62,500$

Mavko, G.M., and Harp, E.L., 1984, Analysis of wave-induced pore pressure changes recorded during the 1980 Mammoth Lakes, california, earthquake sequence: Seismological Society of America Bulletin, v. 74, no. 4, p. 1394-1407.

McGee, K.A., Casadevall, T.J.., Sato, M., Sutton, A.J., and Clark, M.D. 1982, Hydrogen gas monitoring at Long Valley Caldera, $12 \mathrm{P}$.

McKee, E.H., Diggles, M.F., Donahoe, J.L., and Elllot, G.S., 1982, Geologic map of the White Mountains Wilderness and Roadiess Areas, California and Nevada: U.S. Geological Survey Miscellaneous Field Studies Map MF-1361-A, scale $1: 62,500$.

McKee, E.H., and Donahoe, J.L., 1981, Geologlc map of the Benton Range further planning (Rare II) area, Mono County. California: v.s. Geological Survey Miscellaneous Field Studies Map MF-1317-A, scale 1:62,500.

McMechan, G.A.. Luetgert, J.H., and Mooney, W.D., 1985, Imaging of earthquake sources in Long Valley Caldera, California, 1983: Selsmologica

Meador, P.J., and Hill, D.P., 1983, Data report for the August 1982 seismic-refraction experiment in the Mono Craters-Long Valley region. California: U.S. Geological Survey Open-File Report 83-708, scale 1:250,000.

Mlller, C.D., Mullineaux, D.R., Crandell, D.R., and Balley, R.A. 1982 , Potential hazards from future volcanic eruptions in the Long Valley-Mono Lake area, east-central Callfornia and southwest Nevada; a prelimi

Moslem, Heaton, T.H., 1983, Accelerograms from the Mammoth Lakes, California, earthquake sequence of May-July, 1980, recorded

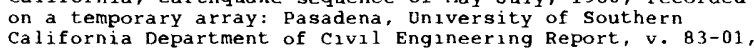
$64 \mathrm{p}$.

Pakiser, L.C., Press, Frank, and Kane, M.F., 1960, Geophysical investigation of Mono Basin, Californa: Geological Society of America Bulletin, v. 71, p. 415-48.

Rundle, J.B., Ellsworth, W.L., Malin, P., McEvilly, T.. Smithson, S.B., and Henyey, T., 1985, Seismic lmaging in Long Valley, California (abs.): Eos, Transactions, American Geophysical union, v. 66 , no. 18, p. 301.

Russell, I.C., 1889, Quaternary history of Mono Valley, California, compiled by Powell, J.w.: U.S. Geological Survey Annual Report 8, 1886-87, p. 281-394.

Russel 1, I.C., 1984, Quaternary history of the Mono valley, California: Lee Vinning, Calif., Artemisia Press, reprinted from U.s. Geological Survey Annual Report 8 .

Sarmiento, John, and Cranswick, Edward, 1984, Seismic-1nduced pore-water pressure records from the Mammoth Lakes,

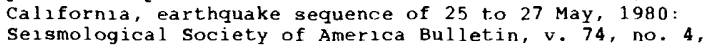
p. $1381-1393$.

Savage. J.C. Lisowski, M., Estrem, J.E., and Castle, R.o., 1985, Deformation of Long Valley Caldera, eastern California,
1983-1984: U.S. Geological Survey Open-File Report 85-41, 16 p. Like inflation: Journal of Geophysical Research, $B, v$, 89 , no. 10 , p. 8315-8324.

Seitz, J.F., 1983, Geologic map of the Tioga Lake, Hall Natural Area, Log Cabin-Saddlebag and Horse Meadow Roadless Areas, Mono County, California: U.s. Geological Survey Miscellaneous Field Studies Map MF-1453-A.

Setmire, J.G., 1984, Water-quality apprasal, Mammoth Creek and Hot Creek, Mono County, California: U.S. Geological Survey Water-Resources Investigations Report 84-4060, $50 \mathrm{p}$.

Sherburne, R.W., 1980, Mammoth Lakes (Calif.) earthquakes of May 1980: California Division of Mines and Geology Special Report 150 .

Sietz, J.F., Chaffee, M.A., olıver, H.W., Federspiel, F.E., Scott, D.F., Cather, E.E., Zilka, N.T., and Leszcykowski, A.M., 1983, Mineral resource potential map of the Tioga Lake-Hall natural area, Log Cabin-Saddlebag, and Horse Meadows roadless areas, Mono County, Cal ifornia: U.S.
Geological Survey Miscellaneous Field Studies Map MF-1453-B Geological Survey Miscellaneous Field Studies Map

scale $1: 62,500$.
Snyder, C.T., 1961, Proposed well site in Bakersfield Grazing District $\mathrm{C}^{-1}$ (Mono Lake area, Mono County), california: 1 p.

Sorey, M.L., and Clark, M.D., 1981, changes in the discharge characteristics of thermal springs and fumaroles in the Long valley caldera, California, resulting from earthquakes on May 25-27, 1980: U.S. Geological Survey Open-File Report $81-203,25 \mathrm{p}$

Turpen, C.D., 1980 , strong-motion records from the Mammoth Lakes (Calif.) earthquakes of May 1980; California Division of Mines and Geology Preliminary Report 27.

v.s. Geological Survey, 1982, Total field aeromagnet $1 \mathrm{c}$ anomaly map, Long Valley Known Geothermal Resource Area, California: v.s. Geological Survey Open-File Report 81-994, scale $1: 24,000$.

U.s. Geological survey, 1984, USGS response plan for volcanic hazards in the Long Valiey Caldera-Mono Craters area, California: U.S. Geological Survey Open-File Report 84-500, $14 \mathrm{p}$.

wood, S.H., 1984, Chronology of late Pleistocene and Holocene volcanics, Long Valley and Mono Basin geothermal areas, eastern California: U.S. Geological Survey Open-File Report

\section{Monterey County}

Alpha, T.R., Dingler, J.R., Jones, D.R., Molzan, D.E., Peterson, C.D., and Morley, J.M., 1981, Physiographic diagram of the upper Carmel Canyon and Point Lobos, California: U.S.

Geological Survey Open-File Report $81-440,1$ sheet.
Bakun, W.H., and Lindh, A.G., 1985, The Parkfield, California, earthquake prediction experiment: Science, v. 229, no. 4714 p. $619-624$.

Bakun, W.H., and Lindh, A.G., 1985, The Parkfield, California, prediction experiment: Earthquake Prediction Research, v. 3, no. $3-4, p .285-304$

Bufe, c.G., 1985, Possible solar influence on repeat times of Parkfield, Californıa, earthquakes (abs.): Earthquake Notes, v. 55 , no. 1, p. 16 .

Davis, C.H., 1912, The geology of the Santa Lucia Mountains, California: Palo Alto, Calif., Stanford University, M.A. thesis.

Durbın, T.J., Kapple, G.W., and Ereckleton, J.R., 1979, Twodimensional and three-dimensional digital flow models for the Salinas valley ground-water basin, California: U.S. Geological Survey Water Resources Investigations Report $78-113,134 \mathrm{p}$ Durham, D.L.' 1974 , Geology of the southern Salınas Valley
area, Calıfornia: v.S. Geological Survey Professional Paper 819, $111 \mathrm{p}$.

English, W.A., 1918, Geology and o1l prospects of the Salinas Valley-Parkfield area, Calıfornia: D.S. Geological Survey Bulletin 691, p. 219-250; (a) pl. 27, scale 1:125,000; (b) pl. 28, scale 1:62,500; (c) fig. 36 , scale $1: 62,500$.

Galliher, E.W., 1930, A study of the Monterey Formation, california, at the type locality: Palo Alto, calif. Stanford University, M.A. thesis.

Hill, G.W., and chin, J.L., 1983, Seismic reflection profiles, south-central Monterey (Calif.): v.s. Geological Survey Open-File Report $82-824,3$ sheets.

Irwin, G.A., 1976, Water-quality investigation, Salinas River, California: U.s. Geological Survey Water Resources Investigations Report 76-110, $47 \mathrm{p}$.

Johnson, M.J., 1983, Ground water in north Monterey County, California, 1980 : v.s. Geological Surve water-Resources Investigations Report 83-4023, 37 p., 3 maps, scale $1: 24,000$.

Kapple, G.W., Mitten, H.T., Durbin, T.J., and Johnson, M.J., 1984, Analysis of the Carmel valley alluvial ground-water basin, California: U.S. Geological Survey Water-Resources Investigations Report 83-4280, $45 \mathrm{p}$.

Keller, M.A., and Isaacs, C.M., 1985, An evaluation of temperature scales for silica diagenesis in diatomaceous sequences including a new approach based or. the Miocene Monterey p. $31-35$.

Kilbourne, R., and Mualchin, L., 1980, Geology for planning: Marina and Salinas $71 / 2$ minute quadra County, California: California Division of Mines and Geology Open-File Report 80-7 SF.

K1lkenny, J.E., 1948, Geology and exploration for oil in salinas Valley, Californa: American Association of Petroleum Geologists Bulletin, v. 32, no. 12, p. 2254-2268, fig. 1 scale $1: 500,000$.

Louderback, G.D., 1899, on the origin of the glaucophane and associated schists of the coast Ranges (Calif.), a contri-

bution to the theory of crystalline schists: Berkeley,
university of California, Ph.D. dissertation.

Majmundar, H.H., 1981, Distribution of heavy elements hazardous to health, Salinas valley region: Calıfornia Division of Mines and Geology Special Report 138.

Moore, c.v., 1969, Some legal and economic 1mplications of sea water intrusion--A case study of ground water management: Natural Resource

Ross, D.C., 1976, Reconnaissance geologic map of the pre-Cenozoic basement rocks, northern Santa Lucia Range, Monterey County, California: v.s. Geological Survey Miscellaneous Field Studies Map MF-750, scale $1: 125,000$.

Seiders, V.M., Esparza, L.E., Sabine, Charles, Spear, J.M., Stebbins, Scott, and Benham, J.R., 1983, Mineral resource potential map of part of the Ventana wilderness and the Black Butte, Bear Mountain, and Bear Canyon roadless areas, Monterey County, California: U.S. Geological Survey
Miscellaneous Field Studies Map MF-1559-A, scale 1:50,000.

Miscellaneous Fleld Studies Map MF-1559-A, scale 1:50,000.
Selders, V.M., Joyce, J.M., Leverett, K.A., and McLean, Hugh, 1983 , Geologic map of part of the Ventana Wilderness and the Black Butte, Bear Mountain, and Bear Canyon roadless areas, Monterey County, California: U.S. Geological Survey Miscellaneous Field Studies Map MF-1559-B, scale 1:50,000.

showalter, Patricia, Akers, J.P., and Swain, L.A., 1984, Design of a ground-water-quality monitoring network for Salinas River drainage basin. California: U.S. Geological Survey water-Resources Investigations Report 83-4049, $74 \mathrm{p}$.

Stinson, M.C., 1981, Mineral land classification of Granite Rock Company limestone deposits in the Plco Blanco area,
Monterey County, California: California Division of Mines and Geology Open-File Report 81-14 SF.

Taliaferro, N.L., 1944, Cretaceous and Paleocene of Santa Lucia Range, California: American Association of Petroleum Geologists Bulletin, v. 28 , no. 4, p. 449-521; (a) fig. 5, scale $1: 62,500$, (b) fig. 9, scale $1: 93,750$.

Younse, G.A., 1980, The stratigraphy and phosphoritıc rocks of the Robinson Canyon-Laureles Grade area, Monterey County, Cal 140 for 


\section{Orange County}

Boon, R.H., and Stephenson, R.E., 1959, Orange County land and water use survey, 1957: California Department water Resources Bullet in 70, 57 p., app.

Bowers, S., 1890, Orange County: California Mining Bureau, State Mineralogist Annual Report 19, p. 399-409.

Brown and Caldwell, 1968, Irvine Ranch sewage survey, phases 1, 2, 3, and 4: Alhambra, Calif.., Brown and Caldwell, report prepared for the Irvine Ranch water District, $161 \mathrm{p}$.

California Department of water Resources, 1959, Orange County land and water use survey, 1957: California Department of water Resources Bulletin 70, 57 p., app.

California Department of water Rescurces, 1967, Orange County land and water use survey, 1964: Calıfornia

Department of water Resources Bulletin 70-64,70 p. fornia Department of Water Resources, 1967, Progress
report on the ground water geology of the Coastal plain of Orange County (Calif.): California Department of water Resources, $138 \mathrm{p}$.

California Department of water Resources, 1967, Progress report on water quality prediction procedure for the Coastal plain of orange County (Calıf.): Calıfornia Department of water Resources, $49 \mathrm{p}$.

California Department of Water Resources, 1968, Sea-water intrusion: Bolsa-Sunset area, Orange county: California Department of water Resources Bulletin 63-2, 167 p.

Corby, G.W., 1922, The geology and paleontology of the San Joaquin and Niguel Hills, Orange County, California: Palo Alto, Calif., Stanford University, M.A. thesis, 69 p., 19 pls., scale 1:62,500

Cordes, E.H., Wall, J.R., and Moreland, J.A., 1966, Progress report on analog model construction, orange County, California: U.S. Geological Survey open-file

report, 16 p., app.
Daviess, S.N., and Bramlette, M.N., 1953, Clay deposits of the Tierra Colorado District, southern Orange County California: U.S. Geological Survey open-file report, scale $1: 24,000$

Dickerson, R.E., 19i4, The Martinez and Tejon Eocene and associated formations of the Santa Ana Mountains: University of California Department of Geological Science Bulletin, v. 8, p. 257-274, pl. 26, scale 1:125,000.

Dolton, G.L., 1952, Geology of the southwest portion of the San' Joaquin Hills, Orange County, California: claremont, Calif., Pomona college, M.A. thesis.

Duggan, M.D., 1961, Geology of a part of the San Joaquin Hills, Orange County, Callfornia: Los Angeles, University

of California, M.A. thesis, 81 p., 7 pls., scale $1: 15,600$.
Goodyear, W.A., 1888, Los Angeles County (Orange): California Mining Bureau, State Mineralogist Annual Report 8, p. $335-$ 342 .

Hardt, W.F., and Cordes, E.H., 1971, Analys is of ground-water system in Orange County, California, by use of an electrical analog model: o.s. Geological Survey open-file report, $60 \mathrm{p}$.

Hoskins, C.w., 1954, Geology and paleontology of Coyote Hilis, Orange County, California: Claremont, Calif., Pomona College, M.A. thesis.

Kapustka, S.F., 1965, water pollution, prevention and corrective measures: U.S. Geological Survey open-file

report, $15 \mathrm{p}$.
Moreland, J.A., and Singer, J.A., 1969, Evaluation of
water-qual ity monitoring in the Orange County wate water-quality monitoring in the orange county water District, California: D.s. Geological Survey open-file report. $27 \mathrm{p}$.

Morton, P.K., Milier, R.V., and Evans, J., 1979, Environmental geology of orange County, California: California Division of Mines and Geology Open-File Report 79-8 LA

Morton, P.K., Miller, R.V., and Fife, D.L., 1973, Geo-environmental maps of orange County, California: California Division of Mines and Geology Preliminary Report 15,4 maps.

Morton, P.K., and Miller, R.V., 1981, Geologic map of Orange County, California, showing mines and mineral deposits: California Division of Mines and Geology Bulletin $204,1 \mathrm{pl}$.

orange County Flood Control District, 1970, Annual hydrology report, 1969-70 season: Orange County, Calif., Flood Control District, v. 6, $145 \mathrm{p}$.

orange county water District, 1972 , Engineer's report on ground-water conditions, water supply, and basin utilization in the Orange County water District: Orange County, Calif., Water District, $80 \mathrm{p}$.

Owen, L.W., 1968, The challenge of water management: orange county Water District, California: Louisiana water Resources Institute Bulletin 3, p. 105-125, 5 figs., 2 tables.

Post, W.S., 1928, Santa Ana investigation: Calıfornia Department of Public Works, Division of Engineering and Irrigation Bulletin 19, $357 \mathrm{p}$.

Sherburne, R.W., Fuller, D.R., Cole, J.W., Greenwood, R.B. Mumm, H.A., and Real, C.R., 1981, Classification and mapping of Quaternary sedimentary deposits for purposes of seismic
zonation, south coastal Los Angeles basin, Orange county. zonation, south coastal Los Angeles basin, Orange County,
California: California Division of Mines and Geology OpenCalifornia: California Division

silberling, N.J., Schoellhamer, J.E., Gray, C.H., Jr., and Imlay, R.W., 1961, Upper Jurassic fossils from the Bedford Canyon Formation, southern California: American Association of Petroleum Geologists Bulletin, v. 45, no. 10 , p. $1746-1748$.

Singer, J.A., 1972, Ground water in the Tustin Plain, orange County, California, in Geologic guidebook to the northern peninsular ranges, Orange and Riverside counties, Cal ifornia: National Association Geology Teachers and South Coast Geological Society, p. 92-96.

\section{Orange County--Continued}

Singer, J.A., 1973, Geohydrology and artificial recharge potential of the Irvine area, Orange County, California:

U.S. Geological Survey open-file report, $41 \mathrm{p}$.
Smith, R.D., 1971, Orange County land and water use survey 1970: Calıfornı Department water Resources report, $30 \mathrm{p}$.

sprotte, E.C., Fuller, D.R., and others, 1980, Classification and mapping of Quaternary sedimentary deposits for purposes of seismic zonation, southern coastal Los Angeles basin, Orange
County, California: California Division of Mines and Geology

Open-File Report 80-19 LA.
Sullwold, H.H., 1940, Geology of a portion of the San Joaquin Hills, Orange County, California: Los Angeles, University of California, M.A. thesis.

Tan, S.S., Miller, R.V., and Evans, J.R., 1984, Environmental geology of parts of the La Habra, Yorba Linda, and Prado Dam quadrangles, Orange County, California: California Division of Mines and Geology Open-File Report 84-24 LA.

Tan, S.S., and weber, F.H., Jr., 1984, Inventory and analysis of recent damaging slope failures and debris flooding. southern Orange County, Calıfornia: California Division of Mines and Geology Open-File Report 84-27 LA.

Vedder, J.G., Yerkes, R.F., and Schoellhamer, J.E., 1957 Geologic map of the San Joaquin Hills-San Juan Capistrano area, Orange County, California: U.S. Geological Survey

wall, J.R., and Dutcher, L.C., 1965, Progress report on water studies in the Orange County Coastal Area,

Woodring, w.P., and Popenoe, w.P., 1945. Paleocene and Eocene stratıgraphy of northwestern Santa Ana Mountains, orange County, California: U.S. Geological Survey Oil and Gas Investigations Preliminary chart 12.

\section{Riverside County}

Adrian, B.M., Day, G.W., and watts, K.C., 1985, Analytical results and sample locality map of stream-sediment and heavy-mineral-concentrate samples from the Chuckwalla Mountains Wilderness Study Area (CDCA-348), Riverside County, Calıfornı: U.S. Geological Survey Open-File Report $85-293,35 \mathrm{p}$.

California Department of water Resources, 1975, Riverside County flood hazard investigation--Murrieta Creek (Calif.): California Department of water Resources Bulletin 183-2, $26 \mathrm{P}$.

California Department of Water Resources, 1979, Ground water quality conditions in Menifee, winchester, and South Perris subareas (Calıf.): California Department of Water Resources Southern District Report.

Cox, B.F., Matti, J.C., Olıver, H.W., and Conyac, M.D., 1983, Mineral resource potential map of the San Jacinto Wilderness, Riverside County, Cal ifornia: v.S. Geologica Survey Miscellaneous Field Studies Map MF-1159-B, scale $1: 62,500$.

Cox, B.F., Mattı, J.C., olıver, H.W., and Conyac, M.D., 1983. Mineral resource potential map of the San Jacinto Wilderness, Riverside County, California: U.S. Geological Survey Miscellaneous Field Studies Map MF-1159-B, scale $1: 62,500$.

Day, G.W., Adrian, B.M.., whittıngton, C.L., and Tompkins, M.L., 1985, Analytical results and sample locality map of stream sediment and heavy-mineral-concentrate samples from the Eagle Mountains Wilderness Study Area (CDCA-334), Riverside
County. California: U.S. Geological Survey Open-File Report

Detra, D.E., Light, T.D., Meier, A.L., and Smaglik, S.M., 1984 , Analytical results and sample locality map of streamsediment, heavy-mineral-concentrate, and rock samples from the Palen-McCoy Wilderness study area (CDCA 325), Riverside County, California: U.S. Geological Survey Open-File Report 84-492, 26 p., scale $1: 62,500$.

Free, E.E., 1914, Sketch of the geology and sorls of the Coachella Basin: Carnegre Institute, Washington publication 193, p. 21-33.

Grauch, V.J., 1984, Aeromagnetic map of the Eagle Mountains area, Riverside County, California: U.S. Geological Survey OpenFile Report 84-502, scale 1:62,500.

Hamilton, Warren, 1984 , Generalized geologic map of the Big Maria Mountains region, northeastern Riverside County, southeastern California: 0.S. Geological Survey Open-file Report 84-407, 8 p., scale $1: 48,000$.

Holmes, J.G., and party, 1904, Soll survey of the Indro area, California: U.S. Department of Agriculture, Bureau of Soils, Report 5, p. 1249-1262, maps 75 and 76.

Hoover, D.B., Broker, Michael, and Stambaugh, T., 1981, E-field ratio telluric survey near the Big Maria Mountains, Riverside County, California: 0.S. Geological Survey openFile Report 81-961, 15 p.

Huberty, M.R., P1llsbury, A.F., and Sokoloff, V.P., 1948, Hydrologic studies in Coachella Valley, California: University of California Agricultural Experiment station,

$31 \mathrm{p}$.
Jones and Stokes Associates, Inc., 1973, Final environmental impact report on utilizing Colorado River water to recharge upper Coachella valley groundwater basin (Calif.): $145 \mathrm{p}$.

Kennedy, M.P., 1977, Recency and character of faulting along the Elsinore fault zone in southern Riverside County (Calif.):
California Division of Mines and Geology Special Report 131.

California Division of Mines and Geology Special Report
Knecht, A.A., 1971, Soil survey of western Riverside area, California: U.s. Departments of Agriculture and Interior, U.S. Bureau of Indian Affairs, and University of California Agricultural Experiment Station.

Kocher, A.E., and Harper, W.G., 1927, soil survey of the Coachelia Valley area, California: U.s. Department of Agriculture, p. 485-535. 


\section{CATEGORY 4: COUNTIES}

\section{Riverside County --Continued}

Kunkel, Fred, 1956, A brief hydrologic and geologic reconnaissance of Pinto Basin, Joshua Tree National Monument, Riverside County, California: U.S. Geological Survey open-file report, $35 \mathrm{p}$.

Lang, D.J., 1979, Water-resources data, 1970-75, for Perris valley and vicinity, Riverside county, California: U.S. Geologlcal Survey Open-File Report 79-1256, 144 p.

Mallory, M.J.. Swain, L.A., and Tyley, S.J., 1980. Potential for using the Upper Coachella valley ground-water basin, California, for storage of artifically recharged water: 0.s. Geological Survey open-file report $80-599,26 \mathrm{p}$.

Matti, J.C., Cox, B.F., Powell, R.E., Oliver, H.W., and Kulzon, Lucia, 1983, Mineral resource potential map of the Cactus Spring roadless area, Rivergide County, Callfornia: D.S. Geological Survey Miscellaneous Field Studies Map MF-1650-A, scale $1: 24,000$.

Mendenhal1, W.C., 1909, Ground waters of the Indio region, California, with a sketch of the Colorado Desert: o.s. Geological Survey water-Supply Paper $225,56 \mathrm{p}$.

Miller, W.J., 1944, Geology of the Palm springs-Blythe strip, Riverside County, California: Californla Journal of Mines and Geology, v. 40, p. 11-72.

Mortensen, C.E., and Myren, G.D., 1981, Short-term tilt events near Anza, California (abs.): Earthquake Notes, v. 52, no. 1, p. 24.

Morton, D.M., Matti, J.C., and Cox, B.F., 1981, Geologic map of the San Jacinto Wilderness, Riverside County, California o.s. Geological Survey Miscellaneous Field Studies Map MF-1159-A, scale $1: 62,500$.

Powel1, R.E., Watts, K.C., and Lane, M.E., 1985, Mineral resource potential of the Chuckwalla Mountains Wilderness study Area (CDCA-348), Riverside County, California: 0.S. Geological Survey Open-File Report 84-674, 25 p.

Powell, R.E., Whittington, C.L., Grauch, v.J.s., and Mccolly, R.A., 1985, Mineral resource potential of the Eagle MounCalifornia: D.S. Geological Survey Open-File Report 84-6.31, $25 \mathrm{p}$.

Sonderegger, A.L., 1921, Coachella valley county water District report on water supply of coachella Valley: Los Angeles, Calif., Coachella valley County water District, $33 \mathrm{p}$.

Stone, Paul, Light, T.D., Grauch, V.J.s., Yeend, W.E., and Schreiner, R.A., 1985 , Mineral resources of the PalenMcCoy WiIderness Study Area, Riverside County, California: U.S. Geological Survey Bulletin 1710-A, $15 \mathrm{p}$.

Tucker, W.B., and Sampson, R.J, 1945, Mineral resources of Riverside County: California Division of Mines Report 42 , p. $121-182$.

Yeend, W.E., 1985, Surficial geologic map of the Palen-McCoy Wilderness Study Area, Rivergide County, Callfornia: U.S.
Geological Survey Open-File Report 85-444, scale $1: 62,500$.

\section{San Benito County}

Bader, J.S., 1969, Chemical-quality analysis of water from selected wells in California, 1965-68: v.s. Geological

Survey open-file report, 11 p.
Bader, J.S., 1969, Ground-water data as of 1967, central coastal subregion, California: U.S. Geological Survey open-file report, $16 \mathrm{p}$.

Blodgett, J.C., 1972, Water temperatures of California streams, Central Coastal subregion: 0.s. Geological Survey open-file report, $60 \mathrm{p}$.

Dupras, Don, 1985, California's new official gem--benitorte: California Geology, v. 39 , no. 1 , p. 3-4

Enos, Paul, 1965, Geology of the Western vallecitas syncline, San Benito County, California: California Division of Mines and Geology Map sheet 5, scale 1:31,250.

Farrar, C.D., 1981, A ground-water level monitoring network, Hollister and San Juan Valleys, San Benito County, California: D.S. Geological Survey Open-File Report 81-66, $9 \mathrm{p}$.

Helley, E.J., 1967, Data for observation wells in San Benito County, California: U.S. Geological Survey

Kerr, P.F., and Schenck, H.G., 1925, Active thrugt faults in San Benito County, California: Geologic Soclety of America Bulletin, v. 36, no. 3, p. 465-494, fig. 3, scale $1: 250,000$.

\section{San Bernardino County}

Baker, C.L., 1911, Notes on the later Cenozoic history of the Mojave Desert region in southeastern California: University of California Department of Geological Science Bulletin, v. 6, p. 33-383, pl. 34, scale 1:750,000.

California Department Water Resources, 1967, Mojave River ground-water basin investigation: California Department of Water Resources Bulletin $84,151 \mathrm{p}$.

California Department of Water Resources, 1965 , Feasibility of serving the Mojave Water Agency from the State Water Project: California Department of water Resources Bulletin 119-12, $77 \mathrm{p}$.

California Department of Water Resources, 1976, Wrightwood (Calif.)--debris flow investigation: California Department of Water Resources Southern District Report.

California Department of Water Resources, 1981, Alternative water supply plans for the Mojave Water Agency: California Department of Water Resources Southern District Report, $61 \mathrm{p}$.

\section{San Bernardino County--Continued}

Cole, K.L., and Webb, R.H., 1985, Late Holocene vegetation changes in Greenwater Valley, Mojave Desert, California:

Cox, B.F., Matti, J.C., Oliver, H.W., and Zilka, N.T., 1983, Mineral resource potential map of the San Gorgonio Wilderness, San Bernardino County, California: U.S. Geological Survey Miscellaneous Field Studies Map MF-1161-C, scale $1: 62,500$.

Cramer, C.H., Harrington, J.M., Chase, G.W., and Bennett, J.H., 1984, Mucroearthquake, geophysical, and geodetuc surveys for earthquake hazards evaluation, eastern San Gabriel Mountains and upper Pomona valley areas, San Bernardino County. California: California Division of Mines and Geology OpenFile Report 84-23 SAC. De Groot, H., 1890, Its mountain plains and valley: California
Mining Bureau, State Mineralogist Annual Report 10, p. $518-$ 539 .

Det:a, D.E., Erickson, M.S., Tucker, R.E., Diggles, M.F., and Parduhn. N.L., 1985, Analytical results and sample locality map of stream-sediment and heav $Y$-mineral-concentrate samples from the Golden valley W1 lderness Study Area (CDCA-170), San Bernardino Count $Y$, California: U.S. Geological Survey OpenFile Report 85-29, 19 p.

Detra, D.E., Goldfarb, R.J., Meler, A.L., and Weaver, S.C., 1985 Analytical results and sample locality map of streamsediment and eolian samples from the Kelso Dunes Wilderness studY area (CDCA 250), San Bernardino Count $Y$, California: v.s. Geological Survey Open-File Report 84-103, 12 p.

Detra, D.E., Meier, A.L., Goldfarb, R.J., Weaver, S.c., 1985 , Analytical results and sample locality map of streamsediment, panned-concentrate, and rock samples from the South Providence Mountains Wilderness study area, San Bernardino County, Calıfornia: v.s. Geological Survey openFile Report 84-118, 29 p., scale $1: 62,500$.

Detra, D.E., Meler, A.L., and Cooley, E.F., 1983, Chemical analysis of rock, minus-80-mesh stream-gediment, and magnetic and nonmagnetic fractions of heavy-mineral concentrate samples of the Turtle Mountain Wilderness study. area $(\mathrm{CDCA}-307)$, San Bernardino County, California: u.S. Geological Survey Open-file Report 83-415, 51 p.

Detra, D.E., and K1 lburn, J.E., 1985, Analytical results and sample locality map of heavy-mineral-concentrate samples from the Bristol/Granite Mountains (CDCA 256) Wilderness Study Area, San Bernardino County, California: o.s. Geological Survey Open-File Report 85-510, 8 p.

Dibble, E.F., 1967, Mojave Water Agency, Water production verification program: Redlands, Calif., 39 p.

verification program: Redlands, Calif., 39 p.
Dibblee, T.W., Jr., 1960, Geology of the Rogers Lake and Kramer quadrangles, Callfornia: U.S. Geological Survey Bulletin 1089-B, $139 \mathrm{p}$

Dıggles, M.F., Tucker, R.E., Clemens, D.E., and Gaps, R.S., 1985, Mineral resources of the Golden valley wilderness Study Area, San Bernardino County, California: 0.s. Geological Survey Bulletin 1708-D, $11 \mathrm{p}$.

Dockter, R.D., 1980, Geophysical, lithologic, and water-qualit data from test well E-1. Emerson Dry Lake, San Bernardino County, California: U.S. Geological Survey Open-File Report $80-869$, 1 sheet.

Dohrenwend, J.C., Turrin, B.D., Wells, S.G., and McFadden, L.D., 1983, Pediment evolution in the cima volcanic field, eastern Mojave Desert, California (abs.): Geological Society of

America, Abstracts with Programs, v. 15, no. 5 , p. 434.
Durbin, T.J., and Hardt, w.F., 1974 , Hydrologic analysis of the Mojave River, California, using a mathematical model: U.S. Geological Survey Water-Resources

Investigations report $17-74,50$ p.
Durbin, T.J., and Morgan, C.0., 1979, Well-response model of the confined area, Bunker Hili ground-water basin, San Bernardino County, California: U.S. Geological Survey Water-Resources Investigations Report 77-129, $45 \mathrm{p}$.

Dutcher, L.C.., and French, J.J., 1965, Progress report on water studies in the Chino-Corona area, upper Santa Ana Valley, report, $36 \mathrm{p}$.

Dyer, H.B., Bader, J.S., Giessner, F.W., and others, 1963, Wells and springs in the lower Mojave valley area, San Bernardino County, California: California Department of Water Resources Bulletin 91-10, 19 p., 7 app.

Eccles, L.A. and Klein, J.M. 1979, Distribution of dissolved nitrate and fluoride in ground water, Highland-East Highlands, San Bernardino, California: 0.S. Geological Survey Water-Resources Investigations Report 78-14, $47 \mathrm{p}$.

Gage, T.B., and simpson, R.W., 1983, Principal facts for 904

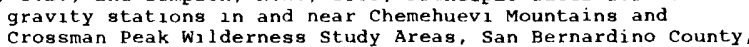
California, and Mojave County, Arizona: o.s. Geological Survey Open-File Report 83-806, $33 \mathrm{p}$.

Gage, T.B., and Simpson, R.W., 1983, Principal facts for gravity stations in and near the whipple Mountains wilderness study Area (CDCA-312), San Bernardino County, California, and
Mohave County, Arizona: U.S. Geological Survey Open-File Report 82-1089, $22 \mathrm{p}$.

Hardt, W.F., 1969, Mojave River basin ground-water recharge with particular reference to the California
floods of January and February 1969: 0.S. Geological Survey open-file report, $13 \mathrm{p}$.

Hardt, W.F., 1971, Hydrologic analysis of Mojave River basin, California, using electric analog model: v.s. Geological Survey open-file report, $84 \mathrm{p}$. Hazzard, J. C. , 1937, Lower Triassic rocks in San
Bernardino County, California: Geological Soclety of America Procedures for 1936 , p. 329.

Hewett, D.F., and Glass, J.J., 1953, Two uranium-bearing pegmatite bodies in San Bernardino County. California: American Mineralogist, v. 38, p. 1040-1050. 


\section{CATEGORY 4: COUNTIES}

\section{San Bernardino County--Continued}

Howard, K.A., and John, B.E., 1984, Geologic map of the sheep Hole-Cadiz Wilderness Study Area, San Bernardino County. California: U.S. Geological Survey Misce

Hulin, C.D., 1934, Geologic features of the dry placers of the northern Mojave Desert, California: California Division of Mines Report 30, p. 417-426.

Hyatt, E.S., and others, 1934, The Mojave Rive investigation: California Division of Water Resources Bulletin 47, $249 \mathrm{p}$.

Irelan, William, 1888, San Bernardino County: California Mining Bureau Report 8 , p. 490-504 (Callco area described in detaill

King, N.E., 1984 , Horizontal deformation in the Mojave Desert block near Barstow, Calıfornıa, 1979-1983 (abs.): Earthquake Notes, v. 55, p. 20

Koebıg and Koebıg, Inc., 1962, Mojave Water Agency supplemental water report: San Diego, Calif., app. A, B, C, D, 69 p.

Koebig and Koebig, Inc., 1965, Preliminary planning for Mojave Water Agency, alternate plans for distribution of imported water: San Diego, Calif., $11 \mathrm{p}$

Koebig and Koebig, Inc., 1966,' study of local water supply and need for supplemental water for Lucerne valley and Yucca-Joshua Valley: San Diego, Calif.., $11 \mathrm{p}$.

Kohler, S.L., 1984, Mineral land classification of the Lanfair valley, Homer Mountain, and Davis Dam 15-minute quadrangles, San Bernardino county. California: California Division of Mines and Geology Open-File Report 84-30 SAC, 68 p.

Kupfer, D.H., and Bassett, A.M., 1956. Preliminary geologic map of part of the southeastern Mojave Desert, San Bernardino county, Cal ifornı: U.S. Geological Survey open-file map, scale 1:120,000.

Kupfer, D.H., and Bassett, A.M., 1962, Geolog 1 C reconnaissance map of part of the southeastern Mojave Desert, California: U.s. Geological
Inventory Field Studies Map MF-205.

Lane, M.E., 1985, Mineral investigation of the Chemehuevi-Needles Wilderness Study Area (AZ-050-004), San Bernardino County California: U.S. Bureau

Marsh, S.P., Moyle, P.R., Knox, R.D., Howard, K.A., Raines, G.L., Hoover, D.P., Simpson, R.W., and Rumsey, C.M., 1982, Mıneral resource potential of the sheep Hole-Cadiz Wilderness study area $(\mathrm{CDCA}-305)$, San Bernardino County, California: U.s. Geological Survey Open-File Report 82-957, $40 \mathrm{P}$.

Marsh, S.P., Ridenour, James, Raınes, G.L., Howard, K.A., Simpson, R.W., Moyle, P.R., W1 ll ett, S.L., and Hoover, D.P., 1982, Mineral-resource potential of the Whipple Mountains wilderness study area (CDCA-312), San Bernardino County, California: v.s. Geological Survey Open-File Report 82-
40 p.

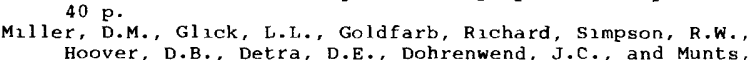
Hoover, D.B. Detra, D.E., Dohrenwend, J.C., and Munts, S.R. 1985, Mineral resources and resource potential map of
the South Providence Mountains Wilderness study Area, San the South Providence Mountains Wilderness Study Area, San
Bernardino County, California: 0.S. Geological Survey Bernardino County, California: D.S. Geological Survey
Miscellaneous Field studies Map MF-1780-A, scale $1: 62.500$

Miller, D.M., Glick, L.L., Goldfarb, Richard, Simpson, R.W., Hoover, D.B., Detra, D.E., and Dohrenwend, J.C., 1984 , Mineral resources and mineral resource potential of the South Providence Mountains Wilderness Study Area, San Bernardino County, California: U.S.

Miller, D.M., John, B.E., Antweller, J.C., Simpson, R.W., Hoover, D.B., Rains, G.L., and kreidier, T.J., 1983, Mineral resource potential map of the Chemehuevi Mountain Wilderness Study Area (CDCA-310), San Bernardino County
California: D.s. Geological Survey Miscellaneous Field California: D.s. Geological Survey Mis
Studies Map MF-1584-A, scale $1: 48,000$

Morton, D.M., Kennedy, M.P., Campbel], R.H, , Barrows, A.G., Jr., Kahle, J.E., and Yerkes, R.F., 1979, Landsliding and mudflows at Wrightwood, San Bernardino County (Calif.)

Morton 1983.Mineraloz, E.A., Obi, C.M., and simpson, R.W., Jr. 1983 , Mineral resource potential map of the Cucamonga roadless areas, San Bernardino County, California: 0.s. Geological Survey Miscella

Moyle, W.R., Jr., 1971, Water wells in the Harper, Superior, and Cuddeback Valley areas, San Bernardino County, California: Californa Department of water Resources Bulletin 91-19, $99 \mathrm{p}$.

Pitkın, J.A., and Duval, J.s., 1981, Interpretatıon of an aerial radlometric survey of the San Gorgonio wilderness area and vicinity, San Bernardıno County, Calıfornı: U.S. Geological Survey Misce

Powell, R.E., Mattı, J.C., Cox, B.F., Oliver, H.W., Wagini, Alexander, and Campbell, H.W., 1983, Mineral resource potential map of the Sugarloaf roadless area, San Bernardino County, California: U.S. Geological Survey M

Reynolds, R.E., 1985, Geologic investigations along Interstate 15. Cajon pass to Manix Lake, California: Redlands

Rumsey, C.M., and McMahan, A.B., 1985, Mineral resources of the Cinder Cones Wilderness study Area, San Bernardino County California: U.S. Bureau of Mines Mineral Land Assessment Report MLA 67-85, 12 p.

Sadler, M., 1982, Geology of the northeast San Bernardino Mountains, San Bernardino County, California: California

San Bernardino County Flood Control District, 1939-79, Biennial report, hydrologic and climatic data: san Bernardino County flood Control District, various pagination.

\section{San Bernardino County--Continued}

Simpson, R.W., Bracken, R.E., and Stierman, D.J., 1984, Aeromagnetic, Bouguer gravity, and interpretation maps of the Sheep Hole-Cadiz Wilderness study area, San Bernardino County, California: U.S. Geological Survey Miscellaneous Field Studies Map MF-1615-B, scale $1: 62,500$.

snyder, C.T., 1960, Proposed well sites in the Bakersfield Grazing District, eastern San Bernardino County. California (Ivanpah Valley, Old Dad Mountain area, and piute Valley): 2 p.

Spencer, J.E., and Turner, R.D., 1985, Geologic map of Homer Mountain and the southern puute Range, southeastern California: U.S. Geological Survey Miscellaneous Field Studies Map MF-1709, scale 1:24,000.

storms, W.H., 1892, Mineral resources of San Bernardino county, California: California state Mining Bureau, state

Mineralogist Annual Report 11, p. 337-369.
Thompson, D.G., 1939, Report of the Committee on underground Waters for 1938-39: American Geophysical Unıon transcripts, August 1939, p. 545-555.

Tucker, W.B., 1921, San Bernardino County: Calıfornia state Mineralogist Report 17, p. 333-374.

Tucker, W.B., and Sampson, R.J., i 930 , San Bernardıno County: 'California State Mineralogist Report 26, no. 3, p.

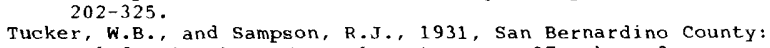
California State Mineralogist Report 27, chap. 3, p. 262-401; map, p. 322, scale 1:500,000

Tucker, W.B., and Sampson, R.J.., 1943, Mineral resources of San Bernardino County: California Journal Mines and Geology, v. 39, no. 4, p. 427-549.

Turrın, B.D., Dohrenwend, J.C., McFadden, L.D., and wells, S.G., $1983, \mathrm{~K}-\mathrm{Ar}$ ages of late Cenozolc basaltic volcanism in the Cima volcanic field, California (abs.): Geological Society
of America, Abstracts with Programs, v. 15, no. 5, p. 422

.s. Department of Agriculture, 1970 , Report and general 422 . soll map of the southwestern desert area of San Bernardino County, California: U.S. Department of Agriculture, Mojave Desert Soll Conservation District, $87 \mathrm{p}$.

wells, S.G., Dohrenwend, J.C., McFadden, L.D., Turrın, B.D., and Mahrer, K.D., 1985, Late Cenozoic landscape evolution on lava $f$ low surfaces of the cima volcanic field, Mojave Desert, California: Geological Society of America Bulletin, v. 96 , no. 12 , p. $1518-1529$.

wells, s.G., Dohrenwend, J.C., McFadden, L.D., and Turrin, B.D., 1983 . Types and rates of degradation of volcanic landforms
in desert climates; examples from the cima volcanic field, Mojave Desert, California (abs.): Geological Society of America, Abstracts with Programs, v. 15, no. 5, p. 422 . woolfenden, L.R.. 1983, A ground-water-quality monitoring network
for the lower Mojave River valley, California: U.s. Geological Survey Water-Resources Investigations Report 83-4148, $58 \mathrm{p}$. 1976 , Geologic guidebook to the

Woyski. M.S., ed.' 1976, Geologic guidebook to the southwestern Mojave
Geological Society.

Wright, L.A.. and others, 1953, Mines and mineral deposits of San Bernardino County. California: California Journal of Mines and Geology, v. 49, no. 1, p. 22-47.

Youngs, L.G., Bezore, S.P., Chapman, R.H., Chase, G.W., 1982, Resource investigation of low- and moderate-temperature areas in San Bernardino, California: California Division of Mines and Geology open-File Report B2-11 SAC.

\section{San Diego County}

Ambriano, J., 1972, Geology of San Diego County--a bibliography of the holdings at San Diego State College: San Diego, California State University Sciences and Engineering Library, $19 \mathrm{p}$.

Babcock, B.A., 1958, Ground water occurrence and quality, San Diego County (Calif.): Los Angeles, University of Southern California, M.S. thesis, $123 \mathrm{p}$.

Bacon, C.F., 1984 , Reconnalssance of geothermal resources near U.S. Naval facilities in San Diego, California: Cal ifornia
Division of Mines and Geology Open-File Report 84-33 sAC.

Bellemin, G.J., and Merriam, R.H., 1958, Petrology and origin of the Poway conglomerate, San Diego County,
California: Geological Society of America Bulletin, v. 69, California: Geolog

calıfornia Department of water Resources, 1964, San Diego County flood hazard investigation: California Department of water Resources Bulletin 112, $44 \mathrm{p}$

California Department of Water Resources, 1967, Ground water occurrence and quality: California Department of
water Resources, San Diego Region, Bulletin 106-2, Water Resources, San Diego R
235 p. (text); v. 2 (pls.).

California Department of Water Resources, 1976, Stage discharge relationships and areas of potential inundation for upper San Diego River (Calif.): California Department of water

Resources Southern District Report.
California Department of Water Resources, 1976, Upper San Diego River (Calif.) flood control investigation: Califor

California Department of Water Resources, 1977, Erosion and sedimentation in San Diego County (Calif.; watersheds: California Department of Water Resources Southern District Report.

California Department of Water Resources, 1983, San Diego County (Calif.) cooperative ground water studies: Reclaimed water use, phase 1: Cal Ifornia Department of Water Resources Southern District Report.

California Department of Water Resources, 1984, San Diego County cooperative ground water studies--reclaimed water use, phase 2: California Department of Water Resources Southern
District Report. 
CATEGORY 4: COUNTIES

\section{San Diego County--Continued}

Calkins, F.C., 1916, An occurrence of nickel ore in San Diego County, California: U.S. Geological Survey Bulletin

Carpenter, F.A., 1913, The climate and weather of San Diego, California: San Diego Chamber of Commerce, $118 \mathrm{p}$.

Christian, J., 1966, Geology in the area of Mount Soledad with foraminifera Identification from the Rose Canyon,
member of the La Jolla formation: San Diego, California member of the La Jolla formation: San Di

Crawford, J.J., 1894, Gold--San Diego County (Calif.): California Mineral Bureau Report 12, p. 237-243.

Crawford, J.J., 1896, Gold--San Diego County (Calif.): California Mineral Bureau Report 13, p. 331-347

Ellis, A.J., and Lee, C.H., 1919, Geology and ground waters of the western part of San Diego County,
California: U.S. Geological Survey Water-Supply Paper 446 $321 \mathrm{p.}, 47 \mathrm{pls}$., $18 \mathrm{figs}$

Emery, K.0., 1945, Mineralogy of caliche from San Diego County, southern California: Southern California Acadamy of Science Bulletin 44, p. 130-135

Eric, J.H., 1948, Tabulation of copper deposits of California, San Diego County: California Division Mines and Geology Bulletin 144, p. 199-357.

Fitzurka, M., 1968, Geology of a portion of the San Diego River valley, California: San Diego, California state University, senior thesis.

Freckleton, J.R., 1981, Water resources of the Santa Ysabel and Mesa Grande Indian Reservations, San Diego County, California: U.S. Geological Survey open-File Report 81-342, $27 \mathrm{p}$

Frederıksen, N.O.. 1983, Middle Eocene palynomorphs from San Diego, California; Part 2, Anglosperm pollen and miscellanea: American Association of Stratigraphic Palynologists Contributions Series, v. 12, p. 32-109, 122-155

Frederiksen, N.O., Carr, D.R., Lowe, G.D., and Wosika, E.P. 1983, Middle Eocene palynomorphs from San Diego, Cal ifornia Part 1, Introduction, spores, and gymnosperm pollen: American Association of stratigraphic Palynologists Contributions Series, v. 12, p. 8-31, 111-123

Goodyear, W.A., 1888, San Diego County (Calif.):
California Mineral Bureau Report 8, p. 516-528 Cal ifornia Mineral Bureau Report 8 , p. 516-5 California Mineral Bureau Report 9, p. 139-154.

Hand, B.M., 1961, Turbidite deposits of the San Diego Trough: Los Angeles, University of Southern California,

Hanks, H.G. 1886, San Diego County (Calıf.): Calıfornı Mineral Bureau Report 6, pt. 1, p. 80-90.

Hart, M., 1964, The Elsinore fault between Banner Grad and vallecito valley, San Diego County, California: San Diego, California State University, senior research paper.

art, M.W., and Dowlen, R.J., eds., 1974, Recent geological and hydrologic studies, eastern San Diego
County and adjacent areas: San Diego Association of County and adjacent areas: San Diego Ass

Hubon, I.A., 1903, Register of mines and minerals, San Diego County, California: California State Mining Bureau, $11 \mathrm{p}$.

Irelan, W.J., 1888, San Diego County (Calıf.): Calıfornıa Mineral Bureau Report 8, p. 512-516

rzbicki, J.A., 1983, Evaluation of the San Dieguito, San Elijo, and San Pasqual hydrologic subareas for reclaimed water use. San Diego county, Cal ifornia: U.S. Geological Survey WaterResources Investigations Report 83-4044, $138 \mathrm{p}$

Jahns, R.H., and Lance, J.F., 1950, Geology of San Dieguito pyrophyllite area, San Diego County, Calıforna California Division
1 , scale $1: 6,000$.

Jobson, H.E., 1980, Thermal modeling of flow in the San Diego Aqueduct, california, and its relation to evaporation: U.s. Geological Survey Professional Paper 1122, $24 \mathrm{p}$

Rennedy, M.P. 1973, Bedrock 11thologies, San Diego coastal area, California, in Ross, A., and Dowlen, R.J. eds., Studies on the geology and geologic hazards of the greater San Diego area, California: San Diego Association of Geologists and Association of Englneering Geologists. Field Trip Guidebook, $152 \mathrm{p}$

Kennedy, M.P., 1975, Geology of the Del Mar, La Jolla and Point Loma quadrangles, western metropolitan area, San
Diego, California: Cal ifornıa Division Mines and Geology Diego, California: California Divis

Kennedy, M.P., and Moore, G.W. 1971. Field trip no. 8 stratigraphy and structure of the area between Oceanside and San Diego, California, geologic road log, in Wilfred. A.B., ed., Geological excursions in southern California: Geological Society of America, Cordilleran Section Riverside, University of Cal

Kennedy, M.P., and Moore, G.W., 1971, Stratigraphic relations of Upper Cretaceous and Eocene formations, San Diego coastal area, California: American Asso

Kennedy, M.P., and Tan, S.S., 1977, Geology of National city, Imperial Beach, and otay Mesa quadrangles, southern San Diego metropolitan area (Calif.): California Di

Kohler, S.L., and Miller, R.v., 1983, Mineral land classification: Aggregate materials in the western San Diego County (Calif.) production-Consumption region: California Division of Mines and Geology Special Report 153

Lillegraven, J.A., 1973, Terrestrial Eocene vertebrates from San Diego County, California, in Ross, A.. and Dowlen, R.J., Studies on the geology and geological Diego Association of Geology and Association of Engineering Geology, Field Trip Guidebook, $152 \mathrm{p}$.

\section{San Diego County--Continued}

Logan, C.A., 1947, Limestone in California, San Diego County: California Journal of Mines and Geology Report 43, no. 3 , p. $175-357$.

McClelland, E.J., 1963, Aquifer-test compllation for the San Diego region, California: U.S. Geological Survey open-file report, $19 \mathrm{p}$.

Merriam, R.H., 1951, Groundwater in the bedrock in western San Diego County, California: California Division Mines and Geology Bulletin 159, p. 117-128.

Merriam, R.H., 1954 (1955), A typical portion of the southern California batholith, San Diego County, in Geology of southern California: California Division Mines and Geology Bulletin 170, map sheet 22, scale 1:62,500.

Merrill, F.J.H., 1916, The counties of San Diego, Imperial (Calif.): California Mineral Bureau Report 14, pt. 5. p. $635-743$.

Moyle, W.R., Jr., 1971, water wells in the San Luis Rey River valley area, San Diego County, California: California

Muckel, D.C., and Blaney, H.F., 1945, Utilization of the waters of lower San Luis Rey Valley, San Diego County. California: U.S. Department of Agriculture, Soll Conservation Service report, $144 \mathrm{p}$

Newman, M.A., 1923, Los Angeles field division, San Diego County (Calif.): California Mineral Bureau Report 18, p. $49,106,223$.

Nunez, E., 1965, Density determinations in the western part of San Diego County: San Diego, California state University, senior research paper.

olmsted, F.H.. 1953, Geologic features and water resources of Campo. Mesa Grande, and La Jolla Reservations,

(Calif.): 0.S. Geological Survey open-file report, $103 \mathrm{p}$

olmsted, F.H., 1953, Geologic features and water resources of Campo, Mesa Grande, La Jolla, and Pauma Indian Reservations, San Diego County, California, part 2, Pauma Reservation: U.S. Geological Survey open-file report, 31 $\mathrm{p}$.

Preston, E.B., 1890, San Diego County (Calif.): California Mineral Bureau Report 10, p. 540-544.

Ray, H.A., and Young, L.E., 1964 , Areas of potentral flood inundation, San Luis Rey River basin, California, in San Diego flood hazard investigation: California Department of water Resources Bulletin 112, appendix G, $21 \mathrm{p}$.

Savage, H.N., 1901, Construction of wells in southern California, in operations at river stations: U.S. Geological Survey water-Supply Paper 52, pt. 6, p. $497-498$.

Schaller, W.T. . 1910, Analyses of tourmaline and associated minerals from San Diego County: U.S. Geological Survey Bulletin 419, p. 280-281.

Schaller, W.T.' 1927, Mineral replacements in pegmatites: American Mineralogist, v. 12, p. 59-63.

Setmire, J.G., and Bradford, W.L., 1980, Quality of urban runoff Tecolote creek draınage area, San Diego County, California: v.S. Geological Survey Water-Resources Investıgations Report $80-70,33 \mathrm{p}$

Shearer, C.F., Taylor, F.A., and Flemıng, R.W., 1983, Digtribution and costs of landslides in the San Diego County, California, during the rainfall years of 1978-79, and 197980: U.S. Geological Survey Open-File Report 83-582, $17 \mathrm{p}$.

Snyder, C.T. 1967, Proposed well sites in the Riverside Grazing District (San Diego County), California: 3 p.
orms, W.H. I893, San Diego County (Calif.): Californa state Mineralogist Report 11, p. 376-393.

Todd, V.R., Learned, R.E., Peters, T.J., and Mayerle, R.T., 1983 , Mineral resource potential maps of the Sill Hill, Hauser, and Caliente roadless areas, San Diego County. California: U.S. Geological Survey Miscellaneous Field Studies Map MF-1547-A, scale $1: 62,500$.

Tucker, W.B., 1921, Los Angeles field division, San Diego county (Calif.): California State Mineralogist Report 17 p. $375-383$.

Tucker, W.B., 1924, Los Angeles field division, San Diego County (Calif.): California State Mineralogist Report 20 p. 49-50, 368-374

Tucker, W.B., 1925, San Diego County: California state Mineralogist Report 21, p. 325-382

Tucker, W.B.. and Reed, C.H., 1939, Mneral resources of San Diego County, California: California Journal of Mines and Geology, v. 35, p. 8-55, pl. 1 .

Tucker, W.B., and Sampson, R.J., 1934, Current mining activity in southern California, San Diego County: Calıfornia D
of Mines, State Mineralogist Report 30, p. $310-327$.

Tucker, W.B., and Sampson, R.J., 1940, Current mining activity in southern California, San Diego County: Californ
of Mines, State Mineralogist Report 36, p. 12 .

v.s. Department of Agriculture, Soll Conservation Service, 1973, Soil survey, San Diego County, Callfornia: O.S. Department of Agriculture, Soll Conservation Service, pt. 1,104 p.. pt. 2, 118 p., 76 maps.

weber, F.H., Jr., 1963, Geology and mineral resources of San Diego County, California: California Department of water Resources Bulletin 106-2, $309 \mathrm{p}$.

Weber, F.H., Jr., 1963, Geology and mineral resources of San Diego County, California: California Division of Mines and Geology County Report 3,709 p.

weber, F.H.. Jr., 1982, Recent slope fallures, ancient landslides, and related geology of the north-central coastal area, San Diego, California: California
and Geology Open-File Report 82-12 LA. 
CATEGORY 4: COUNTIES

\section{San Luis Obispo County}

Addicott, w.o., Poore, R.z., Barron, J.A., McDougall, Kristin, and Gower, H.D., 1981, Miocene biostratigraphy of the Indian creek-Shell creek area, northern La Panza Range, San Luis obispo county, California, in Blake, G.H., ed., Neogene biostratigraphy of the northern La Panza Range, San Luis obispo County, California: Los Angeles, Calif.. Society of Economic Paleontologists and

October 18,1980 , p. $11-38$.
California Department of water Resources, 1958, San Luis Obispo County investigation: Obispo County investigation: California Dep
Water Resources Bulletin 18, v. 1, pl. 7-B.

California Department of Water Resources, 1975, Summary of agroclimatic data collected in San Luis obispo County (Calif.): California Department of Water Resources Southern District Report. Campion, L.F., 1984, Hastorical use of geothermal resource at
Paso Robles, San Luis Obispo County (Calif.): California Geology, v. 37, no. 6, p. 119-122.

Eckel, E.B., Yates, R.G., and Granger, A.E., 1941 Quicksilver deposit's in San Luis obispo County and southwestern Monterey County, California: U.S. Geological Survey Bulletin 922-R, p. 515-580, (a) pl. 78, scale $1: 31,680$; (b) pl. 85 , scale $1: 31: 680$, with larger scale maps.

Fairbanks, H.W., 1904, San Luis Follo, California: U.S. Geological Survey geologic atlas $101,14 \mathrm{p}$. , areal geology sheet, scale $1: 125,000$.

Fernow, D.L., 1960, The mineralization and general geology of the San Luis Range and the Osos Valley. San Luis obispo County California: Los Angeles, University of California. M.A. thesis.

Frizzel1, V.A., Jr., Smith, D.B., Kuizon, Lucia, and Hale, W.N., 1985, Mineral resource potential map of the roadless areas and the Santa Lucia Wilderness in the Los Padres National Forest, southwestern California: U.S. Geological Survey

Graham, D.H., 1938, Geology and petroleum possibilities of a part of the Huasana district. San Luis Obispo County,
California: Los Angeles, University of California, M.A. thesis.

Hall, C.A., Ernst, W.C., Prior, s.W., and Wiese, J.W., $1979(1980)$, Geologic map of the San Luis Obispo-San Simeon region, California: U.S. Geological Survey Miscellaneous Investigations Map I-1097, 3 sheets, scale $1 ; 48,000$. Hall, C.A. and Prior, S.W., 1975, Geologic map of the Cayucos-
San Luis Obispo region, San Luis Obispo County, California 0.s. Geological Survey Miscellaneous Freld Studies Map MF-686, 2 sheets, scale $1: 24,000$

Hart, E.W., 1977, K-feldspar in upper Mesozolc sandstone units near Atascadero, San Luis obispo County, California: California Division of Mines and Geology Special Report 128

Hoots, H.W., Bear, T.L., and Kleunpel1, W.D., 1954, Geological summary of the San Joaquin Valley, in Geology of southern California: California Division of Mines and Geology Bulletin 170, chap. 2, contribution 8, pl. 5-6, 14 figs. scale $1: 250,000$

Kalbourne, R., and Mualchin, 1980, Geology for planning: Cayucos and Cypress Mountain $71 / 2$ minute quadrangles, San Luis obispo County, California: California Division of Mines and Geology Open-File Report 80-6 SF.

Moore, J.G., Charlton, D.W., 1984, ultrathin lava layers exposed near San Luis obispo Bay, Californ

Newsom, J.F., 1903, clastic dikes: Geological Society America Bulletin, v. 14, p. $227-268$, (a) fig. 2, scale $1: 4,000$.

San Luis Obispo County Engineering Department, 1974, Hydrologic and climatological data, seasons of 1970-71 and 1971-72, County of San Luis ob1spo California: San Lu1s

obispo county report, 260 p.
selders, v.M., 1982 (1983), Geologic map of an area near york Mountain, San Luis obispo County, California: U.S. Geological Survey Miscellaneous Investigations Series I-1369, scale $1: 24,000$

Taliaferro, N.L., 1943, Franciscan-Knoxville problem: American Association Petroleum Geologists Bulletin, v. 27 no. 2, p. $109-219$, (b) f1g. 1 , scale $1: 48,000$

walker, G.W., and Griggs, A.B., 1953, Chromite deposits of the southern coast Ranges of California, in Geologic investigations of chromite in California: California p. $39-88$.

\section{Santa Barbara County}

Bookman and Edmonston, Consulting Engineers, 1968, Water requirements of Santa Barbara County, 1967 to 1990: Consulting

report for Santa Barbara County Water Agency, 35 p.
California Department of Water Resources, 1978, Fiood hydrology for the Santa Ynez River (Calif.) watershed: California

Converse, Davis and Associates, 1972, Subsoils and foundation investigation, Lompoc valley regional wastewater reclamation system (stage 2): Pasadena, Calif., $58 \mathrm{p}$

Dalley, D.H., 1960, Stratigraphic paleontology of the Jalama Formation, western Santa Ynez Mountains, Santa Barbara County, California: Los Angeles, University of California, M.A. thesis.

Dibblee, T.W., Jr., 1950, Geology of southwestern Santa Barbara County, California: Point Arguello, Lompoc, Point conception, Los Olivos, and Gaviota 15-minute quadrangles: California Division of Mines Bulletin 150, $95 \mathrm{p}$.

\section{Santa Barbara County--Continued}

Dibblee, T.W., Jr., 1966, Geology of the central Santa California Division of Mines and Geology Bulletin 186, 99 p.

Effinger, W.L., 1935, Gaviota formation of Santa Barbara County, California (abs.): Geological Society of America Proceedings, p. $351-352$.

Evenson, R.E., 1962, Ground-water pumpage in the santa Ynez Valiey, California: U.S. Geological Survey open-file report, 24 p.

Evenson, R.E., wilson, H.D., Jr., and Muir, K.S., 1962, Yield of the Carpinteria and Goleta ground-water basins, Santa Barbara Country. California, 1941-58: v.s. Santa Barbara Country, California, $1941-58$ :

Granata, J.S., Tyson, R.M., Theisen, A.F., and Hemphill, W.R., 1984 , Solar-stimulated visible luminescence of v-bearing phosphatic mudstones in the Santa Margarita Formation, New Cuyama, california (abs.): Geological Society of America, Cuyama, California (abs.): Geological Society
Abstracts with Programs, v. 16, no. 4, p. 222 .

Hal1, C.A., Jr., 1981, Map of geology along the Little pine Fault, parts of Sisquoc, Foxen Canyon, Zaca Lake, Bald Mountain, Los olivos, and Figueroa Mountain quadrangles, Mountain, Los Olivos, and Figueroa Mountaln quadrangles,

H11, M.L., 1932, Mechanics of faulting near Santa Barbara, M.L., 1932, Mechanics of faulting near Santa Barbara,
California: University of Wisconsin, Ph.D. dissertation.

Hughes, J.L., 1977, Evaluation of ground-water quality in the Santa Maria Valley. California: U.S. Geological survey the Santa Maria Valley, California: U.S. Geological

Hughes, J.L., and Freckleton, J.R., 1976, Ground-water data for the Santa Maria Valley, California:

Geological Survey open-file report, $444 \mathrm{p}$.
Isaacs, C.M., 1980, Diagenesis in the Monterey Formation examined lateraliy along the coast near Santa Barbara, California: U.S. Geological Survey Open-File Report $80-606,343 \mathrm{p}$. fine-grained strata of the Miocene Santa Barbara basin, California: Geo-Marine Letters, v. 5, no. 1, p. 25-30.

Isaacs, C.M., Piscjotto, K.A., and Garrison, R.E., 1983, Facies and diagenesis of the Mrovene Monterey Formation, Calıfornia; a summary, in D.K. Larue, ed.., Cenozorc marine sedimentation: Pacific margin, U.S.A.: Los Angeles, Calif. Society of Economic Paleontologists and Mineralogists. Pacific Section, p. $117-132$.

Kew, W.S.W. 1919, Geology of a part of the Santa Ynez River District, Santa Barbara County, Calufornia: University of California Department Geological Science Bulletin, v. 12, no. 1, p. 1-21, pl. 1, scale $1: 84,480$.

LaRocque, G.A... Jr.. upson, J.E.., and Worts, G.F., 1950 , Wells and water levels in principal ground-water basins in Santa Barbara County, Californda:
water-Supply Paper $1068,459 \mathrm{p}$.

LaRocque, G.A. Jr.. 1942, Runoff in the Santa Ynez River Basin, California, following the excessive rainfall of p. $124-129$.

lewis, R.E., 1969, Ground water in Santa Barbara County, California, spring 1967 to spring 1968: U.S. Geological Survey open-file report, $30 \mathrm{p}$.

Merritt, P.M., 1961, water levels in observation wells in Santa Barbara County, California, in 1960: 0.S. Geological

Survey open-file report, $52 \mathrm{p}$.
Merritt, P.M., 1963, Water levels in observation wells in Santa Barbara County, California, in 1962: U.S. Geological Survey open-file report, $55 \mathrm{p}$.

Merritt, P.M., 1964, water levels in observation wells in Santa Barbara county, California, 1963: u.s. Geological

Survey open-file report, $33 \mathrm{p}$.
Miller, G.A.. 1959, Water levels in observation wells in Santa Barbara County, Californ
Survey open-file report, 47 p.

Muir, K.s., 1955, Water levels in observation wells in Santa Barbara county, California, in 1954: U.S. Geological

Survey open-file report, 66 p.
Muir, K.S., Merritt, P.M., and Miller, G.A., 1960, water levels in observation wells in Santa Barbara County, California, in 1959: U.S. Geological Survey open-file report, $21 \mathrm{p}$.

Muir, K.S., and Fenzel, F.W., 1968, Ground water in Santa Barbara County, California, spring 1966 to spring 1967 U.S. Geological Survey open-file report, $32 \mathrm{p}$.

Nelson, R.N., 1925, Geology of the hydrographic basin of the upper Santa Ynez River. California: University of California Department of Geological Science Bulletin,

Porter, L.D., 1978, Compllation of strong-motion records August 1978: California Division of Mines and Geology Preliminary Report 22 .

porter, L.D., Ragsdale, J.T., McJunkin, R.D., 1978, Processed data from the partial strong-motion records of the Santa results: Callfornia Division of Mines and Geology Preliminary Report 23

Porter, L.D., Ragsdale, J.T., and McJunkın, R.D., 1979, Processed data from the strong-motion records of the Santa Barbara earthquake of 13 August 1978 ; final results ( $2 \mathrm{n} 3$ volumes): California Division of Mines and Geology Special Report 144 .

Roberts, A.E., and vercoutere, T.L., 1981, Geology and petrology of the upper Miocene phosphate deposit near New Cuyama, Santa Barbara county, California, with a section on Phosphate resources, by W.T. Fedewa and R.D. Hovland: U.S. Geological Survey Open-File Report 81-1037, 254 p.

Santa Barbara County Water Agency, 1977, Adequacy of the ground-water basins. Santa Barbara County: Santa Barbara county Water Agency staff report, $267 \mathrm{p}$. 


\section{CATEGORY 4: COUNTIES}

\section{Santa Barbara County--Continued}

Shrpman, G.E., 1972, Soil survey of northern Santa Barbara area, California: U.S. Department Agriculture, Soi Conservation Service report, 182 p., 112 maps.

Todd, D.K., 1978, Ground-water basın data, status and needs, a report to the city of Santa Barbara, California: Berkeley, Calıf., David Keith Todd Consulting Engineers, Inc., $94 \mathrm{p}$.

Toups Corp.. 1974, water resources management study, South Coast-Santa Barbara County, a report prepared for the ad-hoc committee on water supply: 219 p.

U.S. Federal Water Pollution Control Administration, Southwest Region, 1967, Santa Ynez River basın, Lompoc project, water quality control study: U.S. Federal Water Pollution Control Administration, $30 \mathrm{p}$

u.s. Geological Survey, 1965, Reports and investigations by the water Resources Division, U.S. Geological Survey, in Santa Barbara County, California, since 1940 (status as of July 1 , 1965): U.S. Geological Survey, $6 \mathrm{p}$.

upson, J.E., 1947, Geology and Ground-water resources of the south coast basins of Santa Barbara County. California: U.S. Geological Survey open-file report, pls. 604 and 605 , scale $1: 25,000$.

Upson. J.E., 1949, Late Pleistocene and Recent change of sea level along the coast of Santa Barbara County, California: American Journal of Science, v. 247, p. 94-115.

upson, J.E., 1951, Geology and ground-water resources of the south-coast basins of Santa Barbara County. California, with a section on surface-water resources, by H.G. Thomasson, Jr.: U.S. Geological Survey water-Supply Paper $1108,144 \mathrm{p}$.

Upson, J.E., and Thomasson, H.G., Jr., 1951, Geology and water resources of the Santa Ynez River basin, Santa Barbara County, Californza: U.S. Geological Survey Water-Supply Paper 1107, $194 \mathrm{p}$

Upson, J.E., and Worts, G.F., Jr., 1949, Geologlc features of four coastal ground-water basins in Santa Barbara county. California: Society of Exploration Geophysicists, meeting at San Francisco, Calif., Feb. 17, 1949, Proceedings, 20 p.

walker, G.W. 1 1948, A study of the sedimentary petrography of the Sierra Blanca Limestone and associated rocks, Santa Barbara County, California: Palo Alto, Calif., Stanford University, M.s. thesis.

Walker, G.W., 1950, Sierra Blanca limestone in Santa Barbara County, California: California Division of Mines Special Report 1A, 5 p., pl. 1, scale $1: 62,500$

Warren, M.A., 1950, Pumpage estimates in the Santa Ynez valley, 1943-48: v.s. Geological survey, 13 .

Wilson, H.D., Jr., 1957, Ground-water appralsal of Santa Yne River basin, Santa Barbara County, California, 1945-52: u.s. Geological Survey open-file report, $181 \mathrm{p}$.

W1 lson Santa Ynez River basin, Santa Barbara County, Calıfornia, 1945-52: U.S. Geological Survey water-Supply Paper 1467 , $119 \mathrm{p}$.

\section{Santa Clara County}

Armstrong, C.F., 1980, Environmental geologic analysis of the Tar Creek South study area, Santa clara County, California: California

Armstrong, C.F., and Wagner, D.L., 1978, Environmental geologic analysis of the Drablo Range study area 1 , southern Santa Clara County, California: California Division of Mines and Geology Open-File Report 78-11 SF.

Averett, R.C., Wood, P.R., and Muir, K.s., 1971, water chemistry of the Santa clara valey, California: U.S. Geological Survey open-file report, $24 \mathrm{p}$.

Bader, J.S., 1969, Ground-water data as of 1967 , central coastal subregion, California: v.s. Geological Survey open-fale report, $16 \mathrm{p}$.

Bakun, W.H., Clark, M.M., Cockerham, R.S., Ellsworth, W.L. Landh, A.G., Prescott, W.H., Shakal, A.F., and Spudich, P. 1984, The 1984 Morgan Hzll, California, earthquake: Science, v. 225 , no. 4659, p. 288-291.

Blodgett, J.C., 1972, water temperatures of California streams, central coastal subregion: v.s. Geological Survey

open-file report, 60 p.
Brady, A.G., and Perez, V., 1983, Processed accelerograms from Coyote Dam, Calıfornia, March 25, 1978: U,S. Geological Survey Open-File Report 83-166,84 p

Burnett, J.L., 1965, Expansible shale resources of the San Jose-Gil roy area, California: California Division of Mines and Geology Special Report 87,32 p., 6 figs. 6 pls.

California Department of Water Resources, 1975, Evaluation of ground water resources: South San Francisco Bay; northern Santa Clara County area: California Department of Water Resources Bulletin 118-1, v. 3, $134 \mathrm{p}$.

California Department of Water Resources, 1981 , Evaluation of ground water resources, south San Francisco Bay, vol. 4 South Santa clara County area: California Department of water Resources Bulletin 118-1, 143 p.

clark, w.o.. 1924, Ground water in Santa Clara Valley Cal ifornia: v.s. Geological Survey Water-Supply Paper 519, $209 \mathrm{p}$.

Hoose, S.N., 1985, The Morgan Hill, Californsa, earthquake of April 24, 1984 ; a preliminary report; v. 1: 0.5 . Geological Survey Open-File Report 84-498-A, $152 \mathrm{p}$.

Hoose, S.N., 1985, The Morgan H1ll, California, earthquake of April 24, 1984; a preliminary report; v. 2: U.S. Geological Survey Open-file Report $84-498-B, 121$ p.

\section{Santa Clara County --Continued}

Jackman, A.P., Walters, R.A., and Kennedy, V.C., 1984, Transport and concentration controls for chloride, strontium, potassium, and lead in Uvas Creek, a small cobble-bed stream in Santa clara County, Calıfornia, U.S.A.; 2, Mathematical modeling:

Kennedy, V.C., Jackman, A.P., Zand, S.M., Zellweger, G.W., and Avanzino, R.J., 1984, Transport and concentration controls for chloride, strontium, potassium and lead in Uvas Creek, a small cobble-bed stream in Santa clara County, California, no. $1-4$, p. $67-110$

Knott, J.M., Pederson, G.L., and M1ddelburg, R.F., 1978, Interim report on streamflow, sediment discharge, and water quality in the Calabazas Creek basin. Santa Clara County, California: U.S. Geological Survey water-Resources Investigations Report 78-2, 41 .

Knott, J.M.. Pederson, G.L., and Middelburg, R.F., 1978, Inter 1 m report on streamflow, sediment discharge, and water quality in the Calabazas Creek basin, Santa clara County, Calıfornıa: U.S. Geological Survey water-Resources Investigations Report 78-2, 47 p.

Nilsen, T.H., 1972, Preliminary photointerpretation map of landside and other surficial deposits of parts of the Los Gatos, Morgan Hill, Gilroy Hot Springs, Pacheco Pass, Quien Sabe, and Hollister 15-minute quadrangles, Santa clara County, Calıfornia: U.S. Geological Survey Miscellaneous Field Studies Map MF-416, 2 sheets, scale $1: 62,500$.

Nilsen, T.H., and Brabb, E.E., 1972, Preliminary photointerpretation and damage maps of landsilide and other surficia deposits in northeastern San Jose, Santa Clara County, Studies Map MF-361, scale 1:24,000.

Poland, J.F., 1984, Case histories; Santa Clara Valley, California, U.s.A.: Studies and Reports in Hydrology, v. 40, p. $279-290$.

Poland, J.F., and Ireland, R.L., 1985, Land subsidence in the Santa Clara Valley, California, as of 1980 : 0.S. Geological Survey Open-File 84-818,93 p.

Wagner, D.L., 1978, Environmental geologic analysis of the Diablo Range study area 2, southern Santa Clara County, California: California Division of Mines and Geology open-file Report $78-12 \mathrm{SF}$.

\section{Santa Cruz County}

Adam, D.P., Byrne, Roger, and Luther, Edgar, 1979, A late Pleistocene and Holocene pollen record from Laguna de las Trancas, northern coastal Santa Cruz County, California: U.S. Geological Survey Open-File Report 79-545, 29 p.

Akers, J.P.., and Jackson, L.E., Jr., 1977, Geology and ground water in western Santa Cruz County, California, with particular emphasis on the Santa Margarita sandstone u.S. Geological Survey Water-Resources Investıgations report 77-15, map.

Blankenbaker, G.G., and Farrar, C.D., 1981, Evaluation of groundwater monitoring network, Santa Cruz County, Californza: U.S. Geological Survey Open-File Report 81-139, 20 p.

Christensen, R.S., 1960, Foraminiferal studies in the lower Tertiary of Soquel Creek, Santa Cruz County, thesis.

Clark, J.C., 1981, Stratigraphy, paleontology, and geology of the central Santa Cruz Mountains, California Coast Ranges: v.s. Geological Survey Professional Paper 1168, 51 p.

Dingler, J.R., 1981, Stability of a very coarse-grained beach at Carmel, California: Marine Geology, v. 44, no. 3-4, p. $241-252$.

Ha11, N.T., Sarna-Wojc1ck1, A.M., and Dupre, W.R., 1974, Faults and their potential hazards in Santa cruz County. California: U.S. Geological Survey Mascellaneous Field Studies Map MF-626, scale $1: 62,500$.

Johnson, M.J., 1980 , Geology and ground water in north-central Santa Cruz County, California: U.S. Geological Survey WaterResources Investigations Report $80-26,33 \mathrm{p}$.

Mitchell, G.D., 1928, The Santa Cruz earthquakes of October 1926: Berkeley, University of California, M.A. thesis.

Muir, K.S., and Johnson, M.J., 1979, Classification of groundwater recharge potential' in three parts of Santa cruz County, California: v.s. Geological Survey Open-File Report 79-1065, 1 map.

Nolan, K.M., Marron, D.C., and Collins, L.M., 1985, streamchannel response to the January $3-5,1982$, storm in the Santa Cruz Mountains, west central California: v.s.

Geological Survey open-File Report $84-248,53$ p.
Phillips. R.L., 1983 , Late Mrocene tidal shelf sedimentation, Santa Cruz Mountains, California, in D.K. Larue, ed. Cenozolc marine sedimentation; pacif lc margin, U.S.A.: Los Angeles, Calif., Society of Economic Paleontologists and Mineralogists, Pacific Section, p. 45-61.

Sylvester, M.A., and Covay, K.J., 1978, Stream-quality in the San Lorenzo basin, Santá Cruz County, California: u.S. Geological Survey Water-Resources Investigations Report $78-19,61 \mathrm{p}$.

weber, G.E., and Lajoze, K.R., 1980, Map of Quaternary faulting along the San Gregor 10 fault zone. San Mateo and Santa Cruz Counties, California: v.s. Geological Survey Open-File Report 80-907, 3 sheets, scale $1: 24,000$.

willis, Robin, 1922, The physiography of the southern Santa Cruz Mountains: Palo Alto, Calif., Stanford University, M.A. thesis. 


\section{Ventura County}

Anderson, T.P., Lloyd, R.C., Kressling, E.W., Kohler, S.L., and Miller, R.v. 1981. Mineral land classification of Ventura
County (Calif.): California Division of Mines and Geology Special Report 145

Baldwin, E.J., 1959, Pliocene turbidity current deposits in ventura basin, California: Los Angeles, University of Southern California, M.A. thesis.

California Department of water Resources, 1959, water quality and water quality problems, ventura County: California Department of water Resources Bulletin 75,2 vs

California Department of Water Resources, 1965 Feasibility of serving the Ventura county flood Control District from the State water project: California
Department Water Resources Bulletin $119-17,86$

California Department of Water Resources, 1976, Planned utiliza$t i o n$ of water resources in Ventura County (Calif.) California Department of water Resources Bulletin 104-8. $46 \mathrm{p}$.

California Division of 011 and Gas, 1969-70, Regional wildcat maps 1-2, 2-1, and 2-2 (1nclude southern and central Ventura Countyl: California Division of O1l and Gas.

California Division of water Resources, 1933, Ventura County investigation: Basic data for the period 1927 to 1932, inclusive: California Department of Public Works, Division of water Resources, Bulletin 46-A, $574 \mathrm{p}$.

California Division of Water Resources, 1933 , Ventura County investigation: California Division of water Resources Bulletin $46,244 \mathrm{p}$.

Cal ifornia state water Rights Board, 1956, ventura county investigation: California State Water Rights Board Bulletin 12 v. 1, 489 p.; v. 2, 243 p.

Conkling, Harold, and others, 1933, ventura county investigation: California Division of water Resources Bullet in $46,244 \mathrm{p}$.

Cronin, T.M., Brouwers, E.M., Quinn, H.A., and Redline, Andrew, 1983, Ostracods from the P1co and Santa Barbara formations ventura basin, Calıfornia, in Larue, D.K., ed., Cenozouc marine sedimentation; Pacific margin, U.S.A.: Society of Economic Paleontologists and Mineralogists, Pacific Section, p. $205-221$

Dart, wakefield, Jr., 1948, The geology of a portion of eastern Ventura basin, california: Pasadena, California institute of Technology, M.S. thesis.

Dickinson, K.A., 1985, Epigenetic uranium deposits in Tertiary sedimentary rocks in Ventura County, California; a preliminary report: U.S. Geological Survey Open-File Report 82-818, $28 \mathrm{p}$.

Dickinson, W.R., and Lowe, D.R., 1966, Stratiqraphic relations of phosphate- and gypsum-bearing upper Miocene strata, upper Sespe Creek, Ventura County, California: American Association of Petroleum Geologists Bulletin, v. 50, no. 11, p. 2464-2481, fig. 2, scale 15/16 inch = i mile.

Dreyer, F.E., 1935, The geology of a portion of Mount Pinos quadrangle, Ventura County, California: Los Angeles, University of California, M.A. thesis.

\section{Ventura County--Continued}

Gale, H.S., 1914, Borate deposits in ventura County California: U.S. Geological Survey Bulletin 540, p. $434-456$.

Hamilton, D.H., 1962, Geology of the proposed Joel McCrea reservoir site and vicinity, Ventura county, California Palo Alto, Calif., Stanford University, M.S. thesis.

Jennings, C.W., and Troxel, B.W., 1954, Ventura basin and adjacent areas in Geology of southern California: California Division Mines Bulletin 170, guidebook 2, $63 \mathrm{p}$

Keller, E.A., Johnson, D.L., Clark, M.N., and Rockwell, T.K. 1982, Tectonic geomorphology and earthquake hazard, north flank, central Ventura basin, California: U.s. Geological Survey Open-File Report 81-376, 179 p.

Keller, M.A., 1985, Silica diagenesis and 1 ithostratigraphy of the Mlocene Monterey Formation of the northwestern Ventura basin, California, including biostratigraphy, pyrolysis results, chemical analyses, and a preliminary temperature zonation of the opal-CT zone: U.S. Geological Survey openFile Report 84-368, 85 p.

McCoy, Gail, and Sarna-Wojcicki, A.M., 1978, Preliminary map showing surficial materials of the Ventura-Oxnard Plain area, Californa: U.S. Geological Survey Open-File Report $78-1065,1$ pl., scale $1: 125,000$.

Putman, w.c., 1942, Geomorphology of the Ventura region. California: Geological Society America Bulletin, v. 53, p. $691-754$.

Sarna-wojcickı, A.M., Williams, K.M., and Yerkes, R.F., 1976, Geology of the Ventura Fault, Ventura County, california: 0.s. Geological Survey MF-781, 3 sheet's, scale $1: 6000$.

Sarna-Wojcicki, A.M., and Yerkes, R.F., 1982, Comment on article by R.S. Yeats on "Low-shake faults of the Ventura basin. Cal ifornia," in J.D. Cooper, compller, Neotectonics in southern California: Geological Society of America Guidebook, p. 17-21.

slosson, J.E., 1966, wave damage, Ventura coastline in Engineering Geology in southern California: Association of Engineering Geologists Special Publication Los Angeles section, p. 323 .

Thomas, R.G., Marliave, E.C., James, L.B., and Bean, R.T. 1954, Geology and hydrology of ventura County in Geology of southern California: California Division Mines Bulletin 170, chap. 6, p. 5-12.

Turner, J.M., 1971, Ventura County water resources management study; Geohydrology of the ventura River system ground water hydrology: ventura county flood Control District Report for the ventira county Board of Supervisors, $31 \mathrm{p}$.

United water Conservation District of Ventura County. 1953, Report of investigation and recommendations for acquisition and construction of a water conservation system: United water Conservation District, $23 \mathrm{p}$. 


\section{Southern California}

Adrian, B.M., Smith, D.B., Frizzell, V.A., Jr., and Vaughn, R.B. 1984, Analytical results and sample locality map of streamsediment, heavy-mineral-concentrate, rock and water samples the Los Padres National Forest, Kern, Los Angeles, San Luis obispo, Santa Barbara, and Ventura Counties, southwestern California: U.S. Geological Survey Open-File Report 84-675, 84 p., scale $1: 250,000$

Allen, C.M., Miller, D.M., Howard, K.A., and Shaw, S.E., 1983, Field, petrologic and chemical characteristics of Jurassic intrusive rocks, eastern Mojave Desert, southeastern california (abs,): Geological Society of America, Abstracts with Programs, v. 15, no. 5, p. 410-411.

Alpha, A.G., 1971, Petroleum potential of Sierra Nevada and eastern desert, California: American Association of Petroleum Geologists, Memoir 15, v. 1, p. 363-371.

American Association of Petroleum Geologists, 1952, Field trip routes, geology, oll fields: American Association of and Mineralogists, and Society of Exploration Geophysicists Joint Annual Meeting, March 1952, Guidebook.

Anderson, D.N., and Hall, B.A., 1973, Geothermal exploration in the first quarter century (A report prepared for the Southern Sierra Power Company by H.N. Siegfried, 1925): Geothermal Resources Council Special Report 3, $191 \mathrm{p}$.

Anderson, F.M., and Martin, B., 1914, Neocene record in the Temblor Basin, California, and Neocene deposits of the San Juan District, San Luis obispo County. California: california Acadamy of science proceedings, 4th series, 4, p. 15-112, pl. 10, scale 1:125,000

Anderson, J.L., and Osborne, R.H., 1980, Petrologic comparison of cataclastic rocks from shallow and deeper crustal levels within the San Andreas fault gystem of southern California: U.S. Geological Survey Open-File Report 80-987, 120 . Anderson, T.P., Lloyd, R.C., Clark, W.B., Miller, R.v., Corbaley,
R., Kohler, S.L., and Bushnell, M.M., 1981, Mineral land classification of the greater Los Angeles (Calif.): classification of sand and gravel source areas, orange CountyTemescal Valley production-consumption region: California
Division of Mines and Geology Special Report 143 , pt. 3 .

Anderson, T.P... Lloyd, R.c. Clark, W.B., Miller, R.v., Corbaley, R., Kohler, S.L., and Bushnell, M.M., 1981, Mineral land classification of the greater Los Angeles (Calif.) area classification of sand and gravel resource areas, San Gabriel valley production-consumption region: California

Division of Mines and Geology Special Report 143, pt. 4. sel1, Thomas, 1857, Geological report, in Report of ascertain the most practicable and economical route for a railroad from the Mississippi River to the Pacific ocean, 1855: 33d Congress, 2d session, Senate Executive Document $78, \mathrm{v}, 7,204 \mathrm{p}$.

Archuleta, R.J., 1982, Hypocenter for the 1979 Imperial Valley (Calif.) earthquake: Geophysical Research Letters, v. 9, no. 6, p. 625-628.

Archuleta, R.J., 1984, A faulting model for the 1979 Imperial Valley (Calif.) earthquake: Journal of Geophysical Research, B, v. 89 , no. 6 , p. 4559-4585.

Archuleta, R.J., 1984, Modeling strong motion data from the 1979 Imperial valley earthquake: World Conference on Earthquake Engineering, Proceedings, v. 8, no. 2, p. 369-376.

Archuleta, R.J., and Bouchon, M., 1984, A study of $Q$ in the Imperial Valley, California (abs.): Earthquake Notes, v. 55, p. 24 .

Azmon, Emanuel, 1960, Heavy minerals in sediments of southern California: Los Angeles, University of Southern California, Ph.D. dissertation.

Bacon, C.R., 1982, Time-predictable bimodal volcanism in the Coso Range, California: Boulder, Colo., Geology, v. 10, no. 2, p. $65-69$.

Bagg, R.M., Jr., 1905, Miocene foraminifera from the Monterey shale of California, with a few species from the
Tejon Formation: U.S. Geological Survey Bulletin 268 , 78

p., fig. 1, scale $1: 62.500$.
Bailey, R.G., and Rice, R.M., 1969, Soil slippage, an indicator of slope instability on chaparral watersheds of southern California: Professional Geographer, v. 21, p. 172-177.

Bailey, T.L., 1947, origin and migration of oil into sespe red beds, California: American Association of Petroleum
Geologists Bulletin, v. 31, no. 11, p. 1913-1935, scale $1: 750,000$.

Bailey, T.L.. 1954, Geology of the western ventura basin, Santa Barbara, Ventura, and Los Angeles Counties, in Geology of southern California: California Division of

Mines Bulletin 170, map sheet 4 , scale 1 inch $=6$ miles.
Baird, A.K., and Miesch, A.T., 1984, Bathol ithic rocks of southern California: U.S. Geological survey professional paper $1284,42 \mathrm{p}$

Bakun, W.H., and McEvilly, T.V., 1981, source directivity for main shocks near Parkfield, California (abs.): Earthquake Notes, v. 52, no. 1, p. 82 .

Bakun, W.H., and MCEvilly, T.V., 1984, Recurrence models and Parkfield, Californa, earthquakes: Journal of Geophysical Research, B, v. 89, no. 5, p. 3051-3058.

Baldwin, T.A., 1971, Petroleum potential of California central coast: American Association of Petroleum Geologists, Memoir 15, v. 1, p. 309-315.

Ball, S.H., 1907, A geologic reconnalssance in southwestern Nevada and eastern Californla: U.s.
Geological Survey Bulletin $308,218 \mathrm{p}$, pl. 1, scale $1: 250,000$.

\section{Southern California--Continued}

Barnes, Ivan, O'Neil, J.R., Rapp, J.B., and White, D.E. 1973, Silica-carbonate alteration of serpentine wall rock alteration in mercury deposits of the Californ

Ranges: Economic Geology, v. 68, p. 388-398.
Barnhard, L.M., Thenhaus, P.C., and Algermissen, S.T., 1982 , Distribution of intensity for the Westmorland, California, earthquake of Apri1 26,
File Report $82-485,37 \mathrm{p}$.

Bateman, P.C.. 1979, Structural, age, and compositional patterns in the Sierra Nevada batholith, california, U.S.A. (abs.): Pacific Scientific Congress, Abstract Papers, no. 14, p. 12-13.

Bateman, P.C., and Irwin, W.P., 1954, Tungsten in southeastern California in Geology of southern California: California Division of Mines and Geology Bulletin 170, chap. 8 , contribution 4 , p. $31-40$, fig. 3 , scale $1: 25,200$.

Bechtel corp., 1964, Engineering report on route studies for delivery of water from the east branch of the California Aqued 80 .

Bedinger, M.s., Langer, W.H., and Moyle, W.R., Jr., 1984, Maps showing ground-water units and withdrawal, Basin and Range Province, southern California: U.S. Geological Survey waterResources Investigations Report 83-4116-A, 6 p.

Bell, K.G., 1960 \{1961), Uranium and other trace elements in petroleums and rock asphalts: U.S. Geological Survey professional paper 356-B, p. 45-65, table 3 .

Bennett, M.J... McLaughl in, P.V., Sarmiento, J.S., and Youd, T.L. Imperial Valley, California: U.S. Geological Survey Open File Report 84-252, 107 p.

Berkstresser, C.F., Jr., 1968, Data for springs in the southern Coast, Transverse, and Peninsular Ranges of California: U.S. Geological Survey open-file report, 21 p.

Berkstresser, C.F., Jr., 1969, Data for springs in the Colorado Desert area of California: U.S. Geological survey open-file report, $13 \mathrm{p}$.

Beyer, L.A., 1983, Density and porosity changes with depth, Sisquoc and Monterey Formations, Santa Maria-Point Conception region, California (abs.), in C.M. Isaacs, ed., Petroleum generation and occurrence in the Miocene Monterey Formation, California: Los Angeles, Calif.. Society of p. 224 .

Beyer, L.A., Robbins, S.L., and clutsom, F.G., 1985, Basic data and preliminary density and porosity profiles for twelve borehole gravity surveys made in the Los Angeles, San Joaquin, Santa Maria and Ventura basins, Califor,

B1schoff, J.L., Shlemon, R.J., Ku, T.L., Simpson, R.D. Rosenbauer, R.J., and Budinger, F.E., Jr., 1981, Úraniumseries and soil-geomorphic dating of the calico archaeological site, California: Boulder, Colo., Geology, v. 9, no. 12, p. $576-582$.

Blackwelder, Elrot, 1931, Pleistocene glacration in the Sierra Nevada and basin ranges: Geological Society of America Bulletin, v. 42, p. 865-922.

Blake, W.P., 1856, Pacific rail road surveys: 33d congress,

v. 5, pt. 3, External w.P., 1857, Geological report on routes in California, in U.S. War Department, Reports of explorations and surveys--for a rall road from the Mississippi River to the Pacific Ocean: 33d Congress, 2d session, House Document 91 , v. 5 , pt. $2,370 \mathrm{p.}$.'

Blanc, R.P., and Cleveland, G.B., 1961, Pleistocene lakes of southeastern California, part i: Callfornia Division of Mines and Geology Mineral Information Service, v. 14, no. 4. p. $1-8$

Blanc, R.P., and Cleveland, G.B., 1961, Pleistocene lakes of southeastern California, part 2: California Division of
Mines and Geology Mineral Information Service, v. 14, no. 5 , p. $1-6$.

Blaney, H.F., 1951, Consumptive use of water: American Society of Civil Englneering Proceedings, v. 77, separate 91. $19 \mathrm{p}$.

Blaney, H.F., and Troxell, H.C., 1933, South coastal basin investigation, water losses under natural conditions from wet areas in southern California

Blankenbaker, B.G., 1978, Antelope Valley-East Kern Water Agency area, California, showing ground-water subunits and areas, location of wells, and lines of equal depth to water: U.S. Geological Survey Open-File Report 78-937, 1 pl.. scale 1:125,000.

Blankenship, R.R., Bentall, Ray, and Waring, G.A., 1965, Thermal springs of the United States and other countries of the world--A summary, revised by R.R. Blankenship and Ray Bentall: U.S. Geological Survey Professional Paper $492,383 \mathrm{p}$.

Bliss, J.D., 1983, Basic data for thermal springs and wells as recorded in GEOTHERM, part $A$ (Calif.): U.S. Geological Survey Open-File Report 83-428, 109 p.

Bliss, J.D., 1983, Basic data for thermal springs and wells as recorded in GEOTHERM, part $B$ (Calif.): U.S. Geological Survey Open-File Report 83-428-B, 860 p.

Bloyd, R.M., 1967, Water resources of the Antelope valley-East Kern Water Agency Agency area, Californa:

U.S. Geological Survey open-file report, $73 \mathrm{p}$.
Bloyd, R.M., 1967, Water-resources inventory for 1966 , Antelope valiey-East Kern Water Agency area, California: U.S. Geological Survey open-file report, $19 \mathrm{p}$.

Blume, J.A., Scholl, R.E., Somerville, M.R., and Honda, K.K. 1980, Damage prediction for an earthquake in southern California: U.S. Geological Survey Open-File Report 80-1145, $173 \mathrm{p}$. 


\section{Southern California--Continued}

Bohannon, R.G., and Howell, D.G., 1982, Kinematic evolution of the junction of the San Andreas, Garlock, and Big Pine
faults, California: Boulder, Colo., Geology, v. 10, no. 7 , p. $358-363$.

Bonillas, Y., 3d, 1935, A study of Mlocene vulcanism in southern california: Pasadena, California Institute of Technology, M.s. thesis.

Bowen, O.E., and Gray, C.H., Jr., 1959, Geology and economic possibilities of the limestone and dolomite deposits of the northern Gabilan Range (Monterey and San Benito Counties), California: California Division of Mines and Geology Special Report 56, 40 p., 1 pl., 4 figs., 35 photos.

Brabb, E.E., ed., 1983, Studies in Tertiary stratigraphy of the California Coast Ranges: U.S. Geological Survey Professional Paper 1213, $93 \mathrm{p}$.

Bracken, R.E.., and simpson, R.W., 1982, Principal facts for gravity stations in the sheep Hole/Cadiz Wilderness study
area (CDCA-305), California: U.s. Geological Survey OpenFile Report 82-882, $31 \mathrm{p}$.

Bradley, w.w., 1918, Quicksilver resources of california: California Division of Mines and Geology Bulletin 78, 389 p., pl. 15, scale $1: 63,360$

Bramlette, M.N., 1945, The Monterey formation of california and the origin of 1 ts siliceous rocks: v.s. Geological Survey Professional Paper 212, $57 \mathrm{p}$

Buhr, G.S., and Lindh, A.G., 1982, Selsmicity of the Parkfield, California, region, 1969 to 1979: U.S. Geological survey Open-File Report 82-205, 89 p.

Burdick, D.J., and Richmond, W.C. 1983, A summary of geologic hazards for proposed ocs 011 and gas lease sale 68 . southern California: U.S. Geological Survey Open-File Report $82-33,41 \mathrm{p}$.

Burford, R.O., and Gilmore, T.D., 1984, Vertical crustal movements in southern California, 1974-1978: U.S. Geological Survey Circular 905, 22 p.

Burke, D.B. 1979, Log of a trench in the Garlock fault zone, Fremont valley, California: U.s. Geological survey

Miscellaneous Eleld Studies Map MF-1028, 1 sheet.
Bycroft, G.N., 1982, Anomalous record of October 15, 1979, Imperial valley, Cal ifornia, earthquake from Coachella cana Engine House No. 4: U.S. Geological Survey Open-File Report $82-317,14 \mathrm{p}$.

California Department of Public Works, Division of Wate Resources, 1932, South coastal basin investigation, precipitation records to and including 1931-32: California Division of water Resources Bulletin 39-A, 162 p.

California Department of Conservation, Division of Mines and Geology, 1954, Geology of southern California:
California Division of Mines and Geology Bulletin 170, 878 p.

California Department of Public Health, 1966, Barstow ground-water study: California Department of Public Heaith, Report to Lahontan Regional Water Quality control Board, $12 \mathrm{p}$.

California Department of Public works, 1939, South coastal basin investigation, records of ground water levels for the year 1938 , seasonal precipitation records to and including 1937-38: California Division of Water Resources Bulletin $39-\mathrm{G}, 115 \mathrm{p}$.

California Department of Public Works, 1941, South coastal basin investigation, records of ground water levels for the year 1939, seasonal precipitation records to and including 1938-1939: California Division of water Resources Bulletin 39-H, 113 p.

California Department of Public Works, 1941, South coastal basin investigation, records of ground water levels for the year 1940 , seasonal precipitation records to and including 1939-40: California Division of Water Resources Bullet in 39-, $107 \mathrm{p}$.

California Department of Public works, 1944, South coastal basin investigation, ground water levels 1941, including San Jacinto and Antelope Valleys from beginning of record, precipitation records 1940-41: Californid Division of Water Resources Bullet in 39-J, 479 p.

California Department of Public Works, 1945 , South coastal bas in investigation, including San Jacinto and Antelope
valley, ground water levels 1942, precipitation records 1941-42: California Division of water Resources Bulletin $39-\mathrm{K}, 138 \mathrm{p}$

California Department of Public Works, 1946, South coastal basin investigation, including San Jacinto and Antelope Valley, ground water levels 1943, precipitation records 1942-43, Cal

california Department of Public works, 1948, South coastal basin investigation, including San Jacinto and Antelope Valley, ground water levels 1944, precipitation records

California Department of Public works, 1948, South coastal basin investigation, including San Jacinto and Antelope valley, ground water levels 1945 , precipitation records 1944-45: California Division of water Resources Bulletin $39-\mathrm{N}, 118 \mathrm{p}$.

california Department of Public works, 1949, South coastal basin investigation, lncluding San Jacinto and Antelope valley, ground water levels 1946, precipitation records $39-0,116 \mathrm{p}$.

California Department of Public Works, 1950, South coastal basin investigation, including San Jacinto and Antelope 1946-47: California Division of Water Resources Bulletin 39-P, $116 \mathrm{p}$.
Calıfornia Department of Public Works, 1953, South coastal basin investigation, ground water levels and precipitation records in Los Angeles. San Gabriel, and Santa Ana basins, and Antelope Valley, and water supply summary for southern portion of California, 1948: Ca

Calsfornia Department of Public Works, 1954, Ground water occurrence and quality, Colorado River basin region California Department of Public Works water-quality Investigations Report 4, 59 p., 9 tables, 11 pls.

Investigations Report 4, 59 p., 9 tables, 11 pls.
california Department of Public works, 1954, South coastal basin investigation, ground water levels and precipitation records in Los Angeles, San Gabriel, and Santa Ana Basins, and Antelope Valley, and water supply sumary for southern portion of California, 1949: Ca

Calıfornia Department of Pubix works, 1955, South coastal basin investigation, ground water levels and precipitation records in Los Angeles, San Gabriel, and Santa Ana basins, and Antelope Valley, and water supply summary for southern portion of California, 1951: California Division of Water Resources Bulletin 39-T, $137 \mathrm{p}$.

california Department of Pubilic Works, 1955, South coastal basin investigation, ground water levels and precipitation records in Los Angeles, San Gabriel, and Santa Ana basins, and Antelope Valley, and water supply summary for southern portion of California, 1952: California Division of water Resources Bulletin 39-u, $136 \mathrm{p}$.

california Department of Public Works, 1955, South coastal basin investigation, ground water levels and precipitation records in Los Angeles, San Gabriel, and Santa Ana Basins, and Antelope valley, and water supply summary for southern Resources Bulletin 39-v, $124 \mathrm{p}$.

Cal ifornia Department of Pubiıc Works, 1956, South coastal basin investigation, ground water levels and precipitation records in Los Angeles, San Gabriel, and Santa Ana basins, and Antelope valley, and water supply summary for southern portion of California, 1954: California Division of Water Resources Bullet in 39-w, 136 p.

California Department of Public Works, Division of Water Resources, 1930, Rainfall penetration and consumptive use of water in Santa Ana River Valley and Coastal Plain: California Division of Water Resources Bulletin 33, 162 p.

california Department of Public Works, Division of Wate Resources, 1933, water losses under natural conditions, parts 1 and 2: Cal fornia Division of Water Resources Bullet in $44,176 \mathrm{p}$.

California Department of Public Works, Division of water Resources, 1933, South coastal bas in investigation, quality of irrigation waters: California Division of water Resources Bulletin 40-A, $131 \mathrm{p}$

california Department of Pubilic Works, Division of water Resources, 1933, South coastal basin investigation, records of ground water levels for the year 1933, seasonal precipitation records to and including 1932-33: California Division of Water Resources Bulletin 39-B, $138 \mathrm{p}$.

California Department of Public Works, Division of water Resources, 1935, South coastal basin investigation, records of ground water levels for the year 1935, seasonal precipitation records to and including 1934-35: California Division of water Resources Bulletin 39-D, $122 \mathrm{p}$.

California Department. of Public Works, Division of water Resources, 1937. South coastal basin investigation, records of ground water levels for the year 1936, seasonal precipitation records to and including 1935-36: California Division of water Resources Bulletin 39-E, $175 \mathrm{p}$.

California Department of Public Works. Division of water Resources, 1938, South coastal basin investigation, records of ground water levels for the year 1937, seasonal precipitation records to and including 1936-37: California Division of Water Resources Bulletin 39-F, $117 \mathrm{p}$.

California Department of Public Works, Division of Wate Resources, 1947, South coastal basin investigation, overdraft on ground water basins: California Division of water Resources Bulletin 53, $256 \mathrm{p}$.

California Department of Water Resources, 1957, water 1956: California Department of Water Resources Bulletin $39-56,170 \mathrm{p}$.

California Department of water Resources, 1958, water supply conditions in southern Californid during 1956-1957: california Department of Water Resources Bulletin 39-57. v. 1,86 p., 17 pls.

Calıfornia Department of water Resources, 1958 , water supply conditions in southern California during 1956-1957: California Department of Water Resources Bulletin 39-57, v. 2, precipitation and water level data, central coastal

P., app. C, $751 \mathrm{p}$.
California Department of water Resources, 1958, water supply conditions in southern Californla during 1956-1957: California Department of Water Resources Bullet in 39-57. v. 3, precipitation and water level data, Lahontan, $346 \mathrm{p} ., 4 \mathrm{pls}$.

California Department of Water Resources, 1959, Santa Ana River investigation: California Department of Water Resources Bulletin $15,207 \mathrm{p}$.

California Department of water Resources, 1960 , Reconnalssance investigation of water resources of Mono and Owens basins. Mono and Inyo Counties: California Department of Water Resources report, $92 \mathrm{p}$. 


\section{CATEGORY 5: SOUTHERN CALIFORNIA AND OFFSHORE}

\section{Southern California---Continued}

California Department of Water Resources, 1960, Water supply conditions in southern California during 1957-1958: v. 1, 78 p., 16 pls.; v. 2, Precipitation and water leve data, central coastal and Los Angeles regions, 432 p.; v. 3 , $348 \mathrm{p}$.

california Department of Water Resources, 1961, Ground water geology, in planned utilization of the ground water basins of the coastal plain of Los Angeles County: California Department of water Resources Bulletin 104, app. A, $191 \mathrm{p}$.

California Department of Water Resources, 1961, Water supply conditions in southern California during 1959-60: California Department of Water Resources Bulletin 39-60, v. 1, 87 p., 16 pls.; v. 2, water level data, Central Coastal and Los Angeles regions, 423 p.; v. 3, water level data, Lahontan, Colorado River basin, Santa Ana, and San Diego regions, $315 \mathrm{p}$.

California Department of Water Resources, 1961, water supply conditions in southern California during 1958-59: California Department of Water Resources Bulletin 39-59, v. 1, 80 p.. $16 \mathrm{pls.;} v .2$, water level data, central coastal and Los Angeles regions, 385 p.; v. 3, water level data, Lahontan, Colora

California Department of Water Resources, 1962, Quality of surface waters in California, 1959 , part 2, southern Callfornia: California Department of water Resources Bulletin 65-59, 179 p.; app. A, 14 p.; app. B, 89 p

California Department of Water Resources, 1962 , water supply conditions in southern California during 1959-1960 California Department of Water Resources Bulletin 39-60, v. 1, 87 p.. 16 pls.; v. 2, Water level data, Central Coastal and Los Angeles reglons, 423 p.; v. 3, water level data, Lahontan, Colorado River basin, Santa Ana, and San Diego regions, $289 \mathrm{p}$.

California Department of Water Resources, 1963, Desert areas of southeastern California, land and water use survey, 1958: California Department of Water Resources Bulletin 101, $74 \mathrm{p}$.

Calıfornia Department of Water Resources, 1963, Water supply conditions in southern California during 1960-61: California Department of Water Resources Bulletin 39-61. v. 1, 90 p., 16 pls.; v. 2, water level data, Central Coastal and Los Angeles regions, 361 p.; v. 3, water level data, Lahontan, Colorado River basin, Santa Ana, and San Diego regions, 236 p.

California Department of Water Resources, 1964, Crustal strain and fault movement investigation: California

Department of Water Resources Bulletin 116-2, map. fornia Department of Water Resources, 1964, Ground

water ment of Water Resources Bulletin 106-1, 439 p.
Department areal code numbers of hydrologic areas in the Southern
District: California Department of Water Resources office report, $57 \mathrm{p}$.

California Department of Water Resources, 1964, San Luis obispo and Santa Barbara Counties land and water use survey, 1959: California Department of Water Resources Bulletin 103, 62 p.

California Department of Water Resources, 1964 , Water supply conditions in southern California during 1961-62: California Department of Water Resources Bulletin 39-62 v. 1, 92 p., 16 pls.; v. 2, Water level data, Central
Coastal and Los Angeles regions, 370 p.; v. 3, Water level data, Lahontan, Colorado River basin, Santa Ana, and San Diego regions, $257 \mathrm{p}$.

California Department of Water Resources, 1965, Hydrologic data, 1963: California Department of Water Resources
Bulletin 130-63, v. 5, Southern California, app. A and B. and attachments, 170 p.; app. C, ground water measurements; pt. 1, Central Coastal and Los Angeles drainage provi

California Department of Water Resources, 1965, Hydrologic data 1963: Bulletin $130-63$, 5 , app., pt. 2, ground water measurements, pt. 2, Lahontan, Colorado River Basın, Santa Ana, and San Diego drainage provinces, $264 \mathrm{p}$ California Department of Water Resources, 1965, Hydrologic
data 1963: California Department of Water Resources Bulletin $130-63$, v. 5 , app. D, surface water quality; app. E, ground water quality, $112 \mathrm{p}$.

California Department of Water Resources, 1965, Interim report on Inyo-Mono area water-resources investigation California Department of Water Resources, 26 .

California Department of Water Resources, 1966, Hydrologic data 1964: California Department of Water Resources Bulletin 130-64, v. 5, Southern California, apps. A and B, 59 p. 7 pls.; app. C, ground water measurements, pt. 1 , Central Coastal and los Angeles drainage provinces, 485 p.; pt. 2, Lahontan, Colorado

Californa 1966, Hydrologic darna Department of Water Resources, 1966, Hydrologic Bulletin 130-64, v. 5, app. c, pt. 2, 301 p.

California Department of Water Resources, 1966, Hydrologic data 1964: Cal ifornia Department of Water Resources Bullet in 130-64, v. 5, app. D, 72 p.

California Department of Water Resources, 1966, Hydrologic data 1964: California Department of Water Resources Bulletan $130-64$, v. 5, app. E, 534 p.

\section{Southern California--Continued}

California Department of Water Resources, 1966, Hydrologic data 1965: California Department of Water Resources Bulletin 130-65, v. 5, southern California, app. A and B, $76 \mathrm{p} ., 7$ pls.; app. C, ground water measurements, 477 p. app. D, surface water

California Department of Water Resources, 1967, Review of Los Angeles water-supply management report in Inyo and Mono Counties: California Department of Water Resources, Senate Resolution $184,14 \mathrm{p}$.

California Department of Water Resources, 1968, Hydrologic data 1966: California Department of water Resources Bulletin 130-66, v. 5, app. A-C, 486 p.; apps. D and E, $203 \mathrm{p}$.

California Department of Water Resources, 1969, Hydrologic data 1967: California Department of Water Resources Bulletin 130-67, v. 5, app. D-F, 259 p.

California Department of Water Resources, 1970 , Hydrologic data 1968: California Department of Water Resources
Bulletin 130-68, v. 5, app. A-C, 423 p.; app. D-F, 207 p.

California Department of Water Resources, 1971 , Hydrologic data 1969: California Department of Water R

California Department of Water Resources, 1972 , Hydrologic data 1970: California Department of Water Resources
Bulletin 130-70, v. 3, 137 p.; v. 5, 469 p.

california Department of Water Resources, 1973 , Hydrologic data 1972: California Department of Water Resources Bulletin 130-72, v. 3, central coastal area, 107 p.; v. 5, southern California, 473 p.

California Department of water Resources, 1974, Hydrologic data 1973: California Department of Water Resources Bulletin 130-73, v. 3, central coastal area, 99 p.; v. 5 , southern California, $483 \mathrm{p}$.

cal Ifornia Department of Water Resources, 1975, Reclamation of water from wastes in southern Cal ifornia: Cali fornia

California Department of Water Resources, 1976, Hydrologic data 1974: California Department of Water Resources southern California, $481 \mathrm{p}$.

California Department of Water Resources, 1976, Reclamation of water from wastes in southern California: California Department of Water Resources Bulletin 80-5, appendix A: Water supply and demand; append $\mathrm{x}$ B: Waste water production and reclamation; appendix C: Criteria for use of reclalmed water; $66 \mathrm{p}$.

California Department of Water Resources, 1977, Hydrologic

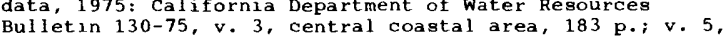
southern California, $487 \mathrm{p}$.

California Department of Water Resources, 1979, Sources of powerplant cooling water in the desert area of southern Water Resources Bulletin 91-24, $55 \mathrm{p}$.

California Department of water Resources, 1981, Investigation under California water code section 275 of use of water by Imperial Irrigation District: California Department of Water Resources Southern District Report.

California Department of Water Resources, 1981, Water action plan for the Owens-Mono area: California Department of Water Resources Southern District Report.

California Division of Mines and Geology, 1980, Aeromagnetic map of the Los Padres area, California: v.s. Geological Survey open-file report $80-986,8$ maps, scale $1: 62,500$.

California Division of 011 and Gas, 1961, California oil and gas fields, maps and data sheets, pt. 2, Los Angeles-ventura basins and central coastal regions: California Division of $O i I$ and Gas, $913 \mathrm{p}$.

California Division of Publ 10 Works, 1954 , South coastal basin investigation, ground water levels and precipitation records in los Angeles, San Gabriel, and Santa Ana basins, and Antelope Valley, and water supply summary for southern portion of California, 1950: Ca

California Division of Water Resources, 1954, Groundwater occurrence and quality, Colorado River basin region of Water Investigations Report 4,59

california Regional Water Qual ity Control Board, Los Angeles Region, 1971, Interim water quality management plan, Santa Clara and Los Angeles River Basin: California Regional Water quality Control Board Summary Report, 111

California Water Resources Control Board, 1956, Los Angeles County, land and water use survey, 1955 : California Water Resources Control Board Bulletin 24, 59 p.

Calzia, J.P., 1982, Petrology and magmatic history of the coxcomb Granodiorite, Coxcomb Mountains, southeastern California (abs.): Geological Society of America, Abstracts with Programs, v. 14 , no. 4, p. 153.

Calzia, J.P., Kilburn, J.E., Simpson, R.W., Jr., Allen, C.M. Leszcykowsk1, A.M., and Causey, J.D., 1983, Mineral resource potential map of the Coxcomb Mountains Wilderness Study Area (CDCA-328), San Bernardino and Riverside Countres. California: $0 . S$. Geological Survey Miscellaneous Field Studies Map MF-1603-A, scale $1: 62,500$.

Campbell, M.R., 1902, Reconnaissance of the borax deposits of Death valley and Mohave Desert, California: 0.s. Geological Survey Bulletin 200, $23 \mathrm{p}$.

Campel1, M.R., 1903, Borax deposits of eastern California, in Contributions to economic geology, 1902: o.s. Geological Survey Bullet in 213, p. 401-405.

Carranza, c. 1965, Surficial geology of a portion of South Panamint Valley, Inyo county, California: Amherst, University of Massachusetts, M.A. thesis. 


\section{Southern California--Continued}

Carson, S.E., and Mattı, J.C., 1983, Contour map showing minimum depth to ground water, upper Santa Ana Rıver valley, Calıfornxa: U.S. Geological Survey Open-File Report' 82-1128, $49 \mathrm{p}$.

Casey, H.E., 1972, Salinity problems in arid lands irrigation, A literature review and selected bibliography:

Castle, R.O., Brown, B.W., Jr., Gilmore, T.D., Mark, R.K., and wilson, R.C., 1983, An examination of the southern California field test for the systematic accumulation of the optical refraction error in geodetic leveling: Geophysical Research Letters, v. 10, no. I1, p. 1081-1084.

Castle, R.o., Elllott, M.R., Church, J.P., and wood, S.H., 1984, The evolution of the southern California uplift, 1955 through 1976: U.S. Geological Survey Professional Paper $1342,136 \mathrm{p}$.

Chandler, T.S., 1971, An optical current meter for measurement of surface velocities in debris-laden flows: pittsburgh, Pa., American Society of Mechanical Engineers, American Institute of Physics, National Bureau of Standards, and Instrument Society of America. Measurements and Control in Science and Industry, May 1971, Proceedings, reprint, p. 93-98.

chandler, T.S.' 1972, Water-resources inventory, spring Agency area, California: U.S. Geological Survey open-file report 14 ,

Chandler, T.S., and Smith, winchell, 1971, Optical current meter use in southern California: American Society of civil Engineers proceedings, Hydraulics Division Journal, v. 97, no. HY9, p. 1461-1469.

Chase, J.S., 1919, California desert tralls: Houghton Mifflin, $387 \mathrm{p}$.

Clapp, W.B., 1904, Seepage measurements in southern California, in Hoyt, J.C., Report of progress of stream measurements for the calendar year 1903, pt. 7, interior basin, Pacific, and Hudson Bay draınage: 0.S. Geologica Survey water-Supply Paper 100, p. 339-356.

Clapp, W.B., 1905, Report of progress of st ream measurements for the calendar year 1904, part 1, the Great Basin and Pacific Ocean drainage in Californı: U.S. Geological Survey Water-Supply Paper 134, 276 p.

clapp, W.B., 1907, The surface water supply of Californa. 1906, with a section on ground water levels in southern California (Great Basin and Pacific Ocean drainage in
California and lower Colorado River drainage): u.s. Geological Survey Paper 213, 219 p.

Clapp, W.B., and Hoyt, J.C., 1906, Report of progress of stream measurements for the calendar year 1905, part 13 , the Great Basin and Pacific Ocean drainages in California, and Colorado River drainage below Gila River: U.S. Geological Survey water-Supply Paper 177, $273 \mathrm{p}$.

clapp, w.B.. and Martin, W.F., 1910, Surface water supply Geological Survey water-Supply paper $251,363 \mathrm{p}$. superseded by U.S. Geological Survey Water Supply Paper 300 .

Clark, B.L., 1930, Tectonucs of the Coast Ranges of middle California: Geological Society of America Bulletin, v. 41, no. 4, p. 747-828

Clark, B.R., 1980, Monitoring stress changes along active faults in southern California: U.S. Geological Survey Open-File Report 80-1168, 85 p.

clark, c.w., 1921, Lower and middle Cambrian formations of the Mohave Desert: University of California Department of Geology Bulletin, v. 13, no. 1, p. 1-7.

clark, M.M., 1982 (1983), Map showing recently active breaks along the Elsinore and associated faults, California, between Lake Henshaw and Mexico: U.S. Geological Survey

clark, M.M., 1984, Map showing recently active breaks along th San Andreas Fault and associated faults between salton sea and Whitewater River-Mıssion Creek, Calıfornia: D.S. Geological Survey Miscellaneous Investigations Series Map I-1483, scale $1: 24,000$

clark, M.M., and Yount, J.C., 1981, Surface faulting along the Hilton Creek Fault associated with the Mammoth Lakes,
California, earthquakes of May 1980 (abs.): Earthquake Notes, v. 52, no. 1 , p. $45-46$.

clark, W.B., 1985, Gold in the California desert: California Geology, v. 38 , no. 8, p. 178-185.

clark, W.B.. 1985, Gold in the Transverse Ranges, southern California: California Geology, v. 38, no. i1, p. 254-260. clarke, F.W. 1914, Water analyses from the laboratory of
the United States Geological Survey: U.s. Geological Survey water-Supply Paper $364,40 \mathrm{p}$.

Clarke, F.W., 1924, The data of geochemistry (5th ed.): u.s. Geological Survey Bulletin $770,841 \mathrm{p}$.

Clifton, H.E., 1981, Progradational sequences in Miocene shoreline deposits, southeastern Caliente Range, California:

Journal of Sedimentary Petrology, v. 51, no. 1, p. 165-184.
Cloos, E., 1931, Der Sierra Nevada, Pluton: Geological Rundschau, Band 22, Heft 6, p. 372-384, Tafel 2, scale $1: 250,000$

Collins, W.D. and Howard, C.S., 1928, Quality of water of Colorado River in 1925-26: U.S. Geological Survey waterSupply Paper 596-B, P. 33-43.

Conkling, H., 1921, Owens Valley project, California: U.S. Reclamation service, $86 \mathrm{P}$.

Conrey, B.L., 1959, Sedimentary history of the early pliocene in the Los Angeles basin, California: Los Angeles, University of Southern California, Ph.D. dissertation.

Conrey, B.L., 1967, Early Pliocene sedimentary history of the Los Angeles Basin, California: California Division of Mines and Geology Special Report 93, 63 p.

\section{Southern California--Continued}

Cotton, W.R., 1972, Preliminary geologic map of the Franciscan rocks in the central part of the Diablo Range, Santa clar and Alameda Counties, California: U.S. Geological Survey Miscellaneou

Cox, B.F., and Morton, D.M., 1978, Generalized map of surficial

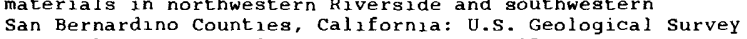
San Bernardino Counties, California: U.S. Geolog
Open-File Report 78-978, 1 pl., scale $1: 125,000$.

Cox, B.F., and Morton, D.M., 1978, preliminary map of surficial materials in northwestern Riverside and southwestern San Bernardino Counties, California: U.S. Geological Survey Open-File Report 78-977, 1 pl., scale 1:48,000.

Crippen, J.R., 1963, Natural water ioss and recoverable water in mountain basins of southern California (abs.): p. 871 .

Crippen, J.R., 1965, Natural water loss and recoverable water in mountain basins of southern California: 0.s.

Crook, Rlchard Jr. alluvial age dating based on progressive weathering, with application to the time-history of fault activity in with application to the time-history of fault activity in
southern California: U.s. Geological survey open-File Report $80-1144,44 \mathrm{p}$.

Crowell, J.c., 1952 , Submarıne canyons bordering central and southern Californa: Journal of Geology, v. 60 , no. 1 , p. 58-83, fig. 6, scale 1:88,500.

Croweli, J.C., 1962, Drsplacement along the San Andreas fault, California: Geological Society of America Special Paper 71,

61 p., fag. 3, scale 1 inch = approx. $3 \mathrm{mlles.}$ Temblor Mountains to Antelope Valley, southern California: Pacific Section, American Association of petroleum Geologists, Society of Economic Paleontologists and Mineralogists, and San Joaquin Geological

crowell, J.C., and walker, J.W.R., 1962, Anorothosite and related rocks along the San Andreas fault, southern California: University of California Publications, Geological Science, v. 40, no. 4, p. 219-288, map 1, scale 1 inch = approx. 2 miles.

Cruff, R.W., and Rantz, S.E., 1965, A comparison of method's used in flood-frequency studies for coastal basins in Californa: U.S. Geological Survey Water-Supply Paper in California: U.S.

Darton, N.H., 1933, Guidebook of the western United States, part F, the Southern Paciflc Lines, New Orleans to Los Angeles: U.S. Geological Survey Bulletin 845, 304 p.,

Davis, J.F., Bennett, J.H., Borchardt, G.A., Kahle, J.E., Rice, S.J., and Silva, M.A.. 1982, Earthquake planning scenario California: California Division of Mines and Geology Special Publication 60 .

Dewitt, Ed, Armstrong, R.L., Sutter, S.F., and Zartman, R.E., 1984, $\mathrm{U}-\mathrm{Th}-\mathrm{Pb}, \mathrm{Rb}-\mathrm{Sr}$, and Ar-Ar mineral and whole-rock isotopic systematics in a metamorphosed granitic terrane, Bulletin, v. 95, no. 6, p. 723-739.

Detra, D.E., Erickson, M.s.. Tucker, R.E., Diggles, M.F., and Parduhn, N.L., 1985, Analytical results and sample locality map of stream-sediment and heavy-mineral-concentrate samples
from the Little Lake Canyon (CDCA-157) and Owens Peak (CDCA158) Wilderness Study Areas, Inyo and Kern Counties, California: U.S. Geological Survey Open-File Report 85-34, $23 \mathrm{p}$.

Dibblee, T.W., Jr., 1962, Geology of Carrizo Plalns and San Andreas Fault: San Joaquin Geological Socrety and Pacific sections, American Association of Petroleum Geologists and Society of Economic Paleontologists and Mineralogists, Guidebook, $52 \mathrm{p}$. , pl. 1, Geologic Map of Callente and
Temblor Ranges, San Luis Obıspo and Kern Counties, scale 1
inch = approx. 2 miles.

Dibblee, T.W., Jr., 1967, Areal geology of the western Mojave Desert,', California: U.S. Geological Survey Professional Paper 522, $153 \mathrm{p} .4 \mathrm{pls}$.

Dibblee, 'T.W., Jr., 1970 , Regional geologic map of San Andreas and related faults in eastern San Gabriel Mountains, San Bernardino Mountains, western San Jacinto Mountains and

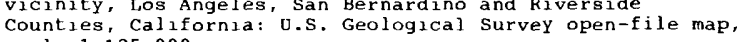
scale 1:125,000.

Dibblee, T.W., Jr.., 1976, The Rinconada and related faults in the southern Coast Ranges, California, and their

Dibblee, T.W., Jr., 1979, Geologic map of the central Diablo Range between Hollister and New Idria, San Benito, Merced, and Fresno Counties, California: v.s. Geological Survey open-File Report 79-358, scale 1:125,000.

Dibblee, T.W., Jr., and Schwade, I.T., 1952, Guıdebook, fleld trip routes, oll fields geology: American Association Petroleum Geologists and Society of Economac Paleontologists and Mineralogists, joint annual meeting. Los Angeles, Calif., scale 1:338,000.

Dickinson. W.E., 1944 , Summary of records of surface waters at base stations in Colorado River Basin,

Diggles, M.F., 1983, Map and interpretation of geochemical anomalies in the White Mountains, Blanco Mountain, Birch Creek, and Black Canyon roadless areas, white Mountains, California and Nevada: U.s. Geological Survey Miscellaneous 


\section{CATEGORY 5: SOUTHERN CALIFORNIA AND OFFSHORE}

\section{Southern California--Continued}

Diggles, M.F., Blakely, R.J., Rains, R.L., and Schmauch, S.W., 1983, Mineral resource potential map of the Blanco Mountain and Black Canyon roadless areas. Inyo and Mono Counties, California: U.s. Geological Survey Miscellaneous Field studies Map MF-1361-C, scale $1: 62,500$.

Diggles, M.F., Dellinger, D.A., Sutley, S.J., Fey, D.L., and Hili, R.H., 1983, Chemical data for samples of rock, streamsediment, and nonmagnetic dense-mineral concentrate in the White Mountains, Blanco Mountain, Birch Creek, and Black Canyon roadless area, White Mountains, California and
Nevada: U.S. Geological Survey Open-File Report 82-984, $190 \mathrm{p}$.

Diller, J.S., and others, 1915, Guidebook of the western United States, part D, the Shasta route and coast line: $1: 500,000$

Doering, W,P., Frledman, Irving, and Veronda, Guldd, 1981, Survey of helium in natural water wells and springs in southwest Montana and vicinity and Imperial valley, California: Part 3 , Ja nuary 1-December 31
File Report $81-893,58$

Dohrenwend, J.C., MCFadden, L.D., Turrin, B.D., and Wells, S.G. 1984, K-Ar dating of the Cima volcanic field, eastern Mojave Desert, California; late Cenozolc volcanic history and landscape evolution: Boulder, Colo., Geology, v. 12, no. 3 p. $163-167$.

Dolton, G.L., Carlson, K.H., Charpentier, R.R, Coury, A.B., Crovell1, R.A., Frezon, S.E., Khan, A.S., Lister, J.H., McMullin, R.H., Pike, R.s., Powers, R.B., Scott, E.W., and Varnes, K.L., 1981, Estimates of undiscovered recoverable conventional resources of oil and gas in the United States: U.S. Geological Survey Circular $860,87 \mathrm{p}$.

Donahoe, J.L., Chaffee, M.A., Fey, D.L., Hill, R.H., and Sutley, s.J., 1983, Geochemical data for samples of rock, stream sediment, and nonmagnetic dense-mineral concentrate in the Andrews Mountain, Mazourka, and Palute roadless areas, Inyo County, California: U.S. Geological Survey Open-File Report 83-403, $152 \mathrm{p}$. Driver, H.L. 1948, Genesis and evolution of Los Angeles
Basin, California: American Association of Petroleum Geologists Bulletin, v. 32, no. 1, p. 109-125.

Dunn, J.E., Holmes, L.C., Strahorn, A.T., and Guernsey, J.E., 1917, Reconnaissance soll survey of the central southern area, California: Field operations of the Bureau of So11s, 1917, p. 2405-2534.

Dupre, W.R., Clifton, H.E., and Hunter, R.E., 1980, Modern sed1mentary facies of the open Pacific coast and pleistocene analogs from Monterey Bay, California: Pacific Coast Paleogeography Symposium 4, proceedings, p. 105-120.

Dupre, W.R., and Tinsley, J.C., 3d, 1980, Maps showing geology and liquefaction potential of northern Monterey and southern Santa Cruz Counties, California: U.S. Geological Survey Miscellaneous Field Studies Map MF-1199, scale $1: 62,500$.

Durbin, T.J., 1975, Selected effects of suburban development on runoff in south-coastal California: Lexington, University of Kentucky, National Symposium on Urban Hydrology and Sediment Control, Proceedings, p.
209-217.

Durham, D.L., 1979, Preliminary map of uranium occurrences in the Temblor Range, Kern and San Luis Obispo Counties, Cal ifornia: 0.s. Geological Survey Miscellaneous Field Studies Map MF-1047, scale 1:24,000.

Durham, J.W., 1954, The marine Cenozolc of southern California, in Geology of southern California: California Division of Mines Bulletin 170, chap. 3, p. 23-31.

Durrell, Cordel1, 1953, Geological investigations of strontium deposits in southern California: California Division of Mines Special Report 32, $48 \mathrm{p}$.

Dutcher, L.C., Hardt, W.F., and Moyle, W.R., Jr., 1972 Ground water in storage in the Imperial Valley area California (abs.): Montreal, Canada,

Dutcher, L.C. Hardt, W.F., and Moyle, W.R., Jr., 1972 Preliminary appraisal of ground water in storage reference to geothermal resources in the Imperial valley area, California: U.S. Geological Survey Circular 649, 57 p.

Easton, W.H., and Imlay, R.W., 1955, Upper Jurassic fossil localities in Franciscan and knoxville formations in southern California: American Association of Petroleum Geologists Bulletin, v. 39, no. 11, p. 2336-2340, fig. 1 scale $1: 48,000$

Eaton, J.E., 1924, Structure of Los Angeles basin and environs: O1I Age, v. 20, no. 6, p. 8-9, 52 (1923); v. 21, no. $1, p$. $16-18,52,54(1924)$.

Eaton, J.P., 1984, Norse analysis of the seismic system employed in the northern and southern California seismic nets: U.S. Geological Survey Open-File Report 84-657,39 p.

Ebert, F.C., 1921, Records of water levels in wells in southern California: U.S. Geological Survey Water-Supply Paper 468, $156 \mathrm{p}$.

Ebert, F.C., 1936, An interpretation of water-table fluctuations at four wells in southern California Transactions, American Geophysical Union, P. 371-378.

Eccles, L.A., 1979, Ground-water quality in the upper Santa Ana River basin, southern California: U.S. Geological Survey

Water-Resources Investigations Report 79-113, 51 p.
Eccles, L.A., 1979, Pesticide residues in agricultural drains, southeastern desert area, California: U.S. Geological Survey Water-Resources Investigations Report $79-16,60 \mathrm{p}$.

Eckis, R., 1934, South coastal basin investigation, geology and ground-water storage capacity of valley fill: California Department of Public Works Bulletin 45, 279 p. 5 pls.

Elders, W.A., 1979, Geology and geothermics of the Salton Trough: Geological Society of America Field Trip Guide, Riverside, University
Contribution $5,109 \mathrm{p}$.

\section{Southern California--Continued}

Eldridge, G.H., and Arnold, R., 1907, The Santa Clara Valley, Puente Hills, and Los Angeles oul districts, 309 $266 \mathrm{p}$.

Elevatorski, E.A., 1968, California fluorspar: California Division of Mines and Geology, Mineral Information

Estrem J.E. v. 21 , no. 9, p. 127-130. 1981 , Measurement of strain on $10-\mathrm{km}$ lines near Parkfield, Callfornia (abs.): Earthquake Notes, v. 52, no. 1, p. 26.

vans, J.G., Pankratz, L., Ridenour, J., Schmauch, S.W.', Mountain wilderness study area and the Cucamonga Wilderness and additions, Los Angeles and San Bernardino Counties, California: U.S. Geological Survey Open-File Report 77-251, $99 \mathrm{p}$.

Evernden, J.F., 1981, Gravity profiles in southern California: Maurice Ewing Series 4, p. 485-496.

Eymann, J.L., 1953, A study of sand dunes in the Colorado and Mojave Deserts (Calıf.): Los Angeles, University of Southern California, M.S. thesis.

Falrbanks, H.W., 1893, Geology of San Diego County lalso portions of Orange and San Bernardino Counties?: California State Mining Bureau, State Mineralogist Report 11 , p. $76-120$.

Fashag, W.F., 1926, Saline lakes, Mojave Desert,

Faughn, J.C., 1979, Map of Antelope valley-Kern Water Agency area, California, showing ground-water subunits and areas 79-1298, scale 1:125,000.

Ferguson, G.C., 1933, A correlation of beds in and around San Diego with certain beds in the Los Angeles Basin, California: Los Angeles, University of Southern california, M.s. thesis.

Ferguson, R.N., and Willis, C.G., 1924, Dynamics of oll-field structure in southern California: American
Association of Geologists Bulletin, v. 8 , no. 5 , p. $576-583$.

Feth, J.H., 1961, Effects of rainfall and geology on the chemical composition of water in coastal streams of California: U.S. Geol

Feth, J.H., 1967 , Chemical characteristics of bulk precipitation in the Mojave Desert region, California o.s. Geological Survey Professional Paper 575-c, p. C222-C 227 .

Fife, D.L., and Brown, A.R., eds., 1980, Geology and mineral wealth of the California desert: South coast Geological Society, $555 \mathrm{p}$.

Finkle, F.C., 1905, Pumping underground water in southern California: U.S. Geological Survey Water-Supply Paper 146 , p. $56-72$.

Fournier, R.O., and Thompson, J.M., 1980, The recharge area for the Coso, California, geothermal system deduced $f$ rom dD and d180 in thermal and non-thermal waters in the region: U.S. Geological Survey Open-File Report 80-454, $27 \mathrm{p}$.

Freeman, W.B., and Bolster, R.H., 1910, Surface water supply of the United States, 1907-8, part 9, Colorado River Basin:

French, J.J., Dutcher, L.C., and Dana, S.w., 1965, Progress report on water studies in the chino-Corona area, upper Santa Ana Valley, California, 1964, part 2: U.S. Geological Survey open-file report, $29 \mathrm{p}$

French, James, ed., 1978, Geologic guidebook to the Santa Ana River Basin, southern California: South Coast Geological Society, $97 \mathrm{p}$.

Frizzell, V.A., Jr., and Claypool, G.E., 1983, Petroleum potential map of Mesozoic and Cenozolc rocks in roadless areas in the Los Padres National Forest, southwestern california: v.S. Geological Survey Miscellaneous Field Studies Map MF-1655-D, scale $1: 250,000$.

Fuis, G.S., Johnson, C.E., and Richter, K.J., 1980, Preliminary catalog of earthquakes in northern Imperial valley. California, April 1978-June 1978: U.S. Geological Survey Open-File Report 80-1167, 21 p.

Fuis, G.S., Kohler, W.M., 1984, Crustal structure and tectonics of the Imperial valley region, California: Sociey of Economic Paleontologists and Mineralog Field Trip Guidebook, v. 40, p. 1-13.

Fuis, G.S., Mooney, W.D., Healy, J.H., McMechan, G.A., and Lutter, W.J., 1984, A seismic refraction survey of the Imperial Valley region, California: Journal of Geophysical Research, B, v. 89, no. 2, p. 1165-1189.

Fuıs, G.s., Mooney, W.D., Kohler, W.M., and Moos, Dan, 1981, A selsmic-refraction survey in the western Mojave Desert,

Fuis, G.S., Whitcomb, J.H., Johnson, C.E., Jenkins, D.J. Richter, K.J., Blanchard, A.C., Fischer, S.A., and Reed, B.A., 1978, Preliminary catalog of earthquakes in southern
Califfornia, October 1976-September 1977: U.S. Geological Survey Open-File Report 78-672, 87 p.

Gale, H.S., 1915, Salines in the Owens, Searles, and panamint basins, southeastern California: U.s. Geologica Survey Bulletin 580-L, p. 251-323.

Gale, H.S., 1932, Southern California: International Geological Congress, 16th session, Guidebook 16, Excursion C-1, 68 p. pl. 6, scale 1:500,000; pl. 1l, scale 1:375,000.

Gan, T.L.. 1962, Heavy minerals in sediments from Owens, China, Searles, and Panamint basins, southern California: Bloomington, Indiana University, Ph.D. dissertation.

Gatewood, J.S., 1945, Floods of September 1939 in Colorado River basin below Boulder Dam: U.S. Geological Survey water-Supply Paper 967-A, pt. 1, p. 1-39. 


\section{Southern California--Continued}

Gibbs, J.F., Fumal, T.E., and Roth, E.F., 1980, In-situ measurements of seismic velocites at 27 locations in the Los Angeles, California, region: v.s. Geological Survey OpenFile Report 80-378, $169 \mathrm{p}$.

Gilbert. C.M., 1938, Welded tuff in eastern California: Geological Society of America Bulletin, v. 49, no. 12, p.

Gleason, G.B., 1947, South coastal basin investigation, overdraft on ground-water basins: California Division of water Resources Bulletin 53, $256 \mathrm{p}$.

Glenn, F.M., 1982, Map of the Antelope Valley-East Kern water Agency area, California, showing ground-water subunits and areas, and well hydrographs (1962-1982): U.S. Geological areas, and well hydrographs $11962-1982$

Goldman, H.B., 1955, Sand and gravei for concrete aggregate: California Journal of Mines and Geology, v. 52 no. 1, p. 79-104.

Gray, C.H., Jr.. Kennedy, M.P., and Morton, P.K., 1971 petroleum potential of southern coastal and mountain area, California: American Association of Petroleum Geologists Memoir 15, v. 1 , p. 372-383.

Greene, H.G., Kennedy, M.P. , and McCarthy, R.J., 1982, New marıne geology map series; a tool for California coastal planners: Symposium on Coastal and Ocean Management 2, Proceedings, p. $2792-2796$

Greene, H.G., Lee, W.H., McCulloch, D.S., and Brabb, E.E., 1973, Fault map of the Monterey Bay region. California: U.S. Geological Survey Miscellaneous Field Studies Map MF-518. scale $1: 200,000$

Griscom, Andrew, 1980 , Salton Trough (Calif.): California Division of Mines and Geology Bulletin 205, p. 20-21.

Grobecker, A.J., 1941, Travel time curves at small distances and wave velocities of principal phases in the southern California ranges: Pasadena, California Institut of Technology, M.S. thesis.

Hake, B.F.. 1930, A study of faulting in the coast Ranges. California: Palo Alto, Calif., Stanford University, M.A.

Hall thesis.

, C.A., Jr., 1982, Pre-Monterey subcrop and structure contour maps, western San Luis Obıspo and Santa Barbara Miscellaneous Field Studies Map MF-1384, scale $1: 62,500$.

Hall, N.T. . and Harms, K.K., 1984, Uncertainties in slip-rates determination for the Pleito thrust fault, northern
Transverse Ranges, California: Earthquake Notes, v. 55, p. 9 .

Hall, W.H., 1888, Irrigation in (southern) California, the field, water supply and works, organization and operation in San Drego, San Bernardino, and Los Angeles Counties: The second part of the report of the State Engineer of California on irrigation and the irrigation questions: Sacramento, Calif.. State printing office, 672 .

Halliday, A.N., Fallick, A.E., Hutchinson, J., and Hildreth, W., 1984 , A N , Sr, and O isotopic investigation into the cause of chemical and isotopic zonation in the Bishop Tuff Californza: Earth and planetary Science Letters, v. 68, no. 3 , p. $379-391$.

Hamlin, Homer, 1904, Water resources of the Salinas Valley, California: U.S. Geological Survey Water-Supply Paper $89,91 \mathrm{p}$.

Handin, J.W., 1949, The source, transportation, and deposition of beach sediment in southern California: Los Angeles, Oniversity of California. Ph. D. dissertation.

Harbeck, G.E., Jr., 1955, The effect of salinity on evaporation: U.S. Geological Survey Professional paper $272-\mathrm{A}, 6 \mathrm{p}$.

Harbeck, G.E.. Jr., 1962, A practical field technique for measuring reservolr evaporation utilizing mass-transfer p. $101-105$

Harbeck, G.E...Jr., and others, 1951, Utılity of selected western lakes and reservoirs for water-loss studies: $0 . s$. Geological Survey Circular 103, $31 \mathrm{p}$.

Hardt, W.F., 1974, U.S. Geological Survey a1ds in water-resources studies of Antelope and Fremont Valleys, Los Angeles and Kern Counties, California: Presentation to Antelope valley Board of Trade, Water seminar, Palmale, Calif.. $9 \mathrm{p}$.

Harkrider, D.G., 1981. Support of the southern California Open-File Report 81-255, 3 p.

Harkrider, D.G., and Nickerson, R.F., 1981, Establishment of a southern California geophysical data and analysis center U.S. Geological Survey Open-F1le Report 81-395, $243 \mathrm{p}$.

Harris, R.A., and Langbein, J.o., 1984, The sensitivity of geodetic networks; detecting the amount and location of slip near Parkfield, California (abs): Eos, Transactions, American Geophysical Union, v. 65, no. 45, p. 853 .

Harrison, J.C., Von Huene, R.E., and Corbato, C.E., 1966, Bouguer gravity anomalies and magnetic anomalies off the coast of southern California: Journal of Geophysical Research, v. 71, p. 4921-4941.

Hart, E., Smith, D., and Saul, R.B., 1979, Summary report, California fault evaluation program, 1978 area--Peninsular Ranges Salton Trough region: California Division of Mine and Geology open-File Report 79-10 SF.

Hartzell, S.H., and Heaton, T.H., 1983, Inversion of strong ground motion and teleseismic waveform data for the fault rupture history of the 1979 Imperial valley, California, earthquake: Sersmological Society of America Bulletin, $v$ 73. no. 6, p. 1553-1583.

Hastorf, C.A., and Tinsley, J.C., 1981, Map showing locations of radiocarbon-dated samples in southern California: U.S. Geological Survey Miscellaneous Field Studies Map MF-1294, scale 1:500,000.

Havelka, D.E.. 1971, Changes of water quality of the Santa Ana River during the past two decades: American Society of Agricultural Engineers. Pacific Region, Annual Meeting. Las Vegas, Nevada, 12 p.

\section{Southern California--Continued}

Hazzard, J.C., 1933, Notes on the Cambrian rocks of the California Department of Geological Science Bulletin, v. 23 , no. 2, p. 57-70, map 1, scale $1: 187,500$.

Hazzard, J.C., Gardner, D.L.. and Mason, J.F., 1938 Mesozoic metavolcanic and metasedimentary rocks in San (abs.): Geological Society of America Proceedings for 1937, p.

Hedel, C.W., 1979, Index maps for large-scale vertıcal black and white aerial photographs of the Hayward and Calaveras faults, California: U.S.

Hedel, C.W., 1979. Index maps for large-scale vertical black and white aerial photographs of the Garlock and Big Pine faults, California: 0.S. Geological Survey Open-File Report 79-286, scale $1: 250,000$.

Hedel, C.W., and Vil ialobos, H.A., 1979, Index maps for largescale vertical black and white aerial photographs along the san Andreas Fault, California: U.S. Geological Survey OpenFile Report 79-287, scale $1: 250.000$.

Hedman, E.R., and Pearson, E.G., 1966, Floods of November and December 1965 in southern California: 0.S. Geological and December 1965 in southern

Henriksen, D.A., 1958, Fillmore oli field, in A gulde to the geology and orl fields of the Los Angeles and ventura regions, California: American Association of Petroleum reglons, California: America.

Henyey, T.L., Teng, Ta-liang, Hammond, D.E., Samms, C.G.,

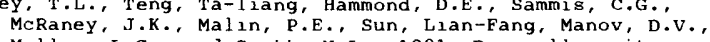
Miller, L.G., and Scott, N.L., 1981, Deepwell monitoring of strain-sensitive parameters over the greater southern
California uplift: U.S. Geological Survey Open-File Report $81-90,64 \mathrm{p}$.

Henyey, T.L., Teng, Ta-l lang, Hammond, D.E., and Sammis, C.G. 1981, Deepwell monitoring of strain-sensitive parameters over the greater southern California
Survey open-file Report $81-881,55 \mathrm{p}$.

Hershey, О.н., 1902, The Quaternary of southern California: University of California Department of Geological Sciences Bulletin, v. 3, p. 1-29, pl. 1, scale 1:125,000.

Hewett, D.F., 1928, Later Tertiary thrust faults in the Mojave Desert, California: National Academy of Science Proceedings,

v. 14, p. 7-12.
Hewett, D.F.. 1928, Two Tertiary epochs of thrust-faulting in Mojave Desert, California: Geolog

Hewett, D.F. 1954, A fault map of the Mojave Desert, California, in Geology of southern California: California Division of $1: 630,000$

Hewett, D.F.. 1955, Structural features of the Mojave Desert region (Calif.): Geological Society of America Scale 1 al Paper 62

H111, M.L., 1954, Tectonics of faulting in southern California, in Geology of southern California: California Division of Mines Bulletin 170 , chap. 4, p. 5-13.

H111, M.L., and Dibblee, T.W., Jr., 1953, San Andreas, Garlock, and Big Pine faults, California: Geological Society of America Bulletin, v. 64, p. 443-458.

H111. R.T., 1928, Southern California geology and Los Angeles earthquakes: Los Angeles, Calif.
California Academy of Science, $232 \mathrm{p}$.

Hills, F.A., 1985, Map showing outcrops of granitic rocks and silicic, shallow-intrusive rocks, Basin and Range Province, southern California: U.S. Geological Survey Water-Resource
Investigations Report 83-4116-D, $38 \mathrm{p}$., scale $1: 500,000$.

Hinckley, H.P. 1944, Review of the Irvine suit and its effect in limiting water conservation operations in San Bernardino County (Calif.): San Bernardino Valley Water Control District Bulletin $3,28 \mathrm{p}$.

Control District Bulletin 3,28 p.
Hinderlider, M.C., Swendsen, G.L., and Chandler, A.E. 1905 , Report on progress of stream measurements for the calendar year 1904, part 10, Colorado River and Great Basin drainage: U.S. Geological Survey Water-Supply Paper $133,384 \mathrm{p}$.

Hinderlider, M.C., and Swendsen, G.L., 1906, Report of progress of stream measurements for the calendar year

Hofmann, W. Briggs, R.C., and Littlefleld. W.M., 1963 , General review of the water resources of southern California for the water year 1952-53 with special reference to the surface runoff for the water year
$1951-52$ : U.S. Geological Survey open-file report, $30 \mathrm{p}$.

Howard, C.S., 1930, Quality of water of the Colorado River in 1926-1928: U.S. Geological Survey Water-Supply Paper

$636-A$, p. 1-14.
Howard, C.S., 1930. Suspended matter in the Colorado River in 1925-1928: U.S. Geological Survey Water Supply Paper

Howard, C.S., 1932, Quality of water of the Colorado River in 1928-1930: U.S. Geological Survey Water-Supply paper $638-\mathrm{D}, \mathrm{p} .145-162$.

Howard, c.s., 1947, Suspended sediment in the Colorado River, 1925-41: U.S. Geological Survey Water-Supply Paper $998,165 \mathrm{p}$.

Howard, K.A., and John, B.E., 1983, Extensional faulting through the upper crust, California-Arizona border (abs.): Geolono. 5 . 309 .

Howard, K.A., and Shaw, S.E., 1982, Mesozoic plutonism in the eastern Mojave Desert, Calıfornia (abs.): Geological Society
of America, Abstracts with Programs, v. 14, no.4, p. 174 . 


\section{Southern California--Continued}

Hoyt, W.C., and Troxell, H.C., 1934, Forests and stream flow: American Society of Civil Engineers Transactions, v. 99, paper 1858, p. 1-105.

Hulsemann, J.E., 1951, Submarine geology of Cortes and Tanner Banks (Calif.): Los Angeles, University of Southern California, M.S thesis.

Hutton, L.K., and Johnson, C.E., 1981, Summary of seismicity in the southern California region (abs.): Earthquake Notes, v. 52, no. 1, p. 63 .

Irelan, Burdge, 1971. Salinity of surface water in the lower Colorado River-Salton Sea area: U.S. Geological

Survey Professional paper 486-E. $40 \mathrm{p}$.
Isaacs, C.M., 1981, Porosity reduction during diagenesis of the Monterey Formation, Santa Barbara coastal area, California. in Garrison, R.E.. ed.. The Monterey Formation and related siliceous rocks of California: Los Angeles. Calif., Society of Economic Paleontologists and Mineralogists, Pacific Section, p. 257-271.

Isaacs, C.M., 1982, Diagenesis of diatomaceous rocks in the Miocene Monterey Formation of California; a review (abs.): International Congress on Sedimentology (Congres International de sedimentologiel, v, 11, p. 14

Isaacs, C.M. 1982, Influence of rock composition on kinetics of silica phase changes in the Monterey Formation, Santa no. 6 , p. $304-308$.

Isaacs, C.M., 1984, Disseminated dolomite in the Monterey Formation. Santa Maria and Santa Barbara areas, California: Society of Economic Paleontologists and Mineralogists, Pacific Section, Field Trip Guidebook, v. 41, p. 155-169. c. C.M. 1984, Geology and physical properties of the Monterey Formation, California: Society of Petroleum Geologists Annual California Regional Meeting, Proceedings. v. 54 , p. 83-96.

Isaacs, C.M., 1985, Field trip guide to deposition and dragenesis areas, California: U.S. Geological Survey Open-E $84-98,65$

Ives, Lt. J.C., 1861, Report upon the colorado River of the West: External document, u.s. 36 th Congress, 1st
session: pt. 1, 131 p.; pt. 2, 14 p.; pt. 3, 154 p.; pt

Ives, Lt. J.C. , and churchill, C., 1858, Exploration of the Colorado River: Washingtó, D.C., United States

Archives, map.
Jahns, R.H., 1954 . Geology of the Peninsular Range Province, southern and Baja California, in Geology of southern 2 , contribution 3 , p. 29-52.

Jahns, R.H., 1954, Northern part of the Peninsular Range province in Geology of southern California: California

Jahns, R.H., 1954, Pegmatites of southern Calıfornia in Geology of southern California: California Division of Mines Bulletin 170, chap. 7, contribution 5, p. 37-50. California Division of mines Bulletin 170, 10 chaps., 5 guidebooks, 34 map sheets, $878 \mathrm{p}$.

Jenkins, O.P., ed., 1943, Geologic formations and economic development of the oil and gas frelds of Californa: California Division of Mines Bulletin 118,773 p.

Johnston, M.J., 1984, Local magnetic fields, uplift, gravity, and dilational strain changes in southern California (abs.): Eos, Transactions, American Geophysical Union, v, 65, no. 45 , p. 854 .

Joyner, W.B., Warrick, R.E., and Funal, T.E., 1981, The effect of Quaternary alluvium on strong ground motion in the Coyote Lake, Californat, earthquake of

Kahle, J.E., Bodin, P.A., and Morgan, G.J., 1985, Preliminary geologic map of the California-Baja California border region: California Division of Mines and Geology Open-File Report 84-59 LA, 8 p., scale 1:250,000.

Kanamori, Hi roo, and McNaliy, Karen, 1981, Seısmicity studes for earthquake prediction in southern California using a mobile seismographic array: U.S. Geological Survey Open-File Report 81-282, $226 \mathrm{p}$.

Keller, Gerta, and Barron, J.A., 1981, Integrated planktic foraminiferal and diatom biochronology for the northeast Pacific and Monterey Formation, in Garrison, R.E., ed.. The Monterey Formation and related siliceous rocks of California: Los Angeles, Calif., Society of Economic Paleontologists and Mineralogists, Pacific Section, p 43-54.

Keller, M.A., 1982, Diagenetic maturity of the Monterey Formation near oja1, California: American Association of Petroleum Geologists, Pacific Section, Pacific Petroleum Geologist Newsletter, June 1982, p. 3-5.

Kew, W.S.W., 1932, Los Angeles to Santa Barbara: International Geologic Congress 16, Gu1debook 15, p. 48-68.

Kilburn, J.E., Detra, D.E., and Chazin, Barbara, 1983, Chemical and statistical analysis of stream sediments, panned heavymineral concentrates, and rocks of the Coxcomb Mountains Wilderness Study Area (CDCA-328), Riverside and San Bernardino Counties, Calıfornia: U.S. Geological Survey Open-F1le Report 83-12, 151 p.

Killkenny, J.E., 1971 , Future petroleum potential of region 2, Pacific coastal states and adjacent continental shelf and slope: American Association of Petroleum Geologists Memoir 15, v. 1, p. 170-177.

King, E.J., Tinsley, J.C., and Preston, R.F., 1982, Maps showing historic floodings in the San Fernando Valley, California, 1934 to 1956: U.S. Geological Survey Open-File Report $81-153,7 \mathrm{p}$

King, F.H., 1898, Principles and conditions of the movement of ground water:

\section{Southern California--Continued}

Kıng, N.E., Savage, J.C., 1984, Regional deformation near Palmdale, California, 1973-1983: Journal of Geophysical Research, B, v. 89, no. 4, p. 2471-2477.

Kıng, N.E., and Savage, J.C., $198 i$, Geodetıc measurement of crustal deformation at the junction of the San Andreas and 25 .

Klein, J.M., and Bradford, W.L., 1980, Dissolved-solıds concentrations and loads in return flows to the Colorado Geological Survey Water-Resources Investigations 80-52, 58

Kleinpell, R.M., 1938, Miocene stratıgraphy of California Tulsa, Oklahoma, American Association of Petroleum Geologists, $450 \mathrm{p}$.

Knapp, R.R., and others, 1962, Cenozorc correlation section across Los Angeles basin from Beverly Hills to Newport. Califorina. American Association of petroleum Geologists, Pacific Section, chart.

Knott, J.M., 1978, Reconnassance assessment of erosion and sedimentation in the Canada de los Alamos basin, Los Angeles and Ventura Counties, California: U.S. Geological Survey open-File Report 78-872, 49 p.

knott, J.M., 1980, Reconnasssance assessment of erosion and sedimentation in the Canada de los Alamos basin, Los Angeles and Ventura Count ies, California: U.S. Geological Survey Water-Supply Paper 2061, 26 p.

Koberg, G.E., 1964, Methods to compute long-wave radiation from the atmosphere and reflected solar radiation from a water surface: U.S. Geological Survey Professional Paper $272-F$, p. $107-136,4$ figs.

Kocher, A.E., and Youngs, F.O., 1926, Soll survey of the Palo Verde area, Cali for Agriculture, p. $571-625$.

Kockelman, W.J., 1983 , Examples of the use of geologic and seismologic information for earthquake-hazard reduction in southern California: U.S. Geological Survey Open-File Report $83-82,59$ p.

Koehler, J.H., 1975, Map of the Antelope Valley-East Kern Water Agency area, California, showing ground-water contours for spring 1975: U.s. Geological survey open-file report, map, scale $1: 125,000$.

Koehler, J.H., and Ballog, A.P., Jr., 1979, Source of powerplant cooling water in the desert area of southern California, reconnassance study: California Department of water Resources Bulletin 91-24, $55 \mathrm{p}$.

Koehler, J.H., and Mallory, M.J., 1981, Addendum to: Sources of powerplant cooling water in the desert area of southern California--A reconnaissance study: U.s, Geological Survey Open-File Report 81-527, 32 p.

kroll, C.G., 1975, Estimate of sediment discharges, Santa Ana River at Santa Ana and Santa Maria River at Guadalupe, California: U.S. Geological Survey Water-Resources Investigations report 40-74, $18 \mathrm{p}$.

Kunkel, Fred, 1960, Reconnasssance of ground water in the western part of the Mojave Desert region, California: U.s. Geological Survey open-file report.

Kunkel, Fred, 1962, Reconnassance of ground water in the western part of the Mojave Desert region, California: U.S. Geological Survey Hydrologic Investigations At las HA-31, scale $1: 316,800$.

Lachenbruch, A.H.. Sass, J.H., and Galan1s, S.P., Jr., 1985, Heat flow in southernmost California and the origin of the Salton Trough: Journal of Geophysical Research, B, v. 90, no. 8 , p. 6709-6736.

Lachenbruch, A.H., and Sass, J.H., 1981, Corrections to 'Heat flow and energetics of the San Andreas fault zone' and some additional comments on the relation between fault friction and observed heat flow: Journal of Geophysical Research, v. 47 , no. 5 , p. $832-838$.

Lamar, D.L., Smith, J.L., La violette, J.W. . Custıs, K. and Scrivner, P.J., 1983, Application of private sitespecific data to regional evaluation of earthquake and
faulting potential in southern California: 0.S. Geological Survey Open-File Report 83-834, $218 \mathrm{p}$.

Lamar, D.L., and Merifield, P.M., 1980, Water level monitoring along San Andreas and San Jacinto faults, southern California, during fiscal year 1979: U.S. Geological survey open-File Report $80-1141,76 \mathrm{p}$.

Lamar, D.L., and Swanson, S.C., 198i, study of seismic activity by selective trenching along the Elsinore fault zone, $81-882,35$.

81-882, 35 p.
Lamb, C.E., 1980 , Map of the Antelope valley-East Kern water Agency area, California, showing ground-water subunits and areas, location of wells, and water-level contours for spring 1979: U.S. Geological Survey Open-File Report 80-1222, 1 map, scale $1: 125,000$.

Lamb, C.E., and Hadley, T.L. 1981, Map of the Antelope ValleyEast Kern Water Agency (Calif.): U.S. Geological Survey Open-F1le Report 81-698, map.

Lamb, C.E., and McIntyre, M.J., compilers, 1978, Map of the Antelope valley-East Kern Water Agency area, California, showing ground-water subunits and areas, and well hydro graphs: U.S. Geolo

Lamb, C.E., and Mermod, M.J., 1973, Ground-water data in Santa Barbara and southern San Luis Obispo Counties,
California, spring 1970 to spring 1973: U.s. Geological

Survey open-file report, 131 p.
Langbein, W. B., 1961, Salinity and hydrology of closed lakes: U.S. Geological survey professional Paper 412, 20 p. 


\section{Southern California--Continued}

Langer, W.H., Moyle, W.R., Jr., Woolfenden, L.R., and Mulvihill, D.A., 1984, Maps showing ground-water levels, springs, and depth to ground water, Basin and Range Province, southern Calıfornia: 0.s. Geological Survey water-Resources Investigations Report 83-4116-B, 6 P.

Larsen, E.S., Jr., 1948, Batholith and associated rocks of Corona, Elsinore and San Luis Rey quadrangles, southern California: Geological Soclety of America, Memolr 29, p. 1-182, pl. 1, scale $1: 125,000$.

Larsen, E.S., Jr., 1951, Crystalline rocks of southwestern California: California Division of Mines Bulletin 159, 136 p.

Larsen, E.S., Jr., 1951, Geologic map of Corona, Elsinore, and San Luis Rey quadrangles, southern California, in Crystall ine rocks of southwestern Cal fornia: Cal forn. Division of Mines Bulletin 159, 128 p., scale 1:125,000.

Larsen, E.S.. Jr., and Keevil, N.B., 1947, Radioactivity Geological Society of America Bulletin, v. 58 , no, 6 , p. 483-494, fIg. 1, scale $1: 625,000$.

Lee, W.H.K, Johnson, C.E., Henyey, T.L., and Yerkes, R.L., 1978 A preliminary study of the Santa Barbara, Callfornia, earthquake of August 13,1978, and its major aftershocks: U.S. Geological Survey Cırcular 797, 11 p.

Lee, W.H.K., Herd, D.G., Cagnett1, V., Bakun, W.H., and Rapport, A., 1979, A preliminary study of the Coyote Lake earthquake of August 6, 1979, and its major aftershocks, California: U.S. Geological Survey Open-File Report 79-1621, 43 p.

Leslie, R.B., 1981, Continuity and tectonic implications of the San Simeon-Hosgri fault zone, central California: U.S.

Geological Survey Open-File Report $81-430,64 \mathrm{p}$.
Levine, Paia, and Yerkes, R.F., 1985, Distribution of abnormally high pore pressures in the western Transverse Ranges, 19 p.

Lewis, R.E., and Miller, R.E., 1968, Geolog1c and hydrologic maps of the southern part of Antelope valley, California: Supplement to U.S. Soll Conservation Service report on the

Lindh, A.G., Bakun, W.H., Ellsworth, W., and O'Neill, M.E., 1983 Long term probability estimates and an earthquake prediction experiment a long the San Andreas Fault system (abs.): Eos,
Transactions, American Geophysical Union, v. 64, no. 45, p. 761 .

Liu, Hsur-Lin, and Heaton, Thomas, 1984, Array analysis of the ground velocities and accelerations from the 1971 San Fernando, California, earthquake: Seismological Society of America Bulletin, v. 74, no. 5, p. 1951-1968.

Lıvingstone, A., Jr., and Putnam, W.C., 1933, Geological journeys in southern California: W.C. Brown Publishers, $154 \mathrm{p}$.

Loew, 0., 1876, Report on the geological and mineralogical character of southeastern California and adjacent regions: U.S. Geographical and Geological Surveys West of the 100 th Meridian, Annual Report to the Chief of Engineers, appendix JJ, p. 173-199, 5 figs.

Lohman, s.W., 1944, Report of the committee on ground water, 1942-43: American Geophysical Union Transactions, pt. 2, January 1944, p. 409-417.

Los Angeles, city of, Department of Public Service, 1916, Complete report on the construction of the Los Angeles P.

Lynch, B.B., 1931, Rainfall and stream run-off in southern California since 1769: Met

Mabey Southern California, 31 p. D.R., 1956, Geophysical studies in the intermontane p. $839-853$

Mabey, D.R., 1960, Gravity survey of the western Mojave Desert, Calıfornia: u.s. Geological Survey Professional Paper 316-D, P. D51-D73.

Mabey, D.R., 1972, Principal facts for gravity stations in the western Mojave Desert, California: U.S. Geological $43 \mathrm{p}$.

Macrostie, W., and Dolcinı, A.J., 1959, Santa Ana River (Calif.) investigation: California state water Resources Board Bulletin 15, 207 p.

Mallory, v.s., 1959, Lower Tertiary biostratigraphy of the California Coast Ranges: Tulsa, Oklahoma, American Association of Petroleum Geologists, 416 p.

Mark, R.K.. Tinsley, J.C., Newman, E.B., Gilmore, T.D., and Castle, R.O., 1981, An assessment of the accuracy of the geodetic measurements that define the southern California uplift: Journal of Geophysical Research, v. 86, no. 4, p. $2783-2808$.

Marsh, S.P.. 1979, Rutile mineralization in the white Mountains andalusite deposit, California: 0.S. Geological Survey OpenFile Report 79-1622, 9 p.

Mase, C.W., Sass, J.H., Brook, C.A., and Munroe, R.J., 1981, Shallow hydrothermal regime of the East Brawley and Glamis known Geothermal Resource Areas, Salton Trough, California: u.s. Geological Survey Open-File Report 81-834, 59 .

Matti, J.C., Cox, B.F., Obl, C.M. Powell, R.E., Hinkle, M.E. and Griscom, Andrew, 1982 , Mineral resource potential map of the whitewater Wilderness study area, Riverside and San Bernardino Counties, California: U.S. Geological Survey

Miscellaneous Field Studies Map MF-1478-A, scale $1: 24,000$.
Matti, J.C., Cox, B.F., and Iverson, S.R., 1983, Mineral resource potential map of the Raywood Flat roadless areas, San Geological Survey Miscellaneous Field Studies Map MF-1563-A scale $1: 62,500$.

\section{Southern California--Continued}

Matt1, J.C., and Morton, D.M., 1982, Geologic history of the Banning fault zone, southern California (abs.): Geological Society
p. 213 .

Maxham, R.M., 1952, Alrborne radioactivity surveys in the Mojave Desert region, Kern, Riverside, and San Bernardino

Counties, Calıfornia: U.S. Atomic Energy Commission, TEI. S.R., and Repenning, C.A., 1982, New evidence for the age of vertebrate Paleontology, v. 2, no. 1, p. 109-113.

May, S.R., and Repenning, C.A., 1982, New evidence for the age of the old woman Sandstone, Mojave Desert, California, in Transverse Ranges, southern California: Geological society Transverse Ranges, southern Califor
of America, Guidebook, p. 93-96.

Mcclelland, E.J., 1964 , Aquifer-test compilation for the Los Angeles and Santa Ana reglons, California: U.S.

Geological Survey open-file report, $127 \mathrm{p}$.
Mcclelland, E.J. Mojave Desert region, California: U.S. Geological Survey open-file report, $47 \mathrm{p}$.

Mccrory, P.A., Greene, H.G., Lajole, K.R., 1977, Map showing earthquake intensity zonation and distribution of Quaternary deposits, San Mateo, Santa Cruz, Monterey Counties. California: U.S. Geological Survey Miscellaneous Field studies Map MF-903, scale $1: 250,000$.

Mccrory, P.A., Greene, H.G., and Lajole, K.R., 1977, Map showing earthquake intensity zonation and distribution of quaternary deposits, San Mateo, Santa Cruz, and Monterey Counties, California: U.S. Geological Survey

McCulloh, T.H., 1960, Gravity variations and the geology of the Los Angeles basin of California, in Short papers in the geological sciences: 0.s. Geological Survey

Professional paper 400-B, P. B325.
McCulloh, T.H. and Stewart, R.J.. 1982, Laumontite in the western Transverse Ranges, Cal ifornia; mark of Neogene (abs.): Geological Society of America, Abstracts with programs, v. 14 , no. 4, p. 213-214

MCGlashan, H.D., 1921, Surface-water supply of the Pacific slope of southern California: U.S. Geological Survey water-Supply Paper 447, $557 \mathrm{p}$.

McGlashan, H.D., 1930, Surface-water supply of Pacific slope basins in southern California, 1894-1927: 0.S. Geological Survey water-Supply Paper 636-E, P. 169-219.

McGlashan, H.D., and Ebert, F.C., 1918, Southern Calıfornia floods of January 1916: U.S. Geological Survey Water-Supply Paper $426,80 \mathrm{p}$.

McKee, E.H., Diggles, M.F., Donahoe, J.L., and Elliot, G.S., 1982, Geologic map of the White Mountains Wilderness and Roadless Areas, California and Nevada: U.S. Geological Survey $\mathrm{Mi}$
$1: 62,500$.

McNeal, J.M., Miller, W.R., and Motooka, J.M., 1982, Geochemical mapping of the distribution of elements in stream sediments, southern Coast Ranges, Cal ifornia (abs.): Geological Society of America, Abstracts with Programs, v. 14, no. 4, p. 214.

Meeker, R.I.., and Reed, H.S., 1908, Surface water supply of Colorado River dralnage above Yuma, 1906: U.S. Geological Survey Water-Supply Paper $211,149 \mathrm{p}$.

Meinzer, O.E., 1923, OutIine of ground-water hydrology:
U.S. Geological Survey water-Supply Paper 494, 71 . U.S. Geological Survey water-Supply Paper 494, 71 . inzer, O.E., 1924, Investigations of ground water in the Congress, Melbourne, Australıa, 1923, v. 2, p. 1284-1290. nzer, O.E., 1927, Plants as indicators of ground water: U.S. Geological Survey water-Supply Paper 577, 95 p. summary of ground-water conditions and resources. utilization of water from wells and springs, methods of scientific investigation, and literature relating to the subject: U.S. Geological Survey water-Supply Paper 836-D. p. $157-232$.

Mendenhall, w.C., 1905, The underground waters of California: National Irrigation Congress 12 , El Paso, Texas, November 15-18, 1904, Proceedings, p- 150-158.

Mendenhall, W.C., 1905, Underground waters of southern Calıfornia: U.S. Geological Survey Water-Supply Paper 146 p. $113-121$.

Mendenhall, w.C., 1907, Fluctuations in ground-water levels in southern Calıforna: U.S. Geological Survey Water-Supply Paper 213, p. 189-205.

Mendenhall, w.C., 1908. Two mountain ranges of souther California (abs.): Geological Society of America Bulletin 18 , p. $660-661$

Mendenhal1, W.C., 1909, A phase of ground-water problems in the West: Economic Geology, v. 4, no. 1, p. 35-45.

Mendenhall, w.c., 1909, Some desert watering places in southeastern Cal ifornia and southwestern Nevada: 0.S.

Mendenhall, w.C., 1909, The Colorado Desert: National Geographic Magazine, v. 20, p. 681-701.

Mendenhall, W.C., 1910, Fluctuations in ground-water levels in southern California: U.S. Geological Survey water-Supply Paper 251, p. 338-348.

Mendenhall, W.C., 1914, Fluctuations in ground-water levels in southern Calıfornia: U.S. Geological Survey Water-Supply Paper 331, p. 425-434.

Merriam, J.C., 1915, Extinct faunas of the Mojave Desert, their in America: Popular Science Monthly, v. 86, p. 245-264.

Merriam, J.C., 1919, Tertiary mammalian faunas of the Mohave Desert: University of Cal ifornia, Department of
Geologic Science Bulletin, v. 11, p. 437-585, illustrations. 
CATEGORY 5: SOUTHERN CALIFORNIA AND OFFSHORE

\section{Southern California--Continued}

Merrill, F.J.H., 1919, Los Angeles, Orange, and Riverside Counties (Calif.): California Mining Bureau Report 15 , p. $461-589$

Metzger, D.G., 1965, A Miocene(?) aquifer in the Parker-Blythe-Cibola area, Arizona and California: U.S. Geological Survey Professional Paper 525-C, p. C203-c205.

Metzger, D.G., 1968, The Bouse Formation (Pliocene) of the Parker-Blythe-Cibola area, Arizona and California: U.S. Geological Survey Professional Paper 600-D, p. D126-D136.

Metzger, D.G., Loeltz, O.J., and Irelan, Burdge, 1973, Geohydrology of the Parker-Blythe-Cibola area, Arizona and Calıfornia: U.S. Geological Survey Professional Paper 486-G, p. G1-G130.

Meyers, J.S., 1962, Evaporation from the 17 western States: U.S. Geological Survey professional paper 272-D,

Mill D. D71-D100. , C.D., 1985, Holocene eruptions at the Inyo volcanic chain, Californa; 1mplications for possible eruptions in p. 14-17.

Miller, D.M., Howard, K.A., and John, B.E., 1982, Prel xmınary geology of the Bristol Lake region, Mojave Desert, California, in Cooper, J.D., ed., Geologic excursions in the California desert: Boulder, Colo., Geological Socjety of America, p. 91-100.

Miller, F.K., and Morton, D.M., 1980 , Potassium-argon geochronology of the eastern Transverse Ranges and southern Mojave Desert, southern California: U.S. Geological Survey Professional Paper 1152, $30 \mathrm{p}$. Miller, G.A., ed., 1973 , Guldebook to the Tertiary geology
of eastern orange and Los Angeles Counties, Calıfornia South Coast Geological Society, $92 \mathrm{p}$.

Mxller, R.E., 1966, Land subsidence in southern Calufornia in Guldebook of engineering geology in southern California: Association of Englneering Geologists, Los Angeles section, annual meeting, Los Angeles, Calif. October 1966, p. 271-279.

Miller, R.E., 1971, The Geological Survey and water for southern California: v.s. Geological Survey open-file

report, 15 p.
M11ler, W.J., 1931, Geologic section across the southern Sierra Nevada of California: University of californ Department of Geological Science Bulletin, v. 20 , p. $331-360$. Miller, W.J., 1935, A geologic section across the southern
Peninsular Range of California: California Journal of Mines and Geology, v. 31, no. 2, p. 115-142, pl. 2, scale $1: 168,960$.

Miller, w.J., 1935, Geomorphology of the southern Peninsular Range of California: Geological Society of America Bulletin, v. 46, p. 1535-1562.

MInch, J.A., 1970, Early Tertiary paleogeography of a portion of the northern Peninsular Range, in Pacific and adjacent Alta California: American Association of Petroleum Geologists Field Trip Guidebook, 160 .

Minch, J.A., 1972, The Late Mesozolc-Early Tertiary framework of continental sedimentation, northern peninsular Ranges, Baja California, Mexico: Riverside, University of California, Ph.D. dissertation.

Moody, J.D., and H1ll, M.J., 1956, wrench-fault tectonics: Geological Society of America Bulletin, v, 67, no. 9, p. $1207-1246$.

Mooney, W.D., and Luetgert, J.H., 1982, A seismic refraction study of the Santa Clara valley and southern Santa Cruz Mountains, west-central California: Selsmological Society of America Bulletin, v. 72, no. 3, p. 901-909.

Moore, B.N. 1935. Some strontium deposits of southeastern California and western Arizona: American Institute of Mining, Metallurgy and Engineering, Technical Publication Transactions, v. 115, p. 356-377, fig. 2, scale $1: 14,400$.

Moore, G.W., and Kennedy, M.P., 1970, Coastal geology of the california border area, in Pacific slope geology of northern Baja California and adjacent Alta callfornia: American Association of petroleum Geologists, Pacific Section, Fall Field Trip Guidebook, p. 4-9.

Moreland, J.A., 1972, Artificial recharge in the upper Santa Ana Valley, southern Calıfornıa: U.S. Geological Survey open-file report, 51 p., 11 fig. 13 tables.

Morton, D.M.. Mattin, J.C., and Tinsley, J.C., 1982, Quaternary history of the cucamonga fault zone, southern California (abs.): Geological Society of America, Abstracts with programs, v. 14, no, 4, p. 218 .

Morton, D.M., Miller, F.K., and Smith, C.C., 1980, Photoreconnalssance maps showing young-looking fault features in the southern Mojave Desert, California: D.S. Geological Surve

Miscellaneous Field Studies Map MF-1051, scal northern peninsular Ranges, southern Cal the Elders, W.A., ed.. Geological excursions in southern California: Riverside, Calif., Geological Society of America, Cordilleran Section. Gueld Trip Guidebook.

Motts, w.S., ed., 1970, Geology and hydrology of selected playas in western United States: Final scientific report, part 2: Amherst, University of Massachusetts, $286 \mathrm{p}$.
e, W.R., Jr., 1965, Water wells in the western part of the Antelope valley area, Los Angeles and Kern counties, California: California Department of Water Resources Bulletin 91-11, 16 p., 6 app.

Moyle, W.R., Jr., 1967, Water welis and springs in Bristo1, Broadwell, Cadiz, Danby, and Lavic valleys and vicinity, San Bernardıno and Riverside Counties. California: California Department of water Resources Bulletin 91-14, 17 p., 5 apps

Moyle, w.R., Jr., 1968, Water wells and springs in Borrego, Carrizo, and San Felipe Valley areas, San Diego and Imperial Counties, California: California Department of water Resources Bulletin 91-15,16 p., 5 apps.

\section{Southern California --Continued}

Moyle, W.R., Jr., 1969, water wells and springs in Panamint, Searles, and Knob valleys, San Bernardino and Inyo Counties, California: California Department of water Resources Bulletin 91-17,110 p.

Moyle, w.R., Jr., 1974, Geohydrologic map of southern Cal ifornia: v.s. Geological Survey water-Resources
Investigations report 48-73, map.

Moyle, W.R., Jr., 1974. Temperature and chemical data for selected thermal wells and springs in southeastern California: v.S. Geological Survey water-Resources Investagations $33-73,12 \mathrm{p}$.

Moyle, W.R., Jr., 1980, Ground-water-level monitoring for earthquake prediction, a progress report based on data
collected in southern California, 1976-79: v.S. Geological survey open-File Report 80-413,60 p.

Murdoch, J., and Webb. R.W., 1942, Notes on some minerals from southern California, part 2: American Mineralogist, v. 27, no. 4, p. 323-330, fag. 2, scale 1:25,000.

Nakata, J.K.., Wilshire, H.G., and Barnes, G.G., 1981, origan of Mojave Desert dust storms photographed from space on January 1, 1973: Geological Society of Ameruca Special paper 186 , p. $223-232$.

Nason, Robert, 1980, Damage in Santa Clara and Santa Cruz Counties, California, from earthquake of 18 April 1906: U.s. Geological Survey Open-File Report 80-1076,68 p.

Nea1, J.T., 1965, Geology, mineralogy, and hydrology of U.S. playas: U.S. Air Force, Cambridge Research Laboratories, Environmental Research Papers, no. 96. dessication polygons of Great Basin playas: Geological Society of America Bulletin, v. 79, p. 69-90.

Newell. F.H, 1901, Report of progress of stream measurements for the calendar year 1899 : U.S. Geological Survey Annual Report 21 , pt. 4 , p. 9-488.

Nilsen, T.H., 1984, Submarine-fan facies associations of the Eocene Butano Sandstone, Santa Cruz Mountains, California: Geo-Marine Letters, v. 3, no. 2-4, p. 179-185.

Noble, L.F., 1931, Nitrate deposits in southeastern California, with notes on deposits in southeastern Arizona and southwestern New Mexico: U.S. Geology Survey Bulletin 820
p., fig. 3, scale $1: 48,000$; fig. 4, scale $1: 48,000$.

Nolan, K.M., and Marron, D.C., 1985, Contrast in stream-channel response to major storms in two mountainous areas of California: Boulder, Colo., Geology, v. 13, no. 2, p. 135138 .

Norris, M.L., 1939, The geology of southern California: George Washington University, M.A, thesis.

o'Neill, M.E., 1984, Source dimensions and stress drops of small earthquakes near Parkfield, California: Seismological

Society of America Bulletin, v. 74, no. 1, p. 27-40.
obradovich, J.D., and Naeser, C.W., 1981, Geochronology bearing of the age of the Monterey Formation and siliceous rocks in California, in R.E. Garrison, ed. 'The Monterey Formation and related siliceous rocks of California: Los Angeles, gists, Pacific Section, p. B7-95.

oliver, H.W., 1980, Peninsular Ranges, in Interpretation of the gravity map of California and 1 ts continental margin: California Division of Mines and Geology Bulletin 205, p $17-20$.

Oliver, H.W., 1980, Transverse Ranges, in Interpretation of the gravity map of Cal fornia and its continental margin: $15-17$.

Peale, A.c., 1886, List and analyses of the mineral springs of the United States (a preliminary study): U.S. Geological

Survey Bulletin 32 (section for Californía, p. 330-342). 2, Virgilio, 1982, The Imperial Valley, California, earthplots: o.s. Geological survey ependent response spectrum

peterson, R.A., 1935, Results of gravity measurements in southern California: Pasadena, California Institute of Technology, Ph.D. dissertation.

Phinney, R.A., and Leary, P.C., 1981, Continuous monitoring and interpretation of crustal velocity changes near Palmale, $331 \mathrm{p}$.

piper, A.M., 1941, Ground-water conditions along the Pacific coast with respect to salt-water intrusion: U.S. Geological Survey Ground Water Division conference on Salt-water problems and methods of investigation, May 1941 .

Piper, A.M., Garrett, A.A., and others, 1953, Native and contaminated ground waters in the Long Beach-Santa Ana
area, California: U.S. Geological Survey Water-Supply Paper $1136,320 \mathrm{p}$.

Piper, A.M., and Poland, J.F., 1944, Geologle features along the southern california coast which influence the chemical character of ground water in the south coastal

basin: u.s. Geological Survey open-file report, $30 \mathrm{p}$.
poland, J.F., 1943, Saline contamination of coastal ground water in southern California: Western City, v. 19, no. 10, p. 46 48 , and 50 .

poland, J.F.. 1947, Ground-water basins of southern California with particular reference to the coastal-plain basins: U.S. Geological Survey report, $18 \mathrm{p}$

poland, J.F., 1949, Major ground-water basins of the state (Calif.): Report of the Interim Fact-finding Committee on water Pollution, Assembly of the State of California, 1949 Regular Session, p. $128-133$.

Poland, J.F., 1959, Hydrology of the Long Beach-Santa Ana area, California, with special reference to the watertightness of the Newport-Inglewood structural zone, with a section on withdrawal of ground water, 1932-41, by Allen Sinnott and J.F. Poland: U.S. Geological Survey 


\section{Southern California--Continued}

Poland, J.F., 1961, The coefficlent of storage in a region of major subsidence caused by compaction of an aquifer
system: 0.S. Geological Survey professional Paper 424-B, p. B52-B54

Poland, J.F., 1971, Land subsidence in the Santa Clara Valley, Alameda, San Mateo, and Santa Clara Counties, California: 0.S. Geological Survey Miscellaneous Field Studies Map MF-336, 1 sheet, scale 1:125,000.

Poland, J.F., 1972, Land subsidence in the western states due to groundwater overdraft: American Water Resources

Association Bulletin, v. 8, no. 1, p. 118-131, $11 \mathrm{figs}$.
pol and, J.F.. piper, A.M. geology' of the coastal zone, Long Beach-santa-water California: U.S. Geological survey Water-Supply paper $1109,162 \mathrm{p}$.

Poland, J.F.. and Davis, G.H., 1969, Land subsidence due to withdrawal of fluids: Geological Society of America,
Reviews in Engineering Geology 2, p. $187-269$, $49 \mathrm{figs}$, ? pls.

Pont1, D.J., 1982, The Quaternary alluvial sequence of the Antelope valley, California (abs.): Geological Society of

America, Abstracts with Programs, v. 14, no. 4, p. 225.
Porcella, R.L., 1984 , Geotechnical investigations at strongmotion stations in the Imperial valley, California (abs.) Earthquake Notes, v. 55, p. 26-27.

Porcella, R.L., 1985, Geotechnical investigations at strongmotion stations in the Imperial Valley, California: U.S. Geological Survey Open-File Report 84-562, $180 \mathrm{p}$.

Powell, R.E., 1982, Crystalline basement terranes in southern eastern Transverse Range, California, in Cooper, J.D., compiler, Geologic excursions in the Transverse Ranges, southern California: Geological Society of America Guidebook, p. 109-136.

Powell, R.E., 1982, Prebatholithic terranes in the crystalline basement of the Transverse Ranges, southern California
(abs.): Geological Society of America, Abstracts with Programs, v. 14 , no. 4, p. 225

Powers, W.R., 3d, 1970, Water-resources inventory, spring 1968 to spring 1969, Antelope Valley-East Kern Water Agency area, California: U.S. Geological Survey open-file report, $15 \mathrm{p}$.

Powers, W.R., 3d, and Irw1n, G.A., 1971, water-resources inventory, spring 1969 to spring 1970 , Antelope Valley-East Kern Water Agency area, California: U.S. Geological Survey open-file report, 19 p.

Pratt, W.P., and Smith, G.I., 1957, Core logs from Owens, China, Searles, and Panamint basins, California: U.S. Geological Survey Bul letin 1045-A, 62 p.

Quinn, H.A., and Cronin, T.M., 1984, Micropaleontology and depositional environments of the Imperial and Palm springs formations, Imperial valley, California: Society of Economic Paleontologists and Mineralogists, Pacific Section, Field Trip Guidebook, v. 40, p. 71-85.

Raines, G.L., Hoover, D.B., and Collins, William, 1984, Remotesensing mineral discoveries in the Mojave Desert of California (abs.): International Symposium on Remote sensing of Environment, Proceedings, v. 3, p. 153-154.

Rantz, S.E., 1970, Urban sprawl and flooding in southern

California: 0.s. Geological Survey Curcular $601-B, 11$ p.
Rantz, S.E., and Eakin, T.E., 1971 , A summary of methods for the collection and analysis of basic hydrologic data for arid regions: U.S. Geological Survey open-file report, $125 \mathrm{p}$.

Ratstein, Yair, Combs, Jim, and Blehler, Shawn, no date, Gravity investigation in southeastern Mojave Desert, Geoscience Contribution $282,30 \mathrm{p}$.

Reichle, Michael, and Brune, J.N., 1982 , Earthquake hazard and prediction in NW Mexico and the California/Mexico border: o.s. Geological Survey Open-File Report 82-62, 30 p.

Reynolds, J.R., and Wagner, C.G., 1975, Application of satellite imagery to geothermal resources exploration: Geothermal Energy, v. 3, no. 5, p. 45-54.

Rice, R.M., and Foggin, G.T., 3d, 1971, Effect of high intensity storms on soil slippage on mountainous watersheds in southern California: Water Resources Research, v. 7, p. 1485-1496.

Richmond, W.C., Cummings, L.J., Hamlin, Scott, and Nagaty, M.E., 1981 , Geologic hazards and constraints in the area of ocs oll and gas lease sale 48, southern California (sale held June 29, 1979): U.S. Geological Survey Open-File Report $81-307,37 \mathrm{p}$.

Robison, J.H., 1981, Data from geothermal gradient wells near Oasis, lower Coachella Valley, California: U.S. Geological Survey Open-File Report 81-41i, $29 \mathrm{p}$.

Rodgers, D.A., 1979, Vertical deformation, stress accumulation, and secondary faulting in the vicinity of the Transverse Ranges of southern California: California Division of Mines and Geology Bulletin 203.

Rogers, A.M., Covington, P.A., and Borcherdt, R.D., 1980, A comparison of ground response in the Los Angeles region from nuclear explosions and the 1971 San Fernando earthquake:
World Conference of Earthquake Engineers 7, Proceedings, p. 625-632.

Rojahn, Christopher, 1980, Selected papers on the Imperial valley, California, earthquake of October 15, 1979: U.s. Geological Survey Open-file Report 80-1094, 70 p.

Roller, J.C., Zoback, M.D., Raleigh, C.B., and Leichti, R.P., 1979, Preliminary report on drilling in and near the san Andreas fault zone, Cal ifornia: Dry Lake valley no. 1: U.s. Geological Survey Open-file Report 79-1206, 12 p.

Ross, D.C., 1983, Generalized geologic map of the southern sierra Nevada, California, showing the location of samples for which K-Ar radiometric age data and $\mathrm{Rb} / \mathrm{Sr}$ data have been determined: U.S. Geological Survey Open-file Report 83-231, scale $1: 250,000$.

\section{Southern California--Continued}

Ross, D.C., 1983, Hornblende-rich, high grade metamorphic terranes in the southernmost Sierra Nevada, California, and Geological Survey Open-File Report 83-465, 56 p.

Ross, D.C., 1983, Petrographic (thin section) notes on selected samples from hornblende-rich metamorhpic terranes in the southernmost Sierra Nevada, California: U.S. Geological Survey Open-File Report 83-587, 35 p.

Ross, D.C., 1985, Mafic gneissic complex (batholithic root?) in the southernmost Sierra Nevada, Ca
Geology, v. 13, no. 4, p. 288-291.

Ross, R.J., Jr., and McAllister, J.F., 1981, Steeply inclined stromatolite columns in upper Tertiary Furnace creek Formation, Death valley, California: The Mountain Geologist, v. 18, no. 3, p. 58-61.

Rowe, P.B., Countryman, C.M., and storey, H.C., 1954 Hydrologic analysis used to determine effects of fire on peak discharge and erosion rates in southern california watersheds: U.S. Forest Service, California Forest and Range Experimental Station, 49 p.

Rymer, M.J.'1982, Geologic map along a k1lometer segment of the San Andreas fault zone, southern Diablo Range, California: $0 . S$. Geological Survey open-File Report 81-1173, scale $1: 12,000$.

Saltus, R.W., 1982, A description of Bouguer anomaly and isostatic residual colored gravity maps of the southwestern Cordiliera (Calif.): U.S. Geological Survey Open-File Report $82-839,8 \mathrm{p}$.

Santa Ana River Watermaster, 1971, Annual report 1969-70: 27 p.

Sarna-Wojcick1, A.M., Bowman, H.R., Meyer, C.E., Russell, P.C., Woodward, M.J., McCoy, Gall, Rowe, J.J., Jr., Baedecker P.A., Asaro, Frank, and Michael, Helen, 1984, Chemical pleistocene ash layers of east-central southern California, v.s. Geological Survey professional Paper 1293, 40 p.

Sarna-Wojcickı, A.M., Bowman, H.W., Meyer, C.E., Russell, P.C., Asaro, Frank, Michael, Helen, Rowe, J.J., Baedecker, P.A., and McCoy, Gail, 1980, Chemical analyses, correlations, and ages of late Cenozolc tephra units of east-central and $80-231,57$.

Sarna-Wojc1ck1, A.M., Pampeyan, E.H., Hall, N.T., 1975, Map showing recently active breaks along the San Andreas fault between the central Santa Cruz Mountains and the northern Gabilan Range, California: U.S. Geological Survey

Sass, J.H., Galanis, S.P., Jr, Lachenbruch, A.H., Marshall, B.V., and Munroe, R.J., 1985, Temperature, thermal cond unconsolidated sediments of the Imperial valley, California: u.s. Geological Survey Open-File Report 84-490, 40 .

U.S. Geological Survey Open-File Report 84-490, 40 p.
Savage, J.C., Prescott, W.H., Lisowsk1, M., and King, N.E., 1981, Strain accumulation in southern California, 1973-1980: 7001

Savage, J.C., Prescott, W.H., and Lisowsk1, M., 1981, Deformation across the salton Trough, California, 1973-1980 (abs.):

Schoel lhamer. the Los Angeles basin, Los Angeles, Orange, and San Bernardino Counties, California: D.s. Geological Survey
O1l and Gas Investigations Map OM-117, scale $1: 125,000$.

Schultejann, P.A., and Engel, A.E., 1983, Integration of Seasat and SIR-A radar with detalled field mapping to define tectonic features and processes in southeastern california (abs.): Geological Society of America, Abstracts with programs, $v .15$, no. 5 , p. 315 .

Schwade, I.T., 1954, Geology of Cuyama valley and adjacent ranges, San Luis obispo, Santa Barbara, Kern, and Ventura countres in Geology of southern California: California Division of Mines Bulletin 170, scale $1: 187,500$.

Scott, K.M., and W1lliams, R.P., 1977, Erosion and sediment yields in the Transverse Ranges, southern California: U.s. Geological Survey Professional Paper $1030,38 \mathrm{p}$.

Scott, M.B., 1977 , Development of water facilities in the Santa Ana River basin, California, 1810-1968: A compilation of historical notes derived from many sources describing ditch and canal companies, diversions, and water rights: U.S. Geological Survey Open-Eile Report $77-398,231$ p., 67 figs.

scott, M.B., and Troxell, H.C., 1948, water losses in the lower Santa Ana Canyon, California: U.s. Geological Survey open-file report, 115 .

Sharp, R.P., 1954, Physiographic features of faulting in southern California in Geology of southern California: California Division of Mines Bulletin 170, chap. 5, $21-28$.

Sharp, R.V., 1980, Variable rates of late Quaternary strike slip on the San Jacinto fault zone, southern Californa: U.S. Geological Survey Open-File Report $80-95,38 \mathrm{p}$

Sharp, R.V., Lienkaemper, J.J., and Rymer, M.J., 1982, surface displacement on the Imperial and Superstition Hills faults triggered by the Westmorland, California, earthquake of 26 April, 1981: U.S. Geological Survey Open-File Report $82-282,38$ p.

Shawe, D.R., 1953, Heavy detrital minerals in stream sands of the eastern Sierra Nevada, between Lee Vining and
Independence, California: Palo Alto, Calif., Stanford University, Ph.D. dissertation.

Shephard, F.P., and Grant, U.S., 4th, 1947, wave erosion along the southern California coast: Geological Society of America Bulletin, v. 58, p. 919-926.

sidler, W.A., 1973, The great flood of January 22, 1862: San Bernardino County Museum Association Quarterly, v. 31, nos. 1 and 2 , p. 6-20 
CATEGORY 5: SOUTHERN CALIFORNIA AND OFFSHORE

\section{Southern California---Continued}

Slater, L.E., and Burford, R.O., 1984, A 2-color EDM experiment to monitor deformation near Parkfield, California (abs.) :
Eos, Transactions, American Geophysical Union, v. 65, no. 45, p. $852-853$.

slawson, W.F., and Savage, J.C., 1983, Deformation near the junction of the creeping and locked segments of the San

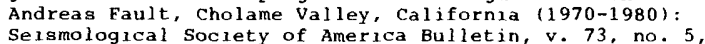
p. $1407-1414$ slichter, C.s. 1904 , Measurement of underflow streams in
southern California: Journal of the Western Society of Engineers, v. 4, p. 632-653. slichter, C.S., 1905, Field measurements of the rate of
movement of underground waters: U.S. Geological Survey water-Supply Paper $140,122 \mathrm{p}$.

Smith, G.I., 1982 , Quaternary paleohydrologic regimes in southeast California desert versus deep-sea isotopic records of "global" climate (abs.): Geological Society of America, Abstracts with Programs, v. 14 , no. 4, p. 235.

Smith, G.I., and Pratt, w.P., 1957, Core logs from Owens, China, Searles, and Panamint basins, california: U.S. Geological Survey Bulletin 1045-A, $62 \mathrm{p}$.

Smith, M.B., Engler, V.L., Lee, D.I., Horn, K.J., and Wayland, R.G., 1974, Reported occurrences of selected minerals in the southern third of California: U.S. Geological Survey Mineral Investigations Resource Map MR-49, scale 1:500,000. Smith, W.C.. 1958, Borate deposits of the Mojave region, 36.

Snyder, C.T., 1968, Examination of nine water-supply sites in the Bakersfield District, California: U.S. Bureau of Land Management, $6 \mathrm{p}$.

Snyder, C.T., Hardman, George, and Zdenek, F.F., 1964, pleistocene lakes in the Great Basin: U.S.' Geological

Survey Miscellaneous Geologic Investigations Map
snyder, H.J., 1955, Ground water in California, the experience of Antelope valley: University of California Collection, Agriculture, Giannini Foundation Ground-water studies $2,171 \mathrm{p}$.

Southern Pacific Co., 1958-61, Southern Pacific mineral survey maps: Southern Pacific Co., Land Department, 94 maps. scale $1: 24,000$.

Southern Pacific Co.. 1964, Minerals for industry, southern California: Southern Pacific Co., Summary of Geologica Survey of $1955-61$, v. 3, 242 p.

Spudich, Paul, and Cranswick, Edward, 1984, Direct observation of rupture propagation during the 1979 Imperial valley earthquake using a short baseline accelerometer array: Seismological Society of America Bulletin, v. 74, no. 6, p. 2083-2114

Spudich, Paul, and Cranswick, Edward, 1984, Soll strains and horizontal propagation velocities of strong ground motions observed during the 1979 Imperial Valley, California. earthquake: World Conference on Earthquake Engineering, proceedings, v. 8, no. 2, p. 231-238.

Spurr, J.E., 1903, Descriptive geology of. Nevada south of the fortieth parallel and adjacent portions of California: U.S. Geological Survey Bulletin 208,229 p., pl. 1, scale $1: 937,500$.

Stanford, G., England, C.B., and Taylor, A.W., 1970, Fertilizer use and water quality: U.S. Department of Agriculture, Agriculture Research Service 41-168, $19 \mathrm{p}$.

stearns, N.D., Stearns, H.T., and Warang, G.A., 1937 Thermal springs in the United States in Contributions to the hydrology of the United States, 1935: U.S. Geological Survey Water-supply paper 679-B, p. B59-B206.

stein, R.S., 1983, Historic vertical deformation in southern California; removal of systematic errors in geodetic leveling (abs.): Geological Association of Canada, Program with Abstracts, v. 8, p. A64.

stepp, J.C.. Laviolette, John, and Christenson, Gary, 1982, Seismic hazard study of the western portion of the Garlock fault (California): U.S. Geological Survey Open-File Report $80-1172,65 \mathrm{p}$.

Stewart, J.H., 1982 , Extensional tectonics in the Death Valley area, California; transport of the panamint Range structural block $80 \mathrm{~km}$ northwestward (abs.): Geological Soclety of
America, Abstracts with Programs, v. 14, no. 4, p. 237 .

stoddard and Karrer, 1964, Plans of the City of Los Angeles to construct the second barrel of Los Angeles aqueduct and increase diversions from the Mono and Owens basins: Los Banos, Calif.. 25 p.

Stone, R.o., 1956, A geologic investigation of playa lakes: Los Angeles, University of Southern Calufornia, Ph.D. dissertation.

Stone, R.S., 1957, Ground-water reconnalssance in the western part of the Mojave Desert, California, with particular respect to the boron content of well water: u.s. Geological Survey open-file report, $102 \mathrm{p}$.

storey, H.c.. 1948, Geology of the San Gabriel Mountalns, California, and its relation to water distribution: u.s. Forest Service, California Forest and Range Experiment Station, scale $1: 250,000$

sylvester, A.G., 1981, Dry tilt and nearfield geodetic investigations of crustal movements, southern California: U.S. Geological Survey Open-File Report 81-293, 95 p.

Szabo, B.J., and Vedder, J.G., 1971, Uranium-series dating of some pleistocene marine deposits in southern California: Earth and Planetary Science Letters, v. 10, p. $283-290$.

Taylor, B.D., Brown, W.M., 3d, and Brownlie, W.R., 1977, Progress report no. 3 on sediment management for southern California mountains, coastal plains, and shoreline: Pasadena, California Institute of Technology, EQL open-file report $77-78,87 \mathrm{p}$.

\section{Southern California--Continued}

Thenhaus, P.C., Perkins, D.M., Zlony, J.I., and Algermissen, S.T., 1981, Probabilistic estimates of maximum seismic horizontal ground motion on rock in coastal California and the adjacent outer continental shelf: U.S. Geological Survey Open-File Report 80-924, 69 p.

Thompson, D.G.. 1921, Routes to desert watering places in the Mohave Desert region, California: U.S. Geological Survey Water-Supply Paper 490-B, p. B87-B269.

Thompson, D.G., 1929, The Mohave Desert region, California, a geographic, geologic, and hydrologic reconnaissance: U.S. 20 figs.

Thompson, D.G., 1934, Report of the Committee on Underground Waters for 1933-34: American Geophysical Union Transactions, June 1934, p. 312-316.

Thompson, D.G., 1942, Report of the Committee on Underground Waters for 1941-42: American Geophysical Union Transactions, pt. 2, November 1942, P. 467-468.

Thompson, T.H., Nuter, Janet, Moyle, W.R., Jr., and Woolfenden, L.R., 1984, Maps showing distribution of dissolved solids and dominant chemical type in ground water, Basin and Range province, southern California: U.S. Geological Survey WaterResources Investigations Report 83-4116-C 7 .

Todd, V.R., and Shaw, S.E., 1985, S-type granitoids and an I-S line in the Peninsular Ranges batholith, southern California: Boulder, Colo., Geology, v. 13, no. 4, p. 231233 .

Tosdal, R.M., and Haxel, Gordon, 1982, Two belts of Late cretaceous to earth Tertiary crystalline thrust faults in southwest Arizona and southeastern California (abs.): Geological Society of America, Abstracts with Programs, v. 14 , no. 4, P. 240 .

Troxel1, H.C.. 1951, The influence of certain physlographic features on flood runoff in southern California: Brussels, Belgium, Assembly of the International Association of Hydrology, August 1951, Presentation, 14 p.; Assenblee Generale de Bruxelles, Tome 4, p. 131-139.

Troxell, B.C., 1956, Distribution of the natural water loss in the mountains of southern california (abs.): Transactions of the American Geophysical Union, v. 37, no. 3 , p. 366, presented at American Geophysical Union, Southwest Region, annual meeting, Los Angeles, University of Cal ifornia, January 26-27, 1956.

Troxel1, H.C., 1957, Water resources of southern California with special reference to the drought of 1944-51: U.S. Geological Survey water-Supply Paper 1366,139 .

Troxell, H.C.. Poland, J.F., and others, 1951, some aspects of the water supply in the south coastal basin: California: U.S. Geological Survey circular 105, 10 p.

rroxel 1, H.C., and Hofmann, Walter, 1954, Hydrology of the Mojave Desert, in Geology of southern California:
California Division of Mines Bulletin 170 , chap. 6 , p.

Troxel1, H.C., and Stafford, H.M., 1949, Natural water losses in mountain drainage areas of southern california: American Geophysical Union Transactions, v. 30, no. 5, p. $752-758$.

Troxel1, H.C., and others, 1942 (1943), Floods of March 1938 in southern California: U.S. Geological Survey water-Supply Paper $844,399 \mathrm{p}$.

Tyson, R.M., Theisen, A.F., Granata, J.S., and Hemphill, W.R., 1984, Detection of visible luminescence from a REE-bearing carbonatite in southern California (abs.): Geological 4 Soclety of America, Abstracts with Programs, v. 16, no. p. 259 .

U.S. Army Corps of Englneers, 1969, Beach erosion control report, cooperative research and data collection program of coast of southern Calıfornia, Cape San Martin to Mexican boundary, three-year report 1964-67-68: U.S. Army Corps of Engineers, Los Angeles District, p. 12-27.

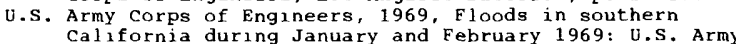
Corps of Englneers, Los Angeles District, p. 507, 41; appendix C, P. $18,48,56,66-67,76,84$.

U.S. Geological Survey and U.S. Bureau of Mines, 1979, Mineral resources of the Minarets Wilderness and adjacent areas, Madera and Mono Counties, Calıfornia: U.S. Geological Survey Open-File Report 79-1472, 196 p.

U.S. Geological Survey, 1947, Summary of records of surface waters at stations on tributaries in the lower Colorado Paper $1049,486 \mathrm{p}$.

U.S. Geological Survey, 1951, Drought in southern California as related to ground-water supply and use: U.S. Geological Survey Ground Water Branch staff report.

U.S. Geological Survey, 1979, Aeromagnetic map of the San Jacinto area, California: U.S. Geological Survey Open-File Report 79-1447, 1 sheet.

u.s. Geological Survey, 1979, Earthquake activity and quaternary deformation of the western Transverse Ranges, California: U.S. Geological Survey Circular 799-A, Recent earthquake activity and focal mechanisms in the western Transverse
Ranges, by W.H.K. Lee, R.F. Yerkes, and M. Simirenko; 799-B, Late Quaternary deformation in the western Transverse
Ranges, California, by R.F. Yerkes and W.H.K. Lee; $37 \mathrm{p}$.

U.S. Geological Survey, 1980 , Aeromagnetic map of the Ventura and Los Angeles counties, Cal ifornia: U.S.

U.S. Geological Survey Open-File Report 80-64, scale $1: 62,500$. area, California: U.S. Geological Survey Open-File Report $80-986$, scale $1: 62,500$.

v.S. Geological Survey, 1982, Mineral resources of the sheep Mountain $W_{1} l d e r n e s s$ Study Area and the Cucamonga Wilderness and additions, Los Angeles and San Bernardino Counties, California: U.s. Geological Survey Bullet in 1506-A-E, 92 p.

U.s. Geological Survey, 1983 , Aeromagnetic map of part of th Geological Survey Open-File Report 83-656, scale $1: 250,000$. 
U.S. Geological Survey, 1983, Aeromagnetic map of the KingmanTrona area, California: U.s. Geological Survey Open-File Trona area, California: U.S. Ge
Report 83-663, scale $1: 250,000$.

v.s. Geological Survey, 1983 , Aeromagnetic map of the salton sea area, California: U.S.

v.s. Geological Survey, 1983 , Aeromagnet $1 \mathrm{c}$ map of the central part of the Inyo National Forest, California: U.s.

U.S. Ceological Survey, 1983, Aeromagnet ic map of the norther part of the Inyo National Forest, California and Nevada: part of the Inyo National Forest, California and Nevada: 1: 250,000 .

v.s. Geological Survey, 1985, Southern California's hydrogeologic setting: U.S. Geological Survey, Water Resources Division
National Meeting 5, San Diego, Calif., November 18-21, 1985, Field Trip Guidebook, 78 p.

Fleld Trip Guidebook, 78 p.
Wallace, R.E., 1949 , Structure of a portion of the san Andreas $r i f t$ in southern California: Geological Society of America Bulletin, v. 60, no. 4, p. 781-806.

wallace, R.E., 1968, Notes on stream channels of fset by the San Ándreas Fault, southern Coast Ranges, California, in Dickinson, W.R., and Grantz, Arthur, eds., Proceedings in Dickinson, W.R., and Grantz, Arthur, eds., Proceed 1
of conference on geologic problems of the San Andreas of conference on geologic problems of the San Andreas
Fault system: Palo Alto, Calif., stanford University publications, Geological Sciences, v. 11, p. 6-2.1.

walter, A.W., and weaver, C.s., 1980 , Catalog of earthquakes in the Coso Range and vicinity, southern California--September 27 , 1975-September $30,1977$.
File Report $80-85,101 \mathrm{p}$.

walter, A.W., and weaver, C.S., 1980, Seismic refraction data for shots recorded in the Coso Range, California: U.S. Geological Survey Open-File Report 80-186, $13 \mathrm{p}$

warner, J.w., 1972, Ground water in Santa Barbara and southern San Luis Obispo Counties, California, spring 1969
to spring 1970: U.S. Geological Survey open-file report, 27 p.
to 1978 , Record sections for two seismic refraction

Warren, D.H., 1978 , Record sections for two seismic refraction
profiles in the Gablian and Diablo Ranges, California: v.S. Geological Survey Open-File Report 78-340, $95 \mathrm{p}$.

watson, R.D., 1981 , A 1 rborne Fraunhofer line discriminator
surveys in southern California, Nevada, and central New surveys in southern California, Nevada, and
Mexico: LPI Technical Report 81-3, p. 28-35.

Mexico: LPI Technical Report 81-3, p. 28-35.
watts, w.L., 1897, OlI and gas yielding formations of Los Angeles, Ventura, and Santa Barbara Counties 1: California State Mining Bureau Bulletin $11,94 \mathrm{p}$.

Weber, F.H., Jr., 1980, Effects on southern California of the rains of February 13-21, 1980: California Division of Mines

and Geology Open-File Report 80-3 LA.
Weber, F.H.' Jr., 1982 , Geology and geomorphology along the San Gabriel fault zone, Los Angeles and ventura counties, File Report 82-2 LA.

Weber, F.H., Jr., Geologic and geonorphic investigation of the San Gabriel fault zone, Los Angeles and ventura Counties, File Report 79-17 LA.

Weber, F.H., Jr., Treiman, J.A., Tan, S.S., and Miller, R.V., 1979, February-March 1978 rains in the Los Angeles region, southern California: California Division of Mines and Geology Open-File Report 79-4 LA.

Geology Open-File Report 79-4 LA.
We1r, J.E.. Jr., Crippen, J.R., and Dutcher, L.C., 1965, A progress report and proposed test-well drilling program for the water-resources investigation of the Antelope Valley-East Kern Water Agency area, Califo
Geological Survey open-file report, $121 \mathrm{p}$.

Geological Survey open-f 1 le report, $121 \mathrm{p}$.
Weiss, L.E., 1954, A study of tectonic style-structural investigation of a marble guartzite complex in southern California: University of California Publications in $1: 5,400$.

Wesson, R.L., 1983, progressive rupture following the $1971 \mathrm{san}$ Fernando earthquake (abs.): Earthquake Notes, v. 54 , no. 3 , p. $36-37$

Wheeler, G.M., 1876, Geology: U.S. Army Engineer Department, report upon U.S. Geographical Surveys west of the $100 \mathrm{th}$

white, D.E., 1957, Magmatic, connate, and metamorphic waters: Geological Society of America Bulletin, v. 68, no. 12 , pt. 1 .

white, D.E., 1957, Thermal waters of volcanic origin Geological Society of America Bulletin, v. 68, no. 12, pt. 1. D.E., 1965, Salıne waters of sedimentary rocks,

White, D.E., 1965, Saline waters of sedimentary rocks,
fluids in subsurface environments, a symposium: American fluids in subsurface environments, a symposium:

Association of Petroleum Geologists Memolr 4 .
White, D.E., 1968 , Environments of generation of some base-metal ore deposits: Economic Geology, v. 63 , no. 4.

White, D.E., 1968, Geothermal energy reservolrs (abs.) Bakersfield, Calif., American Association of Petroleum

Geologists, Symposium on Geothermal Resources.
white, D.E., Barnes, Ivan, and O'Ne11, J.R., 1973, Thermal and mineral water of non-meteoric origin, California coast Ranges:
$547-560$.

Whitney, J.D., 1865, Report of progress and synopsis of the fleldwork from 1860 to 1864 : California Geological the fleldwork from 1860 to 1864

Williams, F.J., 1981, Magnetic field monitoring of tectonic stress in' southern California: U.s. Geological Survey openFile Report $81-384,9 \mathrm{p}$.

File Report $81-384,9$ p.
Williams, R.P., 1971, Variations in low-water streambed elevations at selected stream-gaging stations in southern california: v.s. Geological Survey basic-data compilation. $175 \mathrm{p}$.
Williams, R.P., 1979, Sediment discharge in the Santa clara River basin, Ventura and Los Angeles Counties, California: v.s. Geological Survey Water-Resources Investigations Report $79-78,51 \mathrm{p}$

willis, Bailey, 1938, San Andreas $r i f t$ in southwestern California: Journal of Geology, v. 46, no. 8, p. 1017-1057.

wong, George, 1983, Preliminary map of the mining districts in the Basin and Range area of California: U.S. Geological

woodring ring, w.P., 1931, Distribution and age of the Marine
Tertiary deposits of the Colorado Desert: Carnegie Tertiary deposits of the Colorado Desert: Carnegie

wright, L.A., and Troxel, B.w., 1954, Geologic guide for the western Mojave Desert and Death Valley region in Geology of southern California: California Division of Mines Bulletin 170, Guide 1, map sheets 10 and $11, \mathrm{p} .42$ and 44.

Yeats, R.S., 1965, Pliocene seaknoll at South Mountain, Ventura basin, California: American Association of
Petroleum Geologists Bulletin, v. 49, p. 526-546, fig. 2 , Pet.roleum Geologists Bulletin,
scale $111 / 16$ inches $=1$ mile.

scale $111 / 16$ inches $=1$ mile.
Yeats, R.S., 1968, Rifting and rafting in the southern california borderland in proceedings of conference on geologic problems of San Andreas fault system, Stanford University, May 1968 : Palo Alto, Calif.. Stanford University Publications. Geological Sciences, v. 11, p. 307-322.

Yerkes, R.F., MCCulloh, T.H., Schoellhamer, J.E., and vedder, J.G., 1965, Geology of the Los Angeles basin, California, an introduction: U.S. Ge
Professional paper $420-\mathrm{A}$, p. A1-A57.

Yerkes, R.F., and Lee, W.H.K., 1979, Maps showing faults and fault activity and epicenters, focal depths, and focal mechanisms for 1970-75 earthquakes, western Transverse Ranges, California: U.S. Geological Survey Miscellaneous Field Studies Map MF-1032, 2 sheets, scale $1: 250,000$

Youd, T.L., Bennett, M.J., McLaughlin, P.C., Sarmiento, P.C., and Wieczorek, G.F., 1983, Liquefaction studies in the Imperial Valley, California, a natural laboratory (abs.): Geological
Society of America, Abstracts with programs, v. 15, no. 5, pociety

Yount, J.C., Birkeland, P.W., and Burke, R.M., 1982, Holocene glaciation; Mono Creek, central Sierra Nevada, California
(abs.): Geological Society of America, Abstracts with (abs.): Geological Society of Amer

Zander, G. 1923, Report on water supply and use of water from the whitewater River stream system: Californi Division of Water Rights, Whit ewater Adjudication

Proceedings.
zander, G., 1928, order determining and establishing the several rights by appropriation to the use of the waters of the whitewater River stream system, San Bernardino and Riverside Counties, California: California Division of
water Rights, Whitewater River Adjudication Proceedings.

Zander, G. 1938, Matter of determination of the relative right's of the various claimants to the waters of the whitewater River and its tributaries (Calif.): California Superior Court judgment, and Riverside County.

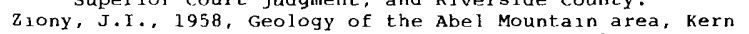
and ventura Counties, California: Los Angeles, University of California, M.A. thesis.

Ziony, J.I., Wentworth, C.M., Buchanan-Banks, J.M., and Wagner H.C., 1974, Preliminary map showing recency of faulting in

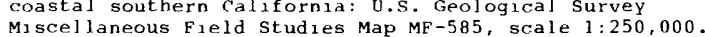

ziony, J.I.., ed., 1985, Evaluating earthquake hazards in the Los Angeles region; an earth-science perspective: U.S.

Zobal, G.P., 1943, The upper Cretaceous paleontology and stratigraphy of the Simi Hills, Los Angeles and ventura stratigraphy of the Simi Hills, Los Angeles and ventura
Counties, California: Pasadena, California Institute of Technology, M.S. thesis.

\section{Offshore}

Alpha, T.R., 1978, Oblique map of Monterey Bay, Calıfornia: U.S. Al pha the the northwestern part:
Report $78-967,1$ pl.

Alpha, T.R., 1981, Oblique map of the southern California inner contunental borderland: U.S. Geological Survey Open-File cont inental borderland: U.S. Geo
Report $81-1312$, scale $1: 340,000$.

Anima, R.J., and Dingler, J.R., 1982, Transect line location map with illustrations of box cores collected from the nearshore areas of Estero Bay, California: U.
Survey Open-F1le Report 82-310, 1 sheet.

Ballantyne, R.S., 1983, Estimated 011 and gas reserve, southern California outer continental shelf, December 31, 1982, U.s. Geological Survey Open-File Report 83-559, 10 p.

Beyer, L.A., 1980, Off shore southern California: California

Bird Division of Mines and Geology Bulletin 205, p. 8-15. C.V., 1979, Estimated oll and gas reserves, southern
Cajlfornia outer continental shelf, January 1, 1978: U.s. Geological Survey Open-File Report 79-345, 9 p.

Bird, c.V., 1980 , Estimated oul and gas reserves, southern
california outer continental shelf, January 1, 1979: u.s. California outer continental shelf, January 1,1979

Bukry, David, 1981, Silicoflagellate stratigraphy of off shore California and Baja California, Deep Sea Drilling Project Leg 63: Initial Reports of the Deep Sea Drilling project. v. $63, P, 539-557$

Cacchione, D.A., Drake, D.E., Grant, W.D., and Tate, G.B., 1984 , Rippled scour depressions on the inner continental shelf of central California: Journal of Sedimentary Petrology, v. 54 no. 4, p. $1280-1291$. 


\section{Offshore--Continued}

Clarke, S.H., Greene, H.G., Fleld, M.E., and Lee, W.H.K.. 1983, Reconnaissance geology and geologic hazards of selected areas of the southern California continental borderland U.S. Geological Survey Open-File Report 83-62, 81 p.
H.E., ed., 1979, Geologic studies of the Point Conception deep stratigraphic test well ocs-Cal 78-164 no. 1 , outer continental shelf, southern california, United states: u.s Geological Survey Open-File Report 79-1218, 148 p.

Corbato, C.E., and Helfer, M.D., 1962, Gravity measurements on the cruise of the U.S.S. Gear, October Institute of Geophysics and planetary physics Inter Report, ONR Contract 233 (19).

crouch, J.K., Holmes, M.L., McCulloh, T.H., Long, A.T., and Brune, R.H. 1978, Multichannel seismic reflection and sonobuoy refraction data in the outer southern California
borderland: U.S. Geological Survey Open-File Report 78-706, border
$3 \mathrm{p}$.

Dingler, J.R., Anıma, R.J., Molzan, D.E., Luepke, Gretchen, and Peterson, C.L., 1982, A field study of littoral processes in Estero Bay, Calif

Drake, D.E., Cacchione, D.A., and Kar1, H.A., 1985, Bottom currents and sediment transport on San Pedro shelf, California: Journal of Sedimentary PetrologY, v. 55, no. 1, p. 15-28.

Eaton, J.P.. 1985. Focal mechan 2 sms of near-shore earthquakes between Santa Barbara and Monterey, California: U.S. Geoloen Santa Barbara and Monterey, Callforna:

Edwards, B.D., ed. Supplement to Open-File Report $80-198$ (lease sale 68) for ocs sale 80 , of fshore southern California: U.S. Geological Survey open-file Report $82-381,14 \mathrm{p}$. Californa: Urbana, University of Illinous. Ph.D.

Emery, K.O., 1951, Continental shelf, southern Californa: American Association of Petroleum Geologists Bullet
35 , no. 2, p. 249-252, fig. 37, scale $1: 1,750,000$.

Emery, K.O. 1960 , The sea off southern Californa. modern habitat of petroleum: New York, John wiley, $366 \mathrm{p}$. y, K.O., Butcher, W.S., Gould, H.R., and Shepard, F.P., 1952, Submarine geology off San Diego, California: Journal of Geology, v. 60 , no. 6, p. $511-548$, fig. 4 .

Emery, K.O., and Shepard, F.P., 1945, Lathology of the sea floor of southern California: Geological society of America Bulletin, v. 56, no. 4, p. 431-478.

Field, M.E., and Edwards, B.D.. 1980, slopes of the southern California continental borderland; a regime of mass trans -

port: Pacific Coast Paleogeography Symposium 4, p. 169-184.
Given. D.D. and Koesterer. C.L. 1983, Station arrival data for a quarry blast on Santa Catalina Island, Californa: U.S. Geological Survey Open-File Report 83-462, $13 \mathrm{p}$.

Greene, H.G., Wolf, S.C., and Blom, K.G., 1978, The marine geology of the eastern Santa Barbara channel, with particular emphasis on the ground-water basins offshore from the oxnard plain, southern California:

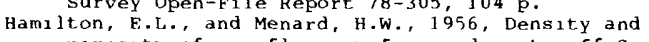
porosity of sea-floor surface sediments off San Diego, California: Amerucan Associat,

Helfer, M.D., Von Huene, R.E., and Caputo, M., 1962. Gravity survey of the Santa Barbara channel with the U.S.S. Rexburg: Los Angeles, University of California Institute of Geophysics and planetary Physics Interim Report, ONR contract 233 (19).

Hill, G.W.', Chin, J.L., and Ho, B.D., 1982, Map showing surface grab sample and gravity core locations, south-central Monterey Bay, California (July 1981-February 1982): U.S.

Geological Survey open-Fx le Report 82-838, scale 1:24,
H11, G.W., and Chin, J.L., 1982, Map showing geophysical trackilnes, south-central Monterey Bay, California (sumer 1981): U.S. Geological Survey Open-File Report 82-837, scale $1: 24,000$.

Junger, Arne, 1979, Maps and selsmic profiles showing geologic structure of the northern channel Islands platform. California continental borderland: U.S. Geological survey Miscellaneous $1: 250,000$.

Junger, Arne, and Wagner, H.C., 1977, Geology of the Santa Monica and San Pedro basins, California continental borderland: U.S. Geological survey Miscellaneous Field Studies Map MF-820, scale $1: 250,000$.

Kal11, F.F., 1980, Estimated oll and gas reserves, southern California outer continental shelf, December 31, 1979 U.S. Geological Survey Open-File Report 80-1041, 8 p.

Kal11, F.F., 1981, Estimated oul and gas reserves, southern Geological Survey Open-File Report $81-623,10 \mathrm{p}$.

Kal11. F.F., 1983, Estumated onl and gas reserves, southern California outer continental shelf, December 31, 1981: U.S. Geological Survey Open-File Report 82-37, $10 \mathrm{p}$.

Karl, H.A., Cacchione, D.A., and Drake, D.E., 1980, Erosion and transport of sediments and pollutants in the benthic boundary layer on the San Pedro shelf, southern California: U.S. Geological Survey Open-File Report 80-386, $100 \mathrm{p}$. 1980 . Recency and character of faulting of falley. metropolitan San Diego, Point La Jolla-Cardiff-by-the-Sea (Calif.): California Division of Mines and Geology Map sheet 41 , scale $1: 50,000$

Kennedy, M.P., Clarke, S.H., Greene, H.G., and Legg, M.R., 1981 , Recency and character of faulting of fshore metropolitan San Diego, Point La Jolla to Mexico: California Division of Mines and Geology Map sheet 42, scale 1:50,000.

Kennedy, M.P., Clarke, S.H., Greene, H.G., and Lonsdale, P.F.. 1985 , Observations from DSRV Alvin of Quaternary faulting on the southern Californa continental margin: U.S. Geological Survey Open-File Report 85-39, 26 p.

\section{Offshore--Continued}

Kennedy, M.P., and Welday, E.E., 1980, Recency and character of faulting offshore metropolitan San Diego (Calif.) Califor $1.50,000$.

Califor $1: 50,000$ , B.A., Cavit, C.D., and McHendrie, A.G., 1981, Free-air Geological Survey Miscellaneous Field Studies Map MF-854, scale $1: 250,000$.

Labelle, R.P., Lanfear, K.J.. Banks, A.D., and Karpas, R.M. 1983, An ollspill risk analysis for the southern California lease offering (February 1984
File Report $83-563$. 117 .

Ludwick, J.C., 1950, Deep water sand layers off San Diego, California: Los Angeles. University of California and

Mann, D.M., McCulloh, T.H., and Crouch, J.K., 1981, Multichannel D.M., McCulloh, T.H., and Crouch, J.K., 1981, Multichan
selsmic-reflection profiles collected in 1978 in the selsmic-reflection profiles collected in 1978 in the
eastern Pacific Ocean of the California coast south of Point Conception: U.S. Geological Survey Open-File Report Point Conception: U.S. Geological

Mann, D.M., and Crouch, J.K., 1983, Multichannel seismic-reflection profiles collected in 1979 in the eastern Pacific Ocean of $f$ the California coast. south of Point Conception: U.S. Geological
$83-0593,4$ p., scale i: 500,000 .

Mclean, Hugh, and Howell, D.G., 1984, Miocene Blanc Fan, northern Channel Islands, California; small fans reflecting tectonism and volcanısm: Geo-Marine Letters, v. 3, no. 2-4, p. $161-$ 166.

Menard, H.W., 1954, Underwater mapping by diving geologists: American Association of Petroleum Geologists Bulletin

Moore, D.G.. 1952, Marine geology of San Pedro Shelf: Los Angeles, University of Southern California, M.S. thesis. , D.G., 1969, Reflection profiling studies of the California continental borderland: structure and Quaternary turbidite basins: Geological Society of America Special Paper 107, $141 \mathrm{p}$.

Moore, G.w., 1972, Offishore extension of the Rose Canyon fault, San Diego. Californid, in Geological Survey Research, 1972: U.S. Geological Survey Professional Paper Research, 1972 : 113 .

Moore, G.W., and Kennedy, M.P., 1976, Acoustic-reflection Profiles, Scripps Utility Boat, August 1973, San Diego Bay, California: U.S. Geological Survey Open-File Report

Moreland, J.A., and Singer, J.A., 1969, A study of deep aquifers underlying coastal orange county, California: Muhs, D.R., and Szabo, B.J., 1982, Uranium-series age of the Eel Colnt terrace, San Clemente Island, 2.10 , no. 1, p. 23-26.

Colo., Geology, v. 10, no. 1, p. 23-26.
Normack, w.R., Ford, G.A., and Chase, T.F., 1980 , Trackline map and acoustic profiles showing deep-tow geophysical dat from the northern segment of the San clemente fault,
California borderland: U.s. Geological Survey open-File Report $80-932$ rerland:

Normark, w.R., and Piper, D.J., 1984, Navy Fan, California borderland; growth pattern and depositional processes: Gorderland; growth pattern and depositional proce

Geo-Marine Letters, ve 3 , no. $2-4$, p. $101-108$.
Poore, R.z., 1981 , Miocene through Quaternary planktonic foraminifers from offshore southern California and Baja Californid: Initial Reports of the Deep Sea Drilling Californid: Initial Reports

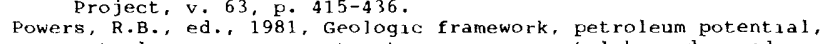
petroleum-resource estimates, environmental hazards, and deep-water drilling technology of the maritime boundary region, off shore southern California borderland:
Geological Survey Open-File Report $81-264,102$ p.

Rapp, J.B., and Kvenvolden, K.A., 1982, Organic geochemistry of sediments on the flanks of Tanner and cortes banks of fahore from southern Californ

Rowland, R.W., Clarke, S.H., Jr., and Greene, H.G., 1983, Marine geological profiles in the southern Californa continenta borderland collected in 1974 on the R/V S. P. L

Geologlcal Survey Open-File Report 82-975, 2 p.
Shepard, F.P., and Emery, K.o., 1941, Submarıne topography

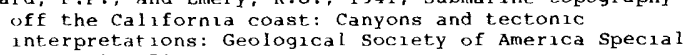
Paper $31,171 \mathrm{p}$.

Shor, G.G.. and Raitt, R.w., 1956, Seismic studies in the southern California continental borderland: International Mexico, D. F.

Terry, R.D., 1956, Biblıography of marine geology and oceanography, California coast: Los Angeles, University of Southern California, M.S. thesis.

vedder, J.G.. Arnal, R.E. Barron, J.A., Bukry, David, Crouch, J.K., and Lee-Wong, Florence, 1981 , Composition and correlation of bedrock and sediment cores, R/V SEA SOUNDER Cruise
S3-79-SC, May 1979 , California continental borderland: U.S. Geological Survey open-File Report $81-744,75 \mathrm{p}$.

vedder, J.G., Beyer, L.A., Junger, A., Moore, G.W.., Roberts, A.E., Taylor, J.C., and wagner, H.C., 1974 ,

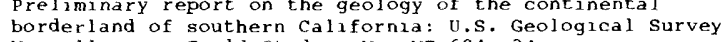
Miscellaneous Field Studies Map MF $-624,34 \mathrm{p}$.

vedder, J.G., Crouch, J.K., Scott, E.W.. Greene, H.G. Cranmer D.. Ilbrahım, M. , Tudor, R.B., and Vinneng, G., 1980, A sumary report of the regional geology, petroleum potentral. environmental geology, and operational considerations in the
area of proposed lease sale no. 68 , off shore southern California: U.s. Geological Survey Open-File Report 80-198, $64 \mathrm{p}$. 


\section{Offshore--Continued}

Vedder, J.G., Crouch, J.K., and Lee-Wong, Florence, 1981, Comparative study of rocks from Deep Sea Drilling Project holes 467,468 , and 469 and the southern California borderland: Initial Report
p. $907-918$.

Vedder, J.G., Taylor, J.C., Arnal, R.E., and Bukry, Davıd, 1980 , Map showng location of selected pre-Quaternary rock samples from the california continental borderland: U.S. Geological Survey Miscellaneous Field studies Map MF-737, scale $1: 250,000$.

Vedder, J.G., and Howell, D.G., 1980, Topographlc evolution of the southern California borderland during late Cenozoic time, in power, D.M., ed., The California islands; proceedings of a multidisciplinary symposium: Santa Barbara. Cal if.. Santa Barbara Museum of Natural History, p. 7-31.

Vernon, J.W., and slater, R.A., 1963, Submarine tar

mounds,' Santa Barbara County, California: American Association of Petroleum
8 , p. $1624-1627$, flg. 1 .

Von Huene, R.E., and Hager, C.L., 1964, Gravity data from two cruises aboard the 0.S.N.S. Charles H. Davis (AGOR-5): Los Angeles, Unıversity of California Institute of Geophysics and Planetary Physics Interim Report 8, ONR Contract 233 (19).

Von Huene, R.E., and Ridlon, J.B., 1966, of fshore gravity anomalies in the Santa Barbara channel, California: Journal of Geophysical Research, v. 71, p. 457-463.

Weaver, D.w., Doerner, D.p., and Nolf, B., 1969, Geology paleontology and Mineral Islands: Soclety of Economic

Wilde, Pat, Normark, W.R., Chase, T.E., and Gutmacher, C.E. 1985, Potential petroleum reservoirs on deep-sea fans off central California, in A.H. Bouma, ed., Submarine fans and related turbidite systems: New York, Springer-Verlag, v. 1, p. $35-41$.

Wrath, W.F., 1936, Marine sedimentation around Catalına and San Clemente Islands: Urbana, University of Illinols, M.S. thesis. 
CATEGORY 6: ARIZONA, CALIFORNIA, MEXICO, AND NEVADA

\section{Arizona}

Blaney, H.F., and Harris, R., 1951, Consumptive use and irrigation requirements of crops in Arizona: U.S. Soil Conservation Service, $49 \mathrm{p}$.

Ross, C.P., 1922, Routes to desert watering places in the Lower Gila Region, Arizona: 0.S. Geological Survey water-Supply Paper 490-c, p. 271-315.

\section{California}

Adams, E.W., and Beatty, W.B., 1962, Bituminous rocks in California: California Division of Mines and Geology, Mineral Information Service, v. 15, no. 4 .

Adams, Frank, 1913, Irrigation resources of California and their utilization: O.S. Department of Agriculture, office Experimental Station Bulletin 254, $95 \mathrm{p}$.

Adams, Frank, 1915, Progress report of cooperative irrigation investigations in California 1912-1914: California Department of Engineering Bulletin 1, $74 \mathrm{p}$.

Addicott, w.o., ed., 1978, Neogene biostratigraphy of selected areas in the Cal ifornia Coast. Ranges: U.S. Geological Survey open-File Report 78-446, $113 \mathrm{p}$.

Agricultural Research Service, 1958 , Determination of evapotranspiration and water penetration for water supply evaluation: $\mathrm{D} . \mathrm{S}$. Department of Agriculture Annual Research Report, 1957, 86 p.

Agricultural Research Service, 1959, Determination of evapot ranspiration and water penetration for water supply evaluation: D.S. Department of Agriculture Annual Research Report, 1958, $108 \mathrm{p}$.

Agricultural Research Service, 1960, Determination of evapotranspiration and water penetration for water supply Report, 1959,69 p.

Agricultural Research Service, 1961, Determination of evapotranspiration and water penetration for water supply
evaluation: U.S. Department of Agriculture Annual Research Report, 1960, $71 \mathrm{p}$.

Agricultural Research Service, 1962, Determination of evapotranspiration and water penetration for water supply Report, 1961, 80 p.

Agricultural Research Service, 1963, Determination of evapotranspiration and water penetration for water supply
evaluation: U.S. Department of Agriculture Annual Research Report, 1962, 33 p.

Agricultural Research Service, 1964, Determination of evapotranspiration and water penetration for water supply
evaluation: U.S. Department of Agriculture Annual Research Report, $1963,43 \mathrm{p}$.

Albers, J.P. 1978, Mineral resource potential of RARE II areas in California for platinum, chromium, nickel, copper, lead, zinc, gold, silver, tungste and mercury: U.S. Geological Survey Open-file Report 78-895, 1 pl., scale $1: 1,000,000$

Albers, J.P., 1980, Metallic mineral deposits in California's tectonic framework: International Union of Geological Sciences, no. 5 , p. 55-74.

Albers, J.P., A lithologic-tectonic framework for the metallogenic provinces of California: Economic Geology and Bulletin of the Society of Economic Geologists, v. 76, no. 4, p. $765-790$.

Albers, J.P., and Fratıcelli, L.A., 1984, Prelimanary mineral resource assessment map of California: U.S. Geologucal Survey Mineral Investigations Resources Map MR-88, scale $1: 1,000,000$.

Anderson, J.G., 1985, Synthesıs of selsmicity and geological data in Cal ifornia: v.s. Geological Survey Open-File Report $84-424,186 \mathrm{p}$.

Anderson, Winslow, 1892 , Mineral springs and health resorts of Cal ifornia: San Francisco, Calif., The Bancroft Co., $384 \mathrm{p}$. Bader, J.S., 1964, A reconnaissance of saline ground water
in California: 0. . Geological Survey open-file report, 14

Bader, J.S., 1965, Reports for California by the Geological Survey, Water Resources Division: o.s. Geological Survey open-file report, $20 \mathrm{p}$.

Bader, J.s., 1967, Reports for California by the Geological Survey, water Resources Division: D.S. Geological Survey open-file report, 49 .

Bader, J.S., 1969, References for well data and water levels in California by the Geological Survey: U.S.

Geological Survey open-file report, $13 \mathrm{p}$.
Bader, J.S., and Kunkel, Fred, 1973, Reports for California by the Geological Survey, Water Resources Division: 0.S. Geological Survey open-file report, $111 \mathrm{p}$.

Balley, E.H., ed., 1966, Geology of northern Californid California Division of Mines and Geology Bulletin 190, 508 Bail p., 1 pl. 165 figs., 142 photos, 23 other illustrations. California Mining Bureau Bulletin 24, p. 105-138.

Bailey, R.A., 1973, Post-subsidence vulcanism and structure of Long valley caldera, California (abs.): Geologic Society of America

Ball Associates, Ltd., 1964, Surface and shallow oll-1mpregnated rocks and shallow oll fields in the onited states: U.S. Bureau of Mines Monograph 12,375 p. Compiled by Ball Associ.
$58-87$.

Ballog, A.P., Jr., and Moyle, W.R., Jr., 1980, water resources and geology of the Los Coyotes Indian Reservation and vicinity, San Diego County, California: U.S. Geologica Survey Open-File Report 80-960, 25 p.

\section{California--Continued}

Banks, H.o., Richter, R.C., Coe, J.J., McPartland, J.W., and Kretsinger, R.W., 1954, Artificial recharge in California: California Division of Water Resources,

unnumbered report, 41 p.
Bertoldi, G.L., 1981, Ground water data collection in California: California Water Resources Center Report, no. 53, p. 58-64.

Bezore, S.P., 1984, Geothermal resources of California: Calfornia Geology, v. 37, no. 6, p. 115-118.

Blake, M.C., Howell, D.G., and Jones, D.L., 1982, Preliminary tectonostratigraphic terrane map of California: D.S. Geological survey open-File Report 82-593, 9 p.

Blaney, H.F., 1954, Consumptive use of ground water by phreatophytes and hydrophytes: International Union of Geodesy and Geophysics, Paper, 10 th General Assembly, Hydrology Publication 37 , v. 2, p. 53-62.

Boalich, E.S., and Castello, w.o. , i 918 , Ant imony graphite, nickel, potash, strontium, tin: California Mining Bureau Préliminary Report 5, $44 \mathrm{p}$.

Bowen, O.E., ed., 1962, Geologic guide to the oll and gas fields of northern California: California Division of Mines and Geology, 412 p., 4 maps, $26 \mathrm{pl}$.

Breckenridge, K.S., and Johnson, M.J., 1985, Catalog of locations; low frequency instrumentation in California v.S. Geological Survey Open-File Report 85-212, 29 p.

Brown, H.J. Stone, paul, Howard, K.A., and Hamlton, warren, 1984, Correlation of metamorphosed Paleozolc strata of the southeastern Mojave Desert region, California and Arizona: Geological Society of America Bulletin, v. 95, no. 12, p. 1482-1486.

California Department of Conservation, Division of O1 1 and Gas, 1942, Summary of operations, California orl fields: Gas, v. 28 , no. 2

California Department of Conservation, Division of $O_{1} 1$ and Gas, 1964, Exploratory wells drilled outside of oll and Department of Conservation, Division of O1l and Gas.

california Department of Public Health, 1962, California domestic water supplies: California Bureau of Sanitary Engineers, 76 p.

California Department of Public Works, 1934, South coastal basin investigation, records of ground water levels for the year 1934, seasonal precipitation records to and including 1933-34: California Department of Public Works Bulletin 39-C, 148 p.

California Department of Public Works, Division of Engineering and Irrigation, 1923, Irrigation requirements of CaI ifornia lands: California Department of Public Works Bulletin 6, app. B, Report to the Legislature of 1923 on the water resources of California, $196 \mathrm{p}$. California Department of Public Works, Division of Water
Resources, 1947, Evaporation from water surface in California: California Department of Public Works Bulletin 54.

California Department of Public Works, Division of Water Resources, 1952, Water quality investigations, ground water basins in Californ

California Department of Water Resources and Department of conservation, 1966. Geothermal power in california: State of California, $8 \mathrm{p}$.

California Department of Water Resources, 1957, The California water plan: California Department of water Resources Bullet in 3, $246 \mathrm{p}$.

California Department of Water Resources, 1958, Sea-water intrusion in California: California Department of Water Resources Bulletin 63,91 p.

California Department of Water Resources, 1960, Quality of surface waters in California: California Department of

Water Resources Bulletin $65-57,358$ p.
California Department of Water Resources, 1960 , Quality of ground waters in California 1958: California Department of Water Resources Bulletin 66-58, $324 \mathrm{p}$

California Department of Water Resources, i965, Dams within jurisdiction of the state of California: California

Department of Water Resources Bulletin $17-65,130 \mathrm{p}$. fornia Department of Water Resources, 1970, California high water, 1968-1969: California Department of water Resources Bulletin 69-69, 93 p.

California Department of Water Resources, 1971, Climatological stations in California, 1971: California Department of water Resources Bulletin 165, $114 \mathrm{p}$.

California Department of Water Resources, 1971, Index of stream gaging stations in and adjacent to California 1970:
California Department of water Resources Bulletin 157, 151

California Department of water Resources, 1972, California state water project in 1972: California Department of water Resources Bulletin 131-72, $172 \mathrm{p}$.

California Department of Water Resources, 1973 , Energy dilemma, California's 20 -year powerplant siting plan: California Department of water Resources, $129 \mathrm{p}$.

Californa Department of Water Resources, 1974, Evaporation from water surfaces in California: California Department of water Resources Bulletin 73-1, 173 p.

California Department of Water Resources, 1974, The California water plan out look in 1974: California Department of water Resources Bulletin 160-74, $186 \mathrm{p}$.

California Department of Water Resources, 1975, Cailfornia's ground water: California Department of water Resources Bulletin $118,135 \mathrm{p}$.

California Department of water Resources, 1975, Inventory of waste water production and waste water reclamation in California 1973: Cal ifornia Department of Water Resources Bulletin $68-73,25 \mathrm{p}$. 


\section{California--Continued}

California Department of Water Resources, 1975, Preliminary evaluation of effects on ground water of $\mathrm{CO} 2$ generated by
class II sanitary landfills: California Department of water Resources Southern District Report.

Calıfornıa Department of Water Resources, 1975, Sea-water intrusion in California: Inventory of coastal ground water basins: Califor

California Department of water Resources, 1975, Urban water use in California: California Department of Water Resources Bulletin 166-2, 172 p.

California Department of water Resources, 1975, vegetative water use in California, 1974: California Department of water Resources Bulletin 113-3, 104 p., 2 pl.

California Department of water Resources, 1977 , Water for powerplant cooling: California Department of Water Resources Bulletin 204, 43 p.

California Department of Water Resources, 1978, Cal ifornia sunshine, solar radiation data: California Department of water Resources Bulletin 187, $110 \mathrm{p}$.

Cal ifornia Department of water Resources, 1978, Index to sources of hydrologic data: California Department of Water Resources Bulletin 230-78, $316 \mathrm{p}$.

California Department of water Resources, 1978, Land use within the California coastal zone: California Department of water Resources Bulletin 207,346 p.

California Department of Water Resources, 1978, The California state water project, 1977 , activities and future management plans: California Department of water Resources Bulletin $132-78,255 \mathrm{p}$.

California Department of water Resources, 1978, water conditions and flood events in California, water year 1976-77: California Department of Water Resources Bulletin $202-77,74 \mathrm{p}$.

California Department of Water Resources, 1978, wind in California: California Department of water Resources Bulletin 185, $267 \mathrm{p}$

California Department of water Resources, 1979, Evaporation from water surfaces in California: California Department of Water Resources Bulletin 73-79, $163 \mathrm{p}$.

California Department of Water Resources, 1980, Ground water basins in California: California Department of water Resources Bulletin $118-80,73 \mathrm{p}$.

California Department of Water Resources, 1981, Index to sources of hydrologic data: California Department of Water Resources Bulletin 230-81, $696 \mathrm{p}$.

California Department of Water Resources, 1981, water well standards, State of California: California Department of Water Resources Bulletin 74-81, $100 \mathrm{p}$.

Calufornia Department of Water Resources, 1982 , Policies and goals for California water management: The next 20 years:

Cal California Department of Water Resources Bulletin 4, $60 \mathrm{p}$. fornia Department of Water Resources, 1983, The California water plan: Projected use and available water supplies to
2010 : California Department of Water Resources Bulletin $160-83,268$ p.

Calufornia Department of Water Resources, 1983, Urban water use in California: California Department of Water Resources Bulletin $166-3,240$ p.

California Department of Water Resources, 1984, Dams within jurisdiction of the state of California: California Department of water Resources Bulletin 17-84, $94 \mathrm{p}$.

California Division of Mines and Geology, 1966, Mineral resources of California: Calufornia Division of Mines and Geology Bulletin 191, $450 \mathrm{p}$.

California Division of Mines and Geology, 1977, Short contributions to California geology: California Division of Mines and Geology Special Report 129

California Division of Mines and Geology, 1983, Technical map of the geothermal resources of California: California Division

of Mines and Geology Geologic Data Map 5, scale 1:750,000. fornia Division of Mines and Geology, 1985, Fault-rupture hazards zones in California: California Division of Mine and Geology special publication 42, revised ed., $24 \mathrm{p}$.

California Division of Mines, 1952, Exploratory well's drilled outside of oxl and gas fuelds in Califorma to
December 31, 1950: California Division of Mines Special Report 23, $77 \mathrm{p}$.

California Division of Mines, 1956. Exploratory wells drilled outside of oxl and gas fields in California to
December 31, 1953: California Division of Mines Special Report 45, $104 \mathrm{p}$.

California Division of 011 and Gas, 1964, Exploratory wells drilled outside of 011 and gas fields in california to December 31, 1963: California Division of oxl and Gas. $320 \mathrm{p}$.

California Division of 011 and Gas, 1973, California oxl and gas fuelds: California Division of $0_{11}$ and Gas, v. 1 and 2 .

California Division of 011 and Gas, 1981, Sixty-seventh annual report of the State 011 and Gas Supervisor: Calyforni Division of $0 x 1$ and Gas Publication PR-06.

California Division of Water Resources, 1952, Groundwater basins in California: California Division of Water Resources Quality of Water Investigations Report $3,44 p$.

california State Mineralogist, 1883, Third annual report: California State Mineralogist. 111 p.

California State Water Resources Board, 1951, water resources of California: California State Water Resources Board Bulletin 1. $648 \mathrm{p}$.

California State Water Resources Control Board, 1955, water utilization and requi rements of California Calufornia Department of Water Resources Bulletin 2, 227

Camp Dresser and Mckee, Inc., 1981, Permit requirements for energy and other natural resources for the state of California: U.S. Geological Survey open-file Report 81-1252, $137 \mathrm{p}$.

\section{California--Continued}

Champion, D.E., Howell, D.G., and Gromme, C.S., 1984, Paleomagnetic and geologic data indicating $2500 \mathrm{~km}$ of northward displacement for the Salinian and related terranes,
California: Journal of Geophysical Research, v. 89, no. 9, p. $7736-7752$.

Chapman, R.H., 1966, Gravity hase station network: California Division of Mines and Geology Special Report 90, $49 \mathrm{p}$.

Chapman. R.H., Bjehler, Shawn, and ollver, H., 1979, Maps showing locations of gravity stations used in the compilation of the gravity map of California and its continental margin: Calufornia Division of Mines and Geology Open-File Report 79-5 SAC.

Chapman, R.H., and Griscom, Andrew, 1980, Coast Ranges (Cal1f.): California Division of Mines and Geology Bulletin 205, p. $24-27$.

Chesterman, C.w., 1956, Pumice, pumicite, and volcanic cinders in California: California Division of Mines Bulletin 174, $119 \mathrm{p}$.

Chun, R.Y.D., Mutchel1, L.R., and M1do, K.W., 1964 , Ground-water management for the Nation's future--optımum conjunctive operation of ground-water basins: American Society of Civil Engineering Proceedings, v. 90, Hydrology 4, p. $79-95,5$ figs.

Clark, B.L.. 1926, The Domengine horizon, muddle Eocene of California: Unuversity of California Department of

clark, M.M., Harms, K.K., Llenkaemper, J.J., Harwood, D.S.. I,ajoie, K.R., Matti, J.C., Perkins, J.A.. Rymer, M.J.. Sarna-Wojcıcki, A.M., Sharp, R.V., Sims, J.D. Tinsley, and map of late-Quaternary faults of California: U.S. Geological Survey Open-file Report 84-106, 13 p.

Clarke, J.W. Conant, G.D. Cooper, Margaret, and others, 1965, Bibliography of North American geology, 1961: 0.s. Geological Survey Bulletin 1197, 663 p.

clarke, J.W. Conant, G.D., Cooper, Margaret, and others, 1966 , Bibliography of North American geology, 1962: v.s. Geological Survey Bulletin 1232,834 p.

clarke, J.W., Conant, G.D., Cooper, Margaret, and others, 1966, Bibluography of North American geology, 1964: U.

Geological Survey Bulletin 1234,944 p.
clarke, J.w.. Cooper, Margaret, Conant, G.D., and others, 1964 , Bibl zography of North American geology, 1960: v.s. Geological Survey Bulletin 1196,777 p.

clements, Thomas, 1943, Sespe oll field, in Geologic formations and economic development of the oll and gas fxelds of California: Cal

Clifton, H.E., 1979, Questions on coastal processes: contest or co-existence with nature: U.S. Geological Survey open-Fil Report 79-1130, $34 \mathrm{p}$.

Collins, William, Chang, Sheng-Huex, and Ralnes, G.L., 1982, Mineralogxcal mapping of sites near Death Valley, California, and Crossman Peak, Arizona, using aurborne nearinfrared spectral measurements (abs.), in Proceedings of the International symposium on remote sensing of environment; second thematic conference; "Remote sensing for exploration geology:" v. 1: Ann Ar

Conservation Commission of Californid, 1912, Report of the Conservation Commission of the state of California: State

of California, $502 \mathrm{p}$.

prepared by the U.S. Geological Survey through 1974: U.S. Geological Survey open-file report, $29 \mathrm{p}$.

crosby, J.W., 3d, and Hof fman, S.R., 1951, Fluorspar in Calufornia: California Journal of Munes and Geology, v.
47, no. 4, p. 619-638, (a) fig. 2, scale 1:54,000; (b) pl. 47, scale $1: 2,400$.

Dalrymple, Tate, 1965 , Flood peak runoff and associated precipitation in selected drainage basins in the United States: 0.s. Geological Survey Water-Supply paper 1813 . $406 \mathrm{p}$.

Darton, N.H., 1896, Catalogue and index of contributions to North American geology, 1732-1891: U.S. Geological Survey Bulletin 127,1045 p.

Darton, N.H., 1902, Preliminary list of deep borings in the United States, part 1, Alabama-Montana: U.S. Geological Survey water-Supply Paper $57,60 \mathrm{p}$.

Darton, N.H., 1905, Preliminary list of deep borings in the United States: U.S. Geological Survey water-Supply Paper $149,175 \mathrm{p}$.

Darton, N.H, and others, 1915, Guidebook of the western United States, part C. The Santa Fe route wath a side trip to the Grand Canyon of the Colorado: U.S. Geological Survey Bulletin 613, p. 151-159, sheet 22 .

Davis, P.M., and Johnston, M.J., 1983, Localxzed geomagnetic fleld changes near active faults Ln California 1974-1980: 9460 .

Davis, S.N., and Turk, L.J., 1969, Best well depth in crystalline rocks: UOP Johnson Drillers Journal, v. 71, no. 4, p. 1-5.

Diggles, M.F., Blakely, R.J., Schmauch, S.W., Ralns, R.L, Lipte
D.A., Winters, R.A., and Iverson, S.R.L., 1983, Mineral resource potential map of the white Mountasns and Burch Creek roadless areas, White Mountains, California and Nevada: U.S. Geological Survey Miscellaneous Field Studxes Map MF-1361-D, scale 1:62,500.

Durfor, C.N., and Becker, Ed1th, 1964, Public water supplies of the 100 largest cities in the United States, 1962: U.S. Geological Survey water-Supply Paper 1812, $364 \mathrm{p}$. Eldridge, G.H., 1901 , The asphalt and bituminous rock deposits of
the United States: 0.s. Geological Survey Annual Report 22, pt. 1, p. 209-452; pl. 50, scale 1:62,500.

Feth, J.H., 1964, Review and annotated b1bliography of ancient lake deposits (Precambrian to pleistocene) in the
western States: v.S. Geological Survey Bulletin 1080, 119 p. 


\section{California--Continued}

Feth, J.H., 1965, Selected references on salıne ground-water resources of the United States: U.S. Geological Survey

Feth, J.H., Roberson, C.E., and Polzer, W.L., 1964 Sources of mineral constituents in water from granitic rocks, Sierra Nevada, California and Nevada: U.S. Geological Survey Water-Supply Paper 1535-I, p. I1-T170.

Forstner, W., 1903, The quicksilver resources of california: California Division of Mines Bulletin 27, 273 p.; p. 148 , scale $1: 63,360$.

Foshag, W.F., and Woodford, A.o., 1936, Bentonitic magnesian clay mineral from California: American Mineralogist, v. 21, no. 4, p. 238-244; fig. 1, scale 1:125,000; fig. 2, scale $1: 1,500$.

Fowler, F.H., 1923, Hydroelectric power systems of California and their extensions into Oregon and Nevada: 0.S. Geological Survey Water-Supply Paper 493, $1276 \mathrm{p}$.

Fremont, J.C., 1845, Report of the exploring expedition to the Rocky Mountains and to Oregon and California (1st ed.): Washington, D.C.

Fuller, M.L., 1905, B1bliographic review and index of papers relating to underground waters published by the v.s. Geological Survey, 1879-1904; 0.s. Geological Survey Water-Supply Paper $120,128 \mathrm{p}$.

Fuller, M.L., Clapp, F.G., and Johnson, B.L., 1906 Bibliographic review and index of underground-water
literature published in the United States in 1905: 0.S.

Geological Survey Water-Supply Paper 163,130 p.
Fuller, M.L., Lines, E.F., and Veatch, A.C.. 1905, Record of deep-well drilling for 1904: U.S. Geological Survey Bulletin 264, $106 \mathrm{p}$.

Fuller, M.L., and Sanford, Samuel, 1906, Record of deepwell drilling for 1905: U.S. Geological Survey Bulletin $298,299 \mathrm{p}$.

Fumal, T.E., Tinsley, J.C., and Joyner, William, 1985, Correlations between shear-wave velocity and other geotechnical properties of near-surface geologic materials in California (abs.): Association of Engineering Geologists Annual Meeting, v. 28, p. 62 .

Gale, H.S. 1912, Nitrate deposits: U.S. Geological Survey Bulletin $523,36 \mathrm{p}$

Gale, H.S., 1914, Late developments of magnesite deposits in California and Nevada: 0.S. Geological Survey Bulletin 540-v, p. 483-520; fig. 54, scale $1: 13,500$

Godwin, L.H.. Haigler, L.B., Rloux, R.L., White, D.E. Muffler, L.J.P., and wayland, R.G., 1971, Classification of public lands valuable for geothermal steam and associated geothermal resources: U.S. Geological Survey Circular $647,18 \mathrm{p}$.

Goodwin, J.G., 1957, Lead and zinc in Calıfornia: California Journal of Mines and Geology, v. 53, nos. 3 and 4, p. $353-758$

Goodyear, W.A., 1887, Petroleum, asphaltum and natural gas in California: California State Mining Bureau, State Mineralogist Annual Report 7, p. 65-115.

Gower, H.D.. 1966, Phosphate in mineral resources of California: California Division of Mines and Geology Bulletin 191, p. 328-332.

Greensfelder, R.w., 1974, Maximum credible rock acceleration from earthquakes in California: California Division of Mines and Geology Map Sheet 23, scale $1: 2,500,000$.

Hadley, D.M., and Cavit, D.S., 1982, Statrstical study of sersmicity associated with geothermal reservolrs in California U.S. Geological Survey Open-File Report 82-1064, 89 p.

Haley, c.s., 1923, Gold placers of California: California Division of Mines Bulletin 92, p. 156

Hamilton, F.M., 1914, Petroleum industry of Californa: California state Mining Bureau Bulletin 69, $364 \mathrm{p}$.

Hamilton, Fletcher, 1920, A review of mining in California during 1919 with notes on outlook for 1920: California Mining Bureau Preliminary Report 6, $43 \mathrm{p}$.

Hanks, H.G., 1882, On the occurrence of salt in California and its manufacture: California Mining Report 2, p. 217-226.

Harms, K.K., Lienkaemper, J.J., and ziony, J.I., 1984, Slip-rate table and map of late Quaternary faults of california: Earthquake Notes, v. 55 , p. 7 .

Hart, E.W., 1978, Limestone, dolomite, and shell resources of the coast Range Province (Calif.): California Division of Mines and Geology Bulletin 197.

Hem, J.D., 1985, Study and interpretation of the chemical characteristics of natural water (3d ed.): v.s. Geological Survey Water-Supply Paper 2254, $263 \mathrm{p}$

Hemley, J.J., 1967, Aqueous solutions and hydrothermal activity: American Geophysical Onion Transactions, v. 48

Hess, F.L., and Larsen, E.S., Jr., 1920, Contact-metamorphic tungsten deposits of the United States: U.S. Geological Survey Bulletin 725-D, p. 245-309.

Hill, J.M., 1912, The mining districts of the Western United States, with a geologic introduction by Waldemar Lindgren: U.S. Geological Survey Bulletin 507, p. 114, $130-131, \mathrm{pl} .5$.

H111, Mary, 1984, Calıfornia landscape, orıgin and evolution Berkeley, University of California Press, $262 \mathrm{p}$

Hill, T.P., 1981 , Chemical composition of sedimentary rocks in Californı and Hawall: U.S. Geological Survey Professional Paper $1097,145 \mathrm{p}$.

Holzer, T.L., 1977. Ground failure in areas of subsidence due to ground-water decline in the United States: International Association of Hydrological Sciences Publication 121. Second International Symposium on Land Subsidence, Anaheim, Calif., 1976 , p. 423-433

Hooker, Marjorle, 1952, Annotated blbllography of North American geology, $1950:$ v.s. Geological Survey Bulletin
985,394 p.

\section{California---Continued}

Hoyt, J.C., 1904, Report of progress of stream measurements for the calendar year 1903, part 4, Interior basin, Pacific and Irrigation Paper 100, 533 p.

Hoyt, J.C., and Wood, B.D., 1905, Index to the hydrographic progress reports of the United States Geological Survey,
1888 to 1903 : U.S. Geological Survey water-Supply Paper 119, $253 \mathrm{p}$.

Hughes, J.L., and Waananen, A.o., 1972, Effects of the January and February 1969 floods on ground water in
central and southern California: U.S. Geological Survey open-file report, 52 p.

Huguenin, Emsle, 1915, State Mineralogist report 15: California State Mining Bureau, p. 30, 730-733, 754.

Inter-Agency Commattee on Water Resources, 1956, Annotated bibliography on hydrology 1951-54 and sedimentation 1950-54 (United States and Canada): Inter-Agency Committee on Water 707

Inter-Agency Commattee on Water Resources, 1964, Annotated bibl lography on hydrology and sedimentation 1959-1962 (United States and Canada): Inter-Agency Committee on Water Resources Joint Hydrology-Sedimentation Bulletin 8 ,
323 p.

International Association of Scientific Hydrology, 1937, Bibliography of hydrology, United States of America, for

nternational Association of Scientific Hydrology, 1938 , Bibliography of hydrology, United States of America, for the year 1937: American Geophysical Union, $68 \mathrm{p}$.

International Association of Sclent lf $1 \mathrm{C}$ Hydrology, 1940 , Bibliography of hydrology, United States of America, for

the year 1939: American Geophysical Union, 86 p.
International Association of Scientific Hydrology, 1941 ,
Bibliography of hydrology, United States of America, for Bibliography of hydrology, United States of Amer.

the year 1940: American Geophysical Onion, 93 p.
Jenkins, O.P., 1938, Geologic map of California: California Division of Mines, 1 map.

Division of Mines, 1 map.
Jenkins, o.P., 1938, Geomorphic map of Calıfornia, in Hinds, N.E.A., Evolution of the California landscape California Division of Mines Bulletin 158, pl. 2 .

Jenkins, O.P., 1938, Geomorphic provınces of Calıfornıa as outlined on the new state geologic map (abs.): American Association of Petroleum Geologists Bulletin, v. 22, no. 12 , p. 1717 .

Jennings, C.W., 1963, Asphalt and butuminous rock, in Mineral commodities of California: California Division of Mines Bulletin 176, p. 59-70.

Jennings, C.W., 1973, State of California preliminary fault and geologic map: California Division of Mines and Geology Preliminary Report 13, 1 map.

Jennings, C.W., Strand, R.G., Rogers, T.H., Stinson, M.C., Burnett, J.L., Kahle, J.E., Streitz, R., and Switzer, R.A., 1975, Fault map of California with locations of volcanoes, thermal springs, and thermal wells: California Division of Mines and Geology, California Geologic Data Map Series, Map 1, scale 1:750,000

Jennings, C.W., and Hart, E.W., 1956, Exploratory wells drilled outside of oll and gas fields in California to December 31, 1953: California Division of Mines Specia

Report 45, 104 p. 2 figs.
Jennings, C.W., compiler, 1977, Geologic map of California: California Division of Mines and Geology Geologic Data Map 2 , scale $1: 750,000$. Jennings, c.W., no date, Faults and geologic data of
California: California Division of Mines and Geology Bulletin 201.

Jet Propulsion Laboratory, 1976, Report on the status of development of geothermal energy resources in California: Jet Propulsion Laboratory Document 5040-25.

John, B.E., and Howard, K.A., 1982, Multiple low-angle Tertiary faults in the Chemehuevi and Mohave Mountains, California and Arizona (abs.): Geological Society of America, Abstracts with Programs, v. 14, no. 4, p. 175-176.

Johnston, M.J.S., Smath, B.E., and Mueller, R.M., 1978, Measurements of local magnetic field observations of fault creep and local earthquakes on the San Andreas fault, $36 \mathrm{p}$.

Jorgensen, L.N., and Pearce, V.F., 1978, Drought in California-water-Resources data for 1977: U.S. Geological Survey OpenFile Report $78-613,117 \mathrm{p}$.

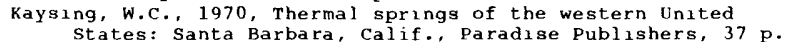

eroher, G.C., United States for 1936-1960, part 1, A-F; part 2, G-O; part 3, P-Z: U.S. Geological Survey Bulletin 1200, 4,341 p.

Kung, R.R., Jussen, V.M., Loud, E.S., and Conant, G.D. 1960 , Bibliography of North American geology, 1957: v.s. Geological Survey Bulletin 1095, $531 \mathrm{p}$.

King, R.R., Jussen, V.M., Pomeroy, J.S., and Sk1tsky, V.L., 1955, Bibliography of North American geology, 1951: v.S. Geological Survey Bulletin 1025, $378 \mathrm{p}$.

Kıng, R.R., Jussen, V.M., Pomeroy, J.S., and Skitsky, V.L., 1956, Bibliography of North American geology, 1952

Kıng, R.R 1953: 0.S. Geological Survey Bulletin 1035, Conant, G.D., 1965, Bibliography of North American geology, 1950-1959: U.S. Geological Survey Bulletin 1195, pt. 1, bıbl lography (v. 1, p. 1-1012; v. 2, p. 1013-1790); pt. 2, Index (v. 3, p. 1791-2796; v. 4. p. 2797-4025).

King, R.R., Thom, E.M.. Loud, E.S., and Hooker, M., 1957 , Bibliography of North Amerzcan geology, 1940-1949: u.s. Geological Survey Bulletin 1049 , pt. 1, bibliography, p. 1-1033; pt. 2, 1ndex, p. 1035-2205.

King, R.R., and others, 1957, B1bliography of North American geology, 1954: 0.S. Geological Survey Bulletin 1054, 484 p. 


\section{California--Continued}

King, R.R., and others, 1958, Bubliography of North American geology, 1955: 0.S. Geological Survey Bulletin 1065, 511 p. King, R.R.. and others, 1959, Bibliography of North American King, Reology, 1956: U.S. Geological Survey Bulletin 1075, 554 P. geology, 1958: D.S. Geological Survey Bulletin 1115, 592 p. istler, R.W., and Peterman, z.E.. 1978, Reconstruction of crustal blocks of California on the basis of initial strontium isotopic compositions of Mesozolc granitic rocks:
v.s. Geological Survey Professional Paper 1071,17 p.

koenig, J.B.. 1970, Geothermal Exploration in the western United States: United Nations Symposium on the Development and vtilization of Geothermal Resource

Special Issue 2, Pisa, Italy, $13 \mathrm{p}$.
Kunz, G.F., 1905, Gems, jewelers' materials, and ornamental stones of California. California State mining Bureau Bulletin $37,155 \mathrm{p}$.

Lagoe, M.B., and McDougall, Kristin, 1983, Distribution of benthic foraminufers across a middle Mlocene basin margin, central californiai paleoenvironmental, tectonsc, and biostratigraphic implications (abs.): American Association

Lee, C.H., 1913, Use and conservation of the underground reservoirs of California: Western Englneering, v. 3, p. $189-194$.

Levorsen, A.I., 1941, Possible future oil provinces of the United States and Canada: Tulsa, Oklahoma, American Association of Petroleum Geologists, $154 \mathrm{p}$.

L גenkaemper, J.J., 1985, Quaternary faults of California: v.s. Geological Survey Open-File Report 85-211, 12 p.

Limerinos, J.T., 1978, Evaluation of thermograph data for Calıfornia streams: U.S. Geological Survey water-Resources Investigations Report 78-66, $38 \mathrm{p}$.

Limerinos, J.T., 1979, Evaluation of thermograph data for California streams: U.S. Geological Survey Water-Resources Investigations Report $78-66,42$.

Lindgren. W. 1887. The silver mines of Calico, California: American Institute of Mining Engineers Transactions, v. 15, p. 717-734; fig. 6, scale $1: 18,000$

Lindh. A.G.. 1983, Preliminary assessment of long-term probabiiities for large earthquakes along selected fault segments of the San Andreas fault system, California: U.S. Geological Survey Open-File Report. 83-63, $15 \mathrm{p}$.

Lippincott, J.B., 1903, California hydrography: U.S. Geological Survey water-Supply Paper 81,488 .

Geological Survey Water-Supply Paper 81,488 P.
Locke, A., Bilingsiey. P., and Mayo, E. B., 1940, Sierra Nevada tectonic pattern: Geological Soclety of America Bulletin, v. 51, p. 513-540.

Luedke, R.G., and Smith, R.L., 1982, Map showing distribution, California and Nevada: U.S. Geologic volcanic centers in Investigations Series Map I-1091-C, scale $1: 1,000,000$.

Martin, R.O.R., and Hanson, R.L., 1966, Reservoirs in the $1838,115 \mathrm{p}$.

Mcclelland, E.J., 1963, Methods of estımating ground-water pumpage in California: U.S. Geological Survey open-file report, $19 \mathrm{p}$.

McIntosh, W.L., and Elster, M.F., 1978, Geologic map index of California: 0.s. Geological Survey.

McKee, E.H. and Klock, P.R., 1984, K-Ar ages of Cenozolc volcanic rocks; Walker Lake $1 \times 2$ degree quadrangle, easter $9-11$.

McLaughlin, R.P., and waring, C.A., 1915, Petroleum industry of California: California Mineral Bureau Bulletin 69, $519 \mathrm{p}$.

McNitt, J.R.. 1960, Geothermal power: California Division of Mines and $1-9$.

McNitt, J.R., 1963, Exploration and development of geothermal power in California: California Division of Mines and Geology Special Report $75,45 \mathrm{p}$.

Meinzer, o.E., 1918, Bubliography and index of the publications of the United States Geological survey relating to ground water: U.S. Geological Survey Water-Supply Paper 427, $169 \mathrm{p}$. NOAA climatological data, relative to USGS earthquake research in California: 0.S. Geological Survey Open-File Report $80-361,37 \mathrm{p}$.

Moore, E.J.. 1984, Tertiary marine pelecypods of California and Baja California: D.S. Geological Survey Professional Paper 1228-A, Nuculidae through Malleidae, P. A1-A108; 1228-B, Propeamussidae and Pectinidae, p. B1-B112.

Mortensen, C.E., Herrıot, J.W., Johnston, M.J.S., Myren, G.D. Silverman, S., Daul, W.B., and Jones, A.C., 1979, Preliminary summary of tiltmeter data from selected tiltmeter sites along the San Andreas fault, California: D.S. Geological Survey Open-File Report 79-1087, $31 \mathrm{p}$.

Murdoch, Joseph, and Webb, R.W., 1966, Minerals of California, Centennial volume (1866-1966): Calıfornıa Division of Mines and Geology Bulletin 189, $559 \mathrm{p}$.

National Academy of Sciences, National Academy of Englneering, $1973(1974)$, Water quality criteria, 1972: v.s. Environmental Protection Agency Report. EPA R3 73033 , $594 \mathrm{p}$.

National Oceanic and Atmospheric Administration, 1965-80, Clumatological data, annual summary no. 13: National Oceanic and Atmospheric Administration, various pagination.

National Oceanic and Atmospheric Administration, published monthly and annually (all data prior to 1940 by D.S. Weather Bureaul, climatological data: National Oceanic and Atmospheric Administration, Climatological data, monthly publications and annual summaries, various pagination.

National Research Council, 1952, Annotated bibllography on hydrology 1941-1950 (United States and Canada): National $408 \mathrm{p}$.

\section{California--Continued}

Nehring, R., 1981, The discovery of significant oll and gas fields in the United States: Sa
Rand Corporation, p. 38-41, $98-100$. 1, F.H., 1903, Report of progress of stream measurements for the calendar year 1901: 0.S. Geological Survey water-Supply

Paper 75, 246 p.

.H. 1903, Report on progress of stream measurements for coast. Water-supply Paper 85, 250 p.

Nichols, D.R., and Buchanan-Banks, J.M., 1974, Se1smic hazards and land-use planning: v.S. Geological Survey Circular $690,33 \mathrm{p}$.

Nickles, J.M., 1923, Geologic 1iterature on North America, 1785-1918: 0.S. Geological Survey Builetin 746, pt. 1 , bibliography, $1167 \mathrm{p}$.

Nickles, J.M., 1924, Geologic literature on North America, 1785-1918: 0.s. Geological Survey Bulletin 747, pt. 2.

index, 658 p.
N1ckles, J.M., 1931, Bibl zography of North American
geology, 1919-1928: D.S. Geological Survey Bulletin 823 $1005 \mathrm{p}$.

Nilsen, T.H., 1984, Oligocene tectonics and sedimentation, California: Sedimentary Geology, v. 38, no. 1-4, p. 305-336.

Noble, L.F., 1954, The San Andreas fault zone from Soledad Pass to Cajon Pass, California: California Division of Mines Bulletin 170

O'Ne11, J.R., and King, Ch1-Yu, 1981, Variations in stableisotope ratios of ground waters in seismically active regions of California: Geophysical Research Letters, v. 8 , no. 5, p. 429-432.

oakeshott, G.B., Braun, L.T., Jennings, C.W., and wells, R., 1952, Exploratory wells drilled outside the oli and gas fields of California to December 31, 1950: California Division of Mines Special Report 23,77 p., 1 pl.

oborn, E.T., 1960 , A survey of pertinent biochemical
i terature: U.S. Geological survey water-Supply Paper 11terature: U.S. Geol

Oll Field Map Books, Inc., 1955, Calufornia oul field map book: 01l Field Map Books. Inc., v. 5, $128 \mathrm{p}$.

oliver, H.w., 1980, General introduct ion, in Interpretation of the gravity map of california and its continental margin: california Division of Mines and Geology Bulletin 205, p. $1-8$.

oliver, H.W., Chapman, R.H., Blehler, Shawn, Robbuns, S.L., Hanna, W.F., Griscom, A., Beyer, L.A., and Silver, E.A., California Division of Mines and Geology Geologic Data Map 3 , scale $1: 750,000$.

oliver, H.W., ed.. 1980, Interpretation of the gravity map of California and its continental margin: California Division of Mines and Geology Bulletin 205, $52 \mathrm{p}$.

Pabst. Adolph. 1928, Observations on inclusions in the granitic rocks of the Sierra Nevada: Berkeley, University of

Parke, D.L., Real, C.R.. and Toppozada, T.R., 1978, Earthquake epicenter map of California: California Division of Mines and Geology Map sheet 39 , scale $1: 1,000,000$.

Peale, A.C. 1894, Natural mineral waters of the United States:

U.S. Geological Survey Annual Report 14, pt. 2 , p. 49-88.
plouff. Donald, 1966 , Digital terrain corrections based on geographic coordinates (abs, and preprint): Geophysics, v. 31, p. 1208

Poore, R.Z., 1980, Age and correlations of California Paleogene benthic foraminiferal stages: D.S. Geological Survey

Poore, R.z., McDougail, Kristin, Barron, J.A., Brabb, E.E., and Kling, S.A., 1981, Microfossil biostratigraphy and biochronology of the type Relizian and Luisian stages of California, in Garrison, R.E., ed., The Monterey Format and related siluceous rocks of California: Los Angeles, glsts, Paciflc section, p. 15-4l.

Pray, L.c., 1957, Rare earth elements: Calufornia Division of Mines Mineral Information Service, v. 10 , no. 6, p. 1-8.

Prose, D.V... and Metzger, S.K.. 1985, Recovery of soils and vegetation in World war 2 military base camps, Mojave Deser
(Calif., Ariz., Nev.): u.s. Geologlcal Survey Open-File Report 85-234, Nev.)

Randa11, L.E., 1961, Annotated bibluography of water-use data, 1960: U.S. Geological Survey Circular $455,14 \mathrm{p}$.

Randolph, J.R., and Delke, R.G., 1966, Bibl lography of hydrology of the United States, 1963: U.S. Geological Survey Water-Supply Paper 1863, $166 \mathrm{p}$.

Ransome, A.L., and Kellogg, J.L., 1939, Quicksulver resources of Callfornia:
report 35, p. $378-380$. S.E. 1969 (1972), Mean annual precipitation in the California region: U.S. Geological Survey open-file report,

5 P. February 1963 in California and Nevada: D.S. Geological Survey open-file report. $74 \mathrm{p}$.

Reed, M.J., 1975, Chemistry of thermal water in selected geothermal areas of California: California Division of $0_{11}$ and Gas Report TR 15, $31 \mathrm{p}$.

Riggs, H.C., 1962, Annotated bibluography of hydrology and sedimentation, United States and Canada, 1955-58: 0.S. Geological Survey Water-Supply Paper 1546, $236 \mathrm{p}$.

Robbuns, S.L., Oliver, H.W., and Plouff, Donald, 1973, Magnet $1 \mathrm{C}$ tape contalning average elevations of topography in california and adjacent regions for areas of $1 \times 1$ minute NTIS-PB-219794,31 p.. magnetic tape.

Roberts, A.E., 1981, Phosphatic rock localities in California: U.S. Geological Survey Open-File Report $81-260,77$ p. 


\section{CATEGORY 6: ARIZONA, CALIFORNIA, MEXICO, AND NEVADA}

\section{California--Continued}

Roberts, C.W., Jachens, R.C., and oliver, H.W., 1981, Preliminary isostatic residual gravity map of California: U.S.

Robinsological Survey Open-File Report 81-573, $39 \mathrm{p}$ bibilography on evaporation and transpiration: U.S. Geological Survey Water-Supply Paper $1539-\mathrm{R}, 25 \mathrm{p}$.

Rodriguez, T.R., 1985, Locations of geophysical monitoring instruments and survey points operated in California and Alaska supported by the Earthquake Hazards Reduction Program: v.s. Geological Survey Open-Eile Report 85-38,
66 p.

Rogers, A.M. attenuation in the southern Great Basin., Nevada-California (abs.): Earthquake Notes, v. 55, p. 24.

Rowe, P.B., and Colman, E.A., 1951, Disposition of rainfall in two mountain areas of California: U.S. Department of Agriculture Technical Bulletin 1048, $84 \mathrm{p}$.

Sarna-Wojcick1, A.M., Bowman, H.W., and Russell, P.C. 1979, Chemical correlation of some late Cenozorc' tuffs of northern and central california by neutron activation analysis: U.S. Geological Survey Professional Paper 1147, $15 \mathrm{p}$.

Saul, L.R., 1983, Turritella zonation across the CretaceousTertiary boundary, California: Berkeley, University of California Publication in the Geological Sciences, v. 125 , $165 \mathrm{p}$.

Schiffman, Peter, Wllliams, A.E., and Evarts, R.C., 1984, Oxygen isotope evidence for submarine hydrothermal aiteration of the Del Puerto Ophiolite, California: Earth and Planetary Science Letters, v, 70, no. 2, p. 207-220.

Schulz, S.s., and wallace, R.E., 1984, The San Andreas Fault: u.s. Geological Survey General Interest Publications, 20 p. Schulz, Sandra, Burford, R.o., and Mavko. Barbara, 1983, Influence of seismicity and rainfall on episodic creep on the Gan Andreas fault system in central California: Journal

Schuyler, J.D., 1897, Reservoirs for irrigation: U.s. Geological Survey Annual Report 18, pt. 4, p. 741-756.

scott, E.W., 1983, Petroleum potential of wilderness lands in California, in petroleum potential of wilderness lands
in the Western United States: v.s. Geological Survey Circular 902-A-P, P. D1-D8.

Scott, E.W., and Miller, B.M., ed., 1982, Petroleum potential of wilderness lands, California: U.S. Geological Survey
Miscellaneous Investigations Series Map I-1538, scale $1: 1,000,000$.

Silva, M.A. 1983, Mines and mineral producers active in California: California Division of Mines and Geology Special Publication 67

Silva, M.A.. 1985, 1984 minıng review: Calıfornıa Geology, v, 38 , no. $10, p .225-231$.

Smith, M.B., 1955, Basement wells in California and Nevada: U.S. Geological Survey open-file report, $130 \mathrm{p}$. h, M.B., 1959, Basement wells in California and Nevada: U.S. Geological Survey open-file report, $130 \mathrm{p}$. h, M.B., 1964, Map showing distribution and configuration of basement rocks in California: v.s. Geological Survey $O_{1} 1$ and Gas Investigations Map OM-215, sheet 1 , north half, lat about 37 to 42 degrees, long about 118 to 124 degrees; sheet 2 , south half, lat about 1:500,000.

Smxth, Winchell, and Hains, C.F., 1961, Flow-duration and high- and low-flow tables for California streams: U.s. Geological Survey open-file report, $600 \mathrm{p}$.

Snedden, L.B., 1943, South Mountain oll field in Geologic formations and economic development of the oll and gas fields of California: Cal

Sohl, N.F., and Wright, W.B., 1980 , Changes in stratigraphic nomenclature by the U.S.' Geological Survey, 1979: U.S. Geological Survey Bulletin $1502-\mathrm{A}, 138$.

Spurr, J.E., 1903, Descriptive geology of Nevada South of the fortieth parallel and adjacent portions of California: U.S. Geological Survey Bulletin 208, 229 p.

stewart, J.H.' 1983, Cenozolc structure and tectonics of the northern' Basin and Range Province, California, Nevada, and p. $25-40$.

Strand, R.G., Koenig, J.B., and Jennings, C.W., 1958 , Index to geologic maps of California to December 31, 1956 California Division of Mines Special Report 52, $127 \mathrm{p}$.

Thom, E.M., 1942 , Bibl lography of North American geology
for 1940 and 1941 : U.S. Geological Survey Bulletin 938 . $479 \mathrm{p}$.

Thom, E.M., 1944, B1bliography of North American geology. 1929-39: U.S. Geological Survey Bulletin 937, pt. 1 ,

Thom, E r lography, p. 1-1063; pt. 2, index, p. 1065-1546. 1942 and 1943 : U.S. Geological Survey Bulletin 949, $460 \mathrm{p}$.
.

Thom, E.M., 1947, Bibl lography of North American geology, $496 \mathrm{p}$.

Thom, E.M., Hooker, Marjorle, and Dunaven, R.R. 1949 , Bibliography of North American geology, 1946 and 1947 : U.S. Geological Survey Bulletin $958,658 \mathrm{p}$.

Thom, E.M., Hooker, Marjorie, and Dunaven, R.R., 1950, Bibliography of North American geology, 1948: U.S.
Geological Survey Bulletin $968,309 \mathrm{p}$.

Thom, E.M., Hooker, Marjorle, and Dunaven, R.R., 1951, Bibliography of North American geology, 1949: U.S Geological Survey Bulletin 977,273 .

Todd, D.K., 1959, Annotated bibllography on artificial recharge of ground water through 1954: U.S. Geological Survey water-Supply Paper $1477,115 \mathrm{p}$.

Toppozada, T.R., Parke, D.L., and Higgins, C.T., 1978, Selsmcity Geology Special Report 135.

\section{California--Continued}

Toppozada, T.R., Real, C.R., and Parke, D.L., 1986, Earthquake history of Calıfornia: California Geology, v. 39, no. 2,

oppozada, T.R., and Parke, D.L., 1981, Preparation of 1soseisma maps and summaries of reported effects for pre-1900 California earthquakes: California Division of Mines and Geology Open-File Report 81-11 SAC.

Toppozada, T.R., and Parke, D.L., 1982, Areas damaged by California earthquakes, 1900-1949: California Division of Mines and Geology Open-File Report 82-17 SAC.

Toppozada, T.R., and Real, C.R., 1982, Preparation of 1soseismal maps and summarles of reported effects for pre-1900 California earthquake

Trask, P.D., 1950, Geologic description of the manganese deposits of California: California Division of Mines Bulletin 152, $378 \mathrm{p}$.

U.S. Bureau of Reclamation, 1972, Inland basins projects, California-Nevada: U.S. Bureau of Reclamation Summary Report, reconnassance investigations, $97 \mathrm{p}$.

v.s. Bureau of Reclamation, 1975, Westside study report on critical water problems facing the eleven western states: U.S. Bureau of Reclamation, $457 \mathrm{p}$.

v.s. Department of Agriculture, office of Experiment Stations, Irrigation in California: v.s. Department of Agriculture Bulletin 235 .

U.S. Environmental Protection Agency, Environmental Studies Board, 1972, Water quality criteria 1972, a report of the Committee on Water Quality Criteria: Washington,

D.C.. v.S. Government Printing office, $594 \mathrm{p}$.

Geological Survey 1957, Water levels and artesian 1955, part 6, southwestern United States: v.s. Geological Survey water-Supply Paper 1409, $280 \mathrm{p}$.

v.S. Geological Survey and Calufornia Division of Mines and Geology, 1966, Geologic map of California: U.S. Geological $1: 2,500,000$

v.s. Geological Survey, 1902, Operations at river stations, 1901, part 2, West of the Mississippi River: U.S. Geological Survey Water-Supply Paper 66, $188 \mathrm{p}$.

v.s. Geological Survey, 1917, Surface water supply of the California: U.S. Geological Survey Water-Supply Paper 391 , $334 \mathrm{p}$.

U.S. Geological Survey, 1936, Water levels and artesian

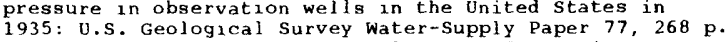

. Geological Survey, 1937, Water levels and artesian pressures in observation wells in the United States in

peological Survey, 1938, water levels and artesian pressure in observation wells in the United States in
1937: U.S. Geological Survey water-Supply Paper 840, 657

Geological Survey, 1939 , water levels and artesian pressures in observation wells in the United States in . J.S. Geological Survey water-Supply Paper 845, 724

v.s. Geological survey, 1940, water levels and artesian 1939: U.S. Geological Survey Water-Supply Paper 886, 933

U.s. Geological survey, 1941, water levels and artesian pressure in observation wells in the united States in 1940 , part 6, southwestern United States: U.S. Geological Survey Water-Supply Paper $911,240 \mathrm{p}$.

v.s. Geological Survey, 1943, Water levels and artesian pressure in observation wells in the United States in Survey water-supplywestern United Stat

u.s. Geological Survey, 1943-60, Surface water supply of the United States, part 11, Pacific slope basins in California: U.S. Geological Survey water-Supply Papers. published annually, various pagination.

v.s. Geological Survey, 1944, water levels and artesian pressure in observation wells in the United States in Survey Water-Supply Paper 949, 344 p.

v.s. Geological Survey, 1945, water levels and artesian pressure in observation wells in the United States in Survey water-Supply Paper 991, $305 \mathrm{p}$

U.s. Geological Survey, 1947, Water levels and artesian pressure in observation wells in the united States in Survey, part 6, southwestern United Stat

v.s. Geological Survey, 1949, Water levels and artesian pressure in observation wells in the United States in 1945, part 6, southwestern United Statea

v.s. Geological Survey, 1949 , Water levels and artesian pressure in observation wells in the United States in

v.s. Geological Survey, 1951, water levels and artesian pressure in observation wells in the United States in Survey Water-Supply Paper 1101, $316 \mathrm{p}$.

U.S. Geological Survey, 1951, Water levels and artesian pressure in observation wells in the United States in Survey Water-Supply Paper $1131,288 \mathrm{p}$

v.s. Geological Survey, 1952, water levels and artesian pressure in observation wells in the United States in Survey water-Supply Paper 1161, $298 \mathrm{p}$. 


\section{California--Continued}

v.s. Geological Survey, 1953, water levels and artesian pressure in observation wells in the United States in Survey water-Supply Paper 1170, $279 \mathrm{p}$.

U.s. Geolog Water-Supply Paper $1170,279 \mathrm{p}$.
und Survey, 1954 , water levels and artesian pressure in observation wells in the United States in Survey Water-Supply Paper 1196, $222 \mathrm{p}$.

U.s. Geological Survey, 1955, water levels and artesian pressure in observation wells in the United States in Survey Water-Supply Paper 1226, 237 p.

U.S. Geological Survey, 1956, Water levels and artesian pressure in observation wells in the United States in Survey Water-supply Paper $1270,253 \mathrm{p}$.

v.s. Geological Survey, 1957, Water levels and artesian pressure in observation wells in the United States in Survey water-Supply Paper 1326, 262 .

U.s. Geological Survey, 1960 , Compliation of records of surface waters of the United States through September 1950, part 10: U.S. Geological Survey Water-supply Paper $1314,485 \mathrm{p}$.

v.s. Geological Survey, 1960, Complation of records of surface waters of the United States through September 1950, part 11-A, Pacif ic Slope basins in California, except Central valley: U.S. Geological Survey water-supply Paper 1315-B, p. 461-874

U.S. Geological Survey, 1963, 1971-75, Water resources data for California: U.S. Geological Survey annual report

U.s. Geological Survey, 1963, Compilation of records of surface waters of the United States, October 1950 to September 1960, part 10, the Great Basin: U.S. Geological

Survey Water-Supply Paper 1734,318 p.
u.s. Geological Survey, 1963 , Ground-water levels in the United States, 1956-60, southwestern states: U.S. Geological Survey Water-Supply paper 1770,160 p.

U.S. Geological Survey, 1964, Compilation of records of surface waters of the United States, October 1950 to September 1960 , part 11, Pacific slope basins in California: U.S. Geological Survey Water-Supply paper $1735,715 \mathrm{p}$.

U.S. Geological Survey, 1966, Geologic and water-supply reports and maps, California, March 1966: U.S. Geological Survey, $25 \mathrm{p}$

u.s. Geological Survey, 1966, Index to catalog of information on water data, surface-water stations reported by Federal agencies: U.S. Geological Survey, 517 p.

U.S. Geological Survey, 1966, Index to catalog of information on water data, water-quality stations reported by Federal agencies: U.S. Geological Survey, 151 p.

U.s. Geological Survey, 1966, Mineral and water resources of California, part 2, water resources: Eighty-ninth Congress, 2d session, U.S. Senate Commission on Interior and

U.s. Geological Survey, 1968, B1bliography of North American geology, 1963: U.S. Geological Survey Bulletin 1233, 1105 p.

U.S. Geological Survey, 1969, Bibliography of North American

t.s. Geology, 1965: U.S. Geological Survey Bulletin 1235, 1144 p.

v.s. Geological Survey, 1970, Bibliography of North American

geology, 1967: U.S. Geological Survey Bulletin $1267,1029 \mathrm{p}$ Geological Survey, 1970 , Surface water supply of the Geological Survey water-Supply Paper 1927, 978 p.

U.s. Geological Survey, 1970, Surface-water supply of the United States, 1961-65, part 11, Pacific slope basins in California, volume 1 , Basins from Tijuana River to Santa $1928,501 \mathrm{p}$.

U.S. Geológical Survey, 1971, B1bllography of North American geology, 1968: U.S. Geological Survey Bulletin 1268,1301 .

U.S. Geological Survey, 1971-74, Water-resources data for California, water years 1971-74, part 1, Surface water Reports CA $71-1,494$ p.; CA $72-1,526$ p.; CA 73-1, 512 p.;

CA 74-1, 510 p. Geological Survey, 1972, Ground-water levels in the United States, 1966-70, southwestern states: U.S.

u.s. Geological Survey Water-Supply Paper 2010, 106 p. water data, Survey, 1974, Catalog of information on Survey, at. A, 163 p.

v.s. Geological Survey, 1974, Surface water supply of the United States, 1966-70, part 10: U.S. Geological Survey Water-Supply Paper $2127,1143 \mathrm{p}$.

U.S. Geological Survey, 1975, Water resources data for California, volume 2, Pacific slope basins from Arroyo Grande to Oregon State I ine except Central Valley: U.S. Geological Survey Water-Data Report CA-75-2, $515 \mathrm{p}$.

v.s. Geological Survey, 1976, Surface-water supply of the United States, 1966-70, part 11, Pacific slope basins in California, volume 1, Basins from $T 1$ juana River to Santa
Marıa River: U.S. Geological Survey Water-Supply Paper $2128,552 \mathrm{p}$.

v.S. Geological Survey, 1976-81, water-resources data for Cal ifornia, water years 1975-80, volume 1, Colorado River basin, southern Great Basin from Mexican border to Mono Lake basin, and Pacific Slope basins from Tijuana River to Santa Maria River: U.S. Geological Survey Water-Data Reports CA-75-1, 548 p.; CA-76-1, 635 p.; CA-77-1, 638 p. CA-78-1, 628 p.; CA-79-1, 599 p.: CA-80-1, 451 p.

\section{California---Continued}

U.S. Geological Survey, 1977, Ground-water levels in the United States, 1971-74, southwestern states: U.S. Geological Survey water-Supply Paper 2162, 86 p.

U.s. Geological Survey, 1977, Surface water supply of the United States, 1966-70, part 16, Hawall and other Pacif 10 $750 \mathrm{p}$.

U.S. Geological Survey, 1978 (1979), Hydrologic unit map of California: U.S. Geological Survey Hydrologic Unit Map, 2 sheets, scale 1:500,000.

U.S. Geological Survey, 1981, Scenarios of possible earthquakes affecting major california population centers, with estimates of intensity and ground shaking: U.S. Geological mates of intensity and ground shaking:

v.s. Public Health Service, 1962, Drinking water standards, 1962 : U.S. Public Health Service Publication $956,61 \mathrm{p}$.

v.s. Weather Bureau, 1878-1975, Climatic summary of the United States 1931-52, supplement to climatic summary of the United States,

U.S. Weather Bureau, 1921, Summary of the climatological data for the United States, by section, climatological data from the establishment of stations to 1919 . inclusive: U.S. Department of Agriculture Section 13, 27

U.s. Weather Bureau, 1932, climatic summary of the United States, cilmatic data from the establishment of stations to 1930, inclusive: U.S. Department of Agriculture Section $18,41 \mathrm{p}$.

U.S. Weather Bureau, 1949-1977, Climatological data California: Annual summaries 1948 through 1976, U.s. Department of Commerce, v. 52 through 81 , various pagination.

v.s. Weather Bureau, 1953-69, climatological data, California: U.S. Weather Bureau Annual Summary 13, v. 57-73, various

S. pagination.

Weather Bureau, 1958, Climatic summary of the United states, supplement for 1931 through 1952: 0.S. Department

v.s. Weather Bureau, 1958, Climatography of the United States No. 11-4, climatic summary of the United States. supplement for 1931 through 1952 (supplement to climatic summary of the United States, Bulletin w, 1930): v.s. weather Bureau, $156 \mathrm{p}$.

valentine, J.W., 1961. Pa leoecologic molluscan geography of the Californian pleistocene: University of California Department

Van winkle, W., and Eaton, F.M., 1910, The quality of surface waters of California: U.S. Geologxcal Survey Water-Supply Paper $237,142 \mathrm{p}$.

vander Leck, L., 1922, Memoranda on asphalt and bituminous sand deposits of California: California State Mining Bureau, State Mineralogist Annual Report 18, p. 230

ver planck, W.E.. 1952, Gypsum in Califarnia: California Division of Mines Bulletin 163,151 p.

ver planck, W.E., 1957, Salt in California: California Division of Mines Bulletin 175, 168 p.

ver Planck, w.E., 1957, Strontium minerals, in Mineral commodities of California: California Division of Mines Bullet in 176, p. 607-611.

vorhis, R.C., 1957, Blbliography of publications relating to ground water prepared by the Geological Survey and cooperating agencies, 1946-55: U.S. Geological Survey water-Suppiy paper 1492, $203 \mathrm{p}$.

waananen, A.O., 1969, Floods of January and February 1969 in central and southern California: U.S. Geological Survey open-file report, $233 \mathrm{p}$.

waananen, A.O., 1973, Floods from small drainage areas in California, a compllation of peak data, October 1958 to September 1973: U.S. Geological Survey open-file report, $261 \mathrm{p}$.

Waananen, A.O., and Crippen, J.R., 1977, Magnitude and frequency of floods in California: v.s. Geological survey water-Resources Investigations 77-21, $96 \mathrm{p}$.

Wahl, K.L., Crippen, J.R., and Knott, J.M., 1980, Floods of January and February 1980 in California: v.s. Geological Survey Open-File Report 80-1005, 56 p.

walker, G.W., Lovering, T.G., and stephens, H.G., 1956 Radioactive deposits in California: California Division of

wallace, R.E., and Schulz, S.S., 1983, Aerial views in color of the San Andreas fault, California: U.S. Geological Survey Open-File Report 83-98, $17 \mathrm{p}$.

waring, G.A.. 1915, Springs of Cailfornia: U.S. Geological Survey Water-Supply Paper $338,410 \mathrm{p}$.

Warıng, G.A.. 1965, Thermal springs of the United States and other countries of the world, a summary: U.s. Geological Survey professional paper 492, $383 \mathrm{p}$.

Waring, G.A., and Meinzer, O.E., 1947, Bibliography and index of publications relating to ground water prepared by the Geological Survey and cooperating agencies: U.S.
Geological Survey Water-Supply paper $992,412 \mathrm{p}$.

watts, W.L., 1901, O11 and gas yielding formations of California: California Mining Bureau Bulletin 19, $236 \mathrm{p}$.

weber, A.H., 1887, Petroleum and asphaltum deposits in northern California: Cal ifornia State Mining Bureau, State Mineralogist Annual Report 7, p. 195-202.

Mineralogist Annual Report 7 P. $195-202$.
Wesson, R.L., and Wallace, R.E., 1985, Predicting the next great earthquake

White, D.E., 1965, Geothermal energy: U.s. Geological Survey circular 519, $17 \mathrm{p}$.

White, D.E., Hem, J.D., and Waring, G.A., 1963, Chemical composition of subsurface waters, in Data on geochemistry Survey professional paper 440-F, p. F1-F67. 
CATEGORY 6: ARIZONA, CALIFORNIA, MEXICO, AND NEVADA

\section{California--Continued}

White, D.E., and Will1ams, D.L., eds., 1975, Assessment of geothermal resources of the United States--1975: U.S Geological Survey C1rcular 726, $155 \mathrm{p}$.

wilkinson, E.R., 1971, California oll and gas seeps: California Division of 011 and Gas, Summary of operations, v. 57, no. 1. p. 5-28

williams, G.R., and others, 1937, Selected bibllography on erosion and silt movement: U.S. Geological Survey Water-Supply Paper $797,91 \mathrm{p}$.

wilmarth, M.G.. 1938, Lexicon of geologic names of the United States (including Alaska): O.s. Geological Survey Bulletin 896 , pt. 1, p. $1-1244$; pt. 2, p. 1245-2396.

wisson, H.M., 1893, American irrigation engineering: o.s. Geological Survey Annual Report 13, pt. 3, p. 101-349.

wood, B.D., 1912, Gaging stations maintained by the United states Geological Survey, 1888-1910, and Survey publications relating to water resources: U.S. Geological Survey Water-Supply Paper 280, $102 \mathrm{p}$.

wood, B.D., 1913, Gazetteer of surface waters of California, part 3, Pacific coast and Great Basin streams: 0.s. Geological Survey water-Supply Paper 297, $244 \mathrm{p}$.

wood, B.D., 1916, Stream-gaging stations and publications relating to water resources, 1885-1913: U.S. Geological Survey water-Supply Paper 340, 195

wood, H.o., 1955, The 1857 earthquake in California: Seismological Society of America Bulletin, v. 45, p. 47

woollard, G.P., 1943, Transcont inental gravitational and magnetic profile of North America and its relation to geologic structure: Geological Society of America Bulletin, v. 54 , no. 6 , p. 747-789; pl. 3, scale $1: 2,187,500$

woollard, G.P., and Rose, J.C., 1963, Internatıonal gravity measurements: Madison, University of Wisconsin, Geophysics and Polar Research Center, $518 \mathrm{p}$.

wootten, T.M., 1979, Activities of the strong motion instrumen tation program of August 3, 1977, to September 14, 1978: California Division of Mines and Geology Special Publication 55 .

wootten, T.M., 1983, A catalog of strong motion accelerograph records recovered by of fice of Strong Motion Studies during 1982: California Division of Mines and Geology Special Report 154, supplement.

wootten, T.M., 1983, Catalog of strong motion accelerograph records recovered by off ice of Strong Motion Studies before January 1, 1982: California Division of Mines and Geology Special Report 154.

Young, A.A., 1945, Irrigation requirements of California: California division of water Resources Bulletin $51 ., 132 \mathrm{p}$.

Young, A.A., 1948, Evaporation from water surfaces in California: Californa Division of water Resources Bulletin 54-A.

Young, A.A., and Blaney, H.F., 1942, Use of water by native vegetation: California Division of Water Resources Bulletin $50,160 \mathrm{p}$

Young, L.E., 1960, Floods from small drainage areas in California, October 1958 to September 1959: U.S. Geological Survey open-file report, $72 \mathrm{p}$

Young, L.E., 1961, Floods from small drainage areas in California, October 1958 to September 1960: O.S. Geological Survey open-file report, $120 \mathrm{p}$

Young, L.E., 1962, Fioods from smail drainage areas in California, óctober 1958 to September 1961 : U.S. Geological Survey open-file report, $156 \mathrm{p}$.

Young, L.E., and RaY, H.A., 1963, Floods from small drainage areas in California, October 1958 to September 1962: 0.S Geological Survey open-file report, $203 \mathrm{p}$.

Young, L.E., and Ray, H.A., 1964, Floods from small drainage areas in California, October 1958 to September 1963: U.S. Geological Survey open-file report, $225 \mathrm{p}$.

Young, L.L., and Jones, B.E., 1953 (1954), Annotated bibllography of U.S. Geological Survey reports on water-power resources, including floods and droughts: U.S. Geological Survey circular 200, revised edition, $32 \mathrm{p}$.

\section{California --Continued}

Youngs, L.G., 1984, An annotated bibliography of geothermal information published or authored by staff of the California Division of Mines and Geology 1960-1984: California Division
of Mines and Geology Special Publication 69.

\section{Mexico}

Durham, J.W., and Allison, E.C., 1960, The geologic history of Baja California (Mexico) and its marine faunas: Systematic Zoology, v. 9, no. 2, p. 47-91.

Lofgren, B.E., and Massey, B.L., 1979, Monitoring crustal strain Cerro Prieto geothermal field, Baja California, Mexico: v.s. Geological Survey Open-File Report 79-204, 38 p.

Lofgren, B.E., and Massey, B.L., 1979, Monitoring crustral strain, Cerro Prieto geothermal field, Baja California, Mexico: U.s. Geological Survey Open-File Report 79-204, $38 \mathrm{p}$.

Reed, M.J., 1975, Geology and hydrothermal metamorphısm in the cerro Prieto geothermal field, Mexico (abs.): Second United Nations Symposium on the Development and Use of Geothermal Resources, San Francisco, Calif., May 20-29, 1975 , v. 2-40

Sumner, J.R., 1972, Tectonic significance of gravity and aeromagnetic investigations at the head of the Gulf of California: Geological Society of America Bulletin, v. 83, p. $3103-3120$.

\section{Nevada}

Balley, E.H., and Phoenix, D.A., 1944, Quicksilver deposits in Nevada: Nevada University Bulletın, Geology and Minerology Series 41 , v. 38 , no. 5 .

Hil1, J.M., 1915, Some mining districts in northeastern California and northwestern Nevada: o.s. Geological Survey Bulletin 594, $200 \mathrm{p}$

Longwell, C.R., Pampeyan, E.H., Bowyer, Ben, and Roberts, R.J., 1965, Geology and mineral deposits for Clark County. Nevada: Nevada Bureau of Mines Bulletin 62, $218 \mathrm{p}$

Mifflin, M.D., 1968, Delineation of ground-water flow systems in Nevada: Desert Research Institute-University of Nevada, Technical Report Series $\mathrm{H}-\mathrm{W}$ Hydrology and water Resources, Publication 4, 111 p.

Nevada Division of Water Resources, 1971, Water for Nevada: Nevada Division of Water Resources Report 3,87 p.

Nevada Division of water Resources, 1972, Water for Nevada: Nevada Division of Water Resources, Nevada Hydrologic Atlas.

Spurr, J.E., 1906, Ore deposits of the Silver Peak quadrangle, Nevada: O.S. Geological Survey Professional Paper 55, $174 \mathrm{p}$.

Stewart, J.H., 1980, Geology of Nevada, A discussion to accompany the geologic map of Nevada: Nevada Bureau of Mines and Geology Special Publication 4, $136 \mathrm{p}$.

U.S. Geological Survey, 1979, water resources data for Nevada, water year 1978: U.S. Geological Survey water-Data Report NV-78-1, $368 \mathrm{p}$.

Winograd, I.J., and Thordarson, W1 $1112 \mathrm{~m}, 1975$, Hydrogeologic and hydrochemical framework, south-central Great Basin, Nevada-California, with special reference to the Nevada test site: U.S. Geological Survey Professional Paper $712-\mathrm{C}, 126 \mathrm{p}$

zietz, Isidore, Gilbert, F.P., and Kirby, J.R., 1978, Aeromagnetic map of Nevada: U.S. Geological Survey 